UNIVERSIDADE DE SÃO PAULO

FACULDADE DE FILOSOFIA CIÊNCIAS E LETRAS DE RIBEIRÃO PRETO - DEPARTAMENTO DE QUÍMICA

JACQUELINE QUERINO ALVES

\title{
Complexos rutênio-catecolaminas como moduladores da angiogênese. Aspectos químicos e biológicos da relação estrutura- atividade
}

Tese apresentada ao Programa de PósGraduação em Química, da Faculdade de Filosofia Ciências e Letras de Ribeirão Preto, da Universidade de São Paulo, como requisito parcial para a obtenção do título de Doutor em Ciências. Área: Química.

Orientador: Prof. Dr. Roberto Santana da Silva

\section{Ribeirão Preto - SP \\ Março de 2017}

Versão corrigida da Tese de Doutorado apresentada ao Programa de Pós-Graduação em Química, no dia 28/03/2017. A versão original encontra-se disponível na Faculdade de Filosofia, Ciências e Letras de Ribeirão Preto/USP. 


\section{FICHA CATALOGRÁFICA}

\section{Alves, Jacqueline Querino}

Complexos rutênio-catecolaminas como moduladores da angiogênese. Aspectos químicos e biológicos da relação estruturaatividade. Ribeirão Preto, 2017.

312 p. : il. ; $30 \mathrm{~cm}$

Tese de Doutorado, apresentada à Faculdade de Filosofia Ciências e Letras de Ribeirão Preto/USP - Área de concentração: Química.

Orientador: Silva, Roberto Santana da

1. rutênio-catecolamina. 2. câncer. 3. angiogênese. 4. membrana corioalantoica. 
ALVES, J. Q. Complexos rutênio-catecolaminas como moduladores da angiogênese. Aspectos químicos e biológicos da relação estrutura-atividade. 2017. 312 f. Tese (Doutorado em Ciências, área de concentração: Química) Faculdade de Filosofia Ciências e Letras de Ribeirão Preto, Universidade de São Paulo, Ribeirão Preto, 2017.

Aprovado em:

Banca Examinadora

Prof. Dr.

Instituição:

Julgamento:

Prof. Dr.

Instituição:

Julgamento:

Prof. Dr.

Instituição:

Julgamento

Prof. Dr.

Instituição:

Julgamento:

Prof. Dr.

Instituição:

Julgamento: 


\section{DEDICATÓRIA}

Aos meus pais, que abriram mão dos seus sonhos para me concederem a Educação que tenho hoje, por serem raios de luz em meu caminho e me ensinarem que "adiante da honra vai a humildade". Ao meu esposo, por ser companheiro, sábio e dedicar-me, todos os dias, um amor imensurável, enfim, uma pessoa em um nível espiritual no qual poucas pessoas que conheço já estão... 


\section{AGRADECIMENTOS}

A DEUS, por mais esta etapa concluída, na certeza de que sem o Seu auxílio eu não teria conseguido; por ser o melhor amigo (sempre!). É gratificante ser Sua filha!

Aos meus pais, por todo ensino, dedicação e amor ao longo da minha vida; por serem quem são e, assim, me possibilitarem ser quem eu sou; por me oferecem o seu melhor, sem esperar nada em troca; a eles minha gratidão e amor sem limites.

Ao meu esposo, por sempre estar presente; por me ajudar tanto; por toda dedicação diária ao nosso amor; por ser o meu lugar de paz e materialização dos melhores sonhos meus.

Ao meu orientador, Roberto Santana, por me proporcionar um aprendizado ímpar durante meu doutorado, me ensinando desde o planejamento de compostos à sua aplicação biológica, passando por uma infinidade de técnicas de caracterização físico-químicas. Se hoje me sinto segura, devo isto à forma como ele conduziu-me durante meu doutorado. Foi um imenso prazer e uma sorte sem precedentes ter sido escolhida para ser sua orientada.

Aos Professores Alexandra Fernandes e Pedro Batista por me recepcionarem na Universidade Nova de Lisboa e por todos os ensinamentos concedidos enquanto estive sob a orientação deles; por me ensinarem muito, em pouco tempo.

À Catarina Roma por todo auxílio durante o período que passei na Universidade Nova de Lisboa.

Aos alunos Pedro Pedrosa, Raquel Vinhas, Fabiana Paradinha pelo auxílio; e a estes e a todos os demais membros do grupo dos Professores Alexandra Fernandes e Pedro Batista pelo período agradável em Portugal.

Ao Dr. Rui Reis me conceder a oportunidade de conhecer a pesquisa no Hospital de Câncer de Barretos.

À Professora Sofia, pelas discussões, ensinamentos durante os últimos quatro anos.

Ao Professor Gilberto Úbida, que sempre disponibilizou seu laboratório para que eu pudesse utilizar o estereomicroscópio, pela confiança e prontidão em ajudar. Assim como o técnico do laboratório, Fernando Martins e ao aluno de doutorado Guilherme Brancini, que sempre me auxiliaram quando precisei.

À Professora Rogéria, pelos ensinamentos dirigidos desde os anos iniciais da graduação, pelas frutíferas discussões e auxílio com alguns experimentos.

À Professora Ana Maria de Oliveira, pelos experimentos em colaboração.

Ao Professor André Formiga, pela realização dos cálculos teóricos. 
À técnica Mayara pelo auxílio com os ensaios de reatividade, gentileza e profissionalismo ímpares.

Ao Professor Olagide, pela colaboração atual e ensinamentos concedidos quando eu ainda estava no Ensino Médio.

À Laena pelos dois anos de amizade, colaborações e ensinamentos ímpares na parte biológica e na leitura da tese. Devo bastante do que aprendi na área biológica a você e sou muito grata por tudo. Espero que você, em breve, esteja ministrando aulas e dividindo seu conhecimento com mais pessoas.

Aos amigos Renata Silveira e Leandro Máximo, pelas colaborações na execução de alguns trabalhos e amizades verdadeiras.

À Tássia Joi pelos quatro anos de amizade, ombro amigo nos momentos de desânimo e colaboração na leitura preliminar da tese.

À Loyanne Barbosa e à Juliana Uzuelli, por serem as primeiras pessoas a me apresentarem o universo biológico e me explicarem que nele as coisas não são tão simples, assim como pela amizade.

À Cássia Dias pelo carinho, companheirismo ímpar, momentos de alegria e tristeza compartilhados, auxílio no tratamento de dados, na execução de experimentos e por me permitir dividir o que aprendi com você.

À Renata Galvão pelo auxílio mesmo à distância, por deixar um arcabouço de conhecimento que serviu de alicerce ao que foi construído em minha tese de doutorado.

À Ana Paula Gaspari, pela amizade, pelas discussões químicas e colaboração nos experimentos envolvendo os ligantes bipiridil.

Ao Felipe Costa, pela colaboração e amizade.

À Laísa Negri, pela amizade, alegria, e constante presença me lembrando que o meu trabalho "estava lindo" e que "eu já tinha bastante resultados".

Aos demais colegas pelo companheirismo e amizade ao longo do doutorado: Natacha Cacita, Jorge Nasser, Fernando Postalli; Lílian Franco.

À Alexia pela amizade e auxílio no tratamento de alguns dos dados.

Ao técnico Clóvis Júnior, por não medir esforços para me auxiliar todas as vezes que precisei, seja com o uso de equipamentos ou com a confecção de esquemas, e pela amizade.

À Juliana Moraes pelo carinho, amizade, frutíferas discussões químicas e presença constante auxiliando no bom funcionamento do laboratório.

Aos técnicos Murilo Helder, José Carlos Tomaz, Vinicius Palaretti, Carlos, pela prontidão em realizar os experimentos quando precisei, principalmente, aqueles que precisei com urgência. 
À Sandra Viviana pela amizade e colaboração.

À Mariete Moreira pelo auxílio quando precisei, pelo constante apoio e amizade.

À Bruna Possato por dividir comigo os quatro anos de doutorado, contribuindo para interessantes discussões que fazem parte desta tese, pela amizade e por compartilhar os momentos de desânimo (não raros) durante a escrita final da tese.

À Anne, minha sobrinha, por seu sorriso diário, fonte de inspiração e mais recente presente que eu poderia receber!

À Karen Marques por me lembrar como ser tia é agradável e gratificante.

À Joyce, Neemias, Chrystoffer e João Paulo, por serem os melhores irmãos e "irmãos" que eu poderia ter, e, aos primeiros, por me presentearem com a Anne.

A todas às demais amizades que o Doutorado me proporcionou e a todos os quais, de alguma forma, contribuíram para a execução deste trabalho.

À Universidade de São Paulo, pelos 12 anos de aprendizado, oportunidade e realizações.

Ao CNPq, pelo suporte financeiro. 
$\mathcal{N} a ̃ o$ me pergunte o quê, ou o quanto, eu sei,

Pois a reposta seria INSIGSNIFICANTE!

Mas o correto $\dot{E}$ :

Pergunte-me o quê, ou o quanto, eu $\mathcal{N}$ Ão sei,

$E$ eu the mostrarei o Universo

Almejando ser descoberto

Que há dentro de uma única célula!

Tolos são aqueles que julgam SER insubstituíveis,

Mais tolos aqueles que pensam

ser sua contribuição científica única!

SÁBIO é aquele que mesmo detendo exímio conhecimento

Julga-se incapaz de compreender a razão pela qual ainda não fomos dizimados!

Jacqueline Querino Alves

Tudo que te vier à mão para fazer, faze-o conforme as tuas forças, porque na sepultura, para onde tu vais, não há obra, nem indústria, nem ciência, nem sabedoria alguma.

(Eclesiastes, 9; 10) 
Minhas - não só pioneiras - impressões...

Não obstante o fato de a escrita em $3^{\text {a }}$ pessoa, sob minhas lentes, sobressair-se no quesito elegância, não relutei à aspiração de escrever uma nota introdutória em $1^{\mathrm{a}}$ pessoa...

Admiradora que sou das ideias de Vygostsky e Bakhtin, não pude deixar de considerar que cada um de nós é único, exatamente porque somos moldados, construídos à medida em que vivenciamos experiências ao longo da vida, pois, o homem é um ser histórico e, portanto, a linguagem pelo mesmo construída, concebida, somente pode ser uma herança histórica da humanidade, mas, concomitantemente, marcada pelas "impressões digitais" de cada uma de suas vivências.

Ao longo da nossa vida, durante as mais diversas situações vivenciadas, passamos pelo processo de produzir e, ao mesmo tempo, sermos produzidos, no âmbito de uma via de mão dupla onde "a linguagem ultrapassa a função de mero instrumento por meio do qual o homem se expressa, e se torna resultado do processo que atua no e pelo próprio homem, constituindo e transformando-o como sujeito social" (Tárrega; Alves, 2013).

Assim, a linguagem é mais ampla e envolve muito além de um conjunto normativo. Por ela se traduzem sentimentos e emoções de maneira singular, os quais não são sempre planejados, mas são reflexos das próprias vivências do homem.

Desta forma, diante das concepções teóricas destes dois russos, eu afirmo, convictamente, que toda a linguagem e ideologia, por mim expostas nesta tese, são permeadas, possuem rastros das minhas vivências como também estudante de uma das ciências humanas...

E é com entusiasmo - ao mesmo tempo contido, para não me delongar nesta empreitada e não cansá-lo - que convido você, leitor, ao meu texto, para juntos refletirmos, tanto a compreensão química dos complexos sintetizados, quanto sua aplicação e seus resultados biológicos e, ao final, conhecer minhas conclusões sobre o tema proposto. 


\section{LISTA DE FIGURAS}

Figura 1: Esquema simplificado da angiogênese tumoral: alterações genéticas em uma célula conduz à evasão apoptótica e, consequentemente, a formação de massa tumoral (A); ao se tornarem insuficientes tanto o oxigênio, quanto os nutrientes, inicia-se o processo que viabiliza a angiogênese, sendo produzidos e liberados fatores de crescimento no entorno do tecido tumoral, os quais se ligam a receptores de crescimento nos vasos sanguíneos vizinhos ao tumor, então os pericitos se afastam, e ocorre a dilatação do vaso (B); ocorre a destruição da membrana basal por proteínas específicas denominadas proteases (C); por meio das fenestrações formadas, células do endotélio vascular são liberadas e proliferam em direção ao gradiente de fatores de crescimento (D); ocorre o início da formação dos novos vasos (E); há, por fim, a formação da estrutura basal do vasos, pelos pericitos (F) ..................................... 45

Figura 2: Receptor tirosina-quinase e ativação de sua via de sinalização ................................. 48

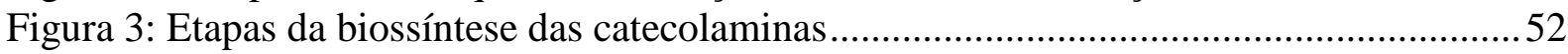

Figura 4: Representação dos quatro tipos de receptores........................................................54

Figura 5: Principais vias de degradação da noradrenalina e da adrenalina ...............................58

Figura 6: Principais vias de degradação da dopamina.......................................................59

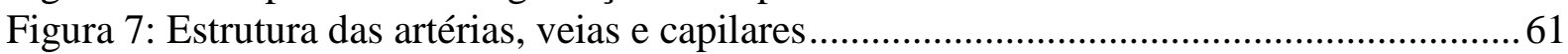

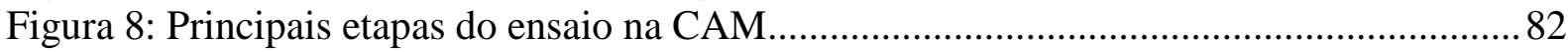

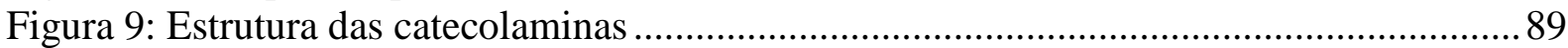

Figura 10: Mecanismo de reação para os complexos do tipo $\left[\mathrm{Ru}\left(\mathrm{NH}_{3}\right)_{4}\right.$ cat-R $\mathrm{Cl}$...................90

Figura 11: Soluções dos complexos $\left[\mathrm{Ru}\left(\mathrm{NH}_{3}\right)_{4}(\text { cat-R })\right]^{+}$, onde cat = isoproterenol, dopamina, noradrenalina, catecol e adrenalina, respectivamente

Figura 12: Cromatograma de $\left[\mathrm{Ru}\left(\mathrm{NH}_{3}\right)_{4}(\text { isoproterenol })\right]^{+}$; coluna $\mathrm{C}_{18} ; 15 \% \mathrm{MeOH}$ em PBS,

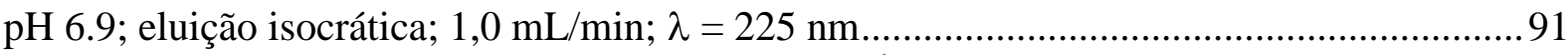

Figura 13: Cromatograma de $\left[\mathrm{Ru}\left(\mathrm{NH}_{3}\right)_{4} \text { (dopamina) }\right]^{+}$; columa $\mathrm{C}_{18} ; 15 \% \mathrm{MeOH}$ em PBS, pH 6.9; eluição isocrática; $1,0 \mathrm{~mL} / \mathrm{min} ; \lambda=225 \mathrm{~nm}$...................................................... 92

Figura 14: Cromatograma de $\mathrm{Ru}\left(\mathrm{NH}_{3}\right)_{4}$ (noradrenalina) $]^{+}$; columa $\mathrm{C}_{18} ; 15 \% \mathrm{MeOH}$ em PBS, pH 6.9; eluição isocrática; $1,0 \mathrm{~mL} / \mathrm{min} ; \lambda=225 \mathrm{~nm}$.......................................................... 92 Figura 15: Cromatograma de $\left[\mathrm{Ru}\left(\mathrm{NH}_{3}\right)_{4}(\mathrm{catecol})\right]^{+}$; columa $\mathrm{C}_{18} ; 15 \% \mathrm{MeOH}$ em PBS, pH

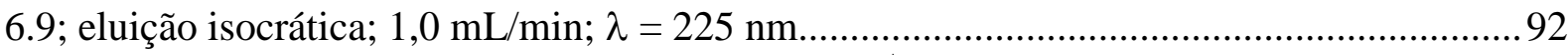
Figura 16: Cromatograma de $\left[\mathrm{Ru}\left(\mathrm{NH}_{3}\right)_{4} \text { (adrenalina) }\right]^{+}$; columa $\mathrm{C}_{18} ; 15 \% \mathrm{MeOH}$ em PBS,

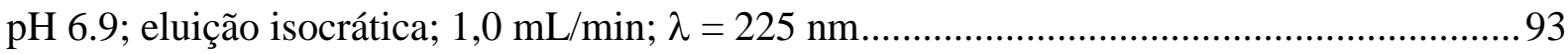

Figura 17: Estados de oxidação do(as) catecol(aminas) ........................................................94

Figura 18: Espectro eletrônico dos complexos $\left[\mathrm{Ru}\left(\mathrm{NH}_{3}\right)_{4}(\text { cat-R) }]^{+}\right.$, coletados em solução

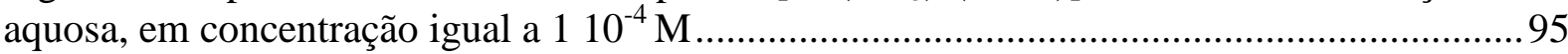

Figura 19: Correlação entre os valores de $\mathrm{pKa}_{1}$ dos ligantes a energia envolvida na transição eletrônica de TCLM

Figura 20: Correlação entre os valores de $\mathrm{pKa}_{2}$ dos ligantes a energia envolvida na transição eletrônica de TCLM.

Figura 21: Correlação entre os valores de $\mathrm{pKa}_{3}$ dos ligantes a energia envolvida na transição eletrônica de TCLM.

Figura 22: Voltamograma cíclico de $\left[\mathrm{Ru}\left(\mathrm{NH}_{3}\right)_{4}(\right.$ isoproterenol $\left.)\right]+, 1,010^{-3} \mathrm{M}$; tampão fosfato

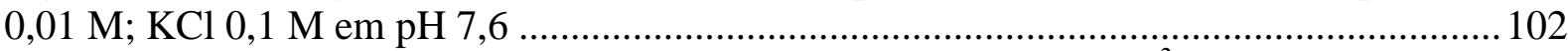

Figura 23: Voltamograma cíclico de $\left[\mathrm{Ru}\left(\mathrm{NH}_{3}\right)_{4}(\right.$ dopamina $\left.)\right]+, 1,010^{-3} \mathrm{M}$; tampão fosfato

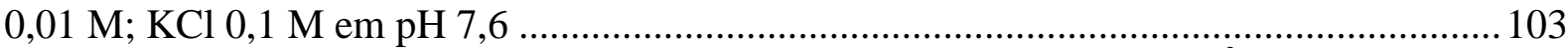

Figura 24: Voltamograma cíclico de $\left[\mathrm{Ru}\left(\mathrm{NH}_{3}\right)_{4}\right.$ (noradrenalina) $]+, 1,010^{-3} \mathrm{M}$; tampão fosfato

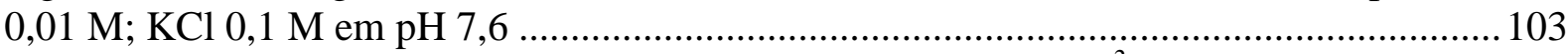

Figura 25: Voltamograma cíclico de $\left[\mathrm{Ru}\left(\mathrm{NH}_{3}\right)_{4}(\right.$ catecol $\left.)\right]+, 1,010^{-3} \mathrm{M}$; tampão fosfato 0,01

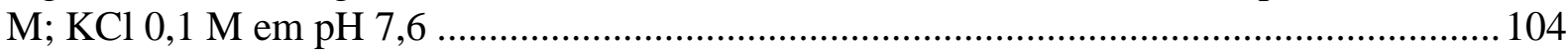


Figura 26: Voltamograma cíclico de $\left[\mathrm{Ru}\left(\mathrm{NH}_{3}\right)_{4}\right.$ (adrenalina) $]+, 1,010^{-3} \mathrm{M}$; tampão fosfato $0,01 \mathrm{M} ; \mathrm{KCl} 0,1 \mathrm{M} \mathrm{em} \mathrm{pH} \mathrm{7,6}$

Figura 27: Relação entre a corrente $\left(i_{\mathrm{pa}}\right)$ e a velocidade de varredura de potencial, para os processos centrados no ligante $\left(\mathrm{A}_{1 / 2}\right)$, para o complexo $\left[\mathrm{Ru}\left(\mathrm{NH}_{3}\right)_{4} \text { (adrenalina) }\right]^{+}$....

Figura 28: Relação entre a corrente $\left(i_{\mathrm{pa}}\right)$ e a velocidade de varredura de potencial, para os processos centrados no metal $\left(\mathrm{B}_{1 / 2}\right)$, para o complexo $\left[\mathrm{Ru}\left(\mathrm{NH}_{3}\right)_{4}(\text { adrenalina })\right]^{+}$................... 106 Figura 29: Mecanismo de formação de aminocromos.

Figura 30: Correlação entre os valores de $\mathrm{pKa}_{1}$ dos ligantes e $E_{1 / 2}$ do processo redox $\mathrm{A}_{1} / \mathrm{A}_{2}$

Figura 31: Correlação entre os valores de $\mathrm{pKa}_{3}$ dos ligantes e $E_{1 / 2}$ do processo redox $A_{1} / A_{2}$

Figura 32: Espectroeletroquímica de $\left[\mathrm{Ru}\left(\mathrm{NH}_{3}\right)_{4}(\text { isoproterenol })\right]^{+} 1,010^{-3} \mathrm{M}$; solução aquosa de $\mathrm{KCl} \mathrm{0,1} \mathrm{M;} \mathrm{pH} \mathrm{7,6;} \mathrm{potencial} \mathrm{aplicado} \mathrm{+0,50V} \mathrm{vs.} \mathrm{Ag} / \mathrm{AgCl}(\mathrm{A}) ; 0,0 \mathrm{~V}$ vs $\mathrm{Ag} / \mathrm{AgCl}(\mathrm{B})$; $0,80 \mathrm{~V}$ vs. $\mathrm{Ag} / \mathrm{AgCl}(\mathrm{C}) ; \mathrm{e} 0,0 \mathrm{~V}$ vs $\mathrm{Ag} / \mathrm{AgCl}$ (D)

Figura 33: Espectroeletroquímica de $\left[\mathrm{Ru}\left(\mathrm{NH}_{3}\right)_{4} \text { (noradrenalina) }\right]^{+} 1,010^{-3} \mathrm{M}$; solução aquosa de $\mathrm{KCl}$ 0,1 M; $\mathrm{pH} 7,6$; potencial aplicado +0,50V vs. $\mathrm{Ag} / \mathrm{AgCl}(\mathrm{A}) ; 0,0 \mathrm{~V}$ vs $\mathrm{Ag} / \mathrm{AgCl}(\mathrm{B}) ;-$ $0,80 \mathrm{~V}$ vs. $\mathrm{Ag} / \mathrm{AgCl}(\mathrm{C}) ;$ e $0,0 \mathrm{~V}$ vs $\mathrm{Ag} / \mathrm{AgCl}$ (D)

Figura 34: Espectroeletroquímica de $\left[\mathrm{Ru}\left(\mathrm{NH}_{3}\right)_{4}(\text { catecol })\right]^{+} 1,010^{-3} \mathrm{M}$; solução aquosa de $\mathrm{KCl}$ $0,1 \mathrm{M} ; \mathrm{pH}$ 7,6; potencial aplicado +0,50V vs. $\mathrm{Ag} / \mathrm{AgCl}(\mathrm{A}) ; 0,0 \mathrm{~V}$ vs $\mathrm{Ag} / \mathrm{AgCl}(\mathrm{B}) ;-0,80 \mathrm{~V}$ vs. $\mathrm{Ag} / \mathrm{AgCl}(\mathrm{C}) ; \mathrm{e} 0,0 \mathrm{~V}$ vs $\mathrm{Ag} / \mathrm{AgCl}$ (D)

Figura 35: Mecanismo redox para os processos eletroquímicos

Figura 36: Estabilidade do perfil espectroscópico de $\left[\mathrm{Ru}\left(\mathrm{NH}_{3}\right)_{4}(\text { isoproterenol })\right]^{+}(\mathrm{A})$;

$\left[\mathrm{Ru}\left(\mathrm{NH}_{3}\right)_{4}(\text { dopamina })\right]^{+}(\mathrm{B}) ;\left[\mathrm{Ru}\left(\mathrm{NH}_{3}\right)_{4}(\text { noradrenalina })\right]^{+}(\mathrm{C}) ;\left[\mathrm{Ru}\left(\mathrm{NH}_{3}\right)_{4}(\text { catecol })\right]^{+}(\mathrm{D}) \mathrm{e}$

$\left[\mathrm{Ru}\left(\mathrm{NH}_{3}\right)_{4} \text { (adrenalina) }\right]^{+}$; com irradiação em $\lambda=660 \mathrm{~nm}$; solução aquosa $10^{-4} \mathrm{M} ; 0-60$

minutos

Figura 37: Estabilidade do perfil espectroscópico de $\left[\mathrm{Ru}\left(\mathrm{NH}_{3}\right)_{4}(\text { isoproterenol })\right]^{+}(\mathrm{A})$;

$\left[\mathrm{Ru}\left(\mathrm{NH}_{3}\right)_{4}(\text { dopamina })\right]^{+}(\mathrm{B}) ;\left[\mathrm{Ru}\left(\mathrm{NH}_{3}\right)_{4}(\text { noradrenalina })\right]^{+}(\mathrm{C}) ; \quad\left[\mathrm{Ru}\left(\mathrm{NH}_{3}\right)_{4}(\mathrm{catecol})\right]^{+}(\mathrm{D}) \mathrm{e}$ $\left[\mathrm{Ru}\left(\mathrm{NH}_{3}\right)_{4} \text { (adrenalina) }\right]^{+}$; com irradiação em $\lambda=660 \mathrm{~nm}$; solução aquosa $10^{-4} \mathrm{M} ; 0-15$ minutos; sonda utilizada: DPBF....

Figura 38: Espectro de absorção na região do infravermelho (pastilhas de CsI): (A)

$\left[\mathrm{Ru}\left(\mathrm{NH}_{3}\right)_{4}\right.$ (isoproterenol) $] \mathrm{Cl},(\mathrm{B})\left[\mathrm{Ru}\left(\mathrm{NH}_{3}\right)_{4}\right.$ (dopamina) $] \mathrm{Cl},(\mathrm{C})\left[\mathrm{Ru}\left(\mathrm{NH}_{3}\right)_{4}\right.$ (noradrenalina) $] \mathrm{Cl}$,

(D) $\left[\mathrm{Ru}\left(\mathrm{NH}_{3}\right)_{4}\right.$ (catecol) $] \mathrm{Cl}$ e (E) $\left[\mathrm{Ru}\left(\mathrm{NH}_{3}\right)_{4}\right.$ (adrenalina) $] \mathrm{Cl}$

Figura 39: Espectro Raman dos complexos no estado sólido: (A)

$\left[\mathrm{Ru}\left(\mathrm{NH}_{3}\right)_{4}\right.$ (isoproterenol) $] \mathrm{Cl},(\mathrm{B})\left[\mathrm{Ru}\left(\mathrm{NH}_{3}\right)_{4}\right.$ (dopamina) $] \mathrm{Cl},(\mathrm{C})\left[\mathrm{Ru}\left(\mathrm{NH}_{3}\right)_{4}\right.$ (noradrenalina) $] \mathrm{Cl}$,

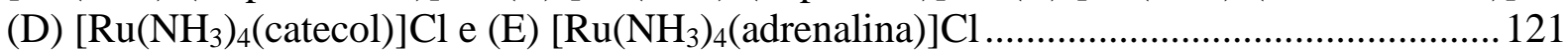

Figura 40: Esquema para mostrar o anel de cinco membros $\mathrm{RuOOC}_{1} \mathrm{C}_{2} \ldots \ldots \ldots \ldots \ldots \ldots \ldots \ldots \ldots . . . . . . . . . .122$

Figura 41: Correlação entre os valores de $\mathrm{pKa}_{1}$ dos ligantes e a energia da transição

vibracional $\mathrm{Ru}-\mathrm{O}$

Figura 42: Correlação entre os valores de $\mathrm{pKa}_{1}$ dos ligantes e a energia da transição

vibracional $\mathrm{RuOOC}_{1} \mathrm{C}_{2}$

Figura 43: Espectro de ${ }^{1} \mathrm{H}$ RMN do complexo $\left[\mathrm{Ru}\left(\mathrm{NH}_{3}\right)_{4} \text { (isoproterenol) }\right]^{+}$em solução de $\mathrm{D}_{2} \mathrm{O}$

$(0,1 \mathrm{M})$

Figura 44: Espectro de ${ }^{1} \mathrm{H}$ RMN do ligante isoproterenol em solução de $\mathrm{D}_{2} \mathrm{O}(0,1 \mathrm{M}) \ldots \ldots . .126$

Figura 45: Espectro de ${ }^{1} \mathrm{H}$ RMN do complexo $\left[\mathrm{Ru}\left(\mathrm{NH}_{3}\right)_{4} \text { (dopamina) }\right]^{+}$em solução de $\mathrm{D}_{2} \mathrm{O}$

$(0,1 \mathrm{M})$

Figura 46: Espectro de ${ }^{1} \mathrm{H}$ RMN do ligante dopamina em solução de $\mathrm{D}_{2} \mathrm{O}(0,1 \mathrm{M})$.

Figura 47: Espectro de ${ }^{1} \mathrm{H}$ RMN do complexo $\left[\mathrm{Ru}\left(\mathrm{NH}_{3}\right)_{4} \text { (noradrenalina) }\right]^{+}$em solução de $\mathrm{D}_{2} \mathrm{O}$ $(0,1 \mathrm{M})$

Figura 48: Espectro de ${ }^{1} \mathrm{H}$ RMN do ligante noradrenalina em solução de $\mathrm{D}_{2} \mathrm{O}(0,1 \mathrm{M}) \ldots \ldots . .130$ 
Figura 49: Espectro de $\mathrm{RMN}$ de ${ }^{1} \mathrm{H}$ do complexo $\left[\mathrm{Ru}\left(\mathrm{NH}_{3}\right)_{4} \text { (adrenalina) }\right]^{+}$em solução de $\mathrm{D}_{2} \mathrm{O}$

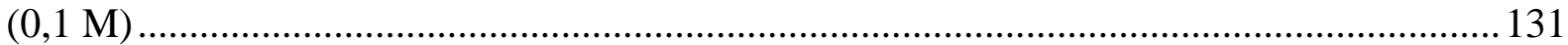

Figura 50: Espectro de ${ }^{1} \mathrm{H}$ RMN do ligante adrenalina em solução de $\mathrm{D}_{2} \mathrm{O}(0,1 \mathrm{M}) \ldots \ldots \ldots \ldots . . . .132$

Figura 51: Espectro de ${ }^{1} \mathrm{H}$ RMN do ligante catecol em solução de $\mathrm{D}_{2} \mathrm{O}(0,1 \mathrm{M}) \ldots \ldots \ldots \ldots \ldots . . . . . .133$

Figura 52: Representação dos orbitais de fronteira Kohn-Sham $\alpha-\mathrm{HOMO}$ (SOMO) e $\beta$ -

LUMO obtidos por PBE0/def2-TZVP para os complexos $\left[\mathrm{Ru}\left(\mathrm{NH}_{3}\right)_{4}(\mathrm{~L})\right]^{+}$, onde $\mathrm{L}=$ catecol

(A), dopamina (B), adrenalina (C), noradrenalina (D), e isoproterenol (E) .......................... 142

Figura 53: Densidades de spin obtidas por PBE0/def2-TZVP para os complexos

[Ru(NH3)4(L)]+ onde $\mathrm{L}=$ catecol (A), dopamina (B), adrenalina (C), noradrenalina (D), e

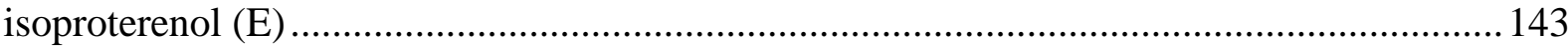

Figura 54: Espectros experimental e simulado para o complexo $\left[\mathrm{Ru}\left(\mathrm{NH}_{3}\right)_{4} \text { (adrenalina) }\right]^{+} \ldots 144$ Figura 55: Espectro de massas de $\left[\mathrm{Ru}\left(\mathrm{NH}_{3}\right)_{4} \text { (isoproterenol) }\right]^{+}$; modo positivo (ESI-MS); íon do complexo $\mathrm{m} / \mathrm{z} 379.11$

Figura 56: Espectro de massas de $\left[\mathrm{Ru}\left(\mathrm{NH}_{3}\right)_{4} \text { (dopamina) }\right]^{+}$; modo positivo (ESI-MS); ́́on do complexo $\mathrm{m} / \mathrm{z} 321.07$

Figura 57: Espectro de massas de $\left[\mathrm{Ru}\left(\mathrm{NH}_{3}\right)_{4} \text { (noradrenalina) }\right]^{+}$; modo positivo (ESI-MS); íon do complexo $\mathrm{m} / \mathrm{z} 337.07$.

Figura 58: Espectro de massas de $\left[\mathrm{Ru}\left(\mathrm{NH}_{3}\right)_{4}(\mathrm{catecol})\right]^{+}$; modo positivo (ESI-MS); íon do complexo $\mathrm{m} / \mathrm{z}, 278.03$

Figura 59: Espectro de massas de $\left[\mathrm{Ru}\left(\mathrm{NH}_{3}\right)_{4} \text { (adrenalina) }\right]^{+}$; modo positivo (ESI-MS); íon do complexo $\mathrm{m} / \mathrm{z} 351.08$

Figura 60: Efeito vasoconstritor induzido pelo complexo $\left[\mathrm{Ru}\left(\mathrm{NH}_{3}\right)_{4}(\text { noradrenalina })\right]^{+}(\mathrm{Ru}-$ NA) ou pelo ligante livre noradrenalina (NA) em aorta de ratos. Contração vascular induzida pelo complexo Ru-NA ou NA em presença (E+) ou ausência (E-) de endotélio vascular (A). Análise da área sob a curva de Ru-NA ou NA, em unidades arbitrárias (B). Dados são apresentados como média \pm E.P.M. * diferente de Ru-NA E+; \# diferente de NA E+. Oneway ANOVA, pós-teste de Newman-Keuls $(\mathrm{P}<0,05), \mathrm{n}=4-6$ 152

Figura 61: Efeito vasoconstritor induzido pelo complexo $\left[\mathrm{Ru}\left(\mathrm{NH}_{3}\right)_{4}(\text { adrenalina) }]^{+}(\mathrm{Ru}-\mathrm{Adr})\right.$ ou ligante livre adrenalina (Adr) em aorta de ratos. Contração vascular induzida pelo complexo Ru-Adr ou Adr em presença (E+) ou ausência (E-) de endotélio vascular (A). Análise da área sob a curva de Ru-Adr ou Adr, em unidades arbitrárias (B). Dados são apresentados como média \pm E.P.M. * diferente de Ru-Adr E+; \# diferente de Adr E+; ** diferente de Ru-Adr E-. One-way ANOVA, pós-teste de Newman-Keuls $(P<0,05), \mathrm{n}=6-7.153$ Figura 62: Efeito vasoconstritor induzido pelo complexo $\left[\mathrm{Ru}\left(\mathrm{NH}_{3}\right)_{4}(\text { dopamina })\right]^{+}$(Ru-Dopa) ou ligante livre dopamina em aorta de ratos. Contração vascular induzida pelo complexo RuDopa ou Dopamina em presença (E+) ou ausência (E-) de endotélio vascular (A), incubados com os antagonistas de receptores $\alpha$ não-seletivo Fenoxibenzamina $(0,3 \mu$ mol.L-1) e $\beta$ nãoseletivo Propranolol $(5 \mu \mathrm{mol} . \mathrm{L}-1)$ por 30 minutos. Análise de potência $\left(p \mathrm{D}_{2}\right)(\mathrm{B})$, efeito máximo (Emax) (C) e número de Hill (D) dos agonistas. Dados são apresentados como média \pm E.P.M. * diferente de Ru-Dopa E+; \# diferente de Dopamina E+; \#\# diferente de Ru-Dopa E-. One-way ANOVA, pós-teste de Newman-Keuls $(\mathrm{P}<0,05), \mathrm{n}=6-8$. 154 Figura 63: Relaxamento induzido pelo complexo $\left[\mathrm{Ru}\left(\mathrm{NH}_{3}\right)_{4} \text { (isoproterenol) }\right]^{+}(\mathrm{Ru}-\mathrm{Iso})$ ou ligante livre isoproterenol (Iso) em aorta de ratos. Relaxamento induzido pelo complexo RuIso ou Iso em presença (E+) ou ausência (E-) de endotélio vascular (A). Análise de potência $\left(p \mathrm{D}_{2}\right)(\mathrm{B})$, efeito máximo (Emax) $(\mathrm{C})$ e número de Hill (D) dos agonistas. Dados são apresentados como média \pm E.P.M. * diferente de Ru-Iso E+; ** diferente de Ru-Iso E-; \# diferente de Iso E+. One-way ANOVA, pós-teste de Newman-Keuls $(P<0,05), \mathrm{n}=5-6 \ldots \ldots . .155$ Figura 64: Ausência de efeito vascular do complexo $\left[\mathrm{Ru}\left(\mathrm{NH}_{3}\right)_{4}(\mathrm{catecol})\right]^{+}$(Ru-Catecol) (A), ligante livre Catecol (B) ou do complexo precursor $\left[\mathrm{RuCl}\left(\mathrm{NH}_{3}\right)_{5}\right]^{2+}(\mathrm{C})$, em presença $(\mathrm{E}+)$ ou 
ausência (E-) de endotélio vascular, em aorta de ratos. Dados são apresentados como média \pm E.P.M. One-way ANOVA, pós-teste de Newman-Keuls $(P>0,05), \mathrm{n}=4$

Figura 65: Mobilização de cálcio intracelular induzida pelos complexos de rutênio ou seus respectivos ligantes livres. A mobilização de cálcio intracelular foi avaliada, por citometria de fluxo, com a sonda fluorescente seletiva para cálcio intracelular Fluo-3AM ( $3 \mu \mathrm{mol} \mathrm{L}^{-1}$, para HUVEC, ou $10 \mu \mathrm{mol} \mathrm{L}^{-1}$, para A7R5, 30 minutos) em células HUVEC (A) ou A7R5 (B), na condição basal ou em presença de estímulo, por 10 minutos, com os complexos $\left[\mathrm{Ru}\left(\mathrm{NH}_{3}\right)_{4}(\text { noradrenalina })\right]^{+}(\mathrm{Ru}-\mathrm{NA})\left(300 \mu \mathrm{mol} \mathrm{L}{ }^{-1}\right)$; $\left[\mathrm{Ru}\left(\mathrm{NH}_{3}\right)_{4}(\text { adrenalina })\right]^{+}(\mathrm{Ru}-\mathrm{Adr})(300$ $\left.\mu \mathrm{mol} \mathrm{L}{ }^{-1}\right) ;\left[\mathrm{Ru}\left(\mathrm{NH}_{3}\right)_{4} \text { (dopamina) }\right]^{+}$(Ru-Dopa) $\left(100 \mu \mathrm{mol} \mathrm{L}^{-1}\right) ;\left[\mathrm{Ru}\left(\mathrm{NH}_{3}\right)_{4}(\text { isoproterenol })\right]^{+}$ (Ru-Iso) $\left(300 \mu \mathrm{mol} \mathrm{L}^{-1}\right)$; [Ru(NH$)_{4}$ (catecol) $]^{+}$(Ru-Catecol) $(300 \mu \mathrm{mol} . \mathrm{L}-1)$; ou respectivos ligantes livres: noradrenalina (NA) $\left(1 \mu \mathrm{mol} \mathrm{L}^{-1}\right)$; adrenalina (Adr) $\left(10 \mu \mathrm{mol} \mathrm{L}^{-1}\right)$; dopamina (Dopa) $\left(10 \mu \mathrm{mol} \mathrm{L}^{-1}\right)$; isoproterenol (Iso) $\left(100 \mu \mathrm{mol} \mathrm{L}^{-1}\right)$; Catecol $\left(10 \mu \mathrm{mol} \mathrm{L}^{-1}\right)$. O ionóforo de cálcio A23187 $\left(10 \mu \mathrm{mol} \mathrm{L}^{-1}\right)$ foi usado como controle positivo de marcação fluorescente. Dados são apresentados como media \pm E.P.M. * diferente de basal; \# diferente do respectivo complexo rutênio-catecolamina; ** diferente do respectivo ligante livre. One-way ANOVA, com pós-teste de Newman-Keuls $(\mathrm{P}<0,05), \mathrm{n}=4$.

Figura 66: Estruturas extraembrionárias de ovo fertilizado

Figura 67: Curvas de sobrevivência dos embriões, referentes aos ensaios na CAM, para os ligantes livres (A) e para os complexos metálicos (B). $\mathrm{n} \geq 3$.

Figura 68: Efeitos angiogênicos induzidos por complexos ou ligantes:

$\left[\mathrm{Ru}\left(\mathrm{NH}_{3}\right)_{4} \text { (noradrenalina) }\right]^{+}(\mathrm{Ru}-\mathrm{NA})$, noradrenalina $(\mathrm{NA}),\left[\mathrm{Ru}\left(\mathrm{NH}_{3}\right)_{4}(\text { adrenalina) }]^{+}(\mathrm{Ru}-\mathrm{Adr})\right.$, adrenalina (Adr), $\left[\mathrm{Ru}\left(\mathrm{NH}_{3}\right)_{4}(\text { isoproterenol) }]^{+}\right.$( $\left.\mathrm{Ru}-\mathrm{Iso}\right)$, isoproterenol (Iso),

$\left[\mathrm{Ru}\left(\mathrm{NH}_{3}\right)_{4} \text { (dopamina) }\right]^{+}$(Ru-Dopa), dopamina (Dopa), $\left[\mathrm{Ru}\left(\mathrm{NH}_{3}\right)_{4}(\text { catecol) }]^{+}\right.$(Ru-Cat), ou o veículo (PBS), na área total de vasos (A) e na lacunaridade (B), na CAM. Os tratamentos aplicados foram na dose de $50 \mathrm{nmol}$ e a área total de vasos (A) e a lacunaridade (B) analisadas $24 \mathrm{~h}$ após os tratamentos. Os dados são apresentados como media \pm E.P.M. " diferente do controle (PBS); " diferente da respectiva catecolamina, n=3-6; One-way ANOVA, NewmanKeuls $(P<0.05)$

Figura 69: Fotografias representativas da modulação da angiogênese induzida por complexos ou ligantes: $\left[\mathrm{Ru}\left(\mathrm{NH}_{3}\right)_{4}(\text { noradrenalina) }]^{+}(\mathrm{Ru}-\mathrm{NA})\right.$, noradrenalina (NA),

$\left[\mathrm{Ru}\left(\mathrm{NH}_{3}\right)_{4} \text { (adrenalina) }\right]^{+}(\mathrm{Ru}-\mathrm{Adr})$, adrenalina (Adr), $\left[\mathrm{Ru}\left(\mathrm{NH}_{3}\right)_{4}(\text { isoproterenol) }]^{+}(\mathrm{Ru}-\mathrm{Iso})\right.$, isoproterenol (Iso), $\left[\mathrm{Ru}\left(\mathrm{NH}_{3}\right)_{4}\right.$ (dopamina) ${ }^{+}$(Ru-Dopa), dopamina (Dopa),

$\left[\mathrm{Ru}\left(\mathrm{NH}_{3}\right)_{4}(\mathrm{catecol})\right]^{+}$(Ru-Cat), ou o veículo (PBS), 24h após os tratamentos. Olympus SZ2-

LHAD stereomicroscopy, $8 \mathrm{x}$

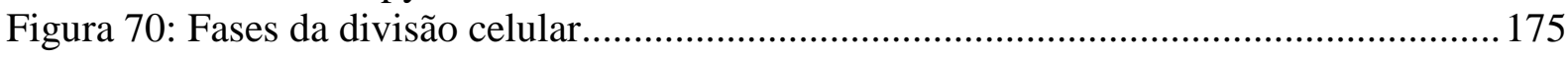

Figura 71: Análise do ciclo celular em células HUVEC após tratamento com

$\left[\mathrm{Ru}\left(\mathrm{NH}_{3}\right)_{4} \text { (noradrenalina) }\right]^{+}(\mathrm{Ru}-\mathrm{NA})$ ou noradrenalina (NA). O ciclo celular diploide foi avaliado em células HUVEC pela intensidade de fluorescência emitida pelo Iodeto de Propídio (IP, $100 \mathrm{mg} \mathrm{mL}^{-1}$ ), por citometria de fluxo, após veículo (PBS) ou tratamento com Ru-NA ou NA $\left(300 \mu \mathrm{mol} \mathrm{L}{ }^{-1}\right)$, por $24 \mathrm{~h}$ e $48 \mathrm{~h}$. As fases do ciclo celular analisadas foram: fase G0/G1; fase S; fase G2/M. Dados são apresentados como média \pm E.P.M. * diferente de veículo 24h; \# diferente de NA 24h ou 48h; ** diferente de veículo 48h. One-way ANOVA, pós-teste de Newman-Keuls $(\mathrm{P}<0,05), \mathrm{n}=3-4$

Figura 72: Recuperação da lesão induzida por complexos e ligantes:

$\left[\mathrm{Ru}\left(\mathrm{NH}_{3}\right)_{4} \text { (noradrenalina) }\right]^{+}(\mathrm{Ru}-\mathrm{NA})$, noradrenalina $(\mathrm{NA}),\left[\mathrm{Ru}\left(\mathrm{NH}_{3}\right)_{4}(\text { adrenalina })\right]^{+}(\mathrm{Ru}-$

Adr), adrenalina (Adr), $\left[\mathrm{Ru}\left(\mathrm{NH}_{3}\right)_{4}(\text { isoproterenol) }]^{+}\right.$(Ru-Iso), isoproterenol (Iso),

$\left[\mathrm{Ru}\left(\mathrm{NH}_{3}\right)_{4}(\mathrm{catecol})\right]^{+}$(Ru-Cat), catecol ou dopamina, em células da linhagem fibroblasto

humano. Os resultados são referentes à recuperação $24 \mathrm{~h}$ após os tratamentos em concentração igual a $200 \mu \mathrm{mol} \mathrm{L}{ }^{-1}$. Controle representa células não tratadas. Dados são apresentados como 
média \pm erro padrão da média (EPM) de pelo menos 2 amostras, com no mínimo duas replicatas. * diferente de Controle; \# diferente da respectiva catecolamina

Figura 73: Recuperação da lesão induzida por complexos e ligantes:

$\left[\mathrm{Ru}\left(\mathrm{NH}_{3}\right)_{4} \text { (noradrenalina) }\right]^{+}(\mathrm{Ru}-\mathrm{NA})$, noradrenalina (NA), $\left[\mathrm{Ru}\left(\mathrm{NH}_{3}\right)_{4}(\text { adrenalina) }]^{+}(\mathrm{Ru}-\right.$

Adr), ou adrenalina (Adr), em células HUVEC. Os resultados são referentes à recuperação

$24 \mathrm{~h}$ após os tratamentos em concentração igual a $200 \mu \mathrm{mol} \mathrm{L} \mathrm{L}^{-1}$. Controle representa células não tratadas. Dados são apresentados como média +/- erro padrão da média (EPM) de pelo menos 3 amostras diferentes (n). * diferente de Controle; \# diferente da respectiva catecolamina, n=3-4; One-way ANOVA com pós-teste de Newman-Keuls $(\mathrm{P}<0,05)$

Figura 74: Fotomicrografias representativas do ensaio de recuperação da lesão induzida por complexos e ligantes: $\left[\mathrm{Ru}\left(\mathrm{NH}_{3}\right)_{4} \text { (noradrenalina) }\right]^{+}$(Ru-NA), noradrenalina (NA),

$\left[\mathrm{Ru}\left(\mathrm{NH}_{3}\right)_{4} \text { (adrenalina) }\right]^{+}$( $\left.\mathrm{Ru}-\mathrm{Adr}\right)$, ou adrenalina (Adr), em células HUVEC. Os resultados são referentes à recuperação $24 \mathrm{~h}$ após os tratamentos em concentração igual a $200 \mu \mathrm{mol} \mathrm{L} \mathrm{L}^{-1}$. Controle representa células não tratadas

Figura 75: Recuperação da lesão induzida por complexos e ligantes:

$\left[\mathrm{Ru}\left(\mathrm{NH}_{3}\right)_{4} \text { (noradrenalina) }\right]^{+}(\mathrm{Ru}-\mathrm{NA})$, noradrenalina $(\mathrm{NA}),\left[\mathrm{Ru}\left(\mathrm{NH}_{3}\right)_{4}(\text { adrenalina })\right]^{+}(\mathrm{Ru}-$ $\mathrm{Adr}$ ), adrenalina (Adr), $\mathrm{Ru}\left(\mathrm{NH}_{3}\right)_{4}$ (isoproterenol) $]^{+}$( $\mathrm{Ru}$-Iso), isoproterenol (Iso), $\left.\mathrm{Ru}\left(\mathrm{NH}_{3}\right)_{4}(\mathrm{catecol})\right]^{+}$(Ru-Cat), ou catecol, em células FR37-CMT. Os resultados são referentes à recuperação $24 \mathrm{~h}$ após os tratamentos em concentração igual a $200 \mu \mathrm{mol} \mathrm{L}{ }^{-1}$. Controle representa células não tratadas. Dados são apresentados como média +/- erro padrão da média (EPM) de pelo menos 3 amostras diferentes (n). * diferente de Controle; \# diferente da respectiva catecolamina, n=3-4; One-way ANOVA com pós-teste de Newman-Keuls $(\mathrm{P}<0,05)$

Figura 76: Recuperação da lesão induzida por complexos e ligantes:

$\left[\mathrm{Ru}\left(\mathrm{NH}_{3}\right)_{4}(\text { noradrenalina })\right]^{+}(\mathrm{Ru}-\mathrm{NA})$, noradrenalina (NA), $\left[\mathrm{Ru}\left(\mathrm{NH}_{3}\right)_{4}(\text { adrenalina) }]^{+}(\mathrm{Ru}-\right.$ $\mathrm{Adr}$ ), adrenalina (Adr), $\mathrm{Ru}\left(\mathrm{NH}_{3}\right)_{4}(\text { isoproterenol) }]^{+}$( $\mathrm{Ru}$-Iso), isoproterenol (Iso),

$\left[\mathrm{Ru}\left(\mathrm{NH}_{3}\right)_{4} \text { (dopamina) }\right]^{+}$(Ru-Dopa), dopamina (dopamina), $\mathrm{Ru}\left(\mathrm{NH}_{3}\right)_{4}(\text { catecol) }]^{+}$(Ru-Cat), ou catecol, em células SF-188. Os resultados são referentes à recuperação 24 h após os tratamentos em concentração igual a $200 \mu \mathrm{mol} \mathrm{L}{ }^{-1}$. Controle representa células não tratadas. Dados são apresentados como média +/- erro padrão da média (EPM) de pelo menos 3 amostras diferentes (n). * diferente de Controle; \# diferente da respectiva catecolamina, $\mathrm{n}=3$ 4; One-way ANOVA com pós-teste de Newman-Keuls $(\mathrm{P}<0,05)$

Figura 77: Fotomicrografias representativas do ensaio de recuperação da lesão induzida por complexos e ligantes: $\left[\mathrm{Ru}\left(\mathrm{NH}_{3}\right)_{4}(\text { noradrenalina) }]^{+}\right.$(Ru-NA), noradrenalina (NA), $\left[\mathrm{Ru}\left(\mathrm{NH}_{3}\right)_{4} \text { (adrenalina) }\right]^{+}$(Ru-Adr), adrenalina (Adr), $\mathrm{Ru}\left(\mathrm{NH}_{3}\right)_{4}$ (isoproterenol)] ${ }^{+}$( $\mathrm{Ru}$-Iso), isoproterenol (Iso), $\left[\mathrm{Ru}\left(\mathrm{NH}_{3}\right)_{4}\right.$ (dopamina) ${ }^{+}$(Ru-Dopa), dopamina (dopamina), $\left.\mathrm{Ru}\left(\mathrm{NH}_{3}\right)_{4}(\mathrm{catecol})\right]^{+}(\mathrm{Ru}-\mathrm{Cat})$, ou catecol, em células SF-188. Os resultados são referentes à recuperação $24 \mathrm{~h}$ após os tratamentos em concentração igual a $200 \mu \mathrm{mol} \mathrm{L} \mathrm{L}^{-1}$. Controle representa células não tratadas

Figura 78: Análise da viabilidade celular de B16F10 após tratamento com complexos ou ligantes livres. Células B16F10 foram tratadas por 24h com Ru-NA ou NA (A); Ru-Adr ou Adr (B); Ru-Dopa ou Dopamina (C); Ru-Iso ou Iso (D); Ru-Catecol ou Catecol (E) em diferentes concentrações (50 a $500 \mu \mathrm{mol} \mathrm{L}{ }^{-1}$ ) ou situação controle (em ausência de tratamento). Dados são apresentados como \% de média \pm E.P.M. do CO. * diferente de CO; \# diferente da respectiva catecolamina na mesma concentração de estudo. One-way ANOVA, pós-teste de Newman-Keuls $(P<0,05), \mathrm{n}=3-4$.

Figura 79: Análise da viabilidade celular de B16F10 após tratamento com complexos ou ligantes livres. Células B16F10 foram tratadas por 48h com Ru-NA ou NA (A); Ru-Adr ou Adr (B); Ru-Dopa ou Dopamina (C); Ru-Iso ou Iso (D); Ru-Catecol ou Catecol (E) em diferentes concentrações (50 a $500 \mu$ mol. $\mathrm{L}^{-1}$ ) ou situação controle (em ausência de 
tratamento). Dados são apresentados como \% de média \pm E.P.M. do CO. * diferente de Controle; \# diferente da respectiva catecolamina na mesma concentração de estudo; a diferente de $100 \mu \mathrm{M}$ Ru-Cat; b Diferente de $10 \mu \mathrm{M}$ Ru-Cat. One-way ANOVA, pós-teste de Newman-Keuls $(P<0,05), \mathrm{n}=3$. . .

Figura 80: Titulação do complexo $\left[\mathrm{Ru}\left(\mathrm{NH}_{3}\right)_{4} \text { (isoproterenol) }\right]^{+}$, a $25^{\circ} \mathrm{C}, \operatorname{com} f s$-DNA, acompanhada por espectroscopia na região do UV-vis....

Figura 81: Titulação do complexo $\left[\mathrm{Ru}\left(\mathrm{NH}_{3}\right)_{4}(\text { dopamina })\right]^{+}$, a $25^{\circ} \mathrm{C}, \operatorname{com} f s$-DNA,

acompanhada por espectroscopia na região do UV-vis.

Figura 82: Titulação do complexo $\left[\mathrm{Ru}\left(\mathrm{NH}_{3}\right)_{4} \text { (noradrenalina) }\right]^{+}$, a $25^{\circ} \mathrm{C}, \operatorname{com} f s$-DNA, acompanhada por espectroscopia na região do UV-vis....

Figura 83: Titulação do complexo $\left[\mathrm{Ru}\left(\mathrm{NH}_{3}\right)_{4}(\text { catecol })\right]^{+}$, a $25^{\circ} \mathrm{C}$, com $f s$-DNA, acompanhada

por espectroscopia na região do UV-vis....

Figura 84: Titulação do complexo $\left[\mathrm{Ru}\left(\mathrm{NH}_{3}\right)_{4}(\text { adrenalina })\right]^{+}$, a $25^{\circ} \mathrm{C}, \operatorname{com} f s$-DNA, acompanhada por espectroscopia na região do UV-vis....

Figura 85: Espectro de absorção do $f s$-DNA na maior concentração utilizada nos ensaios

reportados $\left(309 \mu \mathrm{mol} \mathrm{L}{ }^{-1}\right)$

Figura 86: Espectros de emissão do sistema BET-DNA, na presença de diferentes concentrações de $\left[\mathrm{Ru}\left(\mathrm{NH}_{3}\right)_{4}(\text { isoproterenol })\right]^{+}$

Figura 87: Espectros de emissão do sistema BET-DNA, na presença de diferentes concentrações de $\left[\mathrm{Ru}\left(\mathrm{NH}_{3}\right)_{4} \text { (dopamina) }\right]^{+}$com a regressão linear da equação de Stern-Volmer

Figura 88: Espectros de emissão do sistema BET-DNA, na presença de diferentes concentrações de $\left[\mathrm{Ru}\left(\mathrm{NH}_{3}\right)_{4}(\text { noradrenalina })\right]^{+}$com a regressão linear da equação de SternVolmer.

Figura 89: Espectros de emissão do sistema BET-DNA, na presença de diferentes concentrações de $\left[\mathrm{Ru}\left(\mathrm{NH}_{3}\right)_{4}(\text { catecol })\right]^{+}$.....

Figura 90: Espectros de emissão do sistema BET-DNA, na presença de diferentes concentrações de $\left[\mathrm{Ru}\left(\mathrm{NH}_{3}\right)_{4} \text { (adrenalina) }\right]^{+}$

Figura 91: Espectros de emissão do sistema BET-DNA, na presença de diferentes concentrações de Cisplatina.

Figura 92: Espectros de emissão de fluorescência da HSA, na presença de diferentes concentrações de $\left[\mathrm{Ru}\left(\mathrm{NH}_{3}\right)_{4}(\text { isoproterenol })\right]^{+}$, a $25^{\circ} \mathrm{C}$. Gráfico de Stern-Volmer inserido .. 205 Figura 93: Gráfico da equação $\log \left[\left(\mathrm{I}_{0}-\mathrm{I}\right) / \mathrm{I}\right]=\log \mathrm{K}_{\mathrm{b}}+$ nlog[Q] referente à interação entre HSA e o complexo $\left[\mathrm{Ru}\left(\mathrm{NH}_{3}\right)_{4}(\text { isoproterenol) }]^{+}\right.$, a $25^{\circ} \mathrm{C}(\mathrm{A})$ e Gráfico de Van't Hoff referente à interação entre HSA e o complexo $\left[\mathrm{Ru}\left(\mathrm{NH}_{3}\right)_{4}(\text { isoproterenol })\right]^{+}(\mathrm{B})$...................................205

Figura 94: Espectros de emissão de fluorescência da HSA, na presença de diferentes concentrações de $\left[\mathrm{Ru}\left(\mathrm{NH}_{3}\right)_{4}(\text { dopamina })\right]^{+}$, a $25^{\circ} \mathrm{C}$. Gráfico de Stern-Volmer inserido ........206 Figura 95: Gráfico da equação $\log \left[\left(\mathrm{I}_{0}-\mathrm{I}\right) / \mathrm{I}\right]=\log \mathrm{K}_{\mathrm{b}}+$ nlog[Q] referente à interação entre HSA e o complexo $\left[\mathrm{Ru}\left(\mathrm{NH}_{3}\right)_{4}(\text { dopamina })\right]^{+}$, a $25^{\circ} \mathrm{C}(\mathrm{A})$ e Gráfico de Van't Hoff referente à interação entre HSA e o complexo $\left[\mathrm{Ru}\left(\mathrm{NH}_{3}\right)_{4} \text { (dopamina) }\right]^{+}$(B)

Figura 96: Espectros de emissão de fluorescência da HSA, na presença de diferentes concentrações de $\left[\mathrm{Ru}\left(\mathrm{NH}_{3}\right)_{4}(\text { noradrenalina })\right]^{+}$, a $25^{\circ} \mathrm{C}$. Gráfico de Stern-Volmer inserido.. 207 Figura 97: Gráfico da equação $\log \left[\left(\mathrm{I}_{0}-\mathrm{I}\right) / \mathrm{I}\right]=\log \mathrm{K}_{\mathrm{b}}+\mathrm{n} \log [\mathrm{Q}]$ referente à interação entre HSA e o complexo $\left[\mathrm{Ru}\left(\mathrm{NH}_{3}\right)_{4} \text { (noradrenalina) }\right]^{+}$, a $25^{\circ} \mathrm{C}(\mathrm{A})$ e Gráfico de Van't Hoff referente à interação entre HSA e o complexo $\left[\mathrm{Ru}\left(\mathrm{NH}_{3}\right)_{4}(\text { noradrenalina })\right]^{+}(\mathrm{B})$.................................207

Figura 98: Espectros de emissão de fluorescência da HSA, na presença de diferentes concentrações de $\left[\mathrm{Ru}\left(\mathrm{NH}_{3}\right)_{4}(\text { catecol })\right]^{+}$, a $25^{\circ} \mathrm{C}$. Gráfico de Stern-Volmer inserido ..... 208 Figura 99: Gráfico da equação $\log \left[\left(\mathrm{I}_{0}-\mathrm{I}\right) / \mathrm{I}\right]=\log \mathrm{K}_{\mathrm{b}}+$ nlog[Q] referente à interação entre HSA e o complexo $\left[\mathrm{Ru}\left(\mathrm{NH}_{3}\right)_{4}(\mathrm{catecol})\right]^{+}$, a $25^{\circ} \mathrm{C}(\mathrm{A})$ e Gráfico de Van't Hoff referente à interação entre HSA e o complexo $\left[\mathrm{Ru}\left(\mathrm{NH}_{3}\right)_{4}(\mathrm{catecol})\right]^{+}(\mathrm{B})$. 
Figura 100: Espectros de emissão de fluorescência da HSA, na presença de diferentes concentrações de $\left[\mathrm{Ru}\left(\mathrm{NH}_{3}\right)_{4} \text { (adrenalina) }\right]^{+}$, a $25^{\circ}$ C. Gráfico de Stern-Volmer inserido 209 Figura 101: Gráfico da equação $\log \left[\left(\mathrm{I}_{0}-\mathrm{I}\right) / \mathrm{I}\right]=\log \mathrm{K}_{\mathrm{b}}+\mathrm{n} \log [\mathrm{Q}]$ referente à interação entre HSA e o complexo $\left[\mathrm{Ru}\left(\mathrm{NH}_{3}\right)_{4} \text { (adrenalina) }\right]^{+}$, a $25^{\circ} \mathrm{C}(\mathrm{A})$ e Gráfico de Van't Hoff referente à interação entre HSA e o complexo $\left[\mathrm{Ru}\left(\mathrm{NH}_{3}\right)_{4}(\text { adrenaliina })\right]^{+}$(B) ........................................2. 209 Figura 102: Rota sintética da obtenção dos complexos. 216 Figura 103: Espectro eletrônico dos complexos $\left[\mathrm{Ru}(\mathrm{bpy})_{2}(\mathrm{~L})\right]^{\mathrm{n}+}$, onde $\mathrm{L}=\mathrm{Cl}_{2}(\mathrm{~A})$ (complexo precursor - espectro qualitativo); isoproterenol 1,8 $10^{-4} \mathrm{M}(\mathrm{B})$; dopamina $910^{-5} \mathrm{M}(\mathrm{C})$; noradrenalina $110^{-5} \mathrm{M}(\mathrm{D})$; catecol $910^{-5} \mathrm{M}(\mathrm{E})$; adrenalina $610^{-5} \mathrm{M}(\mathrm{f})$, em metanol .218 Figura 104: Correlação entre os valores de $\mathrm{pKa}_{1}$ dos ligantes a energia envolvida na transição eletrônica de TCML

Figura 105: Espectro de absorção na região do infravermelho (pastilhas de CsI): (A) $\left[\mathrm{Ru}(\mathrm{bpy})_{2}\right.$ (isoproterenol) $] \mathrm{Cl},(\mathrm{B})\left[\mathrm{Ru}(\text { bpy })_{2}\right.$ (dopamina) $] \mathrm{Cl},(\mathrm{C})\left[\mathrm{Ru}(\mathrm{bpy})_{2}\right.$ (noradrenalina) $] \mathrm{Cl}$, (D) $\left[\mathrm{Ru}(\mathrm{bpy})_{2}\right.$ (catecol) $] \mathrm{Cl}$ e (E) $\left[\mathrm{Ru}(\mathrm{bpy})_{2}\right.$ (adrenalina) $] \mathrm{Cl}$

Figura 106: Análise da viabilidade celular de B16F10 após tratamento com complexos ou ligantes livres. Células B16F10 foram tratadas por 48h com Ru-NA, NA ou Ru(bpy) ${ }_{2} \mathrm{NA}(\mathrm{A})$; Ru-Adr, Adr ou Ru(bpy) ${ }_{2} \mathrm{~A}$ (B); Ru-Dopa, Dopamina, ou Ru(bpy) ${ }_{2}$ Dopa (C); Ru-Iso, Iso, ou $\mathrm{Ru}(\mathrm{bpy})_{2}$ Iso (D); Ru-Catecol, Catecol, ou Ru(bpy) ${ }_{2} \mathrm{Cat}$ (E), em diferentes concentrações (10 a $200 \mu \mathrm{mol} . \mathrm{L}^{-1}$ ) ou situação controle ( em ausência de tratamento). Dados são apresentados como \% de média \pm E.P.M. do Controle. * diferente de Controle; \# diferente da respectiva catecolamina na mesma concentração. One-way ANOVA, pós-teste de Newman-Keuls $(P<0,05), \mathrm{n}=3$.

Figura 107: Titulação do complexo $\left[\mathrm{Ru}(\text { bpy })_{2} \text { (isoproterenol) }\right]^{+}$, a $25^{\circ} \mathrm{C}, \operatorname{com} f s$-DNA, acompanhada por espectroscopia na região do UV-vis....

Figura 108: Titulação do complexo [Ru(bpy) (dopamina) $^{+}$, a $25^{\circ} \mathrm{C}, \operatorname{com} f s$-DNA, acompanhada por espectroscopia na região do UV-vis.

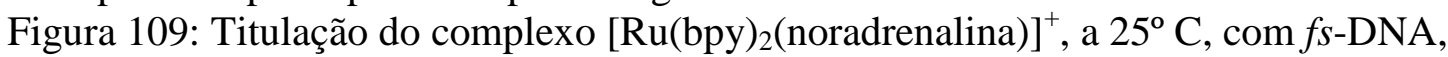
acompanhada por espectroscopia na região do UV-vis.

Figura 110: Titulação do complexo $\left[\mathrm{Ru}(\mathrm{bpy})_{2}(\mathrm{catecol})\right]^{+}$, a $25^{\circ} \mathrm{C}, \operatorname{com} f s$-DNA, acompanhada por espectroscopia na região do UV-vis

Figura 111: Titulação do complexo [Ru(bpy) ${ }_{2}$ (adrenalina) $]^{+}$, a $25^{\circ} \mathrm{C}, \operatorname{com} f s$-DNA, acompanhada por espectroscopia na região do UV-vis.

Figura 112: Espectros de emissão do sistema BET-DNA, na presença de diferentes concentrações de $\left[\mathrm{Ru}(\mathrm{bpy})_{2} \text { (isoproterenol) }\right]^{+}$....

Figura 113: Espectros de emissão do sistema BET-DNA, na presença de diferentes concentrações de $\left[\mathrm{Ru}(\mathrm{bpy})_{2}(\text { dopamina })\right]^{+}$

Figura 114: Espectros de emissão do sistema BET-DNA, na presença de diferentes concentrações de $\left[\mathrm{Ru}(\mathrm{bpy})_{2} \text { (noradrenalina) }\right]^{+}$

Figura 115: Espectros de emissão do sistema BET-DNA, na presença de diferentes concentrações de $\left[\mathrm{Ru}(\mathrm{bpy})_{2}(\mathrm{catecol})\right]^{+}$

Figura 116: Espectros de emissão do sistema BET-DNA, na presença de diferentes concentrações de $\left[\mathrm{Ru}(\mathrm{bpy})_{2} \text { (adrenalina) }\right]^{+}$.....

Figura 117: Espectros de emissão de fluorescência da HSA, na presença de diferentes concentrações de $\left[\mathrm{Ru}(\mathrm{bpy})_{2} \text { (isoproterenol) }\right]^{+}$, a $25^{\circ} \mathrm{C}$. Gráfico de Stern-Volmer inserido.... 238 Figura 118: Gráfico da equação $\log \left[\left(\mathrm{I}_{0}-\mathrm{I}\right) / \mathrm{I}\right]=\log \mathrm{K}_{\mathrm{b}}+$ nlog[Q] referente à interação entre HSA e o complexo [Ru(bpy) ${ }_{2}$ (isoproterenol) $]^{+}$, a $25^{\circ} \mathrm{C}$ (A) e Gráfico de Van’t Hoff referente à interação entre HSA e o complexo $\left[\mathrm{Ru}(\mathrm{bpy})_{2}(\text { isoproterenol) }]^{+}(\mathrm{B})\right.$.... 238 Figura 119: Espectros de emissão de fluorescência da HSA, na presença de diferentes concentrações de $\left[\mathrm{Ru}(\mathrm{bpy})_{2} \text { (dopamina) }\right]^{+}$, a $25^{\circ} \mathrm{C}$. Gráfico de Stern-Volmer inserido 
Figura 120: Gráfico da equação $\log \left[\left(\mathrm{I}_{0}-\mathrm{I}\right) / \mathrm{I}\right]=\log \mathrm{K}_{\mathrm{b}}+$ nlog[Q] referente à interação entre HSA e o complexo $\left[\mathrm{Ru}(\text { bpy })_{2}(\text { dopamina })\right]^{+}$, a $25^{\circ} \mathrm{C}(\mathrm{A})$ e Gráfico de Van't Hoff referente à interação entre HSA e o complexo $\left[\mathrm{Ru}(\mathrm{bpy})_{2}(\text { dopamina })\right]^{+}(\mathrm{B})$

Figura 121: Espectros de emissão de fluorescência da HSA, na presença de diferentes

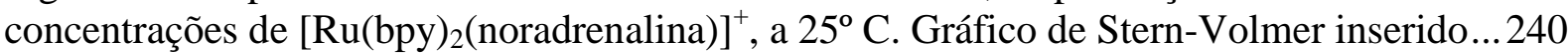
Figura 122: Gráfico da equação $\log \left[\left(\mathrm{I}_{0}-\mathrm{I}\right) / \mathrm{I}\right]=\log \mathrm{K}_{\mathrm{b}}+\mathrm{n} \log [\mathrm{Q}]$ referente à interação entre

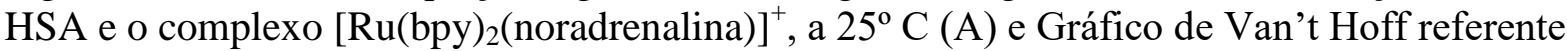
à interação entre HSA e o complexo $\left[\mathrm{Ru}(\mathrm{bpy})_{2} \text { (noradrenalina) }\right]^{+}(\mathrm{B})$.................................240

Figura 123: Espectros de emissão de fluorescência da HSA, na presença de diferentes concentrações de $\left[\mathrm{Ru}(\mathrm{bpy})_{2}(\mathrm{catecol})\right]^{+}$, a $25^{\circ} \mathrm{C}$. Gráfico de Stern-Volmer inserido 241 Figura 124: Gráfico da equação $\log \left[\left(\mathrm{I}_{0}-\mathrm{I}\right) / \mathrm{I}\right]=\log \mathrm{K}_{\mathrm{b}}+$ nlog[Q] referente à interação entre HSA e o complexo $\left[\mathrm{Ru}(\mathrm{bpy})_{2}(\mathrm{catecol})\right]^{+}$, a $25^{\circ} \mathrm{C}(\mathrm{A})$ e Gráfico de Van't Hoff referente à interação entre HSA e o complexo $\left[\mathrm{Ru}(\mathrm{bpy})_{2}(\mathrm{catecol})\right]^{+}(\mathrm{B})$

Figura 125: Espectros de emissão de fluorescência da HSA, na presença de diferentes concentrações de $\left[\mathrm{Ru}(\mathrm{bpy})_{2} \text { (adrenalina) }\right]^{+}$, a $25^{\circ} \mathrm{C}$. Gráfico de Stern-Volmer inserido Figura 126: Gráfico da equação $\log \left[\left(\mathrm{I}_{0}-\mathrm{I}\right) / \mathrm{I}\right]=\log \mathrm{K}_{\mathrm{b}}+\mathrm{n} \log [\mathrm{Q}]$ referente à interação entre HSA e o complexo [Ru(bpy) ${ }_{2}$ (adrenalina) $]^{+}$, a $25^{\circ} \mathrm{C}$ (A) e Gráfico de Van't Hoff referente à interação entre HSA e o complexo $\left[\mathrm{Ru}(\mathrm{bpy})_{2} \text { (adrenalina) }\right]^{+}(\mathrm{B})$

Figura 127: Espectro eletrônico qualitativo do cloridrato de isoproterenol ...........................263

Figura 128: Espectro eletrônico qualitativo do cloridrato de dopamina .................................263

Figura 129: Espectro eletrônico qualitativo do cloridrato de noradrenalina ..........................263

Figura 130: Espectro eletrônico qualitativo do catecol ......................................................264

Figura 131: Estabilidade do perfil espectroscópico de $\left[\mathrm{Ru}\left(\mathrm{NH}_{3}\right)_{4}(\text { isoproterenol) }]^{+}\right.$, com

irradiação em $\lambda=532 \mathrm{~nm}(\mathrm{~A}) ; \lambda=447 \mathrm{~nm}(\mathrm{~B}) ; \lambda=337 \mathrm{~nm}(\mathrm{C})$; solução aquosa $10^{-4} \mathrm{M} ; 0-$

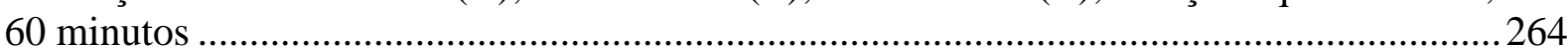

Figura 132: Estabilidade do perfil espectroscópico de $\left[\mathrm{Ru}\left(\mathrm{NH}_{3}\right)_{4} \text { (noradrenalina) }\right]^{+}$, com irradiação em $\lambda=532 \mathrm{~nm}(\mathrm{~A}) ; \lambda=447 \mathrm{~nm}(\mathrm{~B}) ; \lambda=337 \mathrm{~nm}(\mathrm{C})$; solução aquosa $10^{-4} \mathrm{M}$; 0 60 minutos

Figura 133: Estabilidade do perfil espectroscópico de $\left[\mathrm{Ru}\left(\mathrm{NH}_{3}\right)_{4}(\text { adrenalina })\right]^{+}$, com

irradiação em $\lambda=532 \mathrm{~nm}(\mathrm{~A}) ; \lambda=447 \mathrm{~nm}(\mathrm{~B}) ; \lambda=337 \mathrm{~nm}(\mathrm{C})$; solução aquosa $10^{-4} \mathrm{M} ; 0-$ 60 minutos

Figura 134: Espectro de absorção na região do infravermelho (pastilhas de $\mathrm{KBr}$ ): (A)

cloridrato de isoproterenol, (B) cloridrato de dopamina e (C) cloridrato de noradrenalina ...267 Figura 135: Plots dos orbitais alfa e beta Kohn-Sham com as maiores contribuições de Ru 4d obtidas por PBE0/def2-TZVP para o complexo $\left[\mathrm{Ru}\left(\mathrm{NH}_{3}\right)_{4}(\mathrm{catecol})\right]^{+}$..... Figura 136: Espectros experimental e simulado para os complexos $\left[\mathrm{Ru}\left(\mathrm{NH}_{3}\right)_{4}(\text { isoproterenol })\right]^{+}$

Figura 137: Espectros experimental e simulado para os complexos $\left[\mathrm{Ru}\left(\mathrm{NH}_{3}\right)_{4}(\text { dopamina })\right]^{+}$

Figura 138: Espectros experimental e simulado para os complexos

$\left[\mathrm{Ru}\left(\mathrm{NH}_{3}\right)_{4} \text { (noradrenalina) }\right]^{+}$ 279

Figura 139: Espectros experimental e simulado para os complexos $\left[\mathrm{Ru}\left(\mathrm{NH}_{3}\right)_{4}(\text { catecol })\right]^{+} \ldots 280$ Figura 140: Efeitos angiogênicos induzidos por complexos ou ligantes:

$\left[\mathrm{Ru}\left(\mathrm{NH}_{3}\right)_{4} \text { (noradrenalina) }\right]^{+}(\mathrm{Ru}-\mathrm{NA})$, noradrenalina $(\mathrm{NA}),\left[\mathrm{Ru}\left(\mathrm{NH}_{3}\right)_{4}(\text { adrenalina })\right]^{+}(\mathrm{Ru}-\mathrm{Adr})$, adrenalina (Adr), [ $\mathrm{Ru}\left(\mathrm{NH}_{3}\right)_{4}$ (isoproterenol) $]^{+}$( $\mathrm{Ru}$-Iso), isoproterenol (Iso),

$\left[\mathrm{Ru}\left(\mathrm{NH}_{3}\right)_{4} \text { (dopamina) }\right]^{+}$(Ru-Dopa), dopamina (Dopa), $\left[\mathrm{Ru}\left(\mathrm{NH}_{3}\right)_{4}(\mathrm{catecol})\right]^{+}$(Ru-Cat), ou o veículo (PBS), na área total de vasos (A) e na lacunaridade (B), na CAM. Os tratamentos aplicados foram na dose de $50 \mathrm{nmol}$ e a área total de vasos (A) e a lacunaridade (B) analisadas $48 \mathrm{~h}$ após os tratamentos. Os dados são apresentados como media \pm E.P.M. *diferente do 
controle (PBS); \#diferente da respectiva catecolamina, n=3-6; One-way ANOVA, Newman-

Keuls $(P<0.05)$

Figura 141: Fotografias representativas da modulação da angiogênese induzida por complexos ou ligantes: $\left[\mathrm{Ru}\left(\mathrm{NH}_{3}\right)_{4}(\text { noradrenalina) }]^{+}(\mathrm{Ru}-\mathrm{NA})\right.$, noradrenalina (NA),

$\left[\mathrm{Ru}\left(\mathrm{NH}_{3}\right)_{4} \text { (adrenalina) }\right]^{+}(\mathrm{Ru}-\mathrm{Adr})$, adrenalina (Adr), $\left[\mathrm{Ru}\left(\mathrm{NH}_{3}\right)_{4} \text { (isoproterenol) }\right]^{+}(\mathrm{Ru}-\mathrm{Iso})$, isoproterenol (Iso), $\left[\mathrm{Ru}\left(\mathrm{NH}_{3}\right)_{4}\right.$ (dopamina) ${ }^{+}$(Ru-Dopa), dopamina (Dopa),

$\left[\mathrm{Ru}\left(\mathrm{NH}_{3}\right)_{4}(\mathrm{catecol})\right]^{+}$(Ru-Cat), ou o veículo (PBS), 48h após os tratamentos. Olympus SZ2-

LHAD stereomicroscopy, 8x

Figura 142: Titulação do complexo $\left[\mathrm{Ru}\left(\mathrm{NH}_{3}\right)_{4}(\text { isoproterenol })\right]^{+}$, a $30^{\circ} \mathrm{C}$, acompanhada por

espectroscopia na região do UV-vis, $\operatorname{com} f s$-DNA...

Figura 143: Titulação do complexo $\left[\mathrm{Ru}\left(\mathrm{NH}_{3}\right)_{4}(\text { isoproterenol) }]^{+}\right.$, a $37^{\circ} \mathrm{C}, \operatorname{com} f s$-DNA, acompanhada por espectroscopia na região do UV-vis

Figura 144: Titulação do complexo $\left[\mathrm{Ru}\left(\mathrm{NH}_{3}\right)_{4} \text { (dopamina) }\right]^{+}$, a $30^{\circ} \mathrm{C}, \operatorname{com} f s$-DNA,

acompanhada por espectroscopia na região do UV-vis...

Figura 145: Titulação do complexo $\left[\mathrm{Ru}\left(\mathrm{NH}_{3}\right)_{4}(\text { dopamina })\right]^{+}$, a $37^{\circ} \mathrm{C}, \operatorname{com} f s$-DNA,

acompanhada por espectroscopia na região do UV-vis...

Figura 146: Titulação do complexo $\left[\mathrm{Ru}\left(\mathrm{NH}_{3}\right)_{4}(\text { noradrenalina) }]^{+}\right.$, a $30^{\circ} \mathrm{C}, \operatorname{com} f s$-DNA,

acompanhada por espectroscopia na região do UV-vis...

Figura 147: Titulação do complexo $\left[\mathrm{Ru}\left(\mathrm{NH}_{3}\right)_{4} \text { (noradrenalina) }\right]^{+}$, a $37^{\circ} \mathrm{C}, \operatorname{com} f s$-DNA, acompanhada por espectroscopia na região do UV-vis.

Figura 148: Titulação do complexo $\left[\mathrm{Ru}\left(\mathrm{NH}_{3}\right)_{4}(\text { catecol })\right]^{+}$, a $30^{\circ} \mathrm{C}, \operatorname{com} f s$-DNA,

acompanhada por espectroscopia na região do UV-vis.

Figura 149: Titulação do complexo $\left[\mathrm{Ru}\left(\mathrm{NH}_{3}\right)_{4}(\text { catecol })\right]^{+}$, a $37^{\circ} \mathrm{C}, \operatorname{com} f_{s}$-DNA, acompanhada por espectroscopia na região do UV-vis....

Figura 150: Titulação do complexo $\left[\mathrm{Ru}\left(\mathrm{NH}_{3}\right)_{4}(\text { adrenalina })\right]^{+}$, a $30^{\circ} \mathrm{C}, \operatorname{com} f s$-DNA,

acompanhada por espectroscopia na região do UV-vis....

Figura 151: Titulação do complexo $\left[\mathrm{Ru}\left(\mathrm{NH}_{3}\right)_{4}(\text { adrenalina })\right]^{+}$, a $37^{\circ} \mathrm{C}, \operatorname{com} f s$-DNA, acompanhada por espectroscopia na região do UV-vis

Figura 152: Espectros de emissão de fluorescência da HSA, na presença de diferentes concentrações de $\left[\mathrm{Ru}\left(\mathrm{NH}_{3}\right)_{4}(\text { isoproterenol })\right]^{+}$, a $32^{\circ} \mathrm{C}$. Gráfico de Stern-Volmer inserido ..287 Figura 153: Gráfico da equação $\log \left[\left(\mathrm{I}_{0}-\mathrm{I}\right) / \mathrm{I}\right]=\log \mathrm{K}_{\mathrm{b}}+\mathrm{n} \log [\mathrm{Q}]$ referente à interação entre HSA e o complexo $\left[\mathrm{Ru}\left(\mathrm{NH}_{3}\right)_{4}(\text { isoproterenol) }]^{+}\right.$, a $32^{\circ} \mathrm{C}$

Figura 154: Espectros de emissão de fluorescência da HSA, na presença de diferentes concentrações de $\left[\mathrm{Ru}\left(\mathrm{NH}_{3}\right)_{4}(\text { isoproterenol })\right]^{+}$, a $37^{\circ} \mathrm{C}$. Gráfico de Stern-Volmer inserido ..288 Figura 155: Gráfico da equação $\log \left[\left(\mathrm{I}_{0}-\mathrm{I}\right) / \mathrm{I}\right]=\log \mathrm{K}_{\mathrm{b}}+$ nlog$[\mathrm{Q}]$ referente à interação entre HSA e o complexo $\left[\mathrm{Ru}\left(\mathrm{NH}_{3}\right)_{4}(\text { isoproterenol })\right]^{+}$, a $37^{\circ} \mathrm{C}$

Figura 156: Espectros de emissão de fluorescência da HSA, na presença de diferentes concentrações de $\left[\mathrm{Ru}\left(\mathrm{NH}_{3}\right)_{4}(\text { dopamina })\right]^{+}$, a $32^{\circ} \mathrm{C}$. Gráfico de Stern-Volmer inserido .289 Figura 157: Gráfico da equação $\log \left[\left(\mathrm{I}_{0}-\mathrm{I}\right) / \mathrm{I}\right]=\log \mathrm{K}_{\mathrm{b}}+$ nlog[Q] referente à interação entre HSA e o complexo $\left[\mathrm{Ru}\left(\mathrm{NH}_{3}\right)_{4}(\text { dopamina })\right]^{+}$, a $32^{\circ} \mathrm{C}$

Figura 158: Espectros de emissão de fluorescência da HSA, na presença de diferentes concentrações de $\left[\mathrm{Ru}\left(\mathrm{NH}_{3}\right)_{4}(\text { dopamina })\right]^{+}$, a $37^{\circ} \mathrm{C}$. Gráfico de Stern-Volmer inserido 290 Figura 159: Gráfico da equação $\log \left[\left(\mathrm{I}_{0}-\mathrm{I}\right) / \mathrm{I}\right]=\log \mathrm{K}_{\mathrm{b}}+\mathrm{n} \log [\mathrm{Q}]$ referente à interação entre HSA e o complexo $\left[\mathrm{Ru}\left(\mathrm{NH}_{3}\right)_{4} \text { (dopamina) }\right]^{+}$, a $37^{\circ} \mathrm{C}$

Figura 160: Espectros de emissão de fluorescência da HSA, na presença de diferentes concentrações de $\left[\mathrm{Ru}\left(\mathrm{NH}_{3}\right)_{4} \text { (noradrenalina) }\right]^{+}$, a $32^{\circ} \mathrm{C}$. Gráfico de Stern-Volmer inserido.. 291 Figura 161: Gráfico da equação $\log \left[\left(\mathrm{I}_{0}-\mathrm{I}\right) / \mathrm{I}\right]=\log \mathrm{K}_{\mathrm{b}}+\mathrm{n} \log [\mathrm{Q}]$ referente à interação entre HSA e o complexo $\left[\mathrm{Ru}\left(\mathrm{NH}_{3}\right)_{4}(\text { noradrenalina })\right]^{+}$, a $32^{\circ} \mathrm{C}$

Figura 162: Espectros de emissão de fluorescência da HSA, na presença de diferentes concentrações de $\left[\mathrm{Ru}\left(\mathrm{NH}_{3}\right)_{4}(\text { noradrenalina })\right]^{+}$, a $37^{\circ} \mathrm{C}$. Gráfico de Stern-Volmer inserido.. 292 
Figura 163: Gráfico da equação $\log \left[\left(\mathrm{I}_{0}-\mathrm{I}\right) / \mathrm{I}\right]=\log \mathrm{K}_{\mathrm{b}}+\mathrm{n} \log [\mathrm{Q}]$ referente à interação entre HSA e o complexo $\left[\mathrm{Ru}\left(\mathrm{NH}_{3}\right)_{4}(\text { noradrenalina })\right]^{+}$, a $37^{\circ} \mathrm{C}$................................................292 Figura 164: Espectros de emissão de fluorescência da HSA, na presença de diferentes concentrações de $\left[\mathrm{Ru}\left(\mathrm{NH}_{3}\right)_{4}(\mathrm{catecol})\right]^{+}$, a $32^{\circ} \mathrm{C}$. Gráfico de Stern-Volmer inserido

Figura 165: Gráfico da equação $\log \left[\left(\mathrm{I}_{0}-\mathrm{I}\right) / \mathrm{I}\right]=\log \mathrm{K}_{\mathrm{b}}+\mathrm{n} \log [\mathrm{Q}]$ referente à interação entre HSA e o complexo $\left[\mathrm{Ru}\left(\mathrm{NH}_{3}\right)_{4}(\text { catecol })\right]^{+}$, a $32^{\circ} \mathrm{C}$

Figura 166: Espectros de emissão de fluorescência da HSA, na presença de diferentes concentrações de $\left[\mathrm{Ru}\left(\mathrm{NH}_{3}\right)_{4}(\mathrm{catecol})\right]^{+}$, a $37^{\circ} \mathrm{C}$. Gráfico de Stern-Volmer inserido

Figura 167: Gráfico da equação $\log \left[\left(\mathrm{I}_{0}-\mathrm{I}\right) / \mathrm{I}\right]=\log \mathrm{K}_{\mathrm{b}}+$ nlog[Q] referente à interação entre HSA e o complexo $\left[\mathrm{Ru}\left(\mathrm{NH}_{3}\right)_{4}(\mathrm{catecol})\right]^{+}$, a $37^{\circ} \mathrm{C}$

Figura 168: Espectros de emissão de fluorescência da HSA, na presença de diferentes concentrações de $\left[\mathrm{Ru}\left(\mathrm{NH}_{3}\right)_{4} \text { (adrenalina) }\right]^{+}$, a $32^{\circ} \mathrm{C}$. Gráfico de Stern-Volmer inserido 295 Figura 169: Gráfico da equação $\log \left[\left(\mathrm{I}_{0}-\mathrm{I}\right) / \mathrm{I}\right]=\log \mathrm{K}_{\mathrm{b}}+\mathrm{n} \log [\mathrm{Q}]$ referente à interação entre HSA e o complexo $\left[\mathrm{Ru}\left(\mathrm{NH}_{3}\right)_{4} \text { (adrenalina) }\right]^{+}$, a $32^{\circ} \mathrm{C}$.

Figura 170: Espectros de emissão de fluorescência da HSA, na presença de diferentes concentrações de $\left[\mathrm{Ru}\left(\mathrm{NH}_{3}\right)_{4} \text { (adrenalina) }\right]^{+}$, a $37^{\circ} \mathrm{C}$. Gráfico de Stern-Volmer inserido .296 Figura 171: Gráfico da equação $\log \left[\left(\mathrm{I}_{0}-\mathrm{I}\right) / \mathrm{I}\right]=\log \mathrm{K}_{\mathrm{b}}+\mathrm{n} \log [\mathrm{Q}]$ referente à interação entre HSA e o complexo $\left[\mathrm{Ru}\left(\mathrm{NH}_{3}\right)_{4} \text { (adrenalina) }\right]^{+}$, a $37^{\circ} \mathrm{C}$.

Figura 172: Espectro de absorção na região do infravermelho $\mathrm{RuCl}_{2}(\text { bpy })_{2}$ (pastilha de $\mathrm{KBr}$ )

Figura 173: Titulação do complexo $\left[\mathrm{Ru}(\mathrm{bpy})_{2}(\text { isoproterenol) }]^{+}\right.$, a $30^{\circ} \mathrm{C}, \operatorname{com} f s$-DNA, acompanhada por espectroscopia na região do UV-vis

Figura 174: Titulação do complexo [Ru(bpy) $)_{2}$ (isoproterenol) $]^{+}$, a $37^{\circ} \mathrm{C}, \operatorname{com} f s$-DNA, acompanhada por espectroscopia na região do UV-vis.

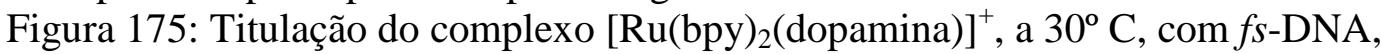
acompanhada por espectroscopia na região do UV-vis....

Figura 176: Titulação do complexo [Ru(bpy) ${ }_{2}$ (dopamina) $]^{+}$, a $37^{\circ} \mathrm{C}, \operatorname{com} f s$-DNA, acompanhada por espectroscopia na região do UV-vis....

Figura 177: Titulação do complexo $\left[\mathrm{Ru}(\text { bpy })_{2} \text { (noradrenalina) }\right]^{+}$, a $30^{\circ} \mathrm{C}, \operatorname{com} f s$-DNA, acompanhada por espectroscopia na região do UV-vis.

Figura 178: Titulação do complexo $\left[\mathrm{Ru}(\text { bpy })_{2} \text { (noradrenalina) }\right]^{+}$, a $37^{\circ} \mathrm{C}, \operatorname{com} f s$-DNA, acompanhada por espectroscopia na região do UV-vis...

Figura 179: Titulação do complexo $\left[\mathrm{Ru}(\mathrm{bpy})_{2}(\mathrm{catecol})\right]^{+}$, a $30^{\circ} \mathrm{C}, \mathrm{com} f s$-DNA, acompanhada por espectroscopia na região do UV-vis

Figura 180: Titulação do complexo $\left[\mathrm{Ru}(\mathrm{bpy})_{2}(\mathrm{catecol})\right]^{+}$, a $37^{\circ} \mathrm{C}, \operatorname{com} f s$-DNA, acompanhada por espectroscopia na região do UV-vis...

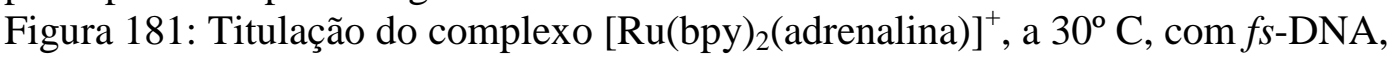
acompanhada por espectroscopia na região do UV-vis...

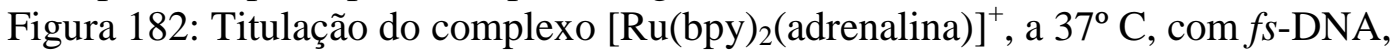
acompanhada por espectroscopia na região do UV-vis

Figura 183: Espectros de emissão de fluorescência da HSA, na presença de diferentes concentrações de $\left[\mathrm{Ru}(\mathrm{bpy})_{2} \text { (isoproterenol) }\right]^{+}$, a $32^{\circ} \mathrm{C}$. Gráfico de Stern-Volmer inserido....303 Figura 184: Gráfico da equação $\log \left[\left(\mathrm{I}_{0}-\mathrm{I}\right) / \mathrm{I}\right]=\log \mathrm{K}_{\mathrm{b}}+$ nlog$[\mathrm{Q}]$ referente à interação entre HSA e o complexo $\left[\mathrm{Ru}(\mathrm{bpy})_{2}(\text { isoproterenol) }]^{+}\right.$, a $32^{\circ} \mathrm{C}$

Figura 185: Espectros de emissão de fluorescência da HSA, na presença de diferentes concentrações de $\left[\mathrm{Ru}(\mathrm{bpy})_{2} \text { (isoproterenol) }\right]^{+}$, a $38^{\circ} \mathrm{C}$. Gráfico de Stern-Volmer inserido.... 304 Figura 186: Gráfico da equação $\log \left[\left(\mathrm{I}_{0}-\mathrm{I}\right) / \mathrm{I}\right]=\log \mathrm{K}_{\mathrm{b}}+$ nlog[Q] referente à interação entre HSA e o complexo $\left[\mathrm{Ru}(\mathrm{bpy})_{2}(\text { isoproterenol) }]^{+}\right.$, a $38^{\circ} \mathrm{C}$

Figura 187: Espectros de emissão de fluorescência da HSA, na presença de diferentes concentrações de $\left[\mathrm{Ru}(\text { bpy })_{2} \text { (dopamina) }\right]^{+}$, a $32^{\circ} \mathrm{C}$. Gráfico de Stern-Volmer inserido..... 
Figura 188: Gráfico da equação $\log \left[\left(\mathrm{I}_{0}-\mathrm{I}\right) / \mathrm{I}\right]=\log \mathrm{K}_{\mathrm{b}}+\mathrm{n} \log [\mathrm{Q}]$ referente à interação entre HSA e o complexo $\left[\mathrm{Ru}(\mathrm{bpy})_{2}(\text { dopamina }]^{+}\right.$, a $32^{\circ} \mathrm{C}$.

Figura 189: Espectros de emissão de fluorescência da HSA, na presença de diferentes concentrações de $\left[\mathrm{Ru}(\mathrm{bpy})_{2} \text { (dopamina) }\right]^{+}$, a $38^{\circ} \mathrm{C}$. Gráfico de Stern-Volmer inserido 306

Figura 190: Gráfico da equação $\log \left[\left(\mathrm{I}_{0}-\mathrm{I}\right) / \mathrm{I}\right]=\log \mathrm{K}_{\mathrm{b}}+$ nlog$[\mathrm{Q}]$ referente à interação entre HSA e o complexo $\left[\mathrm{Ru}(\mathrm{bpy})_{2} \text { (dopamina) }\right]^{+}$, a $38^{\circ} \mathrm{C}$

Figura 191: Espectros de emissão de fluorescência da HSA, na presença de diferentes concentrações de $\left[\mathrm{Ru}(\mathrm{bpy})_{2} \text { (noradrenalina) }\right]^{+}$, a $32^{\circ} \mathrm{C}$. Gráfico de Stern-Volmer inserido... 307 Figura 192: Gráfico da equação $\log \left[\left(\mathrm{I}_{0}-\mathrm{I}\right) / \mathrm{I}\right]=\log \mathrm{K}_{\mathrm{b}}+$ nlog[Q] referente à interação entre HSA e o complexo $\left[\mathrm{Ru}(\text { bpy })_{2} \text { (noradrenalina) }\right]^{+}$, a $32^{\circ} \mathrm{C}$

Figura 193: Espectros de emissão de fluorescência da HSA, na presença de diferentes concentrações de $\left[\mathrm{Ru}(\mathrm{bpy})_{2} \text { (noradrenalina) }\right]^{+}$, a $38^{\circ} \mathrm{C}$. Gráfico de Stern-Volmer inserido... 308 Figura 194: Gráfico da equação $\log \left[\left(\mathrm{I}_{0}-\mathrm{I}\right) / \mathrm{I}\right]=\log \mathrm{K}_{\mathrm{b}}+$ nlog[Q] referente à interação entre HSA e o complexo $\left[\mathrm{Ru}(\text { bpy })_{2} \text { (noradrenalina) }\right]^{+}$, a $38^{\circ} \mathrm{C}$

Figura 195: Espectros de emissão de fluorescência da HSA, na presença de diferentes concentrações de $\left[\mathrm{Ru}(\mathrm{bpy})_{2}(\mathrm{catecol})\right]^{+}$, a $32^{\circ} \mathrm{C}$. Gráfico de Stern-Volmer inserido 309

Figura 196: Gráfico da equação $\log \left[\left(\mathrm{I}_{0}-\mathrm{I}\right) / \mathrm{I}\right]=\log \mathrm{K}_{\mathrm{b}}+$ nlog[Q] referente à interação entre HSA e o complexo $\left[\mathrm{Ru}(\mathrm{bpy})_{2}(\mathrm{catecol})\right]^{+}$, a $32^{\circ} \mathrm{C}$

Figura 197: Espectros de emissão de fluorescência da HSA, na presença de diferentes concentrações de $\left[\mathrm{Ru}(\mathrm{bpy})_{2}(\mathrm{catecol})\right]^{+}$, a $38^{\circ} \mathrm{C}$. Gráfico de Stern-Volmer inserido 310 Figura 198: Gráfico da equação $\log \left[\left(\mathrm{I}_{0}-\mathrm{I}\right) / \mathrm{I}\right]=\log \mathrm{K}_{\mathrm{b}}+\mathrm{n} \log [\mathrm{Q}]$ referente à interação entre HSA e o complexo $\left[\mathrm{Ru}(\mathrm{bpy})_{2} \text { (catecol) }\right]^{+}$, a $38^{\circ} \mathrm{C}$

Figura 199: Espectros de emissão de fluorescência da HSA, na presença de diferentes concentrações de $\left[\mathrm{Ru}(\mathrm{bpy})_{2} \text { (adrenalina) }\right]^{+}$, a $32^{\circ} \mathrm{C}$. Gráfico de Stern-Volmer inserido 311 Figura 200: Gráfico da equação $\log \left[\left(\mathrm{I}_{0}-\mathrm{I}\right) / \mathrm{I}\right]=\log \mathrm{K}_{\mathrm{b}}+$ nlog$[\mathrm{Q}]$ referente à interação entre HSA e o complexo $\left[\mathrm{Ru}(\text { bpy })_{2} \text { (adrenalina) }\right]^{+}$, a $32^{\circ} \mathrm{C}$

Figura 201: Espectros de emissão de fluorescência da HSA, na presença de diferentes concentrações de $\left[\mathrm{Ru}(\mathrm{bpy})_{2} \text { (adrenalina) }\right]^{+}$, a $38^{\circ} \mathrm{C}$. Gráfico de Stern-Volmer inserido 312 Figura 202: Gráfico da equação $\log \left[\left(\mathrm{I}_{0}-\mathrm{I}\right) / \mathrm{I}\right]=\log \mathrm{K}_{\mathrm{b}}+$ nlog[Q] referente à interação entre HSA e o complexo $\left[\mathrm{Ru}(\mathrm{bpy})_{2} \text { (adrenalina) }\right]^{+}$, a $38^{\circ} \mathrm{C}$ 


\section{LISTA DE TABELAS}

Tabela 1: Ordem da potência dos agonistas nos receptores adrenérgicos ..............................55

Tabela 2: Procedência e pureza dos reagentes utilizados ....................................................... 73

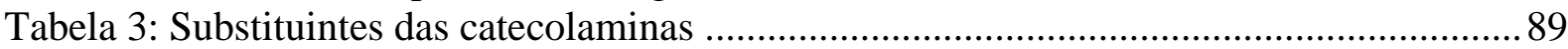

Tabela 4: Tempo de retenção dos complexos nas análises de HPLC .....................................93

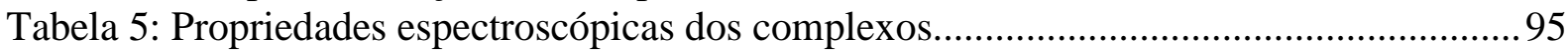

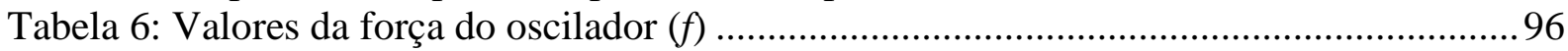

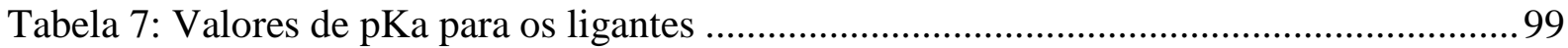

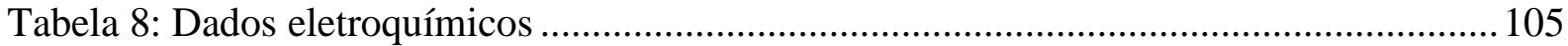

Tabela 9: Atribuições das frequências das vibrações nos espectros de FTIR, em pastilhas de

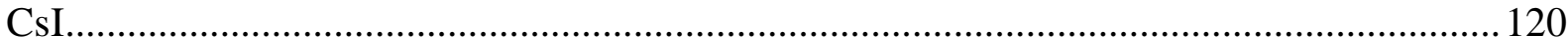

Tabela 10: Atribuições dos sinais observados nos espectros Raman ....................................122

Tabela 11: Tentativa de atribuição dos deslocamentos químicos de ${ }^{1} \mathrm{H}$ RMN dos complexos

Tabela 12: Parâmetros geométricos selecionados para os complexos $\left[\mathrm{Ru}\left(\mathrm{NH}_{3}\right)_{4}(\mathrm{~L})\right]^{+}$obtidos

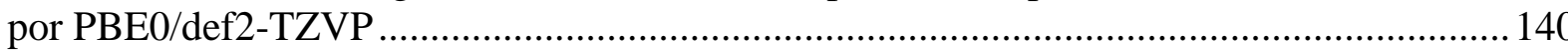

Tabela 13: Valores teóricos e experimentais de $\mathrm{m} / \mathrm{z}$ dos íons dos complexos e seus respectivos

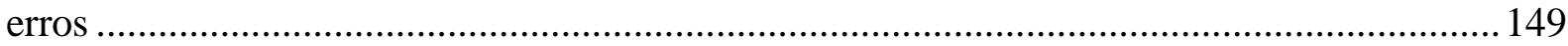

Tabela 14: Tentativa de atribuição de $m / z$ dos íons-fragmento dos complexos .................... 150

Tabela 15: Constantes intrínsecas $\left(\mathrm{K}_{\mathrm{b}}\right)$ da interação dos complexos com of $f$-DNA ............. 195

Tabela 16: Parâmetros termodinâmicos para os processos ................................................. 197

Tabela 17: Constantes de Stern-Volmer para a supressão de fluorescência do sistema BET-

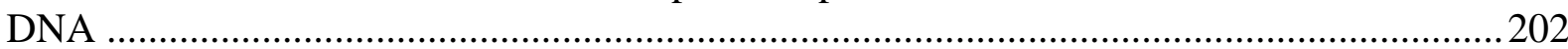

Tabela 18: Parâmetros da interação dos complexos $\left[\mathrm{Ru}\left(\mathrm{NH}_{3}\right)_{4} \mathrm{~L}\right]^{+}(\mathrm{L}=$ isoproterenol, dopamina, noradrenalina, catecol e adrenalina) com HSA: $\mathrm{K}_{\mathrm{sv}} ; \mathrm{K}_{\mathrm{b}} ; n ; \Delta \mathrm{G} ; \Delta \mathrm{H}$ e $\Delta \mathrm{S}$, a 25,32

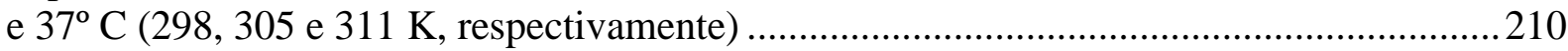

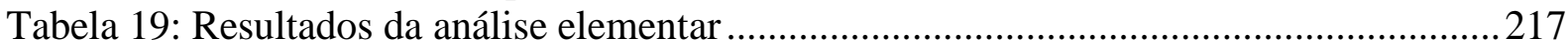

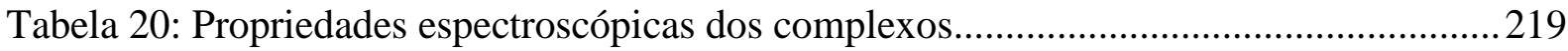

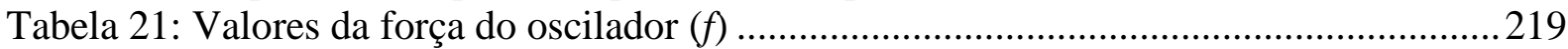

Tabela 22: Atribuições das principais bandas nos espectros de FTIR, em pastilhas de CsI ..224

Tabela 23: Efeitos observados nas bandas dos complexos ..................................................231

Tabela 24: Constantes intrínsecas $\left(\mathrm{K}_{\mathrm{b}}\right)$ da interação dos complexos com of $f_{s}$-DNA.............232

Tabela 25: Parâmetros termodinâmicos para os processos ..................................................233

Tabela 26: Constantes de Stern-Volmer para a supressão de fluorescência do sistema BET-

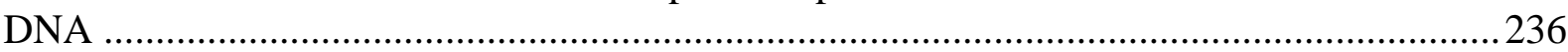

Tabela 27: Parâmetros da interação dos complexos $\left[\mathrm{Ru}(\mathrm{bpy})_{2} \mathrm{~L}\right]^{+}(\mathrm{L}=$ isoproterenol,

dopamina, noradrenalina, catecol e adrenalina) com HSA: $\mathrm{K}_{\mathrm{sv}} ; \mathrm{K}_{\mathrm{b}} ; n ; \Delta \mathrm{G} ; \Delta \mathrm{H}$ e $\Delta \mathrm{S}$, a 25,32 e

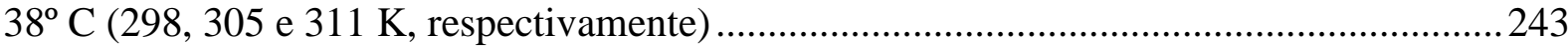

Tabela 28: Coordenadas cartesianas para o complexo $\left[\mathrm{Ru}\left(\mathrm{NH}_{3}\right)_{4}(\text { catecol })\right]^{+}$obtidas por

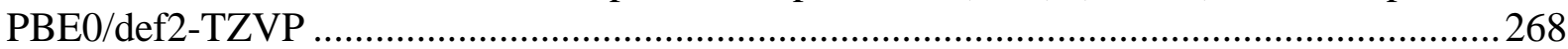

Tabela 29: Coordenadas cartesianas para o complexo $\left[\mathrm{Ru}\left(\mathrm{NH}_{3}\right)_{4}(\text { dopamina })\right]^{+}$obtidas por

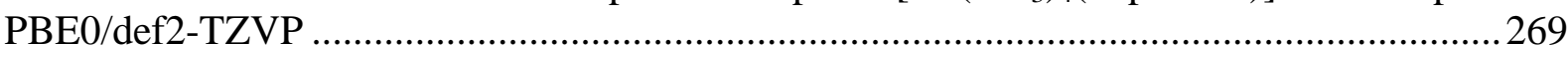

Tabela 30: Coordenadas cartesianas para o complexo $\left[\mathrm{Ru}\left(\mathrm{NH}_{3}\right)_{4}(\text { noradrenalina })\right]^{+}$obtidas por

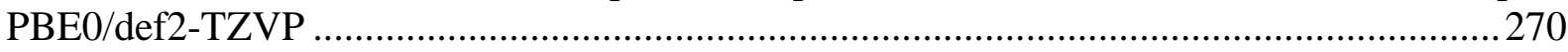

Tabela 31: Coordenadas cartesianas para o complexo $\left[\mathrm{Ru}\left(\mathrm{NH}_{3}\right)_{4}(\text { adrenalina })\right]^{+}$obtidas por

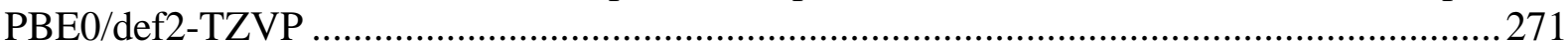

Tabela 32: Coordenadas cartesianas para o complexo $\left[\mathrm{Ru}\left(\mathrm{NH}_{3}\right)_{4}(\text { isoprotereno })\right]^{+}$obtidas por

PBE0/def2-TZVP 
Tabela 33: Orbitais Kohn-Sham obtidos por PBE0/def2-TZVP para o complexo $\left[\mathrm{Ru}\left(\mathrm{NH}_{3}\right)_{4}(\mathrm{catecol})\right]^{+}$. Os orbitais destacados são os orbitais de fronteira.

Tabela 34: Orbitais Kohn-Sham obtidos por PBE0/def2-TZVP para o complexo

$\left[\mathrm{Ru}\left(\mathrm{NH}_{3}\right)_{4} \text { (dopamina) }\right]^{+}$. Os orbitais destacados são os orbitais de fronteira

Tabela 35: Orbitais Kohn-Sham obtidos por PBE0/def2-TZVP para o complexo

$\left[\mathrm{Ru}\left(\mathrm{NH}_{3}\right)_{4} \text { (adrenalina) }\right]^{+}$. Os orbitais destacados são os orbitais de fronteira..

Tabela 36: Orbitais Kohn-Sham obtidos por PBE0/def2-TZVP para o complexo

$\left[\mathrm{Ru}\left(\mathrm{NH}_{3}\right)_{4} \text { (noradrenalina) }\right]^{+}$. Os orbitais destacados são os orbitais de fronteira

Tabela 37: Orbitais Kohn-Sham obtidos por PBE0/def2-TZVP para o complexo

$\left[\mathrm{Ru}\left(\mathrm{NH}_{3}\right)_{4}(\text { isoproterenol })\right]^{+}$. Os orbitais destacados são os orbitais de fronteira 


\section{LISTA DE ABREVIATURAS}

cKIT - receptor de proteína tirosina quinase específico, também chamado de receptor de fator de células tronco ou CD117

$\left[\mathrm{Ca}^{2+}\right]_{\mathrm{i}}-$ cálcio intracelular

A7R5 - células musculares lisas embrionárias de aorta torácica de ratos

ADHFA - ácido dihidroxifenilacético

AHV - ácido homovanílico

AMPc - 3', 5' - monofosfato cíclico de adenosina

B16F10 - células de melanona murino

BET - brometo de etídio

CAM - Chorioallantoic Membrane (membrana corioalantoica)

COMT - catecol-O-metiltransferase

COX-2 - enzima ciclo-oxigenase-2

$\mathrm{DAG}$ - diacilglicerol

DNA - ácido desoxirribonucleico

DOMA - ácido 3,4-diidroximandélico

DOPEG - 3,4-diidroxifeniletilenoglicol

DOPGAL - 3,4-diidroxifenilglicoaldeído

DPBF - 1,3-difenil-isobenzofurano

$\varepsilon$ - coeficiente de absortividade molar

$\mathrm{E}_{1 / 2}$ - potencial de meia onda

EGF - epidermal growth factor (fator de crescimento epidérmico)

EPC - endothelial progenitor cells (células progenitoras endoteliais)

EPR - espectroscopia de ressonância paramagnética eletrônica

ERK-1 / ERK-2 - extracellular signal-regulated kinases (proteínas quinases reguladas por sinais extracelulares) 
ESI - ionização por electrospray

FAK - focal adhesion kinase (quinase de adesão focal);

FGF - fibroblast growth factor (fator de crescimento de fibroblasto)

FGFR - fibroblast growth factor receptor (receptor do fator de crescimento de fibroblasto)

FR37-CMT - células de linhagem metastática de câncer de mama canino

HIF - hypoxia inducible factor (fator indutor de hipóxia)

HOMO - highest occupied molecular orbital (orbital molecular de mais alta energia ocupado)

HSA - human serum albumin (proteína do soro humano albumina)

HUVEC - human umbilical vein endothelial cells (células endoteliais de veia umbilical humana)

IL - interleukin (interleucina)

INCA - Instituto Nacional de Câncer José Alencar Gomes da Silva

$\mathrm{IP}_{3}$ - trifosfato de inositol

$\mathrm{K}_{\mathrm{sv}}-$ constante de Stern-Volmer

LUMO - lowest occupied molecular orbital (orbital molecular de mais baixa energia não ocupado)

$\mu-$ massa reduzida

MAO - monoaminoxidase

MAPK - mitogen activated protein kinase (proteína quinase ativada por mitógenos)

$\mathrm{MeOH}-$ metanol

MMP-2 / MMP-9 - matrix metalloproteinase (metaloproteinase de matriz)

MOPEG (ou MHPG) - 3-metoxi-4-hidroxifeniletilenoglicole

Nox - número de oxidação

PBS - Phosphate-buffered saline (solução salina tamponada)

PDGF - platelet-derived growth factor (fator de crescimento derivado de plaquetas)

PDGFR - platelet-derived growth factor receptors (receptor do fator de crescimento derivado de plaquetas) 
RMN - ressonância magnética nuclear

ROS - reactive oxygen species (espécies reativas de oxigênio - ERO)

RTKs - receptor tirosin kinases (receptores tirosina-quinases)

SF-188 - células de linhagem tumoral de glioblastoma humano pediátrico

SOMO - single occupied molecular orbital (orbital molecular de mais alta energia ocupado por apenas 1 elétron)

TCLM - transferência de carga do ligante para o metal

TCML - transferência de carga do metal para o ligante

TDA - transportador de dopamina

TGF- $\beta$ - transforming growth factor (fator de transformação do crescimento)

$\mathrm{TIE}$ - receptores tirosina-quinase

TNE - transportador de noradrenalina

TVMA-2 - transportador vesicular de monoaminas

UV-vis - espectroscopia de absorção na região do ultravioleta-visível

VEGF - vascular endothelial growth factor (fator de crescimento endotelial vascular)

VEGFR - vascular endothelial growth factor receptor (receptor do fator de crescimento endotelial vascular)

VMA - ácido 3-metoxi-4-hidroximandélico (ácido vanililmandélico)

WHO - World Health Organization (Organização Mundial da Saúde) 


\section{ESTRUTURAS DOS COMPLEXOS}
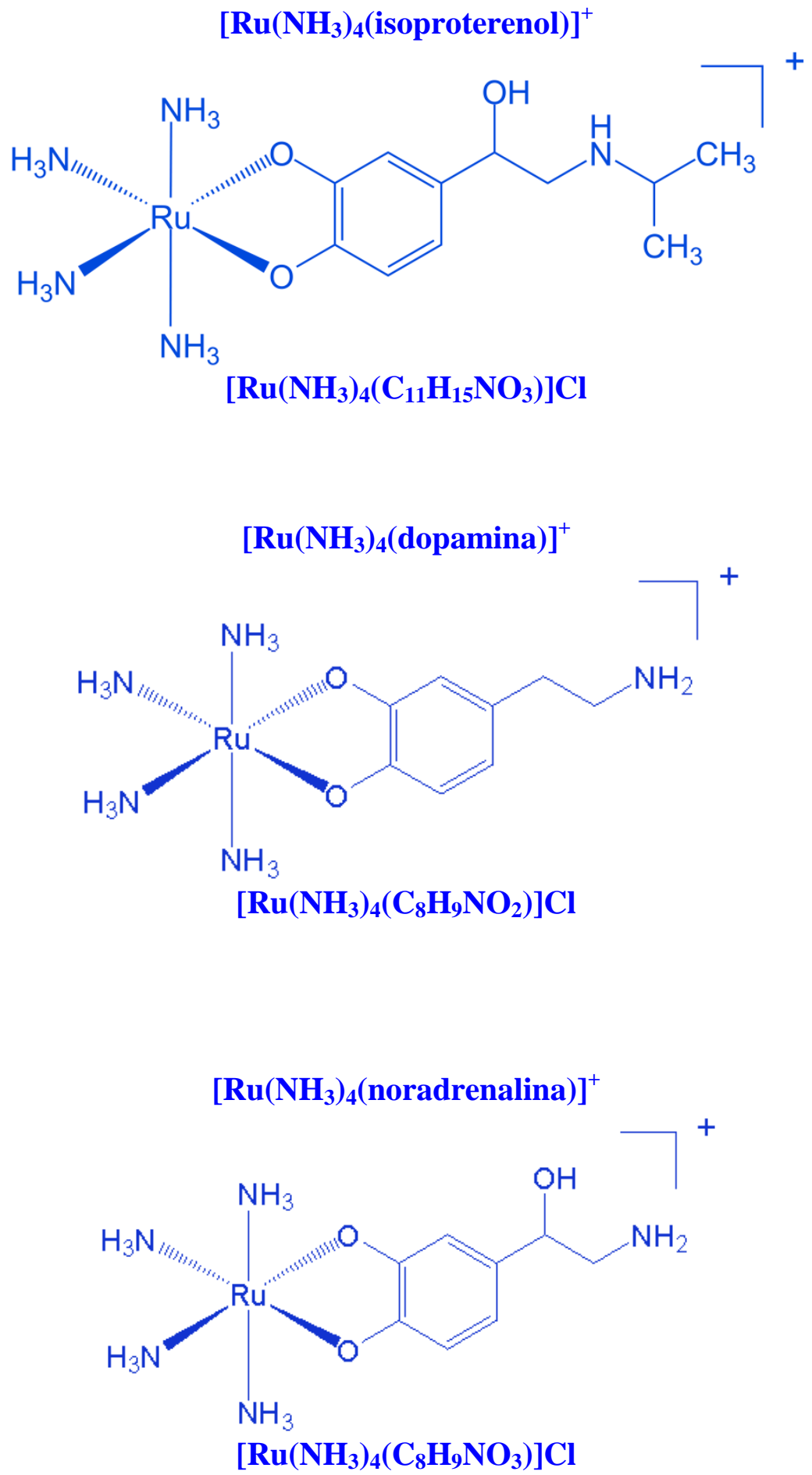

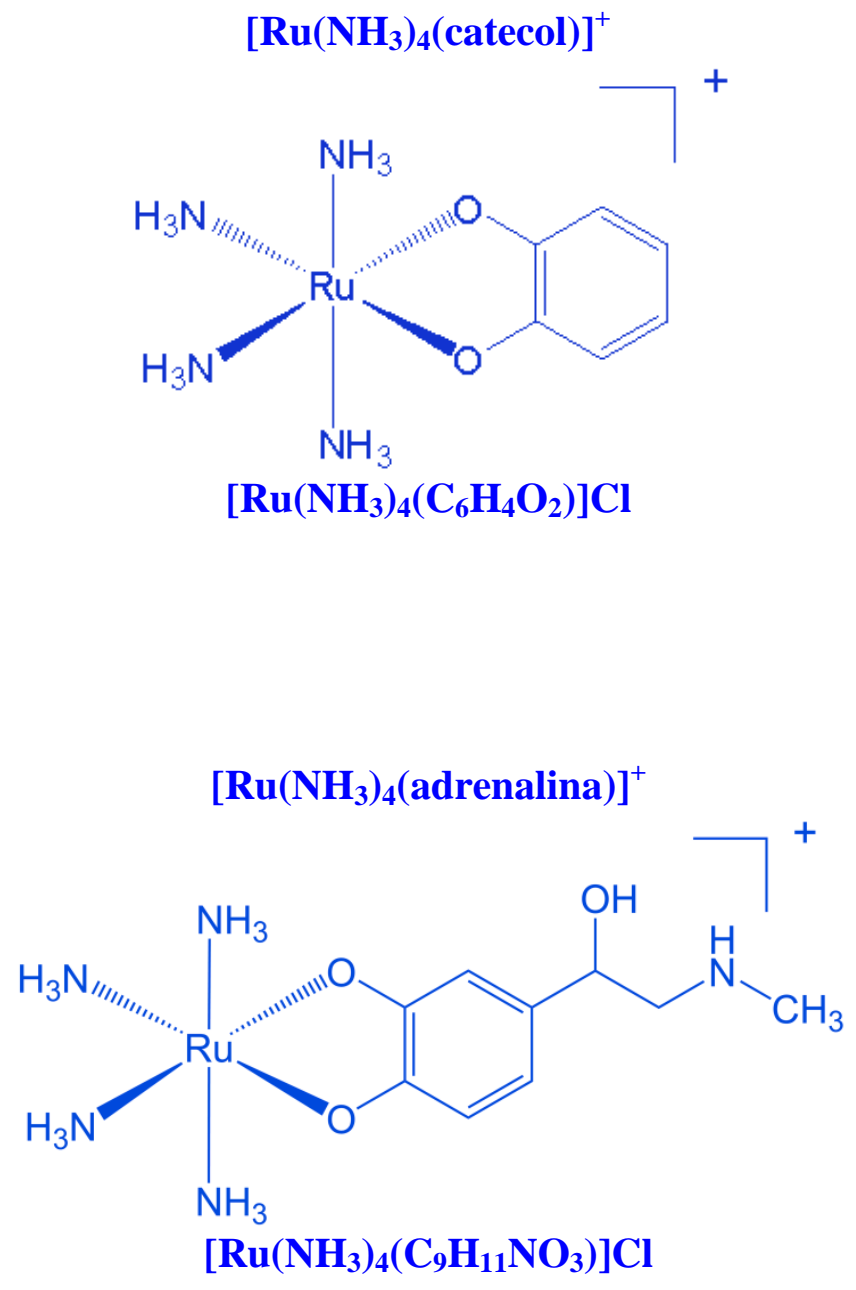
$\left[\operatorname{Ru}(\text { bpy })_{2}(\text { isoproterenol })\right]^{+}$
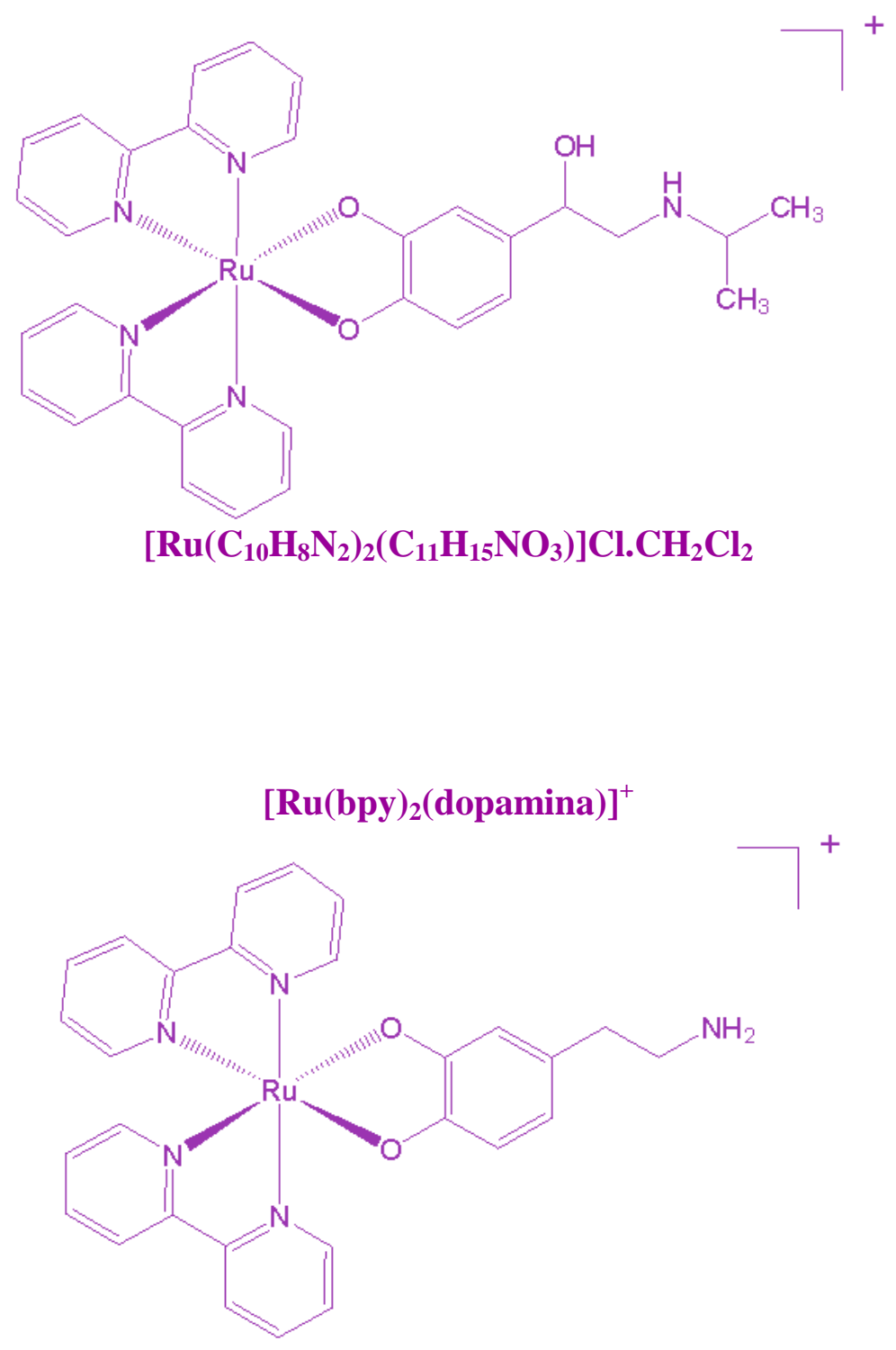

$\left[\mathrm{Ru}\left(\mathrm{C}_{10} \mathrm{H}_{8} \mathrm{~N}_{2}\right)_{2}\left(\mathrm{C}_{8} \mathrm{H}_{9} \mathrm{NO}_{2}\right)\right] \mathrm{Cl} . \mathrm{CH}_{2} \mathrm{Cl}_{2}$ 

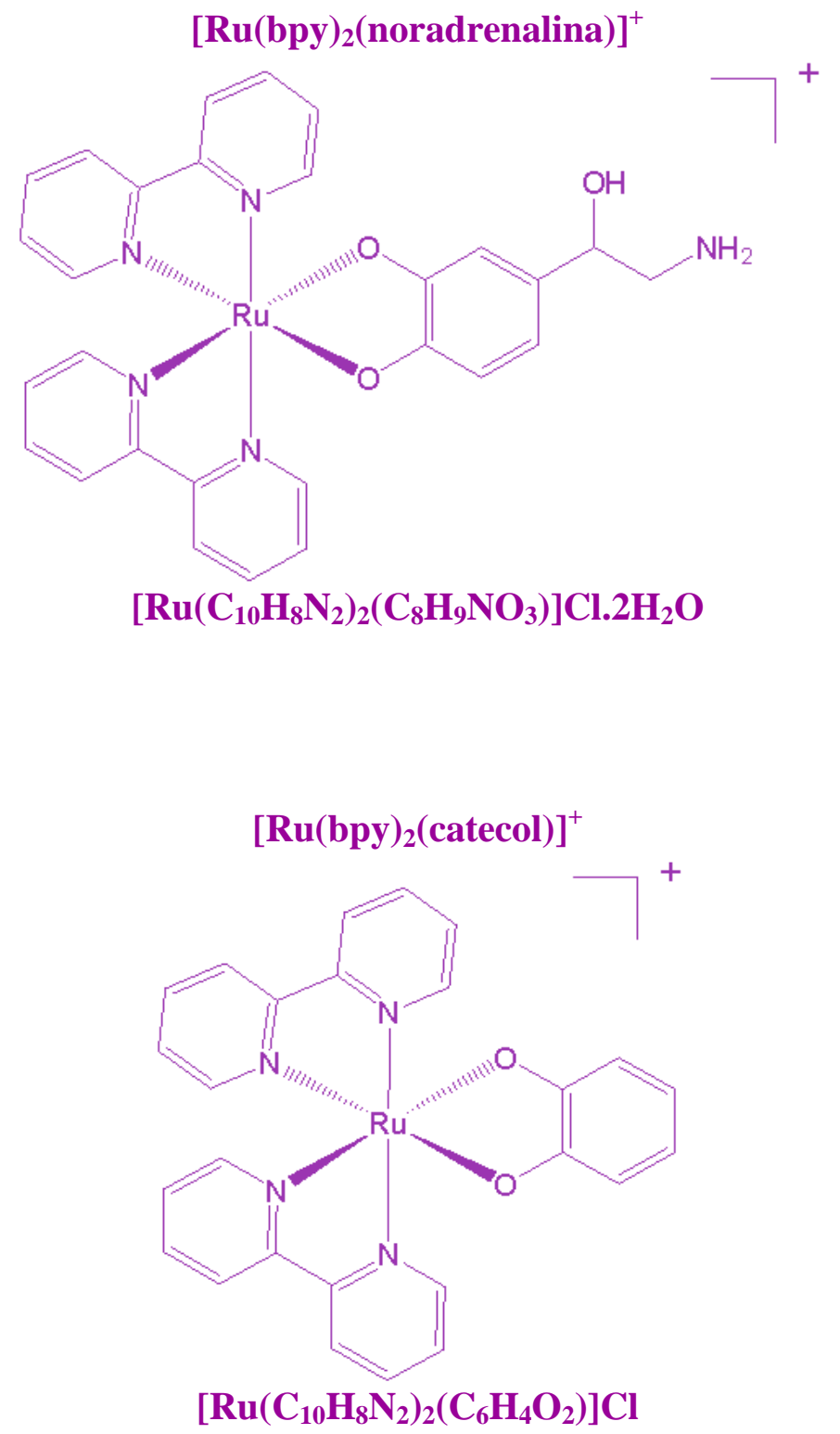


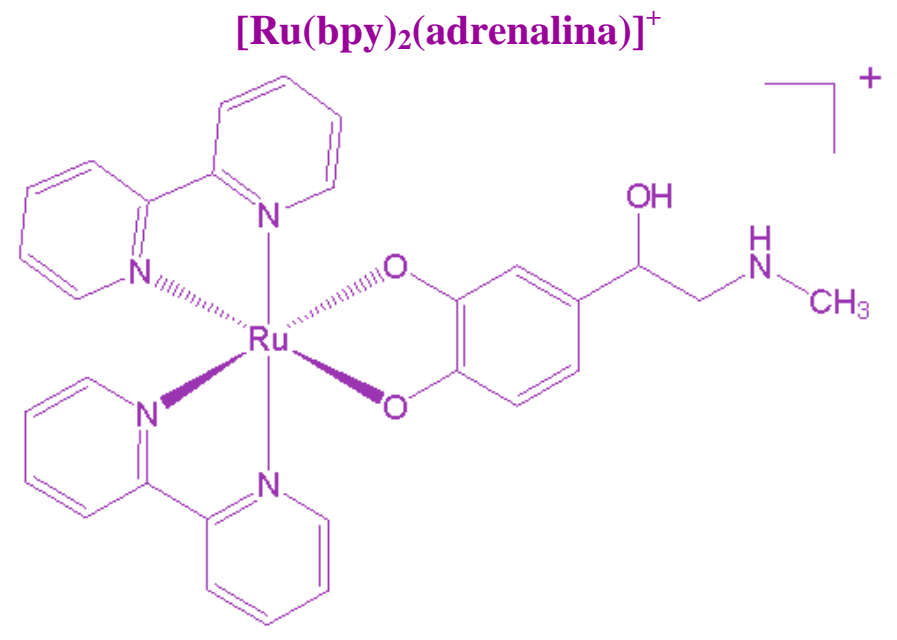

$\left[\mathrm{Ru}\left(\mathrm{C}_{10} \mathrm{H}_{8} \mathrm{~N}_{2}\right)_{2}\left(\mathrm{C}_{9} \mathrm{H}_{11} \mathrm{NO}_{3}\right)\right] \mathrm{Cl} . \mathrm{H}_{2} \mathrm{O}$ 


\section{RESUMO}

O câncer é um problema de saúde mundial que ceifa a vida de muitas pessoas, todos os dias. Nesse sentido, pesquisas voltadas à melhor compreensão do seu progresso e cura são de vital importância. Assim, um importante aspecto do desenvolvimento e crescimento de um tumor é a formação de novos vasos sanguíneos - angiogênese - e o desenvolvimento vascular. As catecolaminas estão envolvidas neste processo, entretanto, sua participação e mecanismos de ação ainda não estão completamente elucidados. Neste sentido, a contribuição específica do sítio catecólico e do sítio amínico, para a interação entre as catecolaminas e seus receptores específicos, bem como a relação com a angiogênese, tornou-se objeto de interesse de estudo. A fim de avaliar a participação de cada grupamento específico, realizou-se a imobilização do sítio catecólico, pela coordenação ao metal rutênio, gerando complexos com fórmula $\left[\mathrm{Ru}\left(\mathrm{NH}_{3}\right)_{4}(\mathrm{cat}-\mathrm{R})\right] \mathrm{Cl}$, onde "cat-R" é isoproterenol, dopamina, noradrenalina, catecol ou adrenalina. Cálculos teóricos e propriedades físico-químicas (por diversas técnicas) foram analisados após a coordenação ao íon metálico. Estudos de estabilidade fotoquímica foram conduzidos. Na sequência, estudou-se a atividade citotóxica e angiogênica destes complexos utilizando-se como plataforma a membrana corioalantoica (CAM) de embriões de galinha. Para avaliar a atividade moduladora do tônus vascular exercida por estes compostos, estudos de reatividade vascular foram conduzidos para os complexos metálicos em comento, em aorta torácica de ratos. Os resultados obtidos sugerem se tratarem de agonistas parciais e/ou antagonistas dos respectivos receptores. Posteriormente, realizaram-se estudos em células para a análise de aumento de cálcio intracelular, em células tratadas com os complexos. Outrossim, ensaios de regeneração celular foram conduzidos com o intuito de se avaliar a atividade antiproliferativa dos complexos metálicos. Embora a possibilidade de interação específica entre os complexos com fórmula $\left[\mathrm{Ru}\left(\mathrm{NH}_{3}\right)_{4}(\right.$ cat- $\left.\mathrm{R})\right] \mathrm{Cl}$ com os receptores celulares tenha sido verificada, estudos de interação com $f s$-DNA, via espectroscopia UV-vis e por deslocamento do brometo de etídio - acompanhada por espectroscopia de fluorescência foram conduzidos. Na sequência, a interação entre os complexos e a proteína do soro humano albumina (HSA) foi analisada, por supressão de fluorescência. Posteriormente, com a finalidade de se entender o quanto a alteração dos coligantes afetaria as propriedades biológicas dos complexos, uma nova série de complexos metálicos com fórmula genérica $\left[\mathrm{Ru}(\mathrm{bpy})_{2}(\mathrm{cat}-\mathrm{R})\right] \mathrm{Cl}$ onde "cat-R" é isoproterenol, dopamina, noradrenalina, catecol ou adrenalina. Essas novas espécies foram caracterizadas por técnicas físico-químicas e testada em alguns dos ensaios biológicos realizados para os complexos precedentes. Os resultados 
evidenciaram que as catecolaminas possuem atividade na angiogênese, sendo que seus efeitos podem ser modulados quando há impedimento do sítio catecólico, por exemplo, pela coordenação ao metal rutênio. Além disso, a substituição dos coligantes amônia, por ligantes piridínicos ocasionou o aumento da citotoxicidade, bem como da interação com DNA (provavelmente por mecanismos de intercalação) e HSA.

Palavras-chave: rutênio-catecolamina; câncer; angiogênese; membrana corioalantoica 


\begin{abstract}
Cancer is a global health problem that causes the death of many people every day. In this way, researches aimed at understanding the progress and cure of this disease are desirable. Therefore, an important aspect of the development and growth of a tumor is the formation of the new blood vessels, known as angiogenesis, and the vascular development. The catecholamines are involved in this process, however, their role and mechanism of action are not completely elucidated. In this way, interaction between catecholamines and its receptors should be of interest, in order to understand the blocking mechanism of angiogenesis. Interactions with receptor should occur by catechol or amine site. In order to evaluate the participation of each specific group, the immobilization of the catechol site has been achieved by coordination to the ruthenium metal ion, generating $[\mathrm{Ru}(\mathrm{NH} 3) 4($ cat- $\mathrm{R})] \mathrm{Cl}$, whereas "cat$\mathrm{R}$ " is isoproterenol, dopamine, noradrenaline, catechol or adrenaline. Theoretical calculations and physical chemistry properties were analyzed after coordination to the metal ion. Photochemical studies were conducted. Subsequently, the cytotoxicity and angiogenic activity of these complexes were studied - using the chorioallantoic membrane (CAM) of chicken embryos - as well the vascular tone modulating activity of these compounds - analyzed in thoracic aorta of rats. The results obtained suggest that they are partial agonists and/or antagonists of the respective receptors. The intracellular calcium increase was analyzed in cells treated with the complexes. Moreover, cell regeneration assays were conducted with the purpose of evaluating the antiproliferative activity of the ruthenium complexes. Although the possibility of specific interaction between $[\mathrm{Ru}(\mathrm{NH} 3) 4($ cat-R) $] \mathrm{Cl}$ complexes with cell receptors have been verified, we have checked also the involvement of DNA on all process. For this fs-DNA interaction studies using UV-vis spectroscopy and with ethidium bromide displacement assay were performed. Afterwards, the interaction between the complexes and Human serum albumin protein (HAS) was evaluated, by fluorescence quenching. The next question to be answered is concerning to the structure of ruthenium complex. Aiming to understand this we have synthesized new $[\mathrm{Ru}(\mathrm{bpy}) 2($ cat- $\mathrm{R})] \mathrm{Cl}$ complexes whereas "cat- $\mathrm{R}$ " is isoproterenol, dopamine, noradrenaline, catechol or adrenaline. Those species were physical chemistry characterized, and they were analyzed by some biological assays. In conclusion, the results showed that catecholamines have activity in angiogenesis, and their effects can be modulated when the catechol site is not available, for example by the coordination of the ruthenium metal. In addition, the substitution of amino ligands by pyridine ligands has
\end{abstract}


resulted in increased cytotoxicity as well as interaction with DNA (probably by intercalating mechanism) and HSA.

Keywords: ruthenium-catecholamine; cancer; angiogenesis; chorioallantoic membrane 


\section{SUMÁRIO}

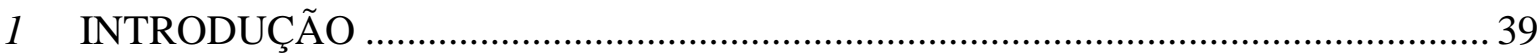

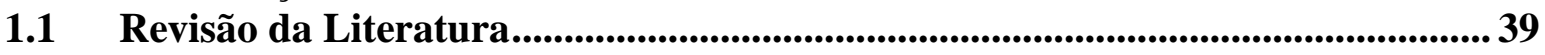

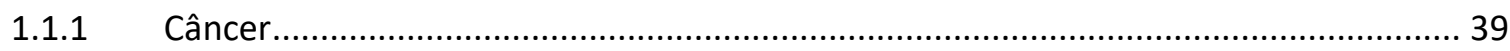

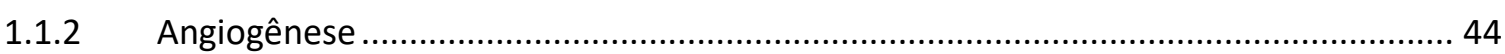

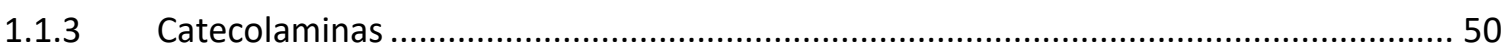

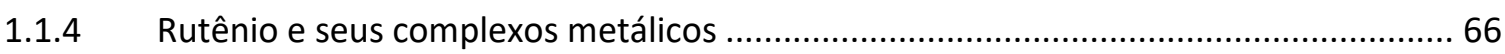

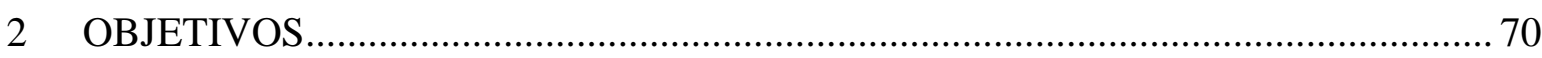

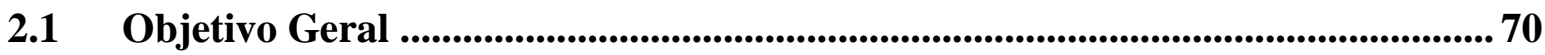

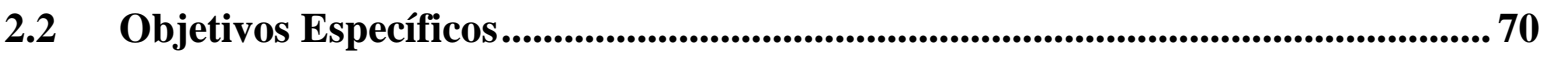

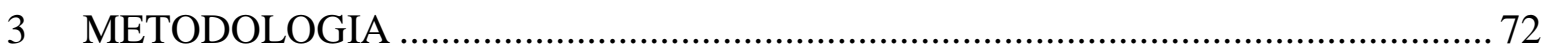

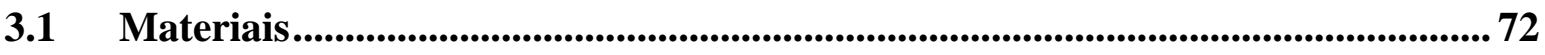

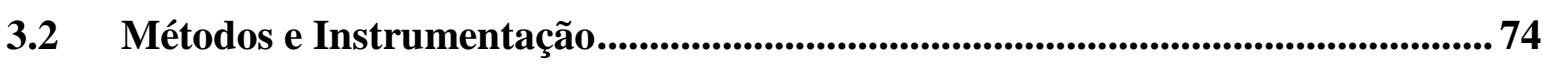

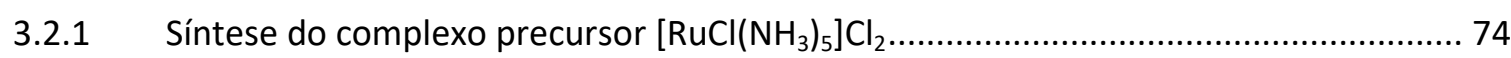

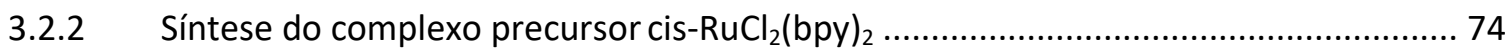

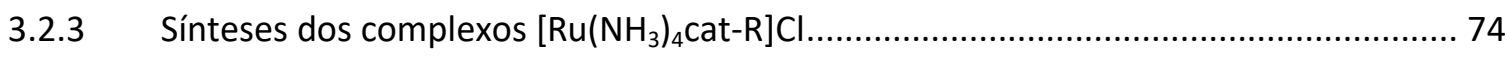

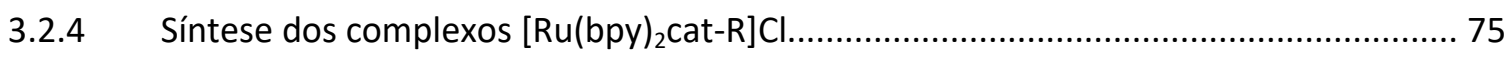

3.2.5 Cromatografia Líquida de Alta Eficiência (CLAE/HPLC) ................................................ 76

3.2.6 Espectroscopia eletrônica de absorção na região UV-vis .............................................. 76

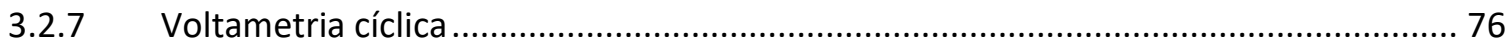

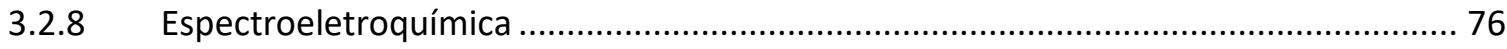

3.2.9 Estabilidade fotoquímica e verificação da produção de oxigênio singleto .................... 77

3.2.10 Espectroscopia de absorção na região do infravermelho ............................................. 77

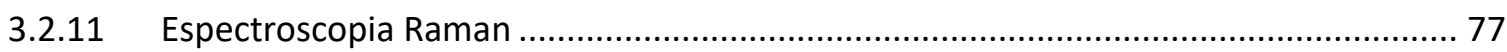

3.2.12 Espectroscopia de ressonância magnética nuclear..................................................... 77

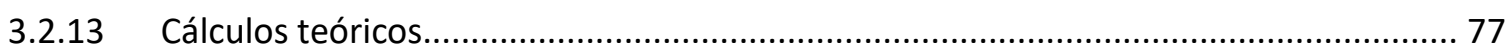

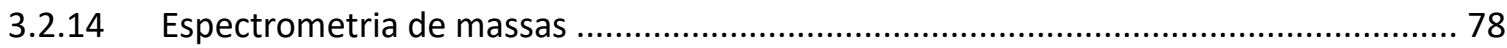

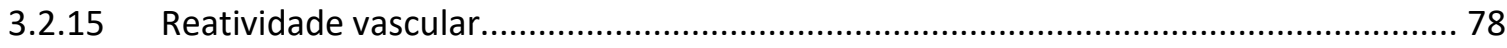

3.2.16 Medida do conteúdo de cálcio intracelular $\left(\left[\mathrm{Ca}^{2+}\right]_{\mathrm{i}}\right)$ nas células HUVEC ou A7R5 ........ 80

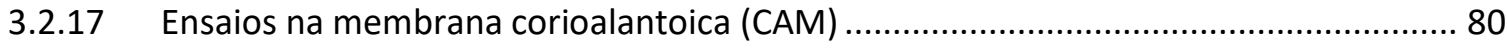

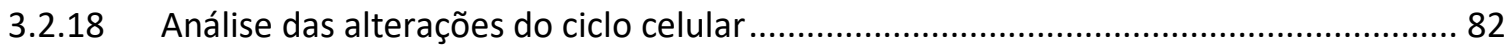

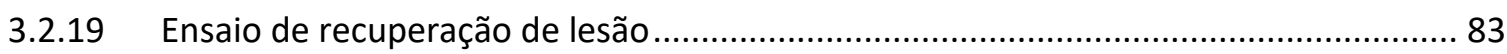

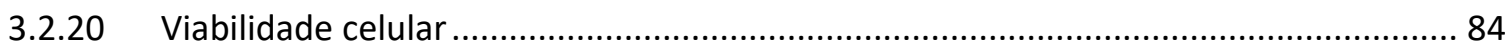

3.2.21 Estudos de interação com fs-DNA - titulação espectofotométrica na região UV-vis ... 85 
3.2.22 Estudos de interação com fs-DNA - deslocamento do brometo de etídio espectroscopia de fluorescência

3.2.23 Interação com proteína carreadora (proteína do soro humano albumina - HSA) mimetizando transporte in vivo

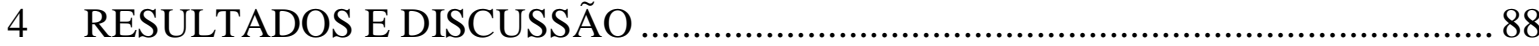

4.1 Parte 1: Complexos com fórmula geral: $\left[\mathrm{Ru}\left(\mathrm{NH}_{3}\right)_{4}\right.$ cat-R]Cl .............................88

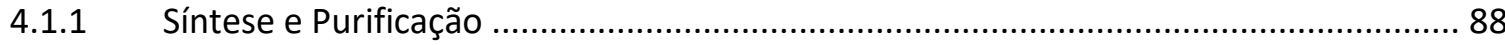

4.1.2 Cromatografia Líquida de Alta Eficiência (CLAE/HPLC) …............................................. 91

4.1.3 Espectroscopia eletrônica de absorção na região UV-vis ............................................. 93

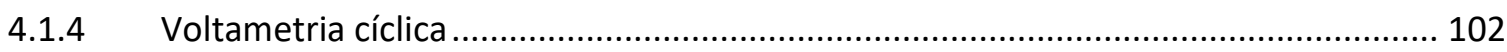

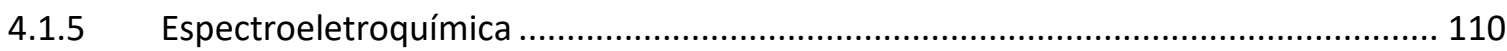

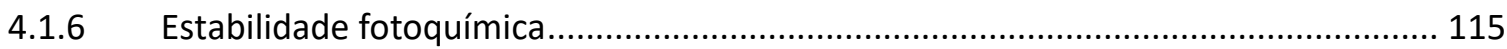

4.1.7 Verificação da produção de oxigênio singleto …………............................................. 117

4.1.8 Espectroscopia de absorção na região do infravermelho ............................................. 119

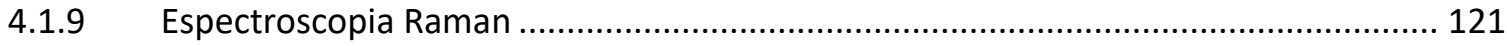

4.1.10 Espectroscopia de ressonância magnética nuclear................................................. 124

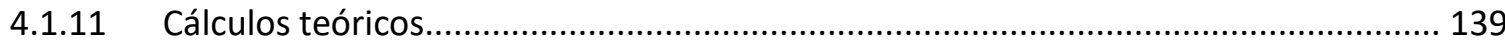

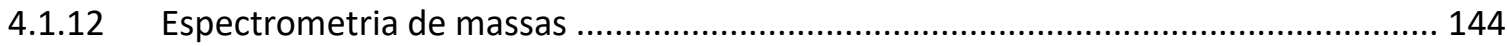

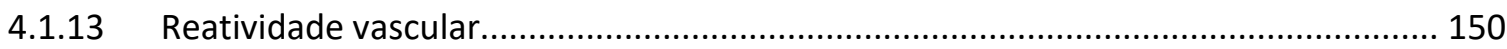

4.1.14 Medida do conteúdo de cálcio intracelular $\left(\left[\mathrm{Ca}^{2+}\right]_{i}\right)$ nas células HUVEC ou A7R5 ...... 162

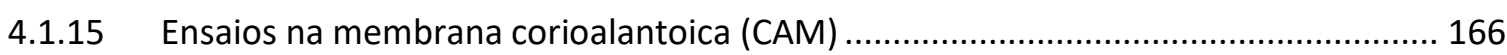

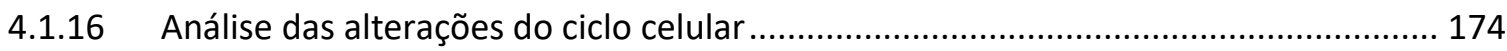

4.1.17 Ensaio de recuperação de lesão ............................................................................ 178

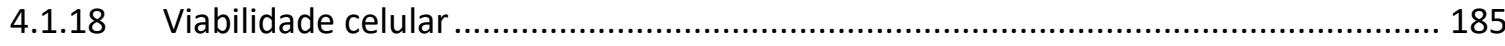

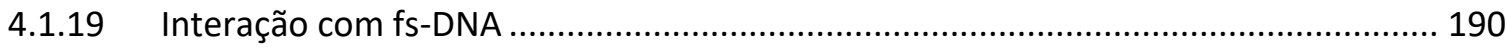

4.1.20 Interação com proteína carreadora (HSA) - mimetizando transporte in vivo............. 203

4.1.21 Considerações finais em relação aos complexos de rutênio-catecolaminas e seus

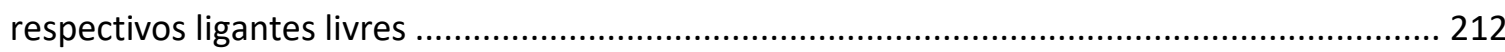

4.2 Parte 2: Complexos com fórmula geral: $\left[\mathrm{Ru}(\mathrm{bpy})_{2} \mathrm{cat}-\mathrm{R}\right] \mathrm{Cl}$............................ 215

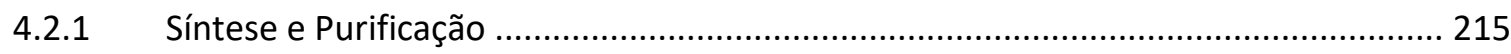

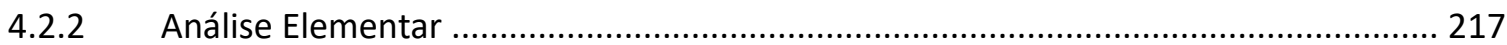

4.2.3 Espectroscopia eletrônica de absorção na região UV-vis ........................................... 217

4.2.4 Espectroscopia de absorção na região do infravermelho …….................................. 223

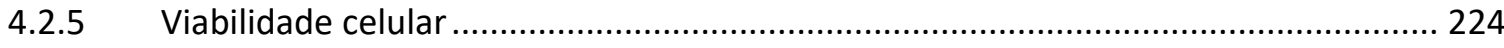

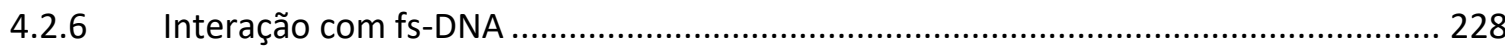


4.2.7 Interação com proteína carreadora (HSA) - mimetizando transporte in vivo

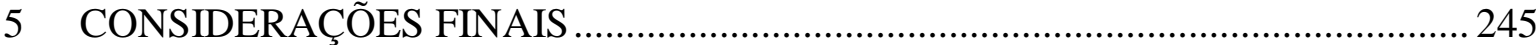

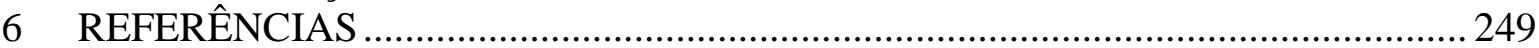

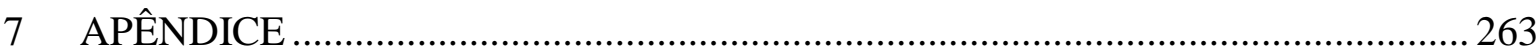

7.1 Parte 1: Complexos com fórmula geral: $\left[\mathrm{Ru}\left(\mathrm{NH}_{3}\right)_{4} \mathrm{cat}-\mathrm{R}\right] \mathrm{Cl}$............................ 263

7.1.1 Espectroscopia eletrônica de absorção na região UV-vis ............................................ 263

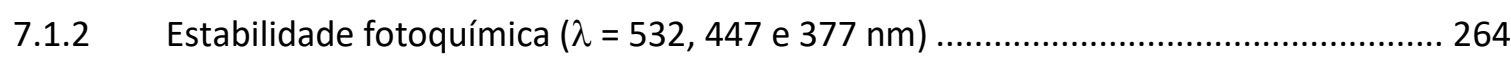

7.1.3 Espectroscopia de absorção na região do infravermelho .......................................... 267

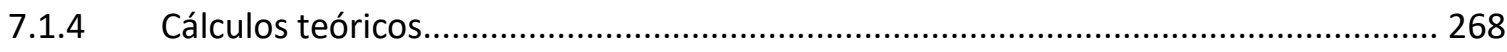

7.1.5 Ensaios na membrana corioalantoica (CAM) ……................................................... 280

7.1.6 Interação com fs-DNA - titulação espectrofotométrica na região do UV-Vis ............. 282

7.1.7 Interação com proteína carreadora (HSA) - mimetizando transporte in vivo............. 287

\subsection{Parte 2: Complexos com fórmula geral: [Ru(bpy $)_{2}$ cat-R]Cl .............................. 297}

7.2.1 Espectroscopia de absorção na região do infravermelho .......................................... 297

7.2.2 Interação com fs-DNA - titulação espectrofotométrica na região do UV-Vis ............. 297

7.2.3 Interação com proteína carreadora (HSA) - mimetizando transporte in vivo............. 303 



\section{INTRODUÇÃO}

A ideologia amplamente adotada por aqueles que se propõem a investigar novos compostos com possíveis atividades anticâncer, se restringe - não raramente - ao método de triagem, qual seja, a investigação da citotoxicidade, utilizando esse tipo de análise como preliminar e como condição sine qua non para o prosseguimento da investigação de outras formas de atividade. Nesse contexto, vê-se uma ânsia crescente pela síntese e caracterização de novas espécies químicas, cuja ênfase é, se não tão somente o ineditismo, a obtenção de compostos com citotoxicidade alta em linhagens cancerígenas, sem qualquer efeito em linhagens saudáveis.

Esse seria um excelente caminho, na hipótese de não existir uma infinidade de compostos a serem estudados, passíveis de atividades biológicas promissoras, os quais são abandonados logo após os primeiros ensaios biológicos. Atualmente, parcela crescente dos pesquisadores têm se ocupado em mostrar que essa, talvez, não seja a forma mais adequada ao futuro da Ciência e que muitos compostos, com promissoras atividades outras, podem ser descartados ainda no início da pesquisa in vitro, devido a tal ideologia amplamente difundida (MIGNOLET et. al., 2016; BARRY, SADLER, 2013; DYSON; SAVA, 2006).

Assim, à luz da ideologia em ascensão, é pretendido, no presente trabalho, entre outros aspectos, destacar a importância da investigação de diversas formas de atividade biológica, além da citotoxicidade, bem como demonstrar a necessidade da investigação de diversos aspectos relacionados à atuação de moléculas endógenas e compostos já conhecidos - cuja análise mais detalhada pode resultar em interessantes descobertas.

\subsection{Revisão da Literatura}

\subsubsection{Câncer}

O câncer é um nome atribuído não a uma doença especificamente, mas a um conjunto de mais de duzentas doenças, que agregam características comuns (INCA, 2016). Originárias de células sadias, as células cancerosas são distinguidas pela perda de parte das suas características intrínsecas, no entanto, ainda guardam algumas propriedades histológicas do tecido originário.

Em condições normais, as células humanas passam por um ciclo natural, que consiste em seu surgimento, divisão e morte. Quando, por eventos oriundos de agentes 
químicos, poluição, radiação, infecções ou condições hereditárias, uma célula sofre mutação e perde a capacidade de se autorregular, inclusive em relação à sua morte, inicia-se um processo de proliferação celular descontrolado, com células se diferenciando constantemente, que culmina, na sequência, na formação de uma massa de células mutadas, a qual se denomina tumor (NEGRI, 2015).

Para melhor compreensão, é necessário salientar que existem duas condições extremas, onde em uma extremidade se encontram tecidos totalmente sadios e, em outra, os tecidos altamente malignos e que entre tais condições, há diversos tipos de tecidos com aspectos e características intermediárias (WEINBERG, 2014).

Neste sentido, tecidos nos quais as células se desvirtuam pouco das características do tecido sadio, porém com crescimento exagerado, são denominados de hiperplásicos; aos tecidos que invadem outros, dos quais as células, no entanto, são normais, denomina-se metaplasia - este tipo de alteração pode ser considerado um passo importante no desenvolvimento de alterações malignas posteriores. Tecidos mais anormais, possuindo células com forma e tamanho diferentes do tecido normal, além da quantidade muito aumentada, são considerados displasias - intermediários entre crescimentos anormais totalmente benignos e pré-malignos. Mais anormais que estes são os adenomas, pólipos, etc., que formam massas de tecidos já visíveis a olho nu. Estas lesões crescem até determinado tamanho, sem, no entanto, invadir outros tecidos, são considerados, pois, tumores benignos. No caso do crescimento de células dos chamados tumores malignos, há invasão de outros tecidos e a área limítrofe entre um tecido e outro não é respeitada pela massa tumoral. Assim, este tipo de tumor é caracterizado por ser invasivo, não possuir bordas bem definidas e sofrer metástase (WEINBERG, 2014).

O processo de metástase é característico dos tumores malignos. Neste, diversos eventos biológicos estão envolvidos, os quais permitem que as células do tumor primário adentrem nos vasos sanguíneos ou linfáticos e se instalem em outras regiões, originando, então, novos tumores, denominados lesões secundárias (WEINBERG, 2014).

Alguns autores, mais tradicionais, preferem o termo câncer apenas para os tumores malignos, entretanto a literatura atual tem utilizado a expressão para denominar tanto os tumores malignos, quanto os benignos. Este conjunto de células que originam o tecido mutado se denomina, também, neoplasma - novos tipos teciduais - termo também reservado apenas para os tumores malignos, por alguns autores (WEINBERG, 2014; NEGRI, 2015). 
Importante salientar que mesmo dentre os tumores malignos, há expressiva diversidade, principalmente quando se considera que existem tumores cuja massa é formada (inicialmente) por um único tipo celular, bem como aqueles formados por diferentes subpopulações celulares geneticamente diferentes, ou seja, nem todas as células do tumor provêm da mesma célula ancestral. São considerados, respectivamente, monoclonais e policlonais (WEINBERG, 2014).

Considerado uma preocupação sem precedentes para as instituições de saúde e pesquisa em todo o mundo, o câncer "que já é a principal causa de morte nos países de alta renda, está prestes a se tornar, nas próximas décadas, uma importante causa de morbidade e mortalidade em todas as regiões do mundo, independentemente dos níveis de recursos." (BRAY et al., 2012 apud JEMAL ET. AL., 2014).

De acordo com estatísticas da Organização Mundial da Saúde (OMS), somente no ano de 2015, 8,8 milhões pessoas morreram em decorrência do câncer, o que se traduz em aproximadamente um caso em cada seis mortes (OMS, 2017). A incidência da doença em comento aumentou de 12,7 milhões em 2008, para 14,1 milhões em 2012, e de acordo com as estatísticas, a tendência é aumentar (cerca de 75\%), atingindo aproximadamente 25 milhões de pessoas ao longo das duas próximas décadas (OMS, 2014). Este aumento se deve não apenas aos hábitos de vida menos saudáveis das populações ao longo dos anos, mas também ao aumento dos recursos para a identificação, cada vez mais precoce, da doença.

Trata-se, pois de um problema mundial, que ceifa a vida de muitas pessoas, todos os dias, em todos os continentes, para o qual novas pesquisas se fazem (ainda) imprescindíveis.

As causas do câncer são muitas e, nem sempre é possível realizar a correta atribuição ao agente causador, no entanto, constituem-se fatores de risco: o tabagismo (prevêse que faleçam, por ano, cerca de 21.400 pessoas com câncer de pulmão, somente na condição de fumantes passivos); infecções (praticamente 100\% dos casos de câncer de colo de útero são decorrentes de infecções, assim como $90 \%$ dos casos de câncer de estômago, entre outros); a obesidade (geralmente também associada ao sedentarismo e à dieta inadequada); a exposição à radiação ultravioleta; a reposição hormonal, bem como o uso de anticoncepcionais orais (houve um pequeno aumento entre as usuárias atuais, na incidência do câncer de mama); e a poluição (JEMAL et. al., 2014; WHO, 2014). 
Atualmente, predomina a incidência mundial do câncer de pulmão entre os homens, tanto em relação aos novos casos, quanto em relação às mortes, da mesma forma que entre as mulheres o mais incidente é o câncer de mama (JEMAL ET. AL., 2014). De acordo com o Instituto Nacional de Câncer José Alencar Gomes da Silva (INCA), nas estatísticas mundiais, somente no ano de 2012, foram acometidas com câncer de pulmão 1,8 milhão de pessoas; de mama, 1,7 milhão de pessoas; de intestino, 1,4 milhão; e próstata, 1,1 milhão (INCA, 2015).

Em relação ao Brasil, é previsto para o biênio 2016-2017, aproximadamente 600 mil novos casos de câncer, dos quais cerca de 180 mil serão de pele não melanoma e, dos 420 mil restantes, predomina o perfil epidemiológico já registrado para a América Latina e o Caribe, onde prevalecem os cânceres de próstata (61 mil) como o mais incidente nos homens e, nas mulheres, o de mama (58 mil) (INCA, 2015).

Como condições de controle, necessárias à redução - tanto da incidência, quanto da taxa de mortalidade - do câncer, se encontram a prevenção (por vacinação, atividade física, proteção solar e redução do tabagismo), o diagnóstico precoce e o tratamento. Este último consiste tanto na quimioterapia (aplicação de compostos químicos ativos contra o câncer); radioterapia (utilização da radiação eletromagnética na região tumoral); cirurgia para extração; e cuidados paliativos (JEMAL et. al., 2014).

Inegáveis são os dados indicando que as mortes decorrentes do câncer são 90\% casos de metástases, em oposição a 10\% decorrentes de tumores primários (WU et. al., 2015). E, em sua maioria, os fármacos são selecionados a partir de estudos pré-clínicos com base na sua potência na inibição do crescimento de tumor primário, acreditando-se que será semelhante a inibição do crescimento das metástases. No entanto, já se sabe que esta ideologia não é adequada e, diversos pesquisadores têm destacado a necessidade de terapias antimetastáticas novas que não bloqueiam apenas o crescimento tumoral - chamado de progressão -, mas também a propagação e/ou formação de metástases (WU et. al., 2015).

É notório que a angiogênese é um processo essencial no crescimento tumoral. Mas, a importância deste processo é vista com (ainda) maior gravidade na fase metastática do câncer. Isto porque nesta fase - bem como na imediatamente anterior - ocorre a proliferação de células cancerígenas para outros órgãos e/ou tecidos, o que acontece via vasos sanguíneos e linfáticos, como também crescimento tumoral acentuado, às vezes, exponencial. Somandose a esses fatores há, ainda, a resistência à quimioterapia convencional (citotóxica), 
geralmente apresentada por pacientes quando em estágios mais avançados da doença e após o uso contínuo de quimioterápicos.

Assim, pesquisas referentes à angiogênese têm sido voltadas mais para a aplicação na fase metastática do câncer, assim como na sua associação a outros quimioterápicos, tanto para auxílio na redução da resistência aos fármacos, quanto para promover a redução dos vasos sanguíneos propriamente.

A literatura tem reportado resultados interessantes quando se apresenta a combinação de espécies citotóxicas com o bevacizumabe - anticorpo monoclonal humanizado anti-VEGF (do inglês vascular endothelial growth factor, o fator de crescimento do endotélio vascular). No entanto, a ação angiogênica deste e outros fármacos e compostos em estudos, ainda não está totalmente elucidada e, não raramente, novas hipóteses têm surgido a fim de explicar tal ação (SHAKED et. al., 2008). Uma das hipóteses é que os fármacos antiangiogênicos seriam de grande importância quando administrados nos períodos de pausa da quimioterapia citotóxica, atuando no impedimento do restabelecimento do tumor no ínterim da quimioterapia citotóxica e, assim, aumentando o grau de durabilidade da resposta tumoral (SHAKED et. al., 2008).

Além disto, estudos reportam que a combinação das duas terapias (citotóxica e antiangiogênica) é essencial para a obtenção de melhores resultados (SHAKED et. al., 2008). No entanto, a busca por espécies antiangiogênicas com custo reduzido, por exemplo, em relação ao anticorpo monoclonal (bevacizumabe), se mostra de importância ímpar, haja vista o fato de se mostrar, não raramente, uma terapia inviabilizada pelo alto custo, por ser geralmente administrada em pacientes com câncer em estágio avançado e que resulta em prolongamento de apenas meses de vida aos mesmos (BERTOLINI, 2011).

Ademais, a maneira de inibição da angiogênese mais utilizada atualmente, antiVEGF, mesmo após sua aprovação como fármaco apresenta resultados de rápido aumento da vascularização tão logo a administração do mesmo é interrompida (EBOS et. al., 2009). Logo, pesquisas, cujas estratégias de bloqueio angiogênico sejam diversas das conhecidas, se fazem necessárias (MARECH et. al., 2015; WU et. al., 2015).

Não obstante a necessidade de mais estudos de elucidação dos mecanismos das substâncias antiangiogênicas, mais resultados têm sido mostrados no sentido de que pacientes tratados também com fármacos antiangiogênicos tiveram $52 \%$ a menos de reincidência tumoral, em relação aos não tratados com esta espécie (FERRARA; KERBEL, 2005). 
Há, ainda, uma nova classe de antiangiogênicos sendo testados, os quais atuam por diversos mecanismos de ação, muitos dos quais ainda não são elucidados e agem, sucintamente, por oclusão dos vasos sanguíneos já existentes, mas recém-formados (são conhecidos como VDA, vascular-disrupting agents, em inglês) (FERRARA; KERBEL, 2015).

Dentre os muitos aspectos relacionados ao câncer, cabe salientar o papel de destaque exercido pela angiogênese. Trata-se de processo imprescindível ao crescimento tumoral e à metástase (RAMOS, 2008), razão pela qual será abordado nos parágrafos subsequentes.

\subsubsection{Angiogênese}

A angiogênese é um processo de formação de novos vasos sanguíneos, a partir de vasos preexistentes, processo este bastante complexo e regulado por diversos fatores pró e antiangiogênicos (FERRARA; KERBEL, 2005; DVORAK, 2005; CHAKROBORTY et. al., 2009). Quando em situações de normalidade, é um processo local, que pode ter duração de dias, como na ovulação; de semanas, como no reparo de tecidos/cicatrização; ou de meses, a exemplo do desenvolvimento embrionário (placentação). Todavia, em havendo processos patológicos, esse evento pode durar anos (NOWAK-SLIWINSKA; SEGURA; IRUELAARISPE, 2014; FOLKMAN, 2007; HOEBEN et. al., 2004).

Referido processo de formação de novos vasos sanguíneos de maneira patológica é, pois, condição sine qua non para o crescimento de tumores e suas metástases (RIBATTI et. al., 2011; FOLKMAN, 2007). Neste processo, as células tumorais liberam fatores de crescimento celular (por exemplo, o fator de crescimento do endotélio vascular - VEGF), ocasionando a migração de células endoteliais progenitoras de vasos sanguíneos vizinhos, em direção ao tumor (figura 1). O tumor recruta vasos para sua nutrição e consequente progressão, haja vista a hipóxia existente no interior dos tumores tão logo o mesmo atinge alguns milímetros cúbicos. $\mathrm{O}$ ambiente de hipóxia é formado em razão do acelerado metabolismo das células tumorais (THIJSSEN et. al., 2007). 
Figura 1: Esquema simplificado da angiogênese tumoral: alterações genéticas em uma célula conduz à evasão apoptótica e, consequentemente, a formação de massa tumoral (A); ao se tornarem insuficientes tanto o oxigênio, quanto os nutrientes, inicia-se o processo que viabiliza a angiogênese, sendo produzidos e liberados fatores de crescimento no entorno do tecido tumoral, os quais se ligam a receptores de crescimento nos vasos sanguíneos vizinhos ao tumor, então os pericitos ${ }^{1}$ se afastam, e ocorre a dilatação do vaso (B); ocorre a destruição da membrana basal por proteínas específicas denominadas proteases (C); por meio das fenestrações formadas, células do endotélio vascular são liberadas e proliferam em direção ao gradiente de fatores de crescimento (D); ocorre o início da formação dos novos vasos (E); há, por fim, a formação da estrutura basal do vasos, pelos pericitos $(\mathrm{F})$

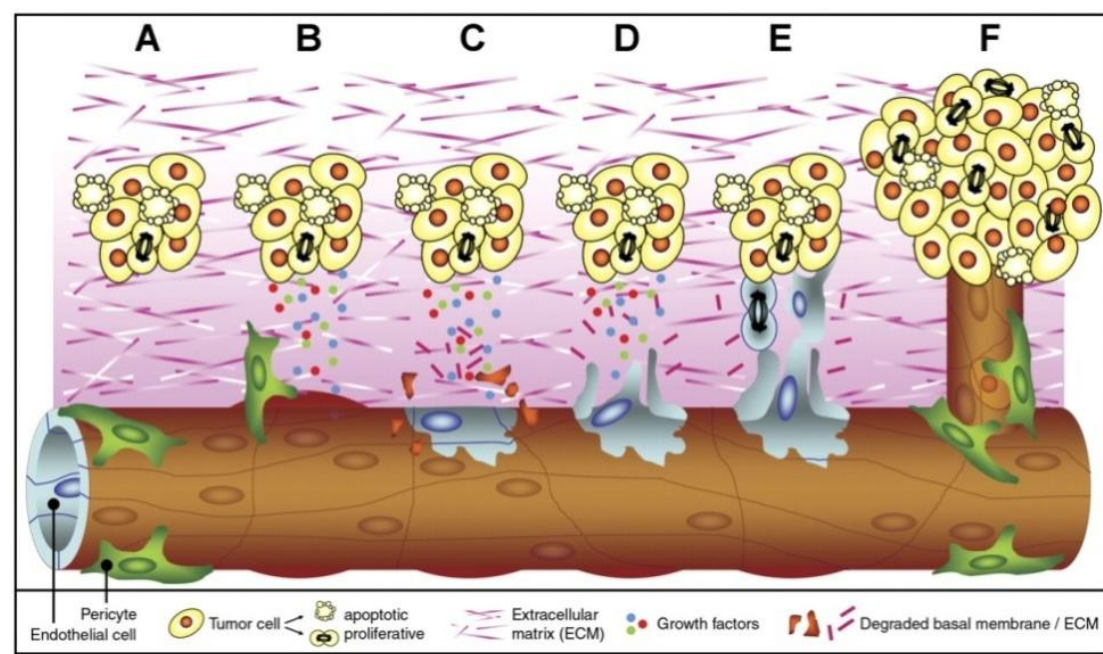

Fonte: THIJSSEN et. al., 2007

Além disso, a angiogênese patológica está relacionada - parcial ou totalmente com diversas doenças não neoplásicas, tais como psoríase, artrite reumatoide e aterosclerose (FOLKMAN, 2007). As descobertas de doenças outras influenciadas ou possibilitadas pela angiogênese patológica, conduziram à compreensão da angiogênese como um "princípio organizacional” (FOLKMAN, 2007), por meio do qual aspectos e sintomas variados, de doenças a priori não correlatas, podem estar relacionados. Consequência disso é que a melhor compreensão do fenômeno, bem como eventuais futuros fármacos, podem subsidiar o tratamento de diversas doenças.

A descoberta da relação existente entre diversas patologias - mormente o câncer e a angiogênese possibilitou uma verdadeira revolução nas pesquisas anticâncer. Todavia, esta relação nem sempre foi de trivial compreensão. Alguns eventos importantes para tal descobertas são narrados a seguir.

\footnotetext{
${ }^{1}$ Pericitos: são células vasculares consideravelmente indiferenciadas, mas que podem se diferenciar, as quais se encontram na membrana basal dos vasos sanguíneos e se localizam externamente ao vaso sanguíneo. Elas podem se diferenciar em células musculares lisas, macrófagos, etc.. São responsáveis pela integridade dos vasos e a sua perda pode levar à vasodilatação e à hemorragia (BERGERS; SONG, 2005).
} 
Em 1939, foi sugerido que os tumores eram capazes de expressar fatores específicos para o crescimento de vasos sanguíneos. Em 1945, em experimento pioneiro, notou-se, in vivo, que o tecido tumoral recrutava vasos sanguíneos em menor tempo e mais intensamente que tecido normal, implantado em gatos, sob as mesmas condições. Complementar ao experimento anterior, Melwin e Algire, em ensaio de implante de tecidos normais e cancerosos, notaram que naqueles, o processo de surgimento e recrutamento de novos vasos sanguíneos só ocorria quando os vasos sanguíneos do hospedeiro se encontravam em distância máxima de $50 \mu \mathrm{m}$, enquanto o tecido tumoral induziu resposta vasoproliferativa em distâncias maiores (IDE et. al., 1939; ALGIRE; CHALKLEY, 1945; MELWIN; ALGIRE, 1956 apud RIBATTI, 2008).

Então, Folkman e Becker (1963) notaram que células tumorais injetadas em órgãos perfundidos isolados, geravam tumores não maiores que $1-2 \mathrm{~mm}^{3}$, devido a não formação de novos vasos sanguíneos - uma vez que em tecidos isolados não há neovascularização -, confirmando a afirmação realizada em 1941, por outros pesquisadores, no sentido de que os tumores que cresceram e se desenvolveram, quando transplantados (de coelho para porco), recrutaram muitos novos vasos sanguíneos, enquanto aqueles para os quais não foram visualizados novos vasos sanguíneos no entorno, continuavam viáveis, mas não cresceram (HARRY; GREENE, 1941).

Folkman ousou, então, em 1971, postular que o crescimento tumoral era angiogênese-dependente e que o impedimento da angiogênese faria com que os tumores não crescessem além de 1 ou $2 \mathrm{~mm}^{3}$. O termo antiangiogênese também foi cunhado neste texto para significar a prevenção do crescimento de novos vasos sanguíneos (FOLKMAN, 1971; RIBATTI, 2008).

Compreendeu-se então, que os tumores são capazes de se manterem viáveis na ausência de neovascularização, com crescimento linear - quando observado - porém na presença de novos vasos sanguíneos, o crescimento é exponencial (RIBATTI, 2008). Além disso, a angiogênese pode ser considerada um parâmetro para o prognóstico de diversos tipos de câncer, haja vista o fato que a densidade de microvasos sanguíneos é aumentada consideravelmente quando em pacientes com metástases, bem como é possível, na fase inicial do tumor primário, por meio da densidade de vasos sanguíneos, selecionar pacientes para uma terapia mais intensa, logo no início do desenvolvimento tumoral (WEIDNER et. al., 1993). Por esta razão, tratamentos que associam compostos citotóxicos com inibidores da angiogênese surtem melhores resultados, pois se o crescimento tumoral é impedido, ou 
mantido de forma reduzida, a possibilidade de se conseguir resultados satisfatórios com fármacos antitumorais ou mesmo cirurgias, é aumentada.

Além disso, em razão de o processo de angiogênese ser limitado em adultos saudáveis, a utilização de terapia antiangiogênica oferece menos efeitos colaterais que as demais, bem como menos resistência (COOK; FIGG, 2010). Esta é, também, mais específica em razão de os vasos sanguíneos formados em angiogênese patológica geralmente serem mal formados, com constantes fenestrações as quais permitem mais facilmente a passagem de compostos que não atravessariam vasos em condições normais (BOZZUTO; MOLINARI, 2015; TRIPATHI et. al., 2015). Há que se considerar, ainda, que as células endoteliais tumorais expressam marcadores específicos, não expressos por células endoteliais normais, bem como se dividem mais rapidamente que as células não tumorais (COOK; FIGG, 2010; LUPO et. al., 2017).

Em recente revisão sobre o tema, Cook e Figg (2010) demonstraram os conhecidos receptores pró-angiogênicos envolvidos na angiogênese tumoral, dos quais os principais são do tipo tirosina-quinases (RTKs) ${ }^{2}$, (do inglês receptor tirosin kinases), os quais são proteínas transmembrana - as quais possuem domínio extracelular, conectado ao domínio intracelular por uma única hélice proteica transmembrana - que comunicam sinais extracelulares (por exemplo, os fatores de crescimento celular) com o ambiente intracelular e estão envolvidos em diversos eventos celulares, tais como migração, proliferação e na angiogênese especificamente. Atuam produzindo cascatas de eventos intracelulares, os quais culminam na transcrição gênica: são ativados pela ligação de um fator de crescimento ao domínio extracelular da proteína, o que ocasiona sua dimerização e posterior fosforilação; o receptor já fosforilado interage com diversas moléculas citoplasmáticas, ocasionando a transdução de sinal e, consequentemente, processos como a angiogênese (entre outros). Qualquer alteração, na regulagem deste tipo de receptor, pode ocasionar a mutação de uma célula (COOK; FIGG, 2010; RANG et. al., 2016; FERRARA; GERBER; LECOUTER, 2003).

\footnotetext{
${ }^{2} \mathrm{O}$ grupo de receptores tirosina-quinase, pertence a um grupo maior de receptores, denominados: receptores ligados à quinases. Eles intermediam as ações de uma grande variedade de proteínas mediadoras, tais como fatores de crescimento e citocinas, entre outros. São constituídos, geralmente, por cadeias únicas e grandes (de até 1000 resíduos de aminoácidos) de proteínas. Possuem em comum o fato de terem uma única região helicoidal transmembrana, a qual se constitui no elo de ligação entre o domínio intra e o extracelular, bem como o fato de possuírem uma proteína quinase no domínio intracelular, capaz de transferir grupos fosfato e fazer a autofosforilaração do receptor. Neste grupo de receptores, estão incluídos, entre outros, os receptores tirosinaquinase (fosforilam grupos de tirosina); os receptores de serina/treonina-quinase (fosforilam grupos de serina ou de treonina); e os receptores de citocinas (não possuem atividade enzimática intrínseca, ativam, pois, diversas quinases) (RANG et. al., 2016).
} 
Figura 2: Receptor tirosina-quinase e ativação de sua via de sinalização

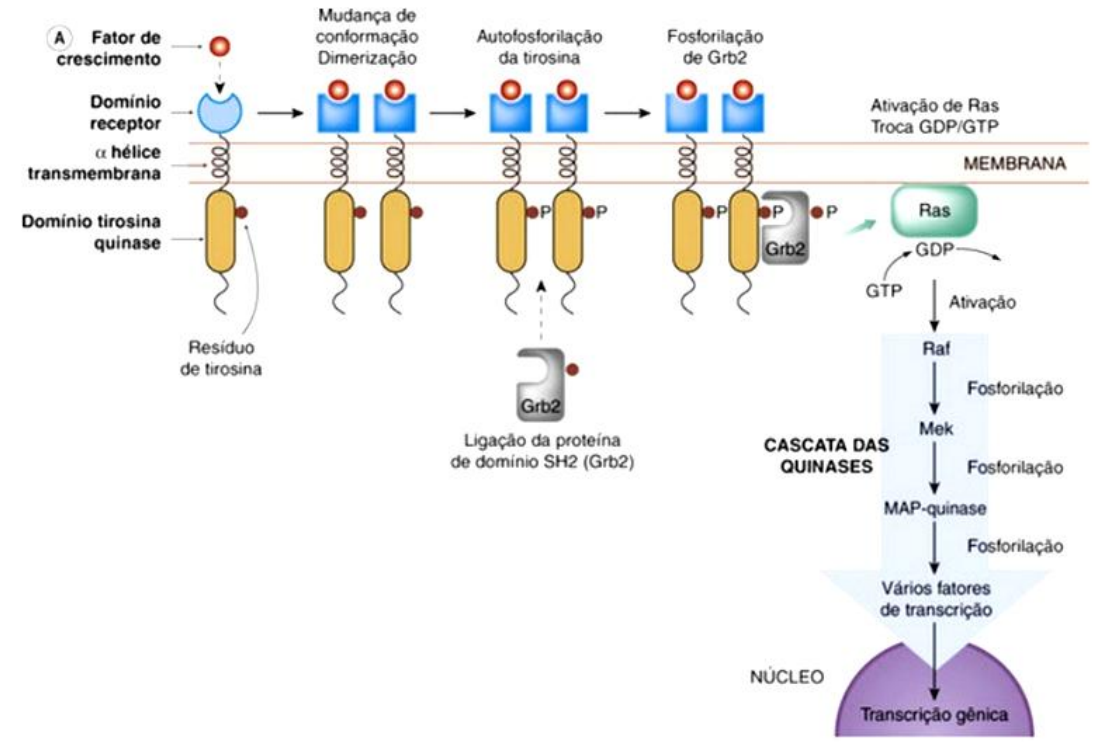

Fonte: RANG et. al., 2016

São muitos os RTKs, bem como seus respectivos ligantes, e a abordagem de todos não é o objetivo deste trabalho. No entanto, alguns dos fatores de crescimento relacionados a este tipo de receptores serão abordados a seguir: o fator de crescimento endotelial vascular $(\text { VEGF })^{3}$ - vascular endothelial growth factor, bem como seu receptor tirosina quinase, são considerados essenciais na angiogênese e atuam, especificamente, na migração celular, proliferação e sobrevivência, sendo que a isoforma VEGF- $\mathrm{A}_{165}$ é comumente superexpressa em diversos tumores e tal superexpressão pode ser associada com a progressão e a metástase. Ao ser expresso pelas células tumorais, o VEGF-A interage na membrana celular, em receptores de células endoteliais vasculares e células derivadas da medula óssea (COOK; FIGG, 2010). O VEGF-A e seu receptor VEGFR-2 constituem-se, atualmente, os principais marcadores de angiogênese, bem como os alvos principais das terapias referentes à angiogênese; o fator de crescimento derivado de plaquetas (PDGF) - platelet-derived growth factor e seus receptores (PDGFR) são conhecidos por participarem da maturação vascular e do recrutamento de pericitos, sendo a superexpressão deste fator e do seu receptor encontradas em tumores, principalmente metastáticos, no entanto, seu papel na angiogênese não está completamente elucidado (CAO; CAO; HEDLUND, 2008; COOK; FIGG, 2010); o fator de crescimento de fibroblasto (FGF) - fibroblast growth factor, é um conjunto de 23

\footnotetext{
${ }^{3}$ O VEGF constitui, de fato, uma família de no mínimo sete fatores de crescimento. No entanto, o mais conhecido, com atividade na angiogênese, e ao qual se faz referência quando a expressão "VEGF é utilizada é o VEGF-A, o qual é encontrado em quatro diferentes isoformas, $\mathrm{VEGF}_{121}, \mathrm{VEGF}_{165}, \mathrm{VEGF}_{189}$ e $\mathrm{VEGF}_{206}$, sendo a isoforma VEGF 165 a mais abundante". (COOK; FIGG, 2010; FERRARA; GERBER; LECOUTER, 2003).
} 
proteínas, as quais atuam na proliferação, migração e diferenciação das células do endolétio vascular. Sobre estas proteínas têm sido reportado que estão superexpressas em células tumorais (CAO; CAO; HEDLUND, 2008; COOK; FIGG, 2010); o fator de crescimento epidérmico (EGF) - epidermal growth factor: é uma família de 11 fatores, os quais juntamente com seus quatro receptores estão envolvidos no processo de angiogênese, todavia de forma indireta, atuando para estimular a expressão de outros fatores pró-angiogênicos, tais como VEGF, interleucina-8 (IL-8) (DE LUCA et. al., 2008; HOEBEN et. al., 2004).

Há ainda outros fatores que estão envolvidos na angiogênese, tais como o fator de crescimento transformador $\beta$ (TGF- $\beta$ ) - transforming growth factor; angiopoietina e seus receptores tirosina-quinase (TIE) e o fator indutor de hipóxia (HIF) - hypoxia inducible factor $^{4}$.

Moléculas inibidoras de receptores de tirosina-quinases se encontram em diversos estágios de desenvolvimento: alguns já aprovados para uso, outros em fase pré-clínica e clínica (COOK; FIGG, 2010; FERRARA; GERBER; LECOUTER, 2003).

Esses receptores são alvos interessantes na terapia antiangiogênica contra o câncer, haja vista o fato de inibirem tanto a transdução de sinais de oncoproteínas, quanto a angiogênese, bem como serem capazes de produzir efeitos tanto em células endoteliais, quanto em células cancerosas, uma vez que ambas expressam este tipo de receptor.

Os primeiros inibidores do processo de angiogênese foram reportados nos anos 80, (FOLKMAN, 2007; RIBATTI, 2008) e, antes disso não se acreditava existirem compostos capazes de atuarem nessa inibição. Desde então, a busca por novas espécies antiangiogênicas, bem como a compreensão de como o processo completo funciona, têm se tornado linha de pesquisa de diversos grupos em todo o mundo, culminando na aprovação do primeiro fármaco com função exclusiva de inibição da angiogênese, Bevacizumab, o qual foi aprovado para uso em casos de câncer colorretal em 2004 (FOLKMAN, 2007). No entanto, este medicamento, vendido sob o nome comercial Avastin ${ }^{\circledR}$ (Roche Holding AG), inibe somente um dos fatores pró-angiogênicios, o VEGF (FOLKMAN, 2007). Posteriormente, outros fármacos antiangiogênicos surgiram, tais como Sutent ${ }^{\circledR}$ (Pfizer) - o qual inibe, além do receptor de VEGF, o receptor do fator de crescimento derivado de plaquetas (PDGFR) - do

\footnotetext{
${ }^{4}$ Importante destacar que os mecanismos descritos podem operar cooperativamente, ou seja, há efeitos sinérgicos de todos os fatores de crescimento, os quais não estão elucidados em sua totalidade (CAO; CAO; HEDLUND, 2008; COOK; FIGG, 2010)
} 
inglês platelet-derived growth factor receptors - e o receptor de proteína tirosina quinase (cKIT) - também chamado de receptor de fator de células tronco ou CD117 (NIH, 2017).

Ademais, em 1998 foi publicado que a neuropilina - que é receptor de membrana orientador do crescimento neuronal, é também receptor de VEGF (FOLKMAN, 2007). A partir de então, começou a ser creditada a hipótese de que o desenvolvimento neuronal, a neurogênese, estaria relacionada (também) à angiogênese (SOKER et. al., 1998). Considerando-se que as catecolaminas estão diretamente relacionadas à atividade neuronal, a hipótese de atuarem igualmente nos mecanismos de angiogênese foi suscitada (NOWAKSLIWINSKA, 2011; DALEPRANE, 2011).

O controle do processo de angiogênese é de suma importância, uma vez que é possível inibir o crescimento do tumor, através da redução do acesso ao oxigênio e nutrientes (BASU et. al., 2005), com consequente prevenção do seu crescimento. É possível, ainda, simultaneamente, associar esta inibição com outras drogas, tais como drogas que matam as células tumorais pela produção localizada de espécies reativas de oxigênio (como na terapia fotodinâmica), que pode resultar em citotoxicidade através de mecanismos de estresse oxidativo, produzindo a morte celular direta (BOWN, 2013).

Assim, entendendo-se que o controle da angiogênese funciona como um considerável bloqueio à progressão, bem como à reincidência tumoral, pesquisas que investiguem novas possibilidades de desenvolvimento de terapia antiangiogênica são de suma importância, tanto no sentido de se compreender mecanismos, quanto de se encontrar moléculas alvos para o controle da angiogênese, uma vez que permitiria a propositura de mais opções terapêuticas. $\mathrm{E}$, dentre os muitos fatores que regulam a angiogênese, a hipótese da importância das catecolaminas e sua atuação merecem destaque (NOWAK-SLIWINSKA, 2011; DALEPRANE, 2011; RIBATTI, 2011).

\subsubsection{Catecolaminas}

Quimicamente, catecolaminas são moléculas que contêm grupos amina e catecol. As catecolaminas endógenas são derivadas do aminoácido tirosina (SARKAR; CHAKROBORTY; BASU, 2013). A dopamina, noradrenalina e adrenalina são as catecolaminas endógenas mais importantes para os seres humanos e o isoproterenol é uma catecolamina sintética, amplamente utilizada em medicamentos. Este é também conhecido como isoprenalina, enquanto noradrenalina e adrenalina também são conhecidas, 
respectivamente, como a norepinefrina e epinefrina - noradrenalina e adrenalina são expressões derivadas do inglês britânico (RANG et. al., 2016).

A noradrenalina é o principal neurotransmissor da maioria das fibras pósglangionares do sistema nervoso autônomo simpático e de algumas partes do sistema nervoso central; enquanto a dopamina é o neurotransmissor principal de várias vias neuronais do sistema nervoso dos mamíferos (mesocorticais e mesolímbicas), sendo esta predominante no sistema nervoso central, no que se refere às catecolaminas; e a adrenalina é o principal hormônio da medula suprarrenal e encontrada em pequenas quantidades no sistema nervoso central, sendo que sua atuação neste último permanece desconhecida (BRUNTON; CHABNER; KNOLLMAN, 2011; BRUNTON et. al., 2010).

As catecolaminas são moléculas dioxoleno e, as endógenas são sintetizadas, principalmente, no cérebro e na medula adrenal, mas são também sintetizadas em células do intestino (não neuronais), plaquetas e linfócitos. A síntese endógena é catalisada por diversas enzimas e cada uma das catecolaminas funciona como precursor para a síntese da outra. Do aminoácido tirosina é sintetizada DOPA, a qual - em reação catalisada pela dopa descarboxilase - é convertida em dopamina. Pela ação da enzima $\beta$-hidroxilase, a dopamina é transformada em noradrenalina. Posteriormente, pela ação de N-metiltransferase, a molécula de noradrenalina é transformada em adrenalina. Este último passo da síntese ocorre somente na medula suprarrenal e em algumas vias neuronais que contém adrenalina, na parte do tronco cerebral, enquanto todas as etapas anteriores ocorrem em nervos simpáticos de forma disseminada. As etapas desta biossíntese são mostradas no esquema a seguir (BRUNTON et. al., 2010; RANG et. al., 2016) (figura 3): 
Figura 3: Etapas da biossíntese das catecolaminas

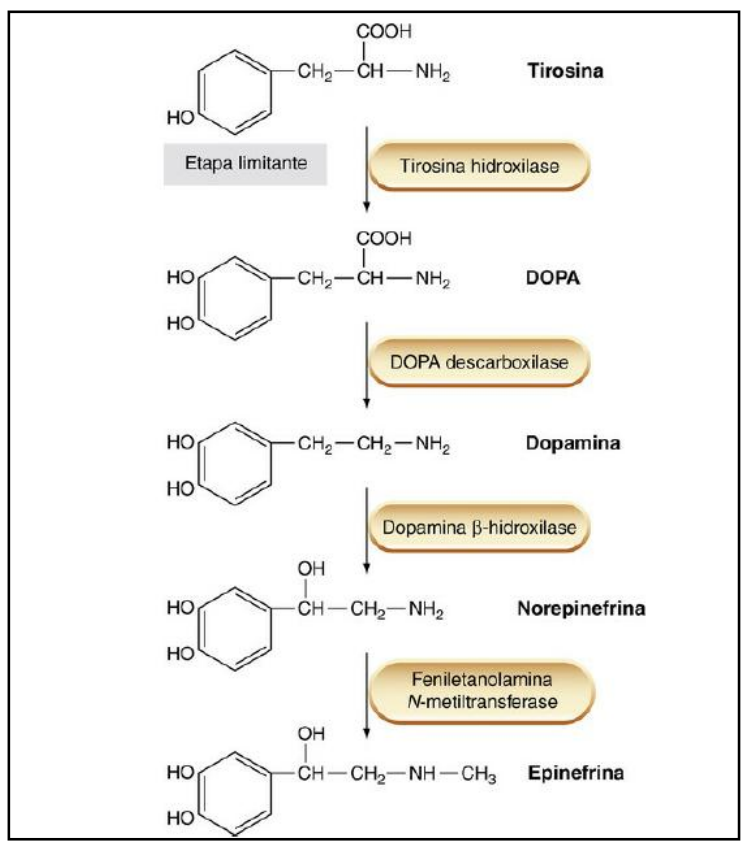

Fonte: RANG et. al., 2016

Após suas sínteses, as catecolaminas são mantidas em vesículas e somente liberadas, controladamente, quando houver estímulos específicos ${ }^{5}$; uma vez liberadas na corrente sanguínea, após produzirem seus efeitos, as catecolaminas são recapturadas para o interior das células. As moléculas que permanecem circulantes são degradadas, porém lentamente. As vias comuns de degradação das catecolaminas são por enzimas que se encontram no interior das células, portanto, a captação é precedente, via de regra, ao metabolismo e à degradação. Existem duas principais vias de captação das catecolaminas do sangue, a captação neuronal (1) e a extraneuronal (2) - esta última ocorre nos músculos liso e cardíaco e no endotélio. Na captação neuronal a velocidade é mais lenta, porém mais seletiva para noradrenalina; na captação extraneuronal há menor seletividade e maior velocidade (RANG; DALE, 1993).

Existem transportadores que realizam essa captura das catecolaminas: o transportador vesicular de monoaminas (TVMA-2), o qual é inespecífico, transportando tanto as catecolaminas em comento como a serotonina, enquanto os transportadores de membrana neuronal são mais específicos, sendo conhecidos o transportador de noradrenalina (TNE) e o transportador de dopamina (TDA). O TNE possui afinidade tanto com noradrenalina (maior),

\footnotetext{
${ }^{5}$ É conhecido que o evento que desencadeia a liberação das catecolaminas é o aumento da concentração intracelular de cálcio, $\left[\mathrm{Ca}^{2+}\right]_{i}$. No entanto os mecanismos completos pelos quais estes eventos ocorrem ainda se encontram apenas parcialmente elucidados (BRUNTON et. al., 2010).
} 
quanto com adrenalina (menor). Devido à maior especificidade, geralmente os transportadores de membrana são alvos de fármacos, por exemplo, a fluoxetina. (BRUNTON et. al., 2010).

As catecolaminas atuam como neurotransmissores e hormônios circulantes e, sua ação pode ocorrer em diversos órgãos e sistemas, dependendo do(s) receptor(es) com o(s) qual(is) elas estejam interagindo. As catecolaminas atuam como agonistas em três diferentes classes de receptores: a noradrenalina, a adrenalina e o isoproterenol atuam em receptores do tipo $\alpha\left({ }_{1} \mathrm{e}_{2}\right)$ e/ou $\beta\left({ }_{1}, \mathrm{e}_{3}\right)$ adrenérgicos, a dopamina, por sua vez, age como agonista nos receptores do tipo $\mathrm{D}_{1}$ e $\mathrm{D}_{2}$ (SARKAR; CHAKROBORTY; BASU, 2013; EISENHOFER; KOPIN; GOLDSTEIN, 2004).

Para melhor compreensão dos receptores, breves considerações são necessárias. Na definição de Rang (et. al., 2016, p. 39), receptores são

$$
\begin{aligned}
& \text { moléculas-alvo por meio das quais os mediadores fisiológicos solúveis - hormônios, } \\
& \text { neurotransmissores, mediadores inflamatórios etc. - produzem seus efeitos (...) e o } \\
& \text { termo receptor geralmente indica uma molécula de reconhecimento para um } \\
& \text { mediador químico através do qual uma resposta é traduzida. }
\end{aligned}
$$

Existem, atualmente, quatro tipos de receptores conhecidos e classificados. São eles: canais iônicos controlados por ligantes diretos; receptores acoplados à proteína G; receptores associados às quinases ${ }^{6}$; receptores nucleares, que são receptores de esteroides, os quais podem interagir diretamente com o DNA, regulam, portanto, a transcrição gênica, no entanto, boa parte destes receptores ainda permanecem órfãos, pois ainda não são conhecidos ligantes para os mesmos (RANG et. al., 2016). Uma representação dos quatro tipos de receptores conhecidos é mostrada a seguir (figura 4):

\footnotetext{
${ }^{6}$ Vide definição anterior ${ }^{2}$.
} 
Figura 4: Representação dos quatro tipos de receptores

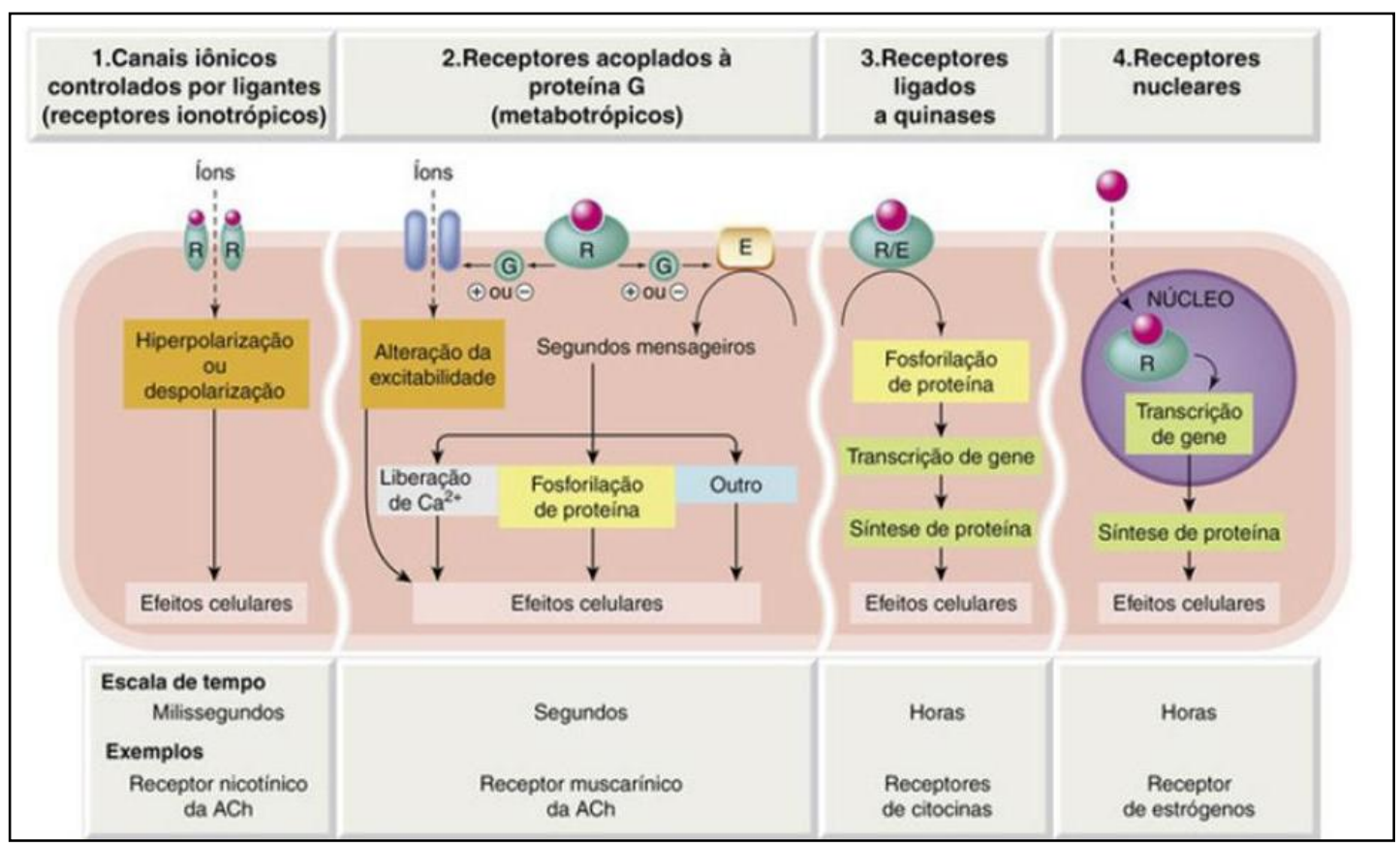

Fonte: RANG et. al., 2016

A maioria dos receptores conhecidos pertence ao tipo "receptores acoplados à proteína G", sendo que os principais são os receptores muscarínicos (da acetilcolina),

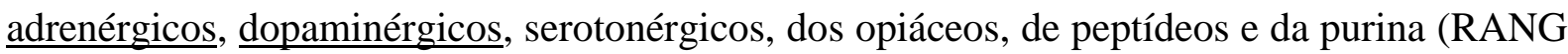
et. al., 2016) (grifos nossos). Tais receptores possuem estrutura hepta-helicoidal (sete hélices transmembranares) e, via de regra, possuem somente uma cadeia de peptídeos, com quantidade de resíduos de aminoácidos que varia de 350 a $400^{7}$. A interação dos receptores com a proteína $\mathrm{G}^{8}$ ocorre na terceira hélice, na parte intracelular (RANG et. al., 2016).

Após sua ativação/alteração conformacional induzida pelos receptores, as proteínas $G$ têm a sua subunidade $\alpha$ dissociada das subunidades $\beta \gamma$ e as subunidades (ora $\alpha$, ora $\beta \gamma$ ) interagem para ativar diversos alvos específicos, dos quais os principais são: adenilil ciclase, uma enzima que catalisa a formação de 3',5'-monofosfato cíclico de adenosina (AMPc); fosfolipase $\mathrm{C}$, que é também uma enzima, mas esta é atuante em sintetizar trifosfato de inositol $\left(\mathrm{IP}_{3}\right)$, o qual promove o aumento de $\left[\mathrm{Ca}^{2+}\right]_{\mathrm{i}}$ no citosol, e diacilglicerol (DAG);

\footnotetext{
${ }^{7}$ Há alguns com até 1100 resíduos (RANG et. al., 2016).

${ }^{8}$ Proteína $\mathrm{G}$ é na verdade uma família de proteínas de membrana, cuja estrutura compreende três subunidades $(\alpha$, $\beta, \gamma$ ), com a subunidade $\alpha$ apresentando atividade GTPásica. Quando o trímero se liga a um receptor ocupado por um agonista, a subunidade $\alpha$ se liga a GTP, dissocia-se e, então, fica livre para ativar um efetor (p. ex., uma enzima de membrana). Em alguns casos, a subunidade $\beta \gamma$ é a espécie ativadora. A ativação do efetor termina quando ocorre a hidrólise da molécula de GTP ligada, o que permite que a subunidade $\alpha$ se recombine com $\beta \gamma$. Existem vários tipos de proteína $\mathrm{G}$, que interagem com diferentes receptores e controlam diferentes efetores (RANG et. al., 2016, p. 101).
} 
canais iônicos, principalmente aqueles para potássio e cálcio; proteína quinase ativada por mitógenos (MAPK - do inglês mitogen activated protein kinase); e outros (RANG et. al., 2016).

$O$ fato de uma variedade de receptores serem acoplados às proteínas $G$, não impede que seus efeitos sejam bastante diversificados e, não raramente, opostos. No entanto, por se tratar de trabalho que tange às catecolaminas, serão enfatizados nas linhas subsequentes apenas os receptores adrenérgicos $\alpha$ e $\beta$ e, posteriormente, os dopaminérgicos.

As catecolaminas possuem diferentes ordens de potência, dependendo dos receptores. Nas respostas envolvendo os receptores do tipo $\alpha_{1}$, o agonista mais potente é noradrenalina, para os receptores $\alpha_{2}$, a adrenalina e, para os três tipos de receptores $\beta$, o isoproterenol:

Tabela 1: Ordem da potência dos agonistas nos receptores adrenérgicos

\begin{tabular}{cl}
\hline Receptor & \multicolumn{1}{c}{ potência dos agonistas } \\
\hline \hline$\alpha_{1}$ & noradrenalina $>$ adrenalina $>>$ isoproterenol \\
$\alpha_{2}$ & adrenalina $>$ noradrenalina $>$ isoproterenol \\
$\beta_{1}$ & isoproterenol $>$ noradrenalina $>$ adrenalina \\
$\beta_{2}$ & isoproterenol $>$ adrenalina $>$ noradrenalina \\
$\beta_{3}$ & isoproterenol $>$ noradrenalina $~$ adrenalina \\
\hline
\end{tabular}

Fonte: Adaptado de RANG et. al., 2016

Entre os receptores do tipo $\alpha_{1}$, a literatura reporta que existem três subtipos $\alpha_{1 \mathrm{~A}}$, $\alpha_{1 \mathrm{~B}}$ e $\alpha_{1 \mathrm{D}}$, enquanto os do tipo $\alpha_{2}$ são classificados em $\alpha_{2 \mathrm{~A}}, \alpha_{2 \mathrm{~B}}$ e $\alpha_{2 \mathrm{C}}$ (RANG et. al., 2016). Entretanto a distinção entre os efeitos proporcionados por cada um deles e sua localização nos diferentes tecidos ainda permanecem não totalmente esclarecidos (BRUNTON; CHABNER; KNOLLMAN, 2011).

No que se refere à ação dos receptores adrenérgicos, é conhecido que os receptores do tipo $\alpha_{1}$ atuam, principalmente, nos vasos sanguíneos, nos brônquios, nos esfíncteres gastrointestinais e da bexiga, no útero e nas vias seminais. Agem ativando a enzima fosfolipase $\mathrm{C}$, a qual produz $\mathrm{IP}_{3}$ e DAG, culminando na liberação de $\left[\mathrm{Ca}^{2+}\right]_{\mathrm{i}}$ (RANG et. al., 2016). Seus principais efeitos são a vasoconstrição, a constrição dos brônquios e a contração de todos os demais órgãos mencionados, diferentemente do trato gastrointestinal, no qual possuem efeito de relaxamento dos músculos lisos. Estes receptores são acoplados às proteínas $\mathrm{G}$ do tipo $\mathrm{G}_{\mathrm{q}}, \mathrm{G}_{\mathrm{i}} / \mathrm{G}_{0}$ (RANG et. al., 2016; BRUNTON et. al., 2010). 
Os receptores do tipo $\alpha_{2}$ atuam, principalmente, em vias neuronais e inibindo a liberação de neurotransmissores (colinérgicos e adrenérgicos). São eles responsáveis por reduzir a formação de AMPc, uma vez que "negativamente acoplados" à adenilil ciclase, culminando na inibição dos canais para $\mathrm{Ca}^{2+}$ e ativando os canais para $\mathrm{K}^{+}$. Atuam promovendo tanto a constrição, a agregação plaquetária e a diminuição da secreção de insulina. Tais receptores são acoplados às proteínas $\mathrm{G}$ do tipo $\mathrm{G}_{\mathrm{i} 1,2}$ ou 3 ou $\mathrm{G}_{0}$ (RANG et. al., 2016; BRUNTON et. al., 2010).

Por sua vez, os três receptores do tipo $\beta$ têm ação por estímulo da adenilil ciclase. Os receptores do tipo $\beta_{1}$ atuam no músculo cardíaco, sendo responsáveis pelos efeitos ionotrópicos e cronotrópicos, que culminam no aumento da força e da frequência cardíacas. Os receptores $\beta_{2}$ promovem o relaxamento dos músculos lisos dos órgãos internos, a glicólise hepática e a dilatação dos vasos sanguíneos e dos brônquios. Por sua vez, os receptores $\beta_{3}$ agem causando efeitos relacionados à termogênese e lipólise, bem como relaxando a musculatura do músculo detrusor da bexiga. Todos estes receptores são acoplados a proteínas G do tipo $\mathrm{G}_{\mathrm{s}}$ (RANG et. al., 2016; BRUNTON et. al., 2010).

De um modo geral, os receptores $\alpha$ e $\beta$ são expressos tanto em células dos músculos liso e estriado cardíaco, quanto em terminações nervosas e células endoteliais, logo, exatamente por possuírem (não raramente) efeitos opostos, suas ações nas respostas aos estímulos, quando ativados simultaneamente - por fármacos, por exemplo - estão apenas parcialmente elucidadas. E, como se pode averiguar em tabela anteriormente apresentada (tabela 1), as mesmas catecolaminas noradrenalina e adrenalina são agonistas em todos os tipos de receptores $\alpha$ e $\beta$-adrenérgicos, forçando à conclusão de se tratar (apenas) de seletividade relativa, entre a maioria dos agonistas dos receptores ora mencionados (RANG et. al., 2016; BRUNTON et. al., 2010).

Os receptores dopaminérgicos são de suma importância e estão relacionados a diversas doenças, tais como a esquizofrenia, o Mal de Parkinson, o Mal de Alzheimer, e o déficit de atenção, sendo localizados no sistema nervoso central. Uma das diferenças em relação aos receptores adrenérgicos está no fato de que os neurônios dopaminérgicos não possuem em sua estrutura a enzima responsável pela conversação de dopamina em noradrenalina, a $\beta$-hidroxilase. São conhecidos duas famílias de receptores dopaminérgicos, denominadas $\mathrm{D}_{1}$ e $\mathrm{D}_{2}$ (RANG et. al., 2016).

Na primeira família, $\mathrm{D}_{1}$, os quais são acoplados à proteína $\mathrm{G}_{\mathrm{s}}$, estão compreendidos os receptores $\mathrm{D}_{1}$ e $\mathrm{D}_{5}$ e a ação destes receptores é via ativação da produção de AMPc, por 
ligação com a adenilil ciclase. Na segunda família, $\mathrm{D}_{2}$, estão os receptores $\mathrm{D}_{2}, \mathrm{D}_{3} \mathrm{e} \mathrm{D}_{4}$. Estes últimos atuam regulando negativamente a adeninil ciclase e, consequentemente, a produção de AMPc, resultando na inibição dos canais para $\mathrm{Ca}^{2+}$ e ativando os para $\mathrm{K}^{+}$. Os receptores da família $\mathrm{D}_{2}$ são acoplados à outra proteína $\mathrm{G}, \mathrm{a}_{\mathrm{i}}$. A afinidade da dopamina pelos receptores dopaminérgicos segue a seguinte ordem: $\mathrm{D}_{1} \sim \mathrm{D}_{2}>\mathrm{D}_{4}>\mathrm{D}_{5}>\mathrm{D}_{3}$ (BRUNTON et. al., 2010; RANG et. al., 2016).

Conhecendo-se a atuação das catecolaminas nos diversos receptores e, considerando-se que a noradrenalina é o mais potente agonista para o receptor $\alpha_{1}$, adrenalina o principal agonista para $\alpha_{2}$, isoproterenol, para $\beta_{1,2}$ e 3 , e dopamina para os receptores dopaminérgicos, tornam-se passíveis de serem compreendidos os efeitos modulados por estas moléculas e seu uso na terapia.

Sendo assim, a adrenalina atua como um forte vasoconstritor, ocasionando aumento da pressão arterial, com efeito predominante nas arteríolas e esfíncteres précapilares, o que ocasiona a redução do fluxo sanguíneo cutâneo, também causa aumento da frequência e do débito cardíacos, do consumo de oxigênio, da frequência da respiração, e do fluxo sanguíneo cerebral e muscular, no sistema nervoso central, esta catecolamina produz poucos efeitos, podendo ocasionar inquietação e cefaleia. A noradrenalina promove aumentos do fluxo sanguíneo coronariano, da pressão arterial, da resistência periférica total e da respiração. Por sua vez, a dopamina, quando em concentrações razoáveis, promove o aumento da pressão (sistólica), quando em concentrações altas, promove a vasoconstrição generalizada. No sistema nervoso central, a dopamina (administrada) não promove efeitos, em razão de não atravessar a membrana hematoencefálica. Por fim, no que se refere ao isoproterenol, a sua administração produz redução da pressão arterial, aumento do débito cardíaco e relaxamento dos músculos lisos, evidente, principalmente, nos brônquios (BRUNTON et. al., 2010; BRUNTON; CHABNER; KNOLLMAN, 2011)

Em relação ao metabolismo das catecolaminas, têm-se duas principais enzimas que degradam as catecolaminas: a monoaminooxidase (MAO) e a catecol- $O$-metiltransferase (COMT). Esta se encontra presente na medula suprarrenal e em várias outras células, porém ausente nos neurônios, enquanto aquela está presente, em grande quantidade, nas terminações nervosas noradrenérgicas, no fígado e também em células do epitélio intestinal, entre outras. A MAO encontra-se conectada à membrana das mitocôndrias (RANG et. al., 2016).

A MAO promove a conversão das catecolaminas em aldeídos, enquanto a COMT promove a metilação das mesmas. Depois de algumas etapas, os principais metabólitos são o 3-metoxi-4-hidroxifeniletilenoglicol (MOPEG ou MHPG) e o ácido 3-metoxi-4- 
hidroximandélico (VMA) (EISENHOFER; KOPIN; GOLDSTEIN, 2004). Nas palavras de Brunton e colaboradores (2010, p. 107):

A norepinefrina e a epinefrina são primeiramente desaminadas por conversão, mediante a ação da monoaminoxidase (MAO), em 3,4-diidroxifenilglicoaldeído (DOPGAL) e, em seguida, reduzidas a 3,4-diidroxifeniletilenoglicol (DOPEG) ou oxidadas em ácido 3,4-diidroximandélico (DOMA). Alternativamente, podem ser inicialmente metiladas pela catecol- $O$-metiltransferase (COMT) em normetanefrina e metanefrina, respectivamente. Em seguida, a maior parte dos produtos de qualquer destas enzimas é metabolizada por outras enzimas para formar os principais produtos de excreção no sangue e na urina, o 3-metoxi-4-hidroxifeniletilenoglicol (MOPEG ou MHPG) e o ácido 3-metoxi-4-hidroximandélico (ácido vanililmandélico, VMA). O MOPEG livre é, em sua maior parte, convertido em VMA. O glicol e, até certo ponto, as aminas $O$-metiladas bem como as catecolaminas podem ser conjugados aos seus correspondentes sulfatos e glicorunídios.

Figura 5: Principais vias de degradação da noradrenalina e da adrenalina

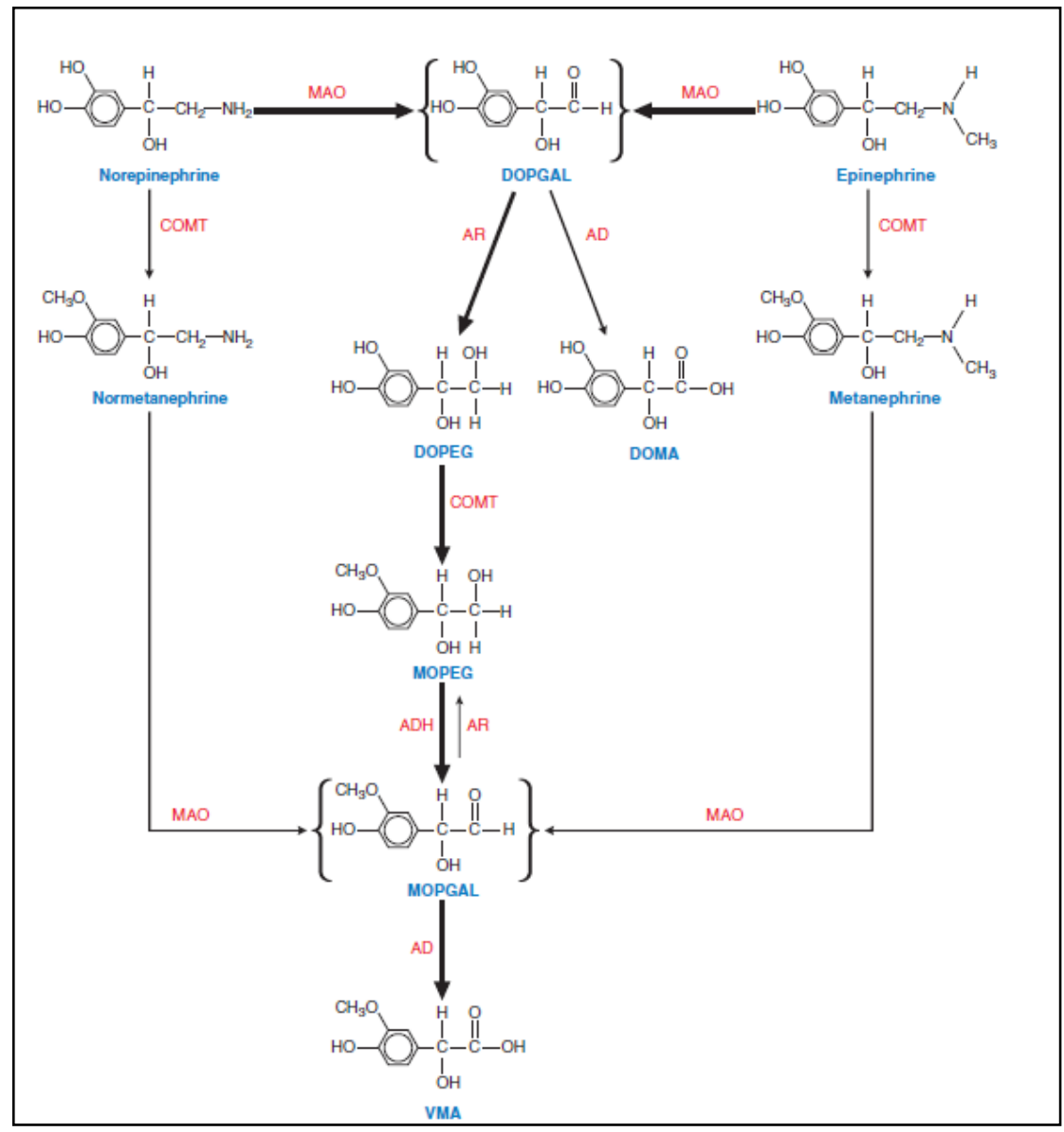

Fonte: BRUNTON; CHABNER; KNOLLMAN, 2011 
Em relação à dopamina, a degradação é semelhante (figura 6), no entanto os principais produtos são o ácido dihidroxifenilacético (ADHFA) e o ácido homovanílico (AHV).

Figura 6: Principais vias de degradação da dopamina

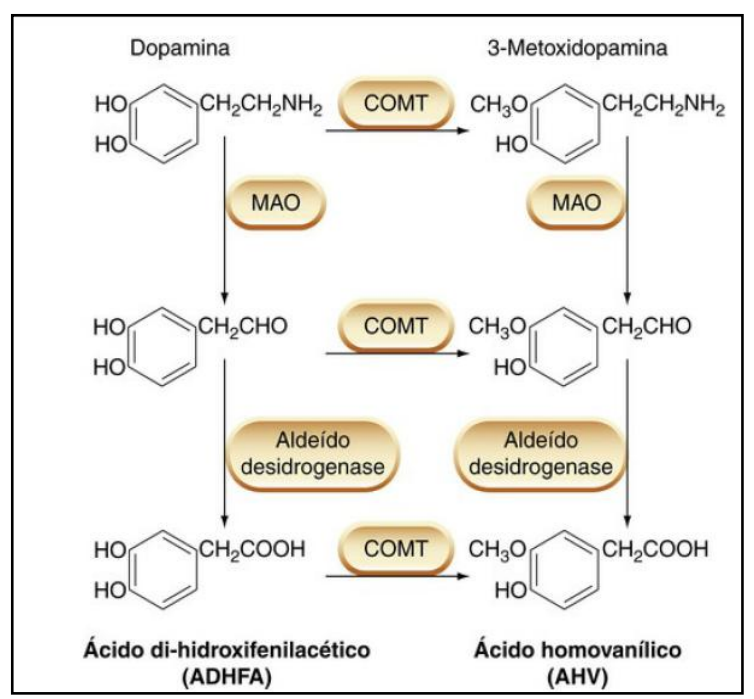

Fonte: RANG et. al., 2016

Há que se considerar, ainda, as modificações as quais podem ser feitas nas moléculas das catecolaminas ${ }^{9}$, a fim de se obter o efeito desejado, quando do desenho de uma droga (RANG; DALE, 1993):

$\checkmark$ Aumentando-se o tamanho dos substituintes no átomo de nitrogênio, o resultado consiste em compostos com maior potência, maior atividade como agonistas $\beta$, bem como com menor possibilidade de serem degradados pela enzima MAO e pela via de captação neuronal (1);

$\checkmark \mathrm{O}$ acréscimo de um grupamento $\alpha$-metílico intensifica a seletividade para os receptores deste tipo $(\alpha)$, de modo que os tornam mais impedidos à via de degradação pela MAO, no entanto continuam passíveis de serem objetos de captação pela via neuronal;

$\checkmark$ A ausência da hidroxila na posição $\beta$ da cadeia carbônica reduz a interação com os receptores adrenérgicos - o que resulta, no caso da noradrenalina, na molécula de dopamina, sendo que "a maioria das aminas simpatomiméticas de ação direta e os

\footnotetext{
${ }^{9}$ Considerações sempre em relação à molécula de noradrenalina.
} 
antagonistas dos receptores $\beta$ (embora nem todos sejam antagonistas dos receptores $\beta$ ) retém este grupo OH crítico" (RANG; DALE, 1993, p. 121);

$\checkmark$ Quando são efetuadas substituições dos grupamentos hidroxilas do anel aromático (por outros "removedores de elétrons ou sua transferência para diferentes posições do anel"), os compostos perdem a afinidade com a enzima COMT, no entanto, a atividade nos receptores é preservada. Via de regra, a substituição dos grupos $-\mathrm{OH}$ catecólicos resulta em compostos que não são captados pela via neuronal (1) (RANG; DALE, 1993, p. 121);

$\checkmark$ A retirada de um ou dois dos grupos $-\mathrm{OH}$ (tiramina, anfetamina, efedrina) resulta em perda da afinidade dos compostos com os respectivos receptores, "embora continuem sendo aminas simpaticomiméticas de ação indireta, uma vez que são substratos de captação 1”(RANG; DALE, 1993, p. 121);

$\checkmark$ Por sua vez, modificações nas cadeias alquílicas ligadas ao átomo de nitrogênio e nos grupos $-\mathrm{OH}$ catecólicos, resultam em antagonistas (com maior potência) dos receptores $\beta$-adrenérgicos.

Diante da concisa exposição feita em relação às catecolaminas (biossíntese, efeitos, captação, metabolismo/degradação, etc.) e aos receptores dos quais as referidas são agonistas, enfatiza-se a sua atuação específica no que tange aos vasos sanguíneos. Para tanto, imprescindível abordar a classificação dos mesmos: os vasos sanguíneos são classificados em três principais tipos, conforme seu diâmetro: artérias, vasos de maior calibre, mais resistentes, as quais geralmente conduzem sangue arterial $^{10}$; veias, que são vasos de calibre intermediário e atuam na condução do sangue venoso (geralmente) ${ }^{11}$; e os capilares sanguíneos, que são os vasos sanguíneos com o menor diâmetro (MONTANARI, 2016).

Os vasos sanguíneos possuem a seguinte estrutura (figura 7):

\footnotetext{
${ }^{10}$ Conduzem sangue venoso na circulação pulmonar.

${ }^{11}$ Conduzem sangue oxigenado na circulação pulmonar.
} 
Figura 7: Estrutura das artérias, veias e capilares

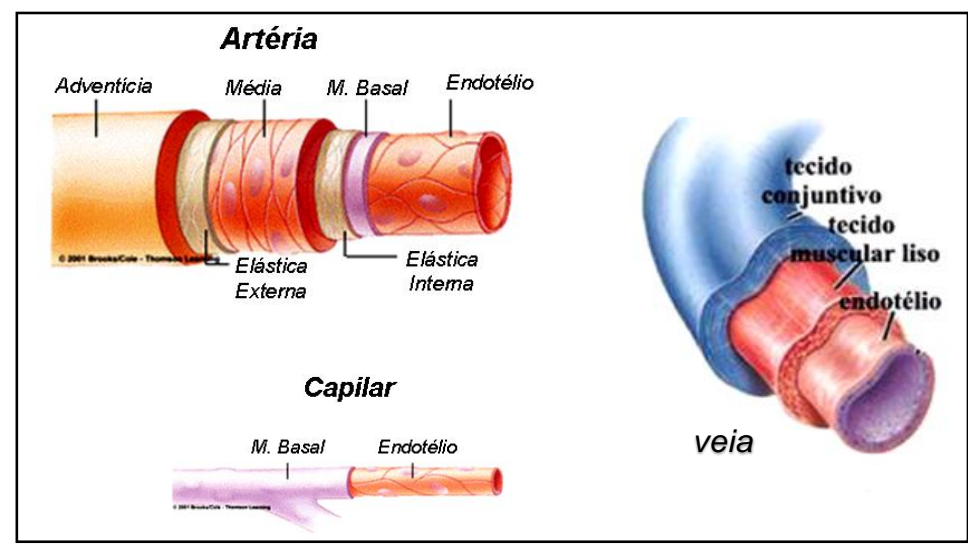

Fonte: Adaptado de LODISH et al., 2005

As artérias, assim como as veias, são constituídas por três camadas, denominadas túnicas: íntima (interna), média e adventícia (externa), as quais possuem em sua estrutura diferentes tecidos celulares. A túnica interna é constituída, principalmente, por células endoteliais - que conferem ao interior superfície lisa - e tecido conjuntivo. A túnica média é constituída, por células de tecido muscular $\operatorname{liso}^{12}$, as quais conferem elasticidade aos vasos sanguíneos. Por fim, a túnica adventícia é composta por tecido conjuntivo, "pode conter feixes musculares (...) há a presença de nervos (...)” (MONTANARI, 2016, p. 113). Os capilares, entretanto, são constituídos apenas pela camada de células endoteliais mescladas com os pericitos ${ }^{13}$, não possuindo, portanto, tecido muscular em sua constituição (MONTANARI, 2016, p. 113).

Em relação aos vasos sanguíneos, a literatura é consolidada no sentido de compreender as catecolaminas como agonistas de receptores que podem promover a constrição e a dilatação deles, tanto por atuação em receptores presentes no tecido endotelial, quanto muscular liso. Não obstante os mecanismos essenciais serem conhecidos, e fato de as catecolaminas serem agonistas que promovem efeitos em vasos sanguíneos, a discussão destas monoaminas como promotoras ou inibidoras da angiogênese ainda é bastante recente, mas tem dado ensejo a este trabalho, em virtude de sua coerente fundamentação.

\footnotetext{
${ }^{12}$ Existem três diferentes tipos de tecidos musculares: o tecido muscular estriado esquelético, associado aos ossos e responsável por movimentos voluntários (presente nos músculos das pernas, braços, etc.); o tecido muscular estriado cardíaco, o qual constitui o coração e possui contração involuntária; e o tecido muscular liso, cuja função é a movimentação involuntária dos órgãos internos, tais como estômago e bexiga, bem como no interior dos vasos sanguíneos. Este tecido é totalmente controlado pelo sistema nervoso autônomo (MONTANARI, 2016).

${ }^{13}$ Vide seção anteior ${ }^{1}$.
} 
As propostas do envolvimento das catecolaminas na angiogênese iniciaram-se com o estudo da dopamina, em artigo no qual Basu (et. al., 2001) e colaboradores afirmaram que esta molécula seria capaz de inibir a angiogênese. Os autores realizaram quantificação de VEGF no sobrenadante de células endoteliais tratadas com dopamina e, em relação às células não tratadas notaram que naquelas havia maior quantidade de VEGF no sobrenadante, o que seria um indício de menor quantidade de receptores de VEGF presentes em células tratadas com a monoamina. Dos experimentos realizados, in vitro, os autores propuseram que a dopamina promove a endocitose dos receptores do fator VEGF, do tipo 2 (VEGFR-2).

Além disso, a utilização de antagonistas para os receptores $\mathrm{D}_{1}, \mathrm{D}_{3}, \mathrm{D}_{4}$, bem como $\alpha$ e $\beta$-adrenérgicos não inibiram a ação da dopamina, no quesito antiangiogênese, razão pela qual postularam que esta catecolamina age via receptores $\mathrm{D}_{2}$, para induzir a endocitose de VEGFR-2. No entanto, o mecanismo, pelo qual os receptores dopaminérgicos $\mathrm{D}_{2}$ (do tipo acoplado à proteína $\mathrm{G}$ ) produzem ações no receptor tirosina-quinase VEGFR-2, não foi descrito (BASU et. al., 2001).

Posteriormente, em 2004, em estudo in vivo pioneiro, a fim de relacionar às catecolaminas à angiogênese, Sarkar e coautores (et. al., 2004) descreveram que a administração de doses de dopamina promoveu inibição da permeabilidade vascular mediada por VEGF. Foi observado, nesses mesmos experimentos, que em animais knockout para os receptores $\mathrm{D}_{2}$, houve aumento da fosforilação dos receptores VEGFR-2. Neste artigo, os autores concluíram que a dopamina age inibindo a fosforilação desse receptor do tipo tirosinaquinase, atuando, de um modo geral, em outras duas cascatas de sinalização mediadas por VEGF: MAPK; e quinase de adesão focal (FAK) - do inglês focal adhesion kinase.

Corroborando todo o reportado anteriormente, Basu e colaboradores (et. al., 2004) verificaram maiores efeito pró-angiogênico e crescimento tumoral em animais knockout para os receptores $\mathrm{D}_{2}$, bem como concluíram que a remoção de nervos periféricos dos animais também aumentou a angiogênese, a permeabilidade vascular, a densidade de microvasos e o tamanho do tumor. Concluíram, diante dos dados, que a fosforilação de VEGFR-2 é essencial à promoção da angiogênese e maior em ratos knockout para $\mathrm{D}_{2}$.

Quando avaliada em tumores gástricos - os quais são altamente angiogênicos verificou-se que a quantidade de dopamina endógena disponível era inversamente proporcional à angiogênese tumoral e, ao serem tratados com dopamina exógena, tanto tumores em ratos, quanto em humanos, apresentaram crescimento retardado (CHAKROBORTY et. al., 2004). 
Posteriormente, foi reportado que a dopamina atua não somente nas células endoteliais maduras, mas também na mobilização das células progenitoras endoteliais (EPC) - do inglês endothelial progenitor cells. A inibição da mobilização das EPC ocorreu na presença de dopamina exógena administrada, acompanhada de coibido crescimento tumoral. Porém tal efeito foi cessado na presença de antagonista específico para receptores $D_{2}$ (CHAKROBORTY et. al., 2008).

No mesmo ano, Sarkar e colaboradores afiançaram que a dopamina, além de originar eventos celulares que culminaram em inibição da angiogênese, quando associada a compostos citotóxicos - doxorubicina e outros - proporcionou resultados ainda melhores do que os observados para ambos os compostos separadamente. Salientou-se, no mesmo texto, que não raramente os compostos que inibem a angiogênese per si não são citotóxicos, assim como seu mecanismo de ação diverge totalmente daquele observado para os compostos com atividade anticâncer ordinária (SARKAR et. al., 2008).

Em 2006, Thaker e colaboradores avaliaram tumores em animais submetidos a condições estressantes e, quando comparados aos respectivos grupos controle (não submetidos ao estresse), observaram-se maiores expressões dos receptores $\beta$-adrenérgicos, das metaloproteinases de matriz (MMP), MMP-2 e MMP-9 e VEGF, bem como maior vascularização. Com estes resultados, os autores concluíram que o estresse aumenta os níveis das catecolaminas e podem funcionar como fatores que influenciam o crescimento tumoral, bem como metástases, além do que noradrenalina e isoproterenol podem funcionar como moléculas precedentes à ação de fatores pró-angiogênicos (THAKER et al., 2006).

Em 2009, no âmbito de um artigo de revisão sobre o tema, reiterou-se todo o anteriormente afirmado para a dopamina, bem como foram reportadas observações para as catecolaminas agonistas dos receptores adrenérgicos. Reportou-se que noradrenalina estimulou o processo de angiogênese em câncer de ovário em ratos e, via ativação dos receptores $\beta$-adrenérgicos, houve aumento de AMPc e, consequentemente, VEGF. Em referência a relatos recentes, os autores postulam aumento de IL-6 e IL-8, como consequência da interação com os receptores $\beta$-adrenérgicos e ativação da proteína tirosina-quinase não receptor Src. Do mesmo modo, pelas justificativas dos artigos anteriores, a dopamina diminuiu a angiogênese em tumores de estômago, cólon, mama e ovário. No entanto, os autores afirmaram que a ação da dopamina também inibiu a expressão de MMP-9, via regulação negativa das proteínas quinases reguladas por sinais extracelulares (ERK-1 e ERK- 
2) - extracellular signal-regulated kinases, todavia os mecanismos ainda permanecem obscuros (CHAKROBORTY et. al., 2009).

Relatou-se que pacientes hipertensos dos quais os tratamentos constavam $\beta$ bloqueadores, apresentaram menor incidência de câncer de próstata, mostrando que antagonistas dos receptores $\beta$-adrenérgicos podem exercer papel importante na compreensão do câncer. No entanto, é necessário que as células tumorais expressem este tipo de receptor, o que se traduz em possibilidades diversas dependendo do tipo da célula tumoral. Neste sentido, efeitos menos gerais são atribuídos à noradrenalina e à adrenalina, quando comparadas à dopamina (TILAN; KITLINSKA, 2010).

Tilan e Kitlinska (2010) também afirmaram que o efeito antiangiogênico nas células endoteliais ocorre tanto nas células já diferenciadas, quanto no recrutamento na medula óssea, das células progenitoras.

Em 2010, Yang acrescentou que as regiões onde (endogenamente) são encontradas maiores quantidades de catecolaminas coincidem com as áreas de mais metástases, assim como o fato de $\beta$-bloqueadores inibirem - além de MMP-2, MMP-9 e MAPK - a enzima cicloxigenase-2 (COX-2).

Reportou-se, ainda, que noradrenalina e adrenalina possuem efeitos antiapoptóticos nas células cancerígenas: em células tratadas com ambas, observou-se que a interrupção prévia no ciclo celular $\left(\mathrm{em}_{2} / \mathrm{M}\right)$ induzida por paclitaxel, foi revertida e, a mitose prosseguiu. No mesmo sentido, evidenciou-se a progressão e angiogênese aumentada em tumores nasofaríngeos, mieloma múltiplo e melanoma, após tratamento com noradrenalina e, após análise das células extraídas dos tumores, foi verificado que todas expressam receptores $\beta$-adrenérgicos. Todavia, há estudos que demonstram que a utilização de $\beta$-bloqueadores pode apresentar resultados diversos daqueles maiormente descritos - razão pela qual mais estudos neste sentido são necessários para a melhor compreensão do papel das catecolaminas na angiogênese tumoral (YANG, 2010).

Em relação à adrenalina, foi reportado que em células de câncer de intestino, a expressão de COX-2, VEGF e MMP-9 foi aumentada quando tratadas com esta catecolamina e, na presença de antagonistas $\beta$-adrenérgicos, o estímulo na expressão destas biomoléculas foi suprimido (WONG et. al., 2011).

Em 2013, reportou-se que a molécula de noradrenalina aciona algumas vias de angiogênese por meio de receptores $\alpha$-adrenérgicos (também), ativando o fator indutor de hipóxia $(\mathrm{HIF}-1 \alpha)$ - hypoxia inductible factor, além do que noradrenalina e adrenalina 
modulam as células de todo o ambiente tumoral, inclusive em relação à atuação de macrófagos e à imunidade na região tumoral, de forma que tudo conduz ao aumento tumoral e às metástases (SARKAR; CHAKROBORTY; BASU, 2013).

Por fim, em 2015, Xiu e colaboradores (2015) verificaram que em animais portadores de tumores submetidos ao estresse, maiores níveis de VEGF foram mensurados em relação àqueles não submetidos a tais condições, assim como os tumores atingiram tamanhos maiores, demonstrando que as catecolaminas atuaram como pró-angiogênicas.

Sucintamente, a intrínseca relação entre as catecolaminas e a angiogênese ainda permanece com diversas lacunas a serem compreendidas - não obstante o quanto se evoluiu em menos de duas décadas na compreensão da relação existente entre as mesmas -, principalmente quando se considera que os principais receptores diretamente envolvidos na angiogênese pertencem à classe de receptores do tipo tirosina-quinase, enquanto as catecolaminas são agonistas de receptores $\alpha$ e/ou $\beta$-adrenégicos ou dopaminégicos.

Assim, apesar de algumas hipóteses, os mecanismos de ação das catecolaminas na angiogênese não são totalmente esclarecidos e alguns resultados divulgados são contraditórios (YANG, 2010), sendo que de um modo geral, prevalecem as necessidades: de mais pesquisas, no sentido de se estudar mais detalhadamente a atuação das moléculas em comento no que tange ao mecanismo bioquímico e biológico, bem como nas vias de atuação envolvidas na produção de novos vasos sanguíneos; de maiores informações, a fim de possibilitar uma melhor compreensão, que, futuramente, poderá dar azo à utilização destas em medicamentos anticâncer (por exemplo), uma vez considerados, inclusive, seu uso clínico para outras doenças, bem como seu baixo custo (CHAKROBORTY et. al., 2009); de se encontrar possíveis compostos antiangiogênicos (ou estruturas moleculares que facilitem o entendimento para a propositura de moléculas com este tipo de ação), vez que estes podem inibir o crescimento de tumores em locais de difícil acesso, bem como inibir a recorrência e as metástases (SARKAR et. al., 2008).

E é sob as lentes do parágrafo antecedente, e diante das necessidades reportadas, que se conduziu o presente trabalho, não com a intenção de se preencher todas as lacunas, responder todas as questões que pairam sobre o tema, ou se esgotar o assunto, mas visando contribuir, em tema multidisciplinar - direta ou indiretamente relacionado à biologia celular, à bioquímica, à farmacologia e à oncologia - valendo-se da química inorgânica, à área denominada química inorgânica biológica. 
Quimicamente, as catecolaminas podem ser associadas aos receptores por dois sítios de ligação - sítio catecólico e sítio amínico. Considerando-se que a angiogênese está relacionada ao efeito ocasionado pela(s) catecolamina(s), e em relação à estrutura química e às formas como ocorrem as interações - as quais culminam nos efeitos na angiogênese pouco é conhecido, acreditou-se na utilização de complexos metálicos como forma de viabilizar a compreensão das suas ações. Pois uma das possibilidades está em se inativar um dos sítios de ação das catecolaminas, por exemplo, na coordenação do sítio catecólico a metal de transição, e avaliar o poder pró ou antiangiogênico destas novas espécies formadas em relação às catecolaminas livres.

O grupo, em cujo âmbito se insere a autora do presente trabalho, relatou previamente a síntese, caracterização e atividade antifúngica de três complexos de rutênio coordenados a catecolaminas (DE LIMA et. al., 2003), logo, valendo-se da experiência do grupo, coerente se demonstra a propositura de estudos utilizando-se compostos de coordenação, para, então, avaliar o efeito ocasionado por espécies coordenadas no que tange à angiogênese tumoral, e compará-los aos das catecolaminas livres, a fim de se verificar o resultado angiogênico ocasionado após a inativação de um dos sítios das catecolaminas - via coordenação ao íon metálico rutênio.

\subsubsection{Rutênio e seus complexos metálicos}

O nome rutênio tem origem russa: em latim "Ruthenia" é Rússia. Possui esta origem em razão de ter sido descoberto nos Montes Urais, na Rússia, sendo também encontrado na América do Sul e, em menores quantidades, na parte ocidental dos Estados Unidos e no Canadá (KREBS, 2006).

O rutênio localiza-se no grupo 8 da tabela periódica, pertencendo aos elementos do grupo da platina, e possui baixa abundância ( 0,01 ppm), sendo portanto, o $74^{\circ}$ elemento em abundância na crosta terrestre (KREBS, 2006; ALVES, 2012).

Possuindo sete isótopos (101 é o mais abundante) e número atômico 44, o rutênio apresenta estados de oxidação que variam de 8+ a 2-, constituindo os estados mais comuns, os de número $2+$ e $3+$ (KREBS, 2006). Quando no estado $\mathrm{Ru}^{2+}$ possui configuração eletrônica $\mathrm{d}^{6}$, lhe garantindo complexos estáveis e com aplicação em diversos sistemas biológicos, principalmente, devido à sua semelhança com o ferro. Nesse estado de oxidação, seus ligantes são comumente carbonil, fosfinas, aminas e heterociclos, via de regra, com geometria octaédrica e diamagnéticos. Quando na configuração $\mathrm{d}^{5}, \mathrm{Ru}^{3+}$, apresenta afinidade com bases 
duras, na classificação de Pearson, com ligantes menores, tais como halogenetos, água e aminas menores.

Atualmente, o rutênio tem se destacado em relação à aplicação dos seus complexos metálicos em diversos sistemas biológicos, ganhando ênfase no cenário dos compostos anticâncer, no qual, recentemente, três complexos estão em fase de testes clínicos (ZENG et. al, 2016). No entanto, não foi de rutênio o primeiro complexo metálico a ser utilizado com fim anticâncer - lugar que é ocupado pela platina.

Em meados dos anos 60, pesquisadores descobriram acidentalmente a atividade anticâncer do complexo cis- $\left[\mathrm{PtCl}_{2}\left(\mathrm{NH}_{3}\right)_{2}\right]$, conhecido como cisplatina, o qual é (atualmente) um metalofármaco amplamente utilizado contra diversos tipos de tumores, empregado contra câncer de testículo, ovário, bexiga, cabeça, pescoço e linfomas. No entanto, além dos seus graves efeitos colaterais, o mesmo encontra resistência de vários tipos de células tumorais e em lesões secundárias, originárias de metástases (PIZARRO; SADLER, 2009; DYSON; SAVA, 2006; FREZZA et. al, 2010). Além do que, não raramente, os complexos de platina apresentam baixa solubilidade em soluções fisiológicas (FREZZA et. al., 2010).

Por esta razão, opções para o tratamento do câncer são constantemente perseguidas, tanto para proporcionar maior eficácia onde há resistência ao cisplatina, quanto visando à diminuição dos efeitos colaterais. Na busca dessas melhoras, foram realizadas modificações químicas, na estrutura do cisplatina, as quais originaram os complexos conhecidos como carboplatina e oxaliplatina (PIZARRO; SADLER, 2009; SOUZA, 2014), os quais também se encontram em uso atualmente.

Como alternativas terapêuticas ao cisplatina, complexos de diversos metais têm sido estudados e testados, sendo os de rutênio os mais promissores, razão pela qual parte dos pesquisadores ao redor do mundo vem desenvolvendo complexos de rutênio não somente com possíveis propriedades anticancerígenas (mas também antimicrobianas, antivirais, entre outras) (ZENG et al, 2016) - o que se deve, em parte, à sua baixa toxicidade. Esta é atribuída ao fato de suas propriedades físico-químicas serem semelhantes às do ferro, podendo, portanto, mimetizar interações do ferro com biomoléculas no organismo, por exemplo, a albumina (RAMOS, 2012; STÍBAL et. al., 2016). Além disso, há autores que postulam serem semelhantes os mecanismos de retirada de excesso de rutênio do organismo (ALLARDYCE; DISON, 2001). As propriedades biológicas deste metal foram descobertas na década de 50 e sua atividade anticâncer, pouco tempo depois, na década de 70 (DYSON; SAVA, 2006; PIZARRO; SADLER, 2009). 
É conhecido que os complexos de platina se ligam covalente e irreversivelmente ao DNA - de onde provém sua citotoxicidade -, enquanto complexos de rutênio têm sido estudados como inibidores de topoisomerases, marcadores de mitocôndrias, produtores de espécies reativas de oxigênio intracelulares, entre outros (ZENG et. al., 2016), além de serem passíveis de interação com o DNA por ligações de hidrogênio, hidrofobicidade, etc. (PIZARRO; SADLER, 2009).

Essa ampla gama de interações do rutênio oferece vantagens em relação aos complexos de platina, pois o rutênio pode assumir vários estados de oxidação acessíveis em condições fisiológicas (II, III e IV) - culminando em reações redox no meio biológico - e fornecer maiores estabilidade e possibilidade de se coordenar diversos ligantes de interesse biológico cujos alvos podem ser mais amplos em relação àqueles almejados pelos complexos de platina, em virtude da geometria octaédrica geralmente assumida por seus complexos. Além do que a possibilidade de se ter variados ligantes coordenados oferece alternativas para que as interações com o DNA ocorram tanto com o metal, quanto com os ligantes (BARRY; PETER, 2013; SOUZA, 2014).

Recentemente, três quimioterápicos à base de rutênio ingressaram em ensaios clínicos, $\quad \mathrm{Na}\left\{\right.$ trans- $\left.\left[\mathrm{RuCl}_{4} \mathrm{DMSO}(\mathrm{Im})\right]\right\} \quad(\mathrm{NAMI}), \quad[\mathrm{ImH}]\{$ trans-[Ru(DMSO$\left.\left.) \mathrm{Cl}_{4}(\mathrm{Im})\right]\right\}$ (NAMI-A) e $[\operatorname{IndH}]\left\{\right.$ trans-[RuCl $\left.\left.4(\operatorname{Ind})_{2}\right]\right\}$ (KP1019), onde $\mathrm{Im}=$ imidazol e Ind = indazol. Tais complexos tiveram seus efeitos atribuídos à redução do metal de $\mathrm{Ru}(\mathrm{III})$ para $\mathrm{Ru}(\mathrm{II})$, no ambiente intracelular, embora haja grupos tentando provar que esta atividade anticâncer não ocorre somente para $\mathrm{Ru}(\mathrm{II})$, mas em todos os estados de oxidação acessíveis em meio biológico (BARRY; PETER, 2013; FREZZA et. al., 2010).

Desses, NAMI foi o primeiro composto de rutênio a ingressar em testes clínicos, porém foi seu sucessor, NAMI-A, que apresentou resultados muito promissores in vivo, atuando como antimetastático e antiangiogênico, embora não demonstrara bons resultados de citotoxicidade in vitro. Este complexo findou as fases I e II dos testes clínicos e atua bloqueando quinases ativadas por mitógenos (e outras quinases) em células endoteliais (DYSON; SAVA, 2006). Por sua vez, KP1019 se encontra no ínterim da fase I dos estudos clínicos (SOUZA, 2014; PIZARRO; SADLER, 2009; MOREIRA, 2016; BARRY; PETER, 2013). Não obstante o fato de se encontrarem em fases de testes clínicos, os mecanismos de ação dos complexos supra ainda não estão integralmente esclarecidos (SOUZA, 2014).

A literatura relaciona as promissoras atividades anticâncer dos complexos de rutênio principalmente, à interação com DNA - quando se utiliza como ligantes moléculas como 2,2'-bipiridina, fenantrolina, etc. (ZENG et. al, 2016), o que direciona às possibilidades 
de serem utilizados em casos nos quais os fármacos de platina oferecem resistência (inerente ou adquirida) (PIZARRO; SADLER, 2009).

Dentre aqueles considerados promissores contra o câncer, têm se destacado complexos de rutênio mononucleares organometálicos, complexos de Ru(II) cujos ligantes são bipiridina, fosfinas e ftalocianinas - estes últimos voltados às de caráter fotodinâmico (NEGRI, 2012; MOREIRA, 2016).

Os resultados obtidos até o momento (com complexos de rutênio), somados ao fato de que a utilização de metais não essenciais direciona, mais facilmente, os complexos às células tumorais, encorajou ao uso de complexos de rutênio no presente trabalho (FREZZA et. al., 2010).

No início dos anos 2000, o grupo reportou a síntese e a caracterização dos complexos de rutênio com fórmula geral $\left[\mathrm{Ru}\left(\mathrm{NH}_{3}\right)_{4}(\right.$ cat- $\left.\mathrm{R})\right] \mathrm{PF}_{6}$, onde "cat- $\mathrm{R}$ é noradrenalina, dopamina e isoproterenol. Tais complexos apresentaram estabilidade em solução por, no mínimo sete dias e interessante comportamento eletroquímico. Foram descritos como complexos de $\mathrm{Ru}(\mathrm{III})$, cuja redução para $\mathrm{Ru}(\mathrm{II})$ observada é totalmente reversível. $\mathrm{Na}$ ausência do rutênio, a oxidação das catecolaminas constitui-se um processo irreversível (DE LIMA et. al., 2003; DE LIMA et. al., 2004).

A atividade biológica desses complexos foi analisada, sendo que os complexos apresentaram resultados antifúngicos expressivos contra Candida albicans, Candida glabrata and Candida tropicalis, enquanto os respectivos ligantes, as catecolaminas, não apresentaram atividade (DE LIMA et. al., 2003).

Diante de todo conteúdo abordado na introdução e, considerando-se que os três complexos já reportados apresentaram estabilidade e sua atividade anticâncer e/ou pró ou antiangiogênica nunca fora explorada, optou-se por trabalhar com os mesmos, porém acrescidos do complexo de catecol (para fins comparativos) e do complexo inédito de adrenalina, a fim de se verificar a atuação deles, quando comparados aos respectivos ligantes livres.

Assim, a hipótese que norteia o presente trabalho é que as catecolaminas atuam sobre a angiogênese e a imobilização de um dos seus sítios de interação modulará (positiva ou negativamente) a sua atividade, fornecendo indícios de seus mecanismos de ação. A averiguação desta resultou neste trabalho/texto, norteando-o os objetivos que seguem na próxima seção. 


\section{OBJETIVOS}

\subsection{Objetivo Geral}

Uma vez apresentada a teoria que embasa o presente trabalho, bem como as justificativas e a hipótese que o norteia, apresenta-se o objetivo geral deste, o qual consiste em compreender a forma de atuação das catecolaminas na angiogênese, bem como os sítios de interação envolvidos na atividade angiogênica destas moléculas endógenas, por meio da coordenação das catecolaminas ao metal rutênio e posteriores ensaios de natureza biológica.

\subsection{Objetivos Específicos}

Fazendo jus ao objetivo geral do trabalho, foram estabelecidos os objetivos específicos. Estes consistiram, portanto, em:

1. Sintetizar e purificar complexos de rutênio, com fórmula geral $\left[\mathrm{Ru}\left(\mathrm{NH}_{3}\right)_{4}(\right.$ cat$\mathrm{R})] \mathrm{Cl}$;

2. Caracterizar por técnicas espectroscópicas e espectrometria de massas os complexos acima mencionados;

3. Realizar estudos de cálculos teóricos, para melhor entendimento das propriedades físico-químicas;

4. Verificar a reatividade vascular, em aorta de ratos tratadas com os complexos e com os ligantes (catecolaminas);

5. Realizar ensaios de citometria de fluxo para medidas de cálcio intracelular;

6. Analisar alterações do ciclo celular;

7. Testar os complexos e os ligantes em relação à atividade angiogênica, na membrana corioalantoica de embriões de galinha;

8. Realizar ensaios de recuperação de lesão celular com linhagens sadia e cancerígena;

9. Conduzir ensaios de viabilidade celular;

10. Verificar a interação com o DNA de esperma de salmão, por espectroscopia de absorção UV-vis;

11. Realizar ensaio de deslocamento do brometo de etídio, acompanhado por espectroscopia de fluorescência; 
12. Avaliar a interação com a proteína do soro humano albumina, acompanhada por espectroscopia de fluorescência;

13. Sintetizar e purificar os complexos com fórmula geral $\left[\mathrm{Ru}(\mathrm{bpy})_{2}(\mathrm{cat}-\mathrm{R})\right] \mathrm{Cl}$;

14. Caracterizar por técnicas espectroscópicas os complexos acima mencionados;

15. Realizar ensaios de viabilidade celular dos complexos supracitados;

16. Verificar a interação com o DNA de esperma de salmão, por espectroscopia de absorção UV-vis;

17. Realizar ensaio de deslocamento do brometo de etídio, acompanhado por espectroscopia de fluorescência;

18. Avaliar a interação com a proteína do soro humano albumina, acompanhada por espectroscopia de fluorescência. 


\section{METODOLOGIA}

A fim de se atingir os objetivos propostos no capítulo precedente, os procedimentos e instrumentação foram desenvolvidos conforme segue.

\subsection{Materiais}

Os reagentes utilizados são apresentados na tabela a seguir (tabela 2): 
Tabela 2: Procedência e pureza dos reagentes utilizados

\begin{tabular}{|c|c|c|}
\hline Reagentes & Pureza & Procedência \\
\hline DPPB 1,3-difenilisobenzofurano & $97 \%$ & "Aldrich Chemistry \\
\hline 2,2'-dipyridil & $99 \%$ & Sigma-Aldrich \\
\hline Acetilcolina & $99 \%$ & Sigma-Aldrich \\
\hline Acetona & $99,50 \%$ & J. T. Baker \\
\hline Acetonitrila & $99,90 \%$ & J.T. Baker \\
\hline Ácido clorídrico & $36,5-38 \%$ em massa & Synth \\
\hline Albumina de soro humano (HSA) & $398 \%$ & Sigma \\
\hline Alumina Neutra; & & Sigma Aldrich \\
\hline Argônio & $99,99 \%$ & White Martins \\
\hline Brometo de etídio & para biologia molecular $10 \mathrm{mg} / \mathrm{mL}$ & Nalgene \\
\hline Catecol & $99 \%$ & Aldrich \\
\hline Cloreto de lítio & $100 \%$ & Sigma-Aldrich \\
\hline Cloreto de rutênio & $99,98 \%$ & Sigma-Aldrich \\
\hline Cloreto de sódio & $99,5 \%$, Grau analítico & Synth \\
\hline DL-Cloridrato de adrenalina & $98 \%$ & Sigma-Aldrich \\
\hline Cloridrato de dopamina & $98 \%$ & Sigma-Aldrich \\
\hline DL-Cloridrato de isoproterenol & $98 \%$ & Aldrich \\
\hline DL-Cloridrato de noradrenalina & $\geq 98 \%$ & Sigma-Aldrich \\
\hline Diclorometano & $99,50 \%$ & Synth \\
\hline Dimetilformamida & $99,90 \%$ & Neon \\
\hline Dimetilsulfóxido (DMSO) & $99,70 \%$ & Vetec \\
\hline DMEM & & Gibco \\
\hline DNA de esperma de peixe, $f s$-DNA & $\leq 1 \%$ de proteína & Sigma \\
\hline Etanol & $99,50 \%$ & Synth \\
\hline Éter dietilico & $100 \%$ & Synth \\
\hline Fenilefrina & $99 \%$ & Sigma-Aldrich \\
\hline Fluo-3AM & & Thermo-Fischer \\
\hline Formaldeído. & $37 \%$ & Synth \\
\hline Hidrazina hidrato & $25 \%$ & Vetec \\
\hline Hidróxido de amônio & $28 \%$ & Sigma-Aldrich \\
\hline Hidróxido de sódio & 98\%, Grau analítico & Synth \\
\hline Metanol & $99,98 \%$ & J.T. Baker \\
\hline Metanol & $99,9 \%$ (HPLC) & Sigma-Aldrich \\
\hline MTT & & Sigma-Aldrich \\
\hline Noradrenalina & $97 \%$ & Sigma-Aldrich \\
\hline Propanolol & $99 \%$ & Sigma-Aldrich \\
\hline RPMI 1640 & & Sigma-Aldrich \\
\hline Tampão fosfato (pastilha) & & Sigma-Aldrich \\
\hline tampãoTris & $99 \%$ & Merck \\
\hline
\end{tabular}




\subsection{Métodos e Instrumentação}

\subsubsection{Síntese do complexo precursor $\left[\mathrm{RuCl}\left(\mathrm{NH}_{3}\right)_{5}\right] \mathrm{Cl}_{2}$}

O complexo de rutênio utilizado como precursor, para a síntese dos complexos metálicos com catecolaminas, foi sintetizado conforme reportado na literatura e há muito consolidado (ALLEN et. al., 1967). Para tanto, 5,0 g de cloreto de rutênio (III) hidratado $\left(\mathrm{RuCl}_{3} \cdot \mathrm{nH}_{2} \mathrm{O}\right)$ foram adicionados em $60,0 \mathrm{~mL}$ de água destilada, em um balão de 500,0 $\mathrm{ml}$ de duas bocas. Com funil de adição, foram, lentamente, gotejados 180,0 mL de hidrazina. O gotejamento durou 3h30min e ocorreu sob forte agitação. Após o término do gotejamento, a solução ficou em agitação por mais 1h30min. Ato contínuo, resfriou-se o balão em banho de gelo. Com uso do funil de adição, $160,0 \mathrm{~mL}$ de ácido clorídrico concentrado foram gotejados. $\mathrm{O}$ gotejamento durou aproximadamente $1 \mathrm{~h} 30 \mathrm{~min}$. $\mathrm{O}$ aquecimento foi reiniciado na sequência, com refluxo. Após ser atingida a temperatura de $100{ }^{\circ} \mathrm{C}$, manteve-se em refluxo por mais 3 horas.

Na sequência, o balão foi retirado do aquecimento e, após o resfriamento, levado à geladeira até o dia seguinte, por aproximadamente 12 horas. Filtrou-se, então, a solução. O sólido (amarelo) foi lavado com porções de etanol e porções geladas de ácido clorídrico 1,0 $10^{-5} \mathrm{~mol} \mathrm{~L}^{-1}$. O sólido foi seco a vácuo e pesado. Obteve-se rendimento de aproximadamente $52,7 \%$.

\subsubsection{Síntese do complexo precursor cis- $\mathrm{RuCl}_{2}(\mathrm{bpy})_{2}$}

Adicionou-se, em um balão de $50 \mathrm{~mL}, 10 \mathrm{~mL}$ de dimetilformamida, 1,5 g de cloreto de rutênio (III), $\mathrm{RuCl}_{3} \cdot 3 \mathrm{H}_{2} \mathrm{O}, 1,90 \mathrm{~g}$ de 2,2'-bipiridina, e $1,7 \mathrm{~g}$ de cloreto de lítio. A solução foi aquecida em banho de glicerina e, após atingir o refluxo, deixada por mais oito horas. Após este período, adicionou-se 30,0 mL de acetona e deixou-se em repouso, na geladeira, por uma hora. O precipitado obtido foi lavado com água gelada e, posteriormente, com acetona e éter, nesta ordem. O sólido obtido foi seco a vácuo e pesado. O rendimento da síntese foi $71,2 \%$.

\subsubsection{Sínteses dos complexos [ $\left.\mathrm{Ru}\left(\mathrm{NH}_{3}\right)_{4} \mathrm{cat}-\mathrm{R}\right] \mathrm{Cl}$}

Preparou-se o meio reacional com 7,5 $\mathrm{mL}$ de água e $7,5 \mathrm{~mL}$ de hidróxido de amônio concentrado. A solução ficou sob atmosfera de argônio por 15 minutos. Foram 
adicionados com um funil, 0,20 $\mathrm{g}$ do precursor, $\left[\mathrm{RuCl}\left(\mathrm{NH}_{3}\right)_{5}\right] \mathrm{Cl}_{2}$. Após a completa redução do rutênio, adicionou-se 0,21 g de cloridrato de isoproterenol, ainda em atmosfera inerte.

A solução foi mantida sob agitação moderada, por 3 horas, após atingir $85{ }^{\circ} \mathrm{C}$. Ao final, desligou-se o fluxo de argônio e adicionou-se $40,0 \mathrm{~mL}$ de acetona. A solução foi mantida na geladeira até o dia seguinte, quando, então, foi filtrada e o precipitado, azul escuro, intenso, foi submetido à purificação. $\mathrm{O}$ complexo foi purificado em coluna cromatográfica usando-se alumina neutra como fase estacionária e solução $66 \%$ de etanol (v/v), como fase móvel, em coluna de $15 \mathrm{~cm}$ de altura e $3 \mathrm{~cm}$ de diâmetro. A segunda fração, de coloração azul, é a de interesse. O sólido foi seco a vácuo e pesado. Obteve-se rendimento de aproximadamente $49,9 \%$.

Para os demais complexos, a síntese foi realizada de maneira semelhante, obtendo-se os seguintes rendimentos: $58,2 \%$, para o complexo de dopamina; $77,4 \%$, para o de noradrenalina; $85,6 \%$, para o de catecol e, $70 \%$, para o de adrenalina.

\subsubsection{Síntese dos complexos $\left[\mathrm{Ru}(\mathrm{bpy})_{2} \mathrm{cat}-\mathrm{R}\right] \mathrm{Cl}$}

Pesou-se $0,150 \mathrm{~g}$ do precursor cis-[ $\left[\mathrm{RuCl}_{2}(\mathrm{bpy})_{2}\right] \cdot \mathrm{H}_{2} \mathrm{O}$ e a mesma quantidade, em mol, para o ligante isoproterenol, 0,077 g. Foram utilizados dois balões para a síntese: ao primeiro (de $50 \mathrm{~mL}$ ), adicionou-se $10,0 \mathrm{~mL}$ de metanol e borbulhou-se argônio por 10 minutos; este balão foi submetido ao aquecimento em banho de glicerina, a $70{ }^{\circ} \mathrm{C}$. No segundo balão, de $10 \mathrm{~mL}$, adicionou-se $5,0 \mathrm{~mL}$ de metanol e borbulhou-se argônio por 5 minutos; na sequência, a este segundo balão, adicionou-se $8,7 \mathrm{mg}$ de $\mathrm{NaOH}$, juntamente com o ligante isoproterenol. Após 1 hora de aquecimento da solução do primeiro balão, transferiuse a solução do balão de $10 \mathrm{~mL}$ (segundo), para o de $50 \mathrm{~mL}$. A solução foi deixada em refluxo por 4 horas. Após o término da reação, o composto foi precipitado pela adição de éter etílico.

O complexo foi purificado em coluna cromatográfica usando-se alumina neutra como fase estacionária e diclorometano como fase móvel. A segunda fração, de coloração roxo-vinho, é a de interesse. O produto foi seco a vácuo e pesado. Obteve-se rendimento de aproximadamente $35 \%$.

Para o demais complexos, a síntese foi realizada de maneira semelhante, obtendose rendimentos de aproximadamente $37 \%$, para o complexo de dopamina; $27 \%$, para o de catecol; 36\%, para o de adrenalina; e 30\%, para o noradrenalina. 


\subsubsection{Cromatografia Líquida de Alta Eficiência (CLAE/HPLC)}

A pureza dos complexos foi verificada por HPLC (Shimadzu LC-20AT detector UV/VIS Arranjo diodo-SPD-M20A), acoplado a um injector Rheodyne 7725; loop de $20 \mu \mathrm{l}$; coluna C18 Ascentis ${ }^{\circledR}(250 \mathrm{~cm} \mathrm{x} \mathrm{4,6} \mathrm{mm).} \mathrm{Solventes:} 15 \%$ de metanol em tampão fosfato, $\mathrm{pH}$ 6,9; eluição isocrática; 1,0 $\mathrm{mL} \mathrm{min}^{-1}$, conforme método já desenvolvido na literatura (DE LIMA, 2001). Os dados foram analisados pelo software Shimadzu CLASS-VP 5.03.

\subsubsection{Espectroscopia eletrônica de absorção na região $U V$-vis}

Os espectros eletrônicos foram obtidos utilizando um espectrofotômetro Agilent HP8453, 190-1100 nm, resolução $1 \mathrm{~nm}$, em cubeta de quartzo com caminho óptico de $1 \mathrm{~cm}$.

\subsubsection{Voltametria cíclica}

Os experimentos eletroquímicos foram realizados em um potenciostato/galvanostato AUTOLAB® PGSTAT30, utilizando-se uma célula eletroquímica convencional de três eletrodos: carbono vítreo como eletrodo de trabalho; fio de platina como auxiliar; e $\mathrm{Ag} / \mathrm{AgCl}$ como eletrodo de referência. Foram usadas como solução tampão: fosfato 0,01 M e KCI 0,1 M, como eletrólito suporte. Os complexos foram utilizados em concentrações finais de aproximadamente $1,010^{-3} \mathrm{M} ; \mathrm{pH}$ 7,6.

\subsubsection{Espectroeletroquímica}

Os experimentos espectroeletroquímicos foram realizados em um potenciostato/galvanostato AUTOLAB® PGSTAT30, utilizando-se uma célula eletroquímica convencional de três eletrodos: uma folha de ouro como eletrodo de trabalho; fio de platina como auxiliar; e $\mathrm{Ag} / \mathrm{AgCl}$ como eletrodo de referência; foram usadas como solução tampão fosfato $0,01 \mathrm{M}$ e KCI $0,1 \mathrm{M}$, como eletrólito suporte. Os complexos foram utilizados em concentrações finais de aproximadamente $1,010^{-3} \mathrm{M} ; \mathrm{pH}$ 7,6. Foram aplicados potenciais de $+0,5 \mathrm{~V} ; 0,0 \mathrm{~V} ;-0,8 \mathrm{~V}$ e $0,0 \mathrm{~V}$, nesta ordem, enquanto os espectros de absorção na região do UV-vis foram registrados em um espectrofotômetro Agilent HP8453, 190-1100 nm, em cubeta de quartzo com caminho óptico de $0,5 \mathrm{~cm}$. 


\subsubsection{Estabilidade fotoquímica e verificação da produção de oxigênio singleto}

Os experimentos de fotoestabilidade foram realizados tanto em soluções aquosas $10^{-4} \mathrm{M}$ como em solução de tampão de fosfato, em cubeta de quartzo de $1 \mathrm{~cm}$ de caminho óptico, com agitação magnética suave. A irradiação foi realizada utilizando-se o equipamento Colibri Quantum Laser Tech, com excitação nos comprimentos de onda: 377 (9 mW), 447 (16 $\mathrm{mW}), 532(31 \mathrm{~mW})$ e $660(33 \mathrm{~mW}) \mathrm{nm}$. Os testes de produção de oxigênio singleto foram realizados adicionando-se $10 \mu \mathrm{L}$ de DPBF (1,3-difenilisobenzofurano), em concentração igual a $8 \mathrm{mM}$, em 2,0 mL de soluções dos complexos, em acetonitrila (com 10\% de água). Os complexos foram irradiados de 1 a 15 minutos, conforme metodologia descrita na literatura (CARNEIRO et. al., 2011).

\subsubsection{Espectroscopia de absorção na região do infravermelho}

Os espectros de absorção na região do infravermelho foram obtidos a partir de amostras dispersas em pastilhas de $\mathrm{CsI}$ (em $\mathrm{KBr}$ para os espectros que constam no apêndice), na região $400-4000 \mathrm{~cm}^{-1}$, com resolução de $4 \mathrm{~cm}^{-1}$, em espectrofotómetro FTIR Bomem, MB 102; com janela de CsI .

\subsubsection{Espectroscopia Raman}

Os espectros de Raman foram adquiridos utilizando um espectroscópio Horiba Jobin Yvon LabRamHR microRaman, com laser de 632,8 nm e 17 mW; tempo de exposição: 80 segundos; 2 acumulações.

\subsubsection{Espectroscopia de ressonância magnética nuclear}

Os espectros de RMN foram registrados em um espectrômetro Bruker (R) Modelo DRX500 - Escudo Ultra (R), 11,74 T, em soluções em $\mathrm{D}_{2} \mathrm{O}$.

\subsubsection{Cálculos teóricos}

Todos os cálculos foram realizados usando o software ORCA (versão 3.0.3) (NEESE; 2012) usando o híbrido U-PBE0 (ADAMO; BARONE; 1999) e a base def2-TZVP (SCHÄFER; HORN; AHLRICHS, 1992; WEIGEND; AHLRICHS, 2005) para todos os átomos, e com o ECP Stuttgart-Dresden para o rutênio (ANDRAE; HÄUßERMANN; DOLG; STOLL; H.PREUß, 1990). A aproximação RIJCOSX (IZSÁK; NEESE, 2011) foi empregada 
em todos os cálculos, juntamente com as funções auxiliares embutidas. Todas as geometrias foram confirmadas como mínimas superfícies de energias potenciais pelo cálculo dos hessianos. Os cálculos TD-DFT (PETRENKO; KOSSMANN; NEESE, 2011) foram realizados no mesmo nível de teoria para obter as energias de excitação verticais para os primeiros 100 estados excitados de dupletos. A densidade de spin e as diferenças de densidade entre os estados foram calculadas usando a análise da população de Mulliken. Todas as representações foram geradas com o software Jmol (www.jmol.org).

\subsubsection{Espectrometria de massas}

Os espectros de massa de alta resolução foram obtidos no modo positivo em Espectrômetro de Massa microTOF-QII (Bruker Daltonics, Billerica, MA, EUA), utilizando uma taxa de fluxo de $300 \mathrm{~mL} \mathrm{~h}^{-1}$; utilizando como fase móvel: água (com $30 \%$ de acetonitrila).

\subsubsection{Reatividade vascular}

\subsubsection{Avaliação da função vascular}

Para estes experimentos, foram utilizados ratos Wistar com aproximadamente 35 dias de idade e 200g, originários do Biotério Central do campus de Ribeirão Preto da Universidade de São Paulo. Estes animais foram mantidos com livre acesso à água e alimento, em temperatura de $27^{\circ} \mathrm{C}$, expostos ao ciclo de luz de $12 \mathrm{~h}$ (claro/escuro). Os ratos foram anestesiados com Isoflurano (Forane ${ }^{\circledR}$ Abbott) e depois sacrificados por decapitação. A aorta torácica foi isolada e dissecada dos tecidos adjacentes. Os procedimentos foram aprovados pelo Comitê de Ética para Uso de Animais, Proc. Nº 16.1.1137.60.0.

\subsubsection{Estudos de reatividade vascular em aorta torácica de ratos}

Após ser isolada e dissecada, a artéria aorta torácica foi cortada em anéis de $4 \mathrm{~mm}$ de comprimento. Para os ensaios na ausência de endotélio vascular, este foi removido mecanicamente. Os anéis foram, então, montados entre dois ganchos de metal inseridos no lúmen da artéria, a fim de produzir tensão. Um dos ganchos permaneceu conectado a um suporte fixo ajustável e o outro a um transdutor de registro de força. Este sistema foi montado em câmara para órgão isolado contendo $5 \mathrm{~mL}$ de solução fisiológica de Krebs, cuja composição segue (em mmol L ${ }^{-1}$ ): $\mathrm{NaCl} 130 ; \mathrm{KCl} 4,7 ; \mathrm{KH}_{2} \mathrm{PO}_{4} 1,2 ; \mathrm{MgSO}_{4} .7 \mathrm{H}_{2} \mathrm{O} 1,2 ; \mathrm{CaCl}_{2}$ 
1,6; $\mathrm{NaHCO}_{3}$ 14,9; glicose 5,5; $\mathrm{pH} 7,4$, sob constante aeração com mistura carbogênica (95\% $\mathrm{O}_{2}$ e $5 \% \mathrm{CO}_{2}$ ), a $37^{\circ} \mathrm{C}$.

Após a montagem, os anéis de aorta permaneceram em repouso por $60 \mathrm{~min}$, sob tensão basal de 1,5 g (tempo e tensão para estabilização). A tensão isométrica foi registrada com um transdutor acoplado a um polígrafo. Na sequência, os anéis de aorta foram estimulados com solução de alta concentração extracelular de cloreto de potássio $(\mathrm{KCl}, 60$ mmol L ${ }^{-1}$ ), seguido de estímulo com o agonista seletivo $\alpha_{1}$-adrenérgico (Fenilefrina $100 \mathrm{nmol}$ $\left.\mathrm{L}^{-1}\right)$, até o início das contrações.

A confirmação da manutenção (ou da remoção) do endotélio vascular foi

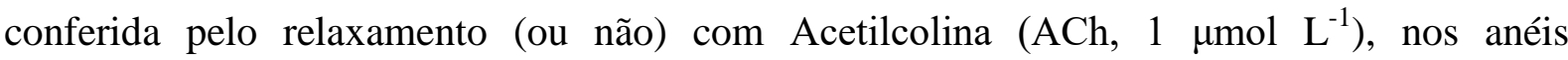
previamente contraídos com Fenilefrina $\left(100 \mathrm{nmol} \mathrm{L}^{-1}\right)$.

Da contração produzida pelos complexos e respectivos ligantes livres, bem como para o complexo precursor, foram construídas curvas concentração-efeito cumulativas. Os compostos foram adicionados com concentrações finais iguais na faixa de $0,1 \mathrm{nmol} \mathrm{L}^{-1}$ a 10 mmol L ${ }^{-1}$, sobre a tensão basal.

Para o complexo de isoproterenol e o respectivo ligante livre, as curvas concentração-efeito cumulativas $\left(0,1 \mathrm{nmol} \mathrm{L}^{-1}\right.$ a $\left.10 \mathrm{mmol} \mathrm{L}^{-1}\right)$ foram construídas sobre contração prévia com Fenilefrina $\left(100 \mathrm{nmol} \mathrm{L}^{-1}\right)$; para o complexo de dopamina e o respetivo ligante livre, todos os ensaios foram realizados na presença de incubação com o antagonista não-seletivo $\beta$-adrenérgico Propranolol $\left(5 \mu \mathrm{mol} \mathrm{L^{-1 } )}\right.$ e do antagonista não-seletivo $\alpha$ adrenérgico Fenoxibenzamina $\left(0,3 \mu \mathrm{mol} \mathrm{L}{ }^{-1}\right)$, por $30 \mathrm{~min}$. Todos os ensaios foram conduzidos em aortas com (E+) ou sem (E-) endotélio vascular.

\subsubsection{Análise estatística}

Os dados são apresentados como as médias \pm erro padrão da média (E.P.M.) de pelo menos 4 preparações de aortas de ratos, obtidas de diferentes animais $(n)$. Os valores são apresentados como porcentagem $(\%)$ de tensão. Para a determinação de $\mathrm{EC}_{50}$ (concentração que produz $50 \%$ da resposta máxima) e de efeito máximo (Emax) utilizou-se o método de regressão não-linear dos mínimos quadrados, com o programa GraphPad Prism (graphPad software, versão 5). $\mathrm{Na}$ análise da potência do agonista, utilizou-se o valor de $p \mathrm{D}_{2}\left(-\log \mathrm{EC}_{50}\right)$, que assume distribuição normal, compatível com manipulações e comparações estatísticas. Porém nem todas as curvas se ajustaram à regressão não linear, assim, para as curvas que não assumiram o padrão sigmoidal, foram realizadas as análises de área sob a curva. $\mathrm{O}$ fator interação foi avaliado utilizando-se a análise de variância de dois fatores, Two-way ANOVA 
$(P<0,01)$, seguida de correção de Bonferroni $(P<0,01)$, para identificação do(s) fator(es) de interação. A comparação entre as médias (que foram quatro ou mais), supondo distribuições normais para a mesma população, foi realizada pela análise de variância, One-way ANOVA $(P<0,05)$, com pós-teste de Newman-Keuls $(P<0,05)$.

\subsubsection{Medida do conteúdo de cálcio intracelular $\left(\left[\mathrm{Ca}^{2+}\right]_{i}\right)$ nas células HUVEC ou A7R5}

Para a realização da medida de cálcio intracelular, $\left[\mathrm{Ca}^{2+}\right]_{\mathrm{i}}$, foi utilizada a técnica de citometria de fluxo. Para tanto, uma suspensão de células HUVEC ou células do músculo liso de aorta de ratos (A7R5) em cultura, sem estímulo prévio, foi submetida à leitura e verificada a autoflorescência (controle/branco). Posteriormente, as células foram incubadas, por 30 minutos, com a sonda fluorescente Fluo-3AM ( $3 \mu \mathrm{mol} \mathrm{L}{ }^{-1}$ para HUVEC e $10 \mu \mathrm{mol} \mathrm{L}{ }^{-1}$, para A7R5). A excitação ocorreu com laser em comprimento de onda igual a $488 \mathrm{~nm}$, com emissão em 530/30 nm. As leituras foram feitas tanto no basal (ausência de tratamento), quanto na presença dos complexos e dos ligantes livres. A concentração utilizada é descrita a seguir: $\left[\mathrm{Ru}\left(\mathrm{NH}_{3}\right)_{4} \text { (noradrenalina) }\right]^{+} 300 \mu \mathrm{mol} \mathrm{L}{ }^{-1}$; $\left[\mathrm{Ru}\left(\mathrm{NH}_{3}\right)_{4} \text { (adrenalina) }\right]^{+} 300 \mu \mathrm{mol} \mathrm{L} \mathrm{L}^{-1}$; $\left[\mathrm{Ru}\left(\mathrm{NH}_{3}\right)_{4}(\text { dopamina })\right]^{+} 100 \mu \mathrm{mol} \quad \mathrm{L}^{-1} ; \quad\left[\mathrm{Ru}\left(\mathrm{NH}_{3}\right)_{4}(\text { isoproterenol })\right]^{+} \quad 300 \mu \mathrm{mol} \mathrm{L}^{-1}$; $\left[\mathrm{Ru}\left(\mathrm{NH}_{3}\right)_{4}(\text { catecol })\right]^{+} 300 \mu \mathrm{mol} \mathrm{L} \mathrm{L}^{-1}$; noradrenalina $1 \mu \mathrm{mol} \mathrm{L} \mathrm{L}^{-1}$; adrenalina $10 \mu \mathrm{mol} \mathrm{L} \mathrm{L}^{-1}$; dopamina $10 \mu \mathrm{mol} \mathrm{L} \mathrm{L}^{-1}$; isoproterenol $100 \mu \mathrm{mol} \mathrm{L}{ }^{-1}$; catecol $10 \mu \mathrm{mol} \mathrm{L} \mathrm{L}^{-1}$.

Para cada protocolo realizado, foi realizada a aquisição de 10.000 eventos em 100 $\mu \mathrm{L}$ de suspensão de células. A mediana da intensidade de fluorescência foi medida em todas as amostras usando o software DIVA. A análise por citometria de fluxo foi realizada em Citômetro de Fluxo (FACS Canto, BD; Processo FAPESP nº 04/09448-5). Os resultados são expressos como a média \pm erro padrão (E.P.M.), de pelo 4 experimentos independentes $(n=4)$. A comparação entre as médias, supondo distribuições normais para a mesma população, foi realizada pela análise de variância, One-way ANOVA $(P<0,05)$ com pós-teste de NewmanKeuls $(P<0,05)$.

\subsubsection{Ensaios na membrana corioalantoica (CAM)}

A fim de estabelecer a melhor condição para ensaios, ovos fertilizados de Legorne Branca, Gallus gallus domesticus e Hissex Brown foram testados. Os melhores resultados foram obtidos com ovos de Legorne Branca, assim, apenas estes resultados serão comunicados neste texto. 
Ovos embrionados de Legorne Branca foram limpos com água a $37^{\circ} \mathrm{C}$, logo após o recebimento. Foram, na sequência, colocados em incubadora, a $37^{\circ} \mathrm{C}$ (variações de até $0,5^{\circ}$ C são aceitáveis) e com umidade de $65 \%$, com movimento de rotação periódico. Estes ovos estavam apenas embrionados e, portanto, estavam no dia "zero" de desenvolvimento, ou seja, somente começariam a se desenvolver com o aquecimento da incubadora.

Ao terceiro dia do desenvolvimento embrionário, com o auxílio de uma pinça esterilizada, foi realizada uma abertura de $3 \mathrm{~mm}$ na casca do ovo, na região correspondente ao saco aéreo. Os ovos foram fechados com fita transparente e retornados à incubadora, porém, a partir deste momento, sem movimento de rotação.

No quinto dia do desenvolvimento embrionário, o orifício foi aumentado para 3 cm de diâmetro para a exposição da membrana corioalantoica (CAM). Ato contínuo, os ovos foram distribuídos randomicamente em grupos: controle (PBS); $\left[\mathrm{Ru}\left(\mathrm{NH}_{3}\right)_{5} \mathrm{Cl}\right] \mathrm{Cl}_{2}$ (complexo precursor); $\left[\mathrm{Ru}\left(\mathrm{NH}_{3}\right)_{4}(\text { noradrenalina })\right]^{+}$; noradrenalina; $\left[\mathrm{Ru}\left(\mathrm{NH}_{3}\right)_{4}(\text { adrenalina })\right]^{+}$; adrenalina; $\left[\mathrm{Ru}\left(\mathrm{NH}_{3}\right)_{4} \text { (isoproterenol) }\right]^{+} ; \quad$ isoproterenol; $\quad\left[\mathrm{Ru}\left(\mathrm{NH}_{3}\right)_{4} \text { (dopamina) }\right]^{+} ; \quad$ dopamina; $\left[\mathrm{Ru}\left(\mathrm{NH}_{3}\right)_{4}(\mathrm{catecol})\right]^{+}$. Na sequência foram fotografados e, posteriormente, os tratamentos foram realizados: duas doses de $50 \mathrm{nmol}$ dos compostos, em solução de PBS, aplicadas nos $5^{\circ}$ e $6^{\circ}$ dias do desenvolvimento embrionário.

Após 24 horas da primeira dose (no $6^{\circ}$ dia do desenvolvimento embrionário) e antes da adição da segunda dose, os ovos foram novamente fotografados. No $7^{\circ}$ dia do desenvolvimento embrionário ( 24 horas após a segunda dose), os ovos foram fotografados também. Em seguida, os embriões foram sacrificados com a aplicação de $100 \mu \mathrm{L}$ de uma solução de formaldeído $10 \%$, e após observada a parada dos batimentos cardíacos do embrião, constatando sua morte, os ovos foram congelados e encaminhados para descarte.

As membranas corioalantoicas foram fotografadas in ovo com um estereomicroscópio Olympus SZX7, aumento de 8x, equipado com uma câmera Olympus Camedia - C5060. A quantidade, a área total dos vasos sanguíneos, bem como o índice de lacunaridade foram quantificados usando o software Image Tool. Os dados são apresentados como a média \pm erro padrão (E.P.M.), de pelo menos 3 animais $(\mathrm{n} \geq 3)$, e foram tratados com o programa GraphPad Prism Versão 5.0 (Corporação de San Diego, CA). Os resultados foram analisados por análise de variância, One-way ANOVA, com pós-teste Newman-Keuls $(P<0,05)$. Os resultados foram expressos como porcentagens em relação ao dia no qual a primeira dose foi adicionada (antes dos tratamentos) (MARTINHO et. al., 2013; NOWAKSLIWINSKA et. al., 2010; NOWAK-SLIWINSKA et. al., 2011). Embora se trate de procedimento considerado in vitro, até o $14^{\circ}$ dia do desenvolvimento embrionário (IACUC , 
2017), o projeto foi submetido e aprovado no Comitê de Ética para Uso de Animais (da Faculdade de Ciências Farmacêuticas de Ribeirão Preto - USP (Proc. No. 16.1.1137.60.0), bem como no Hospital de Câncer de Barretos (Comitê de Ética da Fundação PIO XII IRCAD BRASIL. N ${ }^{o}$ 024.2016). Os animais utilizados foram provenientes do criatório Mário Salviato Ovos Férteis, localizado na cidade de Porto Ferreira.

As principais etapas da metodologia são mostradas a seguir (figura 8):

Figura 8: Principais etapas do ensaio na CAM

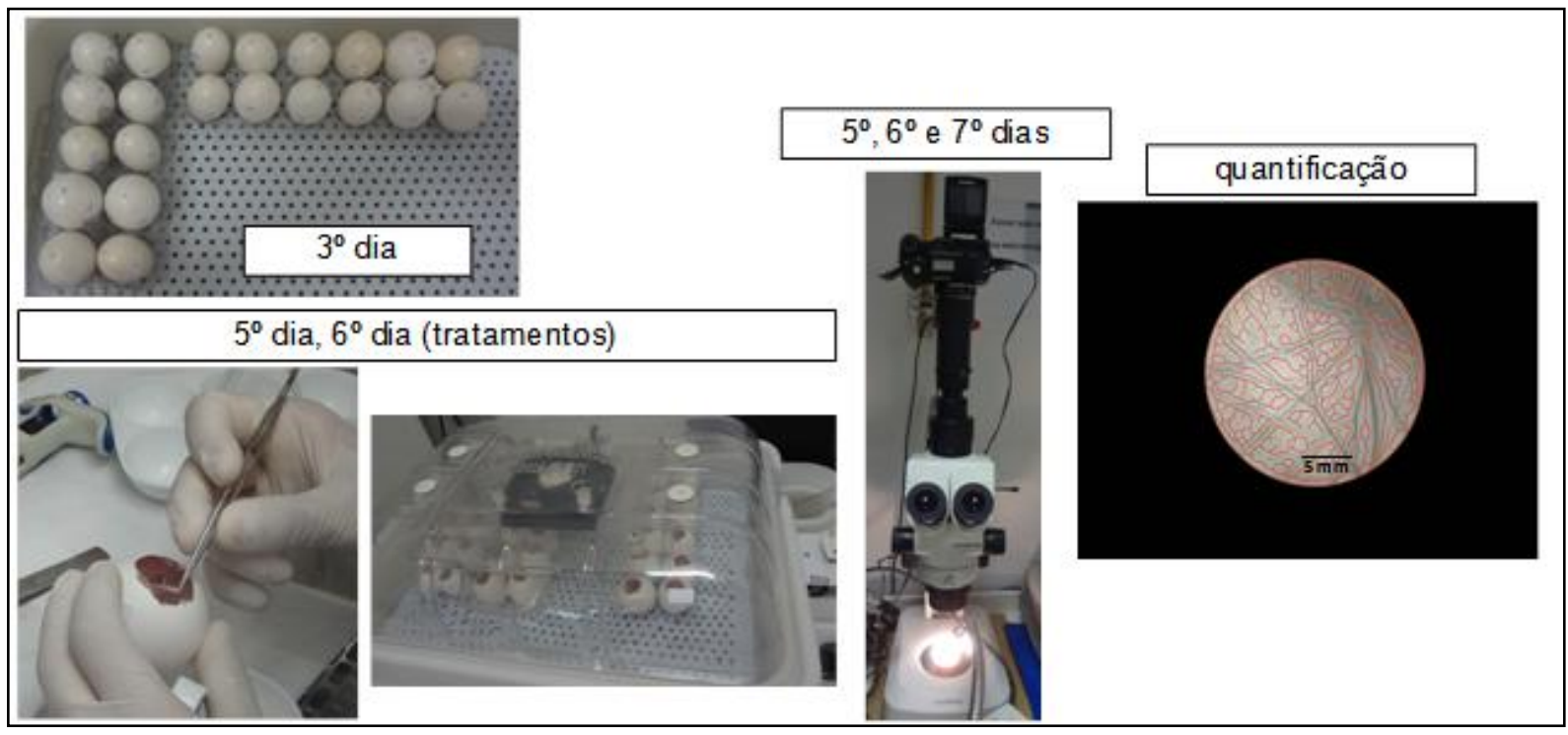

Fonte: Autora

\subsubsection{Análise das alterações do ciclo celular}

As células HUVEC foram analisadas em relação ao ciclo celular, na presença de veículo/controle (PBS), $\left[\mathrm{Ru}\left(\mathrm{NH}_{3}\right)_{4}(\text { noradrenalina })\right]^{+}\left(300 \mu \mathrm{mol} \mathrm{L}{ }^{-1}\right)$, ou noradrenalina (300 $\mu \mathrm{mol} \mathrm{L} \mathrm{L}^{-1}$ ), por $24 \mathrm{~h}$ e $48 \mathrm{~h}$, na passagem 5 . Para tanto, as células foram cultivadas em meio DMEM contendo $10 \%$ de soro bovino fetal $+1 \%$ de solução antibiótica $+25 \mu \mathrm{g} \mathrm{mL}^{-1}$ de sulfato de gentamicina. Na garrafa de cultivo, após atingirem a confluência, as células permaneceram $24 \mathrm{~h}$ antes dos tratamentos em meio de cultura com apenas $0,5 \%$ de soro bovino fetal, a fim de que ocorresse a sincronização do crescimento celular.

Após 24h, foram adicionados o veículo ou os tratamentos. Após o tempo acima descrito, as células foram tripsinizadas (solução de Tripsina-EDTA 1\%), centrifugadas 1100 rpm por 5 minutos e, posteriormente, ressuspendidas em solução $50 \%$ de etanol $92,8 \%(\mathrm{v} / \mathrm{v})$ gelada e mantida a $-20^{\circ} \mathrm{C}$ por $1 \mathrm{~h}$. Na sequência, as células foram centrifugadas novamente e 
ressuspendidas em $50 \mu \mathrm{L}$ de uma solução $100 \mu \mathrm{g} \mathrm{mL}^{-1}$ de RNAse livre de DNAse (Qiagen) por $30 \mathrm{~min}$, a $37^{\circ} \mathrm{C}$.

Ato contínuo, as células foram transferidas para tubos de citometria de fluxo e à elas adicionou-se $200 \mu \mathrm{L}$ de solução de Iodeto de Propídio (PI) $100 \mathrm{mg} \mathrm{mL}^{-1}$. Os tubos foram mantidos no gelo por 1h, ao abrigo da luz. Decorrido o tempo, procedeu-se à leitura da emissão (do PI), após a excitação com laser 488 nm, com emissão em 695/40 nm, por citometria de fluxo, realizada em Citômetro de Fluxo (FACS Canto, BD; Processo FAPESP $\mathrm{n}^{\circ}$ 04/09448-5). A análise foi feita utilizando-se o software ModFit LT 3.3. A comparação entre as médias, supondo distribuições normais para a mesma população, foi realizada pela análise de variância, One-way ANOVA $(P<0,05)$ com pós-teste de Newman-Keuls $(P<0,05)$.

\subsubsection{Ensaio de recuperação de lesão}

No que se refere ao ensaio de recuperação de lesão, o qual avalia crescimento e proliferação celular, foram utilizadas diversas linhagens celulares: células B16F10, SF-188, HUVEC e FR37-CMT.

Após a confluência, as células foram tripsinizadas (solução de Tripsina-EDTA $1 \%$ ), centrifugadas $1100 \mathrm{rpm}$ por 10 minutos e ressuspendidas em meio de cultura e plaqueadas em placas de 24 poços. Aguardou-se $24 \mathrm{~h}$ para a confluência no fundo dos poços, quando, então, realizou-se, com a ponta de uma ponteira de $200 \mu \mathrm{L}$, um risco em cada pocinho, sendo mantidas as mesmas posição e largura (LAI et al., 2015), descartando-se a ponteira após cada utilização. Logo após a realização da lesão, os poços foram fotografados.

Em seguida, trocou-se o meio de cultura para o equivalente sem fenol red e as células reberam os devidos tratamentos com os compostos, ou não (condição controle): $\left[\mathrm{Ru}\left(\mathrm{NH}_{3}\right)_{4} \text { (noradrenalina) }\right]^{+} \quad\left(200 \mu \mathrm{mol} \quad \mathrm{L}^{-1}\right) ; \quad$ noradrenalina $\left(200 \mu \mathrm{mol} \quad \mathrm{L}^{-1}\right)$; $\left[\mathrm{Ru}\left(\mathrm{NH}_{3}\right)_{4}(\text { adrenalina })\right]^{+} \quad\left(200 \mu \mathrm{mol} \quad \mathrm{L}^{-1}\right) ; \quad$ adrenalina $\quad\left(200 \mu\right.$ mol $\left.\quad \mathrm{L}^{-1}\right)$; $\left[\mathrm{Ru}\left(\mathrm{NH}_{3}\right)_{4} \text { (isoproterenol) }\right]^{+} \quad\left(200 \mu \mathrm{mol} \quad \mathrm{L}^{-1}\right) ; \quad$ isoproterenol $\quad\left(200 \mu \mathrm{mol} \quad \mathrm{L}^{-1}\right)$; $\left[\mathrm{Ru}\left(\mathrm{NH}_{3}\right)_{4}(\text { dopamina })\right]^{+}\left(200 \mu \mathrm{mol} \mathrm{L}{ }^{-1}\right)$; dopamina $\left(200 \mu \mathrm{mol} \mathrm{L}^{-1}\right) ;\left[\mathrm{Ru}\left(\mathrm{NH}_{3}\right)_{4}(\text { catecol })\right]^{+}(200$ $\left.\mu \mathrm{mol} \mathrm{L}{ }^{-1}\right)$; catecol $\left(200 \mu \mathrm{mol} \mathrm{L}{ }^{-1}\right)$.

Após 24 horas, as células os poços das placas foram novamente fotografadas. Para tanto, utilizou-se microscópio de fluorescência Nikon Eclipse Ti, objetiva 10x. 


\subsubsection{Viabilidade celular}

As células B16F10 foram cultivadas em meio de cultura RPMI 1640 contendo $10 \%$ de soro bovino fetal, com $1 \%$ de solução antibiótica (Penicilina + Streptomicina + Anfotericina B). Após a confluência, as células foram tripsinizadas (solução de TripsinaEDTA 1\%), centrifugadas $1100 \mathrm{rpm}$ por 10 minutos e ressuspendidas em meio de cultura. Posteriormente, foram plaqueadas em placas de 96 poços ( $1 \times 10^{5}$ células $\left./ \mathrm{mL}\right)$. Após 24 horas (tempo suficiente para atingirem a confluência), estas células foram tratadas com complexos e seus respectivos ligantes livres, por $24 \mathrm{~h}$ e $48 \mathrm{~h}$. O meio foi, então, substituído por uma solução do sal de MTT (brometo de 3-(4,5-dimetil-2-tiazolil)-2,5-difenil-2H-tetrazólio, 0,5 mg mL ${ }^{-1}$ ) em tampão fosfato $\mathrm{pH} 7,4$, sendo $200 \mu \mathrm{L}$ por poço. Com a solução de MTT, as células ficaram incubadas por 3 horas, depois das quais esta solução foi removida e adicionados 200 $\mu \mathrm{L}$ de dimetilsulfóxido (DMSO) por poço, para solubilização do precipitado. Aguardou-se uma hora, tempo suficiente para que o conteúdo ficasse homogêneo. Procedeu-se, então a leitura das placas, a qual foi efetuada em leitor de Elisa, com absorbância lida em $492 \mathrm{~nm}$.

Os complexos $\quad\left[\mathrm{Ru}\left(\mathrm{NH}_{3}\right)_{4}(\text { noradrenalina })\right]^{+} ; \quad\left[\mathrm{Ru}\left(\mathrm{NH}_{3}\right)_{4}(\text { adrenalina })\right]^{+}$; $\left[\mathrm{Ru}\left(\mathrm{NH}_{3}\right)_{4} \text { (isoproterenol) }\right]^{+} ;\left[\mathrm{Ru}\left(\mathrm{NH}_{3}\right)_{4}(\text { dopamina })\right]^{+} ;\left[\mathrm{Ru}\left(\mathrm{NH}_{3}\right)_{4}(\text { catecol })\right]^{+}$e os respectivos ligantes livres noradrenalina; adrenalina; isoproterenol; dopamina e catecol, foram utilizados diluídos diretamente em PBS, uma vez que os mesmos são solúveis nesta solução. Enquanto para $\quad$ os $\quad$ complexos $\quad\left[\mathrm{Ru}(\mathrm{bpy})_{2} \text { (noradrenalina) }\right]^{+} ; \quad\left[\mathrm{Ru}(\mathrm{bpy})_{2} \text { (adrenalina) }\right]^{+}$;

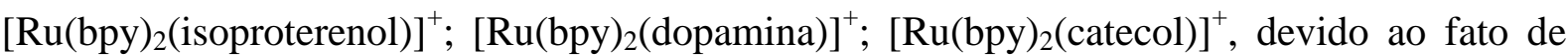
serem insolúveis em água, utilizou-se solução de PBS, contendo 1\% de DMSO.

Os resultados são expressos como porcentagens de células viáveis. A porcentagem de viabilidade celular é definida pela seguinte equação:

$$
\text { Porcentagem de células viáveis }=1-\frac{\text { Absorvância experimental }}{\text { Absorvãncia do controle }} \times 100
$$

(Equação 1)

\subsubsection{Análise estatística}

Análise estatística foi realizada utilizando-se o software GraphPad Prism 5.0, com a análise de variância One-way ANOVA, com pós-teste de Newman-Keuls para a comparação de 3 ou mais grupos $(n \geq 3)$. Os resultados foram expressos como média \pm erro padrão da média (E.P.M.), com valor de significância de $P<0,05$. 


\subsubsection{Estudos de interação com $f s-D N A$ - titulação espectofotométrica na região $U V$-vis}

A metodologia utilizada neste ensaio foi realizada conforme descrições prévias da literatura (TANIMOTO et al., 2012; SIRAJUDDIN; ALI; BADSHAH, 2013). E a opção por trabalhar com a solução de $f s$-DNA, o qual é proveniente de esperma de peixe, ocorreu em função de que o trabalho com o comumente utilizado ct-DNA (Calf Thymus DNA) é mais dificultoso (TANIMOTO et al., 2012).

Os complexos $\quad\left[\mathrm{Ru}\left(\mathrm{NH}_{3}\right)_{4}(\text { noradrenalina })\right]^{+}, \quad\left[\mathrm{Ru}\left(\mathrm{NH}_{3}\right)_{4}(\text { adrenalina })\right]^{+}$, $\left[\mathrm{Ru}\left(\mathrm{NH}_{3}\right)_{4} \text { (isoproterenol) }\right]^{+}, \quad\left[\mathrm{Ru}\left(\mathrm{NH}_{3}\right)_{4}(\text { dopamina })\right]^{+} \quad$ e $\quad\left[\mathrm{Ru}\left(\mathrm{NH}_{3}\right)_{4}(\text { catecol })\right]^{+}$foram solubilizados em tampão tris (50 mM, com $5 \mathrm{mM}$ de $\mathrm{NaCl}, \mathrm{pH} 7,4)$, enquanto os complexos $\left[\operatorname{Ru}(\text { bpy })_{2} \text { (noradrenalina) }\right]^{+}, \quad\left[\operatorname{Ru}(\text { bpy })_{2} \text { (adrenalina) }\right]^{+}, \quad\left[\operatorname{Ru}(\text { bpy })_{2} \text { (isoproterenol) }\right]^{+}$, $\left[\mathrm{Ru}(\mathrm{bpy})_{2}(\text { dopamina })\right]^{+}$e $\left[\mathrm{Ru}(\mathrm{bpy})_{2}(\mathrm{catecol})\right]^{+}$, foram solubilizados em DMSO e, posteriormente, diluídos no mesmo tampão, sendo que a concetração final de DMSO foi 0,5\%. Para todos os complexos, as concentrações das soluções foram $50 \mu \mathrm{M}$, exceto para o complexo $\left[\mathrm{Ru}\left(\mathrm{NH}_{3}\right)_{4}(\text { catecol })\right]^{+}$, para o qual a concentração final da solução foi $25 \mu \mathrm{M}$.

Essas soluções de complexos foram tituladas com alíquotas de $2 \mu \mathrm{L}$ de uma solução $46,7 \mathrm{mM}$ de $f s$-DNA, solubilizado em tampão tris $50 \mathrm{mM}$, com $5 \mathrm{mM}$ de $\mathrm{NaCl}, \mathrm{pH}$ 7,4. As concentrações finais do $f s$-DNA, na cubeta, variaram de 31,1 a $340 \mu \mathrm{M}$.

Para o preparo da solução de $f s$-DNA, pesou-se 9,26 mg e dissolveu-se em 9,26 mL de tampão tris. A solução foi agitada no vórtex, até completa dissolução do sólido. Após o preparo e ao longo de todo o tempo para a realização dos experimentos, a solução foi mantida no gelo. A concentração da solução de $f s$-DNA foi obtida pela Lei de Lambert-Beer, após a leitura do espectro de absorbância. Isso porque o coeficiente de absortividade molar do $f s$ DNA é conhecido: em $260 \mathrm{~nm}$ é igual a $6600 \mathrm{~L} \mathrm{~mol}^{-1} \mathrm{~cm}^{-1}$.

A averiguação da razão $\frac{A_{260}}{A_{280}}$ é essencial para verificação se o DNA está livre de proteínas e, portanto, útil para os ensaios. A razão obtida foi 1,88, a qual indicou que o mesmo poderia ser utilizado nos ensaios (SIRAJUDDIN; ALI; BADSHAH, 2013).

As titulações com $f_{s}$-DNA foram acompanhadas pela leitura de espectros de absorção na região UV-vis e, os tratamentos dos dados serão mostrados quando da discussão dos mesmos.

O experimento foi realizado em três temperaturas $\left(25,30\right.$ e $\left.37^{\circ} \mathrm{C}\right)$, a fim de que fosse possível avaliar os parâmetros termodinâmicos da interação, via equação de van't Hoff. 


\subsubsection{Estudos de interação com fs-DNA - deslocamento do brometo de etídio - espectroscopia de fluorescência}

O deslocamento do brometo de etídio foi monitorado por espectroscopia de fluorescência, conforme metodologia amplamente divulgada na literatura (GAO et al., 2009; ICSEL; YILMAZ, 2013; SIRAJUDDIN; ALI; BADSHAH, 2013).

Para o ensaio, preparou uma solução de $f s$-DNA (tampão tris $50 \mathrm{mM}, \mathrm{pH} 7,4,5$ $\mathrm{mM}$ de $\mathrm{NaCl}$ ), em concentração igual a 45,9 $\mu \mathrm{M}$. À esta solução, foram adicionados $6 \mu \mathrm{L}$ de uma solução concentrada de brometo de etídio (BET) $(2,5 \mathrm{mM})$, obtendo-se ao final BET em concentração $5 \mu \mathrm{M}$ água. Após a adição do BET, a solução de $f s$-DNA foi mantida em repouso por uma hora, a uma temperatura constante de $25{ }^{\circ} \mathrm{C}$. A mesma temperatura foi mantida durante todo o experimento.

Decorrida uma hora, a solução de $f s$-DNA foi titulada com alíquotas de $2 \mu \mathrm{L}$ (para

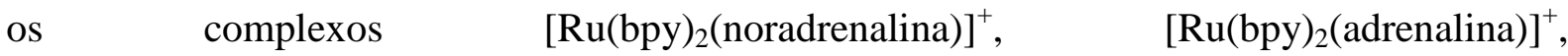
$\left[\mathrm{Ru}(\mathrm{bpy})_{2}(\text { isoproterenol })\right]^{+}, \quad\left[\mathrm{Ru}(\mathrm{bpy})_{2}(\text { dopamina })\right]^{+}$e $\left[\mathrm{Ru}(\mathrm{bpy})_{2}(\mathrm{catecol})\right]^{+}, \quad$ previamente solubilizados em tampão tris) ou $10 \mu \mathrm{L}$ (para os complexos $\left[\mathrm{Ru}\left(\mathrm{NH}_{3}\right)_{4} \text { (noradrenalina) }\right]^{+}$ $\left[\mathrm{Ru}\left(\mathrm{NH}_{3}\right)_{4}(\text { adrenalina })\right]^{+} \quad\left[\mathrm{Ru}\left(\mathrm{NH}_{3}\right)_{4}(\text { isoproterenol })\right]^{+}, \quad\left[\mathrm{Ru}\left(\mathrm{NH}_{3}\right)_{4}(\text { dopamina })\right]^{+} \quad \mathrm{e}$ $\left[\mathrm{Ru}\left(\mathrm{NH}_{3}\right)_{4}(\text { catecol })\right]^{+}$, previamente solubilizados em DMSO) de soluções $10 \mathrm{mM}$ dos complexos, sendo que as concentrações finais dos complexos variaram de 6,7 a $112 \mu \mathrm{M}$, para os complexos com fórmula geral $\left[\mathrm{Ru}(\mathrm{bpy})_{2}(\text { cat-R) }]^{+}\right.$(não ultrapassando o limite de $2 \%$ de DMSO) e, de 33,1 a $500 \mu \mathrm{M}$, para os complexos com fórmula geral $\left[\mathrm{Ru}\left(\mathrm{NH}_{3}\right)_{4}(\text { cat-R) }]^{+}\right.$.

A titulação foi acompanhada por espectroscopia de fluorescência, sendo que a emissão observada se refere ao sistema BET- $f s$-DNA. A excitação foi realizada em $526 \mathrm{~nm}$ e, a emissão observada em $605 \mathrm{~nm}$. A leitura do espectro de emissão foi acompanhada na faixa de 545 a $700 \mathrm{~nm}$. Os espectros de fluorescência foram registrados em Espectrofluorímetro Shimadzu, Modelo RF-5301PC. A análise da supressão de fluorescência, causada pelos complexos, foi analisada pela equação de Stern-Volmer e será discutida quando da apreciação dos resultados.

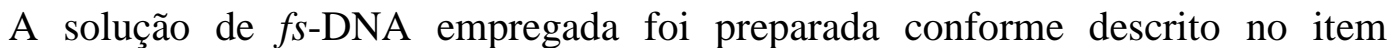
precedente desta metodologia. 


\subsubsection{Interação com proteína carreadora (proteína do soro humano albumina - HSA) - mimetizando transporte in vivo}

A interação com a proteína do soro humano albumina (HSA) foi verificada via titulação espectrofotométrica, a qual foi acompanhada por espectroscopia de fluorescência.

Para os ensaios, foi preparada uma solução de HSA em concentração igual a 1,0 $10^{-6} \mathrm{~mol} \mathrm{~L}{ }^{-1}$, em tampão Tris, $\mathrm{pH}=7,3$. Desta, $2,5 \mathrm{~mL}$ foram adicionados em uma cubeta de fluorescência. A cubeta foi mantida em banho termostático por 5 minutos, a fim de que a solução estabilizasse na temperatura desejada, $25^{\circ} \mathrm{C}$.

À solução da cubeta, foram adicionadas alíquotas de $10 \mu \mathrm{L}$ de solução de cada um dos complexos estudados, com fórmula geral $\left[\mathrm{Ru}\left(\mathrm{NH}_{3}\right)_{4}(\text { cat-R) }]^{+}\right.$, em concentração $5,010^{-3}$ mol L ${ }^{-1}$, em tampão Tris, $\mathrm{pH}=7,3$. Para os complexos com fórmula geral $\left[\mathrm{Ru}(\mathrm{bpy})_{2}(\mathrm{cat}-\mathrm{R})\right]^{+}$, foi preparada uma solução em DMSO, em concentração $8,0210^{-2} \mathrm{~mol} \mathrm{~L}^{-1} \mathrm{e}$, posteriormente, diluída em tampão Tris, $\mathrm{pH}=7,3$, para concentração igual a $8,0210^{-4} \mathrm{~mol} \mathrm{~L}^{-1}$. Desta solução, foram adicionadas alíquotas de $5 \mu \mathrm{L}$ à solução de HSA contida na cubeta, de forma que a porcentagem de DMSO na cubeta foi $\leq 1 \%$.

Os procedimentos foram repetidos, para os complexos com fórmula geral $\left[\mathrm{Ru}\left(\mathrm{NH}_{3}\right)_{4}(\text { cat-R })\right]^{+}$, a 32 e $37^{\circ} \mathrm{C}$, enquanto para os complexos com fórmula geral $\left[\mathrm{Ru}(\text { bpy })_{2}(\text { cat-R })\right]^{+}$, a 32 e $38^{\circ} \mathrm{C}$.

A emissão das soluções foram lidas, na ausência e presença das alíquotas de complexos, após excitação em $\lambda_{\text {exc }} 280 \mathrm{~nm}$. A emissão foi analisada entre 300 e $500 \mathrm{~nm}$. Utilizou-se, para tanto, Espectrofluorímetro Shimadzu, Modelo RF-5301PC. Os procedimentos foram realizados conforme descrito na literatura (CACITA; NIKOLAOU, 2016) e as equações utilizadas seguem descritas no corpo do texto, na parte onde são apresentados os resultados. 


\section{RESULTADOS E DISCUSSÃO}

\subsection{Parte 1: Complexos com fórmula geral: [Ru(NH$)_{4}$ cat-R]Cl}

\subsubsection{Síntese e Purificação}

Tal como narrado anteriormente, a rota sintética ocorreu fundamentada em publicações prévias do grupo (DE LIMA et. al., 2004), todavia, algumas considerações são necessárias e serão elencadas a seguir.

Complexos metálicos de catecol coordenados com rutênio foram anteriormente descritos por Silva e colaboradores, propositores da rota sintética adaptada para este trabalho (SILVA; TFOUNI; LEVER, 1995). Os autores descreveram as sínteses de tetraaminodioxolenorutênio(III), onde dioxoleno é 3,4-diolatobenzoato. Posteriormente, Silva e coautores (2000) publicaram as sínteses e caracterizações de espécies onde dioxoleno é catecol ou 1,2-dihidróxi-4-metoxibenzeno. De Lima, em 2001, publicou a síntese e caracterização de complexos nos quais dioxoleno são dopamina, noradrenalina ou isoproterenol. Os complexos, com carga 1+, foram precipitados com o contraíon hexafluorofosfato.

No trabalho neste texto descrito, visando-se a posterior aplicação biológica, optou-se por precipitar os complexos utilizando o contraíon cloreto, proveniente dos respectivos cloridratos de catecolamina.

Três dos ligantes, dopamina, noradrenalina e adrenalina, foram escolhidos em razão de serem moléculas endógenas; isoproterenol foi escolhido, pois apesar de ser uma catecolamina sintética, é amplamente utilizada como fármaco agonista dos receptores $\beta$ adrenérgicos; e catecol foi escolhido exatamente por não possuir o grupamento amina, razão pela qual será utilizado como balizador dos resultados biológicos. O complexo de adrenalina não fora reportado outrora, tratando-se de complexo inédito.

A estrutura genérica das catecolaminas é mostrada a seguir, bem como os respectivos substituintes na fórmula estrutural (figura 9 e tabela 3 ): 
Figura 9: Estrutura das catecolaminas

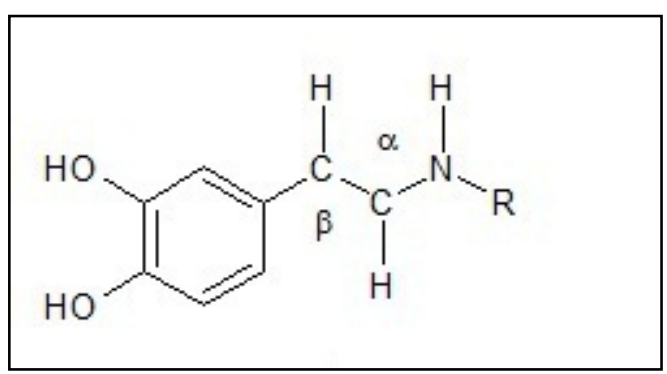

Fonte: Adaptado de DE LIMA, 2001 apud GOODMAN, 1996

Tabela 3: Substituintes das catecolaminas

\begin{tabular}{cccc}
\hline & $\boldsymbol{\beta}$ & $\boldsymbol{\alpha}$ & $\mathbf{N H}-\mathbf{R}$ \\
\cline { 2 - 4 } isoproterenol & $\mathbf{O H}$ & $\mathbf{H}$ & $\mathbf{C H}\left(\mathbf{C H}_{3}\right)_{2}$ \\
adrenalina & $\mathbf{O H}$ & $\mathbf{H}$ & $\mathbf{C H}_{3}$ \\
noradrenalina & $\mathbf{O H}$ & $\mathbf{H}$ & $\mathbf{H}$ \\
dopamina & $\mathbf{H}$ & $\mathbf{H}$ & $\mathbf{H}$ \\
\hline
\end{tabular}

Fonte: Adaptado de DE LIMA, 2001 apud GOODMAN, 1996

A formação dos produtos é totalmente dependente da basicidade do meio (DE LIMA, 2001), além do que realização das sínteses em solução alcalina de hidróxido de amônio é condição sine qua non para a obtenção dos produtos, uma vez que a coordenação ao rutênio pode ocorrer tanto via sítio catecólico, quanto amínico.

O mecanismo proposto para as sínteses é apresentado (genericamente) a seguir (figura 10): 
Figura 10: Mecanismo de reação para os complexos do tipo $\left[\mathrm{Ru}\left(\mathrm{NH}_{3}\right)_{4}\right.$ cat-R $] \mathrm{Cl}$

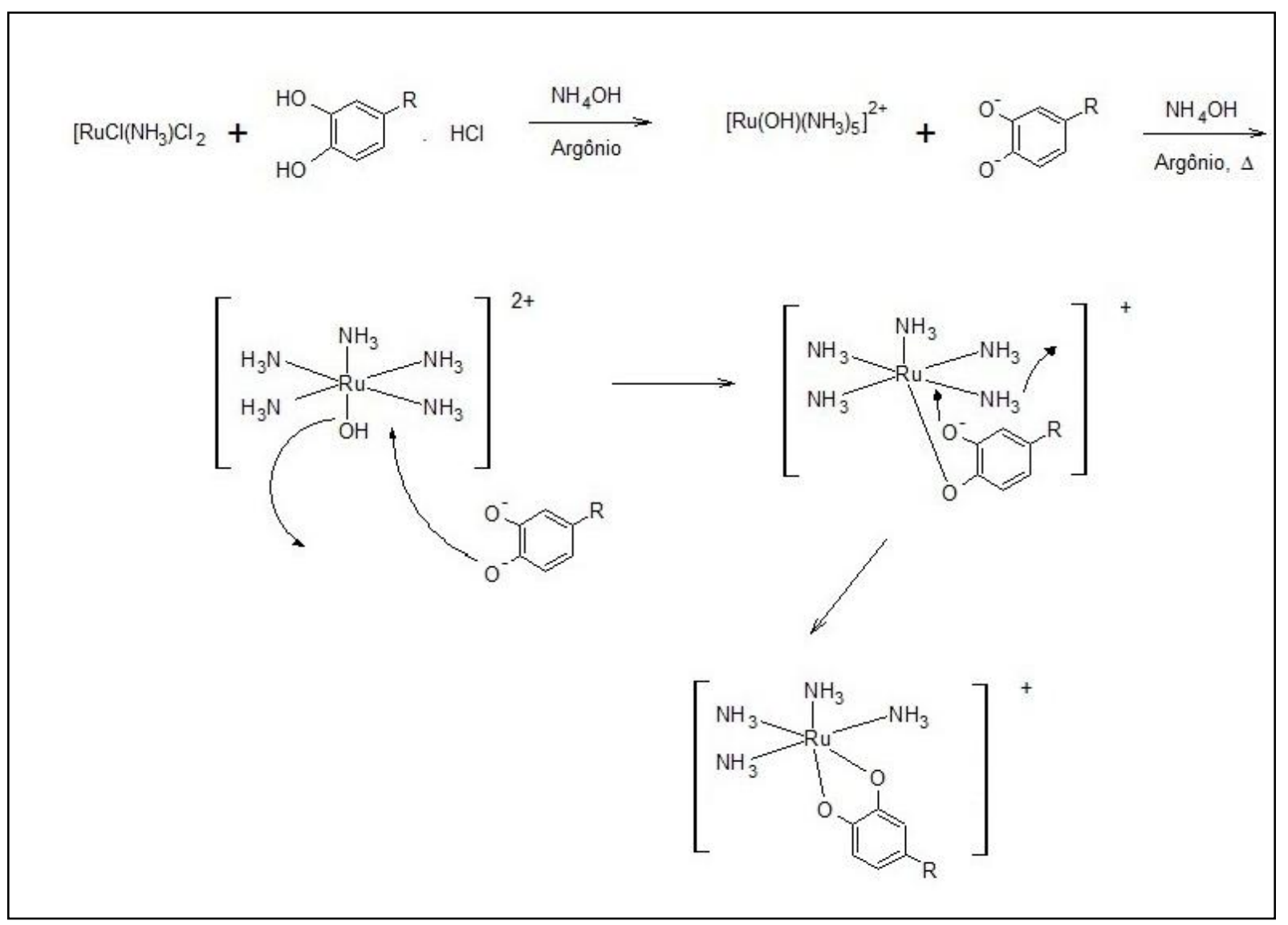

Fonte: Adaptado de DE LIMA, 2001

Conforme pode ser verificado na proposta de mecanismo, acredita-se que a saída do ligante cloreto promova a entrada de uma hidroxila, a qual é posteriormente labilizada pelo primeiro grupamento do catecol, que na segunda etapa promove a saída de um ligante amino para promover a coordenação pelo outro átomo de oxigênio, formando um quelato (DE LIMA, 2001). A coordenação da segunda hidroxila é favorecida pelo efeito quelato, bem como pela basicidade do meio, pois a segunda ionização das catecolaminas ocorre no grupamento amina ( $\left.\mathrm{pKa}_{2}\right)$ e não no segundo fenol ( $\left.\mathrm{pKa}_{3}\right)$ (ARMSTRONG; BARLOW, 1976).

Não obstante o fato de o metal já se encontrar com Nox alto, Ru(III), a condução das sínteses em atmosfera inerte é imprescindível à obtenção dos complexos, uma vez que os ligantes podem ser oxidados e este processo é irreversível (DE LIMA et. al., 2003).

Os rendimentos obtidos, de no mínimo 50\% para as sínteses dos complexos, constituem aspectos positivos quando aplicações biológicas de determinada espécie química são almejadas. 
Todos os complexos são muito solúveis em meio aquoso, o que permitiu que fossem facilmente precipitados com acetona, todavia, não obstante a sua precipitação, a cromatografia em camada delgada (CCD) demonstrou a necessidade de purificação em coluna cromatográfica. Adaptações às etapas de purificação, em relação ao reportado anteriormente por Lima (2001), foram efetuadas e demonstraram bons resultados.

A coloração azul dos complexos, com tonalidades diferentes, pode ser vista na imagem a seguir - coloração esta justificada pelo espectro de absorção na região do UV-vis, discutido a seguir (figura 11):

Figura 11: Soluções dos complexos $\left[\mathrm{Ru}\left(\mathrm{NH}_{3}\right)_{4}(\text { cat-R })\right]^{+}$, onde cat $=$isoproterenol, dopamina, noradrenalina, catecol e adrenalina, respectivamente

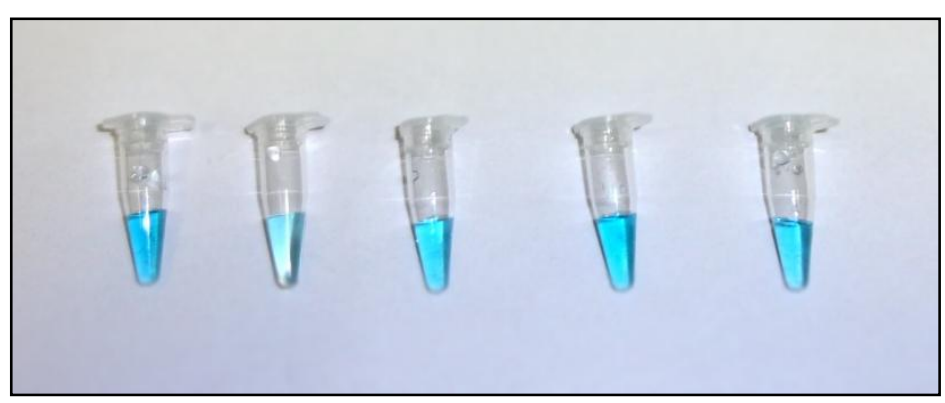

Fonte: Autora

\subsubsection{Cromatografia Líquida de Alta Eficiência (CLAE/HPLC)}

Após purificação em coluna cromatográfica, a pureza dos complexos foi confirmada por CLAE e, de acordo com tais análises, os complexos encontravam-se puros, conforme pode ser verificado nos cromatogramas a seguir (figuras 12 a 16), uma vez que os espectros de absorção coincidem com os esperados para as espécies:

Figura 12: Cromatograma de $\left[\mathrm{Ru}\left(\mathrm{NH}_{3}\right)_{4}(\text { isoproterenol })\right]^{+}$; coluna $\mathrm{C}_{18} ; 15 \% \mathrm{MeOH}$ em PBS, pH 6.9; eluição isocrática; $1,0 \mathrm{~mL} / \mathrm{min} ; \lambda=225 \mathrm{~nm}$

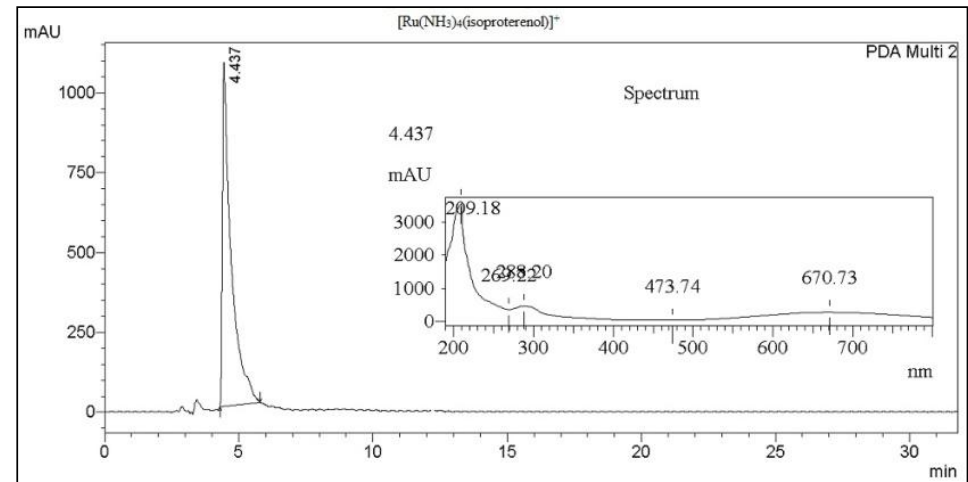

Fonte: Autora 
Figura 13: Cromatograma de $\left[\mathrm{Ru}\left(\mathrm{NH}_{3}\right)_{4}(\text { dopamina })\right]^{+}$; columa $\mathrm{C}_{18} ; 15 \% \mathrm{MeOH}$ em PBS, pH 6.9; eluição isocrática; $1,0 \mathrm{~mL} / \mathrm{min} ; \lambda=225 \mathrm{~nm}$

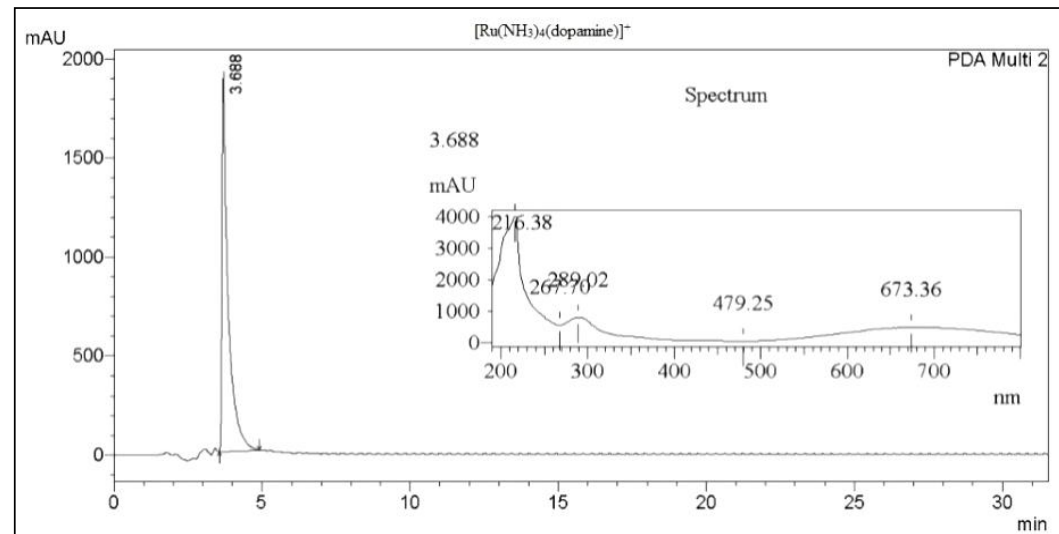

Fonte: Autora

Figura 14: Cromatograma de $\mathrm{Ru}\left(\mathrm{NH}_{3}\right)_{4}$ (noradrenalina)] ${ }^{+}$; columa $\mathrm{C}_{18} ; 15 \% \mathrm{MeOH}$ em PBS, pH 6.9; eluição isocrática; $1,0 \mathrm{~mL} / \mathrm{min} ; \lambda=225 \mathrm{~nm}$

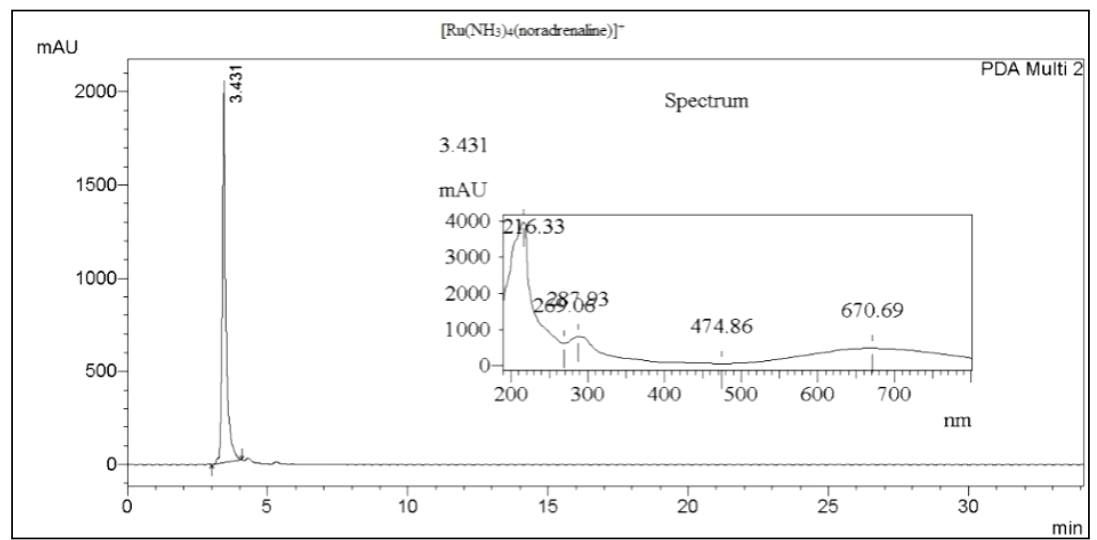

Fonte: Autora

Figura 15: Cromatograma de $\left[\mathrm{Ru}\left(\mathrm{NH}_{3}\right)_{4}(\text { catecol })\right]^{+}$; columa $\mathrm{C}_{18} ; 15 \% \mathrm{MeOH}$ em PBS, pH 6.9; eluição isocrática; $1,0 \mathrm{~mL} / \mathrm{min} ; \lambda=225 \mathrm{~nm}$

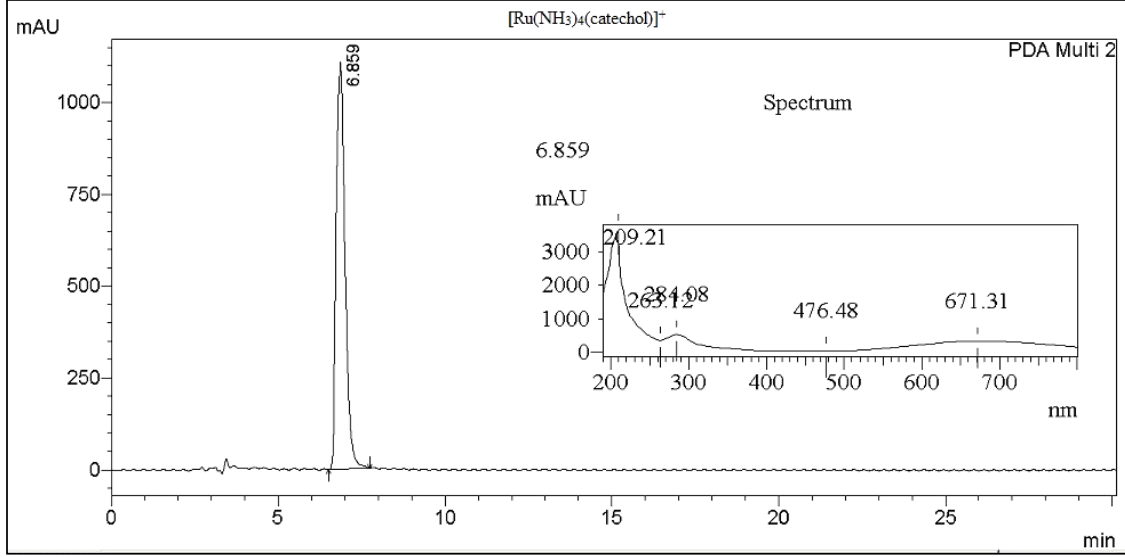

Fonte: Autora 
Figura 16: Cromatograma de $\left[\mathrm{Ru}\left(\mathrm{NH}_{3}\right)_{4}(\text { adrenalina })\right]^{+}$; columa $\mathrm{C}_{18} ; 15 \% \mathrm{MeOH}$ em PBS, pH 6.9; eluição isocrática; $1,0 \mathrm{~mL} / \mathrm{min} ; \lambda=225 \mathrm{~nm}$

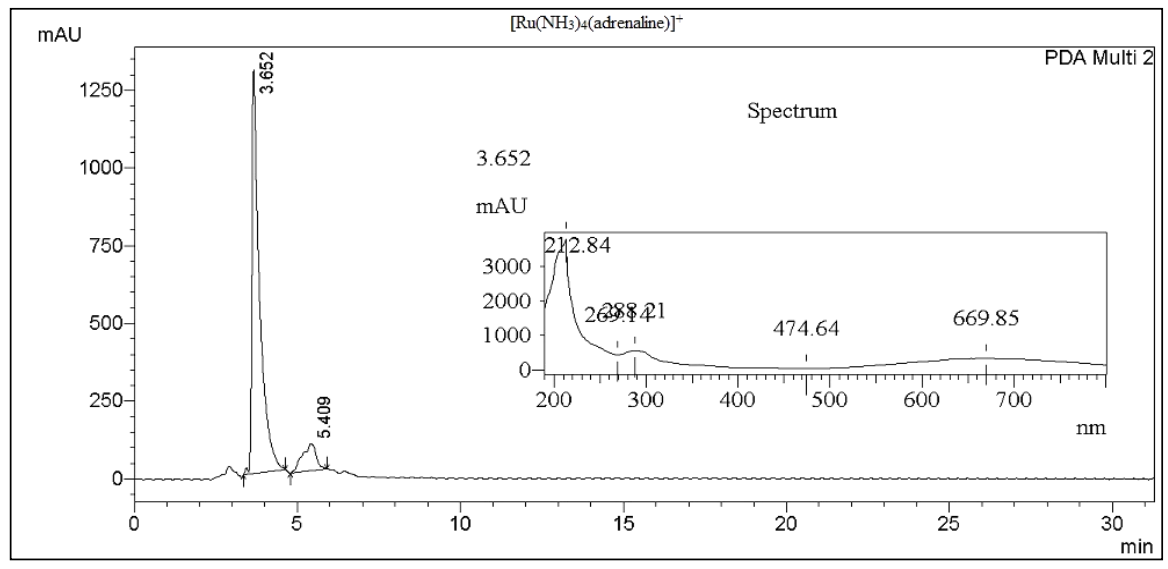

Fonte: Autora

Foi possível aferir que o tempo de retenção ocorreu de acordo com a polaridade dos ligantes: o complexo cujo ligante é o mais polar, noradrenalina, eluiu em menor intervalo de tempo. O comportamento oposto foi observado para o complexo cujo ligante é o catecol, o mais apolar dos ligantes, o qual, portanto, apresentou o maior tempo de retenção - o que é consoante ao esperado para a cromatografia em fase reversa. Os tempos de retenção para todos os complexos estão apresentados na tabela (4) a seguir:

Tabela 4: Tempo de retenção dos complexos nas análises de HPLC

\begin{tabular}{cc}
\hline \multicolumn{2}{c}{ Dados HPLC } \\
\hline & tempo de retenção $(\mathrm{min})$ \\
\cline { 2 - 2 }$\left[\mathrm{Ru}\left(\mathrm{NH}_{3}\right)_{4}(\text { isoproterenol })\right]^{+}$ & 4.437 \\
{$\left[\mathrm{Ru}\left(\mathrm{NH}_{3}\right)_{4}(\text { adrenalina })\right]^{+}$} & 3.652 \\
{$\left[\mathrm{Ru}\left(\mathrm{NH}_{3}\right)_{4}(\text { noradrenalina })\right]^{+}$} & 3.431 \\
{$\left[\mathrm{Ru}\left(\mathrm{NH}_{3}\right)_{4}(\text { catecol })\right]^{+}$} & 6.859 \\
{$\left[\mathrm{Ru}\left(\mathrm{NH}_{3}\right)_{4}(\text { dopamina })\right]^{+}$} & 3.688 \\
\hline
\end{tabular}

Fonte: Dados: Autora; tabela com adaptações de DE LIMA, 2001

\subsubsection{Espectroscopia eletrônica de absorção na região $U V$-vis}

São três os fatores importantes para determinar o número de coordenação de um complexo metálico, o tamanho do átomo ou íon central; o impedimento estérico e as interações eletrônicas, mas, geralmente, átomos dos períodos 5 e 6 , têm tendência a formar complexos com números de coordenação altos, principalmente quando localizados mais à esquerda da tabela periódica, devido ao aumento do raio. Para compostos de coordenação 
envolvendo $\mathrm{Ru}(\mathrm{II})$ e $\mathrm{Ru}(\mathrm{III})$ ( $5^{\circ}$ período), são esperados complexos metálicos com spin baixo, octaédricos e hexacoordenados (SHRIVER et. al., 2008; DE LIMA, 2001). A distribuição eletrônica para $\mathrm{Ru}(\mathrm{III})$, que é um sistema $\mathrm{d}^{5}$, culmina em configuração $\mathrm{t}_{2 \mathrm{~g}}{ }^{5}$, com um elétron desemparelhado, enquanto $\mathrm{Ru}(\mathrm{II})$ resultaria $\mathrm{em}_{2 \mathrm{~g}}{ }^{6}$. Dado o caráter de ácido de Lewis mais duro, $\mathrm{Ru}(\mathrm{III})$ tem preferência por ligantes saturados, bases mais duras, por exemplo, $\mathrm{NH}_{3}$, $\mathrm{OH}^{-}$e $\mathrm{Cl}^{-}$, entre outros. Por sua vez, $\mathrm{Ru}(\mathrm{II})$ tem preferência por ligantes insaturados, principalmente heterociclos, fosfinas, etc.. Enquanto para este íon metálico observa-se afinidade por ligantes $\pi$-receptores, para aquele, a preferência é por $\pi$-doadores.

Os dioxolenos, em geral, podem assumir três estados de oxidação, comumente denominados catecol, semiquinona e quinona (figura 17). A forma como é estabilizado em um complexo metálico depende do estado de oxidação do metal e dos coligantes (MASUI; LEVER; AUBURN, 1991; LEVER et. al., 1993).

Figura 17: Estados de oxidação do(as) catecol(aminas)

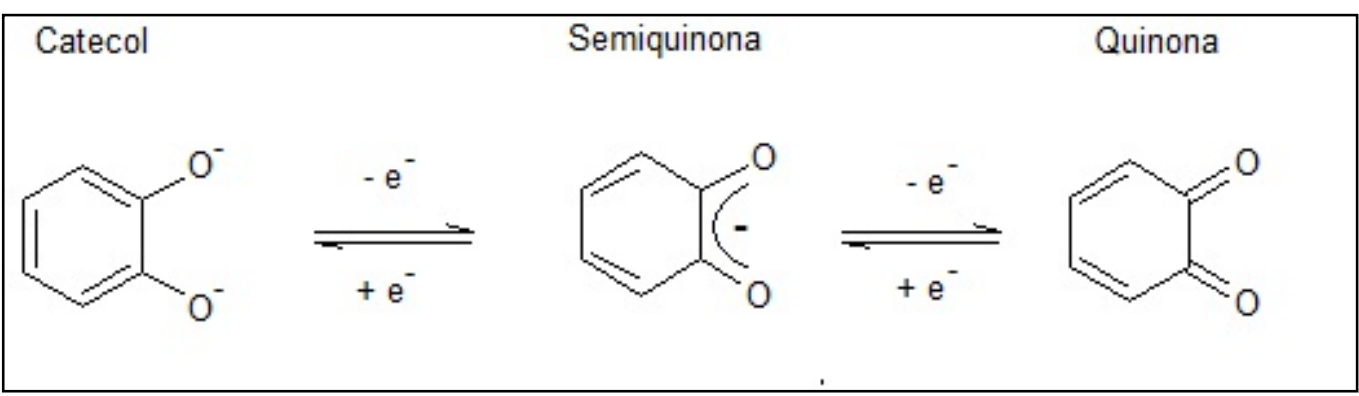

Fonte: Adaptado de DE LIMA, 2001

Para a compreensão da forma como estão estabilizados os respectivos ligantes, bem como o estado de oxidação do metal, os complexos foram caracterizados por espectroscopia de absorção na região UV-vis e os espectros eletrônicos dos complexos são mostrados a seguir (figura 18): 


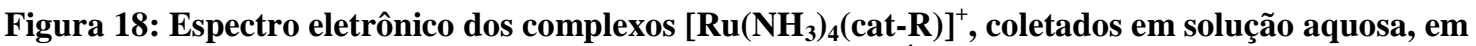
concentração igual a $11^{-4} \mathrm{M}$

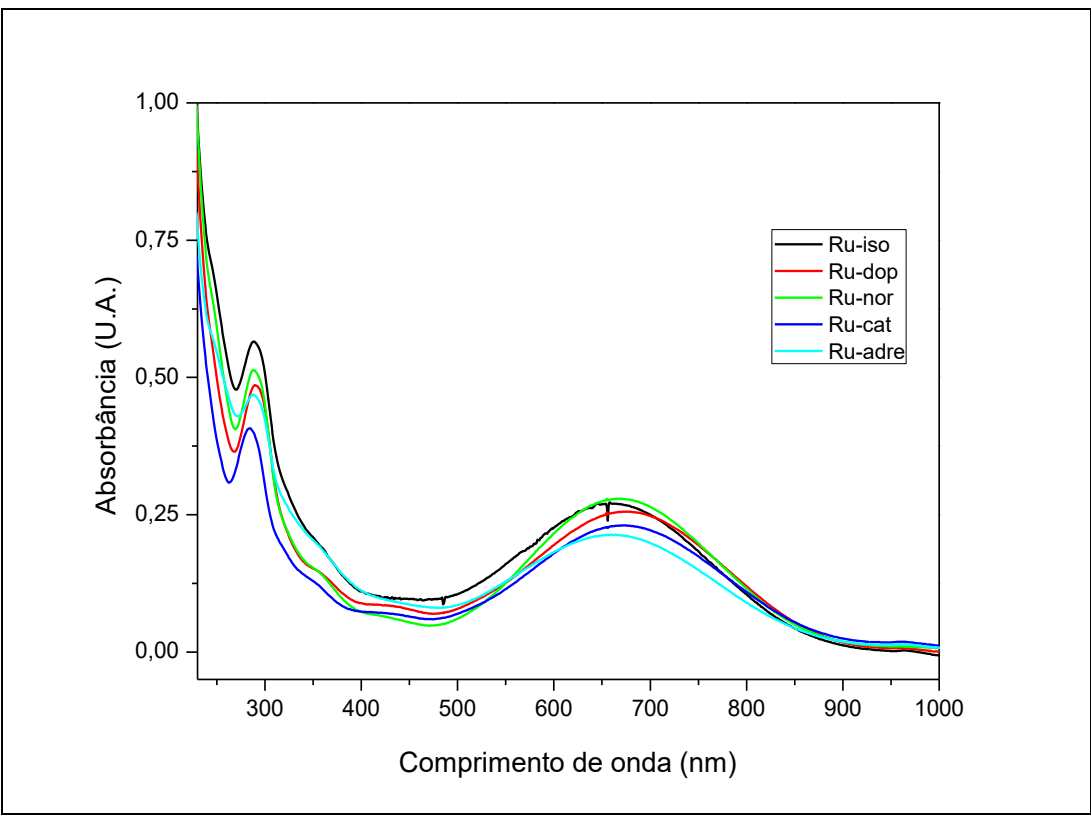

Fonte: Autora

Os complexos exibem bandas características, ao redor de 660 e $290 \mathrm{~nm}$, para as quais o coeficiente de absortividade molar ( $\varepsilon$ ) foi calculado (tabela 5). As bandas na região visível do espectro eletromagnético são atribuídas às transições eletrônicas de transferência de carga do ligante para o metal (TCLM) e, as bandas na região do ultravioleta são atribuídas às transições internas do ligante catecol(amina) $\left(\pi \rightarrow \pi^{*}\right)$ (DE LIMA, et. al., 2003; DE LIMA, et. al., 2004; DA SILVA; TFOUNI; LEVER, 1995; DA SILVA, et. al., 2000; DE LIMA, 2001).

Tabela 5: Propriedades espectroscópicas dos complexos

\begin{tabular}{|c|c|c|c|c|}
\hline Complexo & \multicolumn{2}{|c|}{ IL $\lambda(\mathrm{nm}) ;$ energia $\left(\mathrm{cm}^{-1}\right) ;(\log \varepsilon)$} & \multicolumn{2}{|c|}{ TCLM $\lambda(\mathrm{nm}) ;$ energia $\left(\mathrm{cm}^{-1}\right) ;(\log \varepsilon)$} \\
\hline$\left[\mathrm{Ru}\left(\mathrm{NH}_{3}\right)_{4}(\text { isoproterenol) }]^{+}\right.$ & 288 & $34.720(3,43)$ & 658 & $15.200(3,15)$ \\
\hline$\left[\mathrm{Ru}\left(\mathrm{NH}_{3}\right)_{4}(\text { adrenalina })\right]^{+}$ & 288 & $34.720(3,68)$ & 661 & $15.130(3,30)$ \\
\hline$\left[\mathrm{Ru}\left(\mathrm{NH}_{3}\right)_{4}(\text { noradrenalina })\right]^{+}$ & 289 & $34.600(3,34)$ & 669 & $14.950(3,08)$ \\
\hline$\left[\mathrm{Ru}\left(\mathrm{NH}_{3}\right)_{4}(\mathrm{catecol})\right]^{+}$ & 284 & $35.210(3,28)$ & 674 & $14.840(3,04)$ \\
\hline$\left[\mathrm{Ru}\left(\mathrm{NH}_{3}\right)_{4}(\text { dopamina })\right]^{+}$ & 290 & $34.480(3,39)$ & 675 & $14.810(3,09)$ \\
\hline
\end{tabular}

Fonte: Autora

Embora dos valores do coeficiente de absortividade molar ( $(\varepsilon)$ sejam constantemente utilizados para qualificar a natureza das bandas espectroscópicas é importante considerar que, de fato, de acordo com o princípio de Frank-Condon (COOLIDGE; JAMES; PRESENT, 1936), ocorre para cada transição eletrônica, múltiplas transições vibracionais. 
Assim, embora os valores de $\varepsilon$ encontrados para os complexos $\left[\mathrm{Ru}\left(\mathrm{NH}_{3}\right)_{4}(\right.$ cat$\mathrm{R})]^{+}$estejam no intervalo esperado para as transições permitidas por simetria, devido às suas larguras, para as bandas de TCLM, a forma correta para se expressar a intensidade desta é

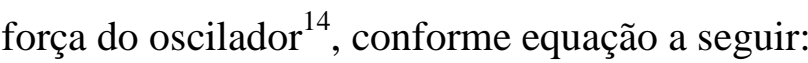

$$
f=4,610^{-9} \cdot \varepsilon_{\text {máx }} \cdot \delta
$$

(Equação 2)

onde $\delta=$ largura da banda $\left(\mathrm{em} \mathrm{cm}^{-1}\right)$, onde $\varepsilon=\varepsilon_{\text {máx }} / 2$ (LEVER, 1984 apud DE LIMA, 2001; DRAGO, 1965).

Os valores encontrados são reportados na tabela a seguir (tabela 6):

Tabela 6: Valores da força do oscilador $(f)$

\begin{tabular}{ccc}
\hline Complexo & & $\Delta_{1 / 2}\left(\mathrm{~cm}^{-1}\right) ; f$ \\
\hline \hline$\left[\mathrm{Ru}\left(\mathrm{NH}_{3}\right)_{4}(\text { isoproterenol })\right]^{+}$ & & $6.011 ; 0,08$ \\
{$\left[\mathrm{Ru}\left(\mathrm{NH}_{3}\right)_{4}(\text { adrenalina })\right]^{+}$} & & $6.165 ; 0,06$ \\
{$\left[\mathrm{Ru}\left(\mathrm{NH}_{3}\right)_{4}(\text { noradrenalina })\right]^{+}$} & & $5.182 ; 0,07$ \\
{$\left[\mathrm{Ru}\left(\mathrm{NH}_{3}\right)_{4}(\text { catecol })\right]^{+}$} & & $5.570 ; 0,06$ \\
{$\left[\mathrm{Ru}\left(\mathrm{NH}_{3}\right)_{4}(\text { dopamina })\right]^{+}$} & & $5.570 ; 0,07$ \\
\hline
\end{tabular}

$\Delta_{1 / 2}$ : largura de banda à meia altura

Fonte: Autora

Transições com valor de $f$ entre $10^{-2}$ e 1 são consideradas transições permitidas (OLIVEIRA, 2009). Para transições do tipo TCML, espera-se que os valores figurem neste intervalo, haja vista serem permitidas pelas regras de seleção. Como se pode aferir da tabela acima, todas as transições acontecem no intervalo esperado, o que corrobora a atribuição da transição como TCLM, ao invés de transição do tipo d-d, as quais também, geralmente, figuram nesta região do espectroeletromagnético - embora seja conhecido que os baixos valores de absortividade molar destas não sejam suficientes para proporcionar a coloração observada nos complexos.

Para as atribuições das transições eletrônicas, diversos fundamentos foram buscados, bem como reconsiderados, no entanto, de um modo geral, a transição mais

\footnotetext{
14 "A força de oscilador $f_{\mathrm{nm}}$ é uma quantidade adimensional que representa a razão entre o coeficiente de absorção integrado observado e o calculado para um único elétron num poço de potencial harmônico tridimensional. Enquanto a absortividade molar é uma medida experimental da intensidade da absorção (...) a força de oscilador, $f_{\text {nm }}$, é uma medida da probabilidade de uma transição eletrônica em um dado comprimento de onda. Essas duas quantidades se equivalem" (OLIVEIRA, 2009, p. 7 - 8).
} 
energética - entre 34.000 e $35.000 \mathrm{~cm}^{-1}$ - foi atribuída por comparação com o espectro eletrônico dos respectivos ligantes livres. A título de exemplo, alguns deles seguem no apêndice deste texto (figuras 108 a 111). Por sua vez, para as transições eletrônicas na região do visível, algumas considerações serão discorridas a seguir.

As transições eletrônicas de transferência de carga são dependentes tanto do estado de oxidação do metal, quanto do ligante e ocorrem quando um elétron sai de um orbital com caráter predominantemente metálico, para um com caráter predominante do ligante. Para a ocorrência de transições eletrônicas de transferência de carga do ligante para o metal, geralmente o metal assume Nox mais altos, enquanto o ligante é uma base de Lewis com maior densidade eletrônica; ela é observada, quando o metal possui orbitais vazios de baixa energia. O oposto é notado (transição eletrônica de transferência de carga do metal para o ligante) quando os complexos são formados por metais em baixo estado de oxidação e por ligantes com orbitais $\pi^{*}$ de baixa energia, comumente ligantes insaturados, aromáticos (SHRIVER et. al, 2008; DE LIMA et. al., 2003).

Uma vez que os ligantes dioxolenos são ligantes não inocentes (SILVA et. al., 2000) e, podem, portanto, assumir diferentes estados de oxidação, para a compreensão da transição eletrônica de TCLM, é imprescindível a abordagem sucinta das características desses ligantes.

Ligantes do tipo dioxoleno têm seu comportamento eletroquímico totalmente influenciado pelo metal ao qual estão coordenados. Haga e colaboradores (1990) descreveram que dioxolenos coordenados ao cromo geralmente são estabilizados na forma de semiquinona, no entanto quando coordenados ao molibdênio e ao tungstênio, são estabilizados na forma de catecolatos: $\mathrm{Cr}^{\mathrm{III}}(\mathrm{sq})_{3}, \mathrm{Mo}^{\mathrm{VI}}(\mathrm{cat})_{3} \mathrm{e} \mathrm{W}^{\mathrm{VI}}(\mathrm{cat})_{3}$. Embora existam essas possibilidades de estados de oxidação, a atribuição e a correta localização das cargas se torna possível devido ao fato de que nesses complexos há considerável diferença de energia entre os orbitais de fronteira do metal e do ligante (HAGA, et. al., 1990; BOONE; PIERPONT, 1987).

No entanto, em se tratando de complexos nos quais os dioxolenos estejam coordenados ao rutênio, a atribuição dos respectivos estados de oxidação é mais complexa e dependente da carga sobre o ligante, sendo que complexos de ósmio e rutênio divalentes, são melhormente descritos de formas diferentes: $\left[\mathrm{Os}^{\mathrm{II}}(\mathrm{cat})_{3}\right]^{4-}$ e $\left[\mathrm{Ru}^{\mathrm{II}}(\mathrm{sq})_{3}\right]^{-}$ou $\left[\mathrm{Ru}^{\mathrm{II}}(\mathrm{q})_{3}\right]^{2+}$. A atribuição dificultosa se deve ao fato de este tipo de ligante possuir orbitais $\pi^{*}$ de baixa energia, os quais possuem energia e simetria suficientes para se misturarem com um dos orbitais d do íon metálico (DE LIMA, 2001; HAGA, et. al., 1990; LEVER, et. al., 1988; SILVA et. al., 2000). 
Além da diferença de energia entre os orbitais de fronteira do metal e do ligante, a estabilização dos dioxolenos na forma de catecol, semiquinona ou quinona é dependente, também, da influência dos coligantes. Neste sentido, observou-se que quando os coligantes eram amônia, em $\left[\mathrm{Ru}^{\mathrm{III}}\left(\mathrm{NH}_{3}\right)_{4}\right]^{3+}$, a estabilização ocorreu na forma de catecol - $\mathrm{Ru}^{\mathrm{III}}$-cat -, enquanto para coligantes bipiridina, em $\left[\mathrm{Ru}^{\mathrm{II}}(\mathrm{bpy})_{2}\right]^{2+}$, observou-se $\mathrm{Ru}{ }^{\mathrm{II}}-\mathrm{sq}$ (LEVER et. al., 1993; MASUI; LEVER; AUBURN, 1991).

No caso específico dos dioxolenos abordados neste trabalho, há que se considerar (também) a influência do efeito indutivo doador dos grupos substituintes do catecol, os quais exercem efeitos consideráveis sobre as propriedades espectroscópicas, como será discutido nas páginas subsequentes.

Não obstante o fato de a atribuição dos estados de oxidação dos ligantes dioxolenos não ser trivial, diante da literatura clássica sobre o tema e diante das razões já apresentadas, mostra-se plausível a atribuição da transição eletrônica com máximo em aproximadamente $660 \mathrm{~nm}$, como TCLM os orbitais $\pi$ cat $\rightarrow \mathrm{d}_{\pi} \mathrm{Ru}{ }^{\mathrm{III}}$ (DE LIMA et. al., 2003).

Além disso, a diferença do comprimento da ligação $\mathrm{C}-\mathrm{O}$ constitui-se mais um indício do estado de oxidação no qual os dioxolenos estão estabilizados em um complexo metálico, pois, na forma de catecolatos o comprimento da ligação é maior quando comparado à forma de sequinona e quinona, respectivamente (DE LIMA, 2001; BOONE; PIERPONT, 1987; HAGA et. al., 1990).

Os pKas não fornecem uma informação direta da densidade eletrônica fornecida pelos ligantes, no entanto, a informação sobre a basicidade dos mesmos pode contribuir para a compreensão das propriedades espectroscópicas, de modo que valores altos de pKas indicam maior disponibilidade eletrônica do par de elétrons do ligante (MOREIRA, 2016), portanto maior caráter doador de densidade eletrônica.

No caso específico dos ligantes dioxolenos do tipo catecolamina, esta correlação não é direta, uma vez que os mesmos possuem três diferentes constantes de ionização, portanto, três valores de pKas, sendo o primeiro referente à ionização da primeira hidroxila, o segundo referente ao grupamento amina e, o terceiro, à segunda hidroxila (ARMSTRONG; BARLOW, 1976; NIH, 2017; BRITTAIN, 2007).

De posse dos dados da literatura para os pKas dos ligantes dioxolenos livres (tabela 7), tentativas de correlação entre os valores obtidos experimentalmente para os espectros de absorção na região UV-vis foram feitas. 
Tabela 7: Valores de pKa para os ligantes

\begin{tabular}{cccc}
\hline & $\mathrm{pKa}_{1}$ & $\mathrm{pKa}_{2}$ & $\mathrm{pKa}_{3}$ \\
\cline { 2 - 4 } isoproterenol & 8,6 & 10,1 & 12,00 \\
adrenalina & 8,76 & 11,28 & 13,07 \\
noradrenalina & 8,55 & 10,32 & 13,49 \\
catecol & 9,45 & & 12,8 \\
dopamina & 8,71 & 10,9 & 13,68 \\
\hline
\end{tabular}

Fonte: NIH, 2017; BRITTAIN, 2007

Foi possível aferir que, em relação à primeira constante de ionização, os complexos apresentam valores de energia, da TCLM, que são diminuídos à medida que há o aumento do $\mathrm{pKa}_{1}$, entretanto, esta variação não é linear. Este comportamento é condizente com o citado na literatura, no sentido de que para maiores valores de pKas, maior densidade eletrônica é fornecida pelo ligante, ao centro metálico, contribuindo para o aumento da energia (desestabilização) dos seus orbitais (MOREIRA, 2016; CUNHA, 1989).

Figura 19: Correlação entre os valores de $\mathbf{p K a} a_{1}$ dos ligantes a energia envolvida na transição eletrônica de TCLM

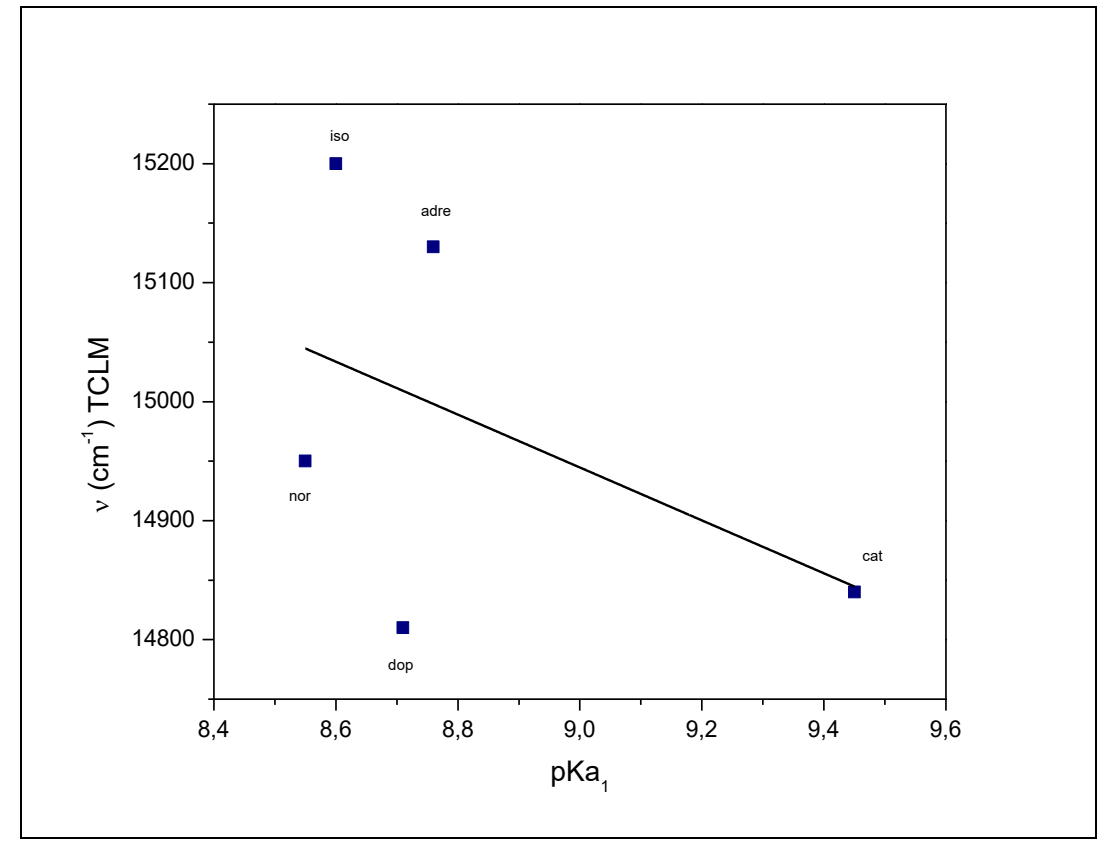

Fonte: Autora

Não obstante o fato de não ser diretamente relacionado ao grupamento catecólico, é foi possível aferir que existe uma relação entre os valores de pKa do grupo amina $\left(\mathrm{pKa}_{2}\right)$ e a energia da transição eletrônica do tipo TCLM (figura 20). Verificou-se, por fim, a relação do 
pKa do segundo grupamento hidroxila e a energia da transição eletrônica em comento (figura 21).

Figura 20: Correlação entre os valores de pKa $\mathrm{a}_{2}$ dos ligantes a energia envolvida na transição eletrônica de TCLM

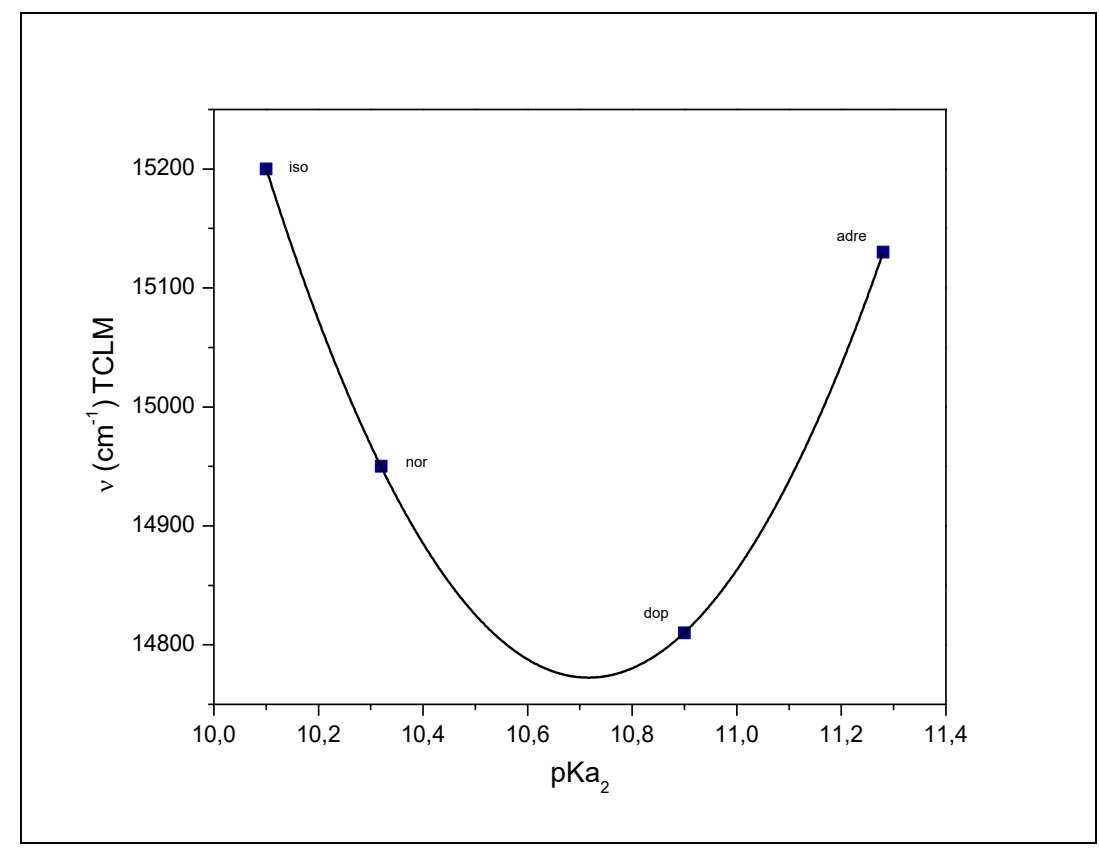

Fonte: Autora

Figura 21: Correlação entre os valores de $\mathrm{pKa}_{3}$ dos ligantes a energia envolvida na transição eletrônica de TCLM

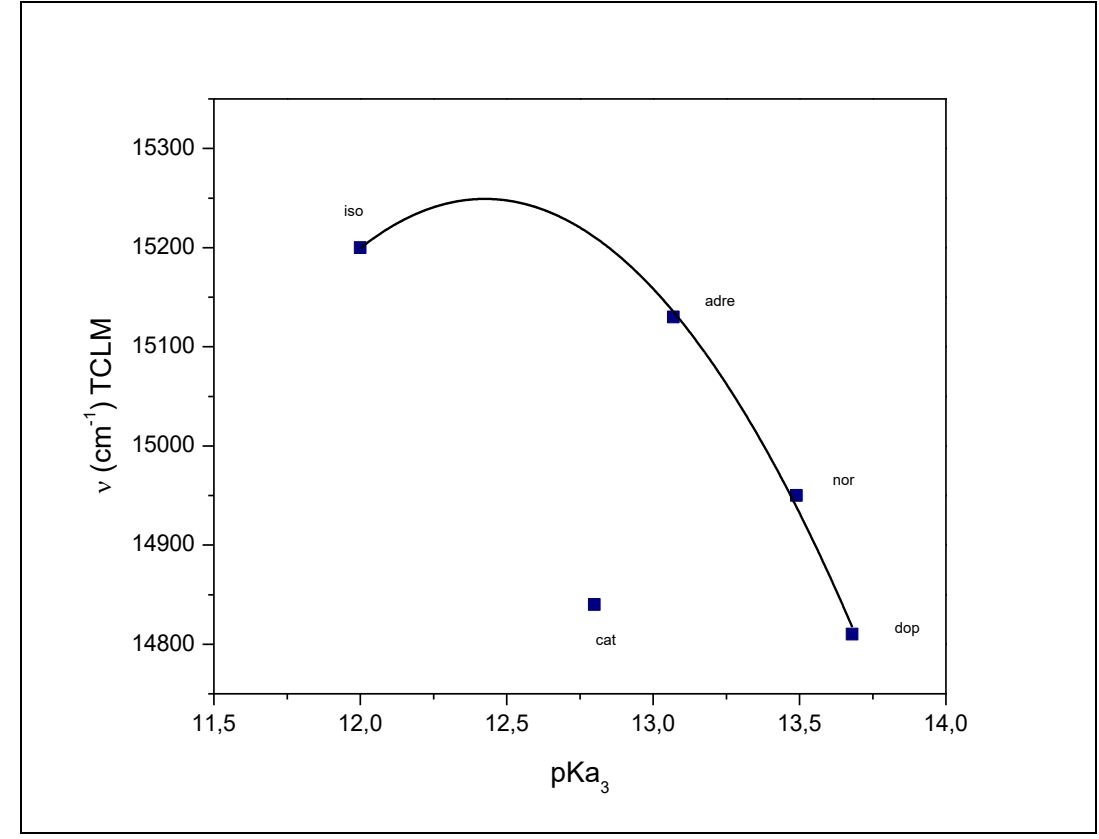

Fonte: Autora 
Dessas correlações se pode concluir que não há linearidade entre os valores de $\mathrm{pKa}_{2}$ e $\mathrm{pKa}_{3}$ com a energia envolvida na transição eletrônica estudada. No entanto, existe relação entre esses valores e, a energia envolvida na transição possui dependência com o quadrado do pKa, demonstrando que o fato de se tratar de ligantes quelatos, com mais de um grupo passível de ionização, resulta em relação muito mais complexa, em cuja resultante os substituintes do grupamento amínico possuem papel não nulo. Esta afirmação é reforçada pelo fato de o catecol não seguir a tendência observada para os outros quatro ligantes na correlação com o pKa $\mathrm{Na}_{3}$

Embora algumas possibilidades de relação, entre os valores de pKas e os parâmetros espectroscópicos, fossem encontradas, insta destacar que a melhor descrição para o deslocamento dos valores da energia das transições eletrônicas TCLM é o caráter doador de densidade eletrônico dos grupos presentes na cadeia carbônica lateral: isoproterenol, noradrenalina e adrenalina, possuem o grupo hidroxila, no carbono $\beta$, sendo assim, predomina o efeito indutivo captor de elétrons deste grupo, logo, menos disponíveis estão os elétrons destes ligantes, razão pela qual doam menos densidade eletrônica - em relação à dopamina e ao catecol - e, consequentemente, promovem menor desestabilização dos orbitais do centro metálico, resultando em transições eletrônicas mais energéticas. O efeito oposto é observado para os dois ligantes que não possuem o grupamento hidroxila no carbono $\beta$, dopamina e catecol, os quais, consequentemente, estão com seus elétrons mais disponíveis, promovendo maior aumento de energia (desestabilização) dos orbitais do metal e, consequentemente, transições eletrônicas menos energéticas.

A menor diferença de energia entre as transições eletrônicas TCLM do complexo de catecol e do complexo de dopamina são, possivelmente, resultantes do fato de naquele os elétrons estarem mais envolvidos no sistema de ressonância do anel aromático - em razão da inexistência de substituição - logo, menos disponíveis na ligação com o metal, contribuindo menos para o aumento da energia dos orbitais do metal.

Em relação à diferença de energia entre as transições eletrônicas existentes nos complexos cujos ligantes são isoproterenol, noradrenalina e adrenalina, é evidente a contribuição dos substituintes na função amina. Observa-se que quanto maior o efeito indutivo doador do grupo (isopropil > metil > hidrogênio), maior a energia da transição TCLM. Embora este efeito seja o oposto ao esperado (SILVA et. al., 2000), possivelmente a presença desses substituintes resulte em orbitais $\pi$ de menor energia. 


\subsubsection{Voltametria cíclica}

Os dioxolenos, em geral, são ligantes não inocentes e podem, portanto, sofrer reações redox, assumindo mais que um estado de oxidação (HAGA; DODSWORTH; LEVER, 1986). As catecolaminas, quando livres, são oxidadas irreversivelmente. Após a coordenação com o íon metálico, os processos redox tornam-se totalmente reversíveis.

Diante do comportamento eletroquímico esperado para esses ligantes, se torna imprescindível as análises por ao menos uma técnica voltamétrica. Assim, os voltamogramas cíclicos dos complexos, os quais foram registrados em solução aquosa, mostram dois pares de ondas, os quais são resultantes de processos centrados nos ligantes catecolaminas e no metal e são mostrados a seguir (figuras 22 a 26):

Figura 22: Voltamograma cíclico de $\left[\mathrm{Ru}\left(\mathrm{NH}_{3}\right)_{4}\right.$ (isoproterenol $\left.)\right]+, 1,010^{-3} \mathrm{M}$; tampão fosfato $0,01 \mathrm{M}$; KCl $0,1 \mathrm{M} \mathrm{em} \mathrm{pH} \mathrm{7,6}$

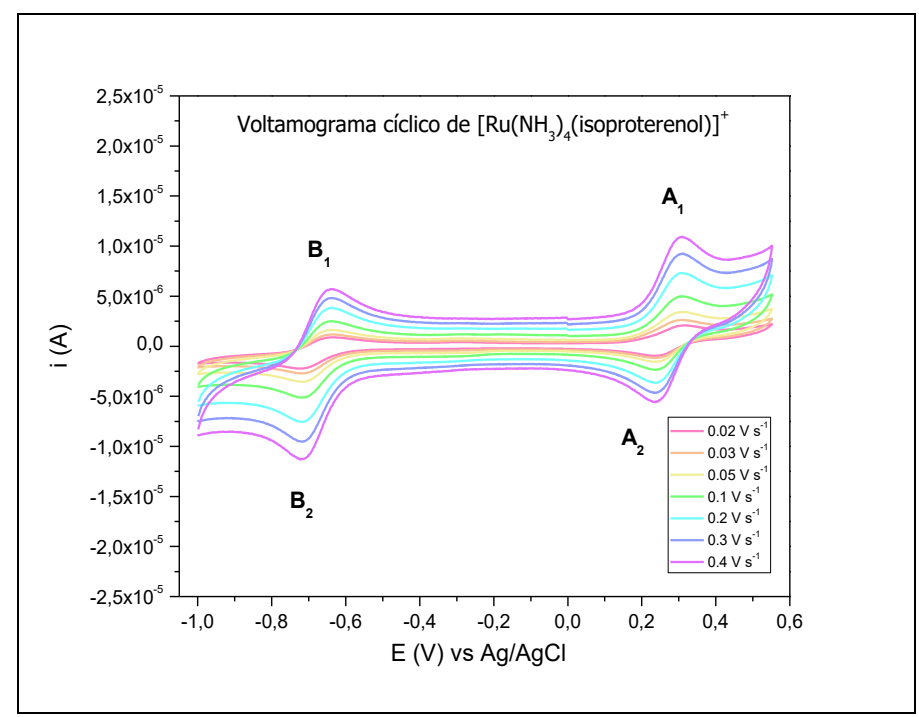

Fonte: Autora 
Figura 23: Voltamograma cíclico de $\left[\mathrm{Ru}\left(\mathrm{NH}_{3}\right)_{4}(\right.$ dopamina $\left.)\right]+, 1,010^{-3} \mathrm{M}$; tampão fosfato $0,01 \mathrm{M}$; $\mathrm{KCl} 0,1$ M em pH 7,6

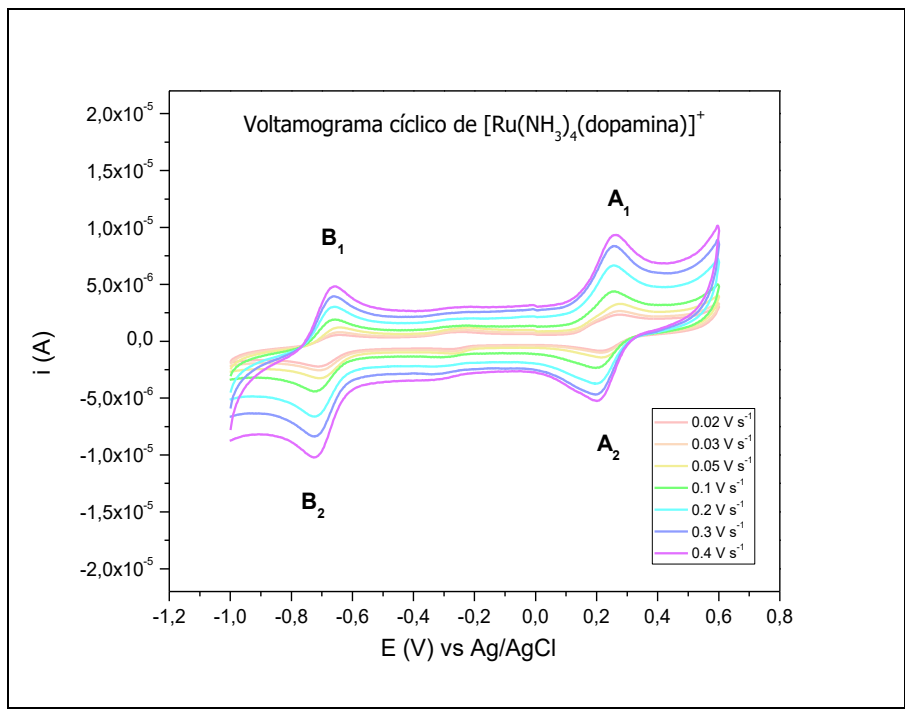

Fonte: Autora

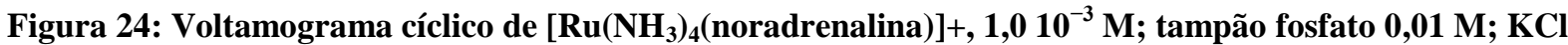
$0,1 \mathrm{M} \mathrm{em}$ pH 7,6

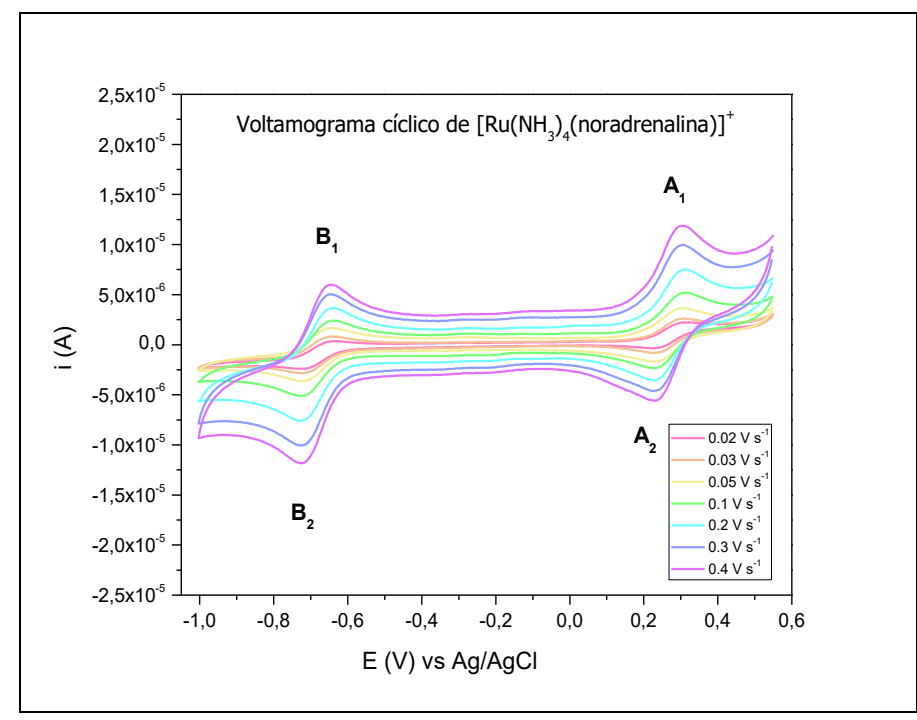

Fonte: Autora 
Figura 25: Voltamograma cíclico de $\left[\mathrm{Ru}\left(\mathrm{NH}_{3}\right)_{4}(\right.$ catecol $\left.)\right]+, 1,010^{-3} \mathrm{M}$; tampão fosfato $0,01 \mathrm{M}$; $\mathrm{KCl} 0,1 \mathrm{M}$ em pH 7,6

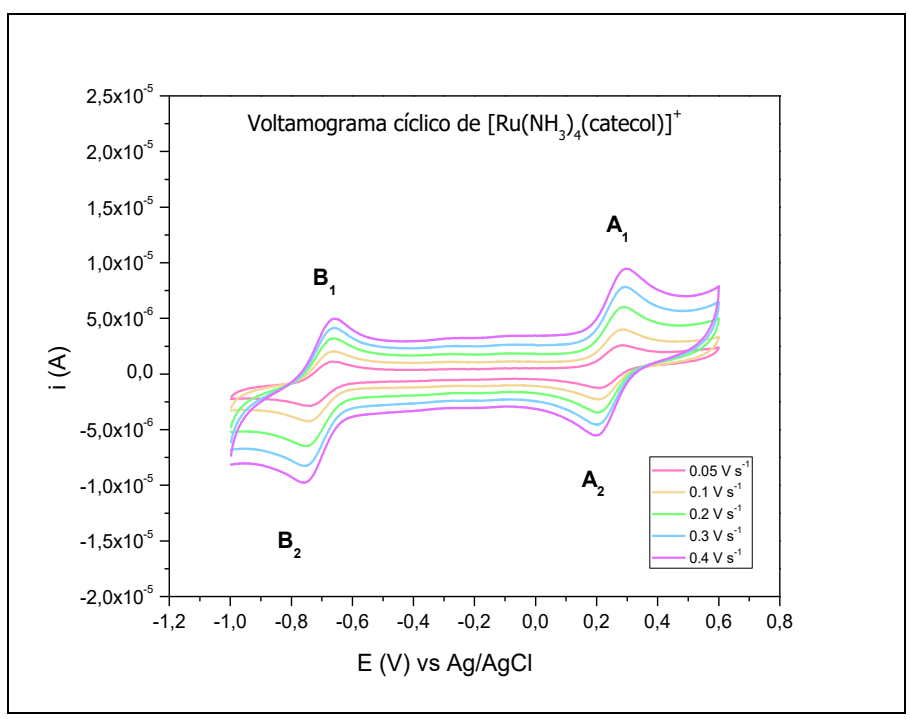

Fonte: Autora

Figura 26: Voltamograma cíclico de $\left[\mathrm{Ru}\left(\mathrm{NH}_{3}\right)_{4}(\right.$ adrenalina $\left.)\right]+, 1,010^{-3} \mathrm{M}$; tampão fosfato 0,01 M; KCl 0,1 M em pH 7,6

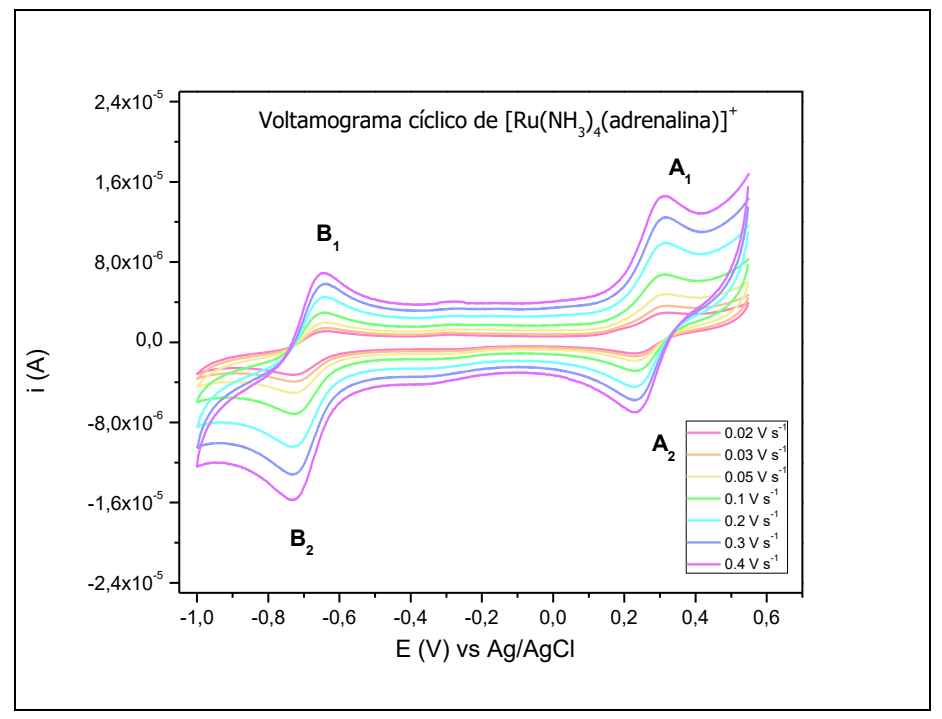

Fonte: Autora

Os potenciais de meia onda $\left(\mathrm{E}_{1 / 2}\right)$ para os dois processos foram calculados e são reportados na tabela a seguir (tabela 8): 
Tabela 8: Dados eletroquímicos

\begin{tabular}{ccc}
\hline & (catecol/quinona) & $\left(\mathrm{Ru}^{\mathrm{III}} / \mathrm{Ru}^{\mathrm{II}}\right)$ \\
\cline { 2 - 3 } & $\mathrm{E}_{1 / 2}(\mathrm{~V})$ & $\mathrm{E}_{1 / 2}(\mathrm{~V})$ \\
{$\left[\mathrm{Ru}\left(\mathrm{NH}_{3}\right)_{4}(\text { isoproterenol })\right]^{+}$} & 0,27 & $-0,68$ \\
{$\left[\mathrm{Ru}\left(\mathrm{NH}_{3}\right)_{4}(\text { adrenalina })\right]^{+}$} & 0,27 & $-0,69$ \\
{$\left[\mathrm{Ru}\left(\mathrm{NH}_{3}\right)_{4}(\text { noradrenalina) }]^{+}\right.$} & 0,27 & $-0,77$ \\
{$\left[\mathrm{Ru}\left(\mathrm{NH}_{3}\right)_{4}(\text { catecol })\right]^{+}$} & 0,32 & $-0,70$ \\
{$\left[\mathrm{Ru}\left(\mathrm{NH}_{3}\right)_{4}(\text { dopamina })\right]^{+}$} & 0,23 & $-0,70$ \\
\hline
\end{tabular}

Fonte: Autora

Os processos redox, os quais foram atribuídos com fundamento na literatura, constituem-se os seguintes: a varredura anôdica, a partir do potencial igual a $0,0 \mathrm{~V}$, promove a oxidação do ligante (em $\left.\mathrm{A}_{1}\right)$, conduzindo à formação de quinona; o processo é reversível $\left(\mathrm{A}_{2}\right.$ $=$ redução do ligante) $\operatorname{com~} \mathrm{i}_{\mathrm{pc}} / \mathrm{i}_{\mathrm{pa}} \sim 1 \mathrm{e} \Delta \mathrm{E}_{\mathrm{p}} \sim 60 \mathrm{mV}$, para todos os complexos, demonstrando se tratar de processo monoeletrônico. A varredura catôdica, partindo do potencial $0,0 \mathrm{~V}$, promove a redução do metal de $\mathrm{Ru}(\mathrm{III})$ a $\mathrm{Ru}(\mathrm{II})\left(\mathrm{em} \mathrm{B}_{2}\right)$; este processo também é reversível $\left(\mathrm{B}_{1}=\right.$ oxidação do metal) e monoeletrônico: $\mathrm{i}_{\mathrm{pc}} / \mathrm{i}_{\mathrm{pa}} \sim 1 \mathrm{e} \Delta \mathrm{E}_{\mathrm{p}} \sim 60 \mathrm{mV}$, para todos os complexos (DE LIMA, et. al., 2003; DE LIMA, et. al., 2004; SILVA; TFOUNI; LEVER, 1995; SILVA, et. al., 2000).

A dependência da corrente, com a raiz quadrada da velocidade - outro parâmetro para se verificar a reversibilidade dos processos - foi avaliada e mostrou-se linear para todos os complexos, tanto nos processos $\mathrm{A}_{1}$ e $\mathrm{A}_{2}$, quanto em $\mathrm{B}_{1}$ e $\mathrm{B}_{2}$. A título de exemplo, são mostrados a seguir os gráficos deste tipo de relação, para o complexo de adrenalina (figuras 27 e 28): 
Figura 27: Relação entre a corrente $\left(i_{\mathrm{pa}}\right) \mathrm{e}$ a velocidade de varredura de potencial, para os processos centrados no ligante $\left(\mathrm{A}_{1 / 2}\right)$, para o complexo $\left[\mathrm{Ru}\left(\mathrm{NH}_{3}\right)_{4}(\text { adrenalina })\right]^{+}$

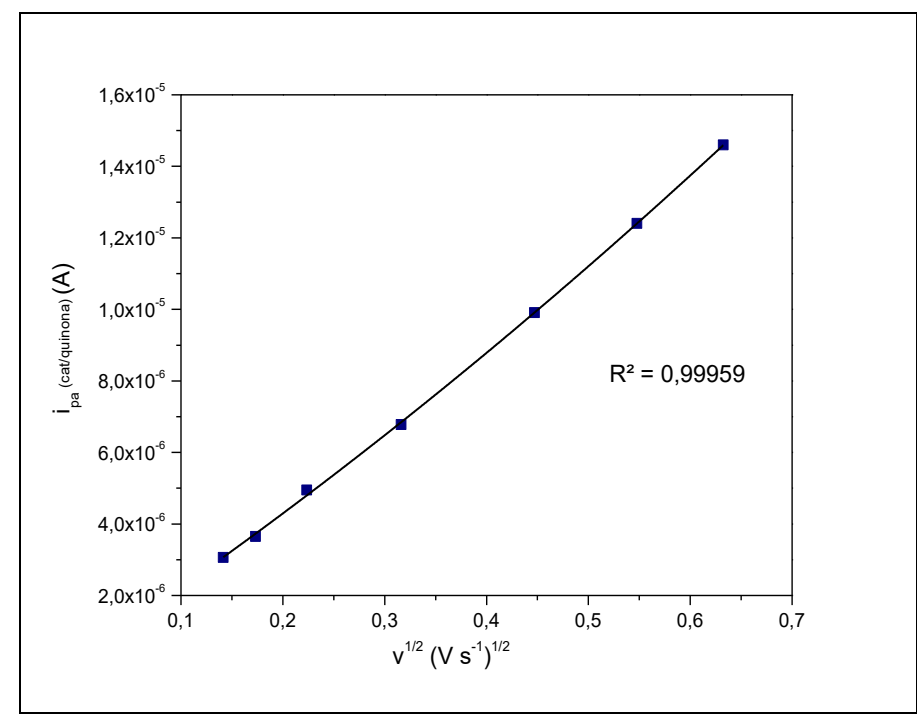

Fonte: Autora

Figura 28: Relação entre a corrente $\left(i_{\mathrm{pa}}\right)$ e a velocidade de varredura de potencial, para os processos centrados no metal $\left(\mathrm{B}_{1 / 2}\right)$, para o complexo $\left[\mathrm{Ru}\left(\mathrm{NH}_{3}\right)_{4}(\text { adrenalina })\right]^{+}$

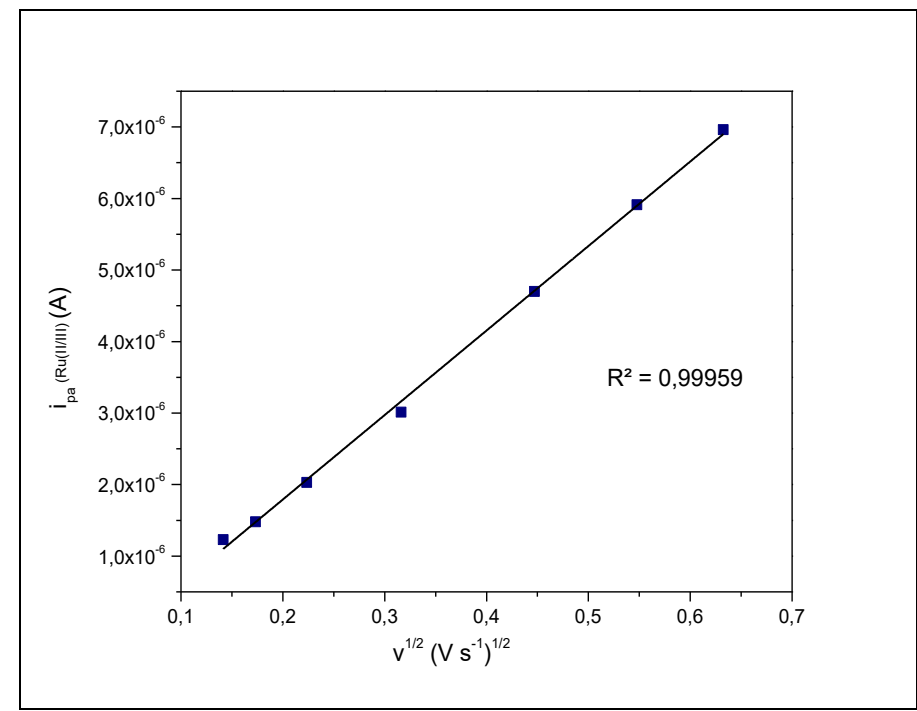

Fonte: Autora

Além disso, das análises dos $\mathrm{E}_{1 / 2}$ é possível inferir que os processos ocorridos em potenciais positivos sofreram variação de aproximadamente $40 \%$ dentro da série de complexos, enquanto aqueles advindos de potenciais negativos sofreram apenas $13 \%$ de variação. Logo, estes dados reafirmam a discussão supra de os processos centrados nos ligantes serem aqueles sucedidos em potenciais positivos, uma vez que mais susceptíveis à variação dos ligantes. 
Em relação ao complexo não publicado pelo grupo previamente $\left[\mathrm{Ru}\left(\mathrm{NH}_{3}\right)_{4}(\text { adrenalina })\right]^{+}$- pode-se afirmar que apresentou $\mathrm{E}_{1 / 2}$ do processo redox centrado no íon rutênio entre os valores observados para o complexo $\left[\mathrm{Ru}\left(\mathrm{NH}_{3}\right)_{4}(\text { isoproterenol })\right]^{+}$e o complexo $\left[\mathrm{Ru}\left(\mathrm{NH}_{3}\right)_{4}(\text { noradrenalina) }]^{+}\right.$, bem como $\mathrm{E}_{1 / 2}$ referente aos processos centrados no ligante, também com valores intermediários dentro da série. Estes resultados são completamente de acordo com os parâmetros estruturais do ligante adrenalina: sua substituição no grupamento amina tem caráter intermediário de densidade eletrônica, em relação aos ligantes isoproterenol e noradrenalina.

Os dados dos potenciais de oxidação são parcialmente consoantes com aqueles obtidos na espectroscopia eletrônica, pois, para os três complexos nos quais se observou os maiores valores de energia para transições eletrônicas do tipo TCLM (isoproterenol, dopamina e noradrenalina), também foram aqueles para os quais se verificou os maiores valores de potencial $\mathrm{E}_{1 / 2}$ para o processo redox centrado no ligante. Para o complexo de dopamina, cujo valor da energia da transição eletrônica foi o menor, também foi encontrado o menor potencial redox. O complexo de catecol destoa da tendência observada para os demais complexos - o que já fora observado quando da análise de outros parâmetros e é justificado pela ausência de substituintes no anel aromático.

A reversibilidade observada no processo de oxidação das catecolaminas constituise um dos aspectos positivos destes complexos - e, possivelmente, é responsável por diversos resultados com relação aos aspectos biológicos, os quais serão discutidos posteriormente neste texto -, uma vez que quando livres, sofrem protonação e consequente ciclização intramolecular, culminando na irreversibilidade do processo. Os produtos da oxidação são denominados aminocromos e o mecanismo de sua formação é mostrado a seguir (figura 29) (DE LIMA et. al., 2004; GRAHAM, 1978): 
Figura 29: Mecanismo de formação de aminocromos

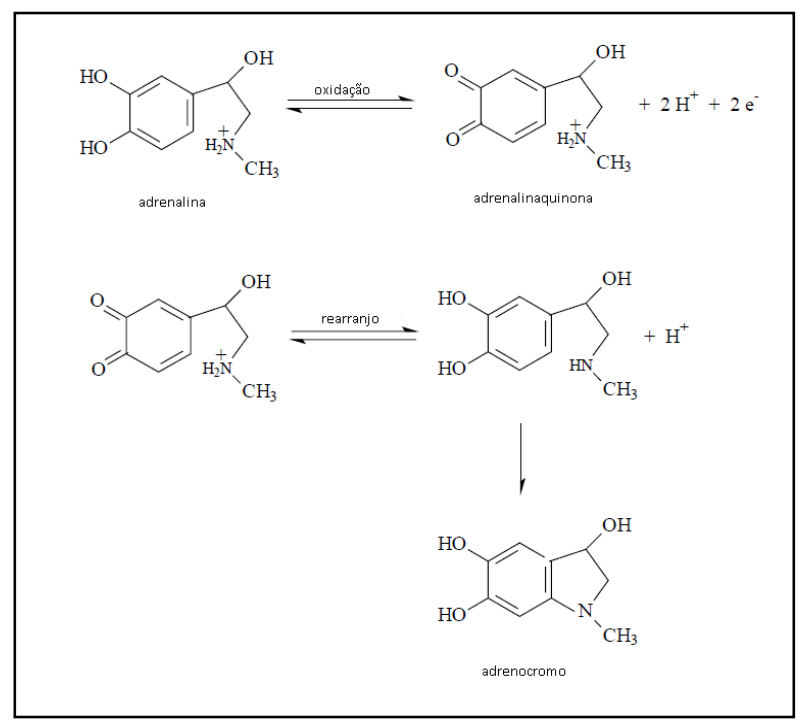

Fonte: Adaptado de DE LIMA et. al., 2004

Se houvesse a formação de aminocromos durante os processos redox estudados, não se observaria reversibilidade nos pares redox $A_{1}$ e $A_{2}$.

Em relação aos pKas, notou-se que os $\mathrm{E}_{1 / 2}$ dos processos redox dos complexos apresentam dependência com o quadrado do $\mathrm{pKa}_{1}$, porém este efeito somente é perceptível para o processo eletroquímico centrado nos ligantes $\left(\mathrm{A}_{1}\right.$ e $\left.\mathrm{A}_{2}\right)$; para os processos envolvendo o íon metálico, não houve essa dependência e, de fato, não possível estabelecer qualquer tipo de correlação. Além disso, para o complexo cujo ligante é dopamina, a tendência não é seguida (figura 30 ): 
Figura 30: Correlação entre os valores de $p K a_{1}$ dos ligantes e $E_{1 / 2}$ do processo redox $A_{1} / A_{2}$

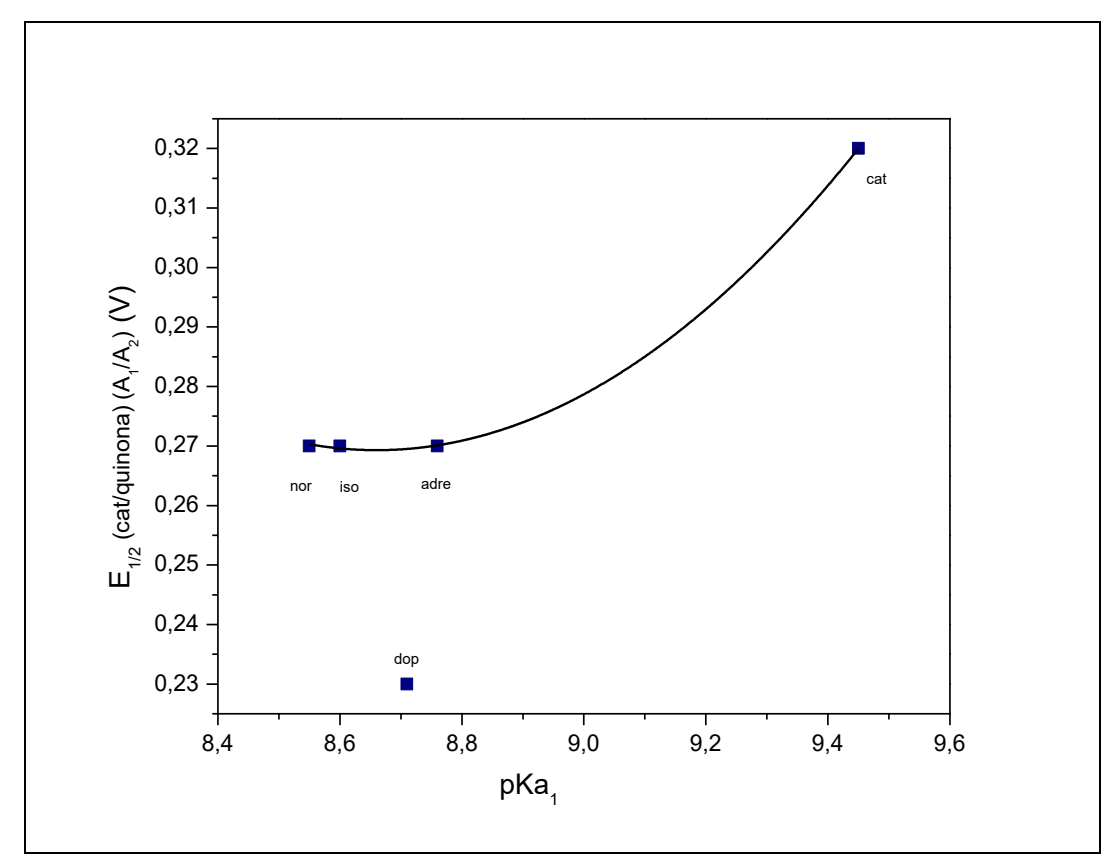

Fonte: Autora

Este comportamento - de dependência dos processos com o $\mathrm{pKa}_{1}$ - corrobora a atribuição prévia de que os processos que ocorrem em potenciais positivos são, necessariamente, centrados nos ligantes.

No que se refere ao $\mathrm{pKa}_{2}$, não foram observadas correlações entre os mesmos e os potenciais eletroquímicos, razão pela qual se pode concluir que os processos eletroquímicos não envolvem os substituintes dos grupamentos amina, embora sua influência ocorra, principalmente, nos processos eletroquímicos envolvendo os dioxolenos.

No que tange ao $\mathrm{pKa}_{3}$, não foi possível (também) observar correlações entre os mesmos e os $\mathrm{E}_{1 / 2}$ dos processos centrados no metal, todavia para os processos centrados no ligantes catecólico, foi possível obter a correção mostrada a seguir (figura 31): 
Figura 31: Correlação entre os valores de $p K a_{3}$ dos ligantes e $E_{1 / 2}$ do processo redox $A_{1} / A_{2}$

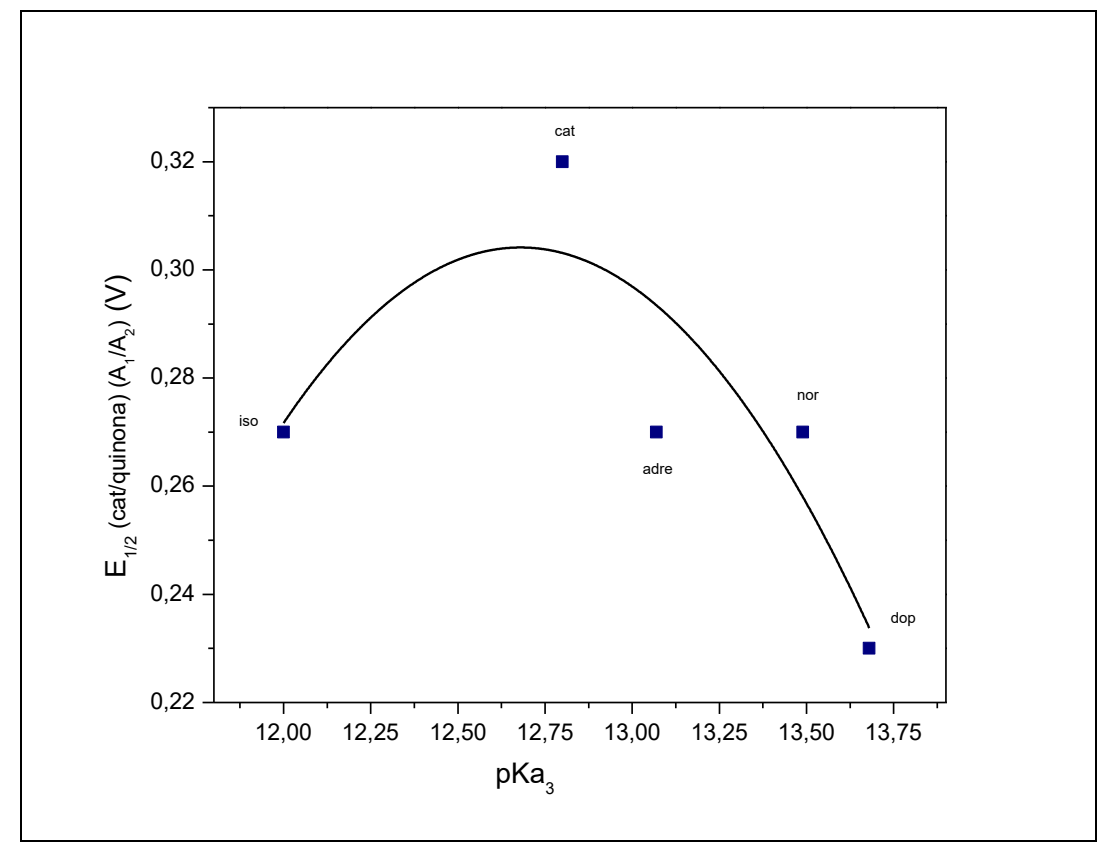

Fonte: Autora

Do gráfico retro, em relação ao $\mathrm{pKa}_{3}$, referente à ionização da segunda hidroxila, nota-se uma dependência quadrática entre os potenciais de meia onda dos processos centrados nos ligantes, com o pKa, no sentido de que com o aumento do $\mathrm{pKa}_{3}$, há uma diminuição de $\mathrm{E}_{1 / 2}$, ou seja, o ligante se oxida mais facilmente à medida que se torna uma base mais forte.

\subsubsection{Espectroeletroquímica}

Foram conduzidos experimentos de espectroeletroquímica com a finalidade de acompanhar as mudanças espectroscópicas, na região do Uv-vis, decorrentes da aplicação de um determinado potencial.

Alguns dos espectros obtidos neste ensaio são mostrados a seguir (figuras 32 a 34): 
Figura 32: Espectroeletroquímica de $\left[\mathrm{Ru}\left(\mathrm{NH}_{3}\right)_{4}(\text { isoproterenol })\right]^{+} 1,010^{-3} \mathrm{M}$; solução aquosa de $\mathrm{KCl} 0,1 \mathrm{M}$; pH 7,6; potencial aplicado +0,50 V vs. Ag/AgCl (A); 0,0 V vs Ag/AgCl (B); -0,80V vs. $\mathbf{A g} / \mathbf{A g C l}$ (C); e 0,0 V vs $\mathrm{Ag} / \mathrm{AgCl}$ (D)

(A)
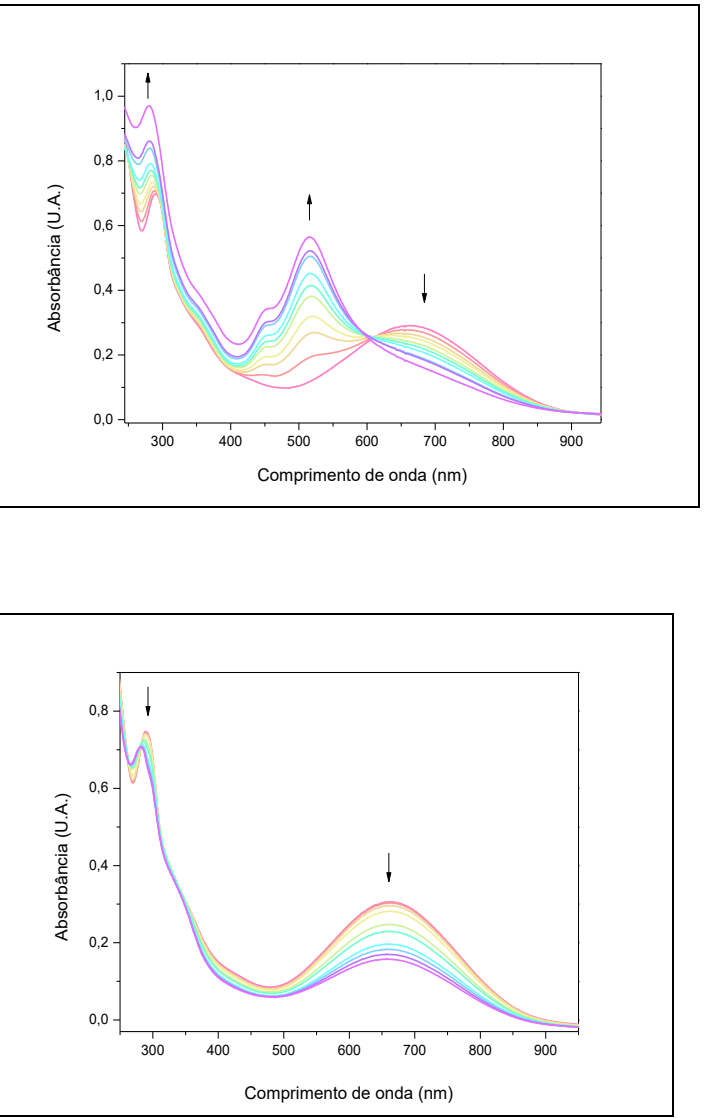

(C)
(D)

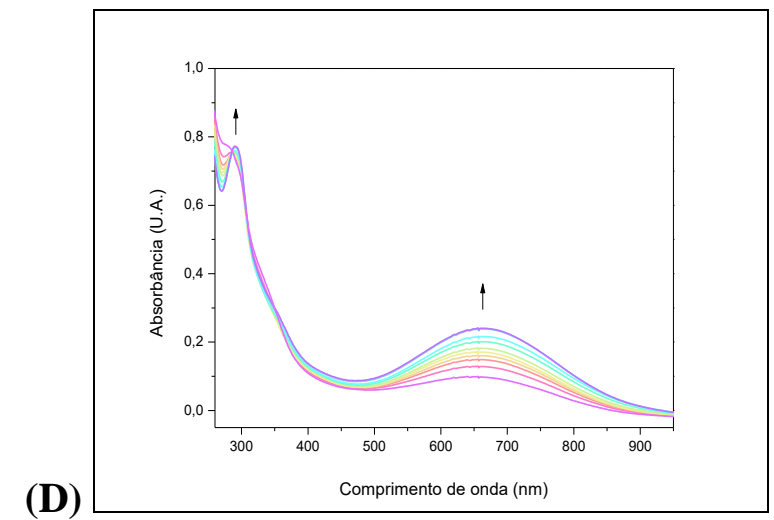

(B)

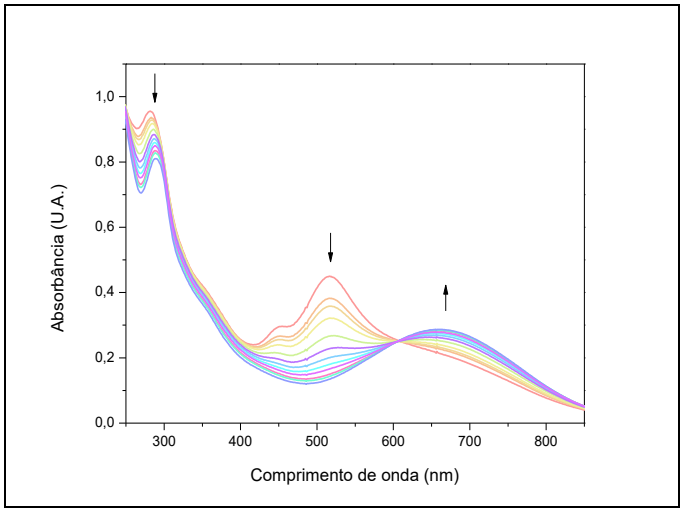

Fonte: Autora 
Figura 33: Espectroeletroquímica de $\left[\mathrm{Ru}\left(\mathrm{NH}_{3}\right)_{4}(\text { noradrenalina })\right]^{+} 1,010^{-3} \mathrm{M}$; solução aquosa de $\mathrm{KCl} 0,1$ $\mathrm{M} ; \mathrm{pH}$ 7,6; potencial aplicado +0,50V vs. $\mathrm{Ag} / \mathrm{AgCl}(\mathrm{A}) ; 0,0 \mathrm{~V}$ vs $\mathrm{Ag} / \mathrm{AgCl}(\mathrm{B}) ;-\mathbf{- 0 , 8 0 \mathrm { V }} \mathrm{vs}$. $\mathrm{Ag} / \mathrm{AgCl}(\mathrm{C}) ; \mathrm{e}$ 0,0 V vs Ag/AgCl (D)

(A)

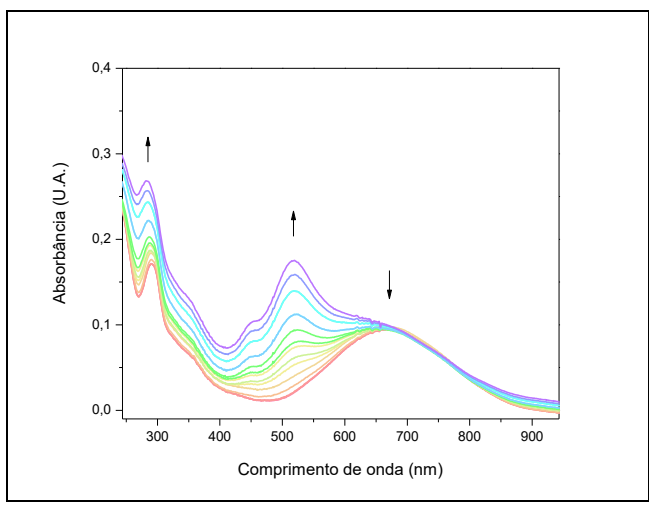

(C)

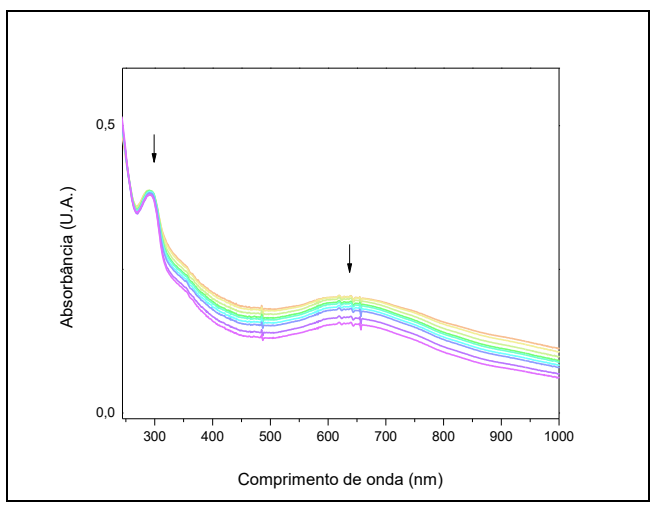

(B)

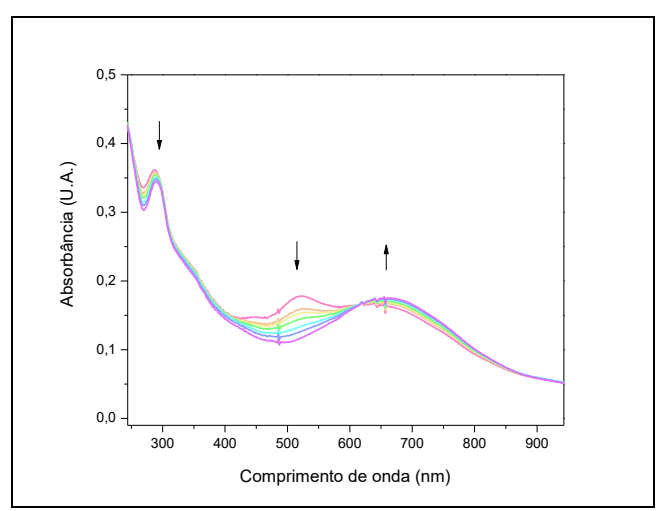

(D)

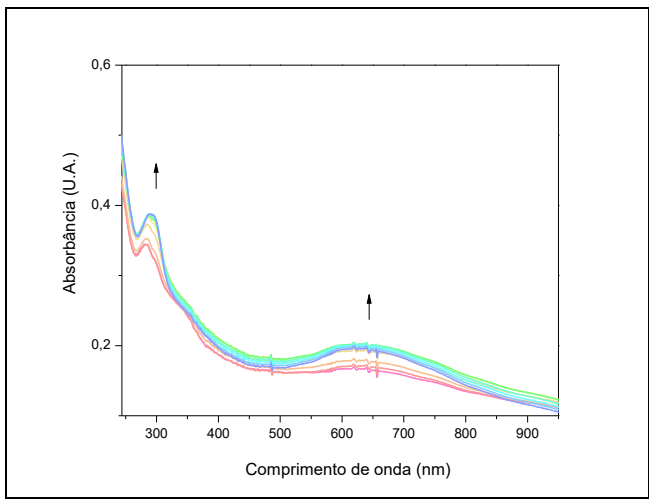

Fonte: Autora 
Figura 34: Espectroeletroquímica de $\left[\mathrm{Ru}\left(\mathrm{NH}_{3}\right)_{4}(\text { catecol })\right]^{+} 1,010^{-3} \mathrm{M}$; solução aquosa de $\mathrm{KCl} \mathrm{0,1} \mathrm{M}$; pH 7,6; potencial aplicado +0,50 V vs. Ag/AgCl (A); 0,0 V vs Ag/AgCl (B); $-0,80 \mathrm{~V}$ vs. $\mathrm{Ag} / \mathrm{AgCl}$ (C); e 0,0 V vs $\mathrm{Ag} / \mathrm{AgCl}(\mathrm{D})$

(A)

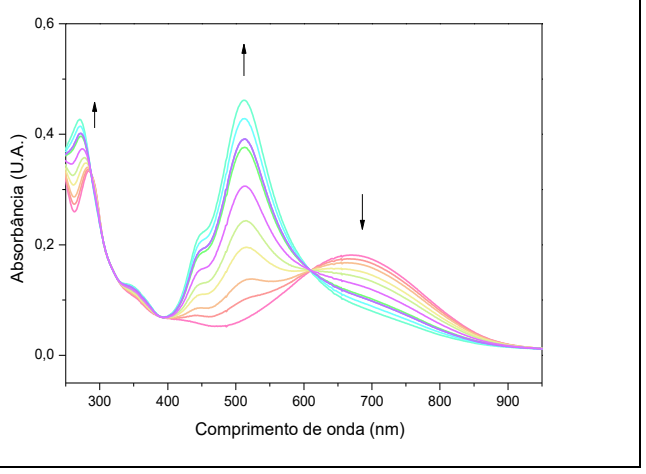

(C)

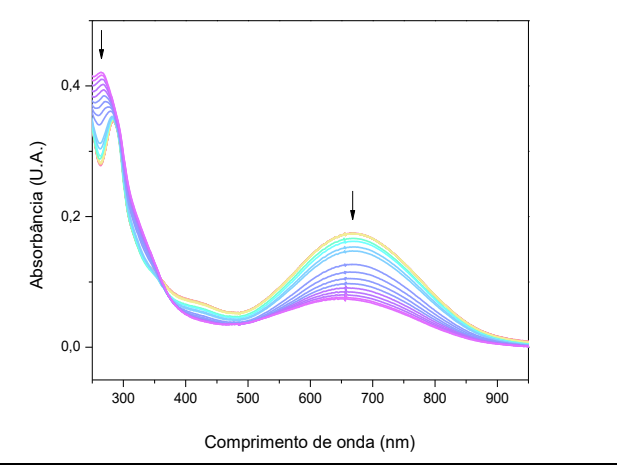

(B)

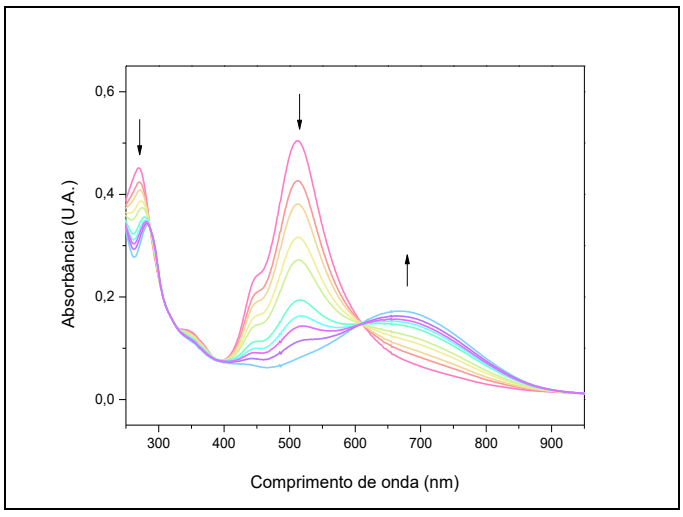

(D)

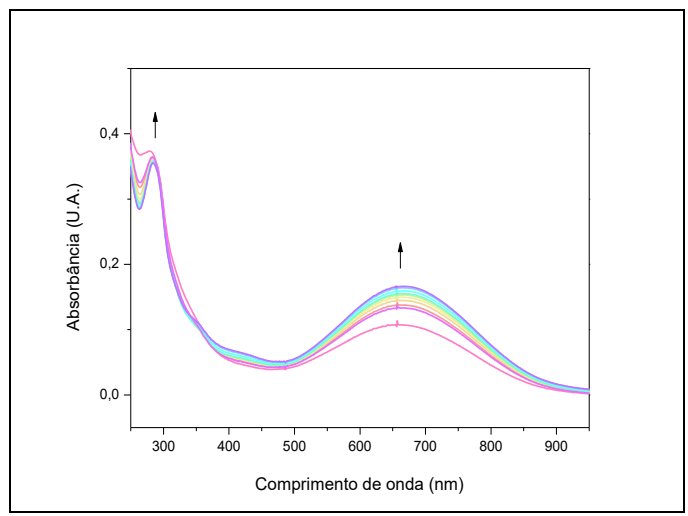

Fonte: Autora

Os dados espectroeletroquímicos corroboraram as atribuições das transições eletrônicas e demonstraram a reversibilidade dos processos: quando foi aplicado um pontencial igual a $0,5 \mathrm{~V}$, houve o desaparecimento da banda na região de $660 \mathrm{~nm}$ e o concomitante surgimento de uma nova banda, em torno de $520 \mathrm{~nm}$ (este ensaio corresponde à letra (A) nos três conjuntos de espectros mostrados).

Tão $\log$ foi finalizado o experimento com a aplicação de $0,5 \mathrm{~V}$, houve a aplicação de 0,0 V (correspondente à letra (B) de todos os conjuntos de espectros) e o comportamento oposto foi observado: diminuição da banda na região de $520 \mathrm{~nm}$, concomitante ao aumento da banda em $660 \mathrm{~nm}$.

Posteriormente, foi aplicado - 0,8 V (resultados correspondentes à letra $(\mathbf{C})$ de todos os conjuntos de espectros) e os resultados foram a diminuição da intensidade da banda de aproximadamente $660 \mathrm{~nm}$. 
Subsequentemente, com 0,0 V, (resultados correspondentes à letra (D) de todos os conjuntos de espectros), o comportamento oposto - ao de (C) - foi observado, com o aumento da intensidade da banda em aproximadamente $660 \mathrm{~nm}$.

O comportamento foi semelhante para todos os complexos estudados e, os fundamentos pelos quais se observa essas alterações espectroscópicas são que a as eletrólises efetuadas implicam no surgimento de uma nova banda de absorção no espectro eletrônico, atribuída à transição eletrônica de TCML, sendo o elétron proveniente de orbital com caráter predominantemente metálico, para orbital com caráter do ligante $\mathrm{d}_{\pi} \mathrm{Ru}^{\mathrm{II}} \rightarrow \pi^{*}$ quinona (DE LIMA et. al., 2003; DE LIMA et. al., 2004).

Este comportamento "espectroeletroquímico" é oriundo da oxidação do ligante (em potenciais positivos, observadas nos espectros (A) dos conjuntos de espectros mostrados), à semiquinona, com posterior rearranjo que promove a redução do metal, resultante em Ru(II)-quinona (SILVA; TFOUNI; LEVER, 1995; SILVA, et. al., 2000; DE LIMA et. al., 2003), explicado pelo mecanismo mostrado a seguir (figura 35):

Figura 35: Mecanismo redox para os processos eletroquímicos

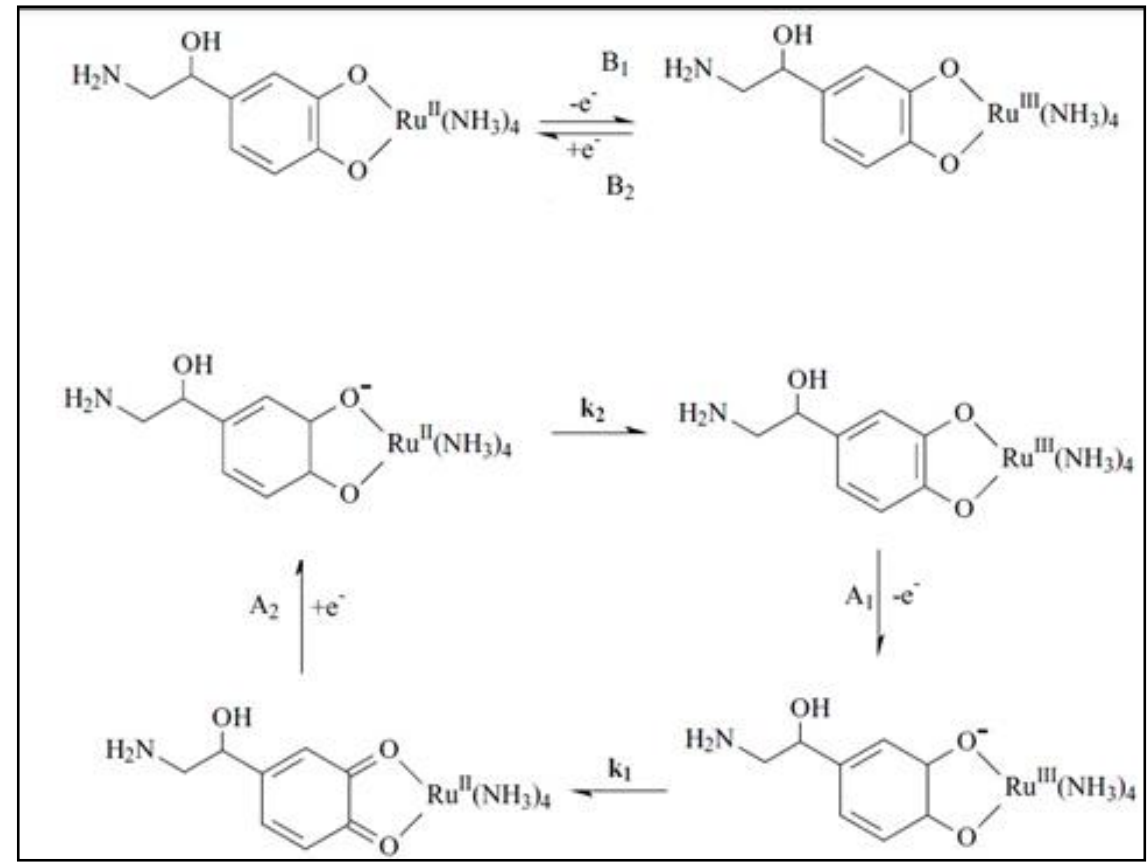

Fonte: Adaptado de DE LIMA, 2004 
Como se pode averiguar no mecanismo supra e nos resultados mostrados nos experimentos deste tópico, a conversão de uma espécie em outra e a reversibilidade de todos os processos - que pôde ser comprovada pelo completo retorno aos espectros eletrônicos das espécies iniciais - reafirma o que já fora explanado que em sistemas cujo metal é o rutênio e os ligantes são catecolaminas, ou derivados do catecol em geral, a deslocalização eletrônica é, deveras, muito grande, realmente possibilitando que, mormente, o elétron desemparelhado esteja, ora no metal, ora no ligante.

\subsubsection{Estabilidade fotoquímica}

Tendo em vista a possível aplicação biológica dos complexos estudados futuramente, os complexos foram avaliados em relação à sua fotoestabilidade, tanto em água, quanto em solução de tampão fosfato, $\mathrm{pH}$ 7,4, e os espectros foram monitorados em função do tempo com irradiação em diferentes comprimentos de onda. Os resultados, referentes à irradiação em $660 \mathrm{~nm}$, são mostrados a seguir (figura 36), enquanto os demais (com irradiação em $377 \mathrm{~nm}, 447 \mathrm{~nm}, 532 \mathrm{~nm}$ ) seguem no apêndice deste trabalho (figuras 131 a 133): 


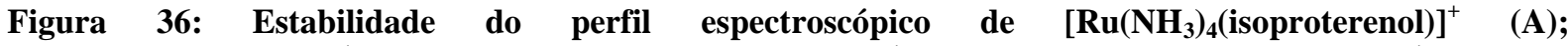
$\left[\mathbf{R u}\left(\mathrm{NH}_{3}\right)_{4}(\text { dopamina })\right]^{+} \quad(\mathrm{B}) ; \quad\left[\mathrm{Ru}\left(\mathrm{NH}_{3}\right)_{4}(\text { noradrenalina })\right]^{+} \quad(\mathrm{C}) ; \quad\left[\mathrm{Ru}\left(\mathrm{NH}_{3}\right)_{4}(\mathbf{c a t e c o l})\right]^{+} \quad$ (D) e $\left[\mathrm{Ru}\left(\mathrm{NH}_{3}\right)_{4}(\text { adrenalina })\right]^{+}$; com irradiação em $\lambda=660 \mathrm{~nm}$; solução aquosa $10^{-4} \mathrm{M} ; 0$ - 60 minutos

(A)

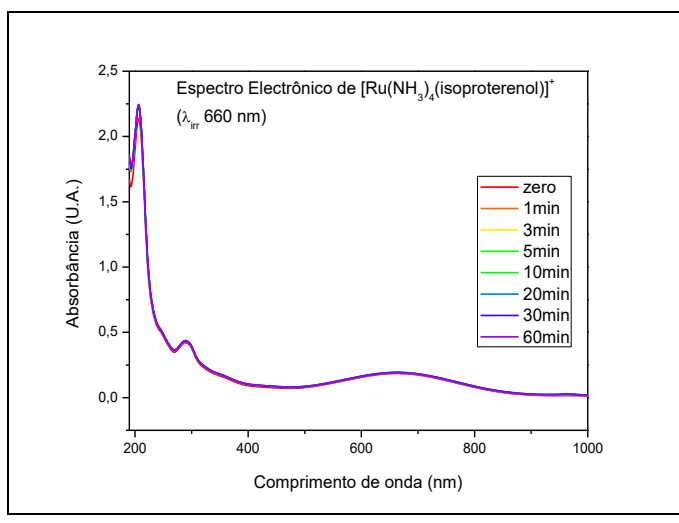

(C)

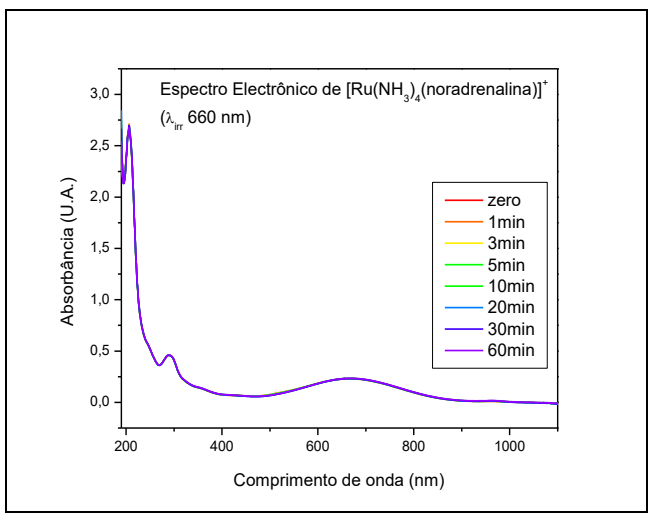

(B)

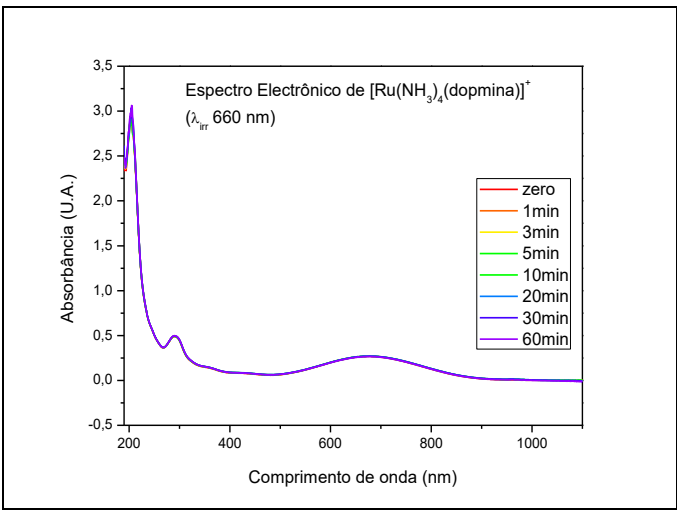

(D)

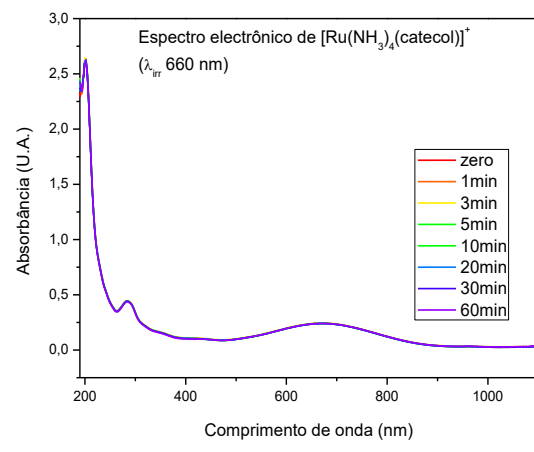

(E)

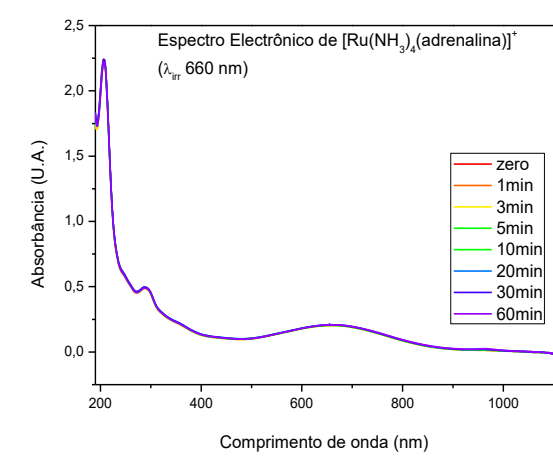

Fonte: Autora

Os resultados foram os mesmos para todas as soluções: no intervalo analisado, de sessenta minutos de irradiação, não ocorreram alterações nos espectros, demonstrando assim que estes complexos são candidatos interessantes às aplicações biológicas, uma vez que são estáveis na presença da luz, bem como em soluções aquosas, por no mínimo uma semana (DE LIMA, 2003). É essencial destacar que este estudo é bastante importante, uma vez que 
compostos com caráter antiangiogênico - finalidade pretendida destes complexos ora estudados - necessariamente devem ser administrados concomitantemente com substâncias citotóxicas. Considerando-se que terapias que envolvem o emprego da radiação luminosa estão experimentando um crescente desenvolvimento, em não havendo instabilidade fotoquímica nos complexos, os mesmos poderão ser associados, por exemplo, à terapia fotodinâmica (BOWN, 2013; RAMOS, 2012; NEGRI, 2015; HEINRICH, 2013).

\subsubsection{Verificação da produção de oxigênio singleto}

Considerando-se a possível aplicação futura dos complexos concomitantemente com complexos ativos na terapia fotodinâmica (por exemplo), os complexos de rutênio foram analisados na presença de uma sonda de oxigênio singleto, 1,3-difenil-isobenzofurano (DPBF), utilizando irradiação com o laser de $\lambda 660 \mathrm{~nm}$, durante intervalos de até 15 minutos. Os espectros são mostrados a seguir (figura 37): 


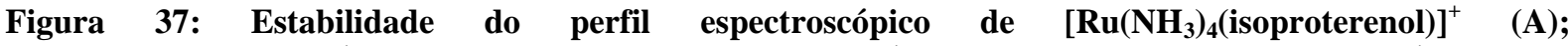
$\left[\mathbf{R u}\left(\mathrm{NH}_{3}\right)_{4}(\text { dopamina })\right]^{+} \quad(\mathrm{B}) ; \quad\left[\mathbf{R u}\left(\mathrm{NH}_{3}\right)_{4}(\text { noradrenalina })\right]^{+} \quad(\mathrm{C}) ; \quad\left[\mathbf{R u}\left(\mathrm{NH}_{3}\right)_{4}(\mathbf{c a t e c o l})\right]^{+} \quad$ (D) e $\left[\mathrm{Ru}\left(\mathrm{NH}_{3}\right)_{4}(\text { adrenalina })\right]^{+}$; com irradiação em $\lambda=660 \mathrm{~nm}$; solução aquosa $10^{-4} \mathrm{M} ; 0$ - 15 minutos; sonda utilizada: DPBF

(A)

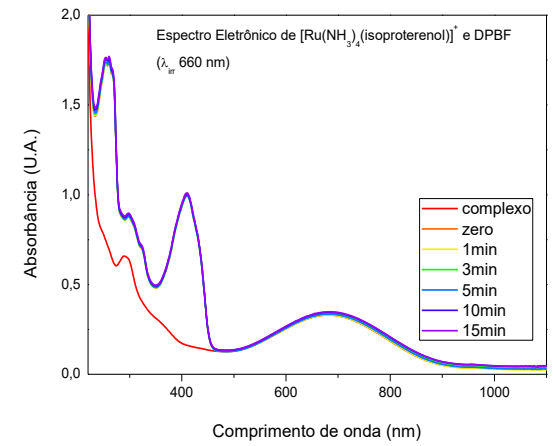

(C)

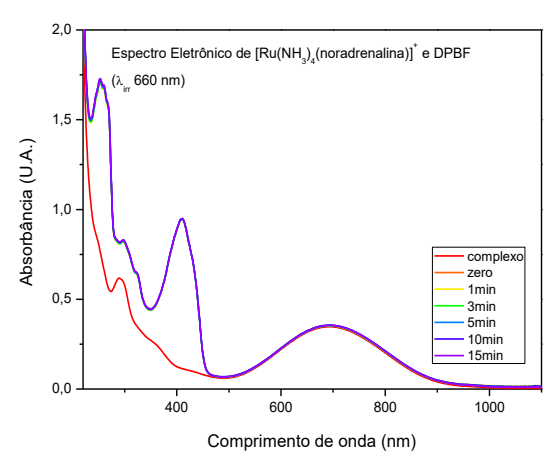

(B)

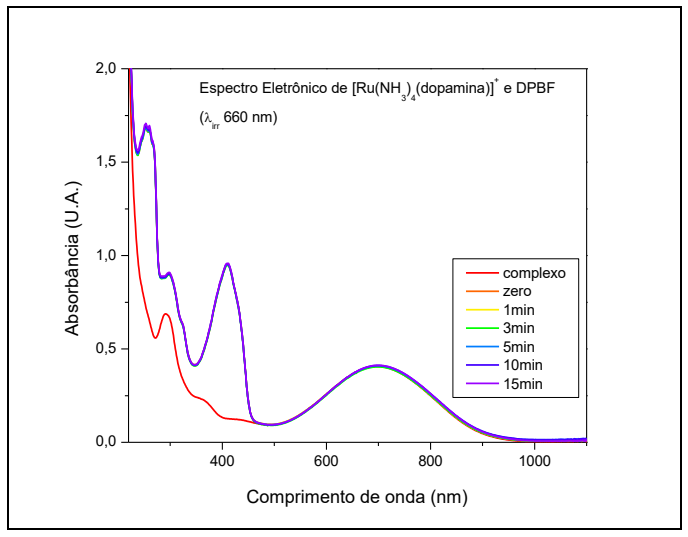

(D)

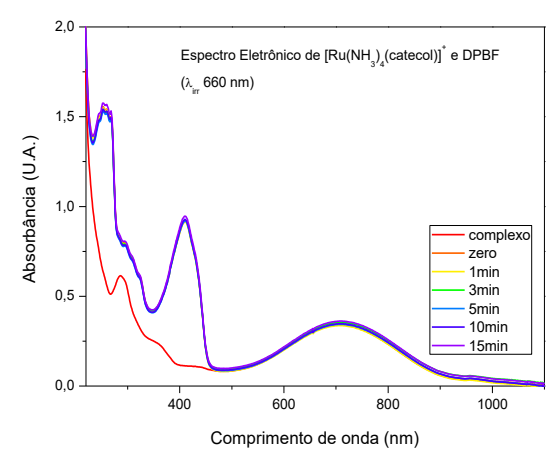

(E)

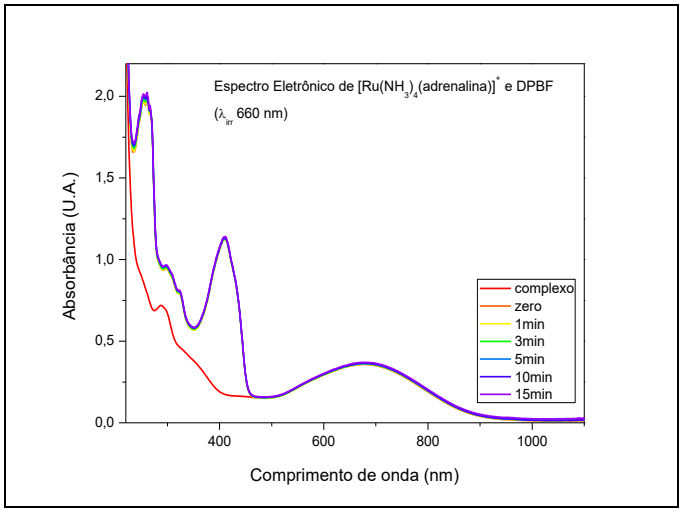

Fonte: Autora

Os complexos não apresentaram produção de oxigênio singleto, na presença da sonda DBPF, o que é interessante para propostas biológicas em associação com outros antitumorais. Isto porque espécies reativas de oxigênio, como o oxigênio singleto, ${ }^{1} \mathrm{O}_{2}$, são interessantes apenas quando geradas controladamente, como na terapia fotodinâmica com agentes fotossensibilizadores, porque, neste caso, eles causam lesões localizadas, apenas nos 
tecidos doentes. Assim, como possíveis candidatos a aplicações angiogênicas, os complexos estudados poderiam ser empregados em associações com fármacos antitumorais e/ou citotóxicos, inclusive com aqueles que agem por produção de espécies reativas de oxigênio (ROS), uma vez que não interfeririam em nada na atuação fotoquímica das outras espécies, dada sua fotoestabilidade (DAVIES, 2003; SULLIVAN; CHANDEL, 2014).

\subsubsection{Espectroscopia de absorção na região do infravermelho}

Dados de absorção na região do infravermelho foram obtidos a partir de espectros de FTIR, os quais são mostrados a seguir (figura 38):

Figura 38: Espectro de absorção na região do infravermelho (pastilhas de CsI): (A) $\left[\mathrm{Ru}\left(\mathrm{NH}_{3}\right)_{4}\right.$ (isoproterenol) $] \mathrm{Cl}, \quad(\mathrm{B}) \quad\left[\mathrm{Ru}\left(\mathrm{NH}_{3}\right)_{4}(\right.$ dopamina $\left.)\right] \mathrm{Cl}, \quad(\mathrm{C}) \quad\left[\mathrm{Ru}\left(\mathrm{NH}_{3}\right)_{4}(\right.$ noradrenalina $\left.)\right] \mathrm{Cl}, \quad(\mathrm{D})$ $\left[\mathrm{Ru}\left(\mathrm{NH}_{3}\right)_{4}(\right.$ catecol $\left.)\right] \mathrm{Cl}$ e $(\mathrm{E})\left[\mathrm{Ru}\left(\mathrm{NH}_{3}\right)_{4}(\right.$ adrenalina $\left.)\right] \mathrm{Cl}$

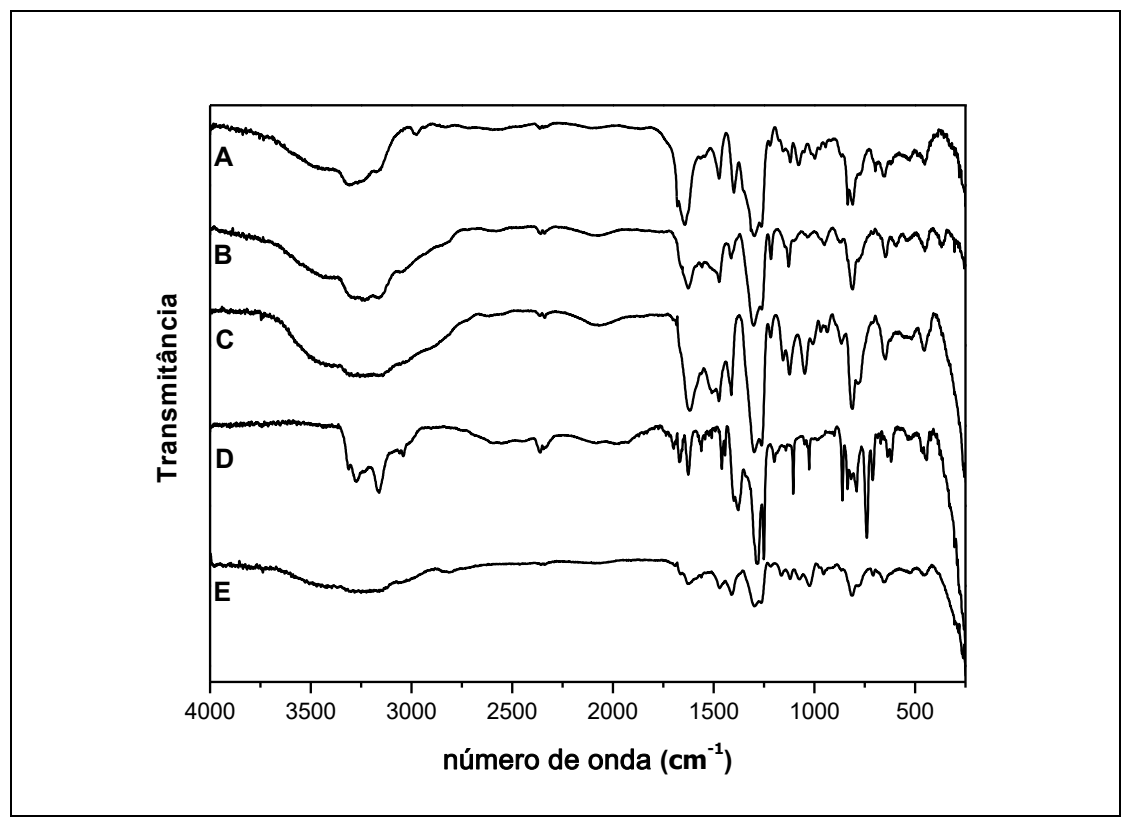

Fonte: Autora

As atribuições foram realizadas com fundamento nas bandas observadas para os ligantes livres (espectros constantes do apêndice, figura 115), bem como nos valores mencionados na literatura para complexos semelhantes e seguem mostradas na tabela a seguir (tabela 9): 
Tabela 9: Atribuições das frequências das vibrações nos espectros de FTIR, em pastilhas de CsI

\begin{tabular}{cccccccc}
\hline frequências $\left(\mathrm{cm}^{-1}\right)$ & $\delta \mathrm{a}(\mathrm{HNH})$ & $\delta \mathrm{s}(\mathrm{HNH})$ & $\delta \rho(\mathrm{HNH})$ & $v \mathrm{Ru}-\mathrm{N}$ & $v \mathrm{C}-\mathrm{O}$ & $v \mathrm{O}-\mathrm{H}$ & $v\left(\mathrm{NH}_{3}\right)$ \\
\hline \hline$\left[\mathrm{Ru}\left(\mathrm{NH}_{3}\right)_{4}(\mathrm{iso})\right] \mathrm{Cl}$ & 1645 & 1306 & 820 & 447 & 1297 & $\sim 3400$ & 3157 \\
{$\left[\mathrm{Ru}\left(\mathrm{NH}_{3}\right)_{4}(\right.$ adre $\left.)\right] \mathrm{Cl}$} & 1624 & 1298 & 812 & 454 & 1296 & $\sim 3400$ & 3143 \\
{$\left[\mathrm{Ru}\left(\mathrm{NH}_{3}\right)_{4}(\mathrm{nor})\right] \mathrm{Cl}$} & 1617 & 1303 & 816 & 455 & 1296 & $\sim 3400$ & 3148 \\
{$\left[\mathrm{Ru}\left(\mathrm{NH}_{3}\right)_{4}(\mathrm{cat})\right] \mathrm{Cl}$} & 1627 & 1287 & 830 & 444 & 1281 & $\sim 3400$ & 3157 \\
{$\left[\mathrm{Ru}\left(\mathrm{NH}_{3}\right)_{4}(\mathrm{dop})\right] \mathrm{Cl}$} & 1624 & 1306 & 811 & 450 & 1300 & $\sim 3400$ & 3168 \\
\hline
\end{tabular}

Fonte: Autora

As bandas referentes aos estiramentos da ligação $\mathrm{Ru}-\mathrm{N}$, na região de $450 \mathrm{~cm}^{-1}$, foram passíveis de visualização em razão de ter sido utilizado iodeto de césio na confecção das pastilhas. A menor frequência para essa vibração foi observada para o complexo de catecol, o que indica que, provavelmente, neste complexo, a interação entre os orbitais do metal e os do ligante orgânico é mais forte, enfraquecendo a ligação Ru-N (NAKAMOTO, 2009).

As bandas largas entre 3000 e $3400 \mathrm{~cm}^{-1}$ são atribuídas aos estiramentos simétrico e assimétrico $\mathrm{N}-\mathrm{H}$, bem como aos estiramentos simétrico e assimétrico $\mathrm{O}-\mathrm{H}$, nos complexos (DE LIMA et. al., 2003; DE LIMA et. al., 2004).

Considerando-se que os dioxolenos podem assumir três estados de oxidação, as frequências das vibrações referentes aos estiramentos $\mathrm{C}-\mathrm{O}$ auxiliam na caracterização deste estado de oxidação, uma vez que a força, bem como o comprimento da ligação, são característicos dos ligantes em cada uma das formas representadas a seguir: $\mathrm{C}=\mathrm{O}$ com o ligante na forma de quinona (ligação mais forte e mais curta, com estiramentos que aparecem entre 1600 e $1675 \mathrm{~cm}^{-1}$ ); C—O com o ligante na forma de semiquinona, apresentando bandas na região entre 1400 e $1500 \mathrm{~cm}^{-1}$, as quais são referentes aos estiramentos da ligação $\mathrm{C}$ - O (para o ligante coordenado neste estado de oxidação, as bandas na região de $1250 \mathrm{~cm}^{-1}$ são pouco intensas); e $\mathrm{C}-\mathrm{O}$ com o ligante na forma de catecolato, apresentando banda do estiramento da ligação C-O entre 1250 e $1400 \mathrm{~cm}^{-1}$ (HAGA; DODSWORTH; LEVER, 1986; SILVA, et. al., 2000; DE LIMA, 2001).

Neste sentido, é possível concluir que todos os ligantes se encontram, nos complexos, na forma de catecolatos, com estiramentos próximos a $1300 \mathrm{~cm}^{-1}$, os quais variam 
pouco quando comparados aos dos respectivos ligantes livres (vide apêndice, figura 115), nos quais a forma observada é, também, a forma reduzida.

\subsubsection{Espectroscopia Raman}

A espectroscopia Raman se mostra especialmente interessante na análise de compostos de coordenação, uma vez que é possível observar sinais referentes às vibrações envolvendo os metais os quais não raramente não são observados na espectroscopia de absorção na região do infravermelho (FTIR) convencional, além do que existe a possibilidade de se ter o efeito Raman ressonante, em razão das transições eletrônicas na região visível do espectro eletromagnético, que os compostos de coordenação geralmente apresentam (FERRARO; NAKAMOTO, 1994; SMITH, DENT, 2005; NAKAMOTO, 2009).

Assim, os complexos foram analisados, na região do infravermelho do espectro, em relação ao deslocamento Raman. Destas análises resultaram os espectros que são mostrados a seguir (figuras 39):

Figura 39: Espectro Raman dos complexos no estado sólido: (A) $\left[\mathrm{Ru}\left(\mathrm{NH}_{3}\right)_{4}\right.$ (isoproterenol)]Cl, (B) $\left[\mathrm{Ru}\left(\mathrm{NH}_{3}\right)_{4}(\right.$ dopamina $\left.)\right] \mathrm{Cl}, \quad$ (C) $\left[\mathrm{Ru}\left(\mathrm{NH}_{3}\right)_{4}(\right.$ noradrenalina $\left.)\right] \mathrm{Cl}, \quad$ (D) $\left[\mathrm{Ru}\left(\mathrm{NH}_{3}\right)_{4}(\right.$ catecol $\left.)\right] \mathrm{Cl}$ e $\quad$ (E) $\left[\mathrm{Ru}\left(\mathrm{NH}_{3}\right)_{4}(\right.$ adrenalina $\left.)\right] \mathrm{Cl}$

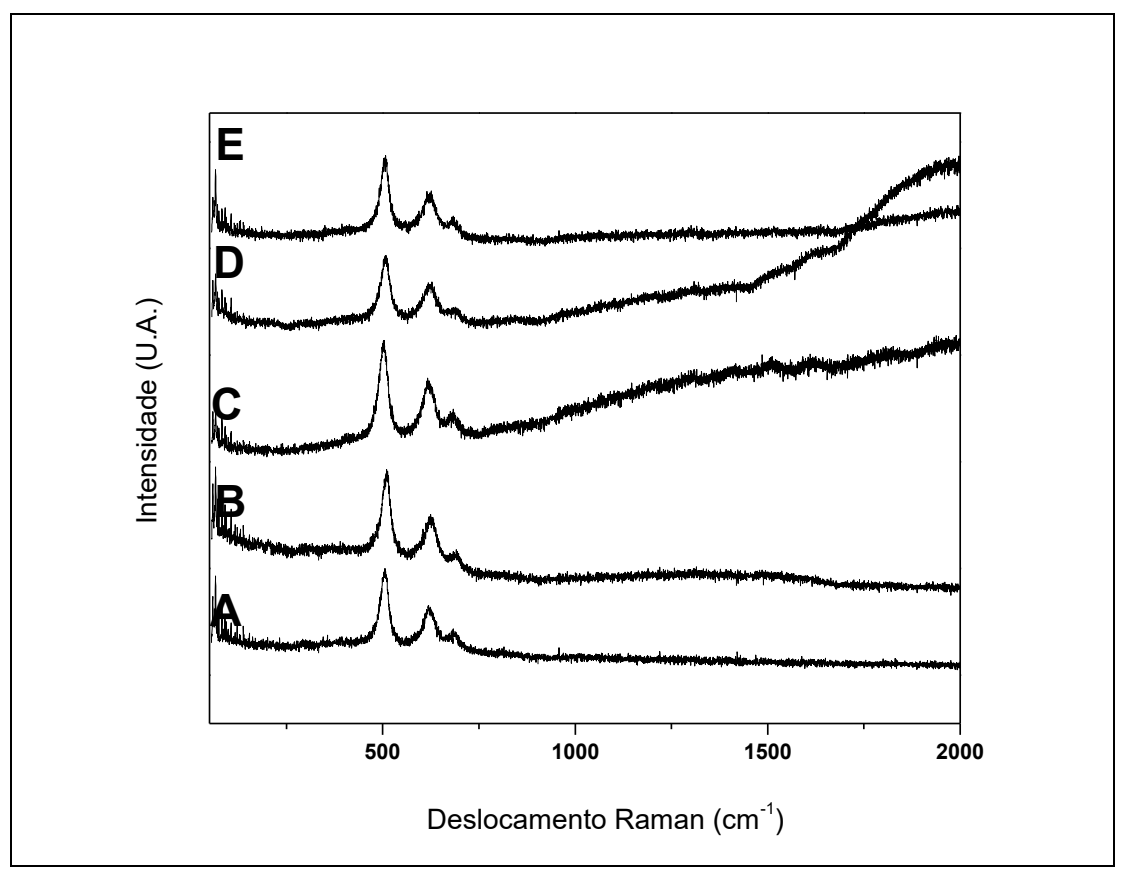

Fonte: Autora

Os complexos dioxolenos de rutênio apresentaram três bandas entre 500 e $700 \mathrm{~cm}^{-}$ ${ }^{1}$, das quais a mais intensa possui o menor número de onda, próximo a $500 \mathrm{~cm}^{-1}$. As bandas de 
menor intensidade podem ser atribuídas aos estiramentos $\mathrm{Ru}-\mathrm{O}$, enquanto as mais intensas, podem ser atribuídas aos estiramentos do anel de cinco membros formado por $\mathrm{RuOOC}_{1} \mathrm{C}_{2}$, onde $\mathrm{C}_{1}$ e $\mathrm{C}_{2}$ são os carbonos ligados aos átomos de oxigênio (figura 40):

Figura 40: Esquema para mostrar o anel de cinco membros $\mathrm{RuOOC}_{1} \mathrm{C}_{2}$

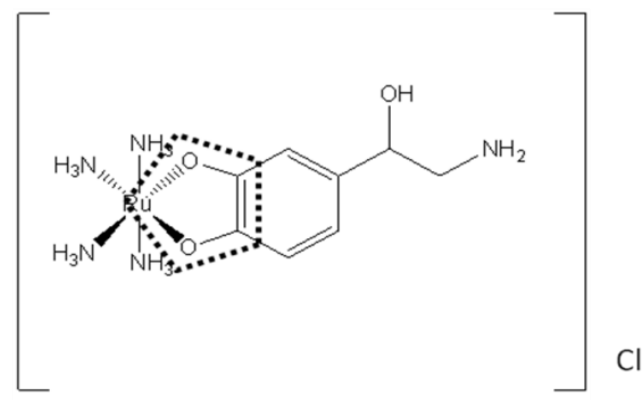

Fonte: Autora

Barreto et. al. (2007), para complexos com Fe(III) com dopamina como ligante, descreveram bandas semelhantes, inclusive no que se refere à intensidade relativa entre as mesmas.

Tabela 10: Atribuições dos sinais observados nos espectros Raman

\begin{tabular}{|c|c|c|c|c|c|c|}
\hline & $\left[\mathrm{Ru}\left(\mathrm{NH}_{3}\right)_{4}\right.$ (iso $\left.)\right] \mathrm{Cl}$ & {$\left[\mathrm{Ru}\left(\mathrm{NH}_{3}\right)_{4}(\mathrm{adre})\right] \mathrm{Cl}$} & {$\left[\mathrm{Ru}\left(\mathrm{NH}_{3}\right)_{4}(\mathrm{nor})\right] \mathrm{Cl}$} & {$\left[\mathrm{Ru}\left(\mathrm{NH}_{3}\right)_{4}(\mathrm{cat})\right] \mathrm{Cl}$} & {$\left[\mathrm{Ru}\left(\mathrm{NH}_{3}\right)_{4}(\mathrm{dop})\right] \mathrm{Cl}$} & {$[\mathrm{CTA}]\left[\mathrm{Fe}(\mathrm{dop})_{2}\right]$} \\
\hline & $\operatorname{Raman}\left(\mathrm{cm}^{-1}\right)$ & $\operatorname{Raman}\left(\mathrm{cm}^{-1}\right)$ & $\operatorname{Raman}\left(\mathrm{cm}^{-1}\right)$ & $\operatorname{Raman}\left(\mathrm{cm}^{-1}\right)$ & $\operatorname{Raman}\left(\mathrm{cm}^{-1}\right)$ & $\operatorname{Raman}\left(\mathrm{cm}^{-1}\right)$ \\
\hline$v \mathrm{RuOOC}_{1} \mathrm{C}_{2}$ & 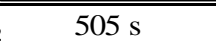 & "505s & (502s & "508s & 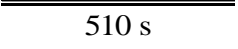 & "568 s \\
\hline$v \mathrm{Ru}-\mathrm{O}$ & $618 \mathrm{~m}$ & $615 \mathrm{~m}$ & $616 \mathrm{~m}$ & $627 \mathrm{~m}$ & $624 \mathrm{~m}$ & $623 \mathrm{w} *$ \\
\hline $\begin{array}{l}v \mathrm{Ru}-\mathrm{O} \\
\text { fonte }\end{array}$ & $\begin{array}{c}680 \mathrm{w} \\
\text { este trabalho }\end{array}$ & $\begin{array}{c}683 \mathrm{w} \\
\text { este trabalho }\end{array}$ & $\begin{array}{c}683 \mathrm{w} \\
\text { este trabalho }\end{array}$ & $\begin{array}{c}689 \mathrm{w} \\
\text { este trabalho }\end{array}$ & $\begin{array}{c}691 \mathrm{w} \\
\text { este trabalho }\end{array}$ & $\begin{array}{c}680 \mathrm{w} * \\
\text { BARRETO et. al., } 2007\end{array}$ \\
\hline
\end{tabular}

Fonte: Autora

Para as bandas referentes aos estiramentos da ligação $\mathrm{Ru}-\mathrm{O}$, observou-se, de um modo geral, que os maiores valores foram obtidos para os complexos de dopamina e catecol, demonstrando que a ligação possui maior constante de força, sinalizando para uma maior interação entre os orbitais destes ligantes e os do metal.

Em relação ao $\mathrm{pKa}_{1}$, a explicação retro também se aplica: quanto mais forte a base conjugada dos ligantes, mais forte é a ligação $\mathrm{Ru}-\mathrm{O}$, culminando em estiramentos de maior energia (figura 41): 
Figura 41: Correlação entre os valores de $\mathrm{pKa}_{1}$ dos ligantes e a energia da transição vibracional Ru-O

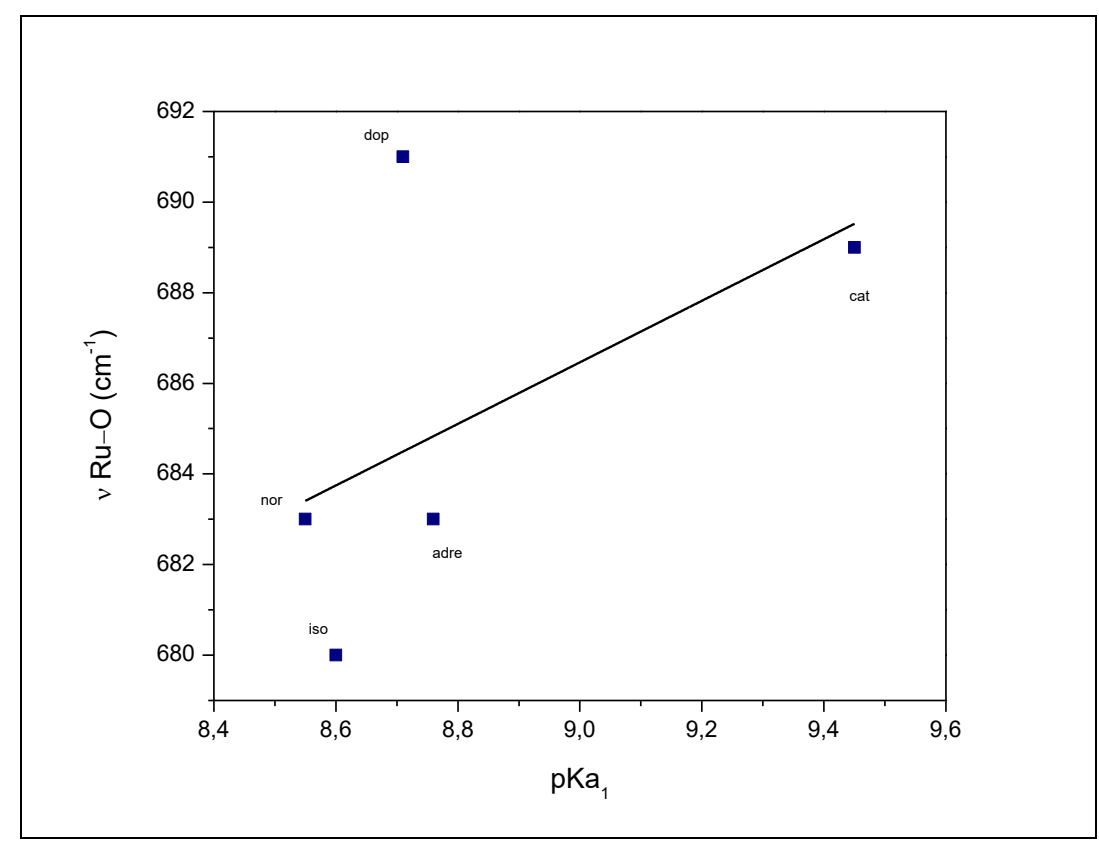

Fonte: Autora

Para as bandas referentes ao anel de cinco membros formado por $\mathrm{RuOOC}_{1} \mathrm{C}_{2}$, observou-se que os maiores valores também foram obtidos para os complexos de dopamina e catecol, porém as transições vibracionais destes complexos ocorrem em menor energia que a observada para o complexo análogo de ferro. Este comportamento não é condizente com o esperado, considerando-se que a massa reduzida ( $\mu$ ) do anel contendo ferro é consideravelmente menor quando comparada ao sistema contendo rutênio (BARRETO et. al., 2007), porém em se tratando de duas catecolaminas coordenadas ao ferro, possivelmente a massa reduzida total do anel influencia nesta vibração.

Em relação ao $\mathrm{pKa}$, a mesma tendência observada para a ligação $\mathrm{Ru}-\mathrm{O}$ foi verificada (figura 42): 
Figura 42: Correlação entre os valores de $\mathrm{pKa}_{1}$ dos ligantes e a energia da transição vibracional $\mathrm{RuOOC}_{1} \mathrm{C}_{2}$

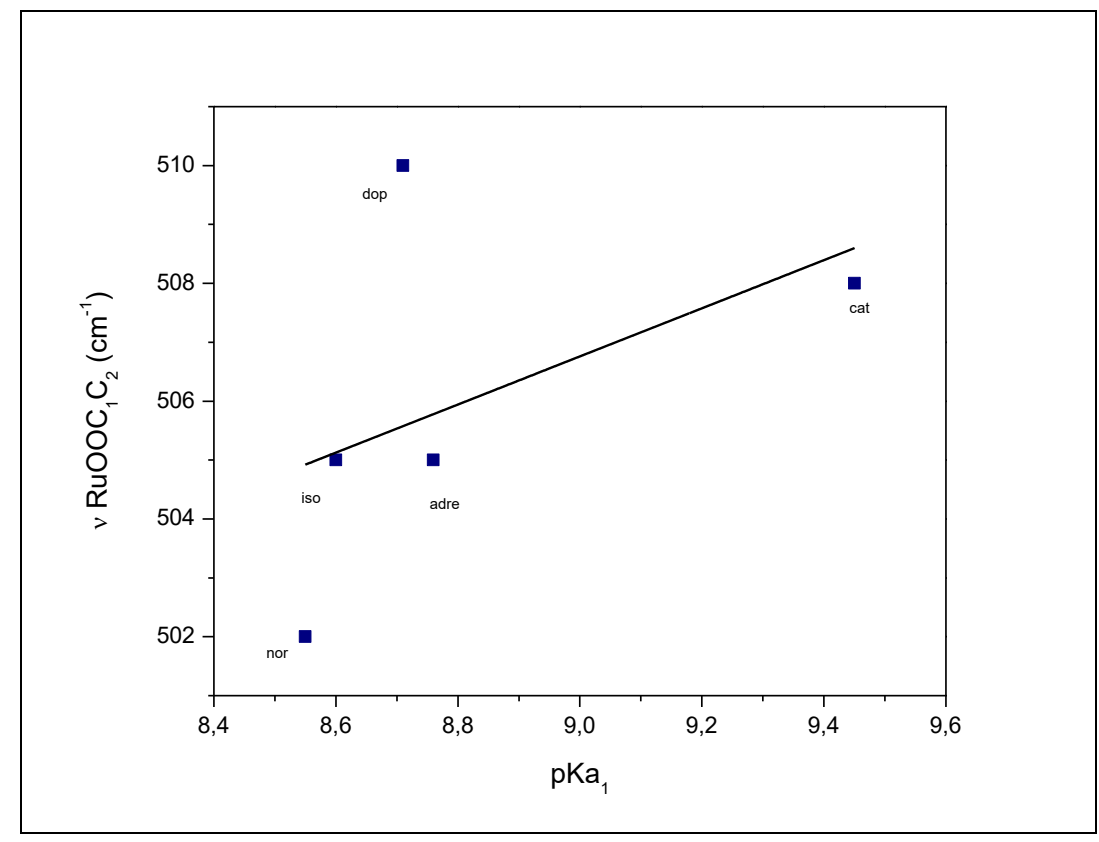

Fonte: Autora

As regiões de mais alta frequência não apresentaram bandas devido ao efeito Raman Ressonante, o qual causa a intensificação apenas dos sinais que se referem às transições vibracionais dos átomos envolvidos na transição eletrônica. Assim, com o efeito de ressonância observado no espectro, é possível confirmar que a transição eletrônica que ocorre na região de $15.000 \mathrm{~cm}^{-1}$ envolve tanto orbitais do ligante, quanto do metal, corroborando a atribuição previamente apresentada (BARRETO et. al., 2007; NAKAMOTO, 2009).

Ademais, apenas o complexo $\left[\mathrm{Ru}\left(\mathrm{NH}_{3}\right)_{4}(\right.$ catecol $\left.)\right] \mathrm{Cl}$ exibiu luminescência em aproximadamente $2000 \mathrm{~cm}^{-1}$, comportamento este atribuído ao fato de que os substituintes do anel aromático favorecem o decaimento não-radiativo - decaimento este menos intenso para o complexo cujo ligante é o catecol, pois possui estrutura nitidamente mais rígida.

\subsubsection{Espectroscopia de ressonância magnética nuclear}

É conhecido que a espectroscopia de ressonância magnética nuclear (RMN) não é amplamente utilizada para complexos paramagnéticos, embora seja possível - não isento de algumas dificuldades, tais como o deslocamento dos sinais - se obter bons espectros. Neste trabalho optou-se por sua utilização, a fim de melhor compreender o efeito paramagnético induzido após a coordenação ao íon metálico. 
Os espectros dos complexos são mostrados a seguir, seguidos dos espectros dos ligantes livres, respectivamente (figuras 43 a 51):

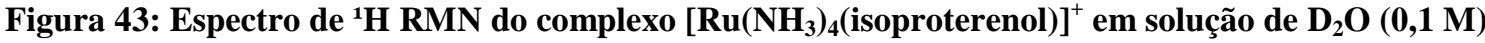

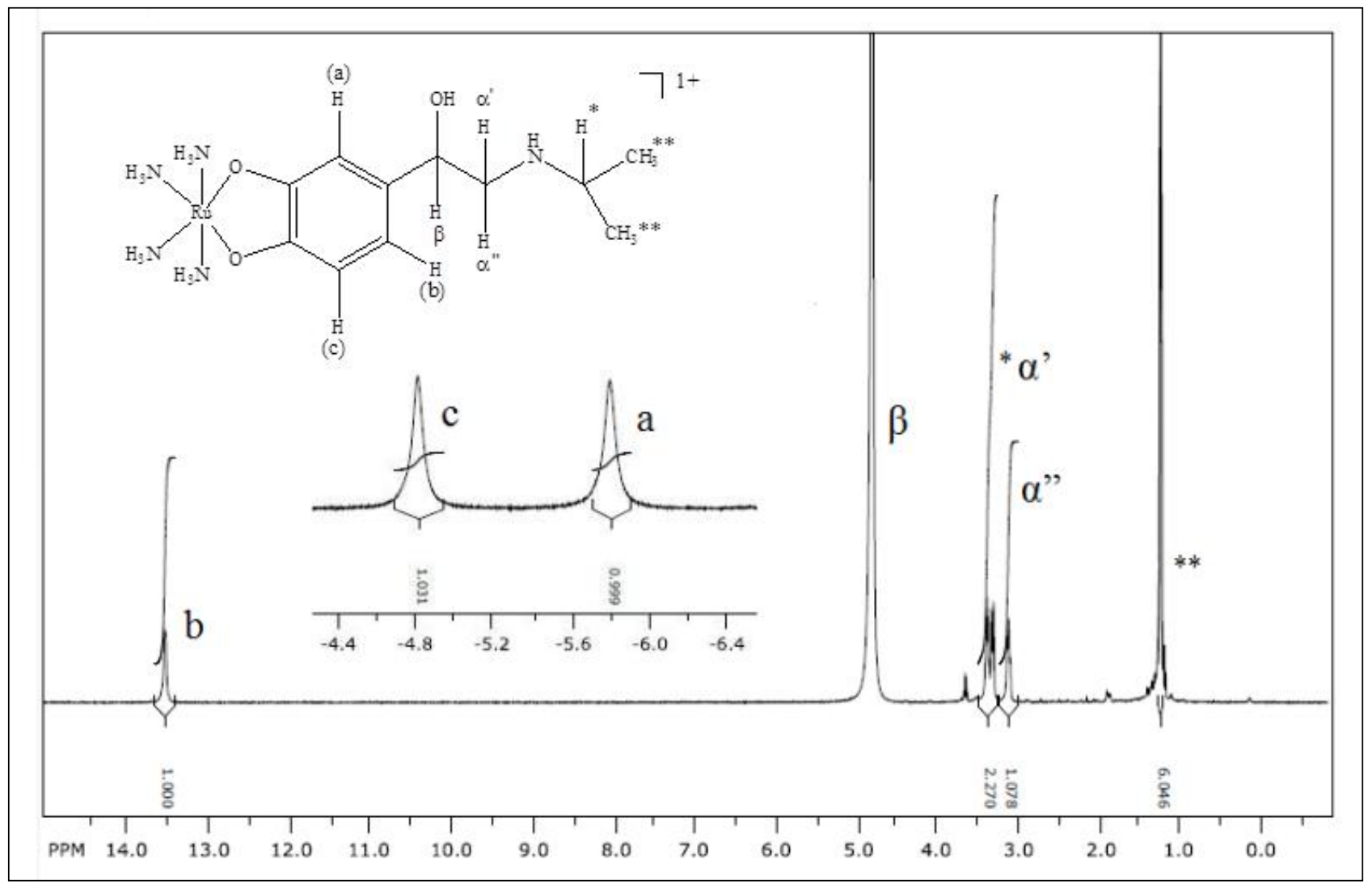

Fonte: Autora 
Figura 44: Espectro de ${ }^{1} \mathrm{H}$ RMN do ligante isoproterenol em solução de $\mathrm{D}_{2} \mathrm{O}(0,1 \mathrm{M})$

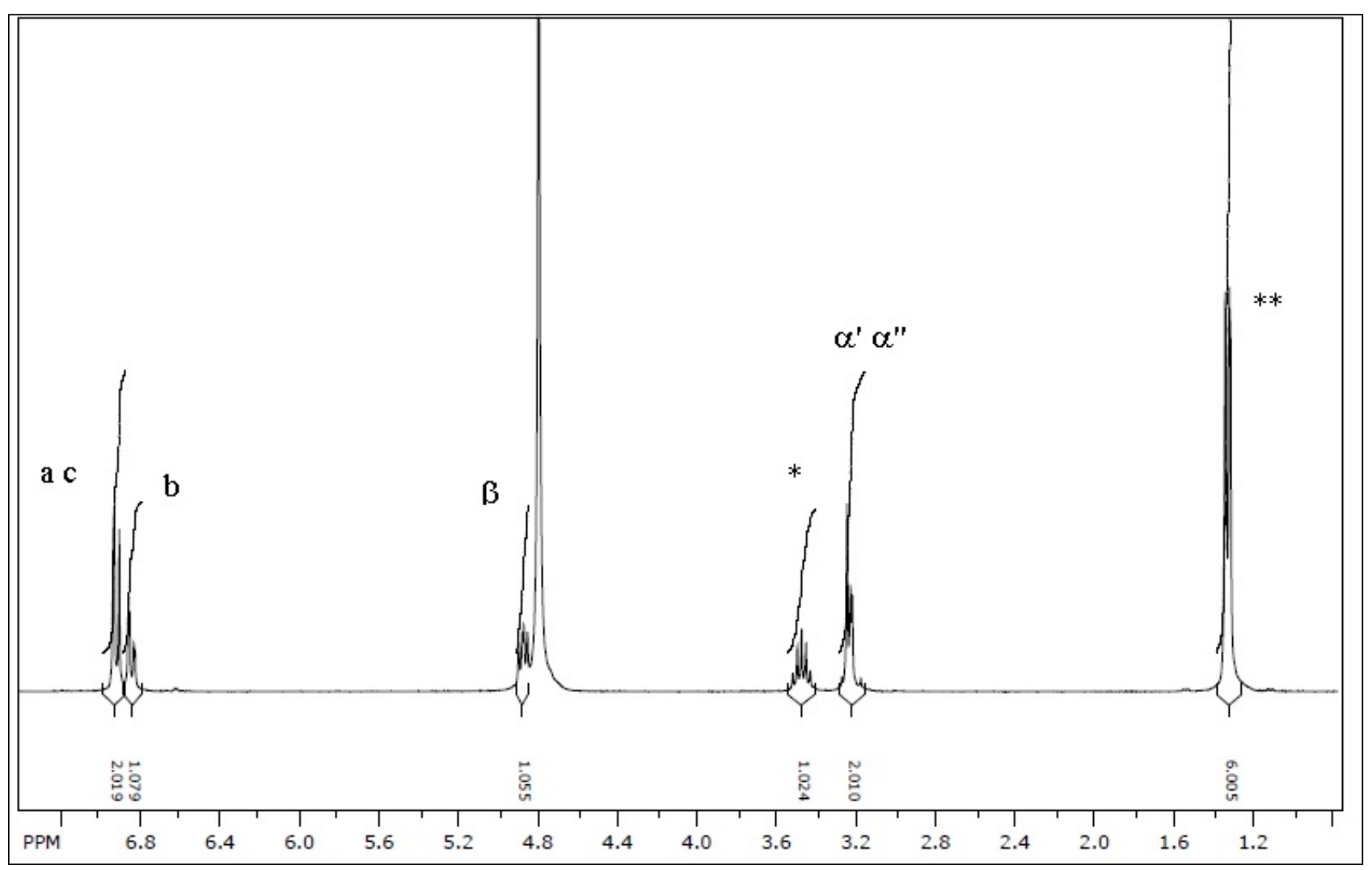

Fonte: Autora 


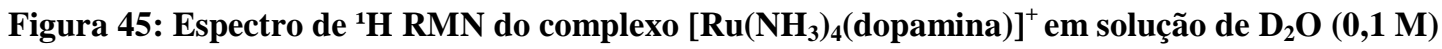

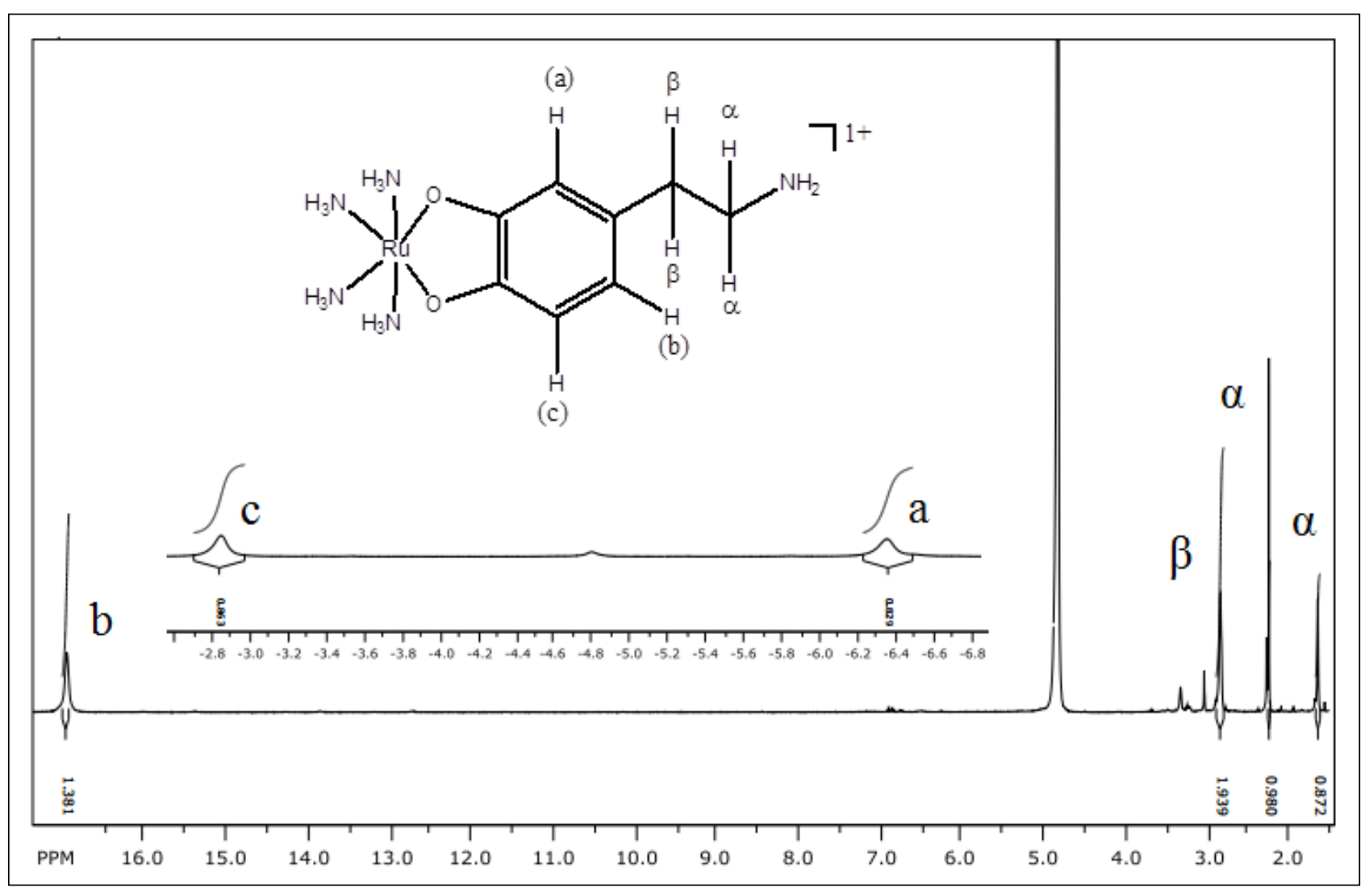

Fonte: Autora 
Figura 46: Espectro de ${ }^{1} \mathrm{H}$ RMN do ligante dopamina em solução de $\mathrm{D}_{2} \mathrm{O}(0,1 \mathrm{M})$

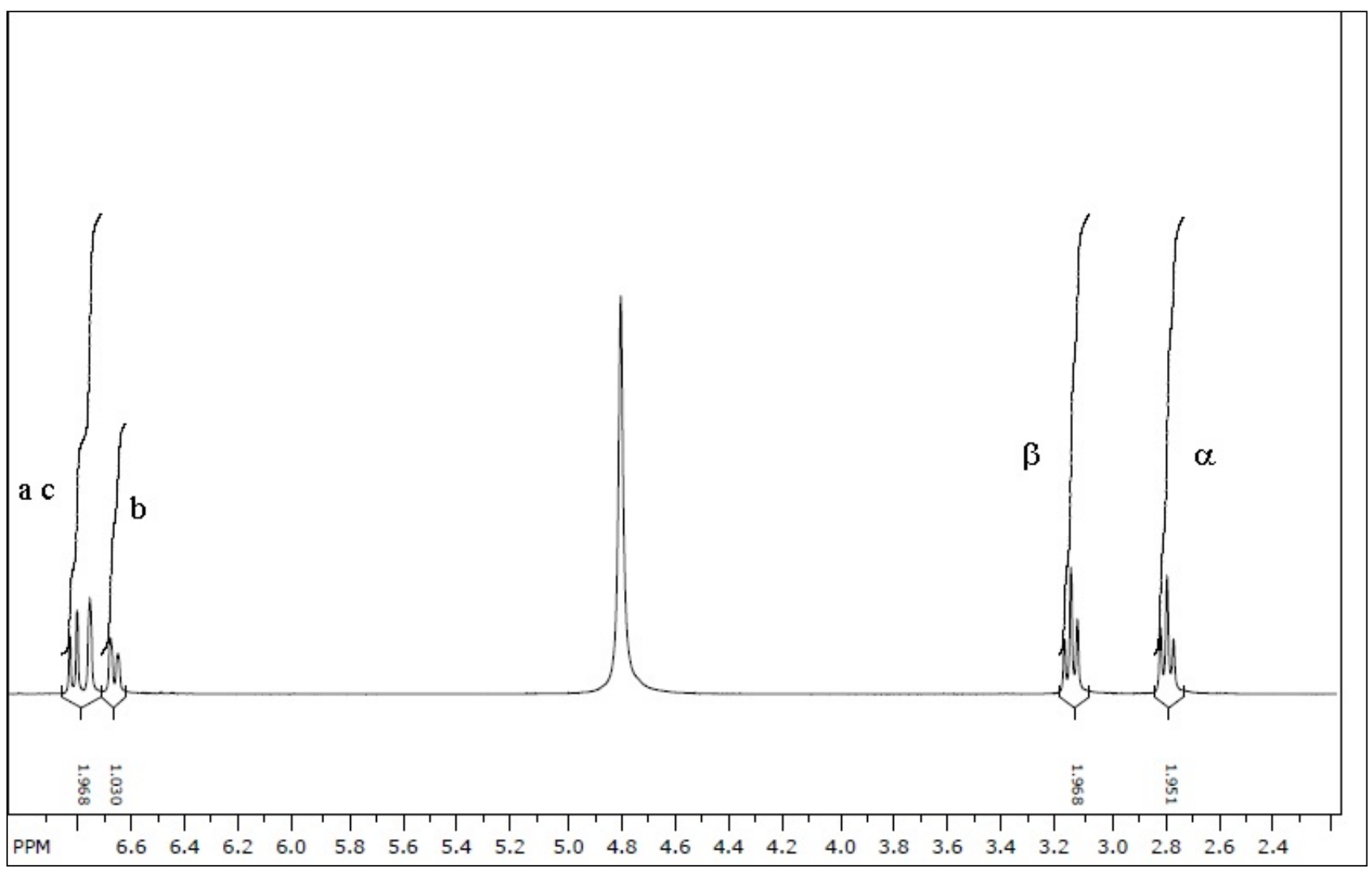

Fonte: Autora 
Figura 47: Espectro de ${ }^{1} \mathrm{H}$ RMN do complexo $\left[\mathrm{Ru}\left(\mathrm{NH}_{3}\right)_{4}(\text { noradrenalina })\right]^{+}$em solução de $\mathrm{D}_{2} \mathrm{O}(0,1 \mathrm{M})$

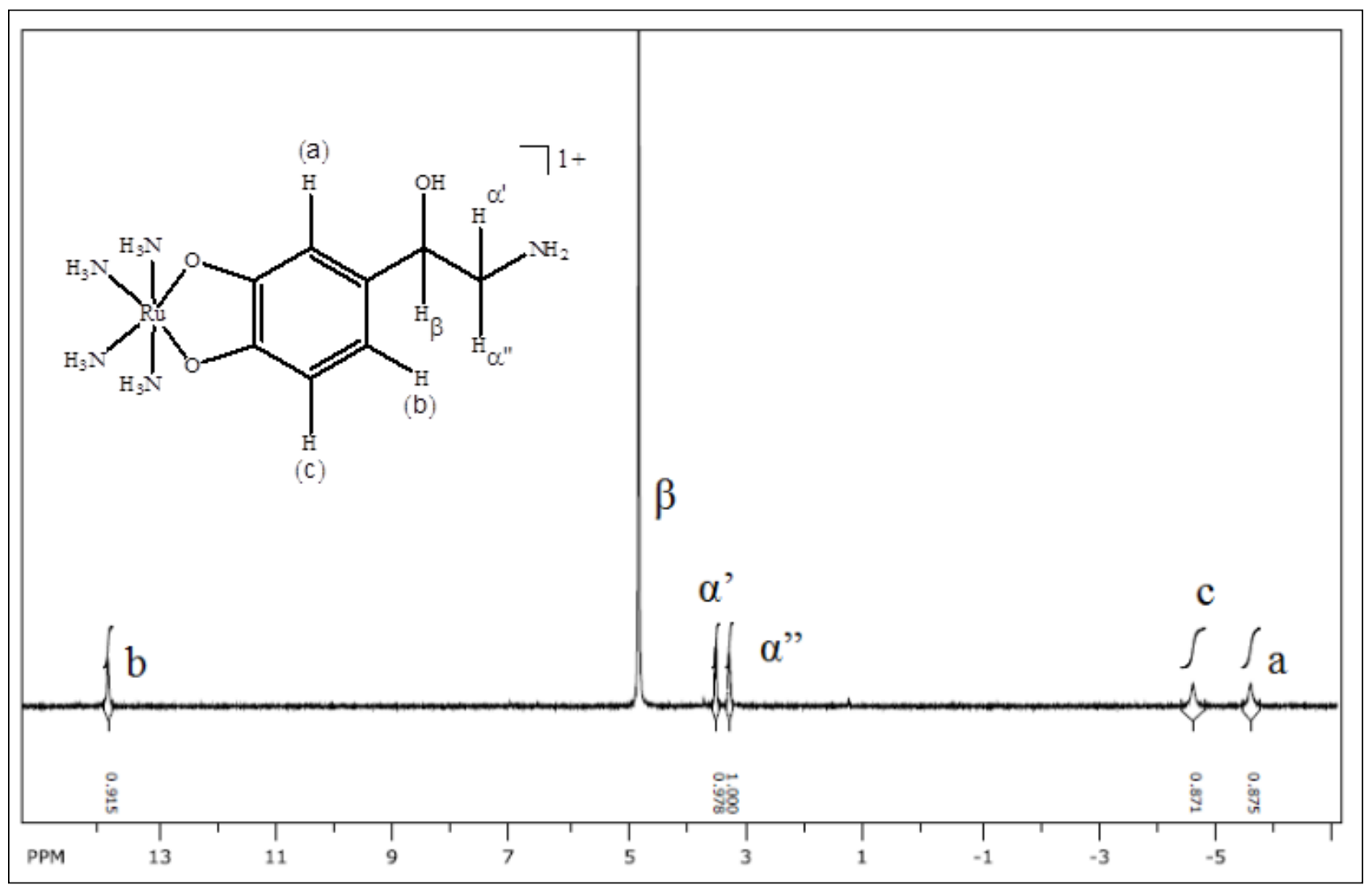

Fonte: Autora 
Figura 48: Espectro de ${ }^{1} \mathrm{H}$ RMN do ligante noradrenalina em solução de $\mathrm{D}_{\mathbf{2}} \mathrm{O}(0,1 \mathrm{M})$

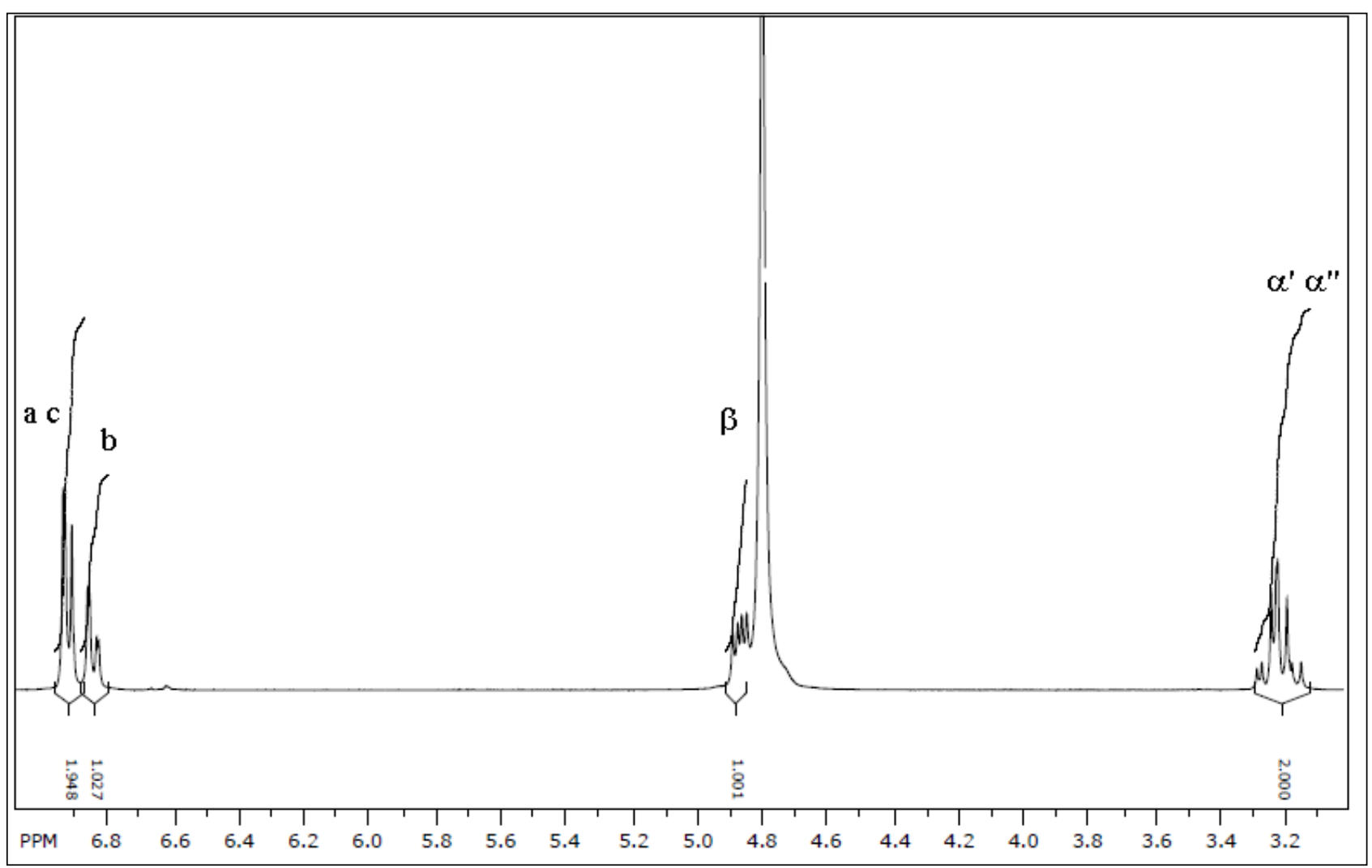

Fonte: Autora 
Figura 49: Espectro de $\mathrm{RMN}^{\mathrm{de}}{ }^{1} \mathrm{H}$ do complexo $\left[\mathrm{Ru}\left(\mathrm{NH}_{3}\right)_{4}(\text { adrenalina })\right]^{+}$em solução de $\mathrm{D}_{2} \mathrm{O}(0,1 \mathrm{M})$

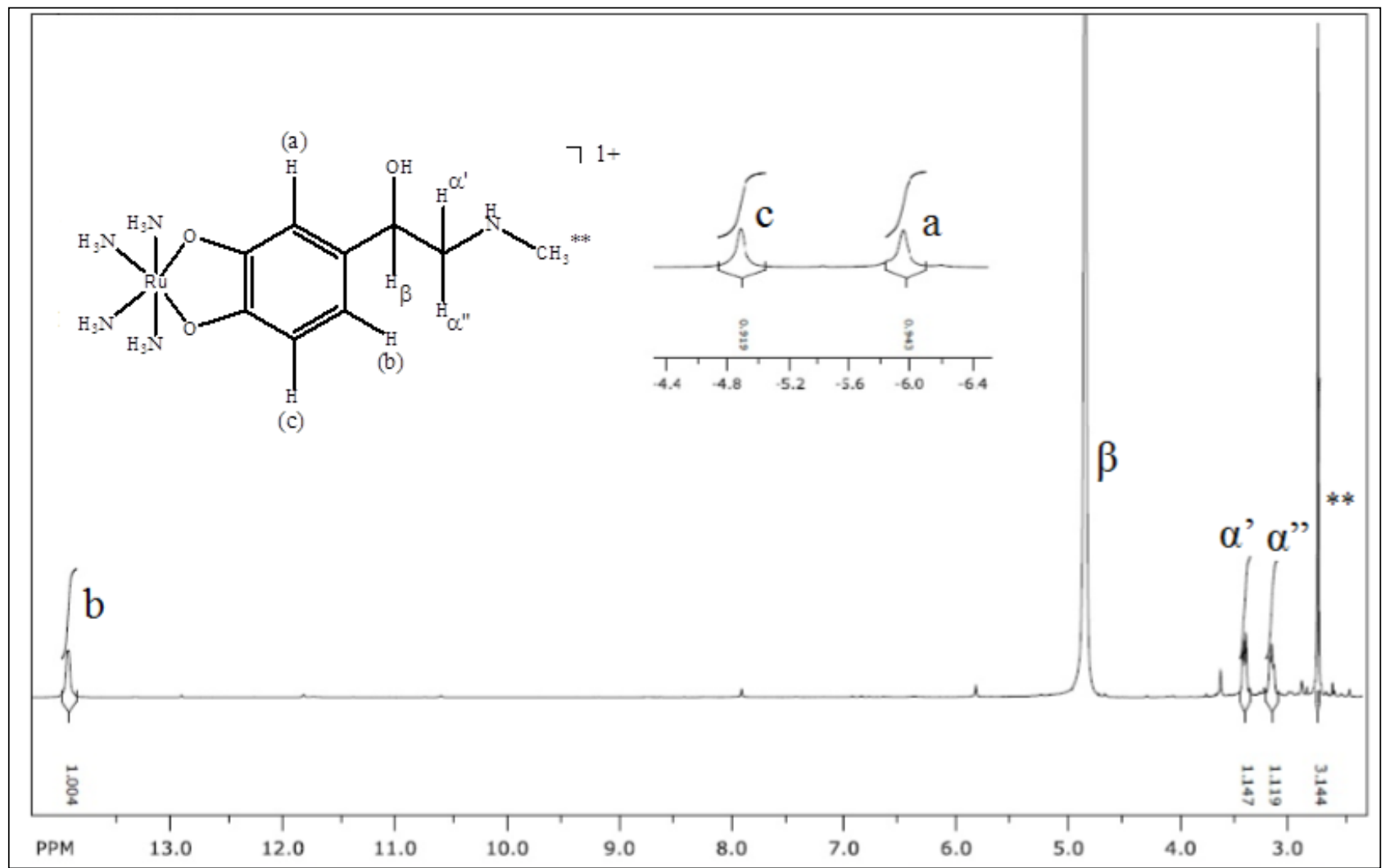

Fonte: Autora 
Figura 50: Espectro de ${ }^{1} \mathrm{H}$ RMN do ligante adrenalina em solução de $\mathrm{D}_{2} \mathrm{O}(0,1 \mathrm{M})$

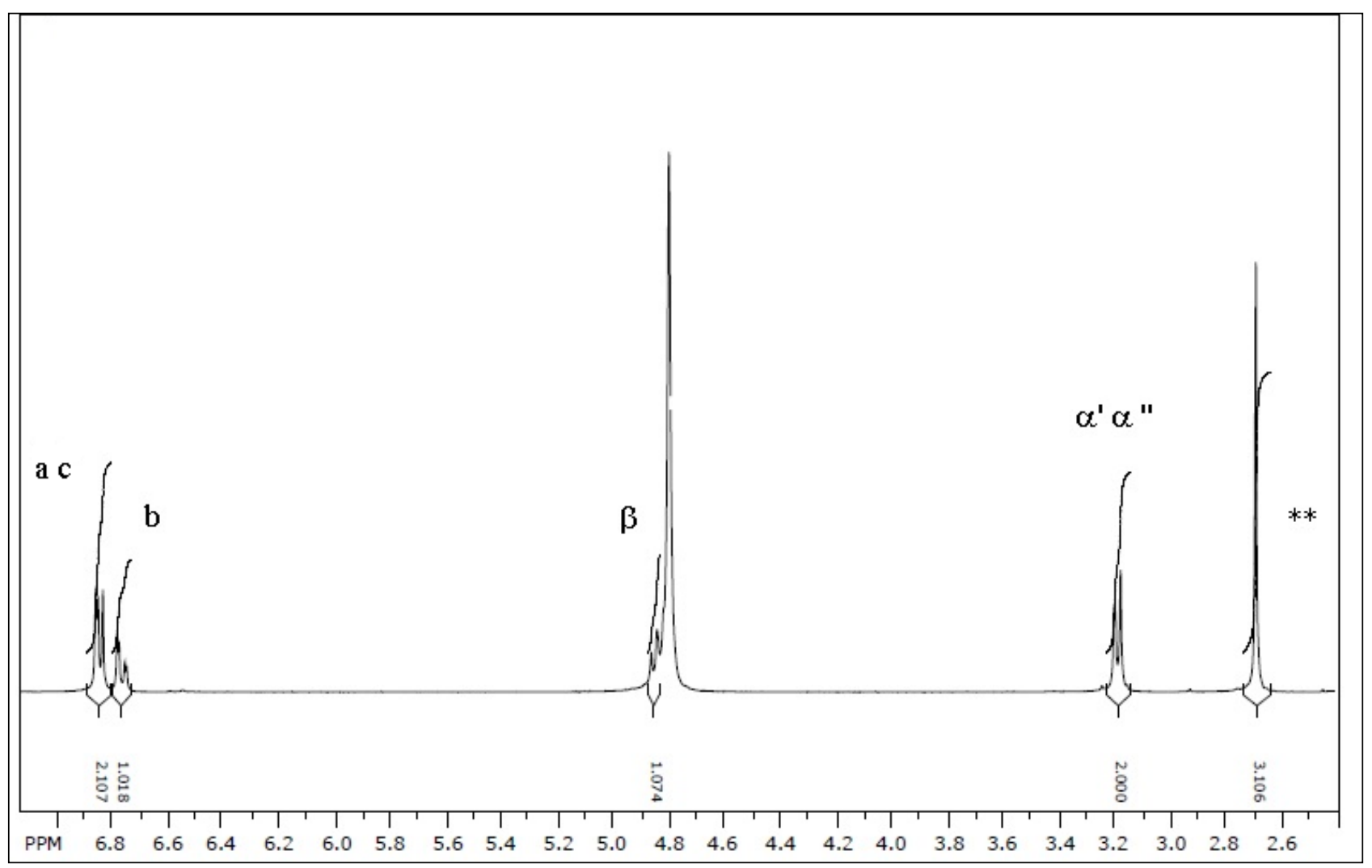

Fonte: Autora 
Figura 51: Espectro de ${ }^{1} \mathrm{H}$ RMN do ligante catecol em solução de $\mathrm{D}_{2} \mathrm{O}(0,1 \mathrm{M})$

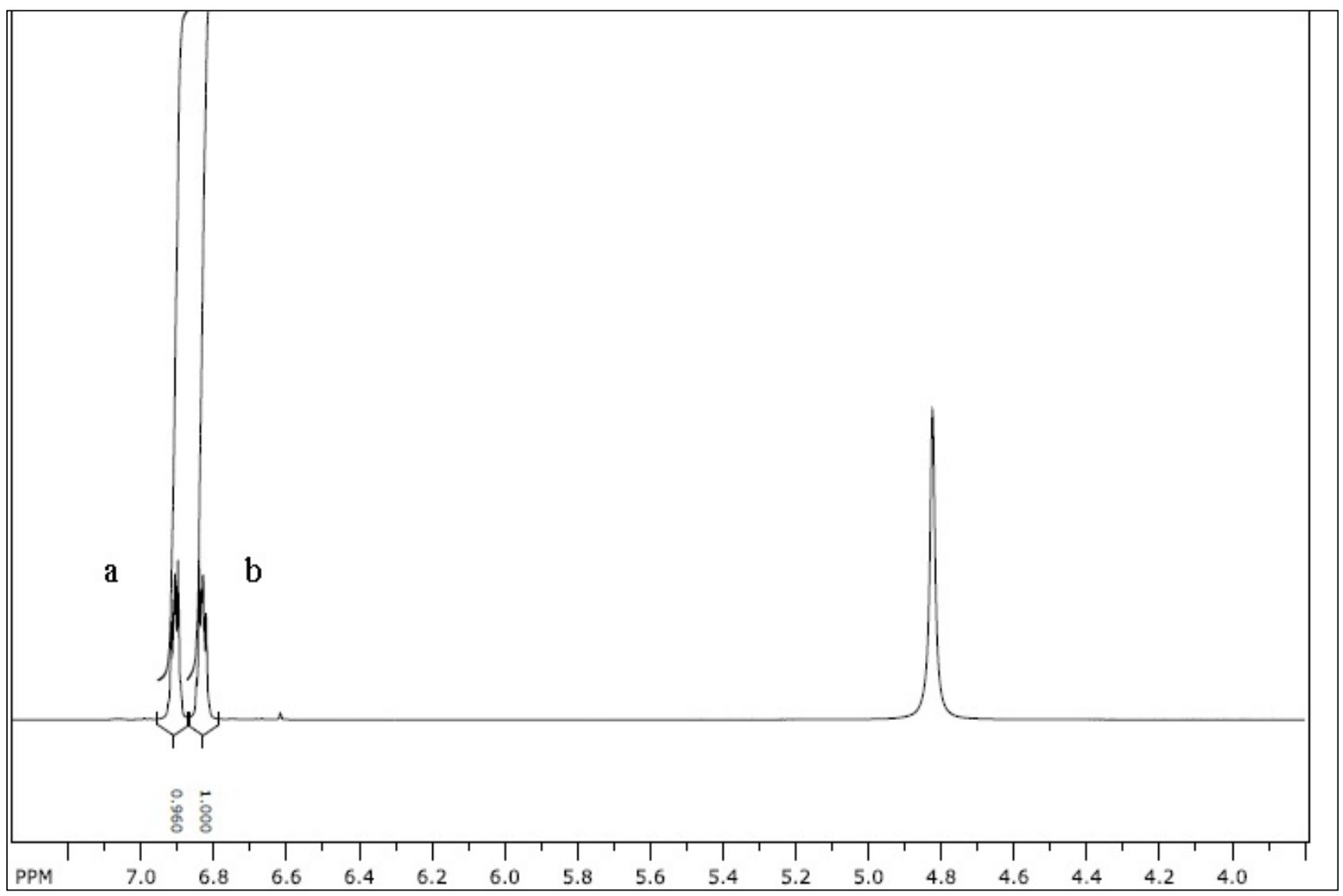

Fonte: Autora

Conforme se pode verificar nos espectros de ${ }^{1} \mathrm{H}$ RMN, os complexos apresentam alguns sinais com grande deslocamento quando comparados aos dos respectivos ligantes livres, mas foram atribuídos por comparação com os espectros destes. Para facilitar a discussão e a visualização da atribuição dos sinais, os deslocamentos químicos são mostrados na tabela a seguir (tabela 11): 
Tabela 11: Tentativa de atribuição dos deslocamentos químicos de ${ }^{1} \mathrm{H}$ RMN dos complexos

\begin{tabular}{|c|c|c|c|c|c|c|c|c|}
\hline \multicolumn{9}{|c|}{ Atribuição ${ }^{1}$ H NMR $\delta(\mathbf{p p m})$} \\
\hline & $\mathbf{H}_{\alpha}{ }^{\prime}$ & $\mathbf{H}_{\alpha}{ }^{\prime \prime}$ & $\mathbf{H}_{\boldsymbol{\beta}}$ & $\mathbf{H}_{\mathrm{a}}$ & $\mathbf{H}_{\mathrm{b}}$ & $\mathbf{H}_{\mathbf{c}}$ & $\mathbf{H}^{*}$ & $\mathbf{H}^{* *}$ \\
\hline$\left[\mathrm{Ru}\left(\mathrm{NH}_{3}\right)_{4}(\text { iso })\right]^{+}$ & 3,3 & 3,1 & 4,8 & $-5,8$ & 13,5 & $-4,8$ & 3,4 & $1,3(6 \mathrm{H})$ \\
\hline isoproterenol & \multicolumn{2}{|c|}{$3,22(2 \mathrm{H})$} & 4,88 & 6,93 & 6,85 & 6,93 & 3,48 & $1,3(6 \mathrm{H})$ \\
\hline$\left[\mathrm{Ru}\left(\mathrm{NH}_{3}\right)_{4}(\text { adre })\right]^{+}$ & 3,4 & 3,15 & 4,8 & $-5,96$ & 13,9 & $-4,89$ & & $2,7(3 H)$ \\
\hline adrenalina & \multicolumn{2}{|c|}{$3,2(2 \mathrm{H})$} & 4,85 & 6,84 & 6,77 & 6,84 & & $2,7(3 \mathrm{H})$ \\
\hline$\left[\mathbf{R u}\left(\mathrm{NH}_{3}\right)_{4}(\mathrm{nor})\right]^{+}$ & 3,5 & $\mathbf{3 , 3}$ & 4,8 & $-5,6$ & 13,9 & $-4,6$ & & \\
\hline noradrenalina & \multicolumn{2}{|c|}{$3,2(2 \mathrm{H})$} & 4,87 & 6,93 & 6,85 & 6,93 & & \\
\hline$\left[\mathrm{Ru}\left(\mathrm{NH}_{3}\right)_{4}(\mathrm{dop})\right]^{+}$ & & 1,6 & $2,8(2 \mathrm{H})$ & $-6,36$ & 17 & $-2,84$ & & \\
\hline dopamina & \multicolumn{2}{|c|}{$2,79(2 \mathrm{H})$} & $3,14(2 H)$ & 6,8 & 6,66 & 6,8 & & \\
\hline catecol & \multicolumn{8}{|c|}{$6,9(2 \mathrm{H}) \quad 6,8(2 \mathrm{H})$} \\
\hline
\end{tabular}

Fonte: Autora

Um espectro de uma espécie paramagnética é facilmente reconhecido porque a maioria dos sinais de ${ }^{1} \mathrm{H}$, para espécies diamagnéticas, aparece em uma faixa comum de 0 a 12 ppm e, os sinais afetados pelo campo paramagnético são observados deslocados para cima ou para baixo desta faixa. De um modo geral, os ${ }^{1} \mathrm{H}$ dos anéis aromáticos apresentaram deslocamentos químicos bastante alterados em relação aos apresentados pelos respectivos ligantes livres, devido ao efeito de anisotropia paramagnética induzido pelo átomo de rutênio paramagnético $\mathrm{Ru}(\mathrm{III})$ (d5). Não obstante este grande deslocamento para regiões de baixo campo magnético, foi possível obter boas integrações, incluindo aquelas referentes aos hidrogênios aromáticos. Os outros átomos de hidrogênio presentes no complexo sofreram pouca ou nenhuma alteração nos valores de deslocamento químico, em relação ao ligante livre. Além disto, os hidrogênios aromáticos apresentaram sinais alargados, nos espectros de RMN de todos os complexos analisados.

Neste sentido, os valores observados nos espectros dos complexos, comparados com os das respectivas catecolaminas livres, demonstraram que os hidrogênios alifáticos dos grupamentos metila (presente em isoproterenol e adrenalina), não apresentaram quaisquer alterações nos seus deslocamentos químicos relacionados às catecolaminas livres. Da mesma forma, $\mathrm{H}^{*}$ presente apenas no isoproterenol, apresentou deslocamento pequeno (para campo alto) quando comparado ao ligante livre.

Para os hidrogênios $\mathrm{H}_{\alpha}$, e $\mathrm{H}_{\alpha}$, os quais apareciam com deslocamentos químicos semelhantes nos espectros das catecolaminas livres, após a coordenação com o metal, observou-se que ambos não possuem mais o mesmo ambiente químico, possuindo, portanto, 
em todos os complexos, diferentes valores de deslocamentos químicos, com $\mathrm{H}_{\alpha}$ mais desblindado que $\mathrm{H}_{\alpha}$,

Para os hidrogênios $\mathrm{H}_{\beta}$, evidenciou-se efeito de blindagem, para todos os complexos, em relação aos respectivos ligantes livres - efeito este pequeno, menor que 0,5 ppm, porém regular em toda a série de complexos. Importante destacar que este sinal está encoberto pelo sinal de $\mathrm{H}_{2} \mathrm{O}$, em diversos espectros - razão pela qual não foi integrado.

Em relação aos hidrogênios do anel aromático, deslocamentos químicos bastante diversos daqueles encontrados para os ligantes livres foram observados, pois para todas as catecolaminas livres, os sinais de hidrogênios aromáticos aparecem entre 6,7 e 6,9 ppm, o que em comparação com os prótons de benzeno $(\delta=7,27 \mathrm{ppm})$ é um pequeno deslocamento para campo alto (LAMBERT et. al., 1975). Além disso, em todos os ligantes livres, os hidrogênios aromáticos ${ }^{1} \mathrm{H}_{\mathrm{a}}$ e ${ }^{1} \mathrm{H}_{\mathrm{c}}$ possuem semelhantes valores deslocamentos químicos. Após a coordenação ao íon metálico, o ambiente químico destes hidrogênios não é mais equivalente, resultando, portanto no desdobramento desses sinais. Nos espectros dos complexos de isoproterenol, noradrenalina e adrenalina, tanto ${ }^{1} \mathrm{H}_{\mathrm{a}}$ quanto ${ }^{1} \mathrm{H}_{\mathrm{c}}$ encontram-se deslocados para regiões de alto campo, existindo entre ambos diferença de aproximadamente $1 \mathrm{ppm}$, com ${ }^{1} \mathrm{H}_{\mathrm{a}}$ mais blindado que ${ }^{1} \mathrm{H}_{\mathrm{c}}$. Para o complexo de dopamina, embora se observe os sinais referentes aos dois hidrogênios deslocados para região de campo mais alto, a diferença entre ambos é maior que $3 \mathrm{ppm}$, sendo ${ }^{1} \mathrm{H}_{\mathrm{a}}$ mais blindado que para os demais complexos (- 6,36 ppm), enquanto ${ }^{1} \mathrm{H}_{\mathrm{c}}$ é menos blindado, comparado aos demais complexos da série.

Para o hidrogênio ${ }^{1} \mathrm{H}_{\mathrm{b}}$, observou-se efeito de desblindagem, em todos os complexos. Porém este efeito é maior para o complexo de dopamina, no qual este sinal aparece em 17 ppm, enquanto para os demais complexos, entre 13 e 14 ppm.

O comportamento espectral observado na técnica de ressonância magnética ocorreu devido ao efeito de anisotropia paramagnética de $\mathrm{Ru}(\mathrm{III})$ (d5), porém independentemente deste efeito, foi possível obter boas intensidades de integração, embora os hidrogênios aromáticos apresentassem sinais largos, para todos os complexos - o que também é característico de sistemas paramagnéticos, em razão da relaxação mais célere, ocorrida em razão da perturbação ocastionada pelo elétron desemparelhado (BERTINI; LUCHINAT, 1996). Lambert (et. al., 1975) propôs que a eletronegatividade do grupo hidroxila, na estrutura do catecol, influenciou os espectros de RMN para as catecolaminas livres, uma vez que sua ação repulsiva influencia os elétrons $\pi$ e promove os deslocamentos químicos para campo mais alto - em relação ao benzeno. Neste trabalho observou-se o mesmo 
comportamento, mas na estabilização do elétron desemparelhado, uma vez que somente $\mathrm{H}_{\mathrm{b}}$ apresentou deslocamento químico em direção a campo baixo.

Os compostos paramagnéticos perturbam os resultados esperados em análises de RMN. Isso ocorre porque os elétrons relaxam mais rapidamente que os núcleos e, consequentemente, os núcleos experimentam, em cada um dos seus níveis de energia $\mathrm{M}_{1}$, as mudanças de orientação dos elétrons entre seus níveis $\mathbf{M}_{\mathrm{s}}$. Os núcleos sentem, portanto, a média do momento magnético dos elétrons. Este momento magnético médio seria equivalente a zero se as populações dos níveis $\mathrm{M}_{\mathrm{s}}$ fossem iguais. Em havendo um elétron desemparelhado, um valor diferente de zero de momento magnético médio é sentido pelos núcleos e, este valor é proporcional à densidade de spin $(\rho)$, a qual, para um único elétron é resultante do quadrado da sua função de onda naquele ponto (BERTINI; LUCHINAT, 1996).

Este campo pode adicionar-se ou subtrair-se ao campo magnético gerado pelo ímã do equipamento (campo magnético externo), o que resulta em deslocamentos das linhas do espectro para regiões de campo mais alto ou mais baixo - dependendo da posição do núcleo analisado em relação ao átomo paramagnético, resultando em efeitos opostos (blindagem/desblindagem) para átomos em posições vizinhas, o que, de fato, foi observado para os hidrogênios aromáticos. Como o momento magnético do elétron é 658 vezes maior do que o momento magnético do núcleo de hidrogênio (e este tem o maior momento magnético dos núcleos, exceto do trítio), as mudanças das linhas espectrais são grandes (BERTINI; LUCHINAT, 1996; BERTINI; DRAGO, 1980; CACITA et. al., 2015).

Além disso, um elétron desemparelhado tem a possibilidade de estar deslocalizado ao longo de todo o orbital molecular, de forma que em cada ponto do espaço onde o orbital molecular que agrega esse elétron desemparelhado tem valor diferente de zero, o momento magnético eletrônico médio percebido pelo núcleo será diferente de zero, além de ser proporcional a $\rho$, contribuindo para que sua influência seja nítida, não somente no centro paramagnético, mas podendo, também, promover deslocamento nas linhas espectrais (de RMN) de átomos não diretamente ligados ao centro paramagnético - o que corrobora as observações feitas nos espectros obtidos e analisados no presente trabalho (BERTINI; LUCHINAT, 1996).

A afirmação anterior é fundamentada, ainda, no fato de que o elétron desemparelhado promove alterações nos elétrons emparelhados, no sentido de promover sua polarização, pois entre dois elétrons emparelhados, aquele com spin alinhado com o elétron desemparelhado, terá preferência para ocupar regiões do orbital molecular próximas ao elétron desemparelhado, enquanto o elétron com spin antiparalelo ao elétron desemparelhado 
tenderá a ocupar locais, do orbital molecular, mais distantes do elétron desemparelhado (BERTINI; LUCHINAT, 1996). Este comportamento, descrito pela Regra de Hund, promove consideráveis alterações na densidade eletrônica da espécie, o que nos complexos estudados em relação aos ligantes livres - é visível em diversas propriedades eletroquímicas, eletrônicas e de ressonância magnética nuclear estudadas.

A interação núcleo-elétron é muito complexa e chamada de interação hiperfina e, o efeito observado (deslocamento hiperfino) em um espectro é resultante da densidade de spin e do efeito de campo externo. A diferença entre o deslocamento químico para um núcleo de uma espécie paramagnética e o mesmo núcleo em uma espécie análoga diamagnética é o deslocamento hiperfino (BERTINI; LUCHINAT, 1996). Existem dois mecanismos diferentes para essa interação ocorrer: o mecanismo de contato ou mecanismo de interação de contato de Fermi e a interação dipolar (de dois dipolos magnéticos) ou mecanismo de pseudocontato, que ocorre entre dois dipolos magnéticos, através do espaço. O pseudocontato se progaga por todos os átomos que possuem orbitais p- $\pi$ disponíveis. Este mecanismo, que se propaga por elétrons $\pi$ e cujo efeito é reduzido com a distância, pode promover deslocamentos químicos para valores inferiores e superiores - o que foi descrito por Bertini e Drago (1980) para porfirinas de $\mathrm{Fe}(\mathrm{III})$ - porque depende da orientação relativa entre o centro paramagnético e os outros núcleos, o que pode causar uma soma ou uma subtração no campo magnético externo detectado pelos núcleos. O acoplamento resulta também no relaxamento nuclear rápido, ocasionando nos sinais largos e no espalhamento dos mesmos no espectro (RASTRELLI; BAGNO, 2010) - o que foi também observado nestes espectros.

O mesmo parâmetro de deslocamento químico observado neste estudo, com os hidrogênios mais próximos ao íon metálico $\left(\mathrm{H}_{\mathrm{a}}\right.$ e $\left.\mathrm{H}_{\mathrm{c}}\right)$ sofrendo efeito de blindagem, enquanto para $\mathrm{H}_{\mathrm{b}}$ se observou efeito de desblindagem, devido à sua maior distância do centro paramagnético, foi observado por Anderson e Beauchamp (ANDERSON; BEAUCHAMP, 1995), nos hidrogênios do anel aromático de ligantes imidazol coordenado com Ru(III) (ALESSIO et. al., 1993).

Para o complexo $\left[\mathrm{Ru}\left(\mathrm{NH}_{3}\right)_{4}(\text { dopamina })\right]^{+}$, a integração dos sinais de hidrogênio do anel aromático foi parcialmente afetada, o que pode ocorrer em compostos paramagnéticos. Atribui-se que tal fato ocorreu devido à ausência do grupo - $\mathrm{OH}$ próximo aos hidrogênios aromáticos. Para o complexo $\left[\mathrm{Ru}\left(\mathrm{NH}_{3}\right)_{4}(\text { catecol })\right]^{+}$não foi possível atribuir os sinais, uma vez que a ausência dos substituintes no anel aromático provoca uma alteração maior (que dos demais complexos) nos valores de deslocamento químico dos seus 
hidrogênios - os quais quando no ligante livre são nitidamente encontrados em 6,8 (dois equivalentes) e 6,9 ppm (outros dois equivalentes).

Além disso, os desvios dos sinais do espectro de RMN estão relacionados com os dados eletroquímicos, uma vez que o complexo $\left[\mathrm{Ru}\left(\mathrm{NH}_{3}\right)_{4}(\text { dopamina })\right]^{+}$apresentou os maiores deslocamentos dos sinais, em relação ao ligante livre. Esse comportamento corrobora o menor valor para $E_{1 / 2}$ para o processo envolvendo o ligante $\left(A_{1} / A_{2}\right)$ deste complexo, uma vez que o menor potencial de oxidação demonstra que o elétron não emparelhado está mais disponível e tem menor estabilidade promovida pelo substituinte do anel aromático. A maior perturbação dos sinais observadas no espectro de RMN, para este complexo em relação aos demais, pode indicar, ainda, maior interação envolvendo os hidrogênios do anel aromático e o centro metálico (de onde provém o efeito paramagnético).

Para o complexo cujo ligante é o catecol, observou-se o efeito oposto na eletroquímica, pois possui o maior potencial de oxidação e consequente menor disponibilidade do elétron desemparelhado, portanto este elétron exibe maior influência no sinal de RMN, o que torna impossível atribuir os sinais. Assim, quanto mais deslocalizado sobre o ligante estiver o elétron desemparelhado, mais intenso o efeito paramagnético e, consequentemente, maior a perturbação observada no espectro de RMN.

Além do fato de que o efeito da coordenação ao íon metálico causa perturbação em vários sinais dos hidrogênios dos ligantes, e de que este efeito é mais intenso para os hidrogênios aromáticos - os quais estão diretamente ligados aos oxigênios coordenados ao rutênio, centro indutor do efeito paramagnético -, é evidente a diferença observada para os complexos dos ligantes isoproterenol, adrenalina e noradrenalina, quando comparados ao da dopamina. Acredita-se que esse comportamento seja completamente explicado pela influência da cadeia carbônica lateral, inclusive após a coordenação ao rutênio, pois a densidade eletrônica é modulada por estes substituintes, consistindo a diferença, entre a dopamina e os demais, o grupamento hidroxila no carbono $\beta$, o qual está presente nos outros três ligantes e ausente na dopamina, razão pela qual se acredita que este grupo (principalmente o oxigênio), sejam responsáveis por estabilizar, parcialmente, o efeito paramagnético.

Reafirmando essa hipótese, tem-se o comportamento do complexo metálico cujo ligante é o catecol, no qual o efeito ocasionado pelo elétron desemparelhado é tão intenso, que os sinais são deslocados para regiões de campo mais alto e/ou mais baixo que aquelas nas quais é possível a captação dos sinais pelo equipamento utilizado. Este efeito é resultante, ainda, da maior sobreposição dos orbitais do ligante dioxoleno com os do metal, o que 
culmina no enfraquecimento da ligação $\mathrm{Ru}-\mathrm{N}$ - visualizado no espectro de absorção na região do infravermelho (FTIR).

Observou-se, ainda, que para o complexo de dopamina ocorreram os maiores deslocamentos dos sinais dos hidrogênios denominados $\mathrm{H}_{\beta}$ e $\mathrm{H}_{\alpha}$, o que demonstra ser o efeito, neste complexo, propagado ao longo da cadeia carbônica, para regiões mais distantes do centro metálico, possivelmente devido ao mecanismo de pseudocontato.

Tais efeitos, juntos, indicam também maior interação entre os orbitais do ligante e do metal para os complexos de dopamina e de catecol, pois neles o efeito do íon paramagnético é maiormente propagado - resultados e hipótese que em nada destoam dos já observados nas outras técnicas de caracterização, nas quais foi possível evidenciar que estes complexos, não raramente, se desviaram das tendências seguidas para os demais, inclusive em relação às tendências de pKa.

No que concerne aos valores de deslocamentos químicos observados, optou-se por não os correlacionar com os valores de $\mathrm{pKa}$, em razão de o efeito promovido pela coordenação ao centro paramagnético ser consideravelmente maior que os efeitos observáveis em razão das diferentes substituições nas cadeias carbônicas laterais.

\subsubsection{Cálculos teóricos}

Conforme já amplamente discutido nos tópicos precedentes, acredita-se que em se tratando de complexos de rutênio com ligantes catecólicos, haja uma mistura orbital maior que a observada para complexos com outros metais, indicando que o elétron desemparelho esteja deslocalizado, não estando restrito aos orbitais do metal. Assim, com a finalidade de melhor compreensão da deslocalização eletrônica observada nos complexos estudados, bem como uma correta concepção da hipótese abordada nos experimentos de RMN dos complexos paramagnéticos, foram realizados cálculos teóricos.

Destes, se pôde concluir que todos os complexos são octaédricos, possuindo parâmetros geométricos muito semelhantes. As distâncias de ligação obtidas são mostradas na tabela (12) a seguir, e demonstram que a distância média $\mathrm{Ru}-\mathrm{NH}_{3}(2,16 \AA)$ para o ligante trans ao ligante catecólico é 0,02 ̊̊ mais longa do que para as outras ligações $\mathrm{Ru}-\mathrm{NH}_{3}$, para todos os complexos: 
Tabela 12: Parâmetros geométricos selecionados para os complexos $\left[\mathrm{Ru}\left(\mathrm{NH}_{3}\right)_{4}(\mathrm{~L})\right]^{+}$obtidos por PBE0/def2-TZVP

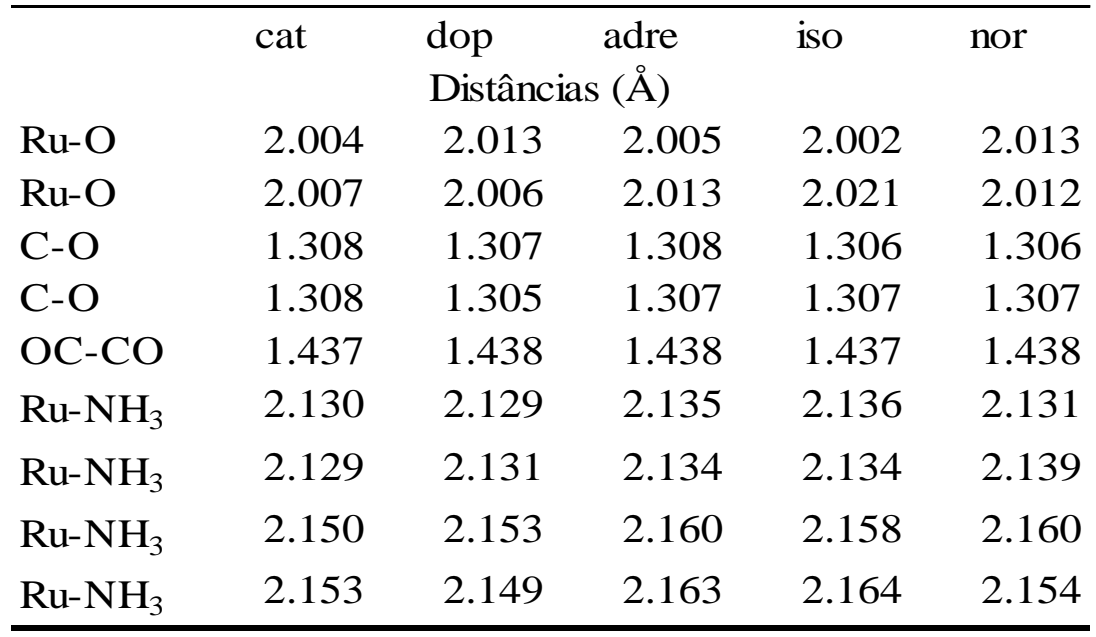

Fonte: Autora

O ligante orgânico é plano, para todos os complexos, com distâncias Ru-O muito similares para toda a série estudada. As coordenadas cartesianas com as geometrias de equilíbrio são apresentadas em tabelas que seguem no apêndice do trabalho (tabelas 28 a 32).

Os orbitais de fronteira Kohn-Sham foram calculados e mostraram-se deslocalizados sobre o ligante, com uma contribuição do orbital $\mathrm{Ru} 4 \mathrm{~d}_{\mathrm{xz}}$, como pode ser visto na figura a seguir, onde os orbitais alfa-HOMO (SOMO) e beta-LUMO são plotados para todos os complexos (figura 52).

Os orbitais alfa e beta com as maiores contribuições dos orbitais $4 \mathrm{~d}$ do metal no complexo $\left[\mathrm{Ru}\left(\mathrm{NH}_{3}\right)_{4}(\text { catecol })\right]^{+}$foram plotados e seguem representados em figura anexa no apêndice (135), mostrando três pares de orbitais ocupados singularmente, correspondendo aos orbitais $\mathrm{t}_{2 \mathrm{~g}}$ (em simetria $\mathrm{O}_{\mathrm{h}}$ ). Orbitais muito semelhantes para todos os outros complexos foram encontrados e os coeficientes MO de Kohn-Sham podem ser encontrados nas tabelas (33 a 37) que seguem no apêndice.

Corroborando as afirmações anteriores, no sentido de intensa deslocalização eletrônica do elétron desemparelhado, o tipo de números de ocupação dos orbitais demonstra, inclusive, ser possível descrever o sistema (também) com um estado de oxidação Ru(II) $4 d^{6}$ associado a um ânion radical como ligante, com o elétron desemparelhado deslocalizado sobre o sistema Ru-L $\pi$, no vácuo e nas condições de contorno que envolvem o cálculo. No mesmo sentido, a análise da densidade de spin obtida pela análise populacional de Mullikan, revelou que o elétron desemparelhado pode estar localizado sobre o ligante catecólico, nos orbitais próximos ao metal. As isosuperfícies que representam as densidades de spin são 
mostradas na figura 53 e podem ser comparadas com os orbitais de fronteira correspondentes ao alfa-HOMO confirmando que este orbital corresponde ao orbital molecular ocupado por apenas um elétron (SOMO). 
Figura 52: Representação dos orbitais de fronteira Kohn-Sham $\alpha$-HOMO (SOMO) e $\beta$-LUMO obtidos por PBE0/def2-TZVP para os complexos $\left[\mathrm{Ru}\left(\mathrm{NH}_{3}\right)_{4}(\mathrm{~L})\right]^{+}$, onde $\mathrm{L}=$ catecol (A), dopamina (B), adrenalina $(C)$, noradrenalina $(D)$, e isoproterenol (E)

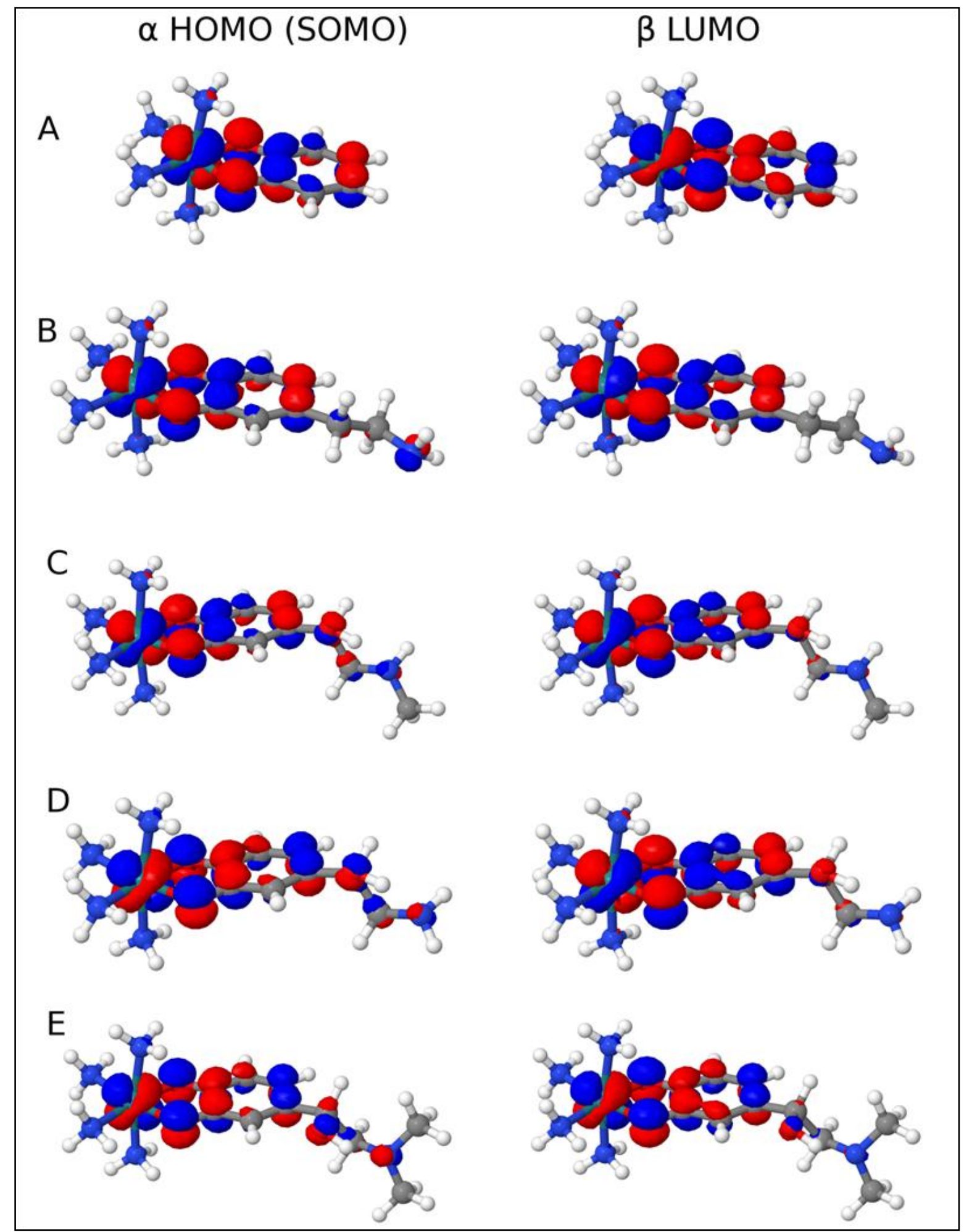

Fonte: Autora 
Figura 53: Densidades de spin obtidas por PBE0/def2-TZVP para os complexos [Ru(NH3)4(L)]+ onde L = catecol (A), dopamina (B), adrenalina (C), noradrenalina (D), e isoproterenol (E)

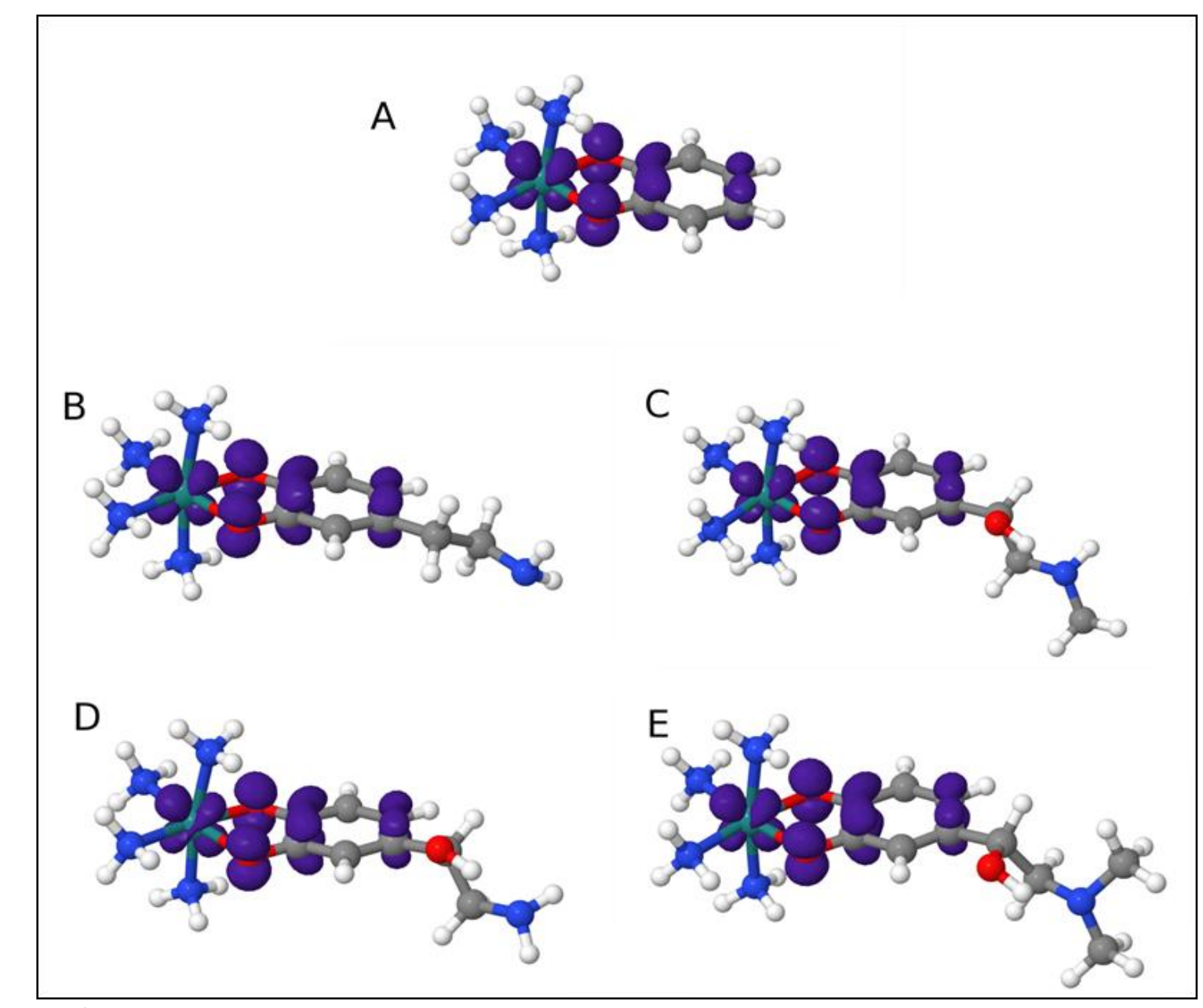

Fonte: Autora

Importante ressaltar, neste ponto, que a distribuição da densidade de spin sobre o ligante explica os deslocamentos químicos de $\mathrm{RMN}$ observados, nos quais os hidrogênios $\mathrm{H}_{\mathrm{a}}$ e $\mathrm{H}_{\mathrm{c}}$ são altamente blindados, uma vez que estão próximos da densidade eletrônica de spin. Esta densidade não se aproxima o suficiente o hidrogênio denominado $\mathrm{H}_{\mathrm{b}}$, o qual não sofre efeito de blindagem após a coordenação ao íon metálico - fato também observado experimentalmente, nos espectros de RMN.

Os cálculos TD-DFT foram utilizados para simular os espectros de absorção UVVis e os resultados concordam muito bem com os dados experimentais, sendo a seguir representado o espectro para o complexo cujo ligante é adrenalina (figura 54), enquanto os demais seguem no apêndice (figuras 136 a 139): 
Figura 54: Espectros experimental e simulado para o complexo $\left[\mathrm{Ru}\left(\mathrm{NH}_{3}\right)_{4}(\operatorname{adrenalina})\right]^{+}$

Fonte: Autora

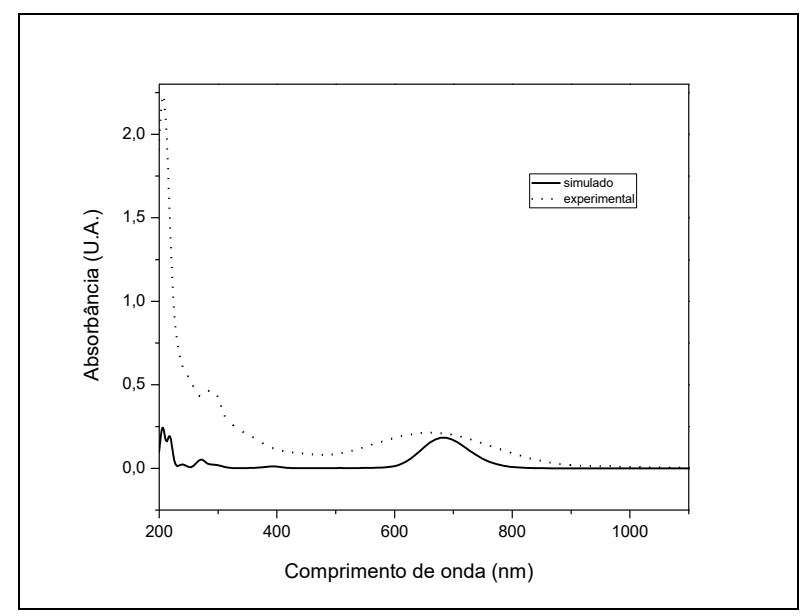

Juntos, os resultados permitem evidenciar que há intensa sobreposição orbital entre o metal e os ligantes catecólicos, demonstrando que o elétron desemparelhado, proveniente do metal, devido à esta intensa sobreposição, pode se localizar não somente no metal, mas também, no ligante - o que dificulta a atribuição de carga nos complexos, os quais concordam ora com a descrição $\mathrm{Ru}(\mathrm{III})$-cat, ora com $\mathrm{Ru}(\mathrm{II})$-sq, levando à conclusão de que em solução possa haver um equilíbrio, coexistindo as duas espécies.

\subsubsection{Espectrometria de massas}

Em relação à caracterização química, foram realizados, ainda, experimentos de espectrometria de massas para os complexos metálicos estudados. Os íons dos complexos foram observados em todos os espectros de massas, com erros menores que 8 ppm em relação às massas teóricas, demonstrando que as fórmulas propostas, para todos os complexos, estão corretas.

Os espectros de massas dos complexos são mostrados a seguir (figuras 55 a 59): 
Figura 55: Espectro de massas de $\left[\mathrm{Ru}\left(\mathrm{NH}_{3}\right)_{4}(\text { isoproterenol })\right]^{+}$; modo positivo (ESI-MS); íon do complexo $m / z 379.11$

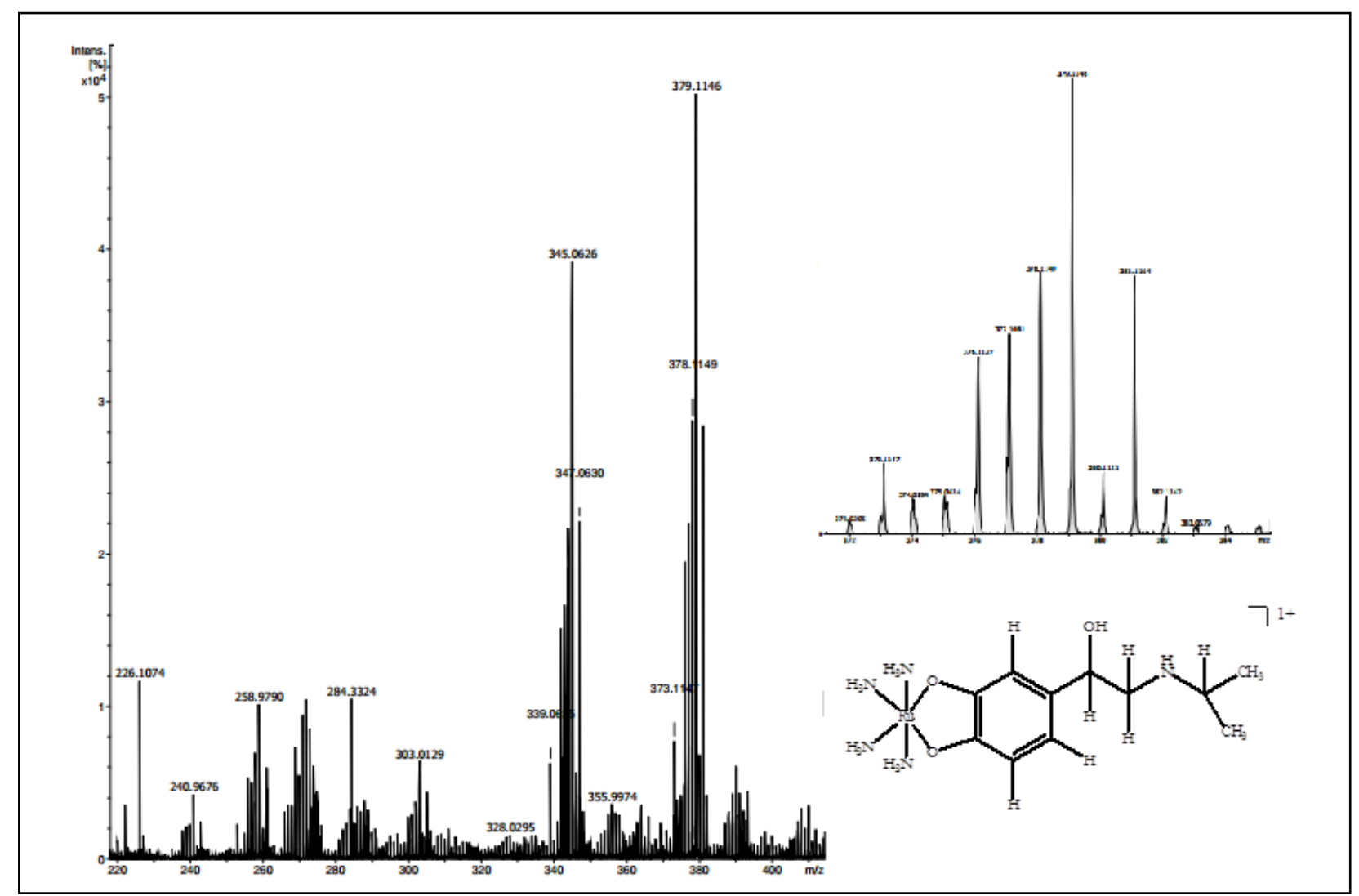

Fonte: Autora 
Figura 56: Espectro de massas de $\left[\mathrm{Ru}\left(\mathrm{NH}_{3}\right)_{4}(\text { dopamina })\right]^{+}$; modo positivo (ESI-MS); íon do complexo $\mathrm{m} / \mathrm{z}$ 321.07

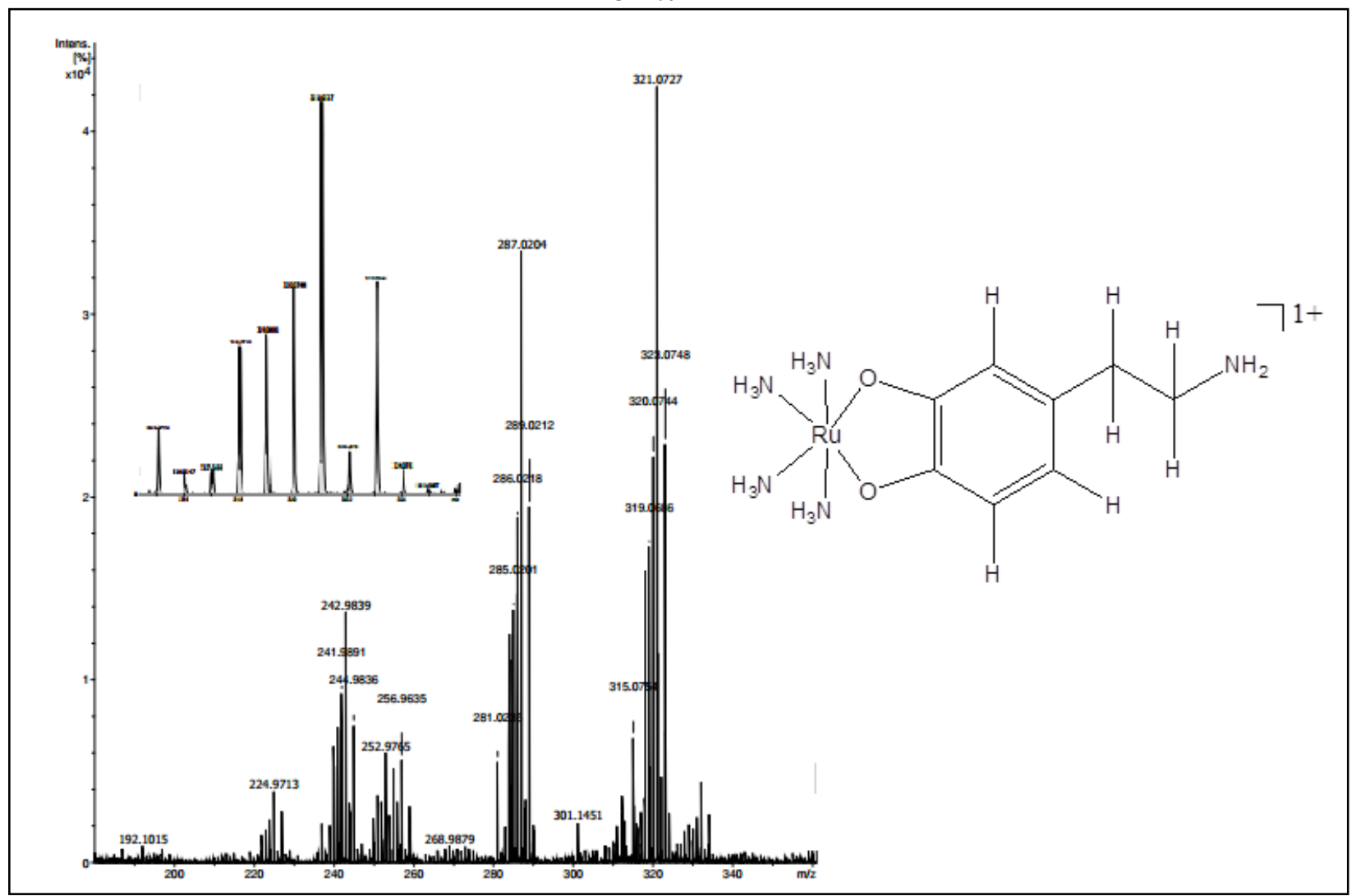

Fonte: Autora 
Figura 57: Espectro de massas de $\left[\mathrm{Ru}\left(\mathrm{NH}_{3}\right)_{4}(\text { noradrenalina) }]^{+}\right.$; modo positivo (ESI-MS); íon do complexo $m / z 337.07$

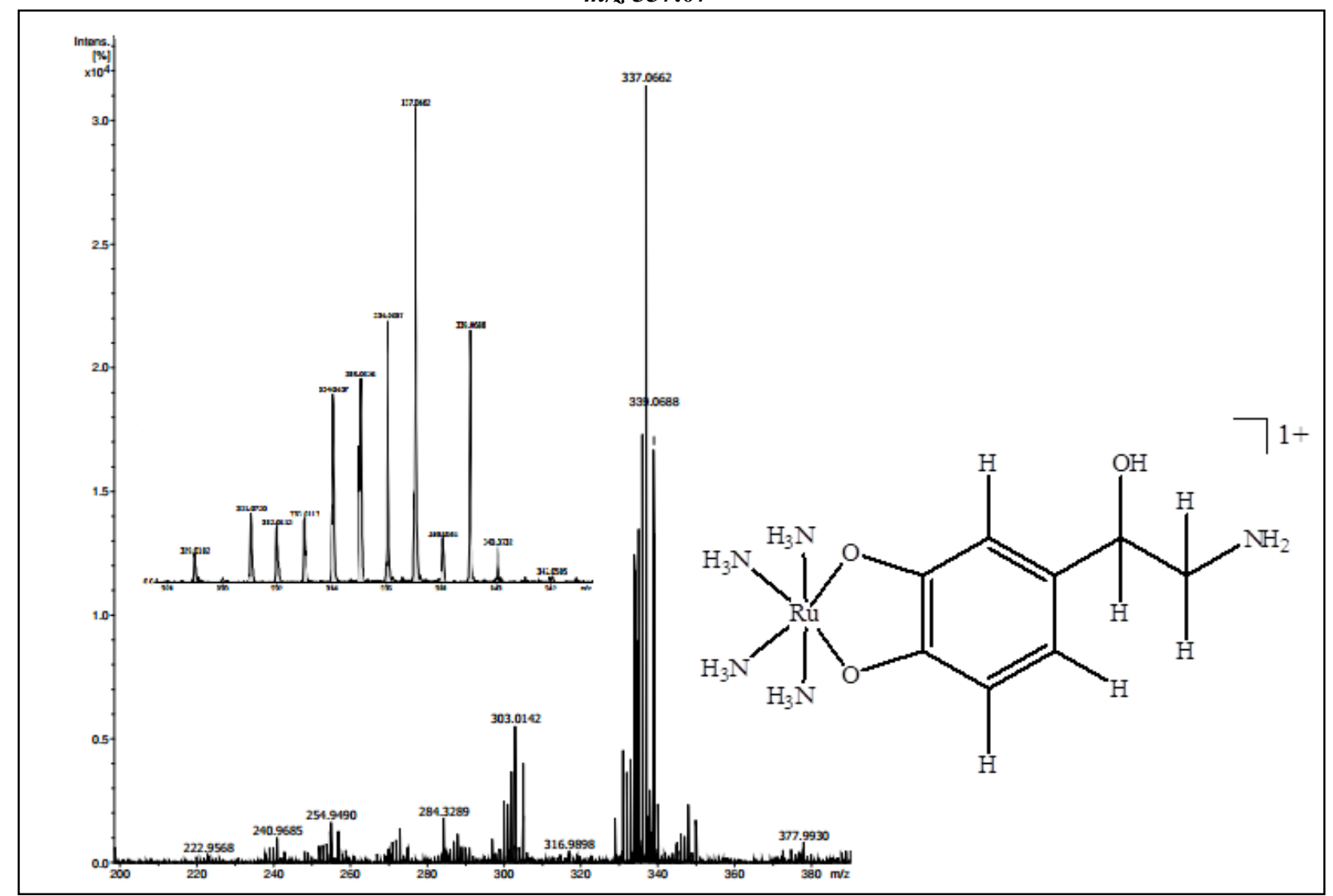

Fonte: Autora 
Figura 58: Espectro de massas de $\left[\mathrm{Ru}\left(\mathrm{NH}_{3}\right)_{4}(\text { catecol) }]^{+}\right.$; modo positivo (ESI-MS); íon do complexo $\mathrm{m} / \mathrm{z}$ 278.03

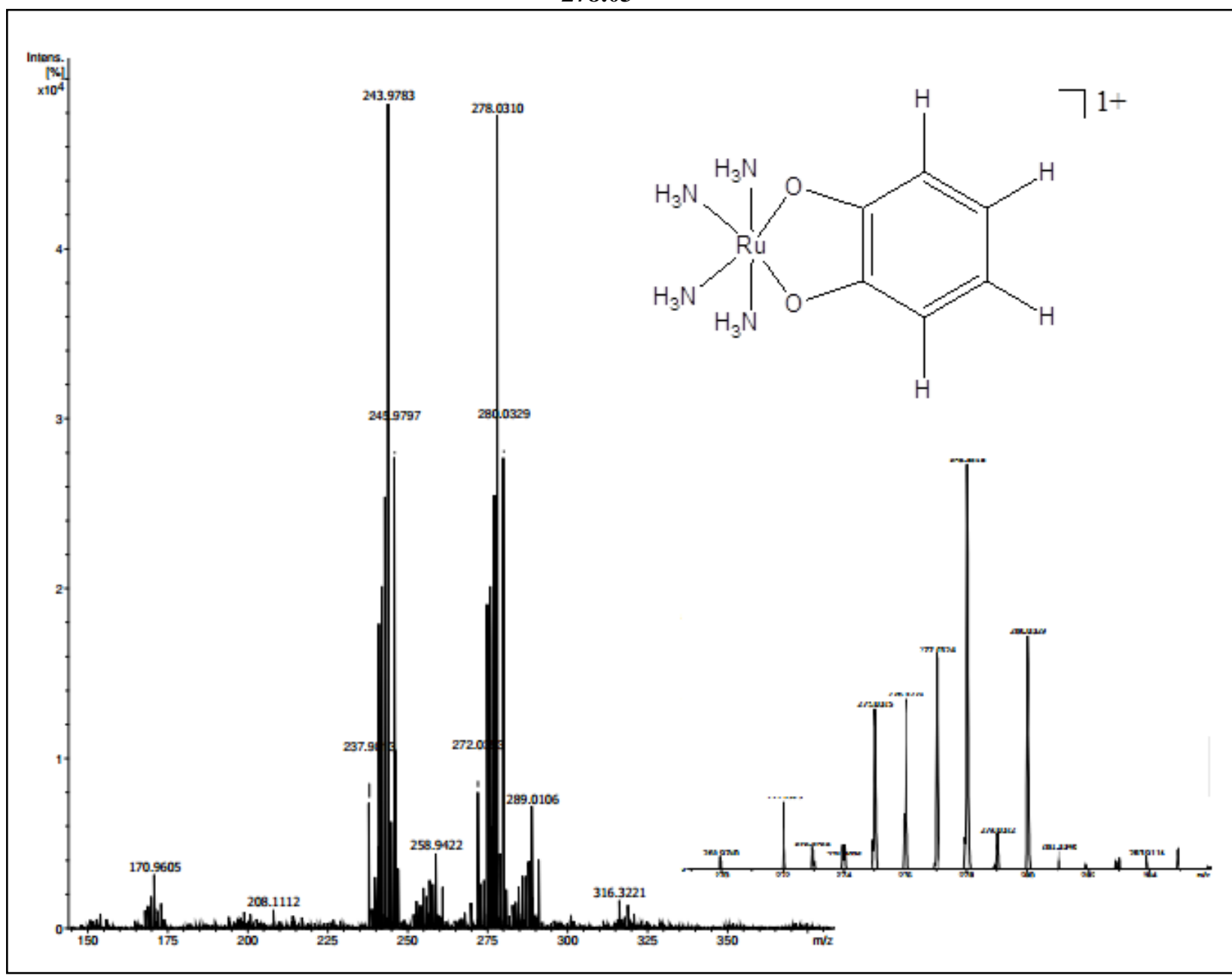

Fonte: Autora 
Figura 59: Espectro de massas de $\left[\mathrm{Ru}\left(\mathrm{NH}_{3}\right)_{4}(\text { adrenalina) }]^{+}\right.$; modo positivo (ESI-MS); íon do complexo $\mathrm{m} / \mathrm{z}$ 351.08

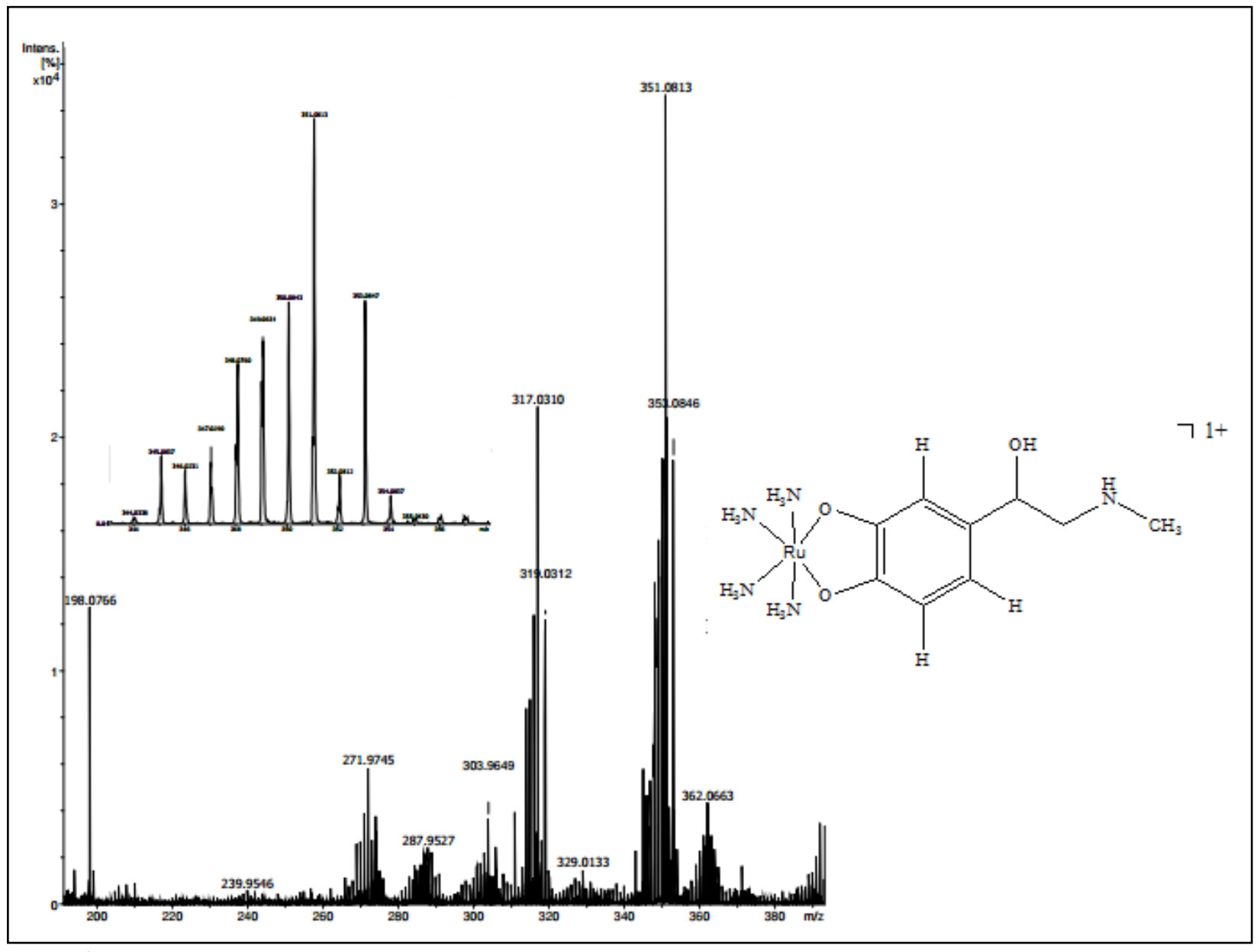

Fonte: Autora

Os valores teóricos foram comparados com os experimentalmente obtidos e são mostrados na tabela a seguir (tabela 13):

Tabela 13: Valores teóricos e experimentais de $m / z$ dos íons dos complexos e seus respectivos erros

\begin{tabular}{cccc}
\hline \multicolumn{4}{c}{ Íons dos complexos $(\mathrm{m} / z)$} \\
\hline & teórico & experimental & erro $(\mathrm{ppm})$ \\
\hline$\left[\mathrm{Ru}\left(\mathrm{NH}_{3}\right)_{4}(\text { isoproterenol })\right]^{+}$ & 379.115190 & 379.1146 & 1.32 \\
{$\left[\mathrm{Ru}\left(\mathrm{NH}_{3}\right)_{4}(\text { adrenalina })\right]^{+}$} & 351.083890 & 351.0813 & 7.41 \\
{$\left[\mathrm{Ru}\left(\mathrm{NH}_{3}\right)_{4}(\text { noradrenalina })\right]^{+}$} & 337.068240 & 337.0662 & 5.93 \\
{$\left[\mathrm{Ru}\left(\mathrm{NH}_{3}\right)_{4}(\text { catecol })\right]^{+}$} & 278.031126 & 278.0310 & 0.36 \\
{$\left[\mathrm{Ru}\left(\mathrm{NH}_{3}\right)_{4}(\text { dopamina })\right]^{+}$} & 321.073326 & 321.0727 & 1.87 \\
\hline
\end{tabular}

Fonte: Autora

Devido à facilidade de fragmentação que as ligações coordenativas possuem, nas situações providenciadas nos experimentos de espectrometria de massas com ionização por 
eletrospray (ESI), fragmentos aparecem nos espectros, no entanto, estes são resultantes de íons-fragmentos advindos dos próprios íons dos complexos.

Os íons-fragmento mais importantes - das primeiras fragmentações - são mostrados na tabela a seguir:

Tabela 14: Tentativa de atribuição de $m / z$ dos íons-fragmento dos complexos

\begin{tabular}{|c|c|c|}
\hline \multicolumn{3}{|c|}{ Atribuições Espectrometria de Massas } \\
\hline \multirow{5}{*}{$\mathrm{Ru}\left(\mathrm{NH}_{3}\right)_{4}(\text { is oproterenol) }]^{+}$} & $m / z$ & íon fragmento \\
\hline & 345.0626 & {$\left[\mathrm{Ru}\left(\mathrm{NH}_{3}\right)_{2}\left(\mathrm{C}_{11} \mathrm{O}_{3} \mathrm{H}_{15} \mathrm{~N}\right)\right]^{+}$} \\
\hline & 303.0129 & {$\left[\mathrm{Ru}\left(\mathrm{NH}_{3}\right)_{2}\left(\mathrm{C} 8 \mathrm{O}_{3} \mathrm{H} 7\right)\right]^{+}$} \\
\hline & 284.3324 & \\
\hline & 258.9790 & \\
\hline \multirow[t]{2}{*}[\mathrm{Ru}(\mathrm{NH}_{3})_{4}(\text{adrenalina})]{$^{+}$} & 317.0311 & {$\left[\mathrm{Ru}\left(\mathrm{NH}_{3}\right)_{2}\left(\mathrm{C}_{9} \mathrm{O}_{3} \mathrm{H}_{11} \mathrm{~N}\right)\right]^{+}$} \\
\hline & 271.9745 & \\
\hline \multirow[t]{3}{*}[\mathrm{Ru}(\mathrm{NH}_{3})_{4}(\text{noradrenalina})]{$^{+}$} & 303.0142 & {$\left[\mathrm{Ru}\left(\mathrm{NH}_{3}\right)_{2}\left(\mathrm{C}_{8} \mathrm{O}_{3} \mathrm{H}_{9} \mathrm{~N}\right)\right]^{+}$} \\
\hline & 284.3289 & \\
\hline & 254.9490 & \\
\hline \multirow[t]{2}{*}[\mathrm{Ru}(\mathrm{NH}_{3})_{4}(\mathrm{catecol})]{$^{+}$} & 243.9783 & {$\left[\mathrm{Ru}\left(\mathrm{NH}_{3}\right)_{2}\left(\mathrm{C}_{6} \mathrm{O}_{2} \mathrm{H}_{4}\right)\right]^{+}$} \\
\hline & 287.0204 & {$\left[\mathrm{Ru}\left(\mathrm{NH}_{3}\right)_{2}\left(\mathrm{C}_{8} \mathrm{O}_{2} \mathrm{H}_{9} \mathrm{~N}\right)\right]^{+}$} \\
\hline \multirow[t]{2}{*}[\mathrm{Ru}(\mathrm{NH}_{3})_{4}(\text{dopamina})]{$^{+}$} & 256.9635 & {$\left[\mathrm{Ru}\left(\mathrm{NH}_{3}\right)_{2}\left(\mathrm{C}_{7} \mathrm{O}_{2} \mathrm{H}_{5}\right)\right]^{+}$} \\
\hline & 242.9839 & {$\left[\mathrm{Ru}\left(\mathrm{NH}_{3}\right)_{2}\left(\mathrm{C}_{6} \mathrm{O}_{2} \mathrm{H}_{3}\right)\right]^{+}$} \\
\hline
\end{tabular}

Fonte: Autora

O padrão isotópico do rutênio está presente em todos os íons dos complexos, bem como nos íons-fragmento, o que demonstra que estes são originários daqueles. Além disto, os complexos possuem padrão de fragmentação similar, envolvendo, principalmente, a perda neutra de dois ligantes $\mathrm{NH}_{3}$ e alguns fragmentos da cadeia carbônica.

\subsubsection{Reatividade vascular}

Como mencionado na introdução deste trabalho, as catecolaminas livres são agonistas de receptores $\alpha$ e $\beta$ adrenérgicos, bem como de dopaminérgicos (dopamina), tendo diferentes ordens de potências nestas interações (RANG et. al., 2016). A fim de verificar qual 
a modificação promovida pela coordenação ao rutênio, com tais receptores, foi realizado o ensaio de reatividade vascular, em aorta torácica isolada de ratos.

Em veias e artérias são encontradas tanto células endoteliais, quanto de músculo liso (MONTANARI, 2016), razão pela qual os ensaios, que produziram curvas concentraçãoefeito cumulativas, foram conduzidos tanto na presença do endotélio vascular (E+), quanto na ausência (E-) - nestes foi removida a túnica interna. Para o ensaio aqui descrito, foram utilizadas artérias aortas.

Para os ligantes noradrenalina, adrenalina, dopamina e catecol e seus respectivos complexos metálicos, bem como para o complexo de rutênio utilizado como precursor nas sínteses destes, as curvas consistiram em concentração-efeito cumulativas para avaliar o efeito vasoconstritor.

Para o ligante isoproterenol e seu respectivo complexo de rutênio foram realizadas curvas concentração-efeito cumulativas para avaliar o efeito vasodilatador. Para viabilizar o efeito, foi necessário promover a contração prévia induzida por Fenilefrina $\left(0,1 \mu \mathrm{mol} \mathrm{L}{ }^{-1}\right)$.

A seguir são mostrados os gráficos de concentração-efeito das interações dos complexos e dos ligantes dioxolenos livres com os receptores presentes em anéis de aortas (figuras 60 a 64). 
Figura 60: Efeito vasoconstritor induzido pelo complexo $\left[\mathrm{Ru}\left(\mathrm{NH}_{3}\right)_{4}(\text { noradrenalina })\right]^{+}(\mathrm{Ru}-\mathrm{NA})$ ou pelo ligante livre noradrenalina (NA) em aorta de ratos. Contração vascular induzida pelo complexo Ru-NA ou NA em presença $(E+)$ ou ausência (E-) de endotélio vascular (A). Análise da área sob a curva de Ru-NA ou NA, em unidades arbitrárias (B). Dados são apresentados como média \pm E.P.M. * diferente de Ru-NA E+; \# diferente de NA E+. One-way ANOVA, pós-teste de Newman-Keuls $(P<0,05)$, n=4-6

(A)
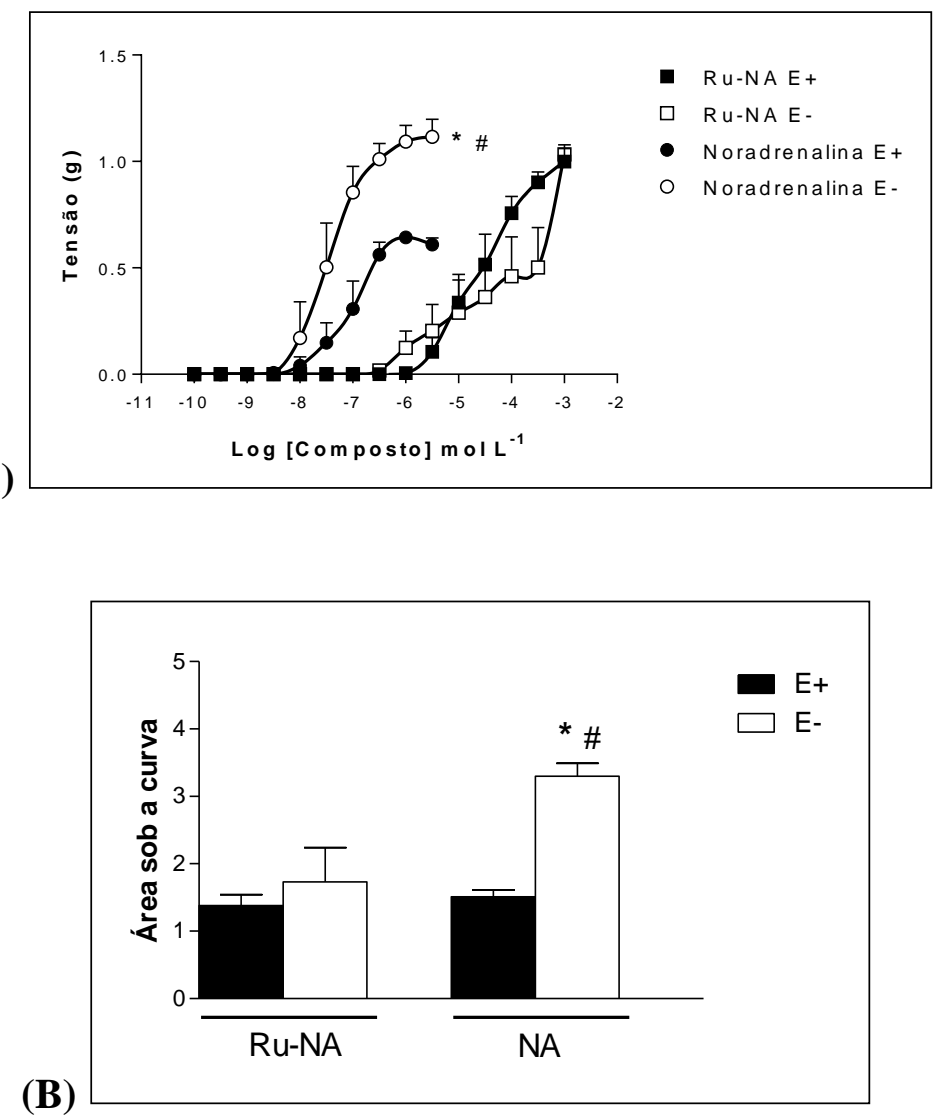

Fonte: Autora 
Figura 61: Efeito vasoconstritor induzido pelo complexo $\left[\mathrm{Ru}\left(\mathrm{NH}_{3}\right)_{4}(\operatorname{adrenalina})\right]^{+}(\mathrm{Ru}-\mathrm{Adr})$ ou ligante livre adrenalina (Adr) em aorta de ratos. Contração vascular induzida pelo complexo Ru-Adr ou Adr em presença (E+) ou ausência (E-) de endotélio vascular (A). Análise da área sob a curva de Ru-Adr ou Adr, em unidades arbitrárias (B). Dados são apresentados como média \pm E.P.M. * diferente de Ru-Adr E+; \# diferente de Adr E+; ** diferente de Ru-Adr E-. One-way ANOVA, pós-teste de Newman-Keuls $(P<0,05)$, $\mathrm{n}=6-7$

(A)
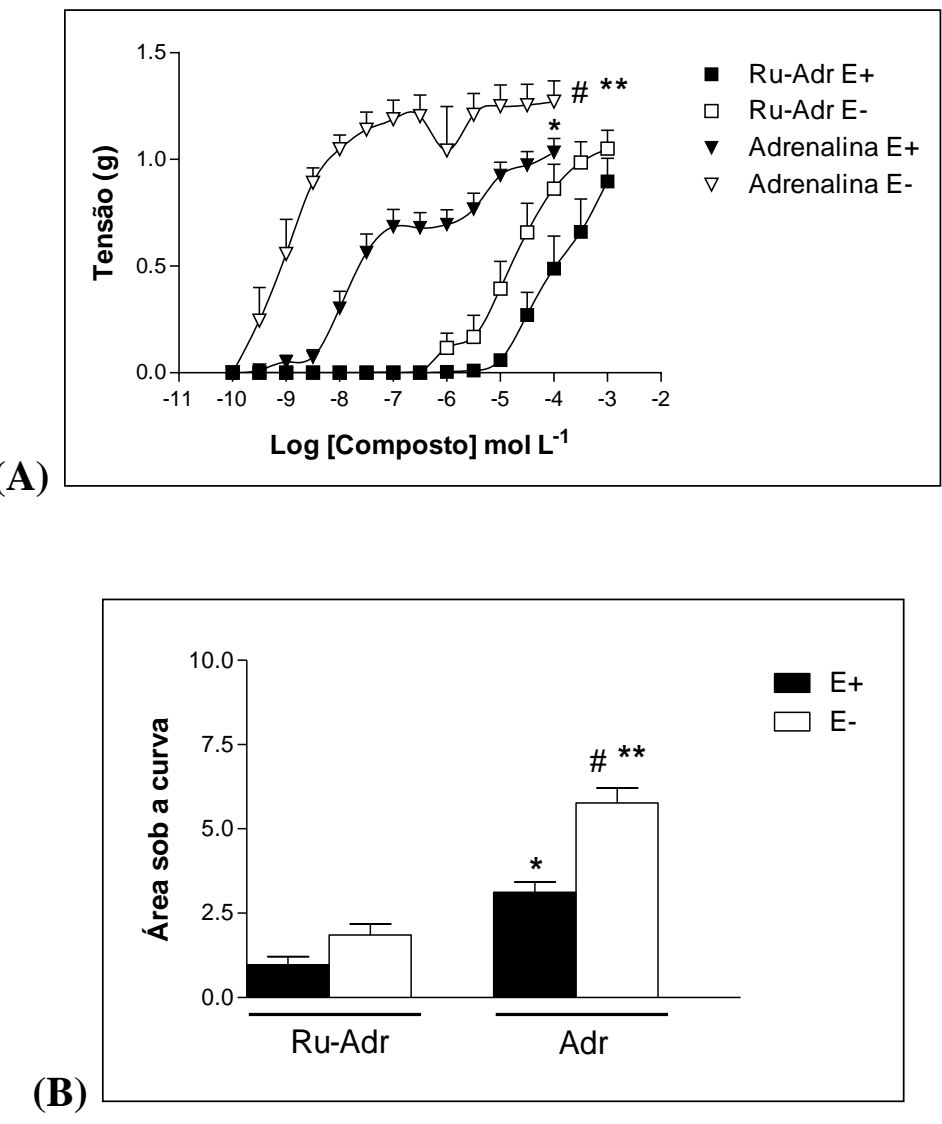

Fonte: Autora 
Figura 62: Efeito vasoconstritor induzido pelo complexo $\left[\mathrm{Ru}\left(\mathrm{NH}_{3}\right)_{4}(\text { dopamina })\right]^{+}(\mathrm{Ru}-\mathrm{Dopa})$ ou ligante livre dopamina em aorta de ratos. Contração vascular induzida pelo complexo Ru-Dopa ou Dopamina em presença $(E+)$ ou ausência (E-) de endotélio vascular $(A)$, incubados com os antagonistas de receptores $\alpha$ não-seletivo Fenoxibenzamina (0,3 $\mu$ mol.L-1) e $\beta$ não-seletivo Propranolol (5 $\mu$ mol.L-1) por 30 minutos. Análise de potência $\left(p D_{2}\right)(B)$, efeito máximo (Emax) $(C)$ e número de Hill (D) dos agonistas. Dados são apresentados como média \pm E.P.M. * diferente de Ru-Dopa E+; \# diferente de Dopamina E+; \#\# diferente de Ru-Dopa E-. One-way ANOVA, pós-teste de Newman-Keuls $(\mathbf{P}<0,05), \mathbf{n = 6 - 8}$

(A)

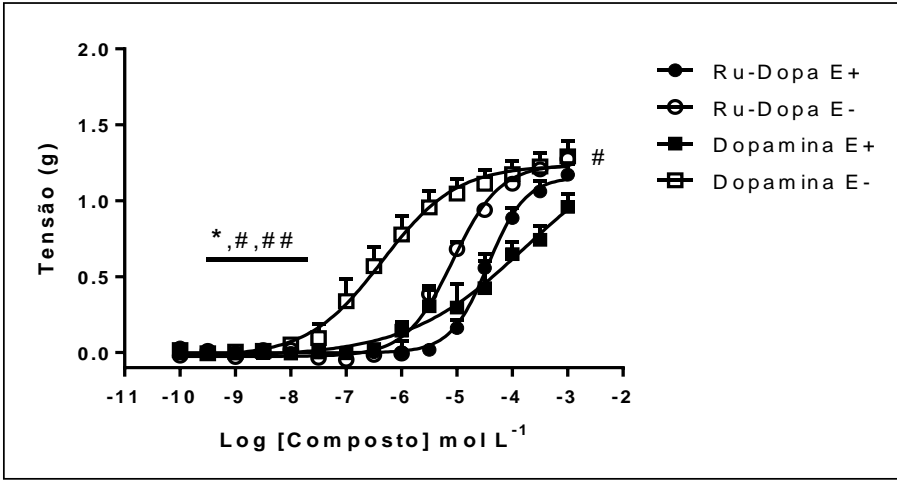

(B)

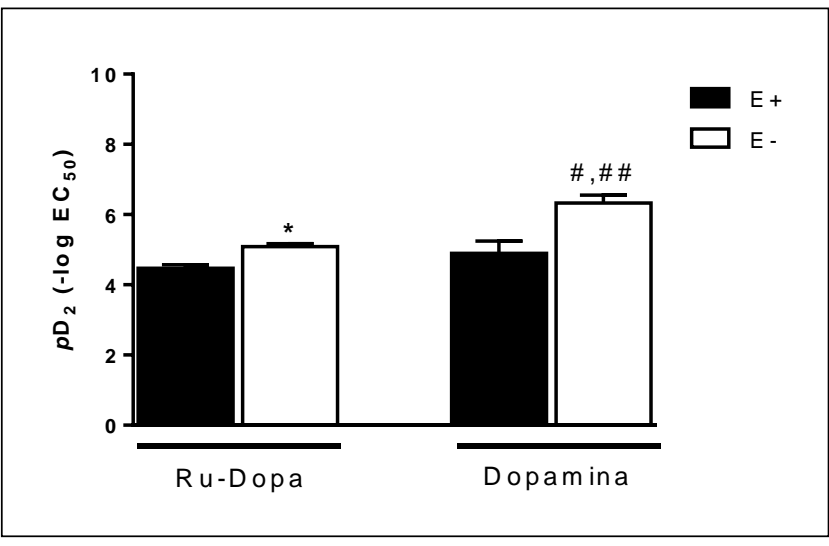

(C)

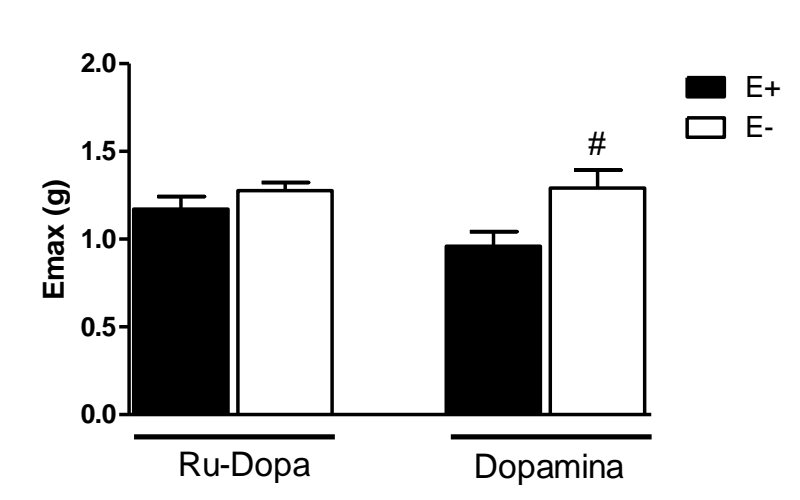


(D)

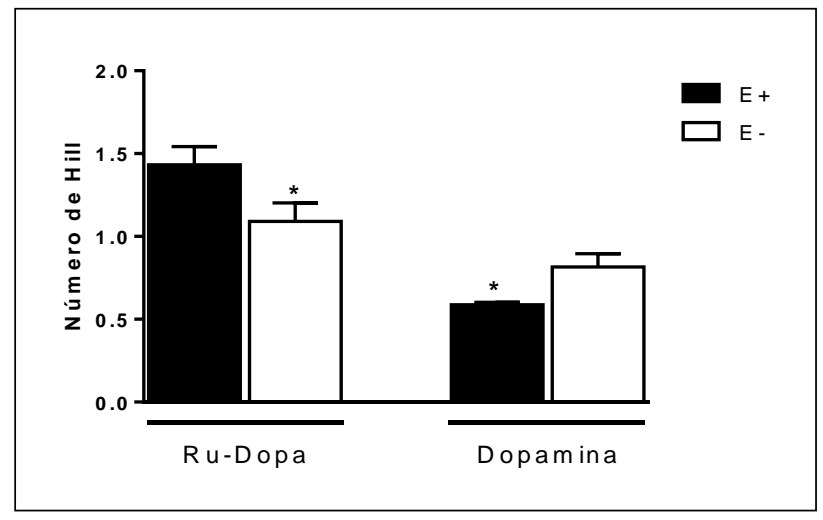

Fonte: Autora

Figura 63: Relaxamento induzido pelo complexo $\left[\mathrm{Ru}\left(\mathrm{NH}_{3}\right)_{4}(\text { isoproterenol })\right]^{+}(\mathrm{Ru}-\mathrm{Iso})$ ou ligante livre isoproterenol (Iso) em aorta de ratos. Relaxamento induzido pelo complexo Ru-Iso ou Iso em presença $(\mathrm{E}+)$ ou ausência $(\mathrm{E}-)$ de endotélio vascular $(\mathrm{A})$. Análise de potência $\left(p \mathrm{D}_{2}\right)(\mathrm{B})$, efeito máximo $(\operatorname{Emax})(\mathrm{C})$ e número de Hill (D) dos agonistas. Dados são apresentados como média \pm E.P.M. * diferente de Ru-Iso E+; ** diferente de Ru-Iso E-; \# diferente de Iso E+. One-way ANOVA, pós-teste de Newman-Keuls $(P<0,05)$, $n=5-6$

(A)
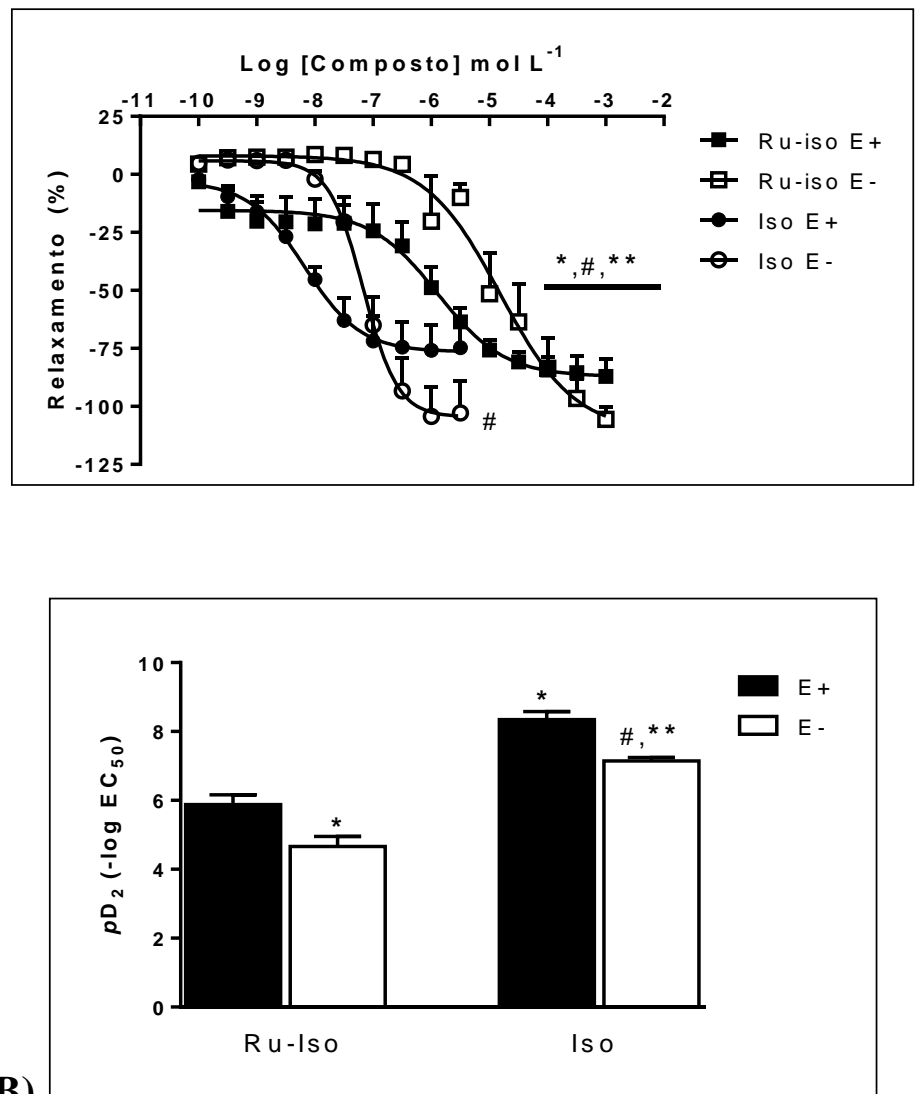

(B) 
(C)

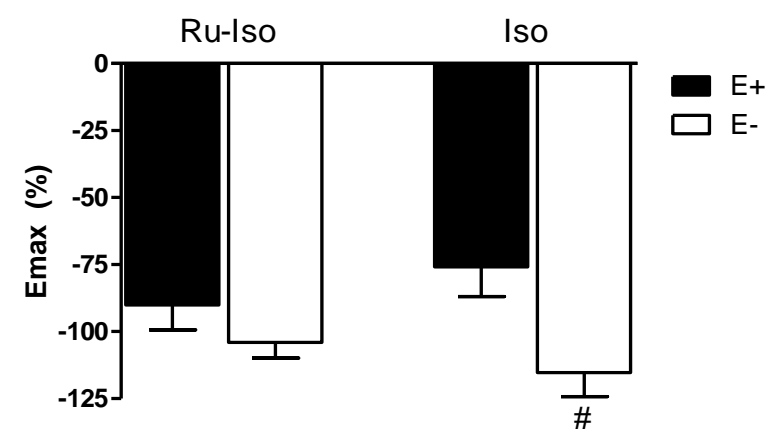

)

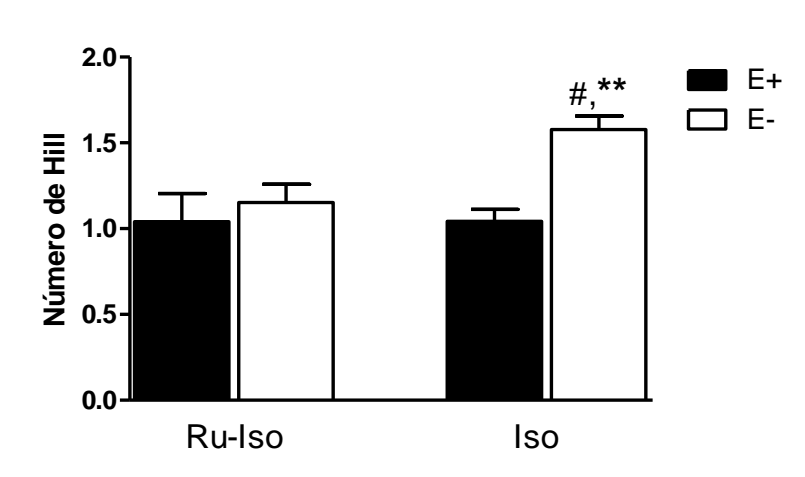

(D)

Fonte: Autora 
Figura 64: Ausência de efeito vascular do complexo $\left[\mathrm{Ru}\left(\mathrm{NH}_{3}\right)_{4}(\text { catecol })\right]^{+}(\mathrm{Ru}-\mathrm{Catecol})(\mathrm{A})$, ligante livre Catecol (B) ou do complexo precursor $\left[\mathrm{RuCl}\left(\mathrm{NH}_{3}\right)_{5}\right]^{2+}(\mathrm{C})$, em presença $(\mathrm{E}+)$ ou ausência (E-) de endotélio vascular, em aorta de ratos. Dados são apresentados como média \pm E.P.M. One-way ANOVA, pós-teste de Newman-Keuls $(P>0,05), n=4$

(A)

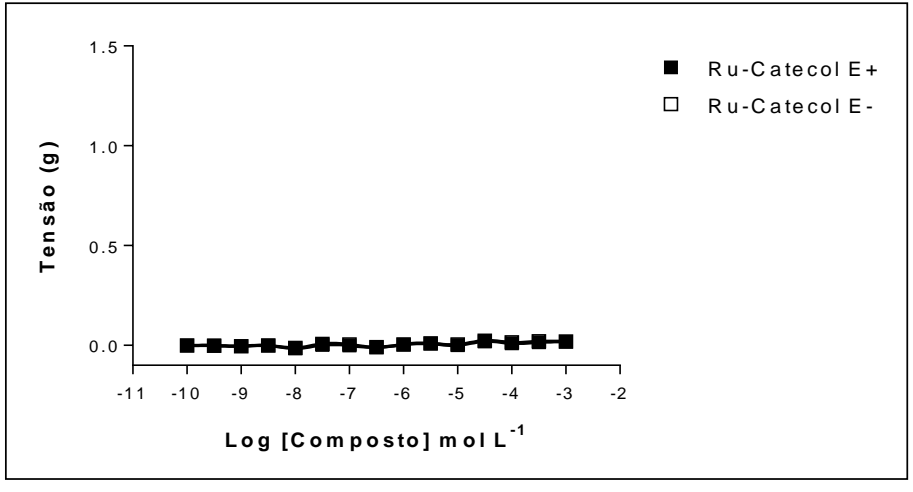

(B)

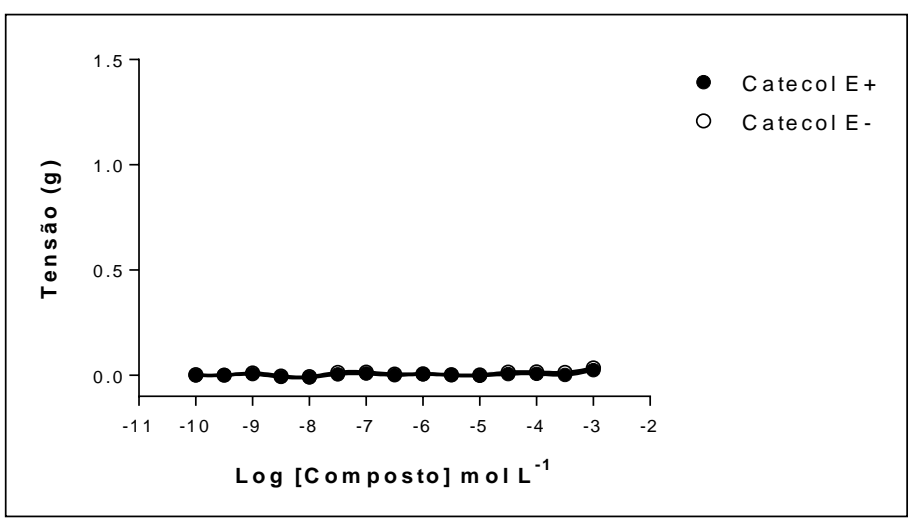

(C)

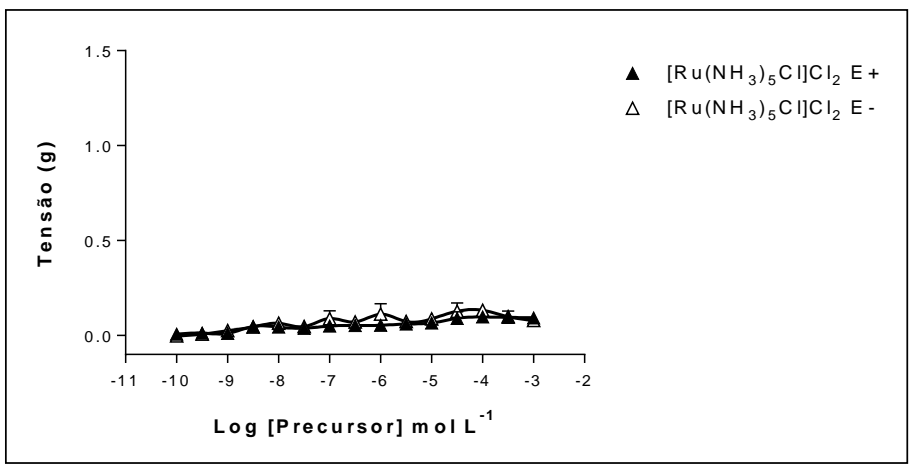

Fonte: Autora

Dos resultados expressos nestes ensaios de reatividade vascular, torna-se possível evidenciar que apenas os complexos de dopamina e isoproterenol, juntamente com seus respectivos ligantes, ajustaram à curva de regressão não-linear. Por essa razão, somente para estes quatro compostos foi possível calcular potência, Número de Hill e efeito máximo. Para 
noradrenalina, adrenalina e seus respectivos complexos, os parâmetros avaliados foram apenas referentes ao efeito total.

Em relação ao perfil de interação obtido para noradrenalina e o correlato complexo metálico, notou-se que o ligante livre apresentou um maior efeito total de contração vascular que o complexo de rutênio, no entanto, a catecolamina livre apresentou maior efeito quando o ensaio foi feito na ausência do endotélio vascular, ou seja, sem a túnica íntima da aorta, enquanto o complexo metálico apresentou efeitos totais semelhantes, tanto na presença quanto na ausência do endotélio vascular.

Este comportamento observado dá fundamento à hipótese de que a coordenação ao íon metálico promove uma interação maior com outro(s) tipo(s) de receptor(es). Em outras palavras, considerando-se que tanto no tecido muscular liso vascular, quanto no endotelial existem receptores $\alpha$ e $\beta$ adrenérgicos e dopaminérgicos, bem como o fato de que as catecolaminas apresentam somente seletividade relativa por estes receptores, o efeito observado (de vasoconstrição) é resultante da somatória dos efeitos promovidos nos diversos receptores. Por esta razão, é possível que a coordenação ao rutênio tenha promovido um prejuízo da ativação de receptores $\alpha$-adrenérgicos musculares, ou ainda que o metal favoreceu a ativação de receptores responsáveis pela modulação negativa da contração (talvez, relacionados com a ativação $\beta$-adrenérgica) - esta última hipótese menos provável, em razão do que já fora reportado na literatura que mudanças nos grupamentos catecólicos tendem a produzir antagonistas, mas com potência maior em receptores $\beta$ adrenérgicos (RANG; DALE, 1993).

Além disso, foi possível observar que a catecolamina livre interage preferencialmente em células do músculo liso vascular e, a coordenação ao metal reduz esta interação, sem, contudo, afetar substancialmente os efeitos promovidos no tecido endotelial.

Em relação ao complexo rutênio cujo ligante é adrenalina e a respectiva catecolamina livre, evidenciou-se (no mesmo sentido observado para noradrenalina livre) que a molécula livre de metal possui maior efeito contrátil total que o complexo metálico, bem como maior efeito total quando na ausência de endotélio vascular. Para o complexo metálico, também foi observado maior efeito total nos vasos sanguíneos ausentes de tecido endotelial, todavia a relação $\frac{\text { efeito(no tecido endotelial) }}{\text { efeito (no tecido muscular) }}$ diminuiu $11 \%$, comparada àquela obtida pra 0 ligante livre, indicando que a coordenação ao metal afetou, principalmente, a interação com os receptores presentes nas células endoteliais - resultado este interessante quando se considera que as células endoteliais são responsáveis pela formação de novos vasos 
sanguíneos. De um modo geral, as mesmas justificativas abordadas para noradrenalina e o respectivo complexo, se aplicam à adrenalina e o complexo em comento.

Especificamente no experimento realizado com a dopamina e no complexo no qual esta é o ligante, os ensaios foram conduzidos na presença de dois antagonistas, incubados 30 minutos antes do início das curvas concentração-efeito cumulativas: a Fenoxibenzamina (antagonista $\alpha$ não seletivo) e Propanolol (antagonista $\beta$ não seletivo). A necessidade de conduzir os ensaios nessas condições se deve ao fato de que em concentrações altas - em relação às fisiológicas - a dopamina perde a seletividade pelos receptores dopaminérgicos. Mais especificamente se pode afirmar que a dopamina ativa receptores $\beta_{1}$, causando efeitos ionotrópicos no músculo cardíaco, assim como também ativa receptores $\alpha_{1}$, promovendo vasoconstrição (BRUNTON; CHABNER; KNOLLMAN, 2011). A fim de serem eliminados quaisquer efeitos resultantes de ativação dos receptores $\alpha_{1}$ e $\beta_{1}$ e, consequentemente, ser obtido resultado apenas da ativação em receptores dopaminérgicos, foi essencial que o experimento fosse conduzido na presença de antagonistas para os receptores adrenérgicos.

Logo, é possível afirmar que todo efeito de contração vascular promovido pela dopamina livre e pelo complexo de rutênio com dopamina, demonstram suas atuações em receptores dopaminérgicos.

A curva deste par dopamina-complexo $\left[\mathrm{Ru}\left(\mathrm{NH}_{3}\right)_{4}(\text { dopamina })\right]^{+}$se ajustou à regressão não linear, motivo que permitiu a análise de parâmetros não analisados para os complexos anteriormente mencionados.

A remoção endotelial aumentou a potência do complexo de dopamina, em relação ao complexo no ensaio com endotélio, e também aumentou a potência da dopamina (sem endotélio) em relação à dopamina (com endotélio). Contudo, a contração desencadeada pela dopamina, sem endotélio, permanece com maior valor de potência que aquela produzida pelo complexo sem endotélio. Isso sugere que a interação do complexo com o receptor alvo parece estar prejudicada pela coordenação ao rutênio, e este efeito fica evidente quando é removida a camada endotelial, tirando a possível modulação exercida pelo endotélio que estava mascarando este efeito. Além disso, a presença do metal parece prejudicar a ativação dos receptores dopaminérgicos sobretudo aqueles ativados na camada de músculo liso vascular.

Em relação ao Número de Hill, algumas considerações prévias serão tecidas. $\mathrm{O}$ Número de Hill é um parâmetro farmacológico que avalia a inclinação de uma curva de concentração-efeito. Está relacionado com a interação droga-receptor, determinando os parâmetros de cooperativismo positivo ou negativo presentes naquela interação droga- 
receptor. $\mathrm{O}$ cooperativismo positivo é aquele no qual este Número é maior que 1 e, no negativo, menor que 1. Enquanto no cooperativismo negativo há a presença de efeitos contrários ao efeito avaliado, que modulam este efeito se opondo ao mesmo, no cooperativismo positivo, ocorrem fatores que favorecem o efeito analisado - no caso destes experimentos aqui reportados (exceto para isoproterenol e seu respectivo complexo ${ }^{15}$ ), fatores que favorecem a contração vascular determinarão cooperativismo positivo, enquanto fatores que favorecem o relaxamento vascular determinarão cooperativismo negativo (GIRALDO et. al., 2002; GRAAF; SCHOEMAKERB, 1999).

Este Número também pode expressar a possibilidade de ativação de dois ou mais receptores em determinada interação, ou, embora sendo referente à interação com um único receptor, desencadear duas ou mais vias de sinalização diferentes. É um parâmetro que reflete (também) possíveis vias de sinalização.

Neste sentido, foi possível aferir que os valores do Número de Hill para dopamina e para o respectivo complexo contendo este ligante são diferentes. Assim, para o complexo foi observado cooperativismo positivo (Número de Hill > 1), enquanto para o dioxoleno livre, cooperativismo negativo (Número de Hill < 1). É, pois, possível inferir que a coordenação ao metal produziu outros tipos de interação - ou inibiu as existentes - em relação àqueles comumente existentes na molécula de catecolamina livre. Isso significa afirmar que, ou a coordenação ao metal promoveu a possibilidade de interação com outro(s) receptore(s), ou apesar de a interação ocorrer no mesmo receptor, esta culminou em diferentes vias de sinalização intracelulares, para promover a resposta final de contração vascular.

Em relação ao complexo cujo ligante é isoproterenol, é importante destacar que o experimento foi realizado para ser verificado relaxamento vascular, isto porque - como mencionado na introdução deste texto - o isoproterenol possui maior potência como agonista de receptores $\beta$ adrenérgicos, os quais são responsáveis por este tipo de efeito. Assim, foi possível observar que o dioxoleno livre possui maior potência na presença da túnica íntima dos vasos. O complexo metálico, por sua vez, apresenta potência reduzida em relação ao ligante livre, todavia, a tendência é mantida (potência maior na presença do endotélio). $\mathrm{O}$ efeito máximo segue a mesma tendência discutida para a potência, para o isoproterenol livre, efeito que não é alterado para o complexo metálico.

O Número de Hill para o ligante livre e para o complexo metálico, são iguais a 1, no ensaio com endotélio, não havendo, portanto, cooperativismo positivo ou negativo. Para os

\footnotetext{
${ }^{15} \mathrm{O}$ raciocínio oposto se aplica para o ensaio realizado para o complexo de isoproterenol e o ligante livre.
} 
ensaios sem endotélio, observou-se que o Número de Hill para a catecolamina livre é consideravelmente maior $(\sim 50 \%)$ que para o complexo metálico, sendo observado efeito de cooperativismo positivo (Número de Hill > 1, para o ligante livre). Estes resultados são passíveis de conduzir à conclusão que, na ausência do tecido endotelial, as vias de sinalização e/ou os receptores envolvidos, no efeito de relaxamento vascular observado, não são o(a)s mesm(a)s. Considerando-se que as catecolaminas apresentam seletividade (apenas) relativa para os receptores adrenérgicos, é possível que para o ligante livre mais de uma via de sinalização esteja sendo ativada, enquanto para o complexo, apenas uma via é ativada - ou há a ativação de apenas um tipo de receptor -, razão pela qual para o complexo metálico este Número é aproximadamente 1.

O complexo metálico contendo como ligante orgânico o catecol e o ligante livre não apresentaram efeito vasoconstritor, assim como foi observado para o complexo precursor $\left[\mathrm{RuCl}\left(\mathrm{NH}_{3}\right)_{5}\right] \mathrm{Cl}_{2}$. Após o ensaio ${ }^{16}$, a viabilidade da aorta foi confirmada com uma solução de agente despolarizante (cloreto de potássio em alta concentração) e, nenhum dos complexos deixou os tecidos das aortas inviável, demonstrando que, de fato, não houve contração vascular em razão da ausência de interação com os receptores responsáveis pelo efeito e não por morte da aorta.

Estes últimos resultados conduzem à conclusão que o sítio amínico é o responsável pelo efeito vasoconstritor ou vasodilatador observado para os demais complexos, uma vez que na ausência deste grupamento alterações no tônus vascular não foram observadas. De um modo geral, pode-se inferir que os complexos de rutênio-catecolaminas se mostraram com menor efeito vascular em relação às respectivas catecolaminas livres - em relação a estas, tanto neste ensaio, quanto em estudos prévios (RASHED; SONGU-MIZE, 1995; DUNLEVY; O’MALLEY; POSTMA, 1996; VROMEN et al., 1996; WANG et al., 2004; GARLAND et al., 2011). O comportamento observado pelos complexos de rutênio indica que os mesmos atuam como agonistas parciais ou mesmo antagonistas dos receptores adrenérgicos ou dopaminérgicos, sendo a redução do efeito atribuída à imobilização do sítio catecólico.

A fim de que se conclua, decisivamente, se estes complexos metálicos agem (ou não) como antagonistas puros, são necessários outros ensaios. Todavia, a produção de efeito no tônus vascular - o que os constitui, desde já, pelo menos agonistas parciais - é suficiente para demonstrar que os referidos complexos apresentam uma ação sobre as células vasculares,

${ }^{16} \mathrm{O}$ procedimento para verificação da viabilidade dos tecidos é realizado também antes da utilização das preparações, nos procedimentos das curvas de concentração-efeito. 
tanto endoteliais, quanto do músculo liso vascular, o que culminou na realização dos experimentos a seguir mencionados, que constituem ensaios com células do endotélio vascular e músculo liso vascular.

\subsubsection{Medida do conteúdo de cálcio intracelular $\left(\left[\mathrm{Ca}^{2+}\right]_{i}\right)$ nas células HUVEC ou A7R5}

O cálcio é importante em diversas vias de sinalização, as quais controlam os mais variados fenômenos fisiológicos, desde a liberação de neurotransmissores, a contração e relaxamento vascular, contração cardíaca, síntese de mediadores intracelulares, apoptose celular, entre outros (ZHANG et. al., 1994).

Para uma melhor compreensão do efeito de contração vascular, necessário se faz uma sucinta abordagem: quando uma célula se encontra em repouso, o íon $\mathrm{Ca}^{2+}$ se encontra preferencialmente no interior das organelas (retículos endoplasmático ou sarcoplasmático ${ }^{17}$ ) e nas mitocôndrias. A contração muscular ocorre como resposta a um estímulo que promoveu o aumento de cálcio no citosol das células. Em se tratando de músculos esqueléticos, a liberação do cátion ocorre do retículo sarcoplasmático, enquanto no músculo cardíaco tal liberação além de oriunda do retículo sarcoplasmático - também é proveniente da entrada de cálcio do meio extracelular, via canais iônicos. Por sua vez, nos músculos lisos vasculares, o aumento do cátion cálcio é viabilizado, também, pela liberação do retículo endoplasmático, porém tal processo é mediado pelo $\mathrm{IP}_{3}$. Neste último tipo de tecido, o aumento de cálcio também pode ocorrer sem a ativação por meio de receptores, por exemplo, por equilíbrio iônico (MONTANARI, 2016).

Assim, uma vez que este íon está diretamente relacionado à contração vascular, sua mobilização no ambiente intracelular foi avaliada em células HUVEC - human umbilical vein endothelial cells (células endoteliais humanas provenientes do cordão umbilical), bem como em células A7R5 (células musculares lisas embrionárias de aorta torácica de ratos), tanto na ausência (condição basal), como na presença dos complexos de rutênio-catecolamina ou dos ligantes livres, via citometria de fluxo (MEDEIROS, 2009). O ionóforo de cálcio A23187 $\left(10 \mu \mathrm{mol} \mathrm{L}{ }^{-1}\right)$ foi usado como controle positivo. Os resultados são mostrados na figura a seguir (figura 65):

\footnotetext{
${ }^{17}$ Nomenclatura específica para o retículo endoplasmático de células musculares (MONTANARI, 2016).
} 
Figura 65: Mobilização de cálcio intracelular induzida pelos complexos de rutênio ou seus respectivos ligantes livres. A mobilização de cálcio intracelular foi avaliada, por citometria de fluxo, com a sonda fluorescente seletiva para cálcio intracelular Fluo-3AM $\left(3 \mu \mathrm{mol} \mathrm{L}^{-1}\right.$, para HUVEC, ou $10 \mu \mathrm{mol} \mathrm{L}^{-1}$, para A7R5, 30 minutos) em células HUVEC (A) ou A7R5 (B), na condição basal ou em presença de estímulo, por 10 minutos, com os complexos $\left[\mathrm{Ru}\left(\mathrm{NH}_{3}\right)_{4}(\text { noradrenalina })\right]^{+}$(Ru-NA) $\left(300 \mu \mathrm{mol} \mathbf{L}^{-1}\right)$;

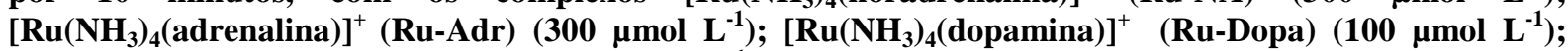
$\left.\left[\mathbf{R u}\left(\mathrm{NH}_{3}\right)_{4}(\text { isoproterenol) }]^{+} \text {(Ru-Iso) }\left(300 \mu \mathrm{mol} \mathrm{L}{ }^{-1}\right) \text {; [Ru( } \mathrm{NH}_{3}\right)_{4}(\mathrm{catecol})\right]^{+}$(Ru-Catecol) $(300 \mu \mathrm{mol} . \mathrm{L}-1)$; ou respectivos ligantes livres: noradrenalina (NA) $\left(1 \mu \mathrm{mol} \mathrm{L^{-1 }}\right)$; adrenalina (Adr) $\left(10 \mu \mathrm{mol} \mathrm{L} \mathrm{L}^{-1}\right)$; dopamina (Dopa) $\left(10 \mu \mathrm{mol} \mathrm{L}{ }^{-1}\right)$; isoproterenol (Iso) $\left(100 \mu \mathrm{mol} \mathrm{L^{-1 }}\right)$; Catecol $\left(10 \mu \mathrm{mol} \mathrm{L}{ }^{-1}\right)$. O ionóforo de cálcio A23187 $\left(10 \mu \mathrm{mol} \mathrm{L}^{-1}\right)$ foi usado como controle positivo de marcação fluorescente. Dados são apresentados como media \pm E.P.M. * diferente de basal; \# diferente do respectivo complexo rutênio-catecolamina; ** diferente do respectivo ligante livre. One-way ANOVA, com pós-teste de Newman-Keuls $(P<0,05), n=4$

(A)
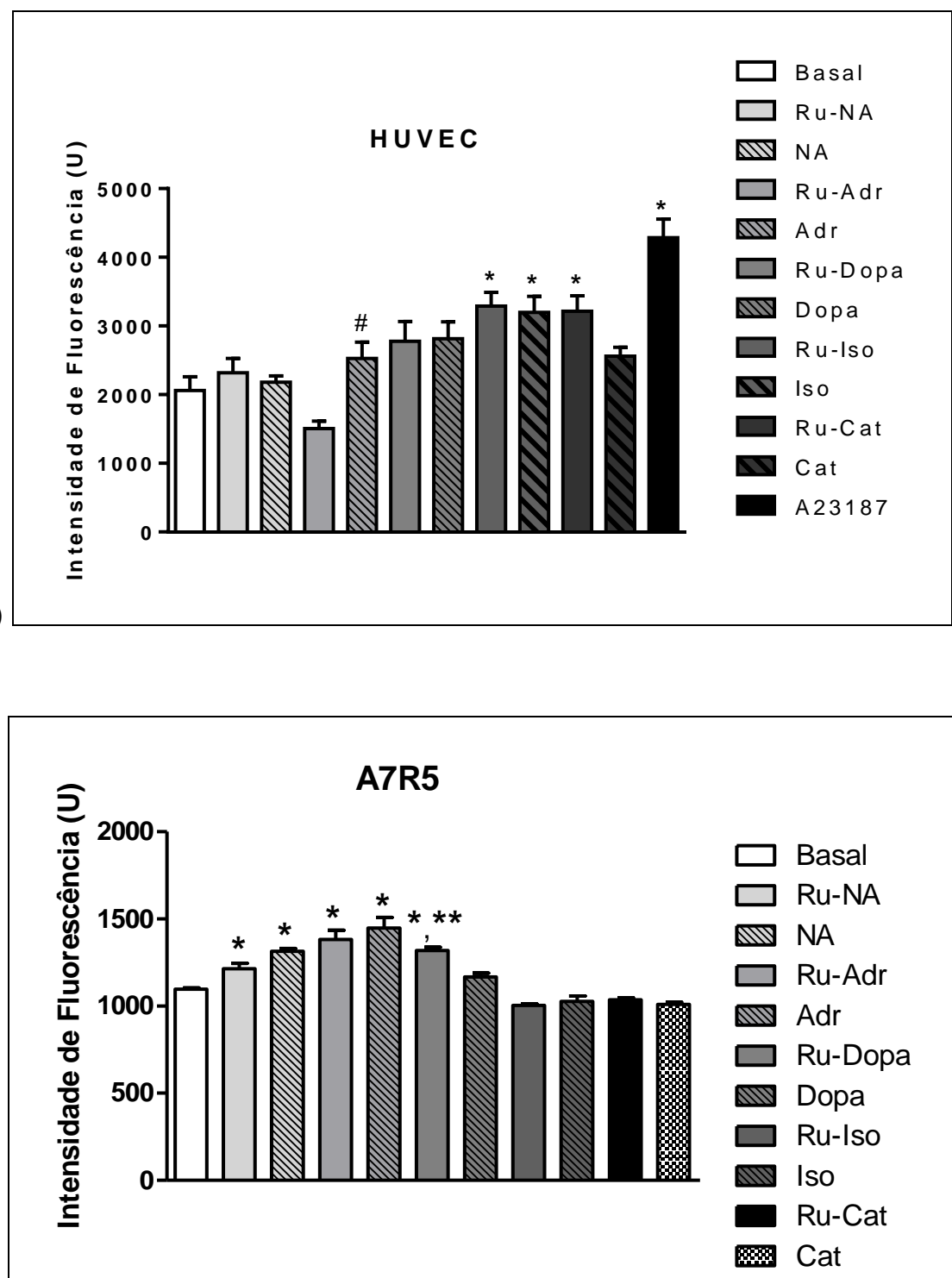

(B)

Fonte: Autora

Dos resultados, é possível afirmar que o conteúdo de $\left[\mathrm{Ca}^{2+}\right]_{i}$, em células HUVEC, aumentou após a incubação com os complexos de isoproterenol e catecol, assim como com os 
ligantes isoproterenol e adrenalina, em relação à condição basal. Além disso, os tratamentos com os ligantes noradrenalina e dopamina, bem como com o complexo de dopamina, demonstraram tendência de aumento do cálcio intracelular, em relação à condição basal, porém estes efeitos não foram estatisticamente significativos.

Ademais, pode ser verificado, nitidamente, que o complexo de adrenalina promoveu efeito oposto ao verificado para o respectivo ligante livre, sugerindo que a coordenação ao metal induz modificações imprescindíveis a esta alteração.

Com relação às células musculares, A7R5, observou-se que houve mobilização de cálcio intracelular naquelas tratadas com os complexos de noradrenalina, adrenalina e dopamina, bem como nas tratadas com os ligantes livres, noradrenalina e adrenalina, em relação ao basal, o que não foi observado para a dopamina livre. Em relação ao ligante livre, o complexo de dopamina aumentou cálcio intracelular, indicando que a coordenação ao íon metálico propicia este efeito. Para os demais tratamentos, não foram observados aumentos significativos de cálcio intracelular, em relação à condição basal.

No que se refere à ação dos receptores adrenérgicos, é conhecido que os receptores do tipo $\alpha_{1}$ atuam nos vasos sanguíneos (entre outros órgãos e tecidos) ativando a enzima fosfolipase $\mathrm{C}$, a qual produz $\mathrm{IP}_{3}$ e DAG, o que promove a liberação de $\left[\mathrm{Ca}^{2+}\right]_{\mathrm{i}}(\mathrm{RANG}$ et. al., 2016; BRUNTON et. al., 2010), enquanto os receptores do tipo $\alpha_{2}$ atuam, reduzindo a formação de AMPc, por inibição da adenilil ciclase, culminando na inibição dos canais de $\mathrm{Ca}^{2+}$ e ativando os canais de $\mathrm{K}^{+}$(RANG et. al., 2016; BRUNTON et. al., 2010); os receptores do tipo $\beta$, por sua vez, atuam via estímulo da adenilil ciclase; ao passo que os receptores dopaminérgicos atuam promovendo uma alteração na formação de AMPc intracelular, sendo que $D_{1}$ e $D_{5}$ ativam a formação de AMPc, enquanto que $D_{2}, D_{3}$ e $D_{4}$ inibem a produção desse segundo mensageiro (SARKAR; CHARKROBORTY; BASU, 2013). Neste sentido, é esperado dos compostos que atuem como agonistas dos receptores $\alpha_{1}$, promoverem aumento de $\left[\mathrm{Ca}^{2+}\right]_{\mathrm{i}}$, enquanto os agonistas de receptores $\beta$ promovam a redução do mesmo.

Desta forma, estes resultados são harmônicos com aqueles relatados no tópico precedente, pois para noradrenalina e o respectivo complexo de rutênio, para os quais foram observados efeitos de contração vascular mais intensa na ausência do endotélio vascular, notou-se aumento da mobilização de cálcio intracelular nas células musculares, mas não nas endoteliais.

Para a catecolamina adrenalina, que apresentou maior efeito total no tônus vascular, quando comparada a todos os demais compostos analisados, observou-se aumento 
do cálcio intracelular apenas nas células de músculo liso vascular, embora nas células endoteliais promova maior mobilização de cálcio quando comparado aos resultados observados para o complexo (apesar de não ser diferente do basal - condição controle), o que pode justificar seu maior efeito vasoconstritor. O complexo, por sua vez, promoveu a mobilização de cálcio, diferente da condição basal, somente nas células do músculo liso vascular. Em relação à adrenalina livre, o complexo de rutênio promoveu redução do efeito vasoconstritor e, o que se constitui um dos motivos pelos quais o complexo promove menor efeito de contração vascular, em relação ao ligante livre.

No que se refere à dopamina, observou-se que corroborando os resultados anteriores, para o complexo metálico, para o qual se obteve Número de Hill >1, notou-se aumento do cálcio intracelular nas células A7R5, enquanto para o ligante livre de rutênio, para o qual foi obtido Número de Hill $<1$, em nenhuma das duas linhagens celulares foi observado aumento de cálcio intracelular. Assim, provavelmente a contração (na presença da dopamina livre) ocorre por outro mecanismo, diferente daquele promovido pelo aumento do cálcio intracelular, e na presença do respectivo complexo metálico, somando-se a este primeiro efeito, há o efeito do aumento do cálcio, de forma que resulta em cooperativismo positivo. De qualquer modo, provavelmente, a via de sinalização ativada pela dopamina demonstra-se diferente daquela ativada pelo complexo de rutênio com este ligante dioxoleno - podendo indicar, ainda, que enquanto o ligante livre esteja agindo preferencialmente como agonista dos receptores da família $\mathrm{D}_{2}$, o complexo esteja ativando vias devido à interação com receptores do tipo $D_{1}$. Isso porque enquanto os receptores $D_{1}$ agem aumentando a produção de AMPc, por ativação da adenilil ciclase, os receptores $\mathrm{D}_{2}$ promovem a inibição da produção de AMPc, culminando na inibição de canais de cálcio e ativação dos de potássio ${ }^{18}$ (CALLIER et al., 2003; COLOMBO, 2014).

No que tange ao isoproterenol, tanto o ligante livre, quanto o complexo de rutênio promoveram o aumento do cálcio, em relação à condição basal, nas células HUVEC, enquanto nas células musculares o mesmo efeito não foi observado. Este resultado corrobora o que fora observado no ensaio de reatividade vascular, uma vez que no efeito de vasodilatação promovido por ambos, a maior potência foi observada para os ensaios conduzidos na presença do endotélio vascular. Este aumento de cálcio intracelular, nas células endoteliais, possivelmente está relacionado com a produção de mediadores endoteliais vasodilatadores, como o óxido nítrico.

\footnotetext{
${ }^{18}$ (...) embora existam estudos demonstrando que atuem (também) no aumento do cálcio citosólico (CALLIER et al., 2003; COLOMBO, 2014).
} 
Em relação ao catecol livre, conforme esperado, não houve mobilização de $\left[\mathrm{Ca}^{2+}\right]_{\mathrm{i}}$, em relação ao basal, em nenhuma das duas linhagens celulares, o que concorda com a ausência de efeito vascular observada no experimento anteriormente descrito. Todavia, de maneira inesperada o complexo de catecol promoveu aumento da concentração de cálcio intracelular em células endoteliais. Contudo, o mesmo não foi obsevado para as células do músculo liso vascular. Este fato de aumento de cálcio nas células endoteliais parece não estar relacionado com a modulação do tônus vascular. No entanto, nada impede que este complexo atue por outras vias de sinalização, exceto aquelas de modulação do tônus vascular, mas que envolvam a mobilização de cálcio intracelular. Entretanto, a identificação de qual via estaria envolvida neste aumento de cálcio intracelular induzido pelo complexo de catecol e seus subsequentes efeitos não se constituem objetivos deste trabalho.

De um modo geral, considerando-se os resultados obtidos neste e no experimento anterior, excetuando-se a dopamina e adrenalina, os ligantes parecem ativar vias semelhantes àquelas ativadas pelos respectivos complexos de rutênio.

\subsubsection{Ensaios na membrana corioalantoica (CAM)}

Por se tratar de ensaio de suma importância ao que fora proposto previamente para este trabalho, bem como em razão de não se tratar de experimento trivial no contexto da Química Inorgânica Biológica, necessárias são algumas considerações sobre este tipo de plataforma experimental biológica.

O modelo elegido para estudar os efeitos angiogênicos das espécies coordenadas ao íon rutênio foi a membrana corioalantoica de embriões de galinha (CAM - Corioalantoic Membrane), pois apresenta diversas vantagens quando comparado às outras plataformas de estudo (RIBATTI, 2008; NOWAK-SLIWINSKA; SEGURA; IRUELA-ARISPE, 2014).

A CAM é formada no quarto dia do desenvolvimento embrionário sendo proveniente da fusão do cório com o alantoide em aves. Esta membrana é extraembrionária e apresenta alta vascularização, possuindo diversas funções, entre as quais a troca gasosa. Localiza-se abaixo da membrana da casca e é responsável, também, pela absorção de cálcio da casca do ovo. É neste anexo extraembrionário que ocorre um processo de angiogênese microvascular, responsável pelo suprimento de oxigênio do embrião. A CAM parte de uma rede de vasos sem diferenciação e transforma-se, em poucos dias, em uma rede complexa de vasos sanguíneos, com artérias, veias e capilares definidos (FERREIRA, 2013; NOWAK- 
SLIWINSKA; SEGURA; IRUELA-ARISPE, 2014; CONNERY, 2013; RIBATTI et. al., 2011).

Nas duas últimas décadas, experimentos que utilizam esta membrana têm sido bastante propagados, vez que são de manipulação e visualização fáceis, economicamente viáveis e se constituem boa plataforma para diversos tipos de estudos, tanto pré-clínicos quanto de crescimento de vasos sanguíneos (NOWAK-SLIWINSKA et. al., 2014). Ademais, o crescimento rápido do embrião, em relação a outros animais, constitui-se outro aspecto positivo, pois os resultados são obtidos em tempo favorável e o preço é cerca de cem vezes inferior ao de um rato comum (NOWAK-SLIWINSKA et. al., 2014; CONNERY, 2013).

Em recente artigo de revisão, Nowak-Sliwinska e colaboradores (2014) demonstraram os diferentes protocolos e, consequentemente as diversas possíveis análises que podem ser realizadas na membrana corioalantoica.

Referida membrana foi inicialmente utilizada em 1911, para o crescimento de tumor na sua superfície. A aplicação empregada neste trabalho, com a finalidade de análise de vasos sanguíneos, demorou a ser utilizada (somente em 2003), mas tem se tornado um método reconhecido e bastante usado (FERREIRA, 2013; AUERBACH et. al., 2003; NOWAKSLIWINSKA et. al., 2014).

Para Connery (2013), o crescimento da membrana CAM inicia-se entre o quarto e quinto dias e têm sua taxa máxima de desenvolvimento entre os dias oitavo a décimo, após o início do desenvolvimento embrionário, com desenvolvimento máximo, final, no décimo segundo dia. No entanto, para Nowak-Sliwinska e colaboradores (2014), este tem início no terceiro dia e completa-se quando do décimo dia, após o início da incubação. Os mesmos autores afirmam, ainda, que os experimentos devem ser realizados entre o sexto e o oitavo dia, pois são os dias nos quais há a maior taxa de crescimento da membrana.

Para possibilitar este crescimento tão acelerado, que, aliás, viabiliza os testes em questão, as células da CAM possuem tempo de vida curto e seu processo de divisão celular é bastante acelerado, pois dentro deste período, vai-se de uma membrana pequena e avascular à uma estrutura complexa de rede de vasos sanguíneos (NOWAK-SLIWINSKA et. al., 2014).

Além de exercer função de órgão respiratório, a CAM possui, também, amplo sistema linfático (CONNERY, 2013). Quando submetida à baixa umidade, a CAM sofre acelerado processo de divisão celular, podendo ocorrer a queratinização da camada epitelial superior, que, geralmente, é única.

A CAM possibilita dois tipos de ensaios, conhecidos como ensaio in ovo e ex ovo. No primeiro, o ovo é mantido dentro da própria casca, do começo ao final do experimento, 
enquanto no segundo, há a transferência para uma placa de petri. No âmbito deste projeto, ambos tipos de ensaios foram realizados, no entanto, somente estão demonstrados neste texto aqueles referentes aos ensaios in ovo (NOWAK-SLIWINSKA et. al., 2014; LIU, 2011).

Muitos agentes com características de interferência na angiogênese têm sido estudados na membrana em comento, desde biomoléculas, anticorpos, medicamentos e moléculas sintéticas e organometálicos (NOWAK-SLIWINSKA et. al., 2014), sendo possíveis experimentos com caráter qualitativo e quantitativo. Para analisar os resultados, têm-se métodos de contagens de vasos sanguíneos, tanto manuais quanto automatizados, utilizando diversas técnicas de visualização, tais como microscopia confocal após a injeção de polímero fluorescente; microscopia de fluorescência; etc. (NOWAK-SLIWINSKA, et. al., 2014). Neste trabalho, utilizou-se a contagem com auxílio de um software (Angio Tool). Além das opções manual e automatizada, há a possibilidade de se estudar tanto os vasos sanguíneos mais calibrosos quanto os capilares.

Em relação aos vasos sanguíneos, pode-se realizar os seguintes estudos: da vasculatura da CAM - o que é feito pela análise do raio de crescimento da zona de inibição e é considerado um método semiquantitativo; da contagem do número de vasos sanguíneos que crescem, verticalmente, em gel previamente implantado, um dos métodos quantitativos; da medida do diâmetro dos vasos sanguíneos - utilizada quando da aplicação de substâncias irritantes sobre a CAM (semiquantitativo); da medida do diâmetro e do comprimento dos vasos sanguíneos - uma análise morfométrica, manual ou computacional; da densidade dos vasos sanguíneos - medida que é realizada por microscopia de fluorescência confocal e considerada análise semiquantitativa; quantificação das ramificações de vasos sanguíneos por $\mathrm{mm}^{2}$ - medida automática para verificação do grau de desenvolvimento da membrana. No que concerne aos capilares, são possíveis os seguinte estudos: medidas de comprimento, diâmetro e densidade dos capilares, por meio de microscopia eletrônica; quantificação das ramificações dos capilares sanguíneos por $\mathrm{mm}^{2}$ - medida automática para verificação do grau de desenvolvimento da membrana; do número e comprimento de capilares em uma determinada área (SEIDLITZ, et. al., 2004), o que é, também, uma análise manual (NOWAKSLIWINSKA, et. al., 2014).

A figura a seguir mostra os anexos embrionários e área vascularizada da CAM. As duas principais áreas vasculares associadas ao desenvolvimento embrionário são o local da fusão do cório com o alantoide e o saco vitelino (CONNERY, 2013) (figura 66): 
Figura 66: Estruturas extraembrionárias de ovo fertilizado

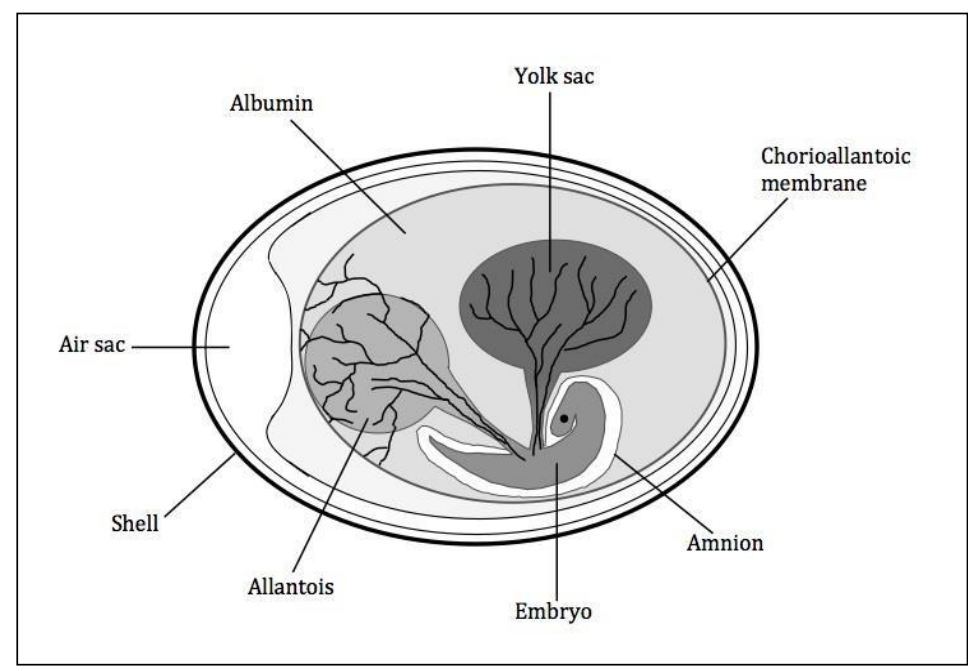

Fonte: CONNERY, 2013

Até o momento, no Brasil, não existe legislação específica relacionada à utilização destes embriões. Neste sentido, segue-se a norma vigente no Estados Unidos da América, a qual considera, até o $12^{\circ}\left(14^{\circ}\right.$ ou $15^{\circ}$ para alguns autores e normas) dia do desenvolvimento embrionário, experimento in vitro, em razão de o embrião não possuir terminações nervosas suficientes para ser senciente (ACUC, 2017; ALEKSANDROWICZ; HERR, 2015).

Este é, pois, de um modelo in vitro - embora simule muito bem experimentos in vivo - bem estabelecido para o estudo da angiogênese, demonstrando-se útil para a compreensão dos efeitos das catecolaminas livres e coordenadas ao íon rutênio, no que se refere às ações tanto pró, quanto antiangiogênicas.

Os ensaios foram realizados com os tratamentos adicionados no $5^{\circ}$ e no $6^{\circ}$ dias do desenvolvimento dos embriões. As imagens foram obtidas tanto no $5^{\circ}$, quanto no $6^{\circ}$ e $7^{\circ}$ dias. Porém, a sobrevida baixa dos embriões fez com que para alguns compostos ficasse inviável a análise após 48 horas da adição dos primeiros tratamentos.

As curvas de sobrevivência, referentes ao conjunto dos experimentos, são mostradas a seguir (figuras 67): 
Figura 67: Curvas de sobrevivência dos embriões, referentes aos ensaios na CAM, para os ligantes livres (A) e para os complexos metálicos (B). $\mathbf{n} \geq 3$
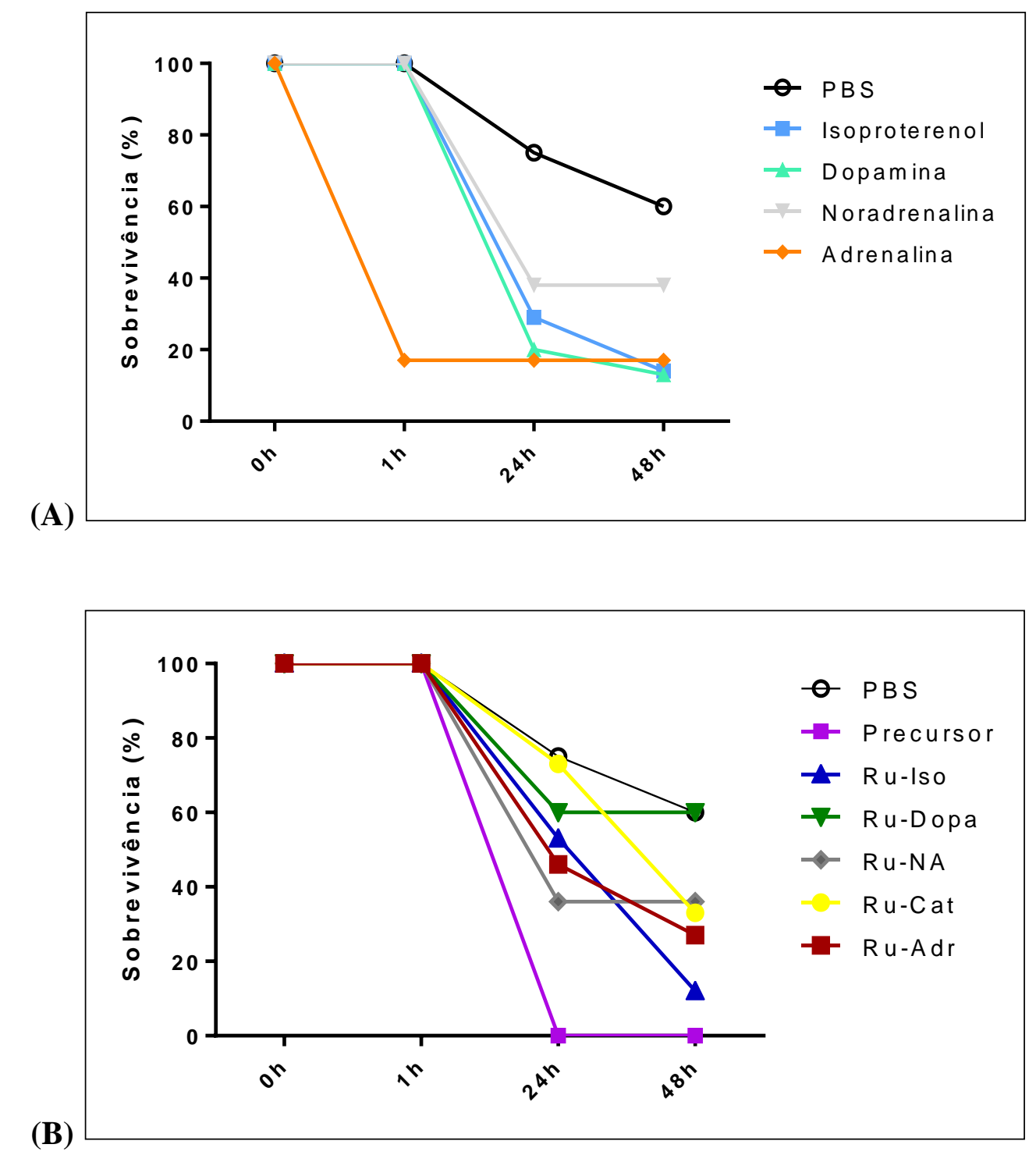

Fonte: Autora

Conforme se pode verificar dos gráficos, o ligante adrenalina demonstrou a maior toxicidade, sendo que a maioria dos embriões morreu logo no período máximo de uma hora após a primeira adição. O complexo precursor promoveu a morte de todos os embriões por lise dos vasos, antes da primeira quantificação - razão pela qual não aparece nos gráficos de quantificação.

O ligante catecol provoca queimaduras na pele e nos olhos, bem como é conhecidamente promotor de hipertensão e convulsões, tóxico e citotóxico, razão pela qual se entendeu ser desnecessário realizar qualquer tipo de ensaio na CAM envolvendo este ligante livre (NIH, 2017). 
No gráfico a seguir são mostrados os resultados referentes às primeiras 24 horas após a adição do tratamento no $5^{\circ}$ dia do desenvolvimento embrionário. Os resultados são expressões da porcentagem de variação da área total de vasos, bem como do índice de lacunaridade (figura 68). As fotografias representativas dos efeitos são mostradas na figura 69:

Figura 68: Efeitos angiogênicos induzidos por complexos ou ligantes: $\left[\mathrm{Ru}\left(\mathrm{NH}_{3}\right)_{4}(\text { noradrenalina })\right]^{+}(\mathrm{Ru}-$ NA), noradrenalina (NA), $\left[\mathbf{R u}\left(\mathbf{N H}_{3}\right)_{4}(\text { adrenalina) }]^{+} \quad(\mathrm{Ru}-\mathrm{Adr}), \quad\right.$ adrenalina $\quad$ (Adr), $\left[\mathrm{Ru}\left(\mathrm{NH}_{3}\right)_{4} \text { (isoproterenol) }\right]^{+}$( $\mathrm{Ru}$-Iso), isoproterenol (Iso), $\left[\mathrm{Ru}\left(\mathrm{NH}_{3}\right)_{4}(\text { dopamina) }]^{+}\right.$(Ru-Dopa), dopamina (Dopa), $\left[\mathrm{Ru}\left(\mathrm{NH}_{3}\right)_{4}(\mathrm{catecol})\right]^{+}$(Ru-Cat), ou o veículo (PBS), na área total de vasos (A) e na lacunaridade (B), na CAM. Os tratamentos aplicados foram na dose de $50 \mathrm{nmol}$ e a área total de vasos (A) e a lacunaridade (B) analisadas $24 \mathrm{~h}$ após os tratamentos. Os dados são apresentados como media \pm E.P.M. "diferente do controle (PBS); "diferente da respectiva catecolamina, n=3-6; One-way ANOVA, Newman-Keuls $(\boldsymbol{P}<\mathbf{0 . 0 5})$

(A)

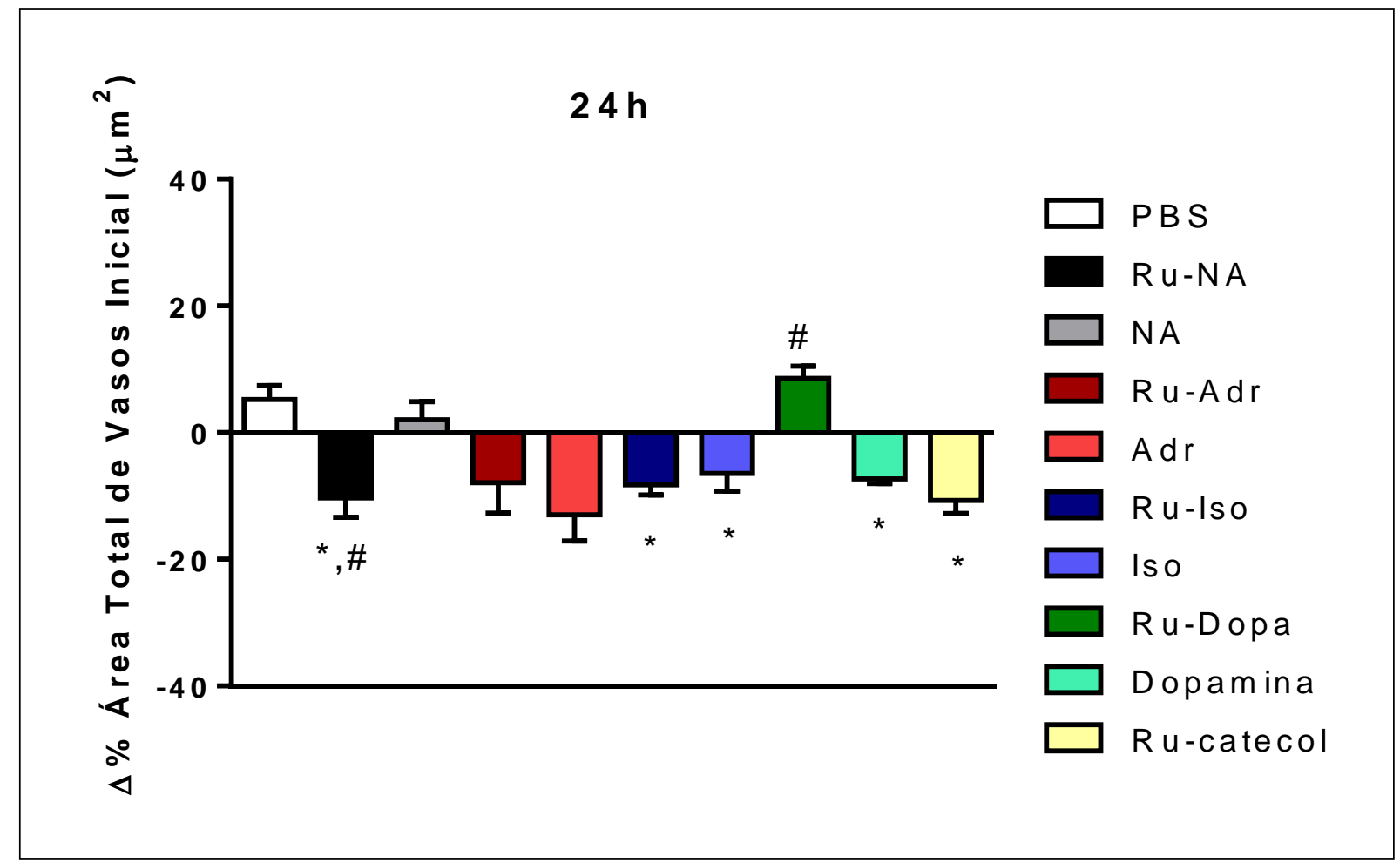

Fonte: Autora 
(B)

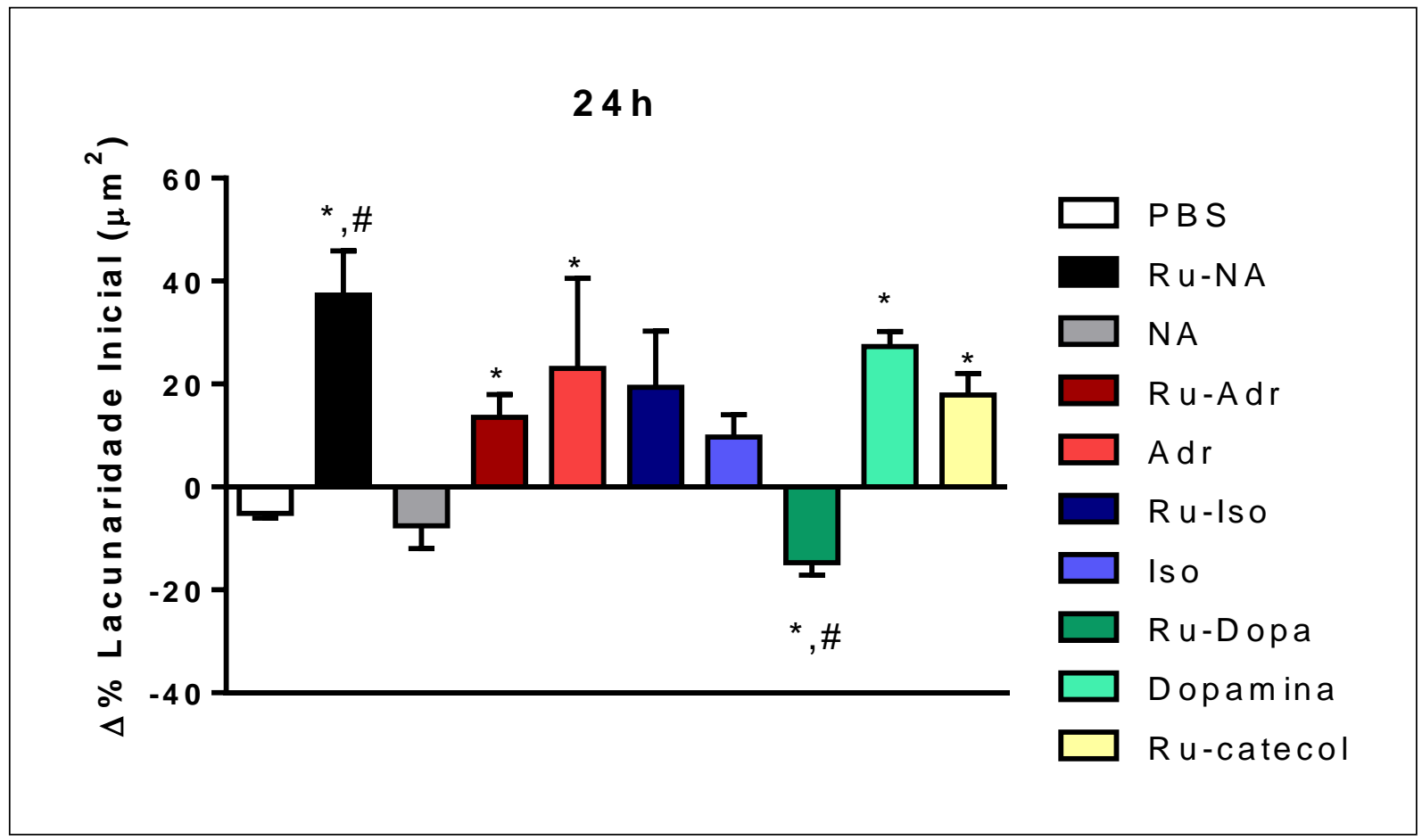

Fonte: Autora

Figura 69: Fotografias representativas da modulação da angiogênese induzida por complexos ou ligantes: $\left[\mathbf{R u}\left(\mathbf{N H}_{3}\right)_{4}(\text { noradrenalina) }]^{+}(\mathrm{Ru}-\mathrm{NA})\right.$, noradrenalina (NA), $\left[\mathbf{R u}\left(\mathrm{NH}_{3}\right)_{4}(\text { adrenalina) }]^{+}(\mathrm{Ru}-\mathrm{Adr})\right.$, adrenalina (Adr), [Ru( $\left.\mathbf{N H}_{3}\right)_{4}$ (isoproterenol) $]^{+}$(Ru-Iso), isoproterenol (Iso), [Ru( $\left.\mathbf{N H}_{3}\right)_{4}(\text { dopamina) }]^{+}$(Ru-Dopa), dopamina (Dopa), $\left[\mathrm{Ru}\left(\mathrm{NH}_{3}\right)_{4}(\mathrm{catecol})\right]^{+}(\mathrm{Ru}-\mathrm{Cat})$, ou o veículo (PBS), 24h após os tratamentos. Olympus SZ2-LHAD stereomicroscopy, $8 x$

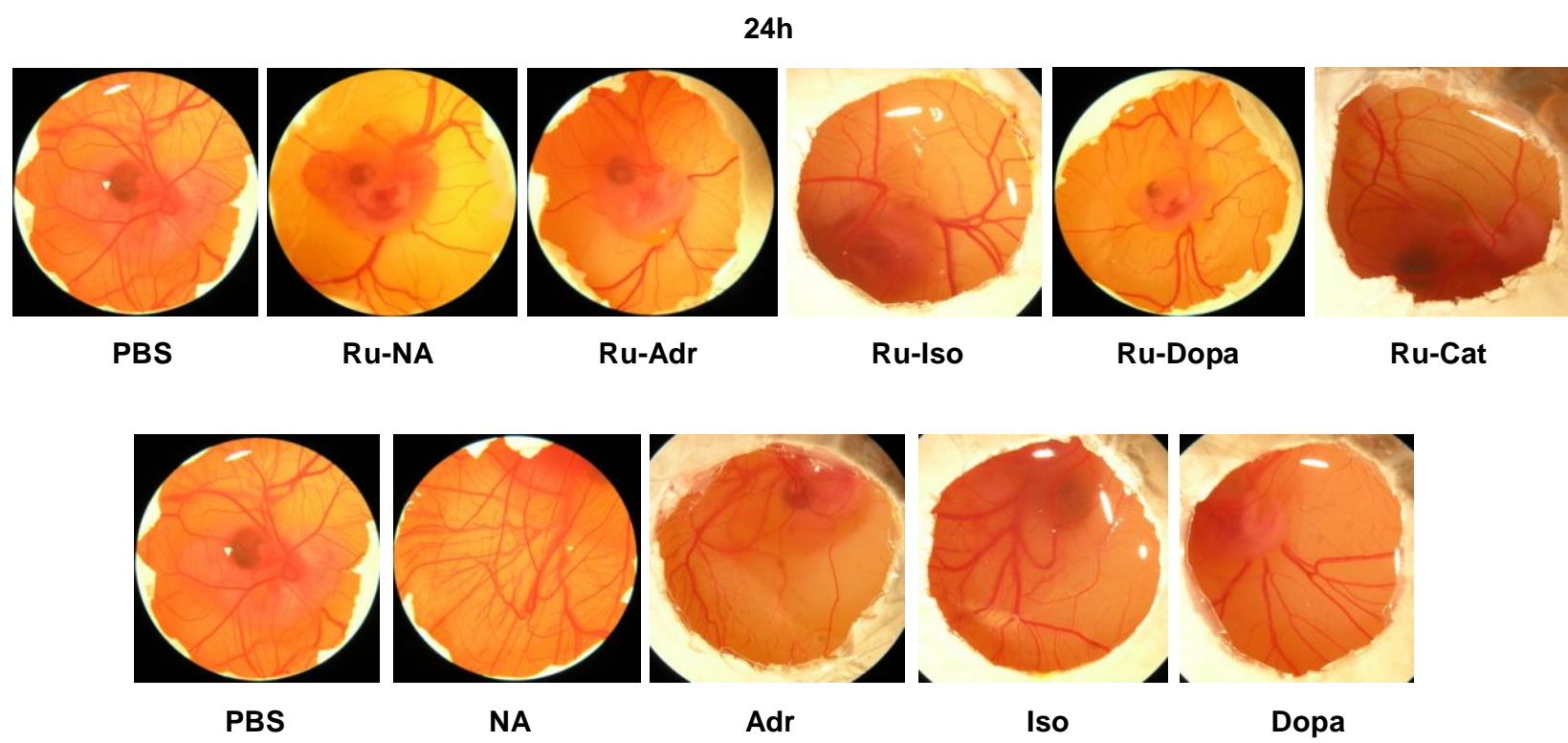

Fonte: Autora 
Em relação à área total de vasos, verifica-se que o veículo (PBS) promoveu aumento da área total de vasos (em relação ao dia no qual houve a aplicação dos tratamentos), o que é esperado, considerando-se que no período utilizado neste estudo a CAM se encontra em crescimento exponencial (AUERBACH et. al., 2003; FERREIRA, 2013). Observou-se que o complexo $\left[\mathrm{Ru}\left(\mathrm{NH}_{3}\right)_{4}(\text { adrenalina })\right]^{+}$possui a mesma tendência de efeito que o respectivo ligante livre, no sentido de reduzir a área vascularizada. Este resultado não é consoante ao disposto na literatura prévia, na qual se encontram achados no sentido de a adrenalina ser próangiogênica (TILAN; KITLINSKA, 2010; SARKAR; CHAKROBORTY; BASU, 2013). No entanto, como discutido na introdução deste texto, o comportamento desta catecolamina não é uniforme e, mesmo sobre as afirmações de seu efeito pró-angiogênico ainda pairam dúvidas (YANG, 2010).

Em relação ao complexo $\left[\mathrm{Ru}\left(\mathrm{NH}_{3}\right)_{4}(\text { catecol })\right]^{+}$, observou-se inibição da área total de vasos e toxicidade não acentuada ${ }^{19}$, o que indica que os efeitos tóxicos do catecol sejam modulados pela coordenação ao metal. O complexo $\left[\mathrm{Ru}\left(\mathrm{NH}_{3}\right)_{4}(\text { isoproterenol })\right]^{+}$e seu ligante livre apresentaram efeitos de inibição da angiogênese (redução da área total de vasos), porém menores que os observados para adrenalina e seu respectivo complexo metálico.

$\mathrm{O}$ complexo $\left[\mathrm{Ru}\left(\mathrm{NH}_{3}\right)_{4} \text { (noradrenalina) }\right]^{+}$, promoveu a redução da área total de vasos sanguíneos, em efeito oposto ao observado para a noradrenalina livre, que promoveu aumento dos vasos sanguíneos (quando comparado ao respectivo complexo metálico), na membrana corioalantoica. O efeito de redução dos vasos evidenciado para este complexo é mais expressivo que o efeito de aumento da área vascular - predito na literatura (SARKAR; CHAKROBORTY; BASU, 2013; CHAKROBORTY et. al., 2009; XIU et. al., 2015) -, observado pelo ligante livre. Pôde-se concluir, deste ensaio, que o complexo promove a alteração do efeito ordinário promovido pela catecolamina livre, o que vem ao encontro dos resultados obtidos na reatividade vascular, para os quais foi verificado que o complexo comporta-se como agonista parcial ou antagonista dos receptores do ligante.

Importante destacar que o experimento foi realizado no ápice do desenvolvimento da membrana corioalantoica, ou seja, o aumento vascular ocorre natural e intensamente neste período, implicando que um comportamento resultante de inibição de crescimento dos vasos sanguíneos é contra a tendência natural e, portanto, deve ser considerado como efeito antiangiogênico que não deve ser ignorado (AUERBACH et. al., 2003; FERREIRA, 2013).

\footnotetext{
${ }^{19}$ vide curva de sobrevivência
} 
Por sua vez, o complexo $\left[\mathrm{Ru}\left(\mathrm{NH}_{3}\right)_{4}(\text { dopamina })\right]^{+}$, promoveu resultados opostos àqueles observados para o ligante livre, pois o ligante, tal como descrito na literatura, apresentou efeitos antiangiogênicos (redução da área total de vasos), enquanto o complexo, aumento da área total de vasos. No mesmo sentido do observado para o complexo de noradrenalina, acredita-se que a coordenação ao íon metálico promova a alteração do receptor, em relação à dopamina livre. Estes resultados corroboram os dados obtidos para os ensaios de reatividade vascular e de quantificação do cálcio intracelular (BASU et. al., 2001; SARKAR et. al., 2008; CHAKROBORTY et. al., 2008; BASU et. al., 2004).

Os resultados de lacunaridade confirmam aqueles obtidos para a área total de vasos, ou seja, para os compostos que resultaram em efeito antiangiogênico, observou-se $\Delta \%$ de lacunaridade positivo e, para aqueles promotores da angiogênese (pró-angiogênicos), observou-se $\Delta \%$ negativo - razão pela qual se abstém da sua discussão.

De um modo geral, deste ensaio se extrai que o comportamento observado para os complexos de dopamina e noradrenalina, respectivamente, apresentam efeitos opostos em relação aos ligantes livres, os quais, por sua vez, apresentaram efeitos condizentes com os reportados na literatura.

Os resultados obtidos após a segunda dose (adicionada no $6^{\circ}$ dia do desenvolvimento embrionário), que são referentes às fotografias tiradas no $7^{\circ}$ do desenvolvimento embrionário, e foram analisados somente para alguns compostos, seguem no apêndice deste texto (figuras 140 e 141). De um modo geral, nota-se que os efeitos mais expressivos ocorrem após a primeira adição, embora o complexo de noradrenalina mantenha seu efeito. Acredita-se que o menor efeito seja promovido pela dessensibilização dos receptores - fenômeno que será abordado posteriormente (RANG et. al., 2016).

\subsubsection{Análise das alterações do ciclo celular}

As células podem se encontrar em dois estágios diferentes: quando em repouso, chamadas de células quiescentes, as células são consideradas fora do ciclo celular, ou seja, em estágio conhecido como $\mathrm{G}_{0}$. Após sofrerem estímulos, geralmente oriundos dos retromencionados fatores de crescimento, as células entram no denominado ciclo celular e preparam-se para a mitose. O ciclo celular, por sua vez, é dividido em quatro fases, denominadas $\mathrm{G}_{1}, \mathrm{~S}, \mathrm{G}_{2}$ e $\mathrm{M}$.

As etapas do ciclo celular, bem como os pontos importantes para eventual impedimento são destacados a seguir (figura 70): 
Figura 70: Fases da divisão celular

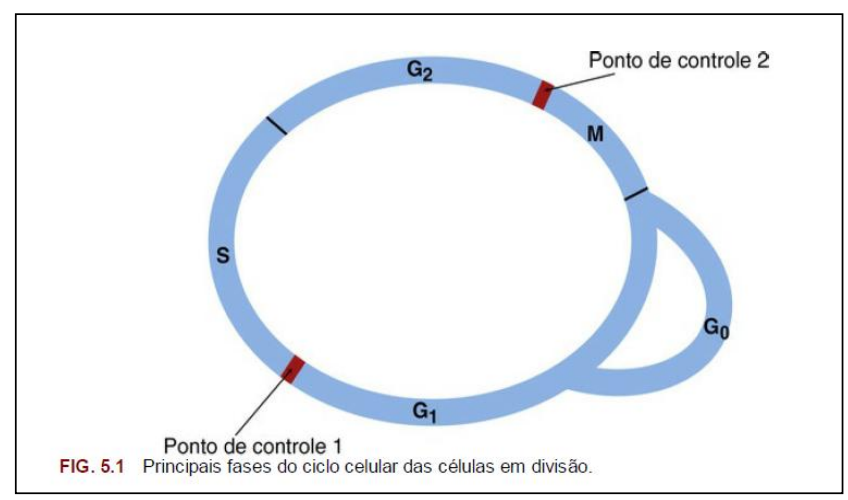

Fonte: RANG et. al., 2016

Na primeira fase, $\mathrm{G}_{1}$, ocorre o preparo para a síntese de DNA. Na segunda, $\mathrm{S}$, o DNA é sintetizado e os cromossomos duplicados. Já na terceira, $\mathrm{G}_{2}$, observa-se o preparo para a divisão propriamente. E, por fim, na fase M (mitose), ocorre a divisão da célula-mãe em duas células-filhas. Este último estágio é composto por quatro fases distintas, denominadas prófase, metáfase, anáfase e telófase (RANG, et. al., 2016).

Sem a pretensão de se esgotar a explanação sobre o ciclo celular, tem-se que o processo de angiogênese é totalmente ciclo-celular-dependente, haja vista a intrínseca necessidade de que as células - tanto do endotélio, quanto os pericitos - se dividam e migrem em prol da formação dos novos vasos sanguíneos. Desta forma, compostos que interfiram no ciclo celular podem se mostrar interessantes no que concerne ao impedimento da angiogênese.

Diante dos resultados apresentados para os efeitos referentes à angiogênese, na membrana corioalantoica, bem como de reatividade vascular e mobilização de $\left[\mathrm{Ca}^{2+}\right]_{\mathrm{i}}$, foram realizados estudos para a compreensão da possibilidade de atuação no ciclo celular, para o complexo rutênio cujo ligante é noradrenalina, assim como para a catecolamina livre. Os resultados, quantificados após 24 e 48 horas de incubação são mostrados a seguir (figura 71): 
Figura 71: Análise do ciclo celular em células HUVEC após tratamento com $\left[\mathrm{Ru}\left(\mathrm{NH}_{3}\right)_{4}(\text { noradrenalina }]^{+}\right.$ (Ru-NA) ou noradrenalina (NA). O ciclo celular diploide foi avaliado em células HUVEC pela intensidade de fluorescência emitida pelo Iodeto de Propídio (IP, $100 \mathrm{mg} \mathrm{mL}^{-1}$ ), por citometria de fluxo, após veículo (PBS) ou tratamento com Ru-NA ou NA $\left(300 \mu \mathrm{mol} \mathrm{L}^{-1}\right)$, por $24 \mathrm{~h}$ e $48 \mathrm{~h}$. As fases do ciclo celular analisadas foram: fase G0/G1; fase S; fase G2/M. Dados são apresentados como média \pm E.P.M. * diferente de veículo 24h; \# diferente de NA 24h ou 48h; ** diferente de veículo 48h. One-way ANOVA, pós-teste de Newman-Keuls $(\mathbf{P}<0,05), n=3-4$

(A)

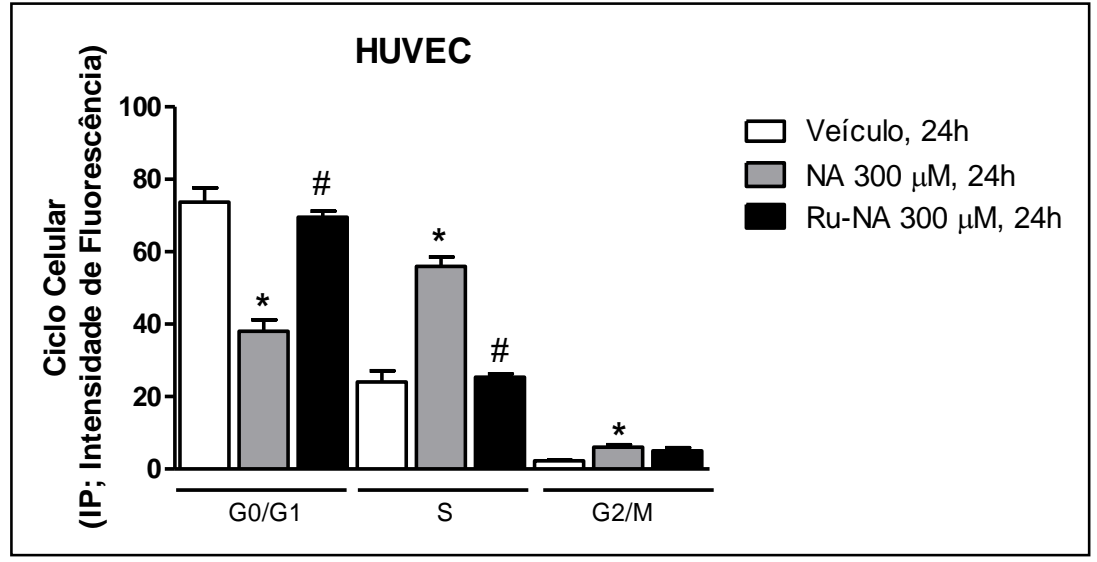

(B)

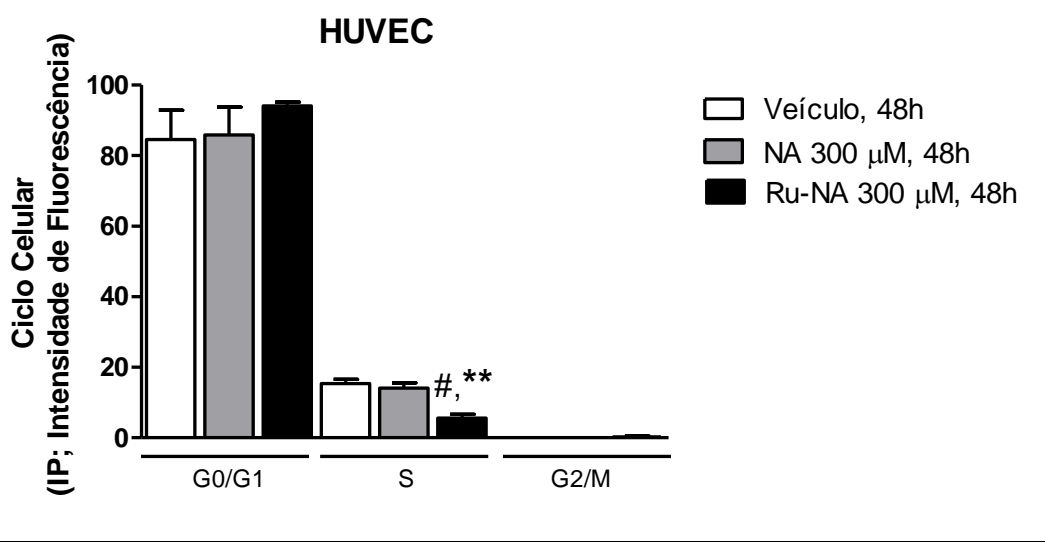

Fonte: Autora

Destes resultados, se pode inferir que para as células endoteliais, após 24 horas de incubação, a catecolamina livre, noradrenalina, promoveu aumento das fases $S$ e $G_{2} / M$ e diminuição de $\mathrm{G}_{0} / \mathrm{G}_{1}$, em relação ao veículo (PBS), o que sugere proliferação celular, induzida por esta catecolamina, uma vez que estas são as fases de preparo que antecedem a mitose.

O complexo metálico, no enquanto, promoveu aumento das fases $G_{0} / G_{1}$ (em relação à noradrenalina livre) e diminuição da fase $\mathrm{S}$ (em relação ao veículo e em relação à noradrenalina livre, em 24 h, e em relação ao PBS e à noradrenalina livre, em 48 h), efeito 
oposto ao observado para o ligante livre e que sugere inibição da mitose, o que, consequentemente, inibe a proliferação celular.

Considerando-se que as células endoteliais são essenciais à formação de novos vasos sanguíneos, parece coerente a propositura que a ligação química que resultou na imobilização do sítio catecólico promove a inibição do efeito proliferativo da noradrenalina, sendo possível, ainda, ousar na suposição de que além de impedir o efeito de proliferação induzido pela mitose, ocorre efeito oposto, no sentido de inibição da divisão de celular. Os resultados obtidos após 24 horas de incubação corroboram o efeito oposto observado para o complexo metálico, quando comparado à noradrenalina livre, nos ensaios realizados na membrana corioalantoica.

Após 48 horas de tratamento, o efeito proliferativo observado anteriormente para a noradrenalina livre é suprimido, não havendo qualquer diferença em relação às células tratadas somente com o veículo. O complexo, por sua vez, embora não tenha promovido alterações nas fases $G_{0} / G_{1}$, manteve o efeito de redução da fase $S$, tanto em relação à noradrenalina livre, quanto em relação ao veículo, indicando redução da fase na qual o material genético é duplicado. Praticamente não foram detectadas células nas fases $G_{2} / M$ neste ensaio.

No mesmo teor da discussão apresentada para os resultados obtidos após 24 horas de incubação, tem-se que após 48 horas os resultados, embora diferentes, são coerentes com aqueles obtidos na membrana corioalantoica. Isso porque naqueles ensaios, após 48 horas, também foram verificadas menores diferenças entre os resultados obtidos, tanto do complexo em relação ao ligante livre, quanto de ambos em relação ao controle, quando comparados àqueles obtidos após 24 horas de incubação. Esse tipo de resultado pode sugerir que após 24 horas houve dessensibilização dos receptores, o que pode ocorrer por endocitose dos receptores ou por fosforilação (RANG et. al., 2016).

O fenômeno da dessensibilização é comum na maioria dos receptores que são acoplados à proteína $\mathrm{G}$ - o que se aplica aos receptores envolvendo as ações da noradrenalina e seu complexo metálico - e consiste no impedimento do receptor ativar os segundos mensageiros, não obstante ainda se ligue aos agonistas. Este evento celular ocorre em curto intervalo de tempo (até minutos), suficiente para ter ocorrido durante o ensaio (RANG et. al., 2016).

Yang (2010) reportou que as catecolaminas adrenalina e noradrenalina promoveram efeitos antiapoptóticos em células tratadas previamente com paclitaxel, revertendo a interrupção do ciclo celular promovida pelo fármaco e culminando na 
continuação da mitose - razão pela qual os resultados obtidos no ensaio, aqui descrito e discutido, demonstram-se coerentes. Além disso, Li et al. (2008) observaram que noradrenalina livre aumentou a proliferação celular em células do músculo liso vascular. E no mesmo sentido, Zhang (et. al., 2011) mostraram que o tratamento de células pancreáticas tumorais com o antagonista seletivo $\beta_{2}$-adrenérgico ICI118551, promoveu aumento da fase $\mathrm{G}_{1}$ e a redução da fase $S$, procedendo também à apoptose celular. Os mesmos resultados não foram observados quando foi utilizado o antagonista seletivo $\beta_{1}$-adrenérgico Metoprolol, indicando que os efeitos proliferativos podem estar relacionados ao receptor adrenérgico $\beta_{2}$. Por fim, Chakroborty e colaboradores (2009), reportaram que noradrenalina estimulou a angiogênese em câncer de ovário de ratos e, por ativação de receptores $\beta$-adrenérgicos, aumentou AMPc e, por conseguinte, VEGF. Por estas razões, persiste a hipótese de que os efeitos observados sejam referentes à atuação em receptores do tipo $\beta_{2}$-adrenérgicos, bem como que o complexo atue preferencialmente como antagonista ou agonista parcial, enquanto o ligante livre, como agonista pleno (CALDERÓN, 2015).

\subsubsection{Ensaio de recuperação de lesão}

Considerando-se o ensaio previamente apresentado (de interferência no ciclo celular), cujos resultados, inibitórios do ciclo celular, foram provocados pelo complexo de noradrenalina, ato contínuo, procedeu-se à realização do ensaio de recuperação da lesão.

Este ensaio, que pode estar ou não associado à migração celular, avalia de forma geral, os efeitos totais de migração e proliferação celular. Neste, a intenção é verificar se após a produção de uma lesão realizada, por exemplo, com a ponteira de uma pipeta, as células migram e/ou se proliferam em direção à lacuna formada, no sentido de fechar a lesão.

Este ensaio foi realizado para quatro linhagens diferentes, sendo que alguns estudos (com células FR37-CMT ${ }^{20}$ e fibroblasto humano) foram conduzidos na Faculdade de Ciências e Tecnologia da Universidade Nova de Lisboa, sob a supervisão dos Professores M. Alexandra R. Fernandes e Pedro Viana Baptista, em laboratório do Departamento de Ciências da Vida e, os demais, no Laboratório ao qual a autora deste trabalho pertence.

Os resultados observados para as quatro linhagens são expressos como porcentagens de recuperação da lesão, após 24 horas, e são mostrados e discutidos nas

\footnotetext{
${ }^{20}$ Linhagem celular de câncer de mama canino, imortalizada no Laboratório em comento (RAPOSO et. al., 2016).
} 
próximas páginas. A seguir (figura 72), são apresentados os resultados para a linhagem de fibrolasto humano:

Figura 72: Recuperação da lesão induzida por complexos e ligantes: $\left[\mathbf{R u}\left(\mathrm{NH}_{3}\right)_{4}(\text { noradrenalina })\right]^{+}(\mathrm{Ru}-\mathrm{NA})$, noradrenalina (NA), $\left[\mathbf{R u}\left(\mathrm{NH}_{3}\right)_{4}(\text { adrenalina) }]^{+}(\mathbf{R u}-\mathbf{A d r})\right.$, adrenalina (Adr), $\left[\mathbf{R u}\left(\mathrm{NH}_{3}\right)_{4}(\text { isoproterenol) }]^{+}\right.$ (Ru-Iso), isoproterenol (Iso), $\left[\mathrm{Ru}\left(\mathrm{NH}_{3}\right)_{4}(\mathrm{catecol})\right]^{+}$(Ru-Cat), catecol ou dopamina, em células da linhagem fibroblasto humano. Os resultados são referentes à recuperação 24h após os tratamentos em concentração igual a $200 \mu \mathrm{mol} \mathrm{L}^{-1}$. Controle representa células não tratadas. Dados são apresentados como média \pm erro padrão da média (EPM) de pelo menos 2 amostras, com no mínimo duas replicatas. * diferente de Controle; \# diferente da respectiva catecolamina

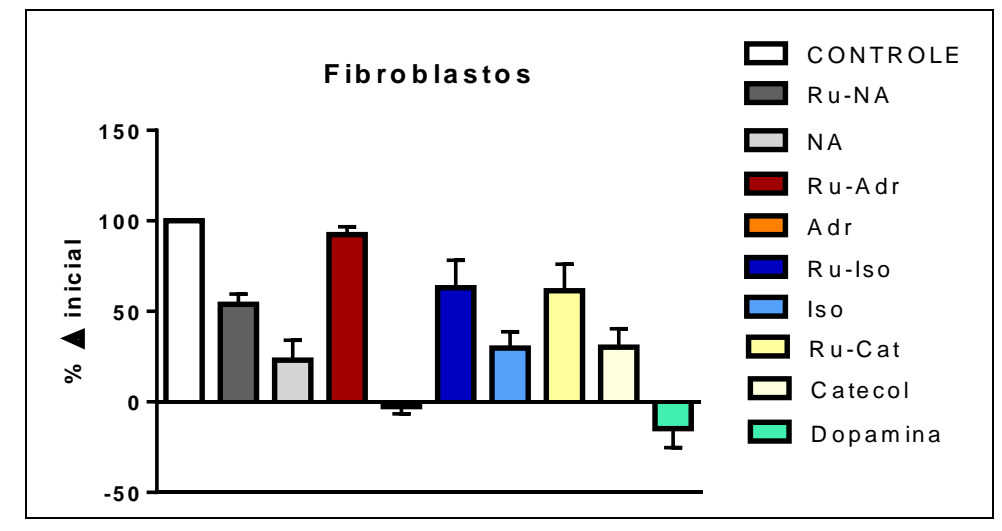

Fonte: Autora

Deste ensaio, embora não esteja com os resultados estatísticos, como os erros são baixos, é possível mensurar que, excetuando-se os ligantes livres adrenalina e dopamina, todos os demais compostos inibiram a recuperação da lesão, quando comparados às células não tratadas. Além disso, é possível afirmar que o complexo de noradrenalina promoveu o fechamento de $50 \%$ da lesão, enquanto com o tratamento com o respectivo ligante livre, esta recuperação foi menor; enquanto o complexo de adrenalina promoveu quase o completo fechamento da lesão, adrenalina livre impediu este efeito; efeitos semelhantes aos observados para o par Ru-NA, foram observados para os complexos e seus respectivos ligantes isoproterenol e catecol. O complexo de dopamina promoveu um pequeno aumento da lesão, o que pode indicar que esta promove contração do citoplasma celular - porém, para mais extensas afirmações, outros estudos são necessários.

Ao contrário do reportado pela literatura amplamente discutida na introdução deste texto, não foram observados efeitos que indiquem a proliferação ou migração celular, promovidas pela noradrenalina e adrenalina, nesta linhagem de células. Este efeito não proliferativo, ou mesmo antiproliferativo, também fora observado para noradrenalina, por Calderón (2015), em células de câncer de boca (carcinoma espinocelular, SCC-25) (TILAN; KITLINSKA, 2010; YANG, 2010; SARKAR; CHAKROBORTY; BASU, 2013). No entanto, 
para o ligante livre dopamina, foi observado o efeito de inibição da recuperação da lesão, o que vai ao encontrado do reportado na literatura para este ligante (BASU et. al., 2004; CHAKROBORTY et. al., 2004; CHAKROBORTY et. al., 2008; CHAKROBORTY et. al., 2009).

De um modo geral, foi verificado que os complexos metálicos promovem respostas semelhantes, porém reduzidas em relação ao respectivo ligante livre - efeito este que fora observado anteriormente no ensaio de reatividade vascular e, reitera a observação de que os complexos atuem como agonistas parciais e/ou antagonistas dos receptores responsáveis pela ação das catecolaminas na proteína G.

Nas células HUVEC, os resultados são mostrados a seguir (figura 73):

Figura 73: Recuperação da lesão induzida por complexos e ligantes: $\left[\mathrm{Ru}\left(\mathrm{NH}_{3}\right)_{4}(\text { noradrenalina })\right]^{+}(\mathrm{Ru}-\mathrm{NA})$, noradrenalina (NA), $\left[\mathbf{R u}\left(\mathrm{NH}_{3}\right)_{4}(\text { adrenalina) }]^{+}\right.$(Ru-Adr), ou adrenalina (Adr), em células HUVEC. Os resultados são referentes à recuperação $24 \mathrm{~h}$ após os tratamentos em concentração igual a $200 \mu \mathrm{mol} \mathbf{L}^{-1}$. Controle representa células não tratadas. Dados são apresentados como média +/- erro padrão da média (EPM) de pelo menos 3 amostras diferentes (n). * diferente de Controle; \# diferente da respectiva catecolamina, n=3-4; One-way ANOVA com pós-teste de Newman-Keuls $(\mathbf{P}<0,05)$

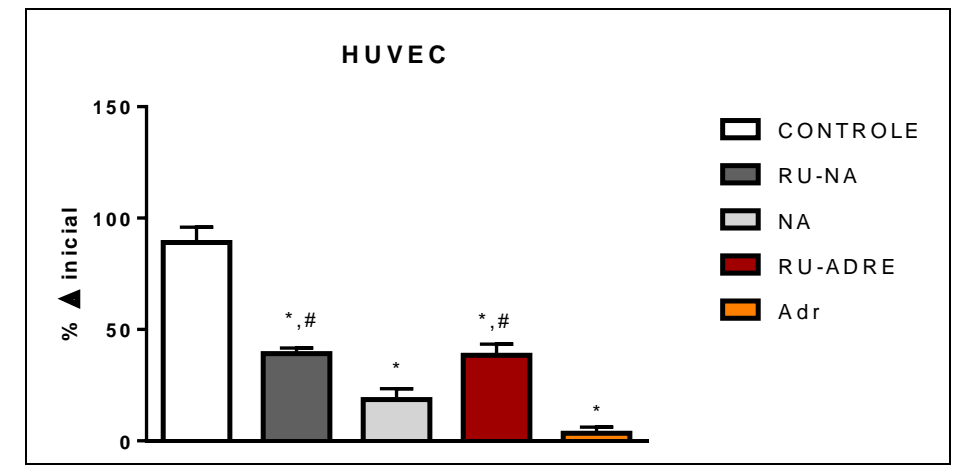

Fonte: Autora

Fotomicrografias representativas deste ensaio são mostradas a seguir (figura 74): 
Figura 74: Fotomicrografias representativas do ensaio de recuperação da lesão induzida por complexos e ligantes: $\left[\mathrm{Ru}\left(\mathrm{NH}_{3}\right)_{4}(\text { noradrenalina })\right]^{+}(\mathrm{Ru}-\mathrm{NA})$, noradrenalina $(\mathrm{NA}),\left[\mathbf{R u}\left(\mathrm{NH}_{3}\right)_{4}(\text { adrenalina })\right]^{+}(\mathrm{Ru}-\mathrm{Adr})$, ou adrenalina (Adr), em células HUVEC. Os resultados são referentes à recuperação $24 h$ após os tratamentos em concentração igual a $200 \mu \mathrm{mol} \mathrm{L}^{-1}$. Controle representa células não tratadas

\section{CONTROLE}

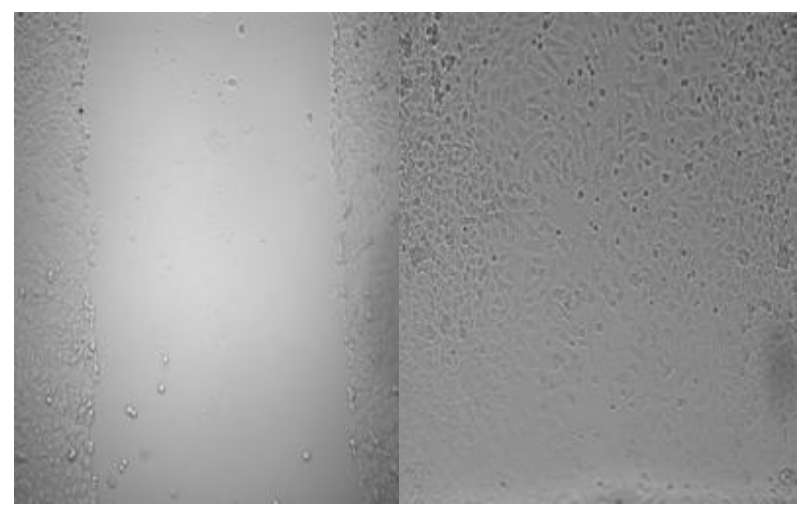

\section{Ru-NA}

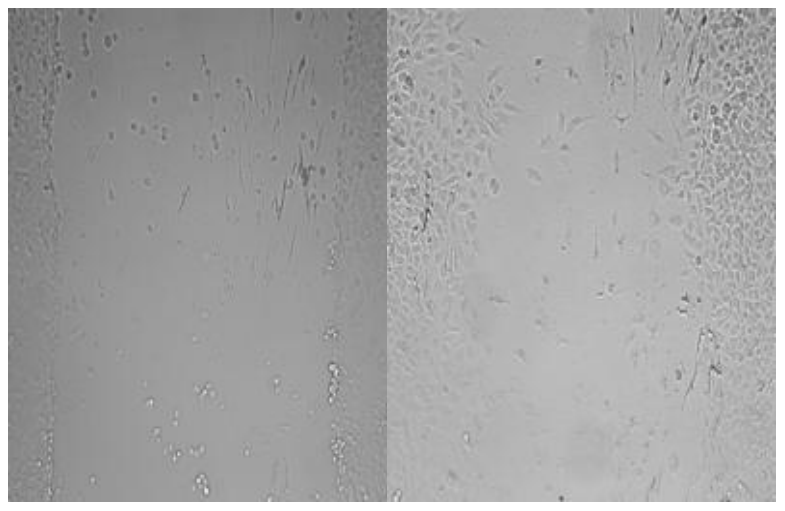

NA

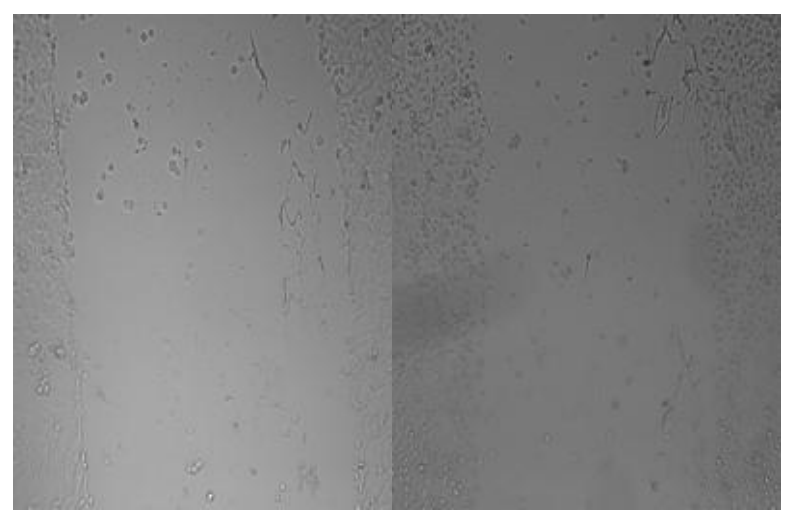

Fonte: Autora

\section{Ru-Adr}

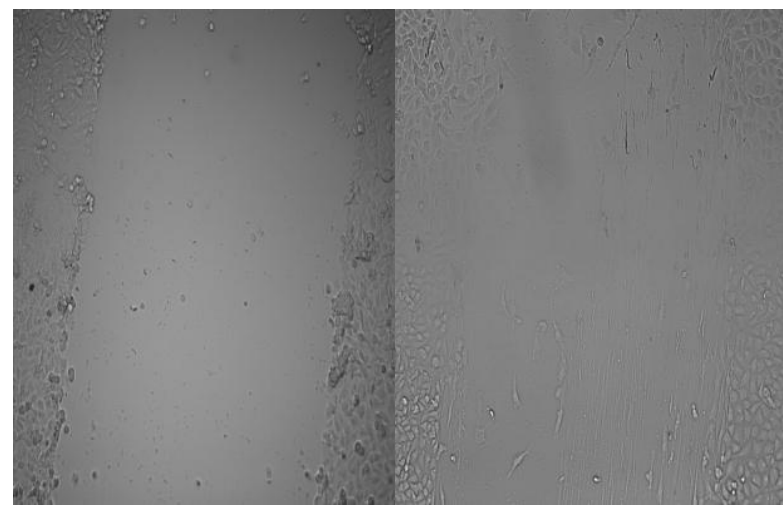

Adr

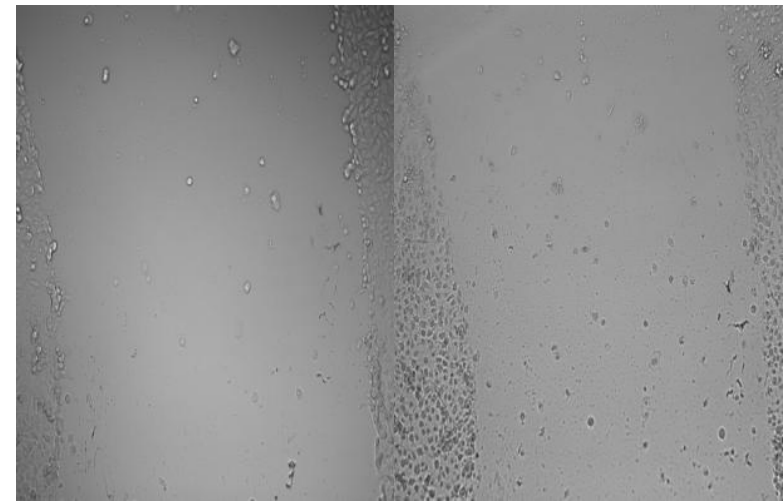


Nesta linhagem, constituída por células do endotélio vascular, foi possível notar que os complexos metálicos de noradrenalina e adrenalina, bem como os respectivos ligantes livres, inibiram a recuperação da lesão, quando comparados às células não tratadas, no entanto, quando comparados às respectivas catecolaminas livres, os complexos promoveram maior recuperação da lesão. Esta diferença foi observada, semelhantemente, para adrenalina e o respectivo complexo metálico, quando da dosagem de cálcio citosólico, pois o ligante livre promoveu maior aumento de cálcio no citosol, podendo sinalizar, portanto algum tipo de morte celular, nesta linhagem celular (PINTON et. al., 2008). De qualquer modo, estes resultados, contrariam as hipóteses da literatura no sentido de que estas catecolaminas promovam efeitos de proliferação celular. No entanto, pode-se afirmar que os poucos ensaios reportados na literatura, envolvendo estes dois dioxolenos, são referentes (de um modo geral) à expressão em células tumorais - o que não é o caso deste ensaio (TILAN; KITLINSKA, 2010; YANG, 2010; SARKAR; CHAKROBORTY; BASU, 2013).

Os resultados para a linhagem FR37-CMT são mostrados no gráfico a seguir (figura 75):

Figura 75: Recuperação da lesão induzida por complexos e ligantes: $\left[\mathrm{Ru}\left(\mathrm{NH}_{3}\right)_{4}(\text { noradrenalina })\right]^{+}(\mathrm{Ru}-\mathrm{NA})$, noradrenalina (NA), $\left[\mathbf{R u}\left(\mathbf{N H}_{3}\right)_{4}(\text { adrenalina) }]^{+}(\mathbf{R u}-\mathrm{Adr}) \text {, adrenalina (Adr), } \mathbf{R u}\left(\mathrm{NH}_{3}\right)_{4} \text { (isoproterenol) }\right]^{+}(\mathbf{R u}-$ Iso), isoproterenol (Iso), $\mathrm{Ru}\left(\mathrm{NH}_{3}\right)_{4}$ (catecol) $]^{+}$(Ru-Cat), ou catecol, em células FR37-CMT. Os resultados são referentes à recuperação 24h após os tratamentos em concentração igual a $200 \mu \mathrm{mol} L^{-1}$. Controle representa células não tratadas. Dados são apresentados como média +/- erro padrão da média (EPM) de pelo menos 3 amostras diferentes $(\mathbf{n})$. * diferente de Controle; \# diferente da respectiva catecolamina, $n=3$ 4; One-way ANOVA com pós-teste de Newman-Keuls $(\mathbf{P}<0,05)$

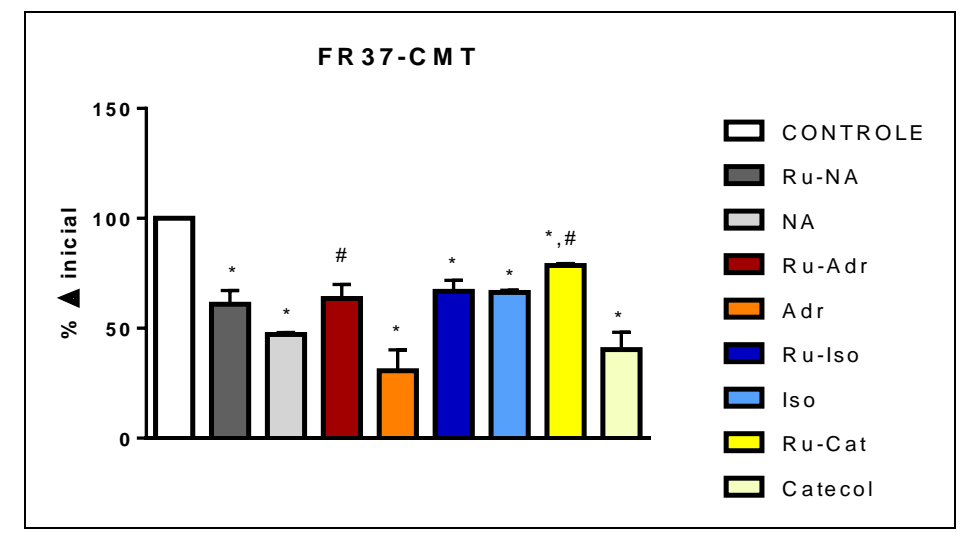

Fonte: Autora

Nesta linhagem celular metastática, de câncer de mama canino, observou-se que todos os complexos metálicos, bem como os respectivos ligantes livres, inibiram a recuperação da lesão, quando comparados ao controle, todavia, quando comparados às 
respectivas catecolaminas (ou catecol) livres, os complexos promoveram maior recuperação da lesão.

Por fim, são mostrados os resultados observado para a linhagem de gliobastoma pediátrico, SF-188, na forma de gráfico (figura 76), bem como as fotomicrografias representativas dos resultados do ensaio (figura 77):

Figura 76: Recuperação da lesão induzida por complexos e ligantes: $\left[\mathbf{R u}\left(\mathrm{NH}_{3}\right)_{4}(\text { noradrenalina })\right]^{+}(\mathrm{Ru}-\mathrm{NA})$, noradrenalina (NA), $\left[\mathrm{Ru}\left(\mathrm{NH}_{3}\right)_{4} \text { (adrenalina) }\right]^{+}(\mathrm{Ru}-\mathrm{Adr})$, adrenalina $(\mathrm{Adr}), \mathbf{R u}\left(\mathrm{NH}_{3}\right)_{4}$ (isoproterenol) $]^{+}(\mathrm{Ru}-$ Iso), isoproterenol (Iso), $\left[\mathrm{Ru}\left(\mathrm{NH}_{3}\right)_{4}(\text { dopamina) }]^{+} \text {(Ru-Dopa), dopamina (dopamina), } \mathbf{R u}\left(\mathrm{NH}_{3}\right)_{4}(\mathbf{c a t e c o l})\right]^{+}$ (Ru-Cat), ou catecol, em células SF-188. Os resultados são referentes à recuperação $24 \mathrm{~h}$ após os tratamentos em concentração igual a $200 \mu \mathrm{mol} \mathrm{L}^{-1}$. Controle representa células não tratadas. Dados são apresentados como média +/- erro padrão da média (EPM) de pelo menos 3 amostras diferentes (n). * diferente de Controle; \# diferente da respectiva catecolamina, n=3-4; One-way ANOVA com pós-teste de Newman-Keuls $(\mathbf{P}<\mathbf{0 , 0 5})$

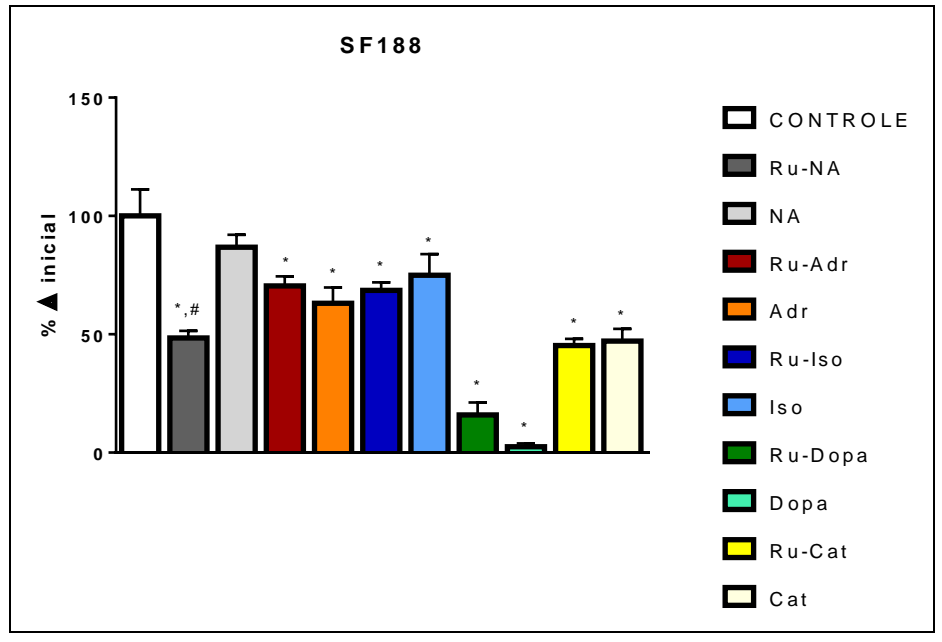

Fonte: Autora

Figura 77: Fotomicrografias representativas do ensaio de recuperação da lesão induzida por complexos e ligantes: $\left[\mathbf{R u}\left(\mathrm{NH}_{3}\right)_{4}(\text { noradrenalina) }]^{+}(\mathrm{Ru}-\mathrm{NA})\right.$, noradrenalina (NA), $\left[\mathbf{R u}\left(\mathbf{N H}_{3}\right)_{4}(\text { adrenalina) }]^{+}(\mathbf{R u}-\mathrm{Adr})\right.$, adrenalina (Adr), $\mathbf{R u}\left(\mathrm{NH}_{3}\right)_{4}(\text { isoproterenol) }]^{+}$(Ru-Iso), isoproterenol (Iso), [Ru( $\left.\mathrm{NH}_{3}\right)_{4}(\text { dopamina) }]^{+}(\mathrm{Ru}-$ Dopa), dopamina (dopamina), $\mathrm{Ru}\left(\mathrm{NH}_{3}\right)_{4}(\text { catecol) }]^{+}$(Ru-Cat), ou catecol, em células $\mathrm{SF}-188$. Os resultados são referentes à recuperação $24 \mathrm{~h}$ após os tratamentos em concentração igual a $200 \mu \mathrm{mol} \mathrm{L}^{-1}$. Controle representa células não tratadas 
CONTROLE

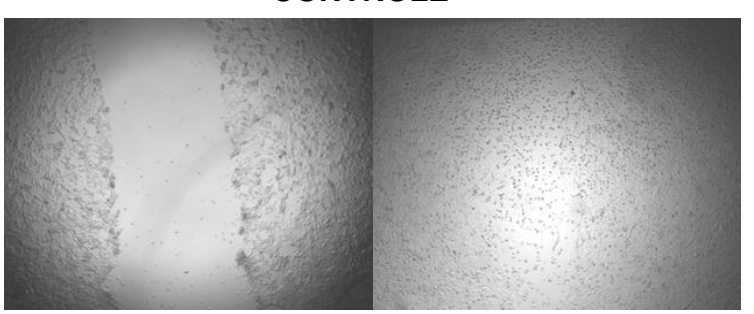

Ru-NA

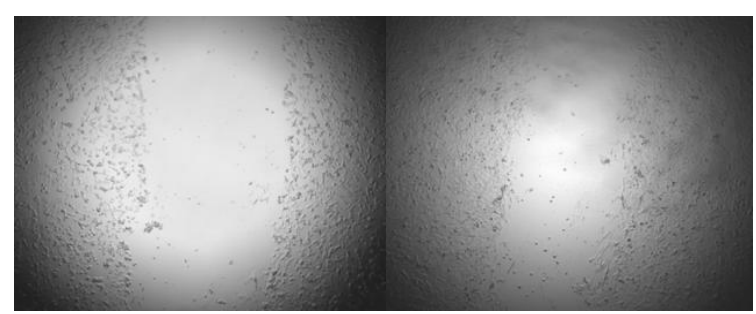

24h após o tratamento

Adr

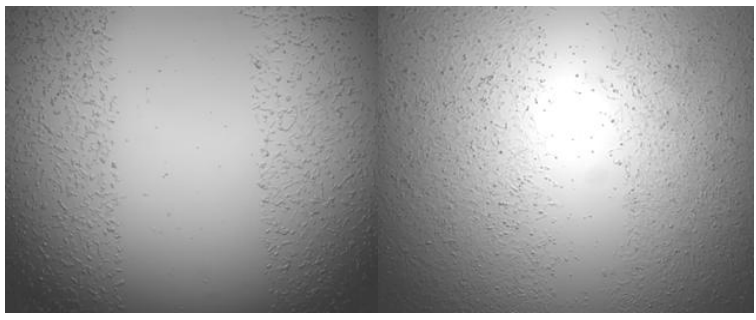

Ru-Iso

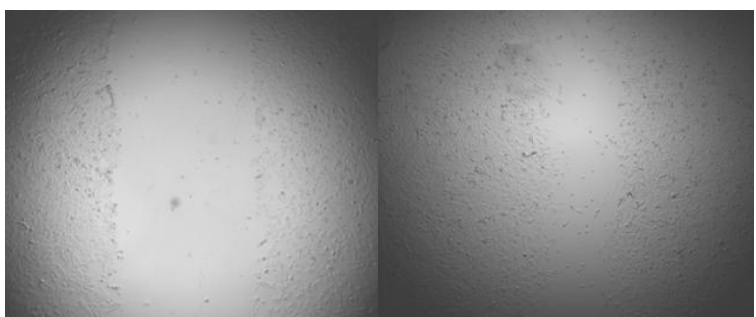

antes do tratamento

24h após o tratamento

Dopa

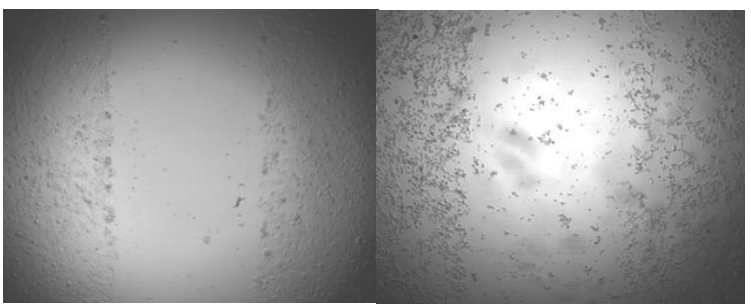

Ru-Cat

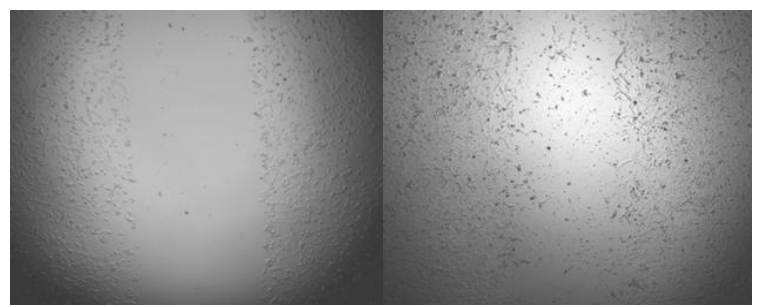

NA

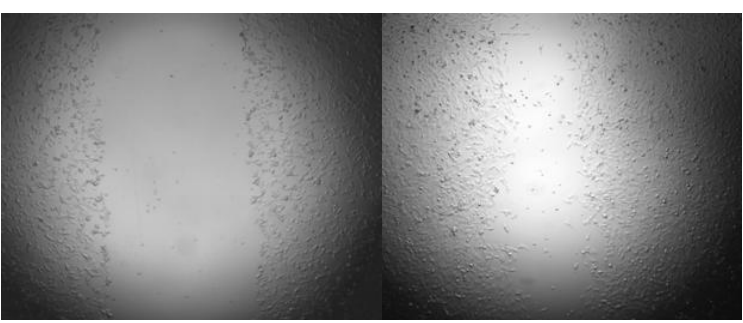

Ru-Adr

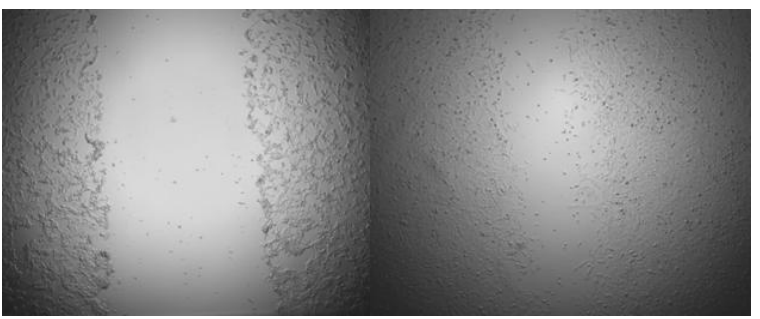

24h após o tratamento

Iso

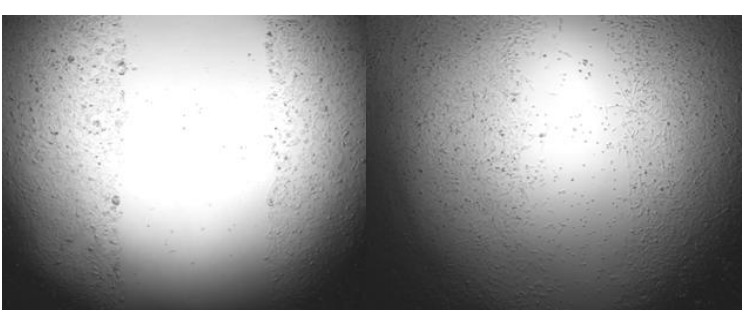

Ru-Dopa

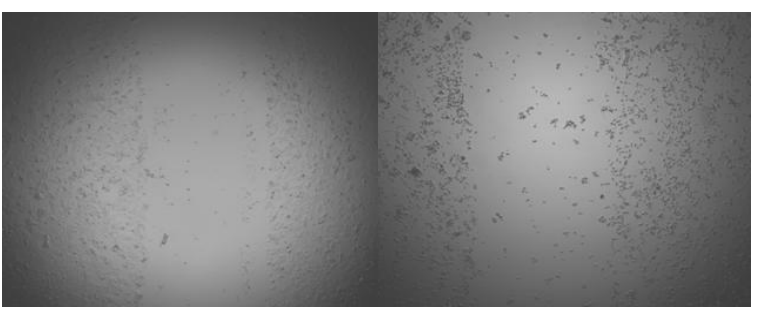

antes do tratamento

24h após o tratamento

Cat

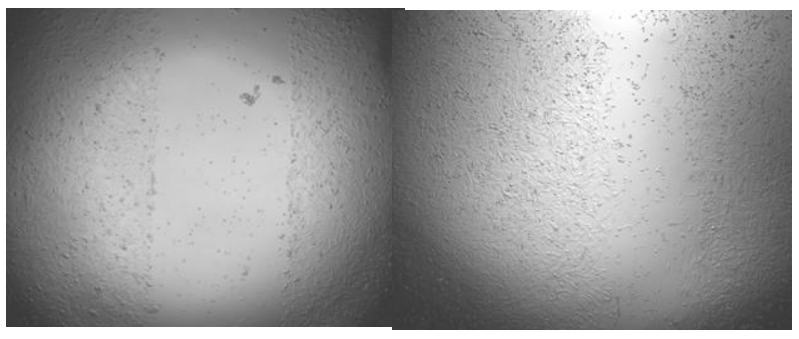

Fonte: Autora 
Nesta linhagem celular de células de gliobastoma humano pediátrico, observou-se que todos os complexos metálicos, bem como os respectivos ligantes livres, inibiram a recuperação da lesão, quando comparados ao controle, mas quando comparados às respectivas catecolaminas (ou catecol) livres, houveram efeitos diversos: para o complexo de catecol não foram observadas quaisquer diferenças em relação ao ligante livre, assim como para os complexos de adrenalina e isoproterenol e seus respectivos ligantes. Para o complexo de dopamina observou-se pequena recuperação da lesão, enquanto efeito totalmente inibitório da recuperação foi observado para o ligante livre; para noradrenalina, o oposto foi observado: à medida que o ligante livre promoveu quase total recuperação da lesão, o complexo inibiu mais que $50 \%$ este recobrimento células.

Assim, desses ensaios é possível concluir que os ligantes livres possuem maior atividade no sentido de inibir a recuperação da lesão, enquanto os complexos, de um modo geral, promovem maior recuperação da lesão. Porém, estes efeitos ocorrem desta forma apenas para células sadias e para a linhagem de origem canina, enquanto para a linhagem tumoral humana, os complexos promoveram (de um modo geral) efeitos semelhantes aos dos respectivos ligantes livres, exceto para o complexo de noradrenalina, o qual promoveu efeito maior inibitório de recuperação da lesão e para o complexo de dopamina, o qual promoveu a recuperação parcial da lesão, enquanto o ligante livre inibiu esta recuperação. Estes resultados corroboram os evidenciados nos ensaios de reatividade vascular, ciclo celular e de angiogênese na CAM.

\subsubsection{Viabilidade celular}

A viabilidade celular dos complexos foi avaliada após 24 horas de incubação com os complexos metálicos e seus respectivos ligantes livres. Os resultados são mostrados a seguir (figura 78): 
Figura 78: Análise da viabilidade celular de B16F10 após tratamento com complexos ou ligantes livres. Células B16F10 foram tratadas por $24 \mathrm{~h}$ com Ru-NA ou NA (A); Ru-Adr ou Adr (B); Ru-Dopa ou Dopamina (C); Ru-Iso ou Iso (D); Ru-Catecol ou Catecol (E) em diferentes concentrações (50 a $500 \mu \mathrm{mol}$ $\mathrm{L}^{-1}$ ) ou situação controle (em ausência de tratamento). Dados são apresentados como \% de média \pm E.P.M. do CO. * diferente de $\mathrm{CO}$; \# diferente da respectiva catecolamina na mesma concentração de estudo. Oneway ANOVA, pós-teste de Newman-Keuls $(P<0,05), n=3-4$

(A)
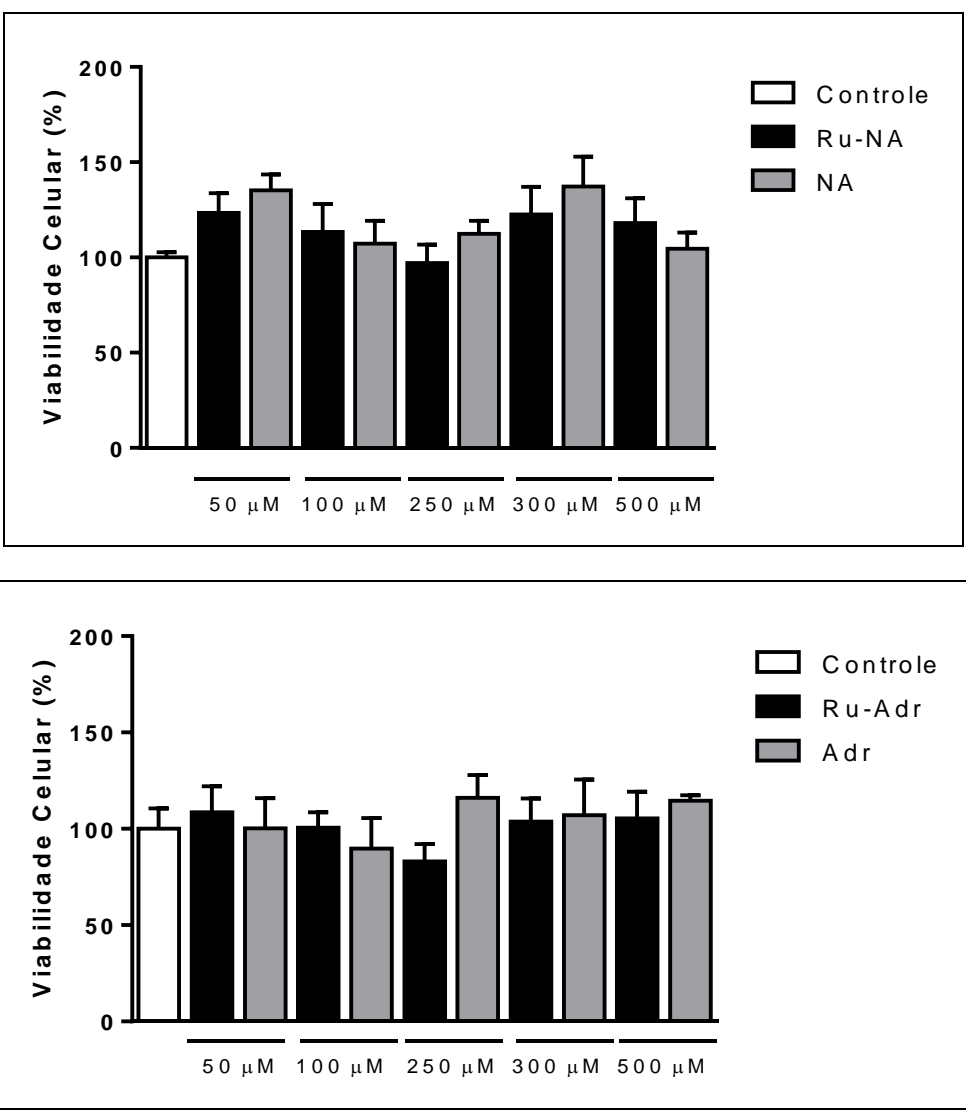

(B)

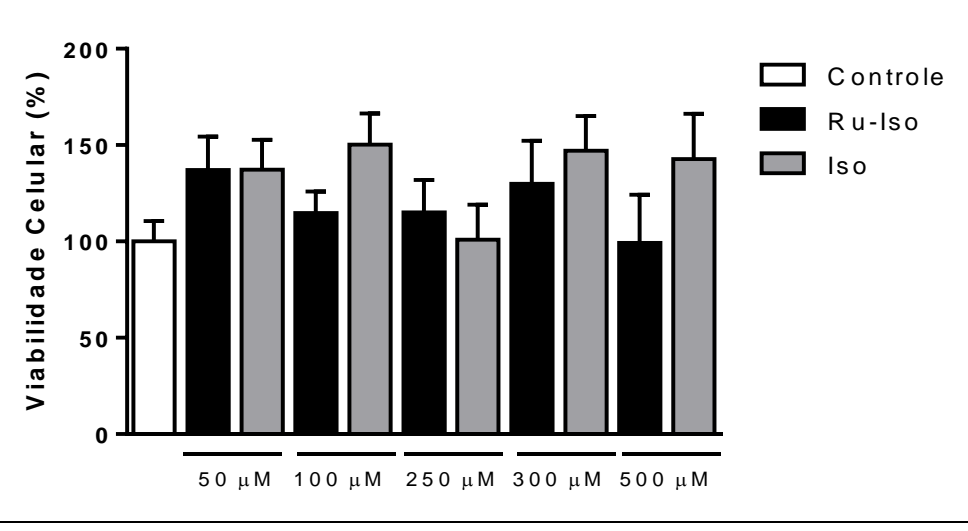


(D)

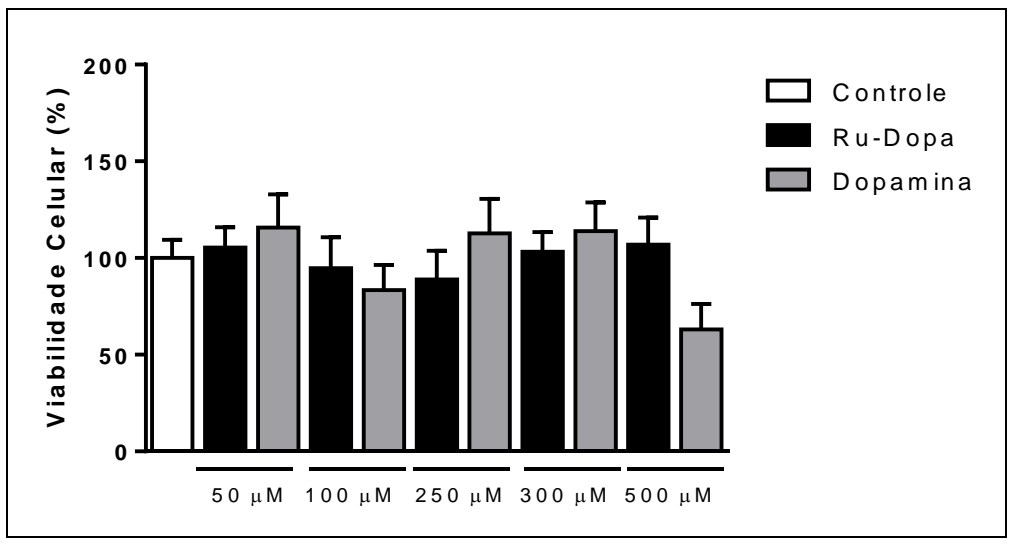

$(\mathbf{E})$

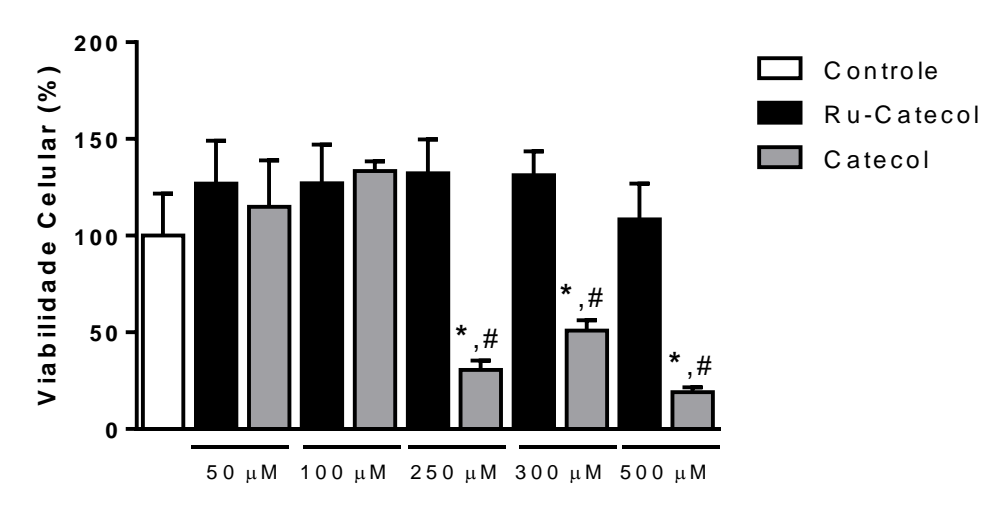

Fonte: Autora

De um modo geral, diante dos resultados deste ensaio, notou-se que os complexos não apresentam valores de viabilidade celular diferentes daqueles observados para o controle, bem como para os ligantes livres, excetuando-se o ligante catecol. Este promoveu a redução da viabilidade celular, enquanto o complexo Ru-Cat não produziu tal efeito, sugerindo que o efeito tóxico causado pelo catecol livre, é mitigado com a imobilização do sítio catecólico.

Não obstante o fato de não ser esperada citotoxicidade destes complexos, estes ensaios foram realizados, novamente, porém utilizando-se 48 horas de incubação, a fim de que possíveis efeitos de aumento (ou de diminuição) da viabilidade pudessem ser melhormente verificados. Os resultados são mostrados na figura a seguir (figura 79): 
Figura 79: Análise da viabilidade celular de B16F10 após tratamento com complexos ou ligantes livres. Células B16F10 foram tratadas por $48 \mathrm{~h}$ com Ru-NA ou NA (A); Ru-Adr ou Adr (B); Ru-Dopa ou Dopamina (C); Ru-Iso ou Iso (D); Ru-Catecol ou Catecol (E) em diferentes concentrações (50 a 500 $\mu$ mol. $\mathrm{L}^{-1}$ ) ou situação controle (em ausência de tratamento). Dados são apresentados como \% de média \pm E.P.M. do CO. * diferente de Controle; \# diferente da respectiva catecolamina na mesma concentração de estudo; a diferente de $100 \mu \mathrm{M}$ Ru-Cat; b Diferente de $10 \mu \mathrm{M}$ Ru-Cat. One-way ANOVA, pós-teste de Newman-Keuls $(P<0,05), n=3$

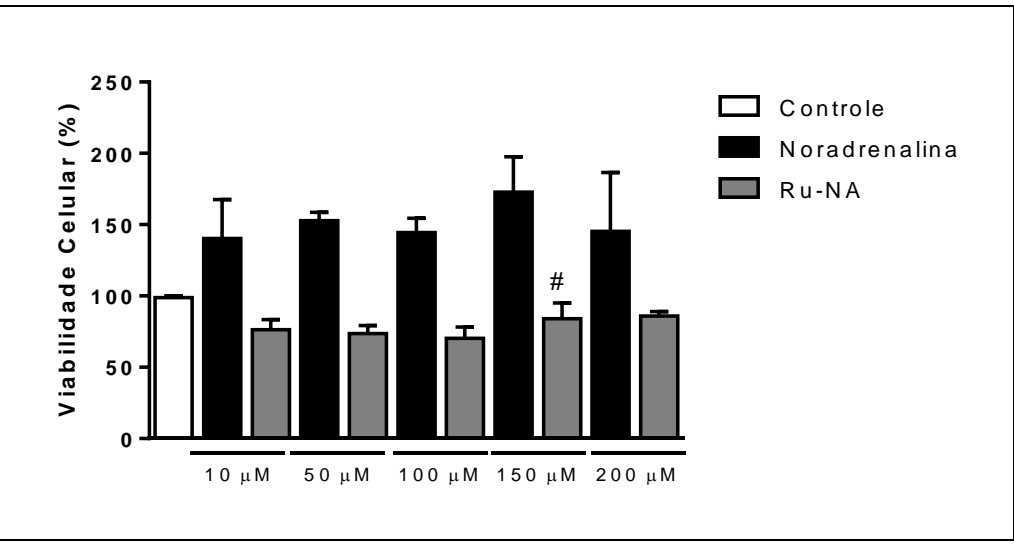

(A)

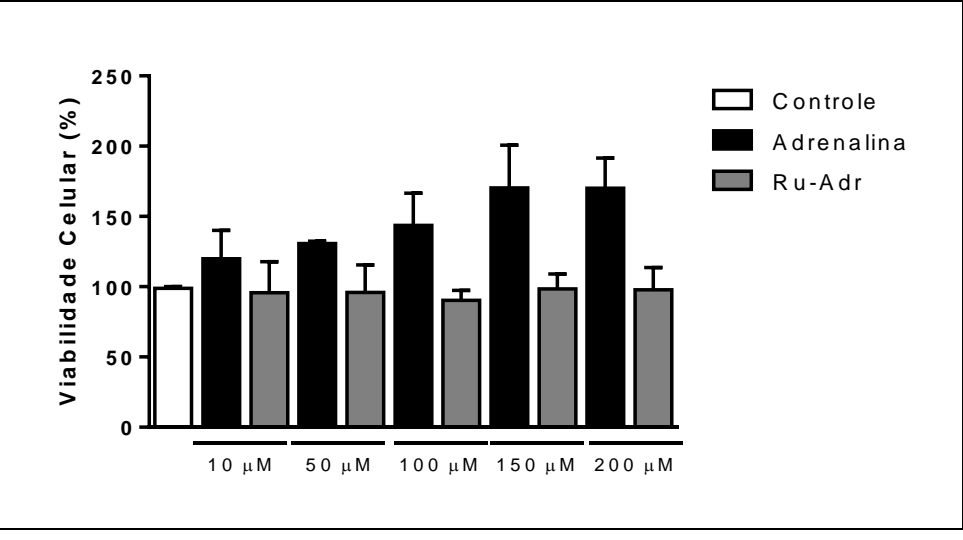

(B)

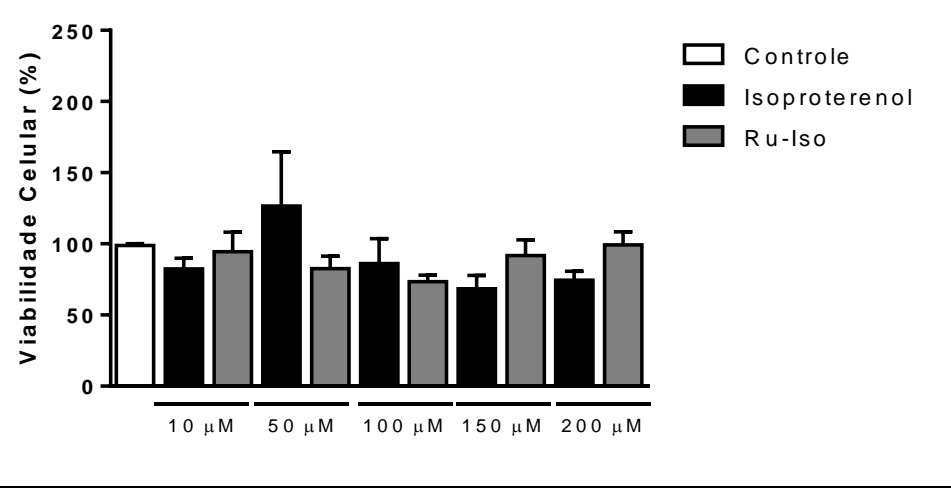

(C) 
(D)

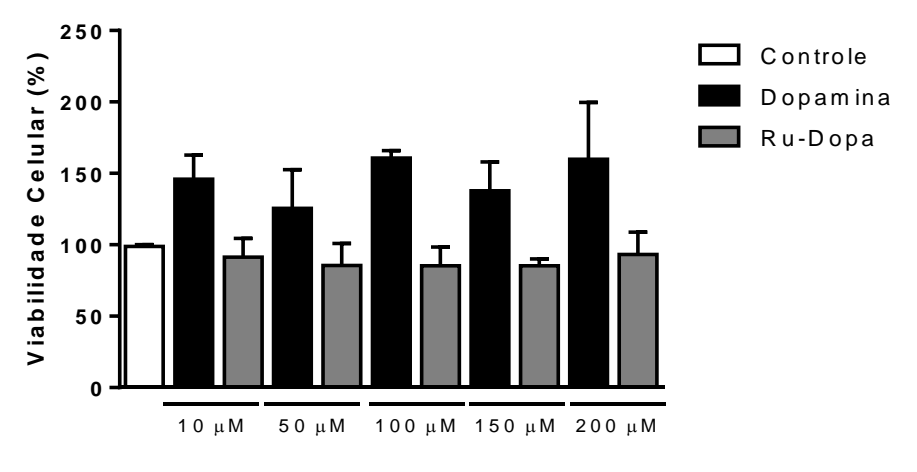

Fonte: Autora

(E)

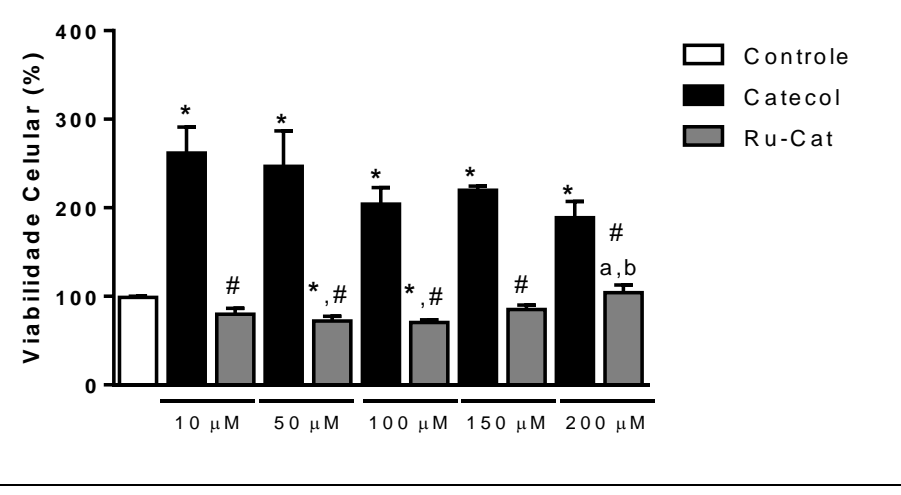

Nos ensaios realizados após 48 horas de incubação, foram observadas algumas tendências, embora nem todas sejam expressas por números estatisticamente significativos: os ligantes noradrenalina, adrenalina, dopamina e catecol apresentaram resultados de viabilidade celular muito maiores que aqueles observados para os controles. Para este aumento da viabilidade celular duas são as hipóteses: os ligantes livres induzem a aceleração da divisão celular, aumentando, de fato, a quantidade de células em cada poço, ou aumentam o metabolismo dessas células, o que também refletiria no aumento da conversão de MTT em formazan. Neste ensaio as duas possibilidades são viáveis, pois em se tratando de neurotransmissores que são também hormônios, o aumento do metabolismo é possível, bem como a proliferação, uma vez que no ensaio da recuperação da lesão foi verificada a possível proliferação celular. Para o isoproterenol este efeito não foi observado.

Os complexos de noradrenalina, adrenalina, dopamina e catecol apresentaram valores de viabilidade celular menores quando comparados aos dos ligantes livres, porém valores em pouco diferem daqueles observados para o controle, indicando que os complexos, 
embora não apresentem efeito de redução da viabilidade celular, impedem o efeito proliferativo ou de aceleração do metabolismo que ocorre na presença dos ligantes livres.

Tal como narrado anteriormente, os pesquisadores observaram que o complexo NAMI-A não apresentou consideráveis resultados no quesito citotoxicidade, porém, quando estudado in vivo, demonstrou propriedades antiangiogênicas e antimetastáticas (BARRY; SADLER, 2013). Assim, o fato de os complexos aqui reportados não apresentarem citotoxicidade elevada não se traduz em ausência de atividade anticâncer, bem como antiangiogênica - razão pela qual os outros ensaios foram conduzidos no sentido de se elucidar estas outras propriedades.

\subsubsection{Interação com fs-DNA}

Com a finalidade de ampliar a compreensão da atuação dos complexos metálicos nas células, bem como para se investigar a possibilidade de interação com o DNA, foram conduzidos ensaios tanto de titulação dos complexos com uma solução de DNA, acompanhado por espectroscopia UV-vis, quanto de deslocamento do brometo de etídio este, acompanhado por espectroscopia de fluorescência.

Considerando-se que o DNA é responsável pela regulagem de funções essenciais nas células, tais como armazenamento das informações genéticas, síntese proteica e divisão celular, experimentos dessa natureza são importantes não somente para a verificação do tipo de interação de um composto específico, mas também para o planejamento de novos compostos.

São descritas três principais formas de interação entre o DNA e os compostos anticâncer: por meio do controle das polimerases e dos fatores de transcrição; possibilitando a ligação do RNA a dupla hélice do DNA, para formar uma tripla hélice de ácidos nucleicos, ou ainda, formando híbridos de uma cadeia de DNA com o RNA, podendo impedir a transcrição; e por meio de ligação de moléculas pequenas às hélices do DNA, através de diversas formas de interação (SIRAJUDDIN; ALI; BADSHAH, 2013).

A ligação composto-DNA pode ocorrer de forma covalente e não covalente. Quando há ligações covalentes, têm-se a formação de adutos - os quais podem ocorrer de duas formas, pela alquilação, que via de regra ocorre na base nitrogenada guanina, ou pela ligação inter ou intracadeias do DNA. Ligações covalentes com o DNA são irreversíveis e resultam na inibição total dos processos celulares regulados por esta biomolécula, de forma que culminam na morte celular (SIRAJUDDIN; ALI; BADSHAH, 2013; MOREIRA, 2016; PRAVIN et. al., 2016). Os complexos de platina são conhecidos por sua facilidade em se 
ligarem covalentemente ao DNA, induzindo, desta forma, diversas vias de sinalização, as quais contribuem, entre outros, para a apoptose (MIGNOLET et. al., 2016).

Interações do tipo não covalente resultam em compostos com menor citotoxicidade, quando comparados àqueles que se ligam covalentemente ao DNA, no entanto, não menos importantes, haja vista que este tipo de interação pode envolver alterações na estrutura tridimensional do DNA, podendo culminar na ruptura da estrutura, bem como no impedimento de interações do tipo proteína-DNA (SIRAJUDDIN; ALI; BADSHAH, 2013).

Para as interações não covalentes, três possibilidades são observadas: a intercalação (ocorre entre as bases nitrogenadas do DNA, sem romper as ligações de hidrogênio existentes entre elas), a qual é mantida por forças de Van der Waals, ligações de hidrogênio, ou interações hidrofóbicas; as interações nas cavidades internas/sulcos do DNA; e as ligações externas à hélice do DNA, as quais ocorrem por interações eletrostáticas (SIRAJUDDIN; ALI; BADSHAH, 2013; NI; LIN; KOKOT, 2006).

No caso de possíveis metalodrogas com ligantes aromáticos há duas possibilidades de interação: tanto pela ligação do metal ao DNA, quanto por intercalação dos ligantes entre as bases nitrogenadas do DNA (LIU; SADLER, 2010; SIRAJUDDIN; ALI; BADSHAH, 2013).

Postulados os diferentes tipos de interação entre os compostos e o DNA, e considerando-se que essas distintas formas de interação produzem alterações espectrais, as quais podem ser acompanhadas - por exemplo, por espectroscopia na região do UV-vis considerou-se que conhecer o comportamento dos complexos, em face da molécula de DNA, seria também importante, não obstante o fato de diversos experimentos de cunho biológico já terem sido conduzidos ao longo do desenvolvimento deste trabalho.

\subsubsection{Interação com $f s$-DNA - titulação espectrofotométrica na região do UV-Vis}

Previamente à utilização do DNA, verificou-se a razão entre as absorbâncias em 260 e $280 \mathrm{~nm}$. A razão encontrada, igual 1,88 demonstra que o DNA estava livre de proteínas e passível de ser utilizado no experimento (SIRAJUDDIN; ALI; BADSHAH, 2013).

Devido à presença de cromóforos nas bases nitrogenadas do DNA, este possui uma banda intensa na região de $260 \mathrm{~nm}$. A literatura é ampla no que se refere à interpretação dos espectros de absorção na região do UV-vis, quando se trata de interação com o DNA, sendo que as alterações podem ser monitoradas tanto nesta região, quanto nas bandas dos próprios complexos, no caso de serem observadas mudanças (ESHKOURFU et. al., 2011; ROCHA, 2014). 
Geralmente, para os compostos que interagem por intercalação, observam-se o efeito hipocrômico e o deslocamento batocrômico, sendo que a banda é reduzida proporcionalmente com o cubo da redução da distância entre o cromóforo e as bases nitrogenadas do DNA, enquanto para aqueles que interagem eletrostaticamente, externamente às hélices - por ligações aos grupamentos fosfato do DNA - é observado o efeito hipercrômico. O hipercromismo é, também, observado para compostos que interagem covalentemente com o DNA, bem como para aqueles que causam danos à estrutura secundária do DNA (LIU et. al., 2002; SIRAJUDDIN; ALI; BADSHAH, 2013; SHAHABADI; MOHAMMADI; ALIZADEH, 2011).

Os experimentos de titulação dos complexos metálicos com a solução de $f s$-DNA, para os cinco complexos, apresentaram perfil semelhante, como pode ser visualizado a seguir (figuras 80 a 84). No corpo do texto serão mostrados os espectros referentes aos ensaios realizados a $25^{\circ} \mathrm{C}$, enquanto os referentes a $30^{\circ}$ e $37^{\circ} \mathrm{C}$ seguem no apêndice deste texto (figuras 142 a 151).

Figura 80: Titulação do complexo $\left[\mathrm{Ru}\left(\mathrm{NH}_{3}\right)_{4}(\text { isoproterenol })\right]^{+}$, a $25^{\circ} \mathrm{C}, \operatorname{com} f s$-DNA, acompanhada por espectroscopia na região do UV-vis

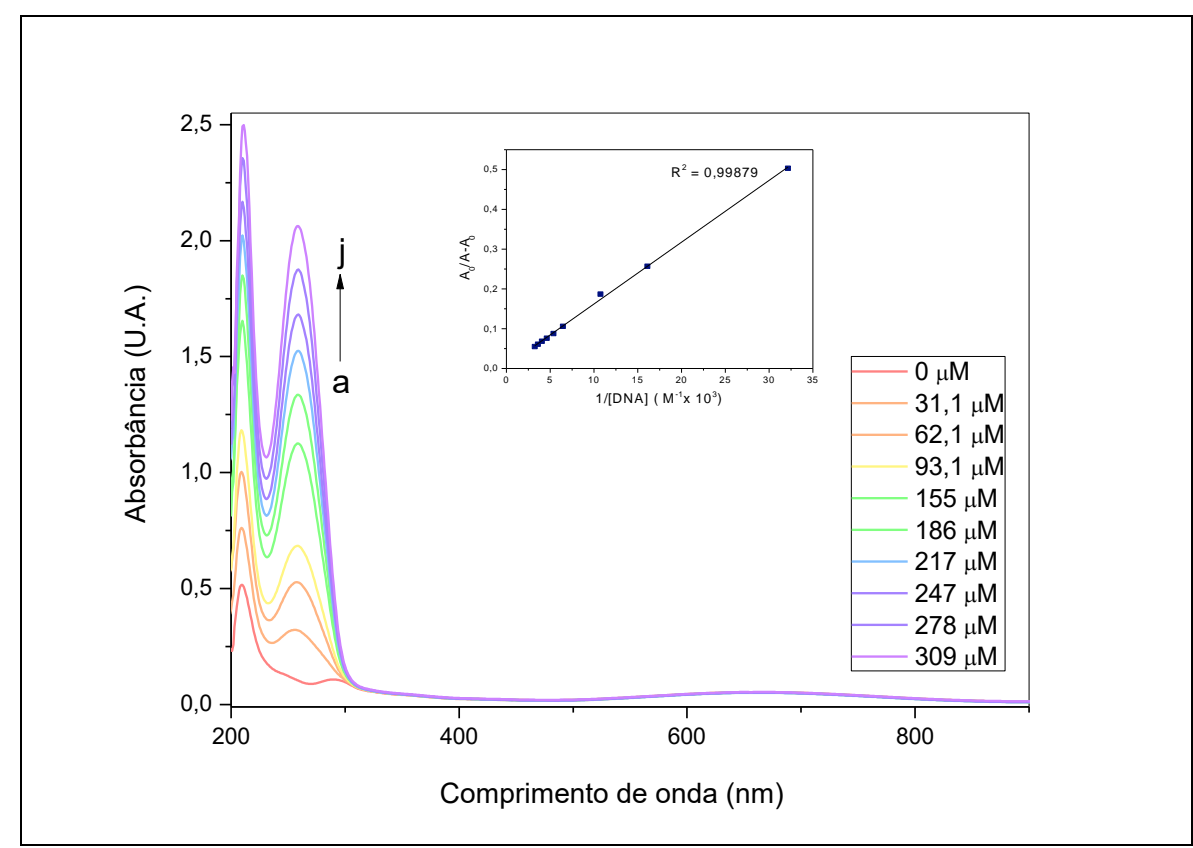

Fonte: Autora 


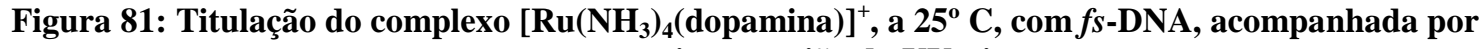
espectroscopia na região do $\mathrm{UV}$-vis

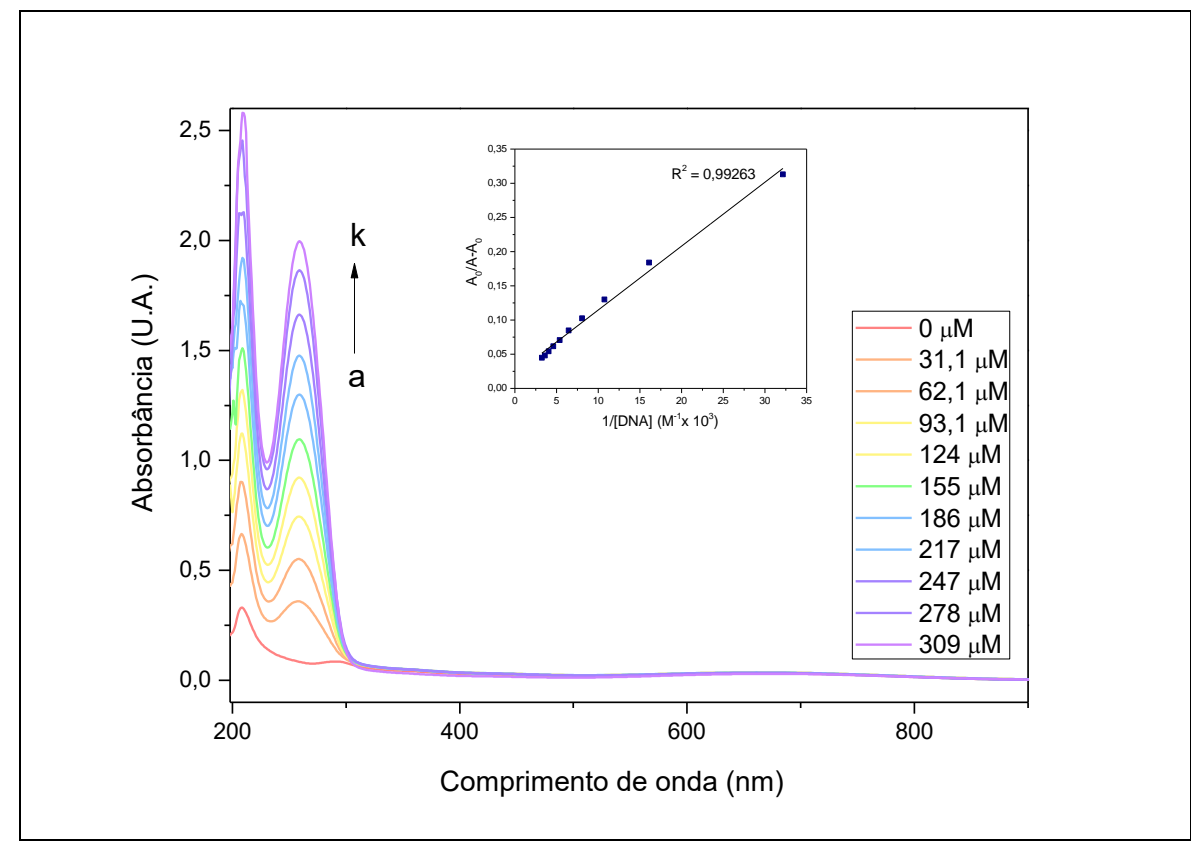

Fonte: Autora

Figura 82: Titulação do complexo $\left[\mathrm{Ru}\left(\mathrm{NH}_{3}\right)_{4}(\text { noradrenalina })\right]^{+}$, a $25^{\circ} \mathrm{C}, \operatorname{com} f s-\mathrm{DNA}$, acompanhada por espectroscopia na região do $\mathrm{UV}$-vis

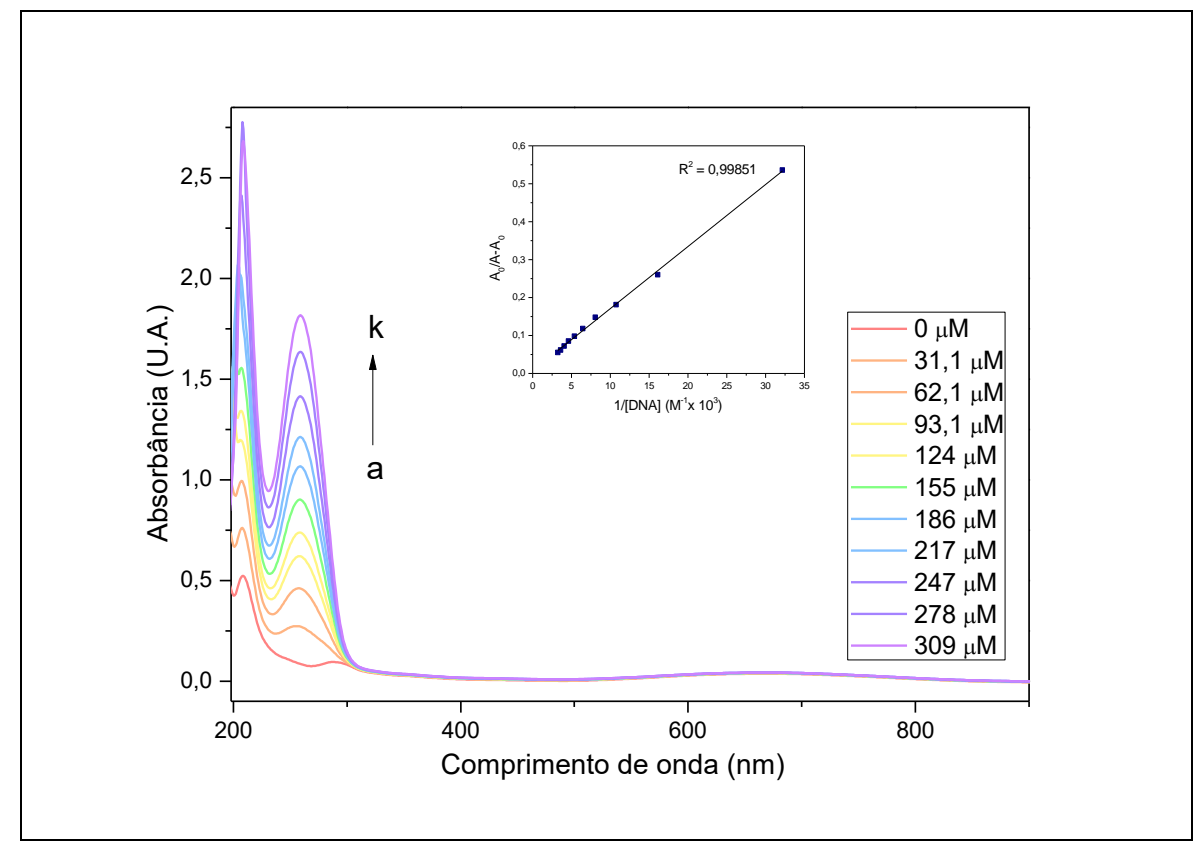

Fonte: Autora 
Figura 83: Titulação do complexo $\left[\mathrm{Ru}\left(\mathrm{NH}_{3}\right)_{4}(\text { catecol })\right]^{+}$, a $25^{\circ} \mathrm{C}, \operatorname{com} f s-\mathrm{DNA}$, acompanhada por espectroscopia na região do $\mathrm{UV}$-vis

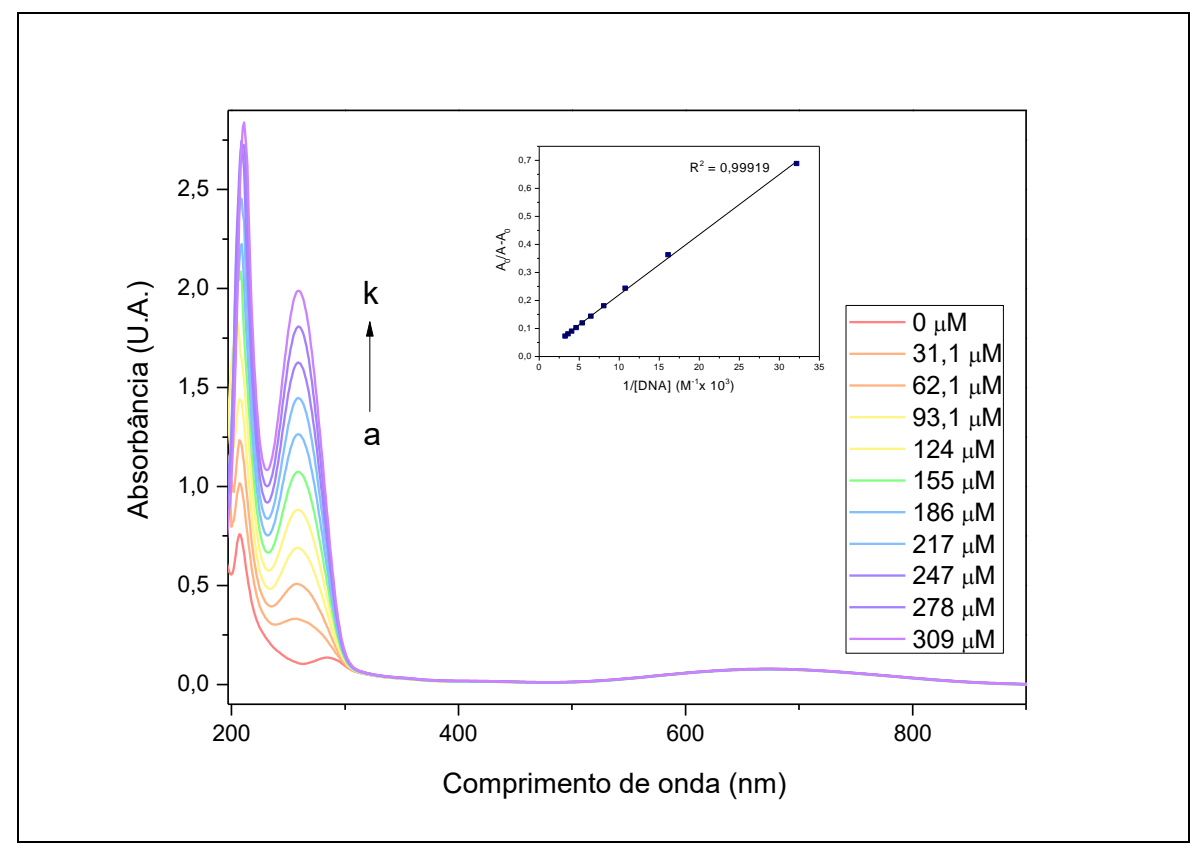

Fonte: Autora

Figura 84: Titulação do complexo $\left[\mathrm{Ru}\left(\mathrm{NH}_{3}\right)_{4}(\operatorname{adrenalina})\right]^{+}, \mathbf{a}^{\circ} \mathrm{C}, \operatorname{com} f s$-DNA, acompanhada por espectroscopia na região do $\mathrm{UV}$-vis

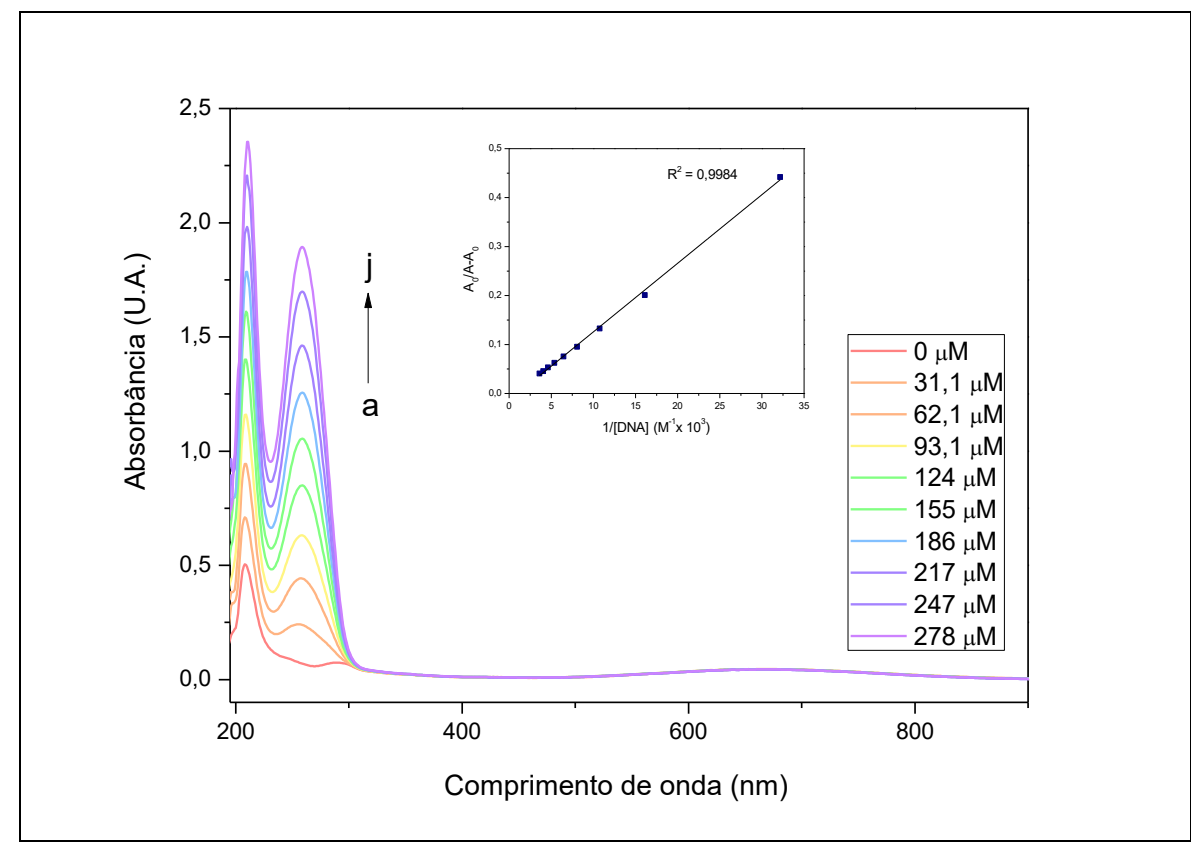

Fonte: Autora 
Para os complexos ora estudados, não foi observada nenhuma outra alteração excetuando-se a banda do DNA, razão pela qual esta foi utilizada para o cálculo da constante intrínseca da interação. Os resultados foram interpretados à luz da equação de BenesiHildebrand, pois não obstante o fato desse modelo matemático ser proposto para interações bimoleculares de moléculas discretas, o mesmo tem sido amplamente utilizado para a interpretação da interação de complexos metálicos com DNA, razão pela qual se optou por sua aplicação na análise deste conjunto de dados. Da razão dos coeficientes linear e angular do gráfico de $\mathrm{A}_{0} /\left(\mathrm{A}-\mathrm{A}_{0}\right)$ versus $1 /[\mathrm{DNA}]$ é possível a obtenção da constante da interação (ESHKOURFU et. al., 2011; SHAHABADI; MOHAMMADI; ALIZADEH, 2011), sendo $\mathrm{A}_{0}$ a absorbância do complexo na ausência do DNA e A, a absorbância em qualquer ponto da titulação.

$$
\frac{A_{0}}{A-A_{0}}=\frac{\varepsilon_{G}}{\varepsilon_{H-G-\varepsilon_{G}}}+\frac{\varepsilon_{G}}{\varepsilon_{H-G-\varepsilon_{G}}} \frac{1}{K[D N A]}
$$

Os valores das constantes de interação são mostrados na tabela a seguir (15), comparados a outros extraídos da literatura:

Tabela 15: Constantes intrínsecas $\left(K_{b}\right)$ da interação dos complexos com ofs-DNA

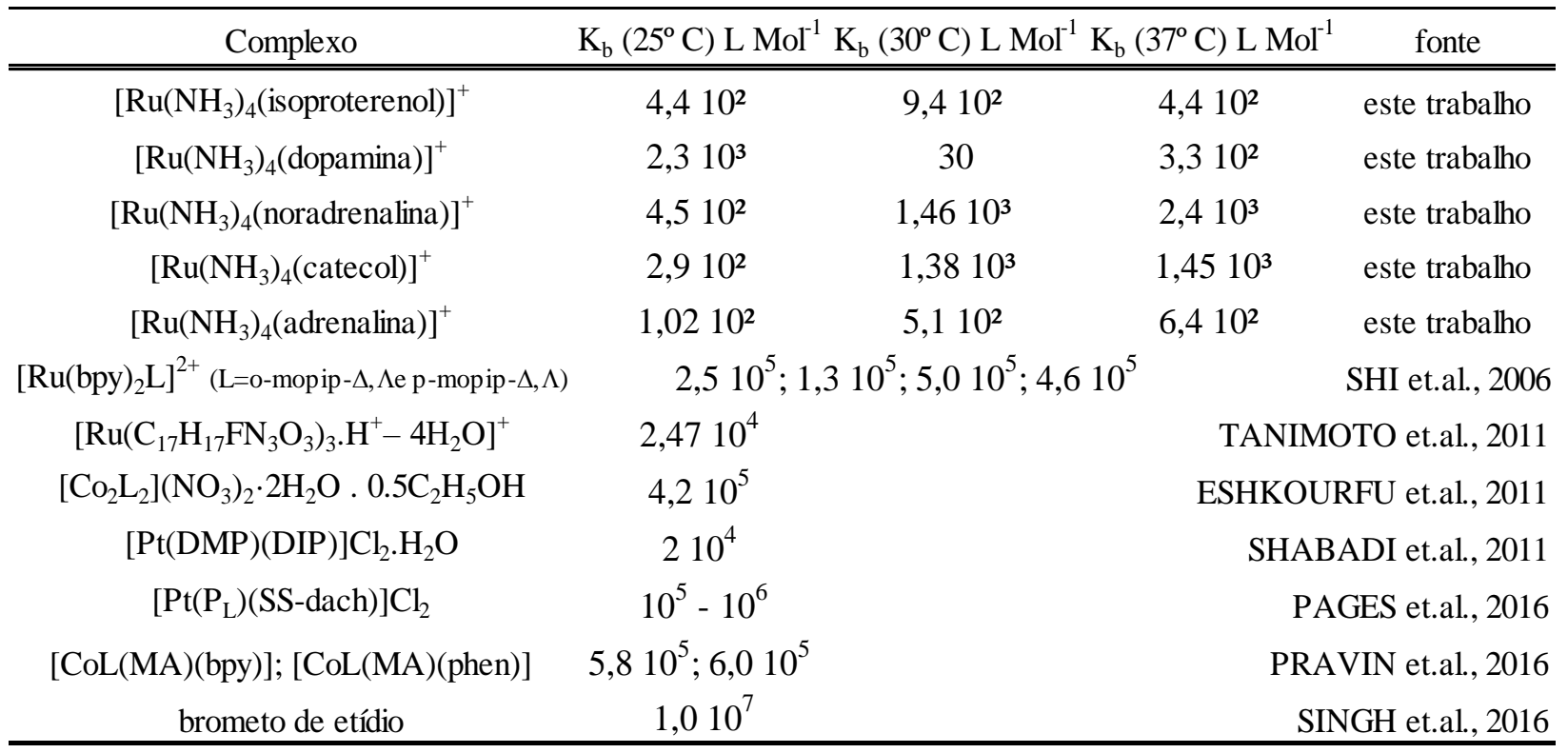

Conclui-se da análise dos dados da tabela supra que, de um modo geral, os maiores valores para as constantes $\mathrm{K}_{\mathrm{b}}$ são os obtidos para a interação dos complexos de noradrenalina e catecol $\left(\sim 10^{3}\right)$. No entanto, os complexos metálicos aqui estudados interagem 
pouco com o DNA, possuindo constantes intrínsecas de ligação $\left(\mathrm{K}_{\mathrm{b}}\right)$ menores que as reportadas na literatura para outros complexos e para intercaladores já conhecidos. As maiores constantes encontradas são referentes à interação de complexos que se ligam covalentemente ao DNA - geralmente de platina - e para intercaladores fortes, tais como o BET (SINGH; SRIVASTAVA; PATRA, 2016; SHI et. al., 2006; SHAHABADI; MOHAMMADI; ALIZADEH, 2011).

O hipercromismo na banda do DNA é compreendido como resultante de interações externas a dupla hélice do DNA, tais como interações eletrostáticas (geralmente nos grupos fosfato), as quais possibilitam maior exposição das bases nitrogenadas e, portanto, maior intensidade de absorção nesta região (ROCHA, 2014). A estrutura dos complexos e os grupamentos existentes (amina e hidroxila) permitem que este tipo de consideração seja aplicada aos complexos estudados, razão pela qual a banda em $260 \mathrm{~nm}$ não deve ser negligenciada e pode ser considerada como ferramenta para acompanhamento da interação.

Além disso, não foram verificadas alterações no que se refere ao espectro do complexo, sendo possível afirmar que se trata de interações fracas, as quais não causam alterações nos orbitais moleculares dos mesmos.

Com a finalidade de comprovação de que as alterações espectrais eram oriundas das interações, e não do efeito de concentração do DNA na solução, um espectro com a solução do DNA na maior concentração utilizada é mostrado a seguir (figura 85):

Figura 85: Espectro de absorção do $f s$-DNA na maior concentração utilizada nos ensaios reportados (309 $\mu \mathrm{mol} \mathrm{L^{-1 }}$ )

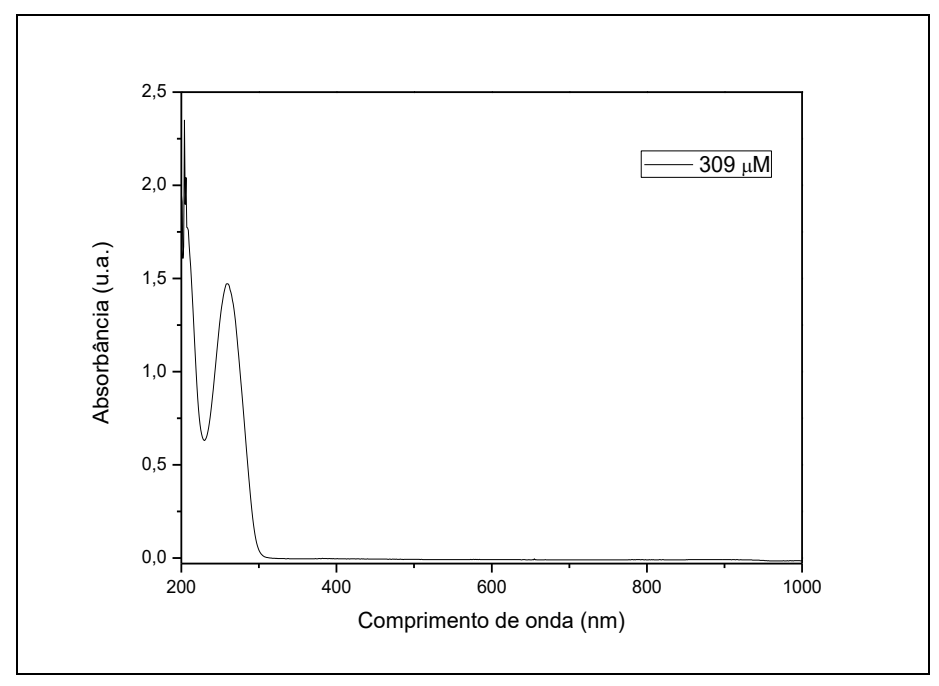

Fonte: Autora 
Pôde-se concluir que o efeito hipercrômico observado para os complexos é maior que 40\% - em relação ao DNA em solução, na mesma concentração - sendo harmônico com a literatura quando são observadas interações eletrostáticas e, consequentemente, distorções na estrutura do DNA, provavelmente no sentido de relaxar a estrutura tridimensional, culminando em maior exposição dos cromóforos (SIRAJUDDIN; ALI; BADSHAH, 2013). Destacam-se neste sentido, os efeitos hipercrômicos calculados para o complexo de catecol, em $30^{\circ} \mathrm{C}$, que foi igual a $43 \%$, para o de noradrenalina (a $37^{\circ} \mathrm{C}$ ), igual a $47 \%$, e para o de isoproterenol (a $\left.37^{\circ} \mathrm{C}\right)$, igual a $53 \%$.

Devido à possibilidade de se verificar o tipo de interação presente, além das informações que podem ser extraídas dos próprios espectros, as titulações foram conduzidas em três diferentes temperaturas. De posse das constantes intrínsecas nas três temperaturas, foi possível a obtenção dos parâmetros termodinâmicos (variação de entropia, $\Delta \mathrm{S}$; entalpia, $\Delta \mathrm{H}$; e energia livre de Gibbs, $\Delta \mathrm{G}$ ) envolvidos nos processos, pela aplicação da equação de Van't Hoff (MOREIRA, 2016):

$$
\ln K_{b}=-\frac{\Delta H}{R T}+\frac{\Delta S}{R} \quad \text { (Equação 4) }
$$

Do gráfico de $\ln \left(\mathrm{K}_{\mathrm{b}}\right)$ versus $1 / \mathrm{T}(\mathrm{K})$, podem ser extraídos os resultados (o coeficiente angular da reta fornece $-\Delta H / R$ e, o linear, $\Delta S / R$, onde $R$ é a constante universal dos gases perfeitos $=8,3145 \mathrm{~J} \mathrm{~mol}^{-1} \mathrm{~K}^{-1}$ ), que são apresentados na tabela a seguir (tabela 16):

Tabela 16: Parâmetros termodinâmicos para os processos

\begin{tabular}{lccccc}
\hline \multicolumn{1}{c}{ Complexo } & $\Delta \mathrm{H}\left(\mathrm{KJ} \mathrm{Mol}^{-1}\right)$ & $\Delta \mathrm{S}\left(\mathrm{J} \mathrm{Mol}^{-1} \mathrm{~K}^{-1}\right)$ & $\Delta \mathrm{G}_{(298 \mathrm{~K})}\left(\mathrm{KJ} \mathrm{Mol}^{-1}\right) \Delta \mathrm{G}_{(303 \mathrm{~K})}\left(\mathrm{KJ} \mathrm{Mol}^{-1}\right)$ & $\Delta \mathrm{G}_{(310 \mathrm{~K})}\left(\mathrm{J} \mathrm{Mol}^{-1}\right)$ \\
\hline \hline$\left[\mathrm{Ru}\left(\mathrm{NH}_{3}\right)_{4}(\mathrm{iso})\right]^{+}$ & $-4,74$ & 37 & -15 & -17 & -16 \\
{$\left[\mathrm{Ru}\left(\mathrm{NH}_{3}\right)_{4}(\mathrm{dop})\right]^{+}$} & -104 & -290 & $-19,2$ & $-8,5$ & -15 \\
{$\left[\mathrm{Ru}\left(\mathrm{NH}_{3}\right)_{4}(\mathrm{nor})\right]^{+}$} & 104 & 402 & -15 & -18 & -20 \\
{$\left[\mathrm{Ru}\left(\mathrm{NH}_{3}\right)_{4}(\mathrm{cat})\right]^{+}$} & 98 & 377 & -14 & $-18,4$ & -19 \\
{$\left[\mathrm{Ru}\left(\mathrm{NH}_{3}\right)_{4}(\mathrm{adr})\right]^{+}$} & 110 & 418 & $-11,5$ & -16 & -17 \\
\hline
\end{tabular}

Fonte: Autora

O valor da energia livre de Gibbs para cada processo foi calculado pela equação:

$$
\Delta G=-R T \ln (K) \quad(\text { Equação 5) }
$$


A literatura (ROSS; SUBRAMANIAN apud MOREIRA, 2016; REIS, 2014) reporta que valores de $\Delta \mathrm{H}>0$ e $\Delta \mathrm{S}>0$ estão associados a interações com caráter hidrofóbico predominante; enquanto valores de $\Delta \mathrm{H}<0$ e $\Delta \mathrm{S}<0$ são referentes a interações do tipo Van der Waals ou ligações de hidrogênio; e valores $\Delta H<0 \operatorname{com} \Delta S>0$, são relativos a interações eletrostáticas. À luz desta interpretação, para os valores de variação de entalpia e entropia encontrados, as interações dos complexos de isoproterenol seriam eletrostáticas; enquanto para o de dopamina, interação de Van der Waals ou ligações de hidrogênio; para os demais complexos, as interações seriam de caráter hidrofóbico.

Considerando-se a estrutura dos complexos, os valores relativamente baixos das constante de interação $\left(K_{b}\right)$ encontrados e o efeito hipercrômico na banda do DNA em 260 $\mathrm{nm}$, as interações entre os relatados complexos e o DNA seriam melhormente descritas como eletrostáticas, ou ainda, ligações de hidrogênio. Especificamente para o complexo cujo ligante é o catecol e para o qual não há a presença de substituintes no anel aromático, pode-se considerar a hipótese de interações hidrofóbicas. Para os complexos de noradrenalina e adrenalina, possivelmente a pequena diferença entre os valores das constantes $\mathrm{K}_{\mathrm{b}}$ a $30^{\circ} \mathrm{C}$ e $37^{\circ} \mathrm{C}$ conduziu a valores inadequados de $\Delta \mathrm{H}$ e $\Delta \mathrm{S}$.

Os valores de $\Delta \mathrm{G}$ negativos indicam que todas as interações analisadas são espontâneas, nas três temperaturas.

Importante destacar que embora este tipo de análise seja corriqueiro, a maneira como as interações (dos mais diversos compostos com o DNA) ocorrem não é totalmente elucidada (SIRAJUDDIN et. al., 2013).

\subsubsection{Deslocamento do brometo de etídio - espectroscopia de fluorescência}

O brometo de etídio (BET) é considerado um forte agente intercalador. Possui estrutura com estendida conjugação que lhe possibilita ser um fluoróforo. No entanto, sua emissão é intensificada quando intercalado na estrutura do DNA (SINGH; SRIVASTAVA; PATRA, 2016). A constante da interação do brometo de etídio com o DNA é $1,010^{7} \mathrm{~L} \mathrm{~mol}^{-1}$.

Uma das formas amplamente utilizadas para a verificação da interação de um complexo com o DNA consiste no experimento de deslocamento do brometo de etídio, cuja análise consiste na quantificação da supressão da fluorescência do brometo de etídio - que ocorre em razão de o fluoróforo ser substituído por outro intercalador (SINGH; SRIVASTAVA; PATRA, 2016; PRAVIN et. al., 2016; LIU et. al., 2002). Os espectros de 
supressão de fluorescência do fluoróforo, no sistema BET-DNA são mostrados a seguir (figuras 86 a 90):

Figura 86: Espectros de emissão do sistema BET-DNA, na presença de diferentes concentrações de $\left[\mathrm{Ru}\left(\mathrm{NH}_{3}\right)_{4}(\text { isoproterenol })\right]^{+}$

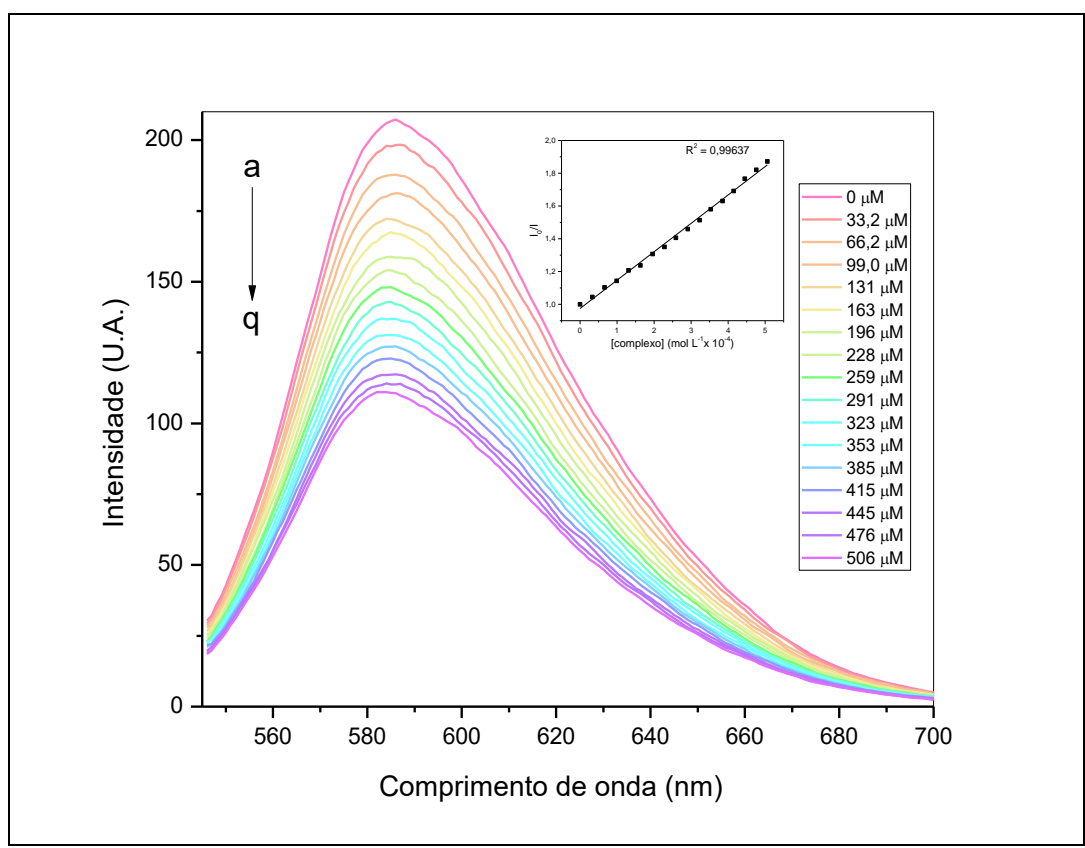

Fonte: Autora

Figura 87: Espectros de emissão do sistema BET-DNA, na presença de diferentes concentrações de $\left[\mathrm{Ru}\left(\mathrm{NH}_{3}\right)_{4}(\text { dopamina })\right]^{+}$com a regressão linear da equação de Stern-Volmer

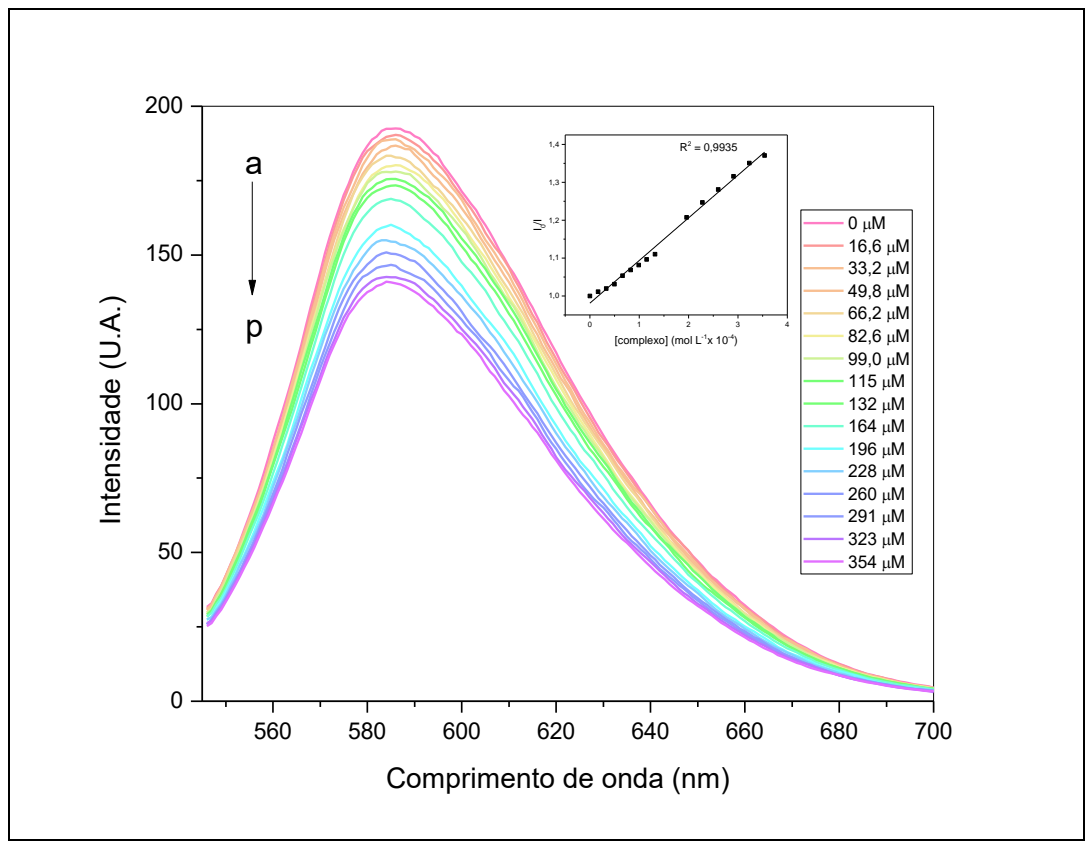

Fonte: Autora 
Figura 88: Espectros de emissão do sistema BET-DNA, na presença de diferentes concentrações de $\left[\mathbf{R u}\left(\mathrm{NH}_{3}\right)_{4}(\text { noradrenalina })\right]^{+}$com a regressão linear da equação de Stern-Volmer

Fonte: Autora

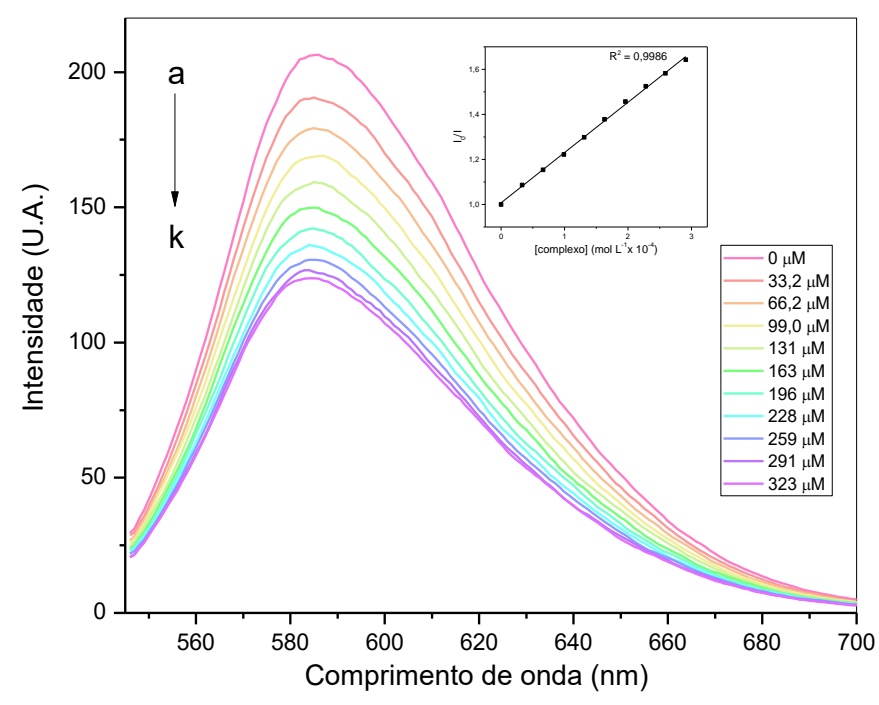

Figura 89: Espectros de emissão do sistema BET-DNA, na presença de diferentes concentrações de $\left[\mathrm{Ru}\left(\mathrm{NH}_{3}\right)_{4}(\text { catecol })\right]^{+}$

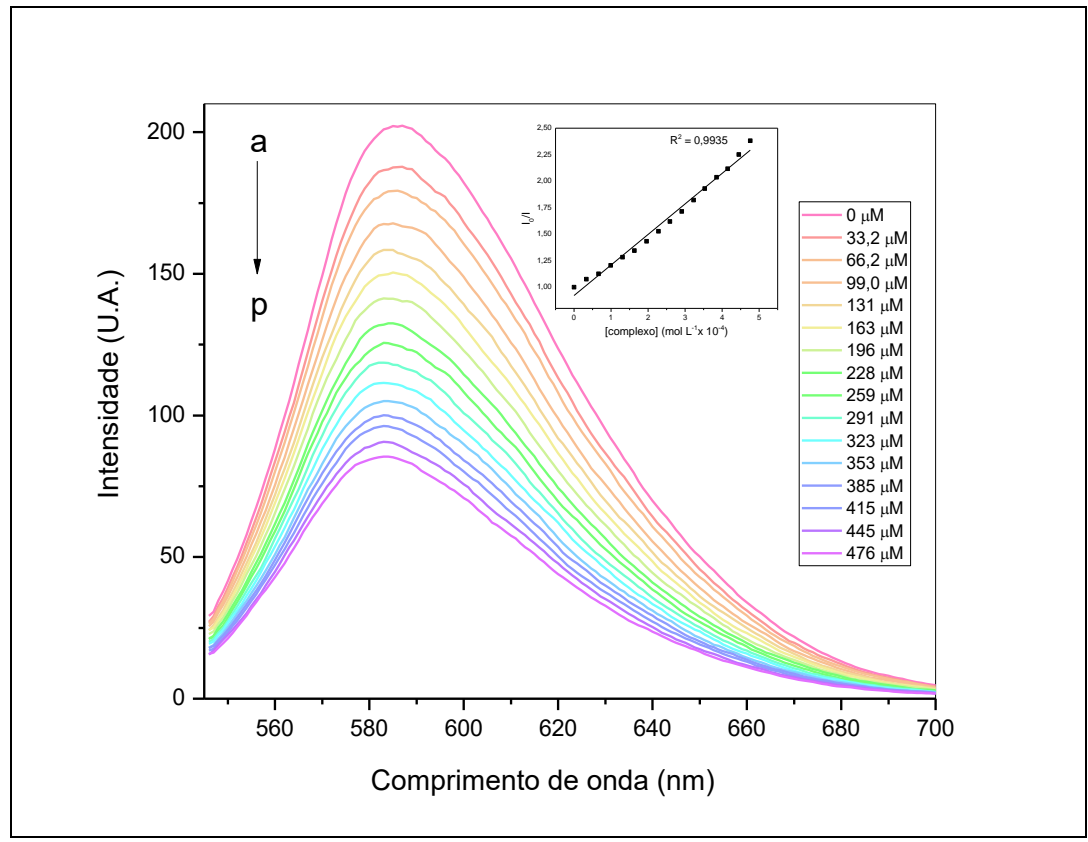

Fonte: Autora 
Figura 90: Espectros de emissão do sistema BET-DNA, na presença de diferentes concentrações de $\left[\mathrm{Ru}\left(\mathrm{NH}_{3}\right)_{4}(\text { adrenalina })\right]^{+}$

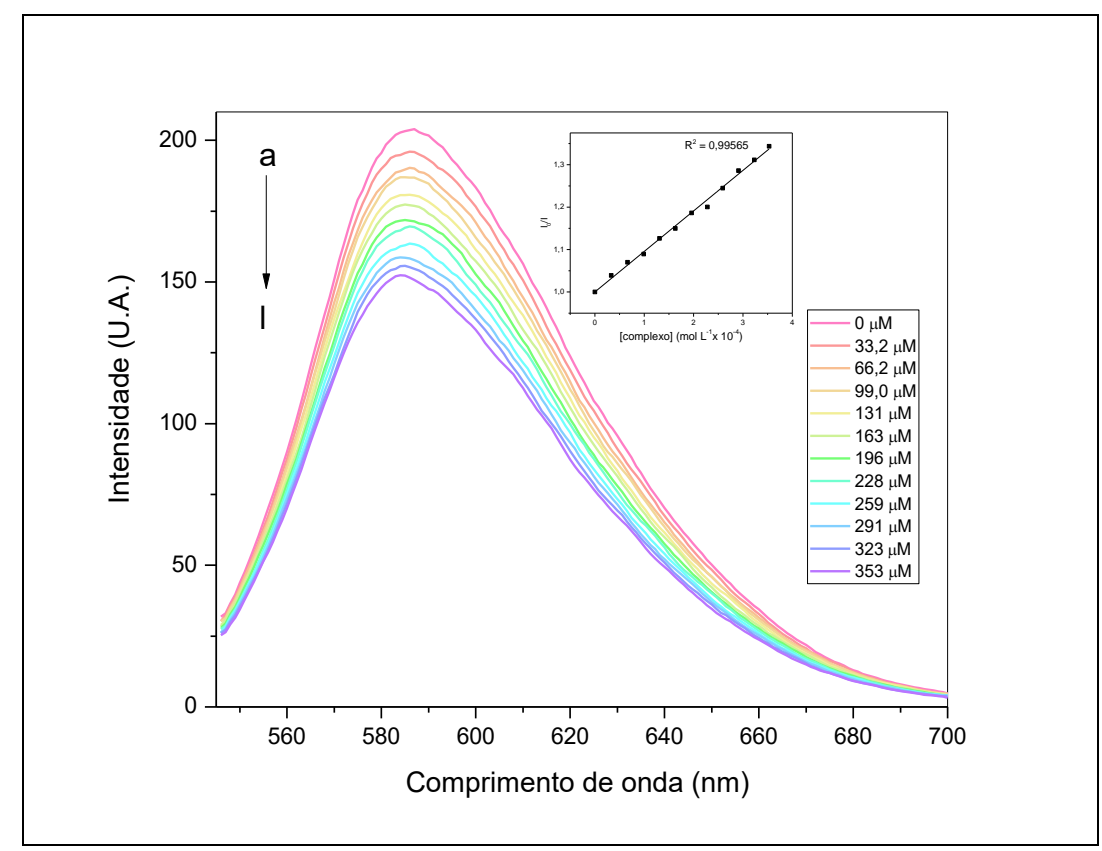

Fonte: Autora

Embora não retrate uma constante de associação direta dos compostos com o DNA, o cálculo da constante de Stern-Volmer, para a supressão da fluorescência do brometo de etídio, é empregado como forma de se mensurar, indiretamente, a capacidade de intercalação dos compostos com o DNA (LIU et. al., 2002; ROCHA, 2014; WU et. al., 2011).

$$
\frac{I_{0}}{I}=1+K_{s v}[Q]
$$

(Equação 6)

Nesta equação, $I_{0}$ é a intensidade da fluorescência na ausência do agente supressor, I é a intensidade da fluorescência na presença do agente, [Q] é a concentração do agente responsável pela extinção/supressão da fluorescência, neste caso, os complexos metálicos em estudo, e $\mathrm{K}_{\mathrm{sv}}$ é a constante de Stern-Volmer para o processo (LAKOWICZ, 1983).

Os valores obtidos para as constantes de Stern-Volmer são apresentados na tabela a seguir (tabela 17), comparados com outros extraídos da literatura: 
Tabela 17: Constantes de Stern-Volmer para a supressão de fluorescência do sistema BET-DNA

\begin{tabular}{ccc}
\hline Complexo & $\mathrm{K}_{\mathrm{sv}} \mathrm{L} \mathrm{Mol}^{-1}$ & fonte \\
\hline \hline$\left[\mathrm{Ru}\left(\mathrm{NH}_{3}\right)_{4}(\text { isoproterenol })\right]^{+}$ & $1,510^{3}$ & este trabalho \\
{$\left[\mathrm{Ru}\left(\mathrm{NH}_{3}\right)_{4}(\text { dopamina })\right]^{+}$} & $1,1310^{3}$ & este trabalho \\
{$\left[\mathrm{Ru}\left(\mathrm{NH}_{3}\right)_{4}(\text { noradrenalina })\right]^{+}$} & $2,2310^{3}$ & este trabalho \\
{$\left[\mathrm{Ru}\left(\mathrm{NH}_{3}\right)_{4}(\text { catecol })\right]^{+}$} & $2,810^{3}$ & este trabalho \\
{$\left[\mathrm{Ru}\left(\mathrm{NH}_{3}\right)_{4}(\text { adrenalina })\right]^{+}$} & $9,610^{2}$ & este trabalho \\
{$[\mathrm{Pt}(\mathrm{DMP})(\mathrm{DIP})] \mathrm{Cl}_{2} . \mathrm{H}_{2} \mathrm{O}$} & $3,5310^{5}$ & SHAHABADI et.al., 2011 \\
$\mathrm{C}_{78} \mathrm{H}_{62} \mathrm{~N}_{26} \mathrm{O}_{28} \mathrm{Zn}_{2}$ & $1,010^{3}$ & WU et. al., 2011 \\
$\mathrm{C}_{48} \mathrm{H}_{40} \mathrm{MnN}{ }_{14} \mathrm{O}$ & $2,010^{3}$ & WU et. al., 2011 \\
{$\left[\eta^{6}-\mathrm{pcymene}\right) \mathrm{Ru}(\mathrm{EtATSC} \mathrm{Cl}] \mathrm{Cl}$} & $3,9410^{4}$ & BECKFORD et. al., 2011 \\
\hline
\end{tabular}

Em relação aos valores $\mathrm{K}_{\mathrm{sv}}$ obtidos para os complexos estudados, as maiores interações foram mensuradas para os complexos de catecol e de noradrenalina. Este resultado é consoante àquele obtido para $\mathrm{K}_{\mathrm{b}}$ (vide seção anterior), para o qual os maiores valores desta constante foram obtidos para esses dois complexos. Tais valores são próximos àqueles reportados para complexos de zinco e manganês (WU et. al., 2011), porém menores que os reportados por Beckford e colaboradores (2011) para um complexo de rutênio.

Em sendo o BET um composto intercalador, os valores obtidos nas constantes de Stern-Volmer demonstram, indiretamente, a capacidade de outro composto se intercalar no DNA e, portanto, deslocar o brometo de etídio. Assim, como previsto, haja vista a estrutura dos ligantes dos complexos, não há evidências de que sejam eles intercaladores, uma vez que as constantes obtidas foram pequenas - o que, novamente, corrobora os resultados obtidos anteriormente para os experimentos de titulação, acompanhados por espectroscopia na região do UV-vis.

O mesmo experimento foi conduzido para o sistema BET-DNA com Cisplatina. Os espectros resultantes podem ser visualizados na figura 91. A ausência de supressão de fluorescência do BET comprova que este fármaco não atua via intercalação no DNA. 
Figura 91: Espectros de emissão do sistema BET-DNA, na presença de diferentes concentrações de Cisplatina

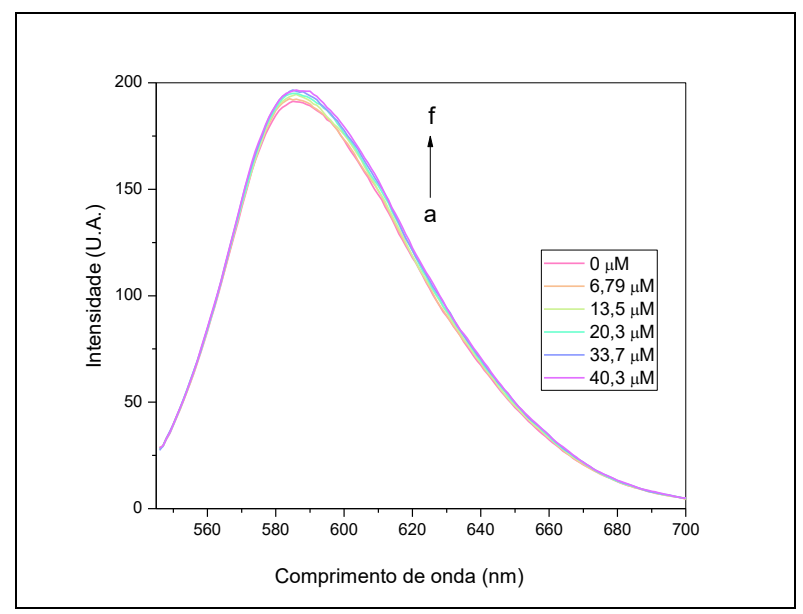

Fonte: Autora

Os resultados apresentados neste tópico do presente trabalho permitem formular a hipótese de que a interação com o DNA não consiste na principal via de interação dos complexos metálicos estudados nas células. Entretanto, parecer apresentar interações de caráter eletrostático, as quais são suficientes para alterar a estrutura do DNA. Além disso, diante da diversidade de outros resultados biológicos apresentados, é possível concluir que a interação nos receptores na membrana das células seja o foco da atuação dos complexos.

\subsubsection{Interação com proteína carreadora (HSA) - mimetizando transporte in vivo}

Considerando-se que os complexos apresentaram interações, ainda que não intensas, com o DNA de esperma de salmão, julgou-se importante verificar a interação dos mesmos com ao menos uma biomolécula humana.

Considerando-se que a proteína mais abundante de sangue humano é a proteína do soro humano albumina (Human Serum Albumin - HSA), constituindo cerca de $60 \%$ da composição plasmática, e que é uma das principais proteínas transportadoras, no corpo humano, sendo responsável pelo transporte de compostos endógenos e exógenos, ácidos graxos, metais, fármacos, etc., o estudo da interação entre a HSA e esses complexos é imprescindível para avaliar toxicidade, metabolismo e biodisponibilidade, além do que esta análise fornece informações importantes sobre a eficácia terapêutica de compostos como potenciais metalodrogas (MOREIRA, 2016; FANALI et. al., 2012). Devida (principalmente) ao resíduo de triptofano (Trp, posição 214), a HSA apresenta fluorescência que possibilita serem as interações, entre os complexos e a mesma, acompanhadas por espectroscopia de fluorescência (MOREIRA, 2016; FANALI et. al., 2012; REIS, 2014). 
Neste trabalho, a interação entre os complexos e HSA foi mensurada por titulação espectofotométrica acompanhada por espectroscopia de fluorescência, sendo o comprimento de onda de excitação $280 \mathrm{~nm}$, em três temperaturas e os resultados da interação são demonstrados por meio das constantes de Stern-Volmer $\left(\mathrm{K}_{\mathrm{sv}}\right)$ (vide equação 6), da constante da interação $\left(\mathrm{K}_{\mathrm{b}}\right)$, e dos parâmetros termodinâmicos (vide equações 4 e 5).

A constante de associação $\left(\mathrm{K}_{\mathrm{b}}\right)$ é obtida ao se plotar $\log \left[\left(\mathrm{I}_{0}-\mathrm{I}\right) / \mathrm{I}\right]$ versus $\log [\mathrm{Q}]$, onde [Q] é a concentração do agente supressor em cada ponto da titulação (no caso, $\mathrm{Q}=$ complexos metálicos) (equação 7); desta mesma equação é possível se obter a quantidade de moléculas $(n)$ que interagem com cada biomolécula de proteína - ou número de sítios de ligação:

$$
\log \left(\frac{I_{0}-I}{I}\right)=\log K_{b}+n \log [Q] \quad \text { (Equação 7) }
$$

Os resultados da interação são mostrados a seguir apenas para as interações ocorridas a $25^{\circ} \mathrm{C}$ (figuras 92 a 101), para as demais (32 e $37^{\circ} \mathrm{C}$ ) os dados seguem no apêndice deste texto (figuras 152 a 171): 
Figura 92: Espectros de emissão de fluorescência da HSA, na presença de diferentes concentrações de $\left[\mathrm{Ru}\left(\mathrm{NH}_{3}\right)_{4}(\text { isoproterenol })\right]^{+}$, a $25^{\circ} \mathrm{C}$. Gráfico de Stern-Volmer inserido

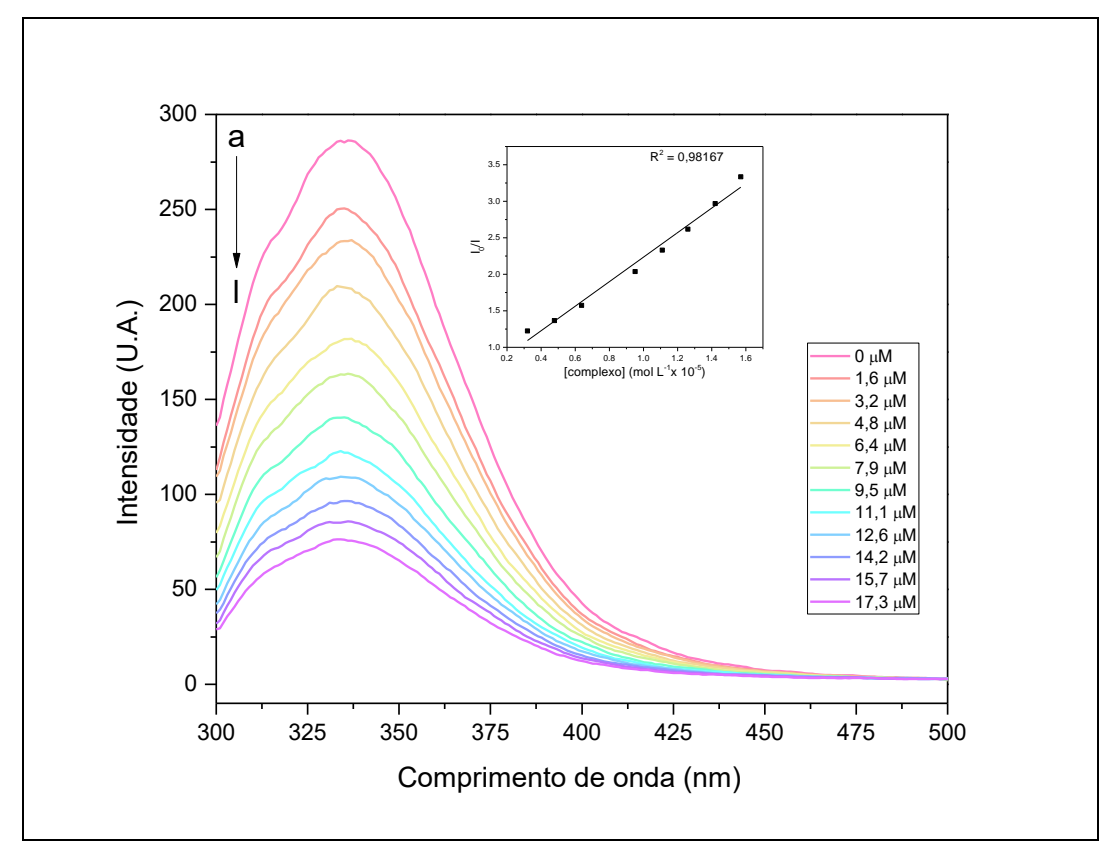

Fonte: Autora

Figura 93: Gráfico da equação $\log \left[\left(\mathrm{I}_{0}-\mathrm{I}\right) / \mathrm{I}\right]=\log \mathrm{K}_{\mathrm{b}}+\mathrm{nlog}[\mathrm{Q}]$ referente à interação entre HSA e o complexo $\left[\mathrm{Ru}\left(\mathrm{NH}_{3}\right)_{4} \text { (isoproterenol) }\right]^{+}$, a $25^{\circ} \mathrm{C}(\mathrm{A})$ e Gráfico de Van't Hoff referente à interação entre HSA e o complexo $\left[\mathrm{Ru}\left(\mathrm{NH}_{3}\right)_{4}(\text { isoproterenol })\right]^{+}(\mathrm{B})$

(A)

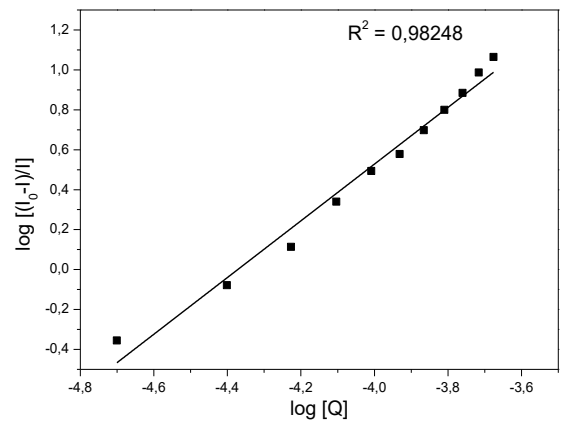

(B)

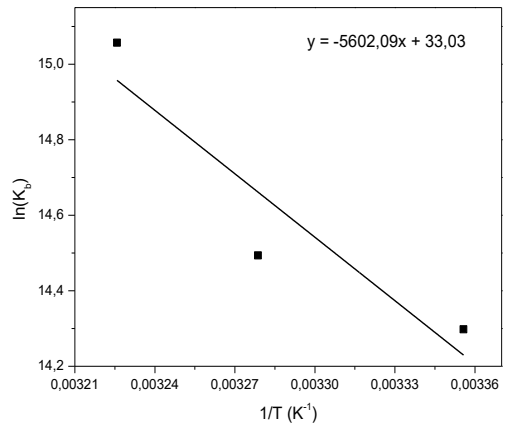

Fonte: Autora 
Figura 94: Espectros de emissão de fluorescência da HSA, na presença de diferentes concentrações de $\left[\mathrm{Ru}\left(\mathrm{NH}_{3}\right)_{4}(\text { dopamina })\right]^{+}$, a $25^{\circ} \mathrm{C}$. Gráfico de Stern-Volmer inserido

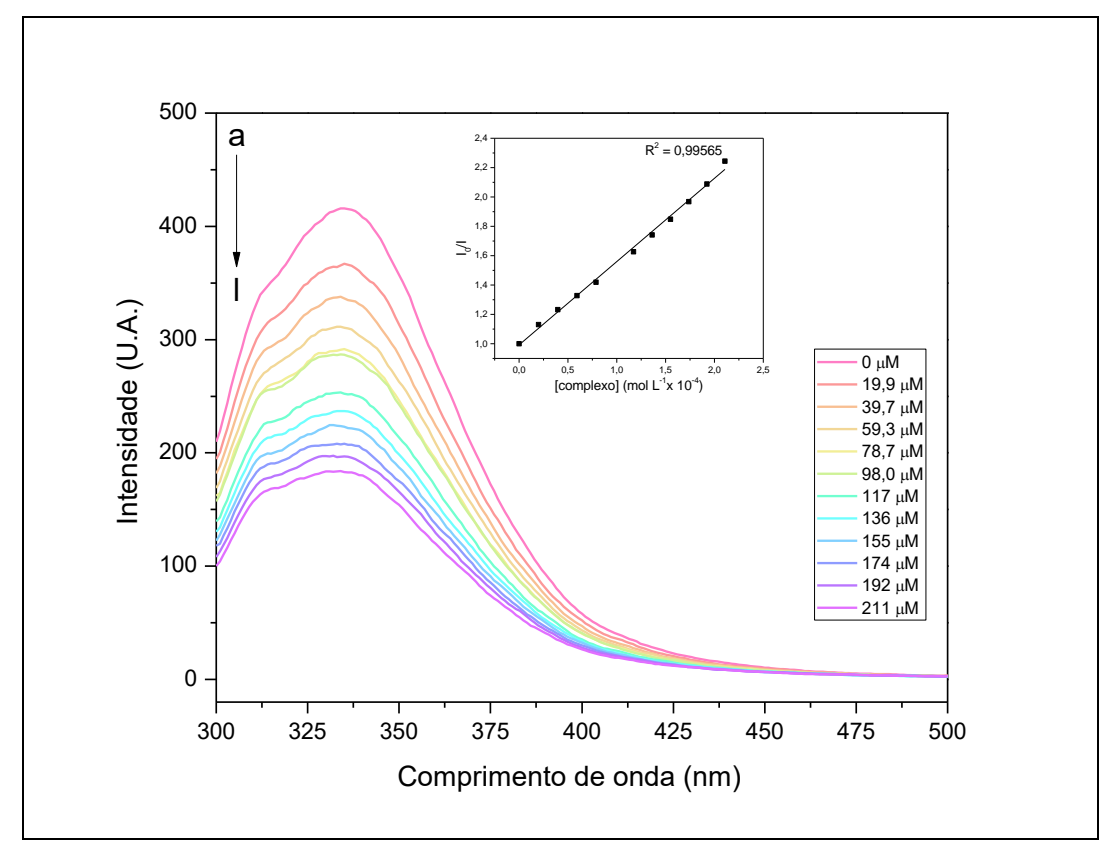

Fonte: Autora

Figura 95: Gráfico da equação $\log \left[\left(\mathrm{I}_{0}-\mathrm{I}\right) / \mathrm{I}\right]=\log \mathrm{K}_{\mathrm{b}}+\mathrm{nlog}[\mathrm{Q}]$ referente à interação entre HSA e o complexo $\left[\mathrm{Ru}\left(\mathrm{NH}_{3}\right)_{4}(\text { dopamina })\right]^{+}, a^{\circ} 5^{\circ} \mathrm{C}(\mathrm{A})$ e Gráfico de Van't Hoff referente à interação entre HSA e o complexo $\left[\mathrm{Ru}\left(\mathrm{NH}_{3}\right)_{4}(\text { dopamina })\right]^{+}(\mathrm{B})$

(A)

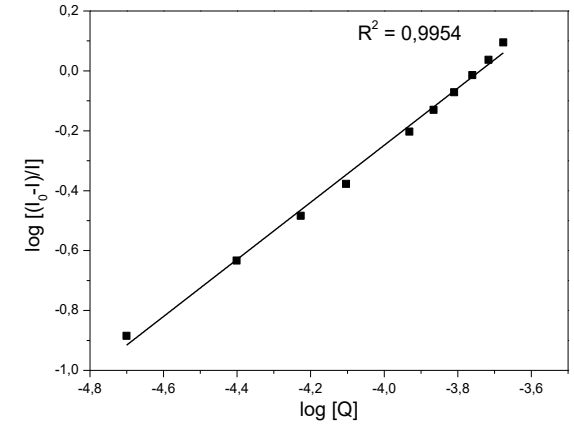

Fonte: Autora
(B)

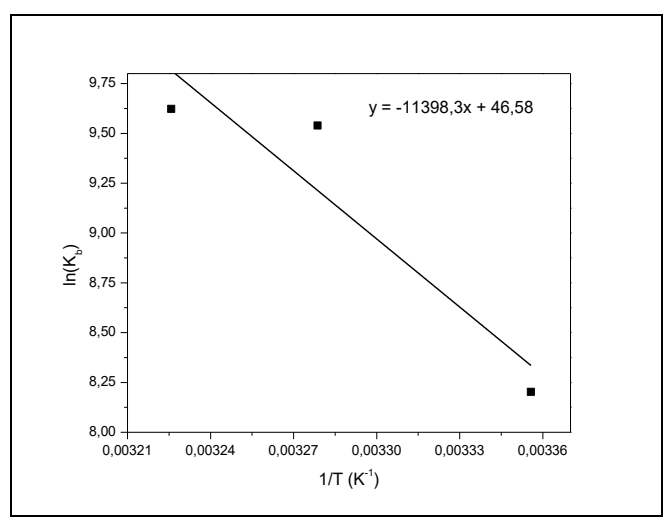


Figura 96: Espectros de emissão de fluorescência da HSA, na presença de diferentes concentrações de $\left[\mathrm{Ru}\left(\mathrm{NH}_{3}\right)_{4}(\text { noradrenalina })\right]^{+}$, a $25^{\circ} \mathrm{C}$. Gráfico de Stern-Volmer inserido

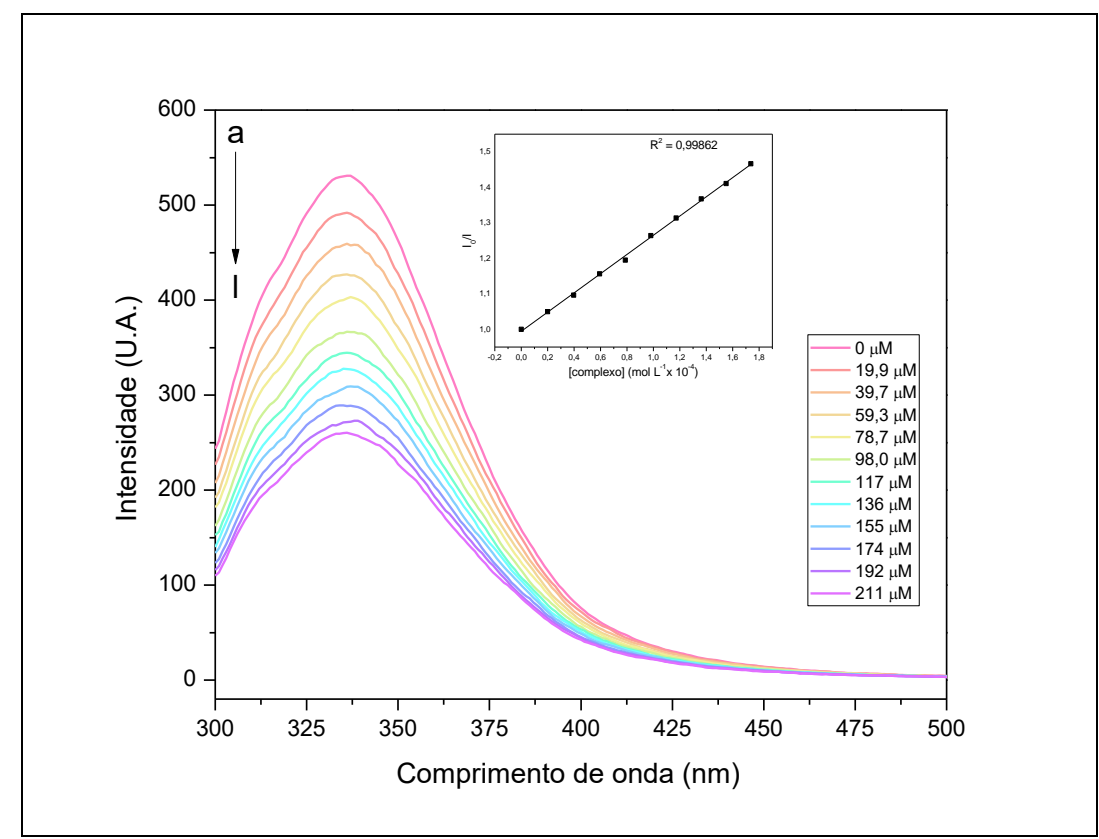

Fonte: Autora

Figura 97: Gráfico da equação $\log \left[\left(I_{0}-I\right) / I\right]=\log K_{b}+n \log [Q]$ referente à interação entre HSA e o complexo $\left[\mathrm{Ru}\left(\mathrm{NH}_{3}\right)_{4}(\text { noradrenalina })\right]^{+}$, a $25^{\circ} \mathrm{C}(\mathrm{A})$ e Gráfico de Van't Hoff referente à interação entre HSA e o complexo $\left[\mathrm{Ru}\left(\mathrm{NH}_{3}\right)_{4}(\text { noradrenalina })\right]^{+}(\mathrm{B})$

(A)

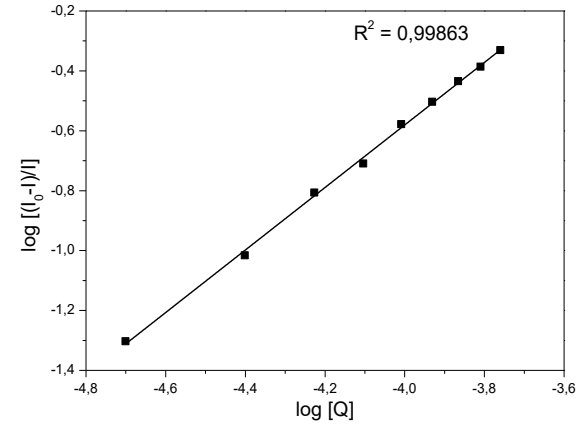

Fonte: Autora
(B)

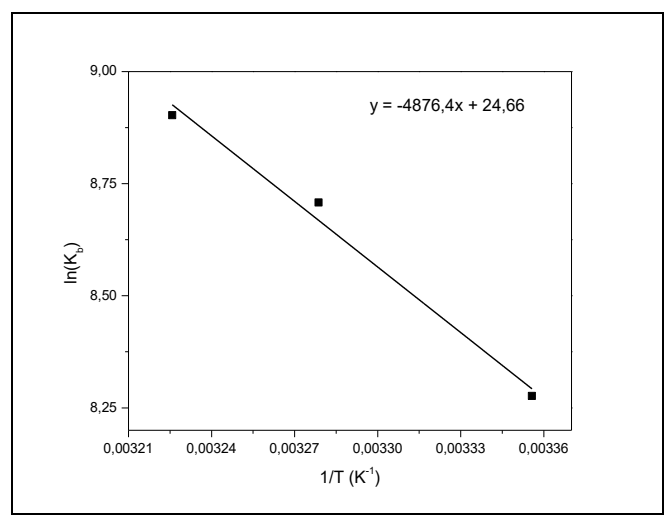


Figura 98: Espectros de emissão de fluorescência da HSA, na presença de diferentes concentrações de $\left[\mathrm{Ru}\left(\mathrm{NH}_{3}\right)_{4}(\text { catecol })\right]^{+}$, a $25^{\circ} \mathrm{C}$. Gráfico de Stern-Volmer inserido

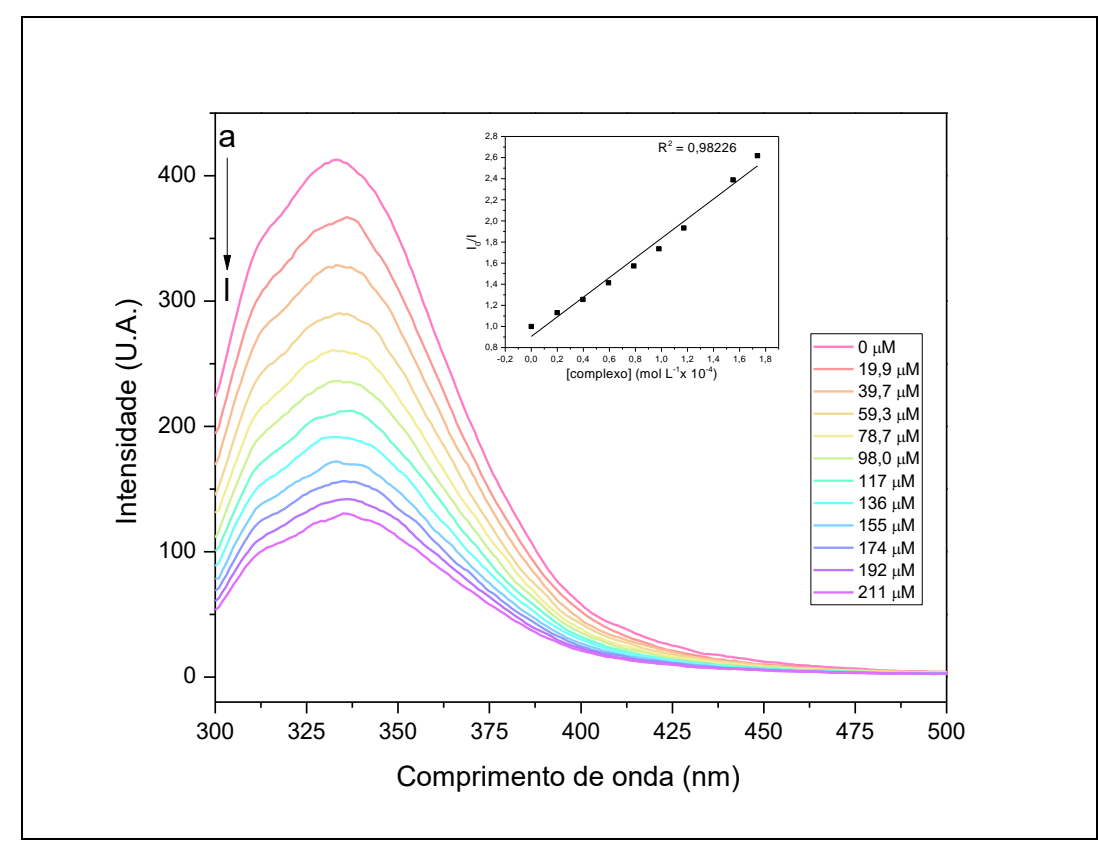

Fonte: Autora

Figura 99: Gráfico da equação $\log \left[\left(I_{0}-I\right) / I\right]=\log K_{b}+n \log [Q]$ referente à interação entre HSA e o

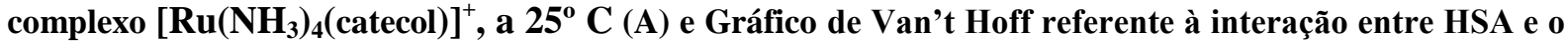
complexo $\left[\mathrm{Ru}\left(\mathrm{NH}_{3}\right)_{4}(\text { catecol })\right]^{+}(\mathrm{B})$

(A)

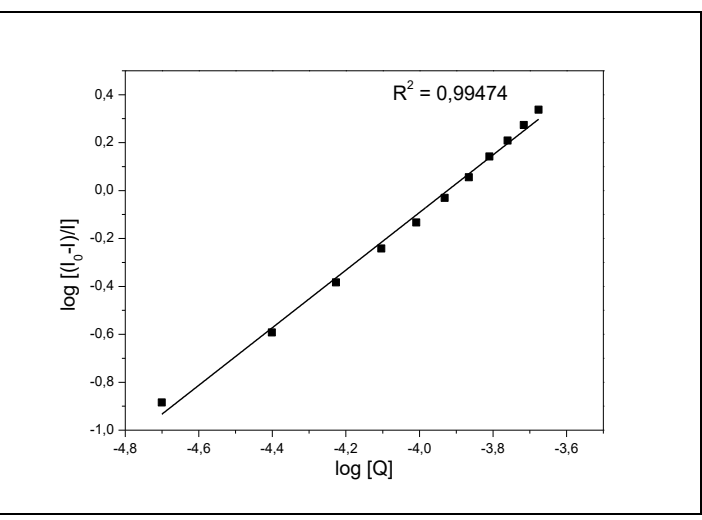

(B)

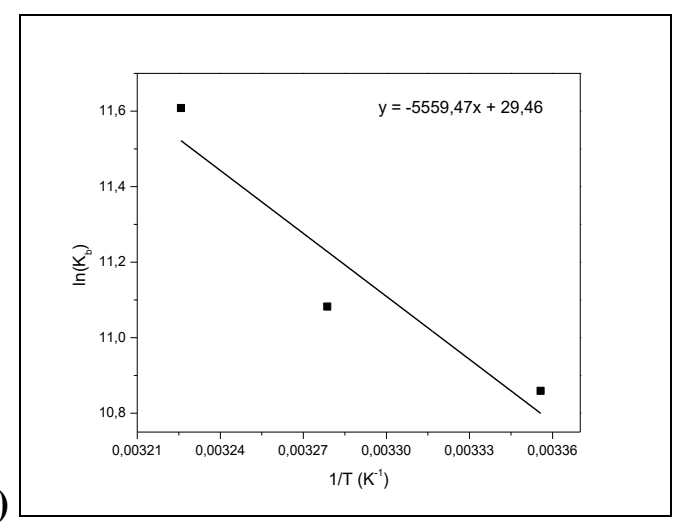

Fonte: Autora 
Figura 100: Espectros de emissão de fluorescência da HSA, na presença de diferentes concentrações de $\left[\mathrm{Ru}\left(\mathrm{NH}_{3}\right)_{4}(\text { adrenalina })\right]^{+}$, a $25^{\circ} \mathrm{C}$. Gráfico de Stern-Volmer inserido

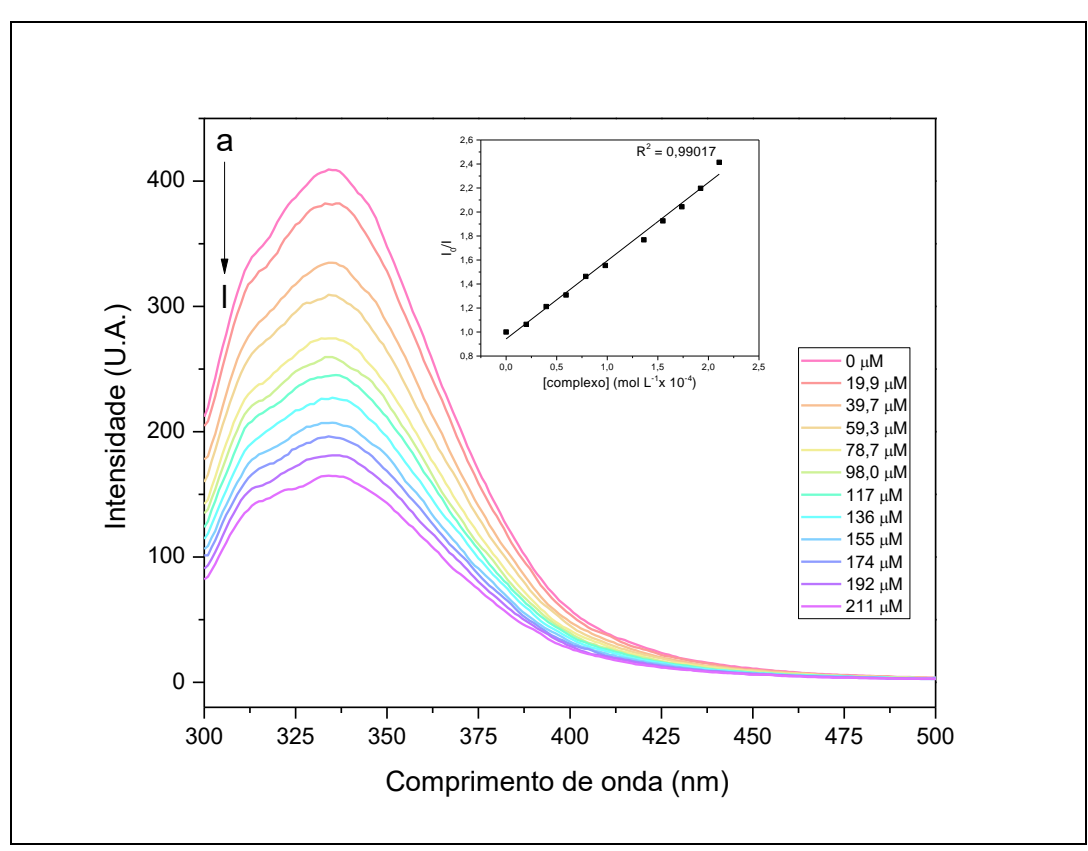

Fonte: Autora

Figura 101: Gráfico da equação $\log \left[\left(\mathrm{I}_{0}-\mathrm{I}\right) / \mathrm{I}\right]=\log \mathrm{K}_{\mathrm{b}}+\mathrm{nlog}[\mathrm{Q}]$ referente à interação entre HSA e o

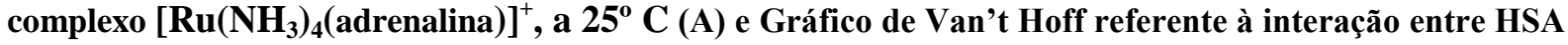
e o complexo $\left[\mathrm{Ru}\left(\mathrm{NH}_{3}\right)_{4}(\text { adrenaliina })\right]^{+}(\mathrm{B})$

(A)

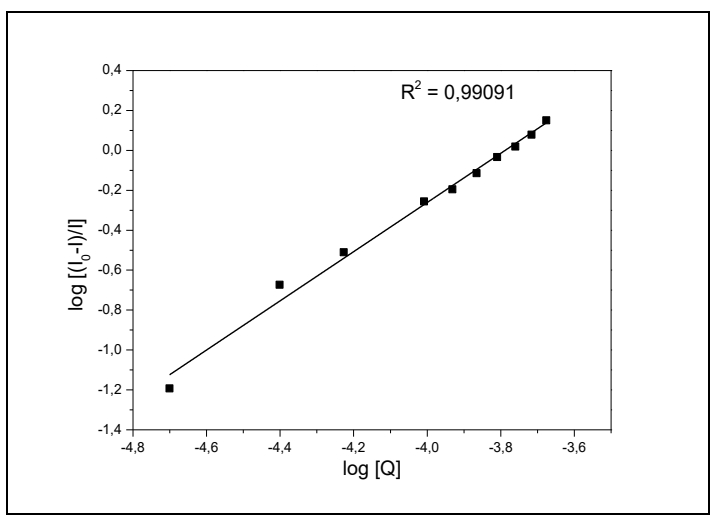

Fonte: Autora
(B)

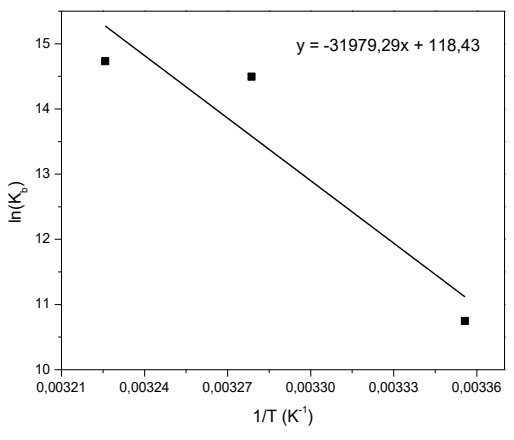

Para facilitar a discussão dos resultados, os mesmos seguem sumarizados na tabela 18: 
Tabela 18: Parâmetros da interação dos complexos $\left[R u\left(N_{3}\right)_{4} L\right]^{+}(\mathrm{L}=$ isoproterenol, dopamina, noradrenalina, catecol e adrenalina) com HSA: $K_{s v} ; K_{b} ; n ; \Delta G ; \Delta H$ e $\Delta S$, a 25,32 e $37^{\circ} \mathrm{C}(298,305$ e 311 $\mathrm{K}$, respectivamente)

\begin{tabular}{|c|c|c|c|}
\hline \multicolumn{4}{|c|}{$\left[\mathrm{Ru}\left(\mathrm{NH}_{3}\right)_{4}(\text { iso })\right]^{+}$} \\
\hline $\mathbf{T}$ & 298 K & $305 \mathrm{~K}$ & $310 \mathrm{~K}$ \\
\hline $\mathrm{K}_{\mathrm{SV}}\left(10^{3} \mathrm{M}^{-1}\right)$ & 33 & 36,1 & 34 \\
\hline $\mathrm{K}_{\mathrm{b}}\left(10^{3} \mathrm{M}^{-1}\right)$ & 1620 & 1970 & 3760 \\
\hline$n$ & 1,4 & 1,4 & 1,5 \\
\hline$\Delta \mathrm{G}\left(\mathrm{kJ} \mathrm{mol}^{-1}\right)$ & -35 & -37 & -39 \\
\hline$\Delta \mathrm{H}\left(\mathrm{kJ} \mathrm{mol}^{-1}\right)$ & & 47 & \\
\hline$\Delta \mathrm{S}\left(\mathrm{J} \mathrm{mol}^{-1} \mathrm{~K}^{-1}\right)$ & & 275 & \\
\hline \multicolumn{4}{|c|}{$\left[\mathrm{Ru}\left(\mathrm{NH}_{3}\right)_{4}(\mathrm{dop})\right]^{+}$} \\
\hline $\mathbf{T}$ & 298 K & $305 \mathrm{~K}$ & $310 \mathrm{~K}$ \\
\hline $\mathrm{K}_{\mathrm{SV}}\left(10^{3} \mathrm{M}^{-1}\right)$ & 5,68 & 5,54 & 5,25 \\
\hline $\mathrm{K}_{\mathrm{b}}\left(10^{3} \mathrm{M}^{-1}\right)$ & 3,65 & 13,9 & 15,1 \\
\hline$n$ & 0,9 & 1,1 & 1,1 \\
\hline$\Delta \mathrm{G}\left(\mathrm{kJ} \mathrm{mol}^{-1}\right)$ & -20 & -24 & -25 \\
\hline$\Delta \mathrm{H}\left(\mathrm{kJ} \mathrm{mol}^{-1}\right)$ & & 95 & \\
\hline$\Delta \mathrm{S}\left(\mathrm{J} \mathrm{mol}^{-1} \mathrm{~K}^{-1}\right)$ & & 390 & \\
\hline \multicolumn{4}{|c|}{$\left[\mathrm{Ru}\left(\mathrm{NH}_{3}\right)_{4}(\text { nor })\right]^{+}$} \\
\hline 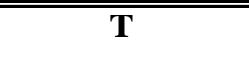 & $298 \mathrm{~K}$ & $305 \mathrm{~K}$ & $310 \mathrm{~K}$ \\
\hline $\mathrm{K}_{\mathrm{SV}}\left(10^{3} \mathrm{M}^{-1}\right)$ & 2,71 & 2,49 & 2,15 \\
\hline $\mathrm{K}_{\mathrm{b}}\left(10^{3} \mathrm{M}^{-1}\right)$ & 3,93 & 6,05 & 7,35 \\
\hline$n$ & 1 & 1 & 1,1 \\
\hline$\Delta \mathrm{G}\left(\mathrm{kJ} \mathrm{mol}^{-1}\right)$ & -21 & -22 & -23 \\
\hline$\Delta \mathrm{H}\left(\mathrm{kJ} \mathrm{mol}{ }^{-1}\right)$ & & 40,5 & \\
\hline$\Delta \mathrm{S}\left(\mathrm{J} \mathrm{mol}^{-1} \mathrm{~K}^{-1}\right)$ & & 210 & \\
\hline \multicolumn{4}{|c|}{$\left[\mathrm{Ru}\left(\mathrm{NH}_{3}\right)_{4}(\mathrm{cat})\right]^{+}$} \\
\hline $\mathbf{T}$ & $298 \mathrm{~K}$ & $305 \mathrm{~K}$ & $310 \mathrm{~K}$ \\
\hline $\mathrm{K}_{\mathrm{SV}}\left(10^{3} \mathrm{M}^{-1}\right)$ & 9,3 & 8,25 & 7,34 \\
\hline $\mathrm{K}_{\mathrm{b}}\left(10^{3} \mathrm{M}^{-1}\right)$ & 52 & 65 & 110 \\
\hline$n$ & 1,2 & 1,2 & 1,3 \\
\hline$\Delta \mathrm{G}\left(\mathrm{kJ} \mathrm{mol}^{-1}\right)$ & -27 & -28 & -30 \\
\hline$\Delta \mathrm{H}\left(\mathrm{kJ} \mathrm{mol}^{-1}\right)$ & & 46 & \\
\hline$\Delta \mathrm{S}\left(\mathrm{J} \mathrm{mol}^{-1} \mathrm{~K}^{-1}\right)$ & & 240 & \\
\hline \multicolumn{4}{|c|}{$\left[\mathbf{R u}\left(\mathrm{NH}_{3}\right)_{4}(\operatorname{adre})\right]^{+}$} \\
\hline$\overline{\mathbf{T}}$ & $298 \mathrm{~K}$ & $305 \mathrm{~K}$ & $310 \mathrm{~K}$ \\
\hline $\mathrm{K}_{\mathrm{SV}}\left(10^{3} \mathrm{M}^{-1}\right)$ & 6,62 & 33,1 & 33,5 \\
\hline$\Delta \mathrm{G}\left(\mathrm{kJ} \mathrm{mol}^{-1}\right)$ & -27 & -37 & -38 \\
\hline$\Delta \mathrm{H}\left(\mathrm{kJ} \mathrm{mol}^{-1}\right)$ & & 270 & \\
\hline$\Delta \mathrm{S}\left(\mathrm{J} \mathrm{mol}^{-1} \mathrm{~K}^{-1}\right)$ & & 980 & \\
\hline
\end{tabular}

Fonte: Autora 
A medida da intensidade da supressão da fluorescência $\left(\mathrm{K}_{\mathrm{sv}}\right)$ está diretamente relacionada à força da interação entre os complexos e a proteína HSA, logo, se espera que quanto maior a constante de supressão da fluorescência, maior seja a interação dos complexos com a proteína.

Para a série de complexos estudados, a média dos valores das constantes de SternVolmer é da ordem de $10^{3}$. Exceção foi observada para o complexo de isoproterenol, para o qual a constante foi maior em todas as temperaturas estudadas (da ordem $10^{4}$ ), bem como para o de adrenalina, nos ensaios realizados em 32 e $37^{\circ} \mathrm{C}$ (da ordem $10^{4}$ ).

Este comportamento é justificado quando se observa que o complexo de isoproterenol possui a substituição mais apolar na cadeia carbônica lateral, seguido do complexo de adrenalina - o qual possui grupamento metílico no nitrogênio da cadeia carbônica.

Os valores de $\mathrm{K}_{\mathrm{sv}}$ também permitem inferir o tipo de supressão de fluorescência ocorrido no sistema: descrita previamente por George Stokes, o qual notou que a fluorescência do quinino em ácido sulfúrico diluído foi reduzida após a adição de íons cloreto, do ácido clorídrico (GEDDES, 2001), o processo é denominado como extinção dinâmica (ou colisional) da fluorescência se nele o tempo de vida e intensidade da fluorescência forem reduzidos na presença de um supressor, Q. Enquanto no mecanismo de supressão estática da fluorescência, há a formação de um complexo entre a espécie fluorescente e o supressor. Na supressão dinâmica ou colisional, o supressor da fluorescência, deve se difundir na espécie fluorescente durante o tempo de vida do estado excitado - favorecendo decaimento não radiativo. Na supressão estática é formado um complexo entre o fluoróforo e o supressor, o qual não é fluorescente (LAKOWICZ, 1983). Este mecanismo é desfavorecido pelo aumento da temperatura, enquanto aquele, favorecido.

Assim, se pode postular que o mecanismo de supressão de fluorescência observado é o estático, uma vez que com o aumento da temperatura, houve a diminuição dos valores de $\mathrm{K}_{\mathrm{sv}}$, para todos os complexos, exceto para o de adrenalina. Para este, foi observado tendência que indica supressão dinâmica da fluorescência, razão pela qual o valor de $\mathrm{K}_{\mathrm{b}}$ obtido no gráfico (figura 101 B) não foi considerado nas análises (LAKOWICZ, 1983).

Em relação às constantes de ligação $\left(\mathrm{K}_{\mathrm{b}}\right)$, observa-se o mesmo comportamento evidenciado para as constantes de Stern-Volmer, reafirmando que, para o caso do complexo que possui como ligante o isoproterenol, a interação com a proteína em comento é mais intensa, demonstrando maior afinidade dos complexos que possuem substituições mais apolares na cadeia carbônica, uma vez que os outros compostos apresentam constantes de 
ligação da ordem de $10^{3}$, enquanto este complexo demonstrou constante da ordem $10^{6}$ - o que segundo Olson e Christ (1996) indica uma interação forte, porque normalmente as constantes variam na faixa de $10^{4}$ a $10^{6} \mathrm{~mol}^{-1} \mathrm{~L}$.

Ademais, é possível evidenciar que cada molécula de proteína interage, aproximadamente, com uma molécula de complexo, para todos os complexos, nas três temperaturas $(n \sim 1)$.

No que se refere aos parâmetros termodinâmicos, todos os valores de variação da energia livre de Gibbs são negativos, indicando que embora não pronunciada para todos os complexos, a interação é espontânea em todos os casos estudados. Observa-se, ainda, que os menores valores são encontrados para os compostos que apresentaram as maiores interações, quais sejam, isoproterenol e adrenalina.

Conforme proposto por Ross e Subramanian (1981), os valores obtidos para as variações de entalpia e entropia dos processos podem ser associados às diferentes forças que governam as interações, que podem ser de natureza eletrostática, hidrofóbicas e de van der Waals - conforme já mencionado na seção anterior.

No estudo da interação com esta proteína carreadora do soro humano, para todos os complexos desta série, os valores dos parâmetros termodinâmicos foram $\Delta \mathrm{H}$ e $\Delta S>0$, indicando que forças de natureza hidrofóbica mantém esta interação. Os resultados desses parâmetros estão de acordo com os valores de $K_{b}$ obtidos, dado o fato de os complexos que apresentaram as maiores interações, serem aqueles cujas cadeias carbônicas são mais apolares: isoproterenol e adrenalina.

\subsubsection{Considerações finais em relação aos complexos de rutênio-catecolaminas e seus respectivos ligantes livres}

\subsubsection{Ru-Iso e Iso}

No caso do isoproterenol, para o qual ligante e complexo promoveram aumento de cálcio intracelular, nenhuma diferença entre eles foi observada na viabilidade celular, demonstrando que este, provavelmente, seja um dos mecanismos pelos quais estes compostos agem nas células.

Além disso, para este par de compostos, foram observadas pequenas mudanças na contração vascular, quando comparados entre si. No ensaio de recuperação da lesão, por sua vez, a mesma tendência foi observada para ambos (de regeneração da lesão) para as células sadias fibroblastos, bem como para as duas linhagens cancerígenas, SF188 e FR37-CMT. No ensaio da CAM, o complexo não provocou resultados diversos daqueles observados para o 
ligante livre e, embora em relação ao controle tenha promovido redução da área de vasos, esta foi pequena quando comparada aos demais compostos com efeito antiangiogênico estudados neste trabalho. Assim, é possível concluir que esta catecolamina indica não ter atuação expressiva nos processos tanto de angiogênese, quanto de citotoxicidade. Dentre as catecolaminas, parece exercer o papel menos expressivo nesses efeitos, embora esteja no rol dos complexos com maiores interações com a proteína do soro humano albumina.

\subsubsection{Ru-Adr e Adr}

Para este par complexo metálico-ligante observou-se resultados que sugerem ser o complexo agonista parcial dos receptores do ligante. Para eles, o aumento do cálcio intracelular nas células endoteliais é oposto - enquanto semelhante nas células musculares. Sobre estes compostos, observou-se que a coordenação ao metal nitidamente promoveu efeitos de redução da viabilidade celular, embora tenha promovido efeito oposto nos ensaios de recuperação de lesão. No ensaio na CAM, promoveu efeito semelhante ao promovido pelo complexo de Ru-noradrenalina, porém com efeito reduzido em relação a esta, razão pela qual se postula que este efeito esteja, principalmente, relacionado ao receptor $\alpha_{1}$-adrenérgico, para o qual noradrenalina é um agonista mais potente, em relação à adrenalina.

$\mathrm{Na}$ viabilidade celular, o complexo demonstrou resultados menores, embora somente diferentes do ligante livre - pois para este se observou aumento da viabilidade celular, enquanto o complexo impede este aumento - e não do controle. De um modo geral, o complexo parecer atuar como agonista parcial dos receptores nos quais a adrenalina possui efeito.

\subsubsection{Ru-NA e NA}

Este parece ser um dos pares complexo-ligante cujos efeitos são mais promissores, pois em relação a estes observou-se interrupção do ciclo celular realizada pelo complexo, mas não pelo ligante livre, observou-se redução da angiogênese, na CAM, pelo complexo, enquanto aumento foi observado para o ligante livre. Em relação à viabilidade celular, enquanto foi evidenciado o aumento da viabilidade celular para o ligante, para o complexo notou-se redução desta. Sendo observado, ainda, menor atividade agonista do complexo, em relação ao ligante, nos tecidos responsáveis pela contração vascular. Diante deste conjunto de dados, é possível concluir que os efeitos opostos observados, pelo complexo em relação à catecolamina livre, indicam que enquanto o ligante livre atua, preferencialmente, como agonista $\alpha_{1}$, ao complexo podem ser atribuídas tanto interações como agonista parcial 
de $\alpha_{1}$, como de antagonista de $\beta$ - o que também contribuiria no sentido de melhor justificativa para o seu efeito antiangiogênico (CHAKROBORTY et. al., 2009; ZHANG et. al., 2011; CALDERÓN, 2015). Além disso, este complexo promoveu (seletivamente) a inibição da recuperação da lesão apenas nas células de origem cancerígena humana (SF-188).

\subsubsection{Ru-Dopa e Dopamina}

Este par também se demonstra promissor no sentido de que a coordenação ao íon metálico promoveu a alteração das respostas observadas para o ligante livre, pois no ensaio na CAM, enquanto o ligante mostrou-se antiangiogênico, o complexo apresentou resultados proangiogênicos, este fato pode ser reflexo da interação com diferentes tipos de receptores possivelmente, o complexo interage com receptores da família $\mathrm{D}_{1}$, enquanto o ligante livre, nestes ensaios, tenha maior interação com $\mathrm{D}_{2}-$, o que refletiria, inclusive, na mobilização de cálcio intracelular, que é promovida pelo ligante, nas células do músculo liso vascular, mas não pelo complexo. Estes resultados concordam com os dados a priori publicados, no sentido de que os efeitos antiangiogênicos da dopamina ocorrem via receptor $\mathrm{D}_{2}$. Pois, considerandose: que este receptor induz a inibição dos canais de cálcio; que para o ligante livre, de fato, não houve aumento de cálcio intracelular; para o complexo houve aumento de cálcio intracelular; os resultados da reatividade vascular mostram que ambos atuam, possivelmente, por receptores ou vias diferentes; e os resultados na CAM indicam efeitos opostos, é possível concluir que as ações sejam provenientes de receptores dopaminérgicos diferentes (CALLIER et al., 2003; COLOMBO, 2014).

$\mathrm{Na}$ viabilidade celular os resultados também são expressivos, uma vez que o ligante livre parece atuar na proliferação e este efeito, com a coordenação do íon rutênio, torna-se prevenido. A modificação nas respostas biológicas ocasionadas pelo complexo metálico, quando comparados à catecolamina livre, são atribuídas à alteração da densidade de spin no anel aromático, intensamente deslocalizada sobre a nuvem eletrônica do anel aromático.

\subsubsection{Ru-Cat e catecol}

Não obstante o fato de este ligante, embora dioxoleno, não ser uma catecolamina, os resultados providenciados em ensaios realizados com estes compostos serviram para demonstrar a importância do sítio amínico, para a promoção dos efeitos angiogênicos, bem como para a contração vascular - consequentes da interação com os receptores adrenérgicos. O aumento do cálcio intracelular foi verificado para o complexo metálico de catecol, o qual promoveu redução da viabilidade celular, em relação ao ligante livre. Acredita-se que o 
complexo metálico apresente efeitos tóxicos reduzidos em relação ao metal e efeitos citotóxicos aumentados, embora não seja capaz de induzir a contração vascular e, neste aspecto, mantém-se semelhante ao ligante livre. A diferença entre efeitos tóxicos e citotóxicos é creditada ao fato de que ambas as vias comuns de degradação das catecolaminas estejam inviabilizadas no complexo metálico - não há sítio de interação disponível para as duas vias de degradação, quais sejam, das enzimas COMT e MAO. Além disso, para o complexo cujo ligante é o catecol observaram-se as maiores interações com o DNA, indicando que este complexo pode atuar, por exemplo, por interação com o DNA das células, diferentemente dos complexos cujos dioxolenos coordenados são catecolaminas. A modificação nas respostas biológicas promovidas pelo complexo metálico, em relação ao catecol, são atribuídas, também, à alteração da densidade de spin no anel aromático, intensamente deslocalizada sobre a nuvem eletrônica do anel aromático.

\subsection{Parte 2: Complexos com fórmula geral: [Ru(bpy) ${ }_{2}$ Cat-R]Cl}

\subsubsection{Síntese e Purificação}

Com a intenção de avaliação do efeito biológico relacionado às catecolaminas, ocasionado pela substituição dos quatro ligantes amônio por duas moléculas de bipiridinas, optou-se pela síntese dos complexos que segue nesta segunda parte do capítulo de resultados da tese, principalmente, considerando-se que ligantes deste tipo, N-heterociclos, são conhecidos por mimetizarem biomoléculas, tais como proteínas e ácidos nucleicos, o que facilita sua interação no meio biológico (SOUZA, 2014; SANTIAGO, 2004).

Complexos bis(bipiridil)dioxolenorutênio(II) foram outrora reportados na literatura, sendo dioxoleno o catecol não substituído e com substituições no anel, especificamente, 3,5-di-terc-butil-catecol (BOONE; PIERPONT, 1987); 3,5-di-terc-butilcatecol, catecol e tetraclorocatecol (HAGA; DODSWORTH; LEVER, 1986); 3,5-di-tercbutil-catecol, catecol e tetraclorocatecol (HAGA et. al., 1990), utilizando rutênio e também ósmio; catecol, 2-aminofenol e 1,2-diaminobenzeno (MASUI; LEVER; AUBURN, 1991). No entanto, para catecolaminas, a literatura não traz qualquer referência.

Embora a literatura não reporte a síntese de complexos que possuem concomitantemente bipiridinas e catecolaminas, a rota sintética foi conduzida semelhantemente ao realizado para outros complexos com dioxolenos, apenas com sutis modificações as quais serão comentadas a seguir (MASUI; LEVER; AUBURN, 1991; BOONE; PIERPONT, 1987; HAGA; DODSWORTH; LEVER, 1986). 
Os complexos reportados na literatura, com carga 1+, foram precipitados com os contraíons hexafluorofosfato ou perclorato (BOONE; PIERPONT, 1987; HAGA; DODSWORTH; LEVER, 1986; HAGA et. al., 1990), no entanto, neste trabalho, propendendo-se às aplicações biológicas, os complexos foram precipitados com o contraíon cloreto, derivado dos respectivos cloridratos de catecolamina.

A escolha dos ligantes ocorreu pelas razões já expostas, quando da abordagem dos outros complexos metálicos. Assim, foram utilizados como ligantes isoproterenol, dopamina, noradrenalina e adrenalina, bem como o catecol, a fim de se ter um parâmetro de comparação, em razão deste último não ser um complexo inédito.

A realização das sínteses em atmosfera inerte é imperiosa à obtenção dos complexos, tanto para ser evitada a oxidação - já descrita anteriormente - irreversível dos ligantes, quanto do metal, que no caso destes complexos, utiliza-se um precursor contendo $\mathrm{Ru}(\mathrm{II})$ e, acredita-se que o produto formado possui o mesmo estado de oxidação do precursor.

A formação dos produtos é totalmente dependente da basicidade do meio (DE LIMA, 2001), para proporcionar a desprotonação do sítio catecólico e viabilizar a coordenação ao centro metálico.

A rota sintética é apresentada (genericamente) a seguir (figura 102):

Figura 102: Rota sintética da obtenção dos complexos

\begin{tabular}{|c|c|c|}
\hline & $\begin{array}{c}\mathrm{MeOH} ; \text { Cat-R.HCl; } \\
\mathrm{NaOH}\end{array}$ & \\
\hline 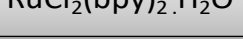 & refluxo & {$\left[\mathrm{Ru}(\mathrm{bpy})_{2}(\mathrm{cat})\right] \mathrm{Cl}$} \\
\hline
\end{tabular}

Fonte: Autora

No que se refere à proposta de mecanismo, acredita-se que haja a saída de um dos ligantes do tipo cloreto, promovendo a coordenação do primeiro grupamento do catecol e, posteriormente, por efeito quelato - já mencionado na parte 1 deste capítulo da tese -, haja a saída do segundo ligante cloreto, para promover a coordenação pelo outro átomo de oxigênio.

Os rendimentos obtidos foram consideráveis - no mínimo $40 \%$ - visando-se aplicações biológicas futuras.

Nos artigos referentes aos complexos análogos, geralmente, os autores não descrevem a purificação dos complexos, exceto por sucessivas reprecipitações. Para os complexos utilizando catecolaminas como ligantes dioxolenos, observou-se que o rendimento é menor que o obtido para os complexos previamente descritos (HAGA; DODSWORTH; LEVER, 1986), assim foi necessário purificar os complexos por cromatografia em coluna, 
obtendo-se produto que foi posteriormente seco, isto em razão de a (re)precipitação, per si, não ser seletiva o suficiente para a obtenção dos complexos puros.

Todos os complexos possuem coloração escura com tonalidades diferentes entre o roxo/vinho e marrom. Haga e colaboradores (1986) descreveram que complexos com fórmula $\left[\mathrm{Ru}(\mathrm{bpy})_{2}\right.$ catecol-R] são verdes, $\left[\mathrm{Ru}(\mathrm{py})_{4}\right.$ catecol-R] apresentam coloração marrom, enquanto $\left[\mathrm{Ru}(\mathrm{bpy})_{2} \text { semiquinona-R }\right]^{+}$são rosa/marrons e, [Ru(bpy $)_{2}$ quinona-R], azuis. Logo, conforme a literatura, a coloração dos complexos sugere a obtenção de rutênio(II), com os dioxolenos estabilizados na forma de semiquinona (HAGA; DODSWORTH; LEVER, 1986).

\subsubsection{Análise Elementar}

Os valores calculados e os obtidos experimentalmente para as análises elementares são apresentados na tabela a seguir (tabela 19). Tais valores são condizentes com as fórmulas propostas, para os complexos com carga 1+, isolados com contraíon cloreto.

Tabela 19: Resultados da análise elementar

\begin{tabular}{|c|c|c|c|}
\hline & \multicolumn{3}{|c|}{ Experimentais (Calculados) } \\
\hline & $\overline{\mathrm{C}}$ & $\overline{\mathrm{HH}}$ & $\overline{\mathrm{N}}$ \\
\hline$\left[\mathrm{Ru}(\mathrm{bpy})_{2}\right.$ (iso) $] \mathrm{Cl} . \mathrm{CH}_{2} \mathrm{Cl}_{2}$ & $48,1 \%(51,7 \%)$ & $4,3 \%(4,5 \%)$ & $9,3 \%(9,4 \%)$ \\
\hline$\left[\mathrm{Ru}(\mathrm{bpy})_{2}(\mathrm{dop})\right] \mathrm{Cl} \cdot \mathrm{CH}_{2} \mathrm{Cl}_{2}$ & $47,0 \%(50,9 \%)$ & $3,5 \%(3,9 \%)$ & $\%)$ \\
\hline$\left[\mathrm{Ru}(\mathrm{bpy})_{2}\right.$ (nor) $] \mathrm{Cl} .2 \mathrm{H}_{2} \mathrm{O}$ & $50,3 \%(51,5 \%)$ & $4,5 \%(4,5 \%)$ & $9,8(10,7 \%)$ \\
\hline$\left[\mathrm{Ru}(\mathrm{bpy})_{2}(\mathrm{cat})\right] \mathrm{Cl}$ & $52,0 \%(56,0 \%)$ & $3,8 \%(3,6 \%)$ & $10,1(10,5 \%)$ \\
\hline$\left[\mathrm{Ru}(\mathrm{bpy})_{2}\right.$ (adre) $] \mathrm{Cl} \cdot \mathrm{H}_{2} \mathrm{O}$ & $48,2 \%(53,5 \%)$ & $4,6 \%(4,5 \%)$ & $11,2(10,8 \%)$ \\
\hline
\end{tabular}

Fonte: Autora

Considerando-se os resultados da análise elementar, pelos quais se conclui que todos os complexos foram isolados com o contraíon cloreto, bem como o fato de o complexo precursor ser constituído por $\mathrm{Ru}(\mathrm{II})$ e todas as considerações teóricas já apresentadas quando da análise da série tetraaminodioxolenorutênio(III), é imperiosa a conclusão que para os complexos metálicos desta série, o metal seja diamagnético e, o ligante, paramagnético, estabilizado na forma de semiquinona (carga 1 -).

\subsubsection{Espectroscopia eletrônica de absorção na região $U V$-vis}

Os espectros eletrônicos dos complexos foram registrados e são mostrados a seguir (figura 103): 
Figura 103: Espectro eletrônico dos complexos $\left[\mathrm{Ru}(\mathrm{bpy})_{2}(\mathrm{~L})\right]^{\mathrm{n+}}$, onde $\mathbf{L}=\mathrm{Cl}_{2}(\mathrm{~A})$ (complexo precursor espectro qualitativo); isoproterenol $1,810^{-4} \mathrm{M}(\mathrm{B})$; dopamina $9 \mathbf{1 0}^{-5} \mathrm{M}(\mathrm{C})$; noradrenalina $10^{-5} \mathrm{M}(\mathrm{D})$; catecol $910^{-5} \mathrm{M}(\mathrm{E})$; adrenalina $610^{-5} \mathrm{M}(\mathrm{f})$, em metanol

(A)
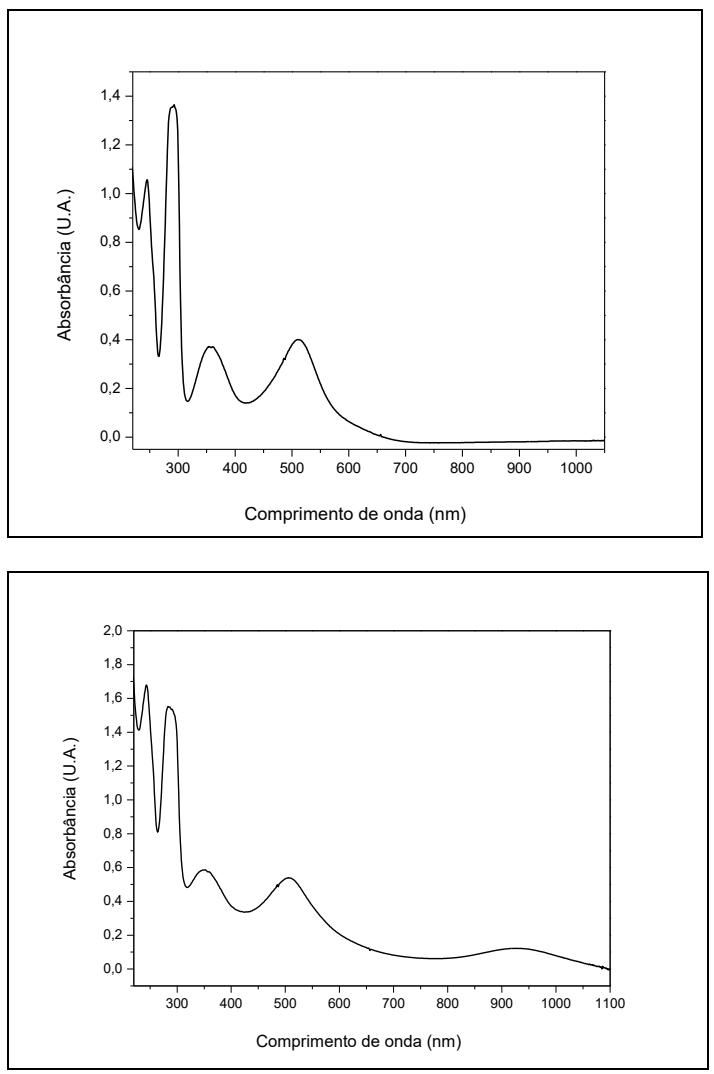

(C)

(B)

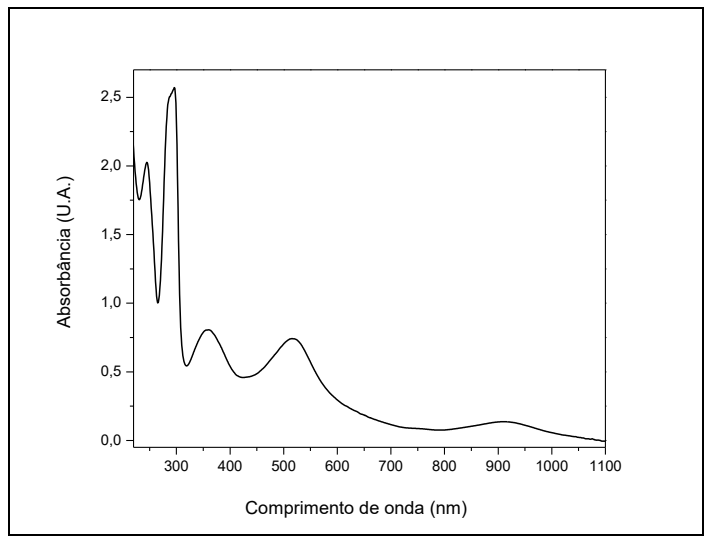

(D)

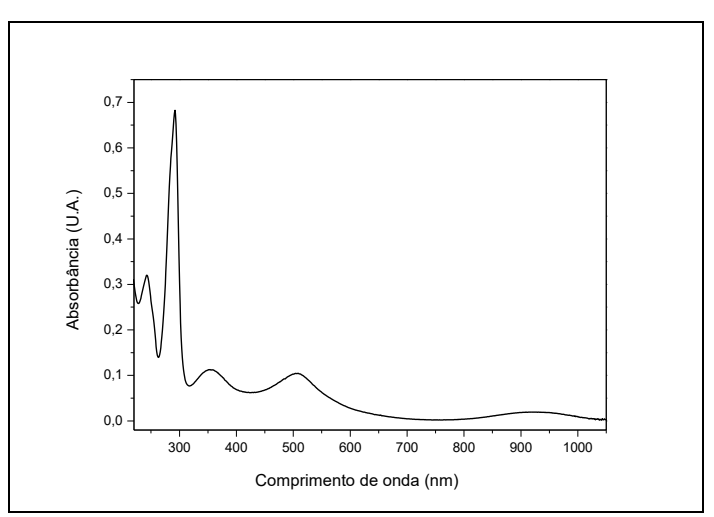

(E)

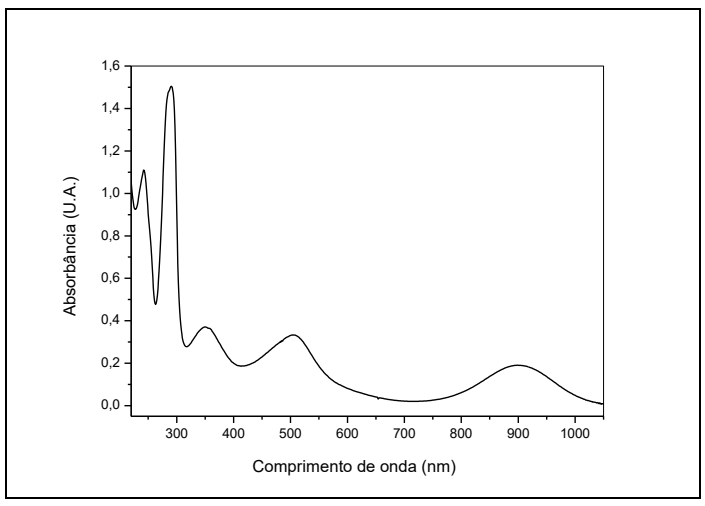

Fonte: Autora

É possível notar que os complexos sintetizados exibem bandas características, ao redor de 350, 500 e $900 \mathrm{~nm}$ - além de outras na região do ultravioleta - para as quais o coeficiente de absortividade molar ( $\varepsilon$ ) foi calculado (tabela 20): 
Tabela 20: Propriedades espectroscópicas dos complexos

\begin{tabular}{cccc}
\hline$\left[\mathbf{R u}(\mathbf{b p y})_{\mathbf{2}}(\mathbf{L})\right]^{+}$ & $\boldsymbol{\lambda}_{\text {máx }}(\mathbf{n m})$ & energia $\left(\mathbf{c m}^{-\mathbf{1}}\right)$ & $\log \boldsymbol{\varepsilon}$ \\
\hline \hline \multirow{2}{*}{$\mathrm{L}=$ catecol } & 903 & 11074,20 & 3,21 \\
& 505 & 19801,98 & 3,1 \\
& 352 & 28409,09 & 3,22 \\
\hline \multirow{2}{*}{$\mathrm{L}=$ isoproterenol } & 910 & 10989,01 & 2,81 \\
& 514 & 19455,25 & 3,21 \\
& 353 & 28328,61 & 3,31 \\
\hline \multirow{2}{*}{$\mathrm{L}=$ adrenalina } & 916 & 10917,03 & 3,32 \\
& 500 & 20000,00 & 3,9 \\
& 351 & 28490,03 & 3,9 \\
\hline \multirow{2}{*}{$\mathrm{L}=$ dopamina } & 921 & 10857,76 & 2,58 \\
& 510 & 19607,84 & 3,66 \\
$\mathrm{~L}=$ noradrenalina & 355 & 28169,01 & 3,67 \\
\hline & 922 & 10845,99 & 3,15 \\
& 503 & 19880,72 & 3,7 \\
& 362 & 27624,31 & 3,89 \\
\hline
\end{tabular}

Fonte: Autora

Não obstante o fato de os valores de $\varepsilon$ encontrados para os complexos estarem no intervalo esperado para as transições permitidas por simetria, em razão de as bandas na região do infravermelho próximo serem largas, calculou-se a força do oscilador, para a banda atribuída como transição eletrônica de transferência de carga do metal para o ligante (TCML), cujos valores são descritos na tabela a seguir (tabela 21):

Tabela 21: Valores da força do oscilador $(f)$

\begin{tabular}{cc}
\hline Complexo & $\Delta_{1 / 2}\left(\mathrm{~cm}^{-1}\right) ; f$ \\
\hline \hline$\left[\mathrm{Ru}(\text { bpy })_{2}(\right.$ isoproterenol $\left.)\right]+$ & $2.607 ; 0,01$ \\
{$\left[\mathrm{Ru}(\mathrm{bpy})_{2}\right.$ (adrenalina) $]+$} & $3.421 ; 0,03$ \\
{$\left[\mathrm{Ru}(\mathrm{bpy})_{2}(\right.$ noradrenalina $\left.)\right]+$} & $1.828 ; 0,02$ \\
{$\left[\mathrm{Ru}(\mathrm{bpy})_{2}\right.$ (catecol) $]+$} & $1.823 ; 0,02$ \\
$\left[\mathrm{Ru}(\mathrm{bpy})_{2}\right.$ (dopamina $\left.)\right]+$ & $2.974 ; 0,02$ \\
\hline
\end{tabular}

$\Delta_{1 / 2}:$ largura de banda à meia altura

Fonte: Autora

Conforme mencionado anteriormente, transições com valor de $f$ entre $10^{-2}$ e 1 são consideradas permitidas. Logo, os valores calculados para as transições presentes nos complexos sintetizados, de fato, legitimam as transições como do tipo TCML (OLIVEIRA, 2009). Importante salientar que embora - da primeira análise dos espectros eletrônicos - seja 
possível aferir que o coeficiente de absortividade molar da banda, (na região do infravermelho) para o complexo cujo ligante dioxoleno é o catecol, seja maior, os valores de $f$ mostram que elas são equivalentes, demonstrando que neste tipo de transição eletrônica seja conveniente utilizar este cálculo em detrimento da corriqueira análise de $\varepsilon$.

Os espectros eletrônicos dos complexos desta série são bastante diferentes daqueles apresentados na primeira parte deste texto. No entanto, suas propriedades são condizentes com as descrições da literatura - a qual descreve que para complexos de rutênio coordenados com heterociclos, o metal é estabilizado como Ru(II) (DE LIMA, 2001; LEVER, 1988; LEVER et. al., 1988; MASUI; LEVER; AUBURN, 1991). Além disso, quando o íon é $\mathrm{Ru}(\mathrm{II})$, os ligantes dioxolenos são, preferencialmente, estabilizados na forma de semiquinona (DE LIMA, 2001; HAGA, 1990; CUNHA et. al., 1996).

$\mathrm{O}$ complexo cis-[Ru(bpy $\left.)_{2} \mathrm{Cl}_{2}\right]$, precursor utilizado nas sínteses, tem sido amplamente explorado na literatura, bem como a atribuição das transições eletrônicas do seu espectro eletrônico. Tanto a banda em aproximadamente 520, quanto em aproximadamente $370 \mathrm{~nm}$ são atribuídas às transições eletrônicas de transferência de carga do metal para ligante $(\mathrm{TCML})$, especificamente, $\mathrm{d}_{\pi} \mathrm{Ru}^{\mathrm{II}} \rightarrow\left(\right.$ bpy) $\pi^{*}$ (1) e $\mathrm{d}_{\pi} \mathrm{Ru}^{\mathrm{II}} \rightarrow$ (bpy) $\pi^{*}$ (2), respectivamente, enquanto bandas na região do ultravioleta, em 297 e 243 nm, são atribuídas à transições internas do ligante (IL) (SAUAIA, 2001; HAGA; DODSWORTH; LEVER, 1986).

Posteriormente à coordenação aos ligantes dioxolenos, observaram-se deslocamentos hipsocrômicos das bandas referentes às transições eletrônicas TCML, em relação ao complexo precursor - comportamento este resultante do fato de os ligantes dioxolenos provavelmente promoverem a estabilização dos orbitais do metal, em razão do seu caráter mais retirador de densidade eletrônica, quando na forma de semiquinona. Na região do $\mathrm{UV}$, as pequenas alterações observadas, em relação ao complexo precursor, são advindas das transições eletrônicas intraligante, das próprias catecolaminas (ou catecol).

Assim, considerando-se os valores de $\varepsilon$ calculados, bem como as semelhanças entre estes complexos e o precursor, para as bandas na região visível do espectro eletromagnético são mantidas as mesmas atribuições efetuadas para o precursor, transições eletrônicas de transferência de carga do metal para o ligante (TCML), embora tenham ocorrido deslocamentos dos comprimentos de onda máximos de absorção (HAGA; DODSWORTH; LEVER, 1986; LEVER, et. al., 1988; DE LIMA, 2001).

Após a coordenação dos ligantes dioxolenos, há o surgimento de uma banda de absorção na região do infravermelho próximo, com $\lambda_{\text {máx }}>900 \mathrm{~nm}$, para os complexos neste 
texto reportados. Esta transição eletrônica é atribuída à transferência de carga de orbital predominantemente metálico, para predominantemente do ligante dioxoleno: $\mathrm{d}_{\pi} \mathrm{Ru}^{\mathrm{II}}\left(\mathrm{a}_{1}{ }^{2} \mathrm{~b}_{1}{ }^{2} \mathrm{a}_{2}{ }^{2}\right) \rightarrow \mathrm{sq}\left(3 \mathrm{~b}_{1}\right)$ (HAGA; DODSWORTH; LEVER, 1986; LEVER, et. al., 1988; DE LIMA, 2001). Em publicação mais recente, Schmidt e colaboradores (2014), descreveram a mesma transição, observada para complexo cujo dioxoleno é 1,10-fenantrolina-5,6-diona, quando o ligante é radical (semiquinona), na região de $950 \mathrm{~nm}$ e a atribuíram à $\mathrm{d}_{(\mathrm{RuII} \pi)} \rightarrow$ $\pi_{\text {(sqSOMO) }}$ (SCHMIDT et. al., 2014).

O máximo de absorção desta banda é bastante sensível a pequenas substituições nos ligantes dioxolenos - o que reafirma esta atribuição como uma transição envolvendo este ligante - além do fato de Haga e colaboradores (1986) terem observado que tanto para o complexo precursor contendo $\left[\mathrm{Ru}(\mathrm{bpy})_{2}\right]^{2+}$, quanto $\left[\mathrm{Ru}(\mathrm{py})_{4}\right]^{2+}$, a coordenação ao ligante dioxoleno promovia o aparecimento desta banda.

As atribuições retroapresentadas são fundamentadas nas publicações prévias, para complexos semelhantes, as quais serão brevemente discutidas a seguir: Haga e colaboradores afirmaram, em 1986, que em todos os complexos metálicos envolvendo dioxolenos e iminas (piridina e bipiridina), independentemente do estado de oxidação do dioxoleno, o metal foi estabilizado como $\mathrm{Ru}(\mathrm{II})$. Os autores reportaram a síntese de $\left[\mathrm{Ru}(\mathrm{bpy})_{2}(\text { dioxoleno })\right]^{\mathrm{n}+}$, sendo dioxoleno é catecol, 3,5-ditercbutil-catecol e tetracloro-catecol. O produto das sínteses foi $\left[\mathrm{Ru}(\mathrm{bpy})_{2}(\text { catecol-R) }]^{+}\right.$, porém, por eletrólise foram obtidos $\left[\mathrm{Ru}(\mathrm{bpy})_{2} \text { (quinona-R) }\right]^{2+}$ e, por oxidação promovida pelo oxigênio atmosférico, foram obtidos $\mathrm{Ru}(\mathrm{bpy})_{2}$ (semiquinona-R). Os autores reportaram, ainda, que os comprimentos das ligações são condizentes com Ru(II)semiquinona, entretanto, persiste um contrassenso, pois há distorções na estrutura que indicam que o metal possui caráter parcial de $\mathrm{Ru}(\mathrm{III})$, com o elétron desemparelhado parcialmente localizado no metal (HAGA; DODSWORTH; LEVER, 1986). O paramagnetismo do complexo foi confirmado por espectroscopia de ressonância paramagnética eletrônica (EPR). Além disso, Lever e colaboradores (1988) descreveram que a banda (TCML) na região do infravermelho próximo é característica de complexos cujo ligante dioxoleno esteja na forma de radical, semiquinona - esta atribuição foi realizada pelos autores com auxílio da técnica de Espectroscopia Raman ressonante (LEVER, et. al., 1988).

Embora seja preferida a descrição destes complexos como Ru(II)-semiquinona, todos os artigos referentes ao tema afirmam que nestes sistemas há deslocalização eletrônica, devido à grande sobreposição entre os orbitais d do metal e os orbitais de fronteira dos 
dioxolenos - deslocalização esta não observada pra outros metais coordenados aos ligantes em destaque (HAGA; DODSWORTH; LEVER, 1986; LEVER, et. al., 1988).

Em relação às energias envolvidas nas transições eletrônicas TCML, tanto para bpy, quanto para o dioxoleno, observou-se que para os complexos cujos ligantes possuíam substituintes mais doadores de densidade eletrônica, as transições sofreram deslocamento hipsocrômico, em relação ao catecol (não substituído), enquanto deslocamento batocrômico foi observado para o complexo cujo substituinte do catecol possui maior caráter de receptor de densidade eletrônica (HAGA; DODSWORTH; LEVER, 1986).

Comparados aos dados publicados previamente, observa-se que no contexto geral, os complexos sintetizados neste trabalho seguem a tendência observada previamente para ligantes mais oxidantes, uma vez que a transição eletrônica na região do infravermelho próximo foi observada em maiores comprimentos de onda, quando o dioxoleno utilizado foi catecolamina - em relação ao catecol (HAGA; DODSWORTH; LEVER, 1986).

A tendência observada para esta transição, em relação à variação do pKa (figura $^{2}$ 104) é oposta àquela observada para os complexos anteriormente relatados neste trabalho, o que corrobora as atribuições feitas como transições eletrônicas TCLM para aqueles e, TCML, para estes.

Figura 104: Correlação entre os valores de $\mathrm{pKa}_{1}$ dos ligantes a energia envolvida na transição eletrônica de TCML

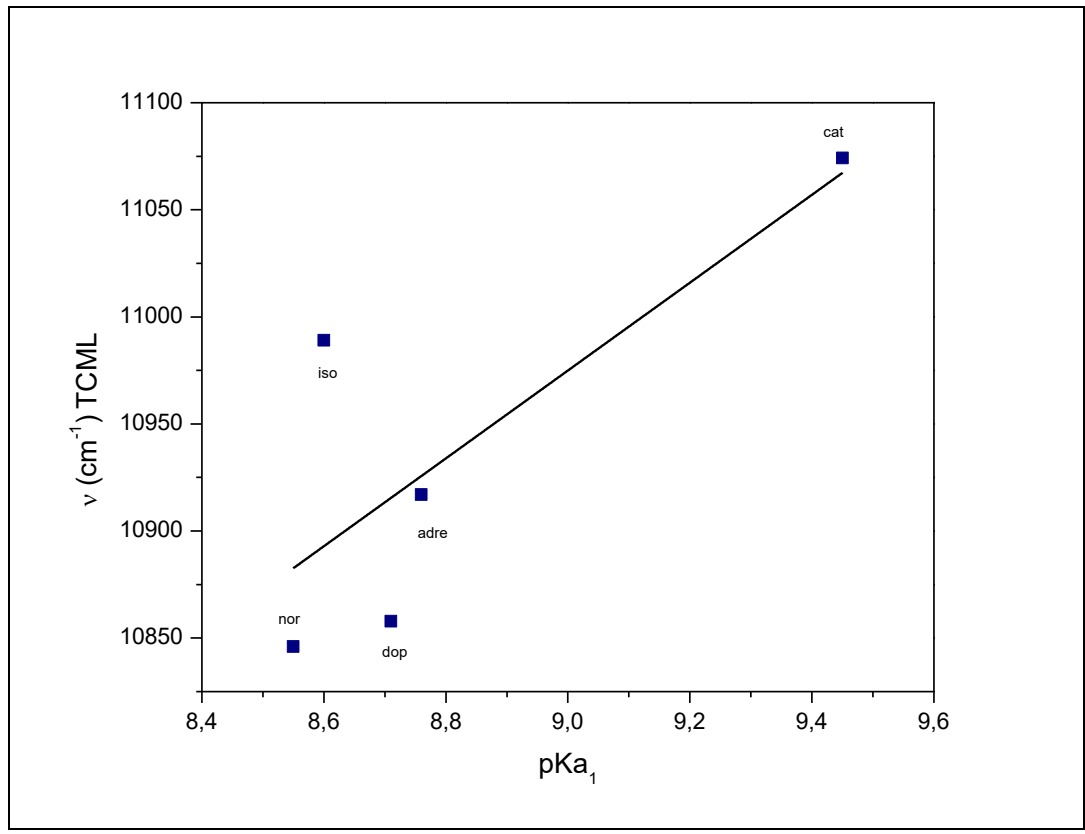

Fonte: Autora 


\subsubsection{Espectroscopia de absorção na região do infravermelho}

Os complexos também foram caracterizados por espectroscopia de absorção na região do infravermelho e os espectros obtidos são mostrados a seguir (figura 105):

Figura 105: Espectro de absorção na região do infravermelho (pastilhas de CsI): (A) $\left[\mathbf{R u}(\text { bpy })_{2}\right.$ (isoproterenol) $] \mathrm{Cl}, \quad(\mathrm{B}) \quad\left[\mathrm{Ru}(\mathrm{bpy})_{2}(\right.$ dopamina $\left.)\right] \mathrm{Cl}, \quad(\mathrm{C}) \quad\left[\mathrm{Ru}(\mathrm{bpy})_{2}(\right.$ noradrenalina $\left.)\right] \mathrm{Cl}, \quad$ (D) $\left[\mathrm{Ru}(\mathrm{bpy})_{2}(\right.$ catecol $\left.)\right] \mathrm{Cl}$ e (E) $\left[\mathrm{Ru}(\mathrm{bpy})_{2}(\right.$ adrenalina $\left.)\right] \mathrm{Cl}$

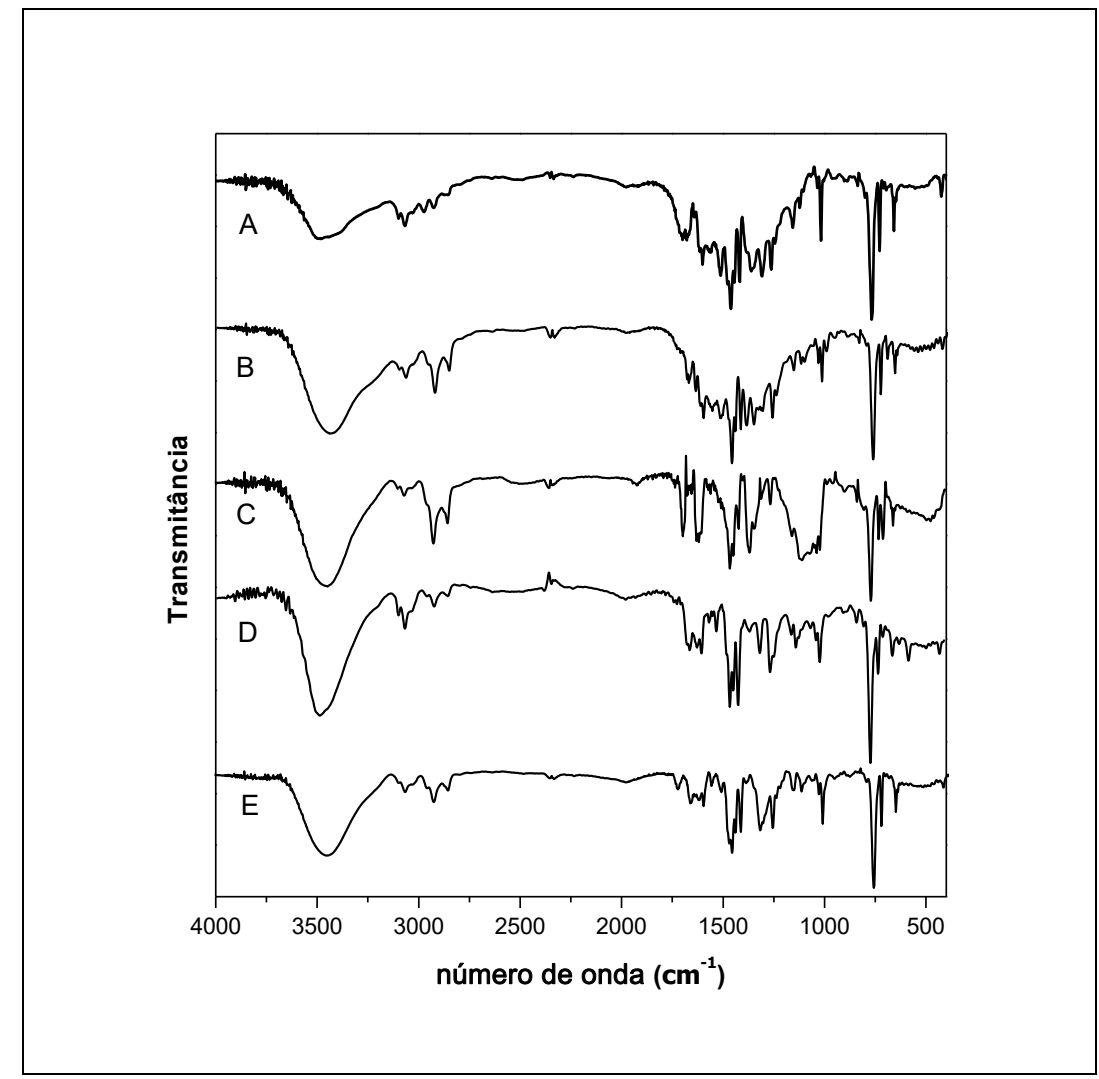

Fonte: Autora

As atribuições das transições observadas nos espectros, as quais foram realizadas com fundamento nas bandas observadas para os ligantes livres (espectros constantes do apêndice, figura 134), bem como nos valores reportados na literatura para complexos semelhantes e o precursor utilizado (espectro no apêndice, figura 172), seguem mostradas na tabela a seguir (tabela 22): 
Tabela 22: Atribuições das principais bandas nos espectros de FTIR, em pastilhas de CsI

\begin{tabular}{|c|c|c|c|c|c|}
\hline \multirow[b]{2}{*}{ Atribuições } & \multicolumn{3}{|c|}{$\left[\mathrm{Ru}(\mathrm{bpy})_{2}(\right.$ iso $\left.)\right] \mathrm{Cl}\left[\mathrm{Ru}(\mathrm{bpy})_{2}(\right.$ adre $\left.)\right] \mathrm{Cl}\left[\mathrm{Ru}(\mathrm{bpy})_{2}\right.$ (nor) $] \mathrm{Cl}$} & \multicolumn{2}{|c|}{$\left[\mathrm{Ru}(\mathrm{bpy})_{2}\right.$ (cat) $] \mathrm{Cl}\left[\mathrm{Ru}(\mathrm{bpy})_{2}(\mathrm{dop})\right] \mathrm{Cl}$} \\
\hline & $\operatorname{IV}\left(\mathrm{cm}^{-1}\right)$ & $\operatorname{IV}\left(\mathrm{cm}^{-1}\right)$ & $\operatorname{IV}\left(\mathrm{cm}^{-1}\right)$ & $\operatorname{IV}\left(\mathrm{cm}^{-1}\right)$ & $\operatorname{IV}\left(\mathrm{cm}^{-1}\right)$ \\
\hline$\delta(\mathrm{bpy})_{\mathrm{anel}}$ & 768 & 771 & 772 & 765 & 771 \\
\hline$v \mathrm{C}-\mathrm{O}$ & 1462 & 1458 & 1464 & 1420 & 1468 \\
\hline$v \mathrm{O}-\mathrm{H}$ & 3480 & 3448 & 3460 & 3492 & 3434 \\
\hline
\end{tabular}

Fonte: Autora

A banda característica da deformação no plano, presente no complexo precursor devido ao anel aromático dos ligantes bipiridil, na região de $770 \mathrm{~cm}^{-1}$, está presente em todos em complexos e praticamente não sofre deslocamentos após a coordenação ao ligante catecólico. As bandas na região de 1604, 1443 e $1418 \mathrm{~cm}^{-1}$, presentes no complexo precursor caracterizam a vibração $(\nu \mathrm{C}=\mathrm{C})$ do anel aromático do ligante bipiridil e estão presentes nos complexos sintetizados. Na região de 1506 a $1540 \mathrm{~cm}^{-1}$, são encontradas as bandas concernentes às vibrações $(v \mathrm{C}=\mathrm{N})$ do ligante bipiridil (VEGAS, 2013; ROCHA, 2014; STRUKL; WALTER, 1971). Por fim, as bandas na região entre 1250 e $1300 \mathrm{~cm}^{-1}$, presentes na primeira série de complexos reportada, indicando a forma reduzida do ligante, catecolato, estão ausentes nestes complexos. Porém, é possível evidenciar uma banda relativamente intensa em aproximadamente $1500 \mathrm{~cm}^{-1}$, para todos os complexos, o que ratifica a estabilização dos dioxolenos na forma de semiquinona nesta série de complexos (HAGA; DODSWORTH; LEVER, 1986; DE LIMA, 2001).

Devido à limitação temporal, bem como de páginas (deste texto), os resultados obtidos com as demais técnicas utilizadas na caracterização destes complexos não serão aqui reportados. No entanto, é importante salientar que dados de voltametria cíclica, bem como de RMN e EPR são harmoniosos com os reportados aqui, demonstrando a pureza e correta caracterização dos mesmos.

Uma vez caracterizados, os complexos desta série foram submetidos a alguns dos ensaios biológicos, dos quais a primeira série fora objeto.

\subsubsection{Viabilidade celular}

Devido à observação preliminar, realizada quando da análise dos outros complexos, este experimento foi realizado apenas com o tempo de incubação maior. Assim a viabilidade celular foi avaliada após 48 horas de incubação com os complexos metálicos e seus respectivos ligantes livres. Para melhor visualização e comparação dos resultados, são 
mantidos nos gráficos os resultados obtidos para os complexos metálicos abordados na parte 1 deste capítulo de resultados da tese. Os resultados são mostrados a seguir (figura 106):

Figura 106: Análise da viabilidade celular de B16F10 após tratamento com complexos ou ligantes livres. Células B16F10 foram tratadas por 48h com Ru-NA, NA ou Ru(bpy) $)_{2} \mathrm{NA}$ (A); Ru-Adr, Adr ou Ru(bpy) ( $_{2} \mathrm{~A}$ (B); Ru-Dopa, Dopamina, ou Ru(bpy) $)_{2}$ Dopa (C); Ru-Iso, Iso, ou Ru(bpy) $)_{2}$ Iso (D); Ru-Catecol, Catecol, ou $\operatorname{Ru}(b p y)_{2} \operatorname{Cat}(E)$, em diferentes concentrações $\left(10\right.$ a $200 \mu$ mol..$\left.^{-1}\right)$ ou situação controle ( em ausência de tratamento). Dados são apresentados como \% de média \pm E.P.M. do Controle. * diferente de Controle; \# diferente da respectiva catecolamina na mesma concentração. One-way ANOVA, pós-teste de NewmanKeuls $(P<0,05), \mathbf{n}=3$

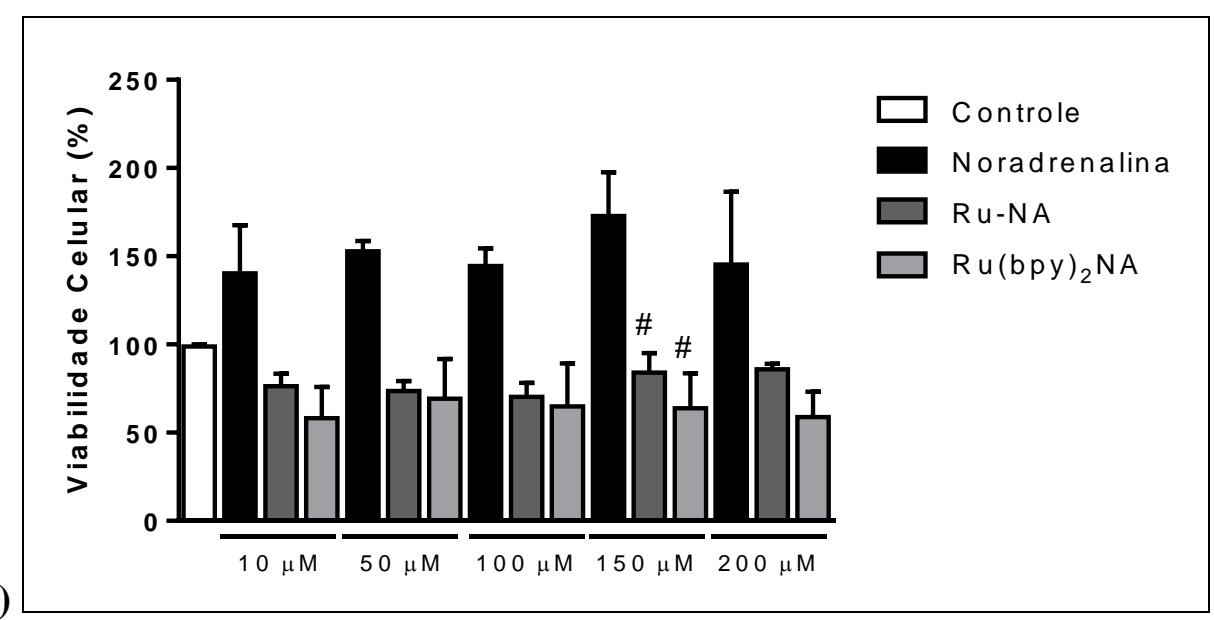

(A)

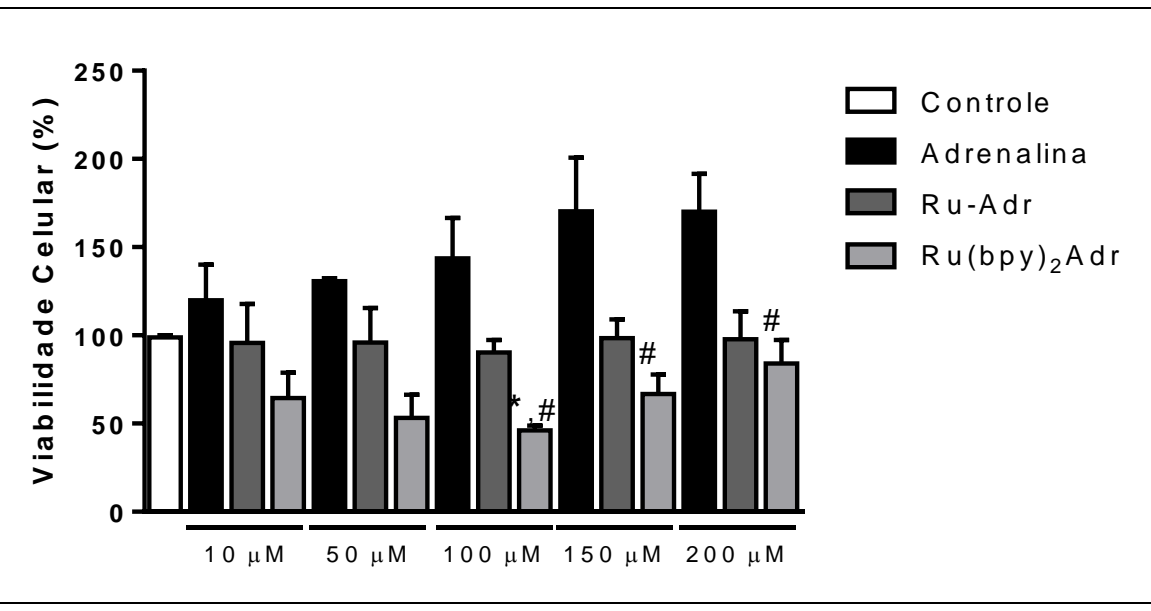

(B) 
(C)

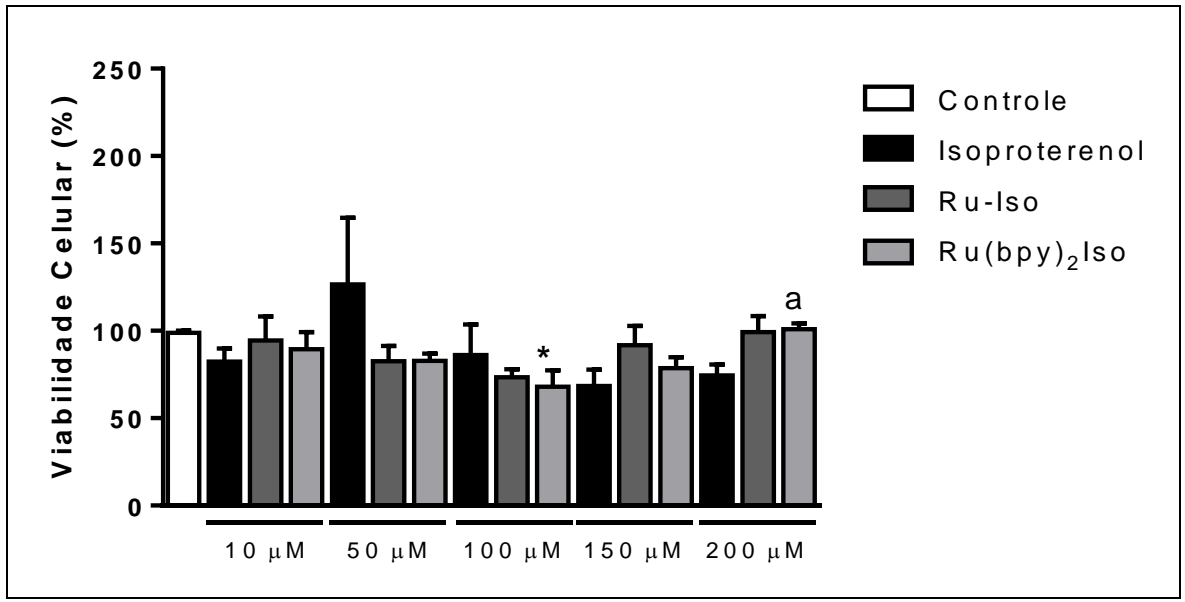

a:diferente do complexo bipiridil $100 \mu \mathrm{M}$

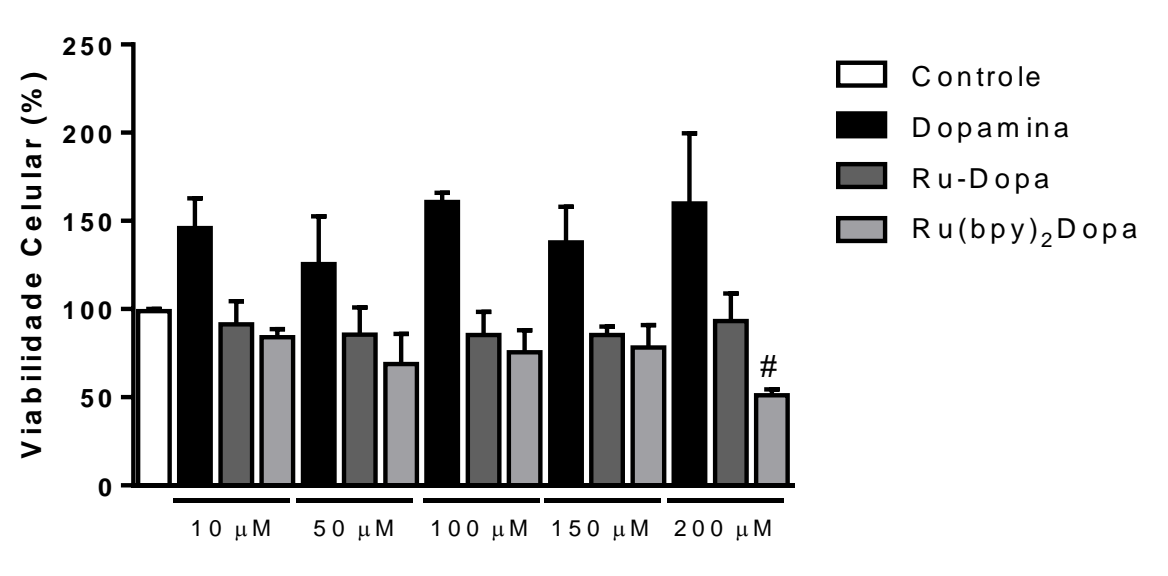

(D)

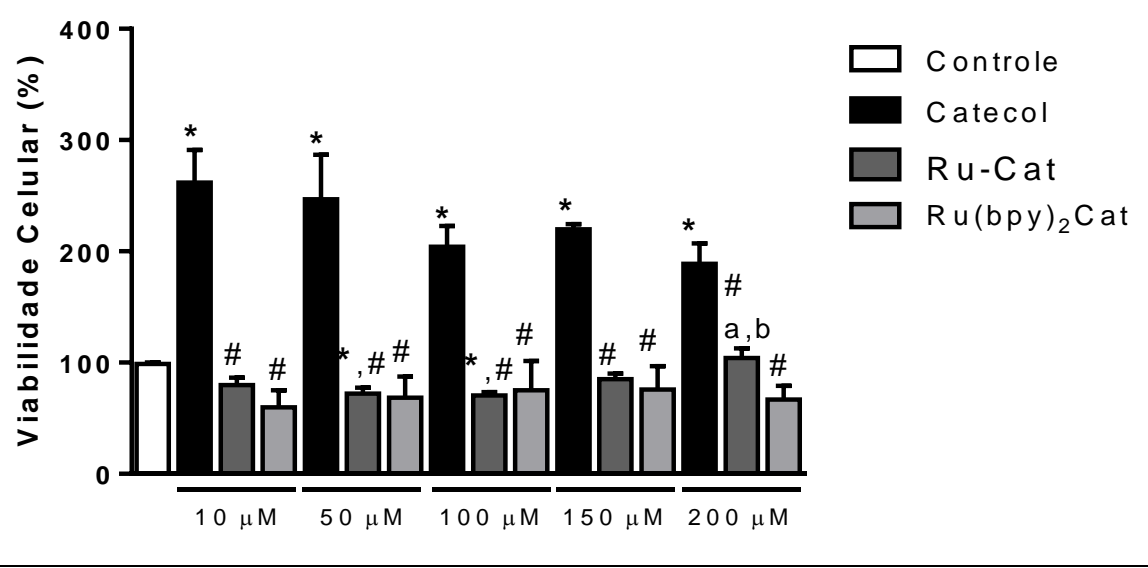

a: Diferente de $100 \mu \mathrm{M} \mathrm{Ru-Cat;} \mathrm{b:} \mathrm{Diferente} \mathrm{de} 10 \mu \mathrm{M}$ Ru-Cat

Fonte: Autora 
$\mathrm{O}$ complexo $\left[\mathrm{Ru}(\mathrm{bpy})_{2}(\text { noradrenalina })\right]^{+}$apresentou certa tendência que indica menores valores de viabilidade celular (aproximadamente $70 \%$, em $150 \mu \mathrm{M}$ ), quando comparado ao respectivo complexo tetramino, bem como ao ligante livre, nas mesmas concentrações, embora não estatisticamente significativo. Estes resultados estão de acordo com o esperado, haja vista os ligantes não-dioxolenos serem conhecidamente intercaladores do DNA, conforme será discutido no próximo tópico (SHI et. al., 2006; PRAVIN et. al., 2016). O ligante livre aumentou a viabilidade celular e o complexo tetramino não se motra citotóxico, tal como já mencionado na parte 1 deste capítulo.

$\mathrm{O}$ complexo $\left[\mathrm{Ru}(\mathrm{bpy})_{2}(\text { adrenalina })\right]^{+}$apresentou a mesma tendência observada para o anterior, assim como seus respectivos ligante e complexo tetramino, porém apresentou valores de viabilidade celular menores $(46 \%$ em $100 \mu \mathrm{M})$ que os verificados para o complexo de noradrenalina.

Para o complexo $\left[\mathrm{Ru}(\mathrm{bpy})_{2}(\text { isoproterenol) }]^{+}\right.$, assim como observado para o respectivo tetramino, não foram observadas alterações expressivas na viabilidade celular.

$\mathrm{O}$ complexo $\left[\mathrm{Ru}(\mathrm{bpy})_{2}(\text { dopamina })\right]^{+}$, por sua vez, apresentou resultados muito semelhantes em relação ao respectivo tetramino, embora na concentração maior, $200 \mu \mathrm{M}$, tenha apresentado expressiva redução da viabilidade celular (51\%).

Para o complexo $\left[\operatorname{Ru}(\text { bpy })_{2}(\text { catecol })\right]^{+}$, não foram observadas alterações expressivas na viabilidade celular, em relação ao complexo tetramino. No entanto, as diferenças são expressivas, significativas em quase todas as concentrações trabalhadas, em relação ao ligante livre.

De um modo geral, excetuando-se o complexo de isoproterenol e catecol, os complexos desta série apresentaram tendência de redução da viabilidade celular, em relação aos anteriores, assim como impedem o efeito de aumento da viabilidade induzido pelos respectivos ligantes livres. Os menores valores de viabilidade celular encontrados para os complexos desta seção, quando comparados aos anteriores podem ser atribuídos ao estado de oxidação do íon metálico, Ru(II), o que lhe garante maior afinidade com as bases nitrogenadas do DNA, bem como ao fato de os complexos possivelmente interagirem com o DNA, haja vista as propriedades de intercalação já conhecidas dos ligantes bipiridil (SOUZA, 2014). 


\subsubsection{Interação com fs-DNA}

\subsubsection{Interação com $f s$-DNA - titulação espectrofotométrica na região do UV-Vis}

Conforme demonstrado previamente para os complexos tetraminos, o ensaio de interação com DNA também foi realizado para os complexos contendo como ligantes bipiridil. Os espectros resultantes da interação são mostrados a seguir (figuras 107 a 111). No corpo do texto serão mostrados os espectros referentes aos ensaios realizados a $25^{\circ} \mathrm{C}$, enquanto os referentes a $30^{\circ}$ e $37^{\circ} \mathrm{C}$ seguem no apêndice deste texto (figuras 173 a 182):

Figura 107: Titulação do complexo $\left[\operatorname{Ru}(\text { bpy })_{2}(\text { isoproterenol })\right]^{+}, a^{\circ} 5^{\circ} \mathrm{C}, \operatorname{com} f s$-DNA, acompanhada por espectroscopia na região do $\mathrm{UV}$-vis

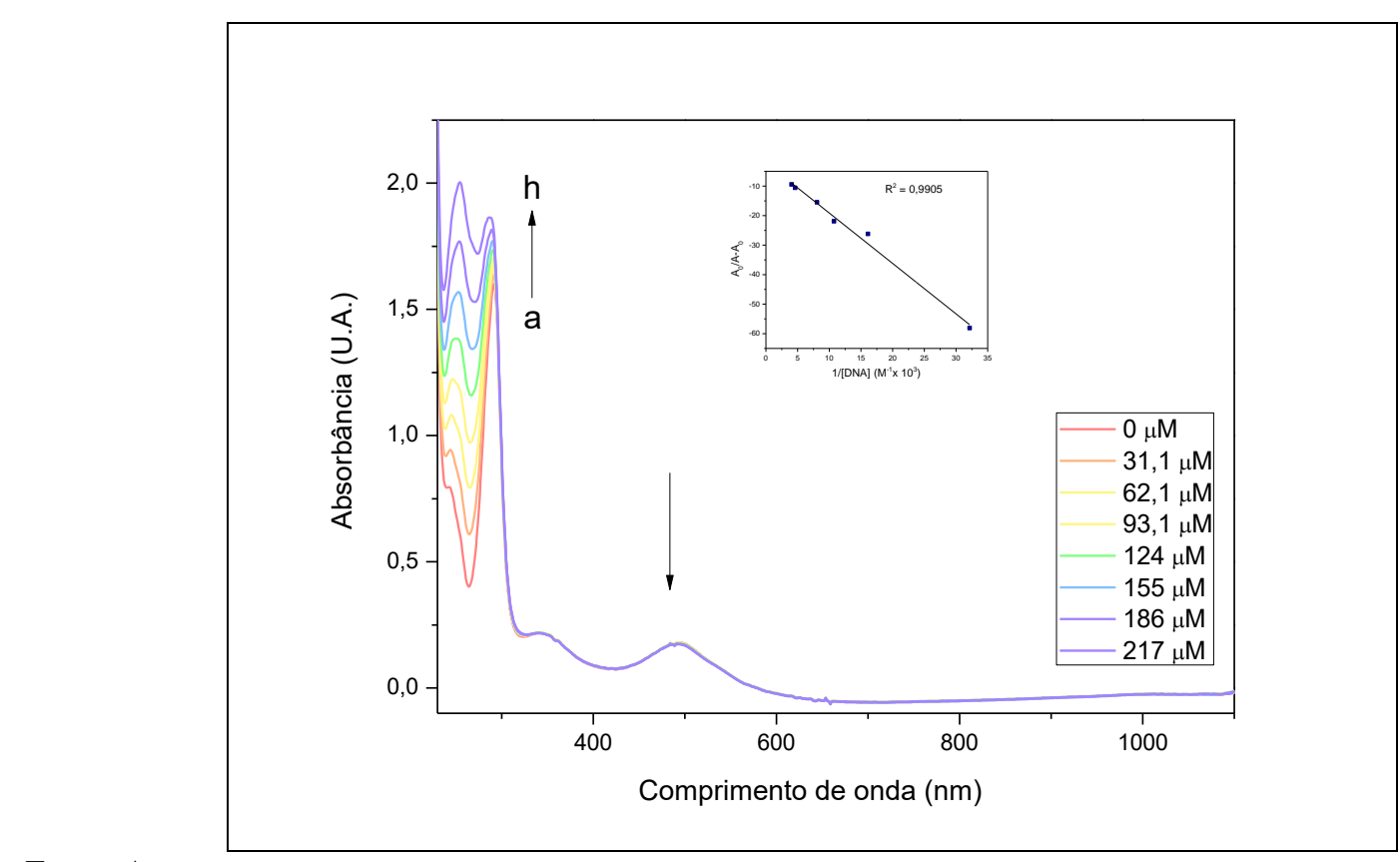

Fonte: Autora 
Figura 108: Titulação do complexo $\left[\operatorname{Ru}(\text { bpy })_{2}(\text { dopamina })\right]^{+}$, a $25^{\circ} \mathrm{C}$, com $f s$-DNA, acompanhada por espectroscopia na região do UV-vis

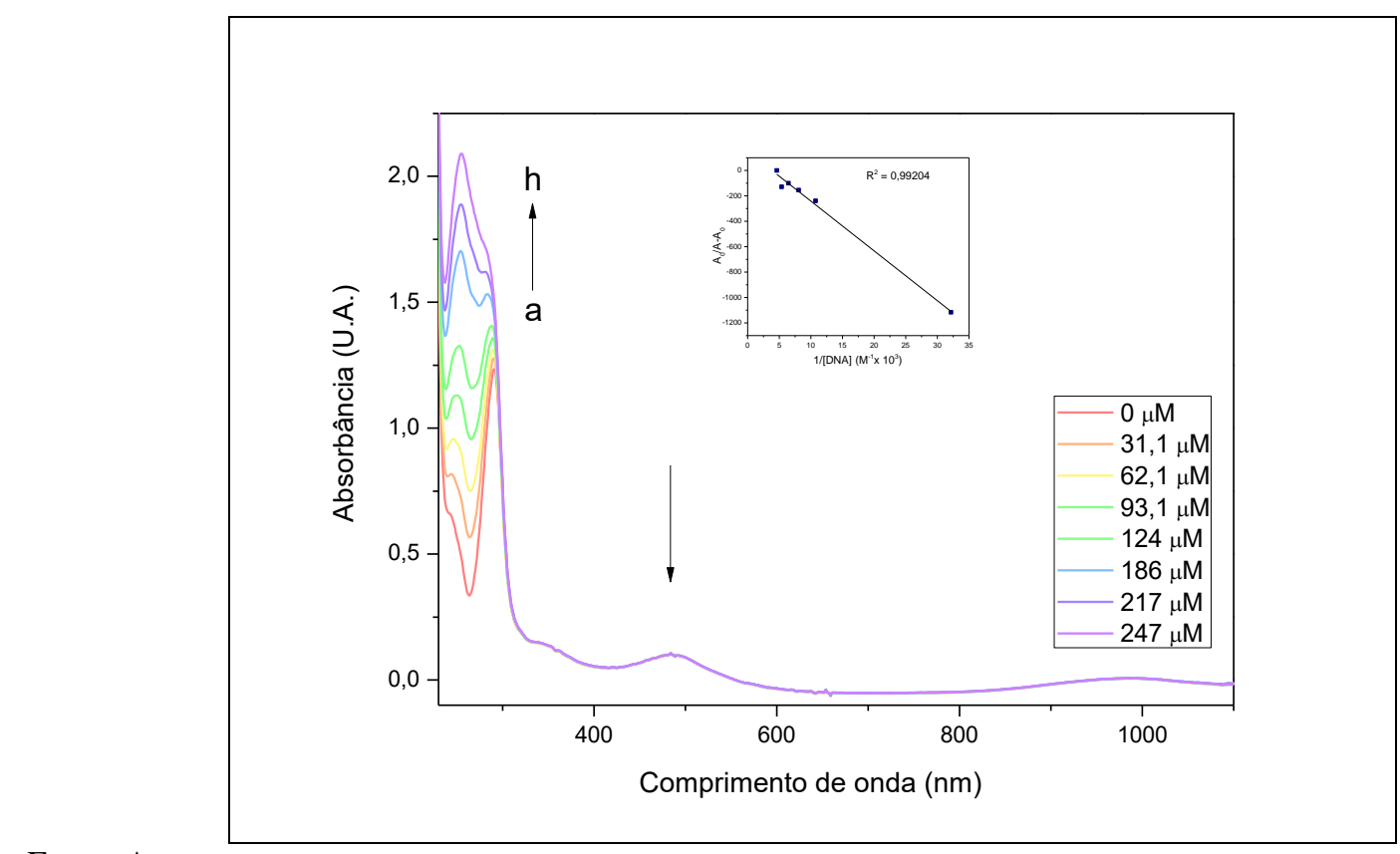

Fonte: Autora

Figura 109: Titulação do complexo $\left[\mathrm{Ru}(\mathrm{bpy})_{2}(\text { noradrenalina })\right]^{+}, \mathrm{a}^{\circ} 5^{\circ} \mathrm{C}, \operatorname{com} f s$-DNA, acompanhada por espectroscopia na região do UV-vis

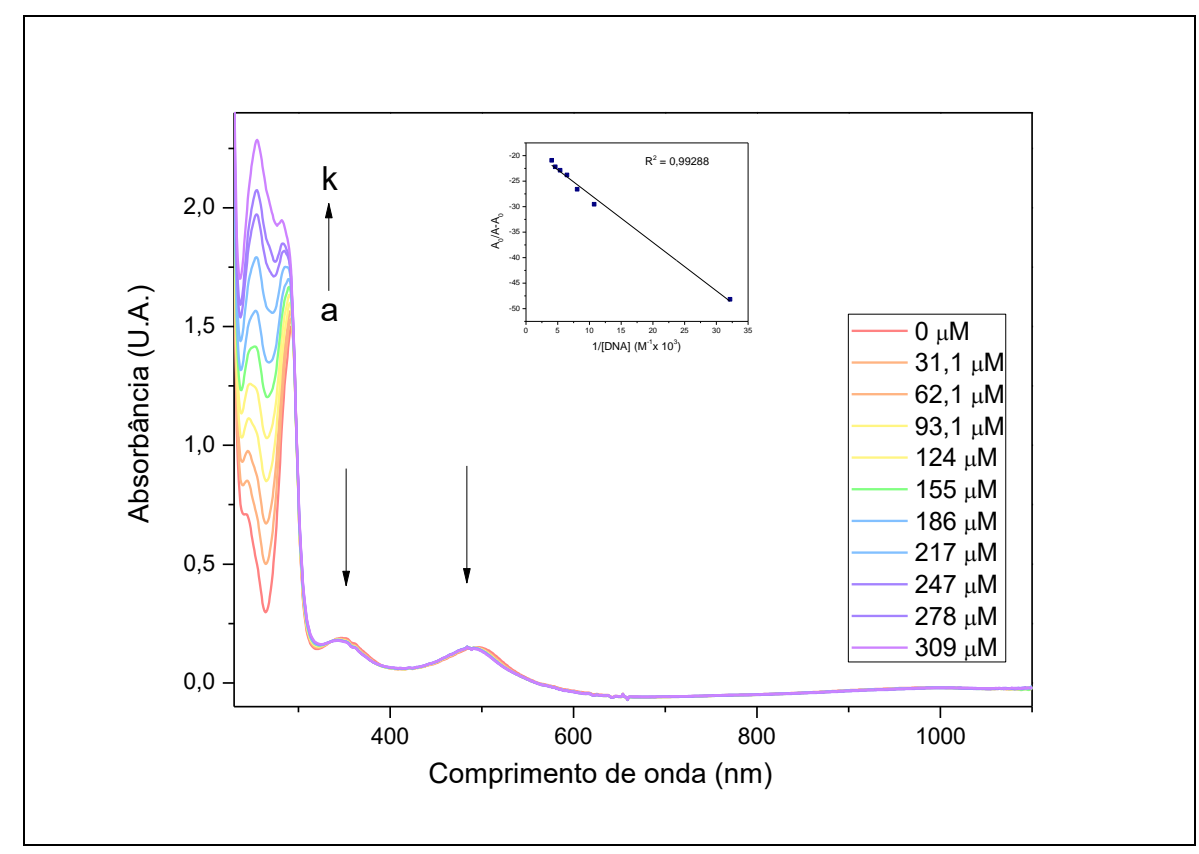

Fonte: Autora 


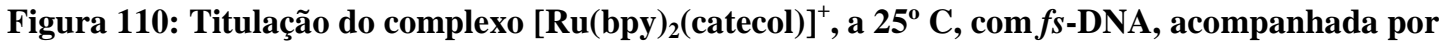
espectroscopia na região do $\mathrm{UV}$-vis

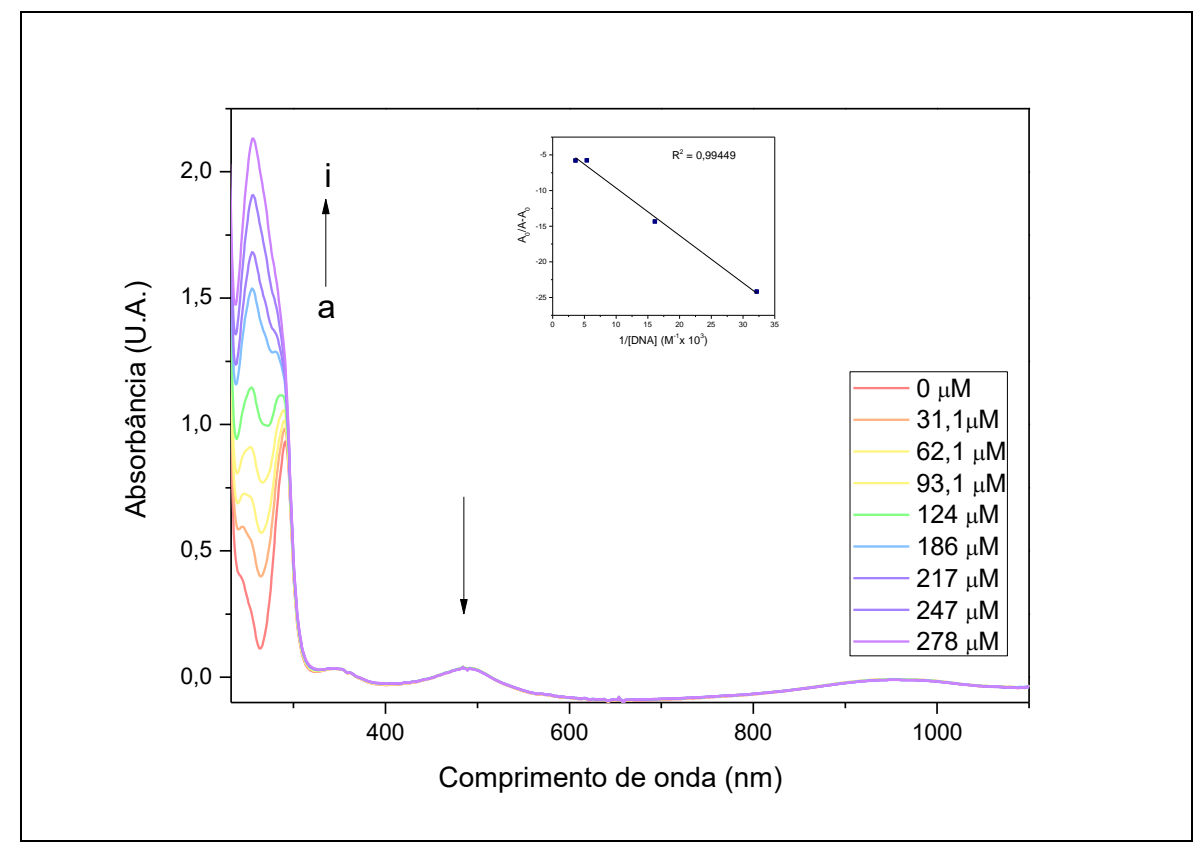

Fonte: Autora

Figura 111: Titulação do complexo $\left[\operatorname{Ru}(b p y)_{2}(\operatorname{adrenalina})\right]^{+}, a^{\circ} \mathbf{C}, \operatorname{com} f s$-DNA, acompanhada por espectroscopia na região do $\mathrm{UV}$-vis

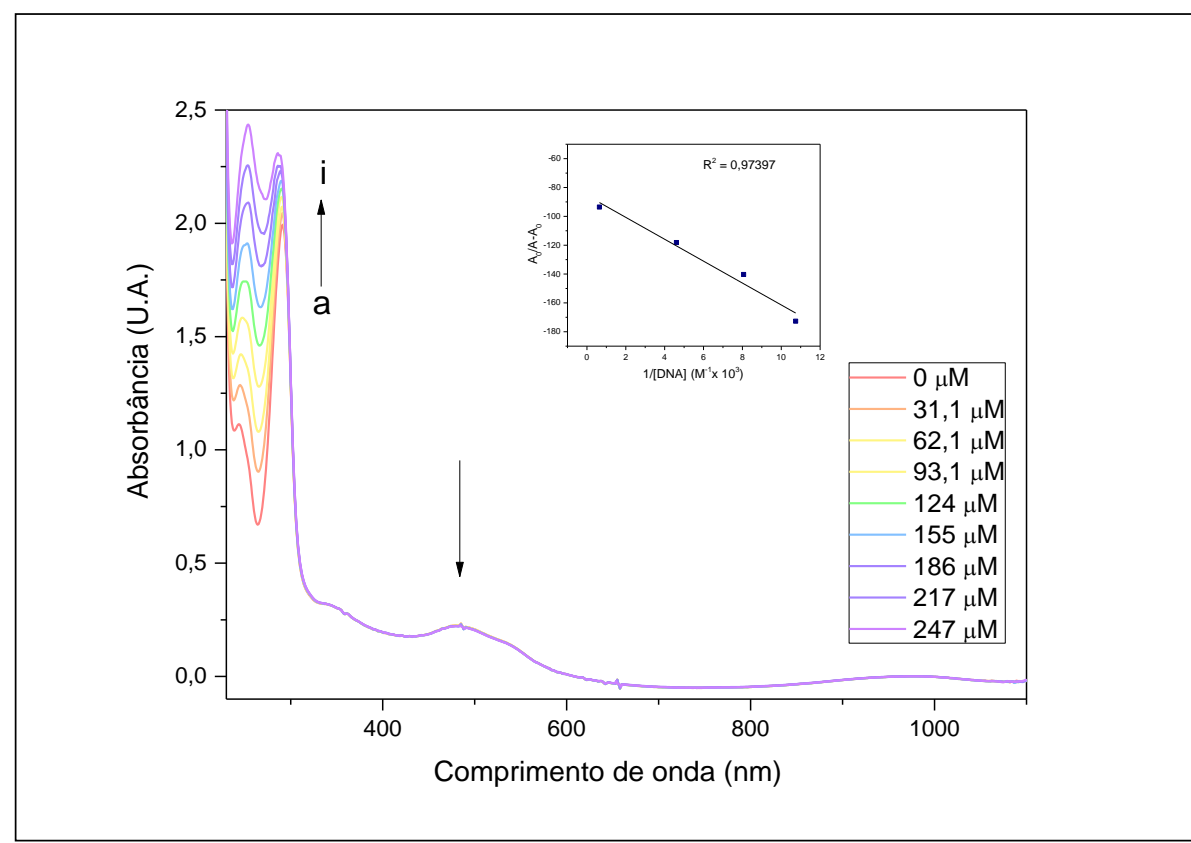

Fonte: Autora 
Para esta classe de complexos, foi possível verificar nítidas alterações espectrais oriundas da interação dos complexos com a biomolécula. Na banda do complexo, na região de $250 \mathrm{~nm}$, coincidente com a região da banda do DNA, observou-se efeito hipercrômico. No entanto, além deste efeito, é possível verificar, também, deslocamento batocrômico no máximo de emissão.

Por outro lado, nas bandas do tipo TCML, na região de aproximadamente $490 \mathrm{~nm}$, verificou-se hipocromismo, sem deslocamento do máximo de emissão, para todos os cinco complexos. Foram observados pontos isosbésticos nas regiões de 450 e $530 \mathrm{~nm}$.

Foi observado, também, para o complexo cujo ligante é noradrenalina, hipocromismo nas bandas de $340 \mathrm{~nm}$, com deslocamento hipsocrômico de $\Delta \lambda=2 \mathrm{~nm}$, efeito este, porém, menor que o observado na região de $490 \mathrm{~nm}$. Os efeitos hiper e hipocrômico, bem como os deslocamentos hipso e batocrômico das bandas, estão resumidos na tabela a seguir (23):

Tabela 23: Efeitos observados nas bandas dos complexos

\begin{tabular}{cccc}
\hline Complexo & efeito(\%) $\lambda \sim 240 \mathrm{~nm}$ & efeito(\%) $\lambda 346 \mathrm{~nm}$ & efeito(\%) $\lambda \sim 490 \mathrm{~nm}$ \\
\hline \hline$\left[\operatorname{Ru}(\text { bpy })_{2}(\text { iso })\right]^{+}$ & hiperc.(181a;52b) $\Delta \lambda^{*} 12 \mathrm{~nm}$ & & hipoc.(7a) $\Delta \lambda 0 \mathrm{~nm}$ \\
{$\left[\operatorname{Ru}(\text { bpy })_{2}(\text { dop })\right]^{+}$} & hiperc.(228a;40b) $\Delta \lambda^{*} 12 \mathrm{~nm}$ & & hipoc.(5a) $\Delta \lambda 0 \mathrm{~nm}$ \\
{$\left[\operatorname{Ru}(\text { bpy })_{2}(\text { nor })\right]^{+}$} & hiperc.(244a;54b) $\Delta \lambda^{*} 12 \mathrm{~nm}$ & hipoc.(4a) $\Delta \lambda^{\#} 2 \mathrm{~nm}$ & hipoc.(8a) $\Delta \lambda 0 \mathrm{~nm}$ \\
{$\left[\operatorname{Ru}(\text { bpy })_{2}(\text { cat })\right]^{+}$} & hiperc.(400a;46b) $\Delta \lambda^{*} 13 \mathrm{~nm}$ & & hipoc.(20a) $\Delta \lambda 0 \mathrm{~nm}$ \\
{$\left[\operatorname{Ru}(\text { bpy })_{2}(\text { adr })\right]^{+}$} & hiperc.(119a;58b) $\Delta \lambda^{*} 11 \mathrm{~nm}$ & hipoc.(4a) $\Delta \lambda 0 \mathrm{~nm}$ \\
\hline
\end{tabular}

* deslocamento batocrômico; ${ }^{\#}$ deslocamento hipsocrômico;

a: em relação à banda do complexo livre; b: em relação ao DNA livre na concentração máxima

Fonte: Autora

Singh e colaboradores (2016) afirmam que hipocromismo observado nas bandas do complexo é resultado de interação do modo intercalação, devido à possibilidade de empilhamento planar dos ligantes com as bases nitrogenadas do DNA. Os mesmos autores encontraram constantes da mesma ordem de grandeza daquelas obtidas para os complexos ora reportados, para complexos com ligantes semelhantes. Tais interações são consideráveis, porém não fortes tais como aquelas normalmente reportadas para os considerados intercaladores fortes (constantes da ordem de $10^{6}$ ).

Uma vez que a literatura prioriza a utilização das bandas do próprio complexo, em detrimento daquelas do DNA, quando alterações em ambas são verificadas, optou-se por 
realizar os cálculos da constante da interação na região de $490 \mathrm{~nm}$, as quais são reportadas na tabela a seguir (24):

Tabela 24: Constantes intrínsecas $\left(K_{b}\right)$ da interação dos complexos com o $f s$-DNA

\begin{tabular}{ccccc}
\hline Complexo & $\mathrm{K}_{\mathrm{b}}\left(25^{\circ} \mathrm{C}\right) \mathrm{L} \mathrm{Mol}^{-1}$ & $\mathrm{~K}_{\mathrm{b}}\left(30^{\circ} \mathrm{C}\right) \mathrm{L} \mathrm{Mol}^{-1}$ & $\mathrm{~K}_{\mathrm{b}}\left(37^{\circ} \mathrm{C}\right) \mathrm{L} \mathrm{Mol}^{-1}$ & fonte \\
\hline \hline$\left[\mathrm{Ru}(\text { bpy })_{2}(\mathrm{iso})\right]^{+}$ & $1,210^{3}$ & $4,410^{3}$ & $1,210^{2}$ & este trabalho \\
{$\left[\mathrm{Ru}(\mathrm{bpy})_{2}(\mathrm{dop})\right]^{+}$} & $3,810^{3}$ & $7,410^{3}$ & $1,810^{4}$ & este trabalho \\
{$\left[\mathrm{Ru}(\mathrm{bpy})_{2}(\mathrm{nor})\right]^{+}$} & $1,410^{4}$ & $2,410^{3}$ & 9,710 & este trabalho \\
{$\left[\mathrm{Ru}(\text { bpy })_{2}(\mathrm{cat})\right]^{+}$} & $2,310^{3}$ & $1,0110^{3}$ & $7,010^{3}$ & este trabalho \\
{$\left[\mathrm{Ru}(\text { bpy })_{2}(\mathrm{adr})\right]^{+}$} & $1,1310^{4}$ & $1,710^{2}$ & $4,510^{3}$ & este trabalho \\
\hline
\end{tabular}

Fonte: Autora

Os valores mais altos encontrados para as constantes foram para os complexos de noradrenalina $\left(\mathrm{a} 25^{\circ} \mathrm{C}\right)$ e de dopamina $\left(\mathrm{a} 37^{\circ} \mathrm{C}\right)$. Quando comparadas às constantes obtidas para os complexos reportados previamente neste texto, respectivamente, pode-se aferir que as constantes, de um modo geral, são maiores para estes últimos - algumas aproximadamente 10 vezes. Esse efeito deve-se à presença das bipiridinas, que são conhecidamente ligantes intercaladores (SHI et. al., 2006; PRAVIN et. al., 2016; LIU et. al., 2002).

Considerando-se que a compreensão do efeito ocasionado pela troca de ligantes é pretendida para se compreender a atuação dos complexos envolvendo as catecolaminas, podese considerar que os ligantes do tipo bipiridinas contribuem para aumentar a interação dos complexos com o DNA.

Liu e colaboradores (2002), ao trabalharem com complexos macrocíclicos de cobre, reportaram constantes de diferentes ordem de grandeza ao trocarem os substituintes do macrociclo de piridinas $\left(\mathrm{K}_{\mathrm{b}}=2,1 \quad 10^{5} \mathrm{~L} \mathrm{~mol}^{-1}\right)$, para amina $\left(\mathrm{K}_{\mathrm{b}}=4,010^{3} \mathrm{~L} \mathrm{~mol}^{-1}\right)$ e hidroxila $\left(\mathrm{K}_{\mathrm{b}}=7,810^{2} \mathrm{~L} \mathrm{~mol}^{-1}\right)$. Apesar de a ordem de grandeza da interação ser menor, este efeito pode ser comparado ao observado para os complexos reportados neste trabalho, para os quais se observou maiores constantes para aqueles cujos ligantes eram bipiridinas, ao invés de amônia. Este comportamento é explicado pelo fato de que as piridinas em geral são conhecidamente ligantes intercaladores, enquanto nos demais complexos, há possibilidades de interação por ligação de hidrogênio e/ou interação eletrostática (LIU et. al., 2002).

Além disso, há que se considerar que a mudança nas bandas de absorção, observadas para os cinco complexos metálicos desta seção, sugerem interações que alteram os orbitais moleculares dos complexos - o que pode ser destacado, inclusive, pela presença dos pontos isosbésticos. Considerando-se que essa banda é referente à transição eletrônica do tipo 
TCML, a mudança ocasionada pela interação com o DNA pode ser resultante tanto da alteração dos orbitais do metal, quanto dos orbitais dos ligantes - com o que se conclui se tratar de interação mais intensa em relação à observada para os complexos metálicos reportados inicialmente.

Tal como já reportado para os outros complexos metálicos, os experimentos também foram conduzidos em três temperaturas e, de posse dessas informações, foram calculados os parâmetros termodinâmicos (variação de entropia, $\Delta \mathrm{S}$; entalpia, $\Delta \mathrm{H}$; e energia livre de Gibbs, $\Delta \mathrm{G}$ ) para as interações com o DNA (tabela 25):

Tabela 25: Parâmetros termodinâmicos para os processos

\begin{tabular}{cccccc}
\hline Complexo & $\Delta \mathrm{H}^{\mathrm{o}}\left(\mathrm{KJ} \mathrm{Mol}^{-1}\right)$ & $\Delta \mathrm{S}^{\mathrm{o}}\left(\mathrm{J} \mathrm{Mol}^{-1} \mathrm{~K}^{-1}\right)$ & $\Delta \mathrm{G}_{(298 \mathrm{~K})}\left(\mathrm{KJ} \mathrm{Mol}^{-1}\right)$ & $\Delta \mathrm{G}_{(303 \mathrm{~K})}\left(\mathrm{KJ} \mathrm{Mol}^{-1}\right)$ & $\Delta \mathrm{G}_{(310 \mathrm{~K})}\left(\mathrm{J} \mathrm{Mol}^{-1}\right)$ \\
\hline \hline$[\mathrm{Ru}(\mathrm{bpy}) 2(\mathrm{iso})]^{+}$ & $-1,6$ & -476 & -18 & -21 & -12 \\
{$[\mathrm{Ru}(\mathrm{bpy}) 2(\mathrm{dop})]^{+}$} & 995 & 402 & -20 & -22 & -25 \\
{$[\mathrm{Ru}(\mathrm{bpy}) 2(\mathrm{nor})]^{+}$} & -320 & -995 & -24 & -20 & -25 \\
{$[\mathrm{Ru}(\mathrm{bpy}) 2(\mathrm{cat})]^{+}$} & 79 & 326 & -19 & -17 & -23 \\
{$[\mathrm{Ru}(\mathrm{bpy}) 2(\mathrm{adr})]^{+}$} & -35 & $-52,5$ & -23 & -13 & -22 \\
\hline
\end{tabular}

Fonte: Autora

Para os complexos de isoproterenol, noradrenalina e adrenalina, cujos valores foram de $\Delta \mathrm{H}<0$ e $\Delta \mathrm{S}<0$, atribui-se a interações do tipo Van der Waals ou ligações de hidrogênio, enquanto para os complexos de dopamina e catecol - cujos resultados foram $\Delta \mathrm{H}$ $>0$ e $\Delta S>0$ - acredita-se que se trata de interações com caráter predominantemente hidrofóbico, indicando que os compostos são intercaladores (SIRAJUDDIN; ALI; BADSHAH, 2013; NI; LIN; KOKOT, 2006).

Diante dos resultados, entende-se existir predominância do caráter hidrofóbico dos ligantes piridínicos e que este efeito é maior para os dois complexos nos quais o ligante catecólico não possui o grupamento hidroxila na posição $\beta$ da cadeia carbônica, quais sejam, catecol e dopamina.

Para os demais complexos - de isoproterenol, noradrenalina e adrenalina - os quais possuem em comum o grupamento hidroxila na posição $\beta$ da cadeia carbônica, houve a predominância das forças de Van der Waals ou ligações de hidrogênio, resultado este que é harmônico com a existência do grupamento $\mathrm{OH}$.

\subsubsection{Deslocamento do brometo de etídio - espectroscopia de fluorescência}

Tal como conduzido para a série de complexos precedente, o experimento de deslocamento do brometo de etídio, acompanhado por espectroscopia de fluorescência, foi 
realizado para estes complexos. Os espectros de supressão de fluorescência do fluoróforo, no sistema BET-DNA são mostrados a seguir (figuras 112 a 116):

Figura 112: Espectros de emissão do sistema BET-DNA, na presença de diferentes concentrações de $\left[\mathbf{R u}(\text { bpy })_{2} \text { (isoproterenol) }\right]^{+}$

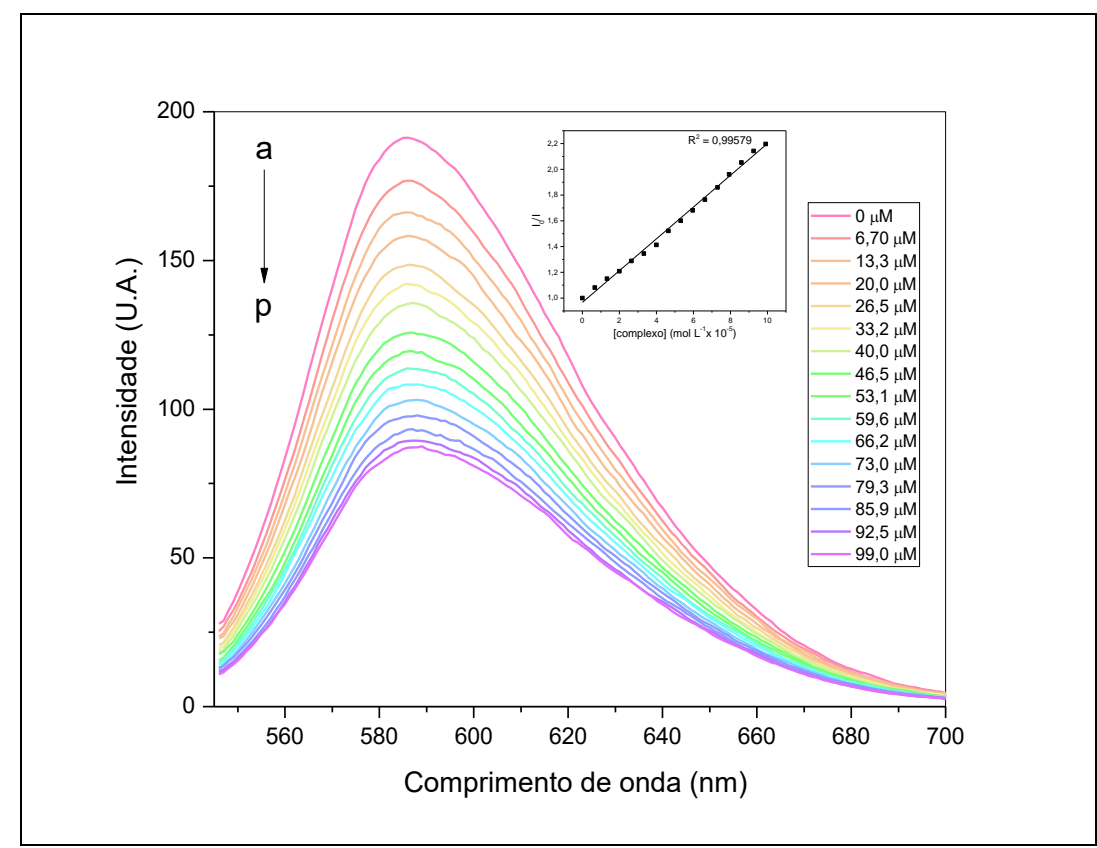

Fonte: Autora

Figura 113: Espectros de emissão do sistema BET-DNA, na presença de diferentes concentrações de $\left[\operatorname{Ru}(\text { bpy })_{2} \text { (dopamina) }\right]^{+}$

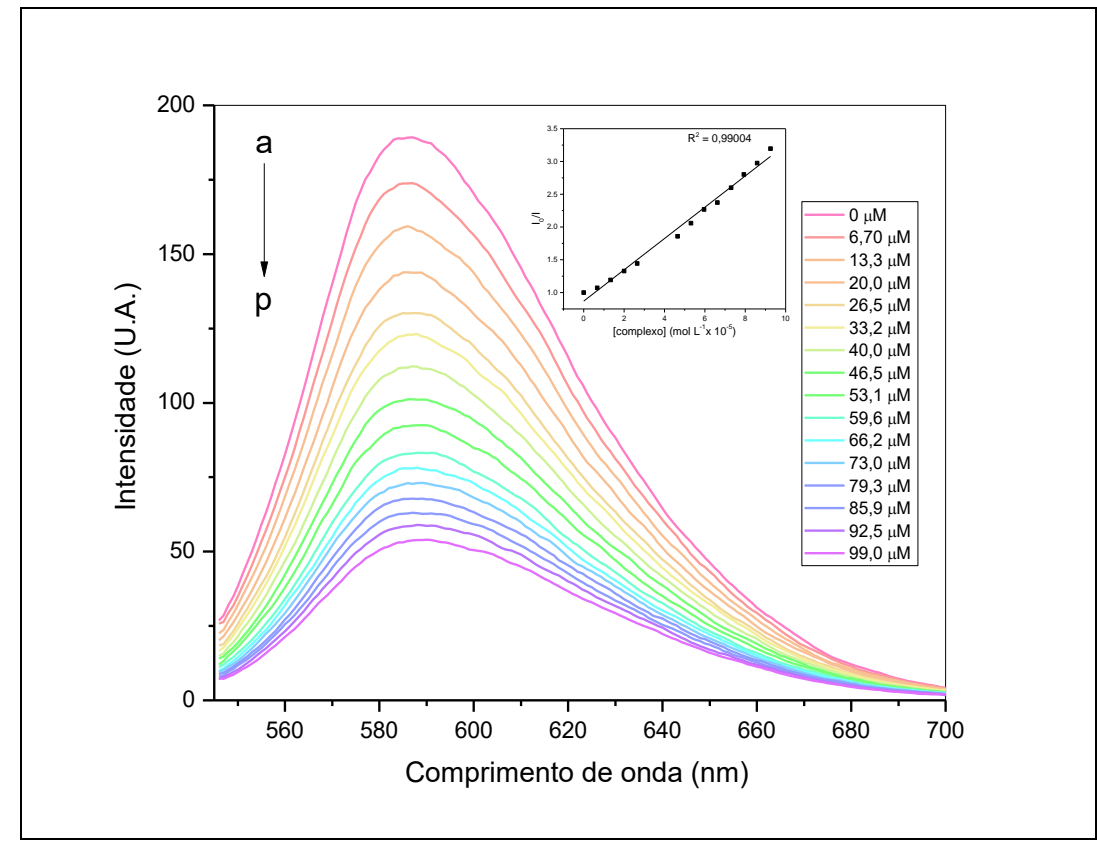

Fonte: Autora 
Figura 114: Espectros de emissão do sistema BET-DNA, na presença de diferentes concentrações de $\left[\operatorname{Ru}(\text { bpy })_{2}(\text { noradrenalina })\right]^{+}$

Fonte: Autora

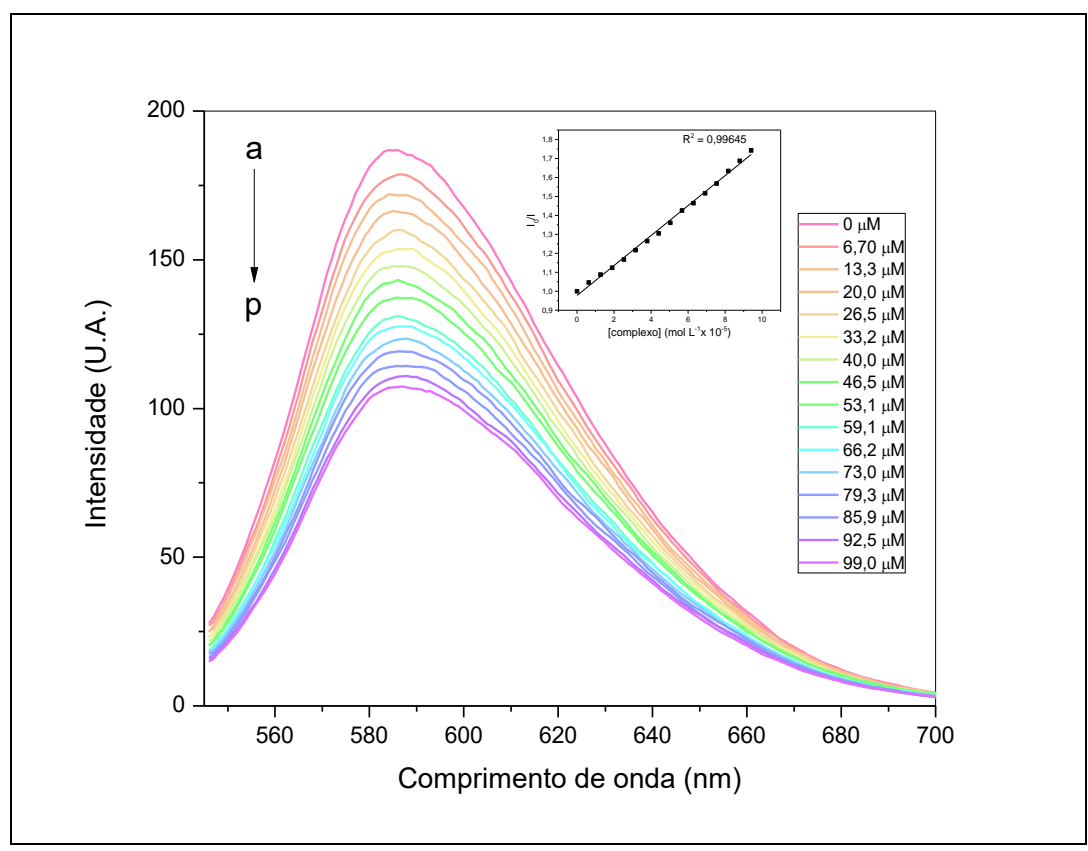

Figura 115: Espectros de emissão do sistema BET-DNA, na presença de diferentes concentrações de $\left[\operatorname{Ru}(\text { bpy })_{2}(\text { catecol })\right]^{+}$

Fonte: Autora

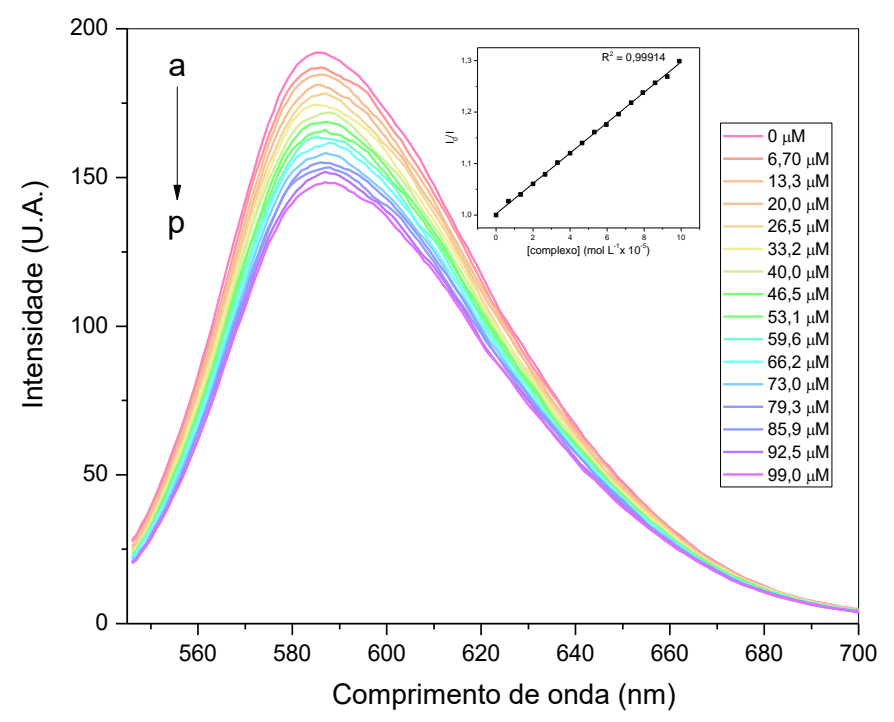


Figura 116: Espectros de emissão do sistema BET-DNA, na presença de diferentes concentrações de $\left[\operatorname{Ru}(\text { bpy })_{2} \text { (adrenalina) }\right]^{+}$

Fonte: Autora

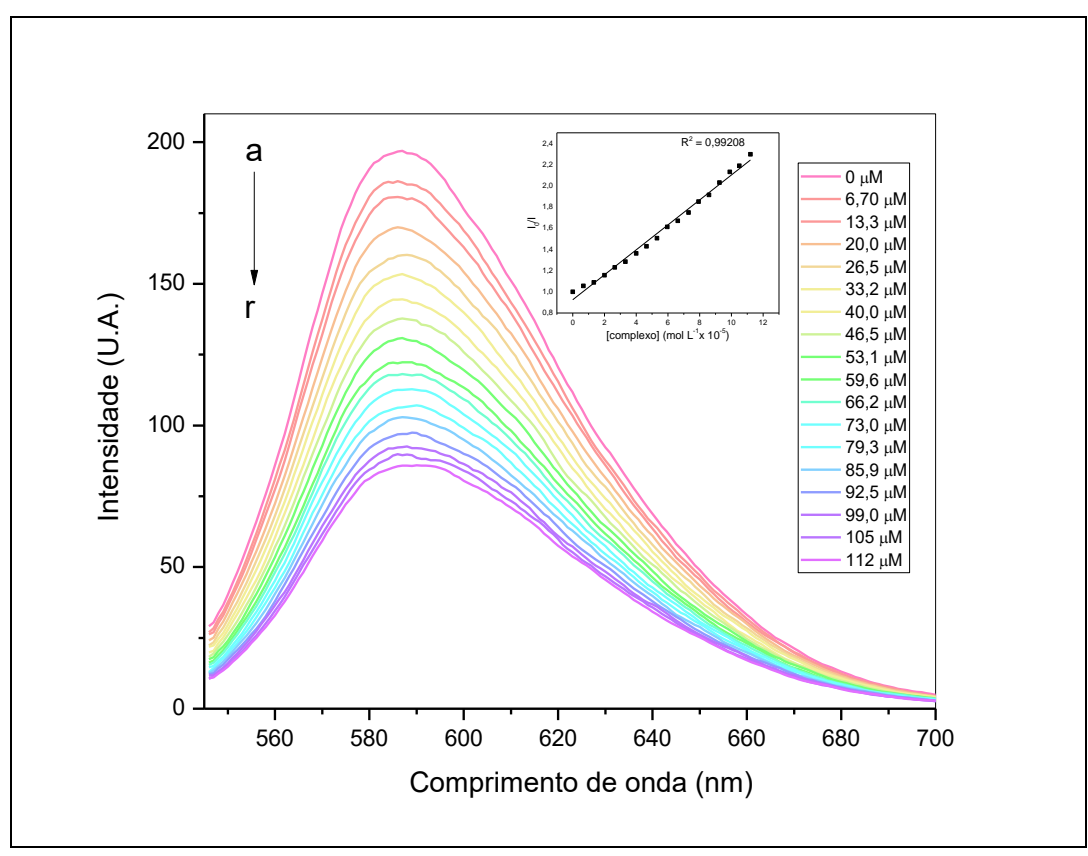

As constantes de Stern-Volmer para os processos, a fim de se analisar (indiretamente) a intensidade das interações, foram calculadas e são apresentadas na tabela a seguir (tabela 26):

Tabela 26: Constantes de Stern-Volmer para a supressão de fluorescência do sistema BET-DNA

\begin{tabular}{ccc}
\hline Complexo & $\mathrm{K}_{\mathrm{sv}} \mathrm{L} \mathrm{Mol}^{-1}$ & fonte \\
\hline \hline$\left[\mathrm{Ru}(\mathrm{bpy})_{2}(\right.$ iso $\left.)\right]$ & $1,210^{4}$ & este trabalho \\
{$\left[\mathrm{Ru}(\mathrm{bpy})_{2}(\mathrm{dop})\right]$} & $2,410^{4}$ & este trabalho \\
{$\left[\mathrm{Ru}(\mathrm{bpy})_{2}(\mathrm{nor})\right]$} & $7,910^{3}$ & este trabalho \\
{$\left[\mathrm{Ru}(\mathrm{bpy})_{2}(\mathrm{cat})\right]$} & $3,010^{3}$ & este trabalho \\
{$\left[\mathrm{Ru}(\mathrm{bpy})_{2}(\mathrm{adr})\right]$} & $1,210^{4}$ & este trabalho \\
\hline
\end{tabular}

No que tange aos valores de $\mathrm{K}_{\mathrm{sv}}$ obtidos, interações de intensidades semelhantes foram verificadas para os complexos de isoproterenol, dopamina e adrenalina, seguidos pelo de noradrenalina. A menor interação foi verificada para o complexo de catecol.

Valores de constantes da ordem de $10^{4}$ são encontrados para compostos que atuam como intercaladores parciais, ou fracos (PRAVIN et. al., 2016). Os resultados são consoantes a literatura que descreve bipiridinas como intercaladores. 
Em relação aos resultados obtidos para os complexos análogos das tetraminas, excetuando-se o complexo cujo ligante é o catecol, estes possuem constantes aproximadamente dez vezes maiores, de forma que o efeito de intercalação pode ser atribuído à troca dos quatro ligantes amônia, pelas duas bipiridinas. Pravin e colaboradores (2016) descreveram que ligantes como fenantrolina e bipiridina facilitam o empilhamento $\pi$ entre as bases nitrogenadas do DNA, bem como o acoplamento do orbital $\pi^{*}$ do composto intercalador com os orbitais das bases nitrogenadas do DNA. Estes resultados confirmam aqueles obtidos na titulação do complexo, com alíquotas de DNA, acompanhada por espectroscopia de absorção na região UV-Vis.

Tais resultados corroboram aqueles obtidos nos ensaios de viabilidade celular, nos quais se pôde verificar que os complexos cujos ligantes são as bipiridinas apresentam menores valores de viabilidade celular quando comparados àqueles cujos ligantes são quatro aminas. Possivelmente, tal efeito é resultante da possibilidade de estes últimos complexos intercalarem no DNA, enquanto aqueles, não.

\subsubsection{Interação com proteína carreadora $(\mathrm{HSA})$ - mimetizando transporte in vivo}

Assim como realizado para a série de complexos anteriormente descrita neste texto, para esta também foi verificada a interação com a proteína do soro humano albumina (HSA). Os resultados da interação são mostrados a seguir, para as interações ocorridas a $25^{\circ} \mathrm{C}$ (figuras 117 a 126), para as demais temperaturas $\left(32\right.$ e $\left.38^{\circ} \mathrm{C}\right)$ os dados seguem no apêndice deste texto (figuras 183 a 202): 
Figura 117: Espectros de emissão de fluorescência da HSA, na presença de diferentes concentrações de

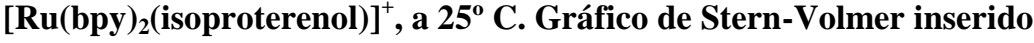

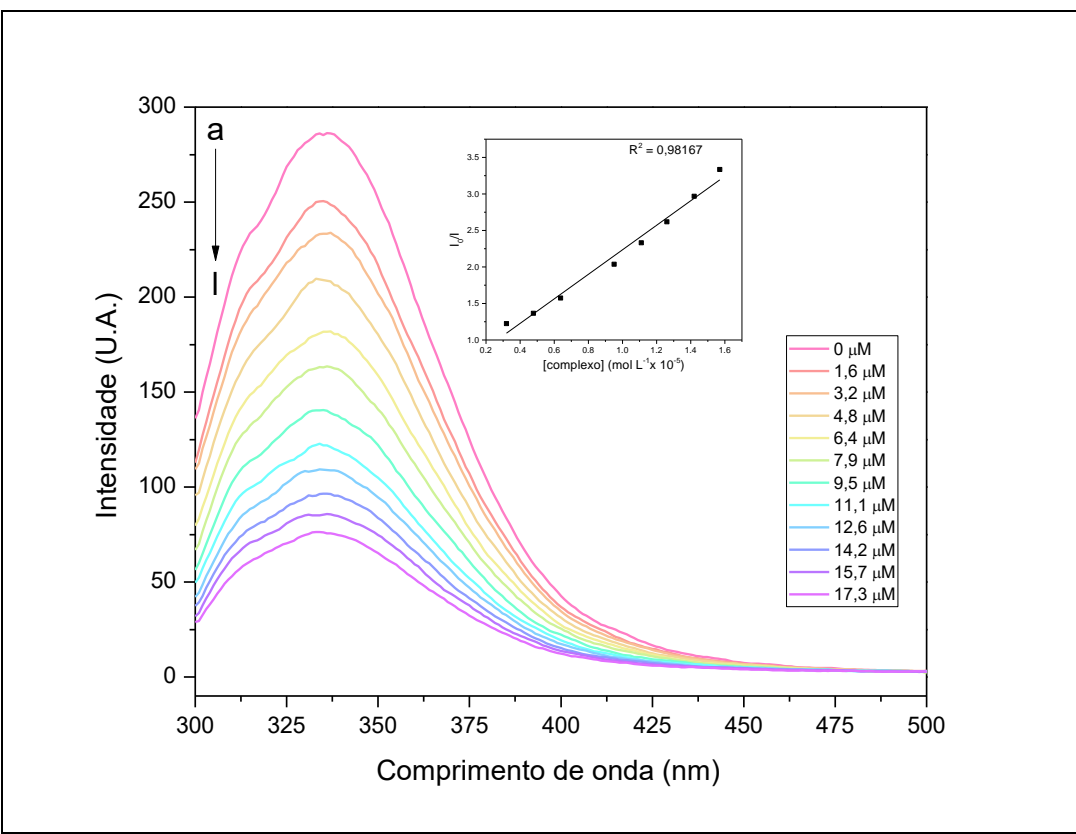

Fonte: Autora

Figura 118: Gráfico da equação $\log \left[\left(I_{0}-I\right) / I\right]=\log K_{b}+n \log [Q]$ referente à interação entre HSA e o complexo $\left[\operatorname{Ru}(\mathrm{bpy})_{2}(\text { isoproterenol })\right]^{+}$, a $25^{\circ} \mathrm{C}$ (A) e Gráfico de Van't Hoff referente à interação entre HSA e o complexo $\left[\operatorname{Ru}(\text { bpy })_{2}(\text { isoproterenol })\right]^{+}(B)$

(A)

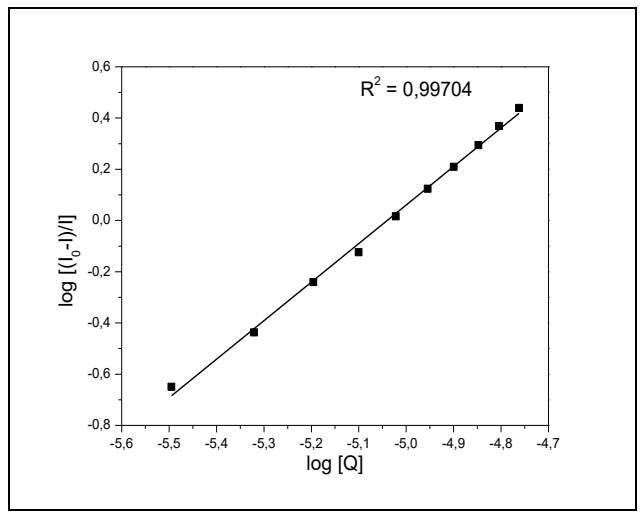

(B)

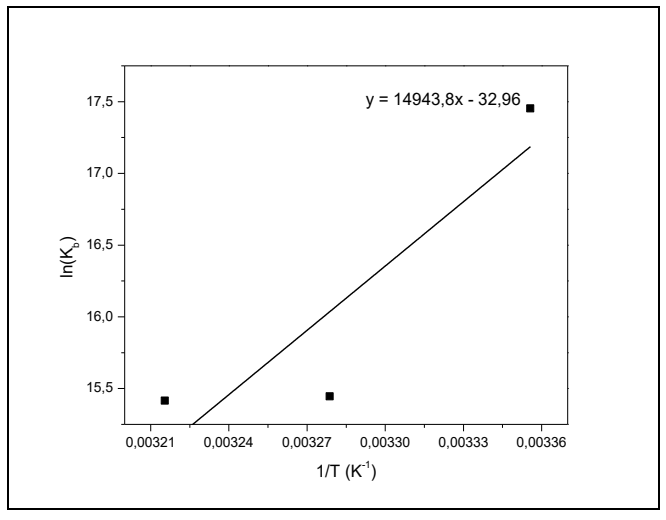

Fonte: Autora 
Figura 119: Espectros de emissão de fluorescência da HSA, na presença de diferentes concentrações de $\left[\operatorname{Ru}(\text { bpy })_{2}(\text { dopamina })\right]^{+}$, a $25^{\circ}$ C. Gráfico de Stern-Volmer inserido

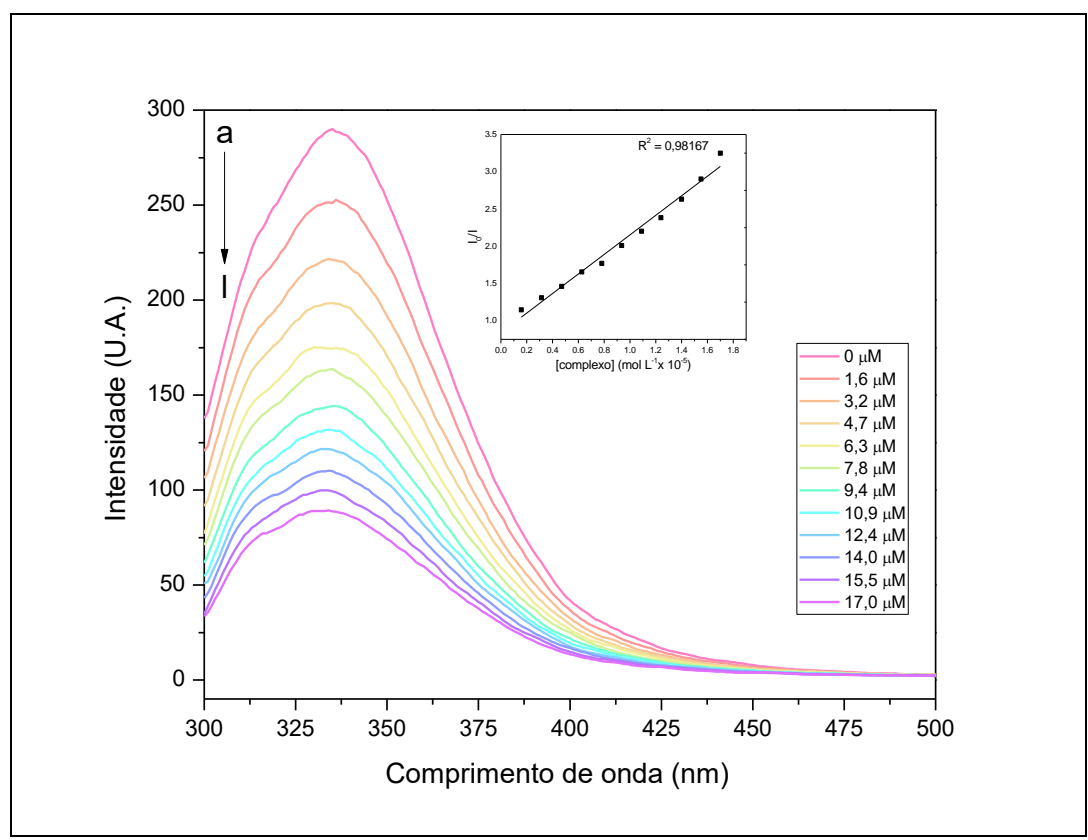

Fonte: Autora

Figura 120: Gráfico da equação $\log \left[\left(I_{0}-I\right) / I\right]=\log K_{b}+n \log [Q]$ referente à interação entre HSA e o complexo $\left[\operatorname{Ru}(\text { bpy })_{2}(\text { dopamina })\right]^{+}, a^{\circ} \mathrm{C}(\mathrm{A})$ e Gráfico de Van't Hoff referente à interação entre HSA e o complexo $\left[\operatorname{Ru}(\text { bpy })_{2}(\text { dopamina })\right]^{+}(B)$

(A)

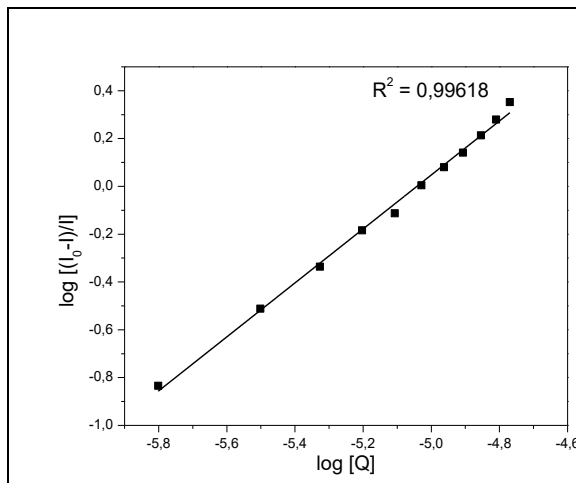

Fonte: Autora
(B)

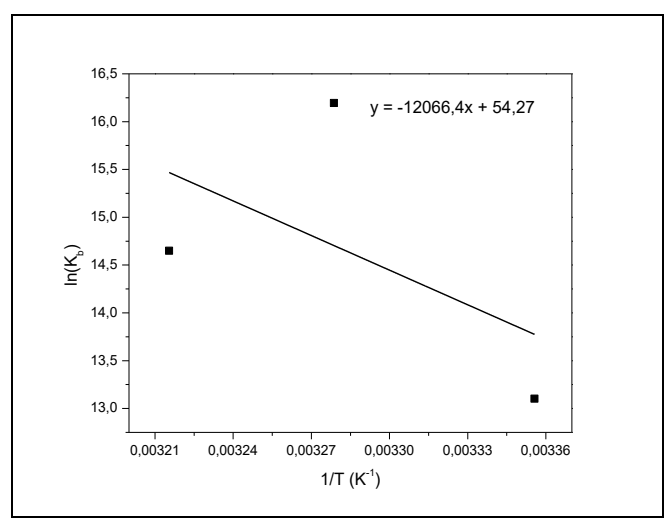


Figura 121: Espectros de emissão de fluorescência da HSA, na presença de diferentes concentrações de $\left[\mathbf{R u}(\text { bpy })_{2} \text { (noradrenalina) }\right]^{+}$, a $25^{\circ}$ C. Gráfico de Stern-Volmer inserido

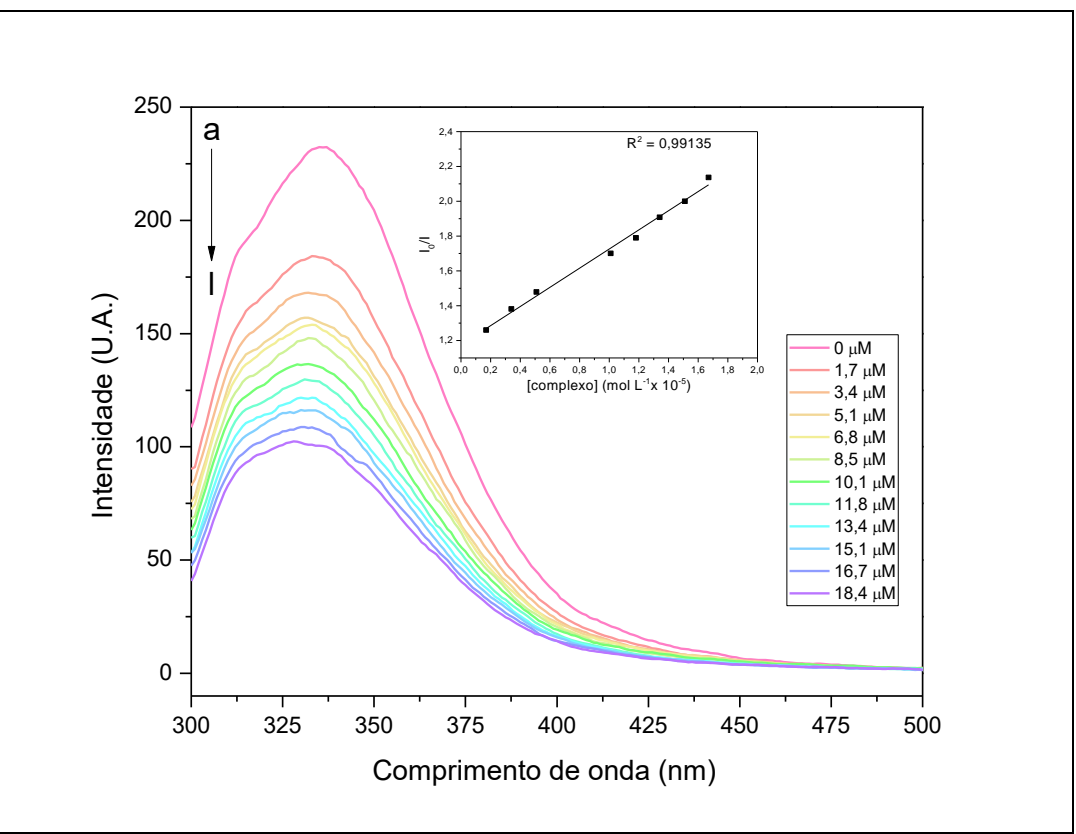

Fonte: Autora

Figura 122: Gráfico da equação $\log \left[\left(I_{0}-I\right) / I\right]=\log K_{b}+n \log [Q]$ referente à interação entre HSA e o complexo $\left[\mathrm{Ru}(\mathrm{bpy})_{2} \text { (noradrenalina) }\right]^{+}$, a $25^{\circ} \mathrm{C}(\mathrm{A})$ e Gráfico de Van't Hoff referente à interação entre HSA e o complexo $\left[\operatorname{Ru}(\text { bpy })_{2}(\text { noradrenalina })\right]^{+}(B)$

(A)

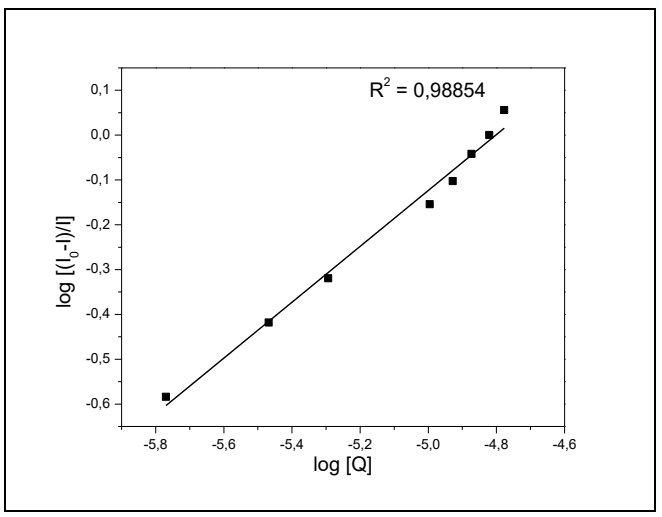

(B)

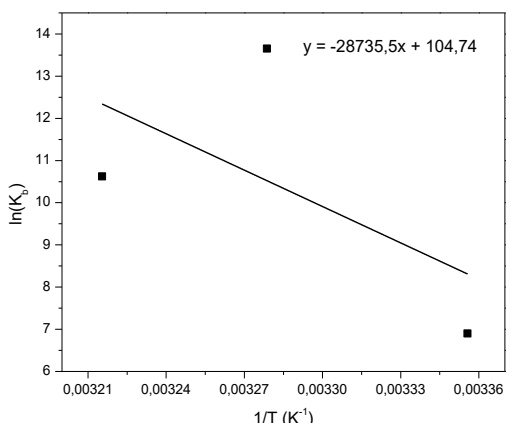

Fonte: Autora 
Figura 123: Espectros de emissão de fluorescência da HSA, na presença de diferentes concentrações de $\left[\operatorname{Ru}(\text { bpy })_{2}(\text { catecol })\right]^{+}$, a $25^{\circ}$ C. Gráfico de Stern-Volmer inserido

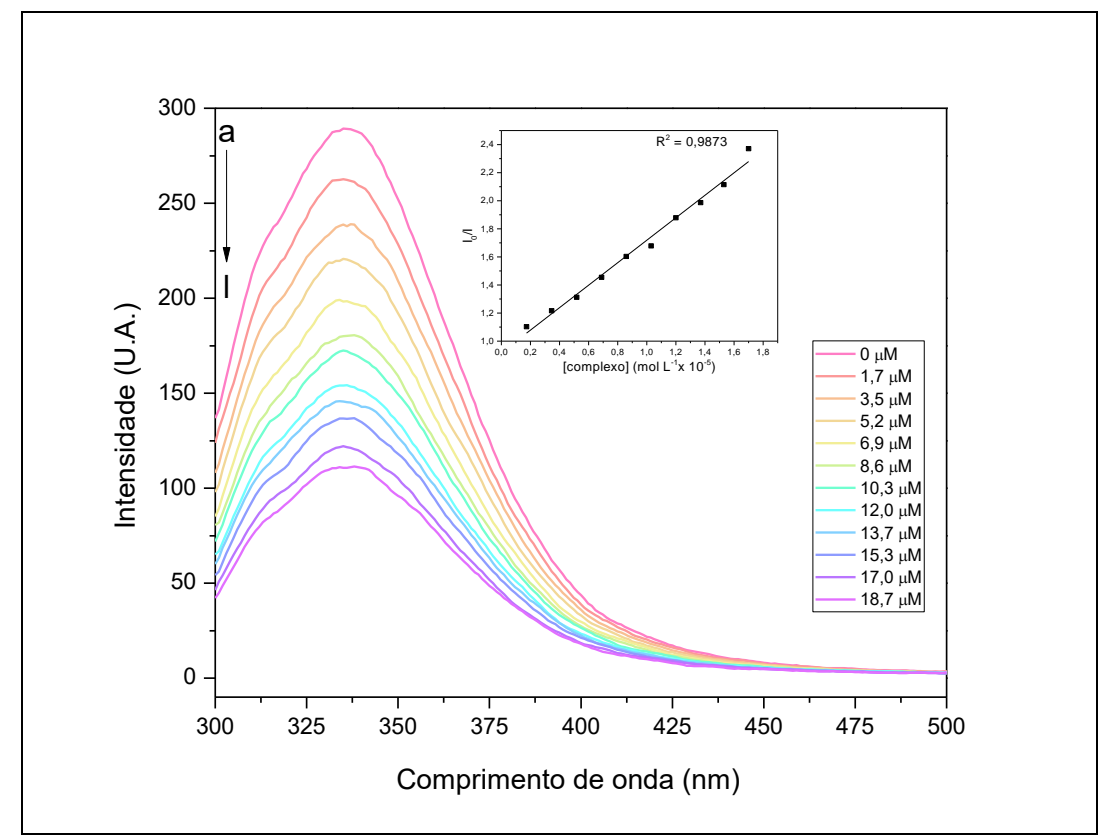

Fonte: Autora

Figura 124: Gráfico da equação $\log \left[\left(I_{0}-I\right) / I\right]=\log K_{b}+n \log [Q]$ referente à interação entre HSA e o complexo $\left[\operatorname{Ru}(\text { bpy })_{2}(\text { catecol })\right]^{+}$, a $25^{\circ} \mathrm{C}(\mathrm{A})$ e Gráfico de Van't Hoff referente à interação entre HSA e o complexo $\left[\mathbf{R u}(\text { bpy })_{2}(\text { catecol })\right]^{+}(B)$

(A)

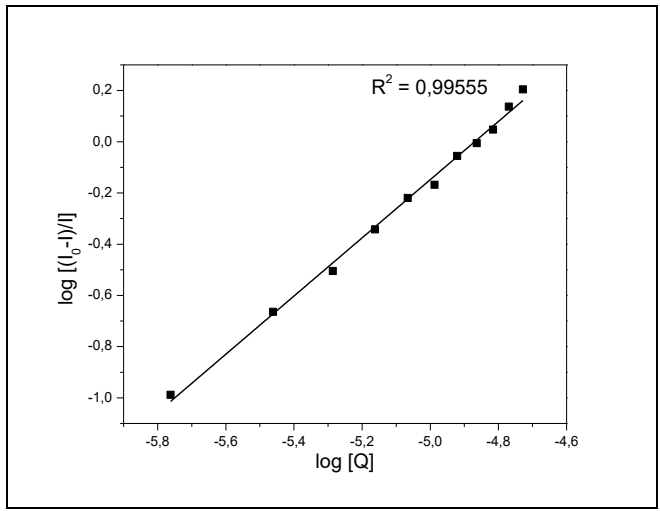

(B)

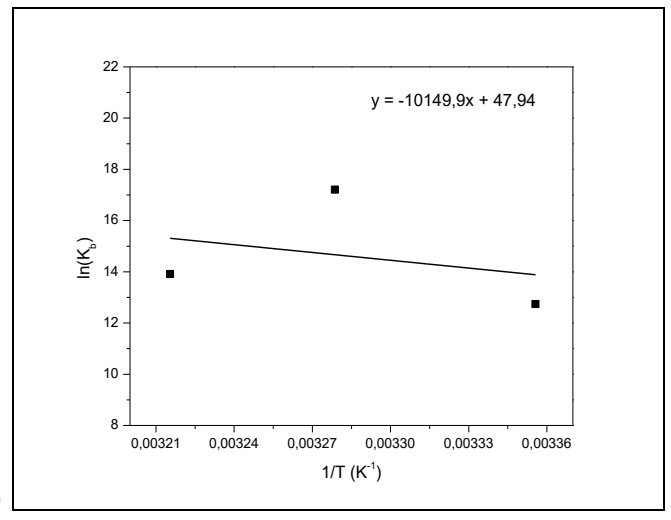

Fonte: Autora 
Figura 125: Espectros de emissão de fluorescência da HSA, na presença de diferentes concentrações de $\left[\operatorname{Ru}(\text { bpy })_{2}(\text { adrenalina })\right]^{+}$, a $25^{\circ}$ C. Gráfico de Stern-Volmer inserido

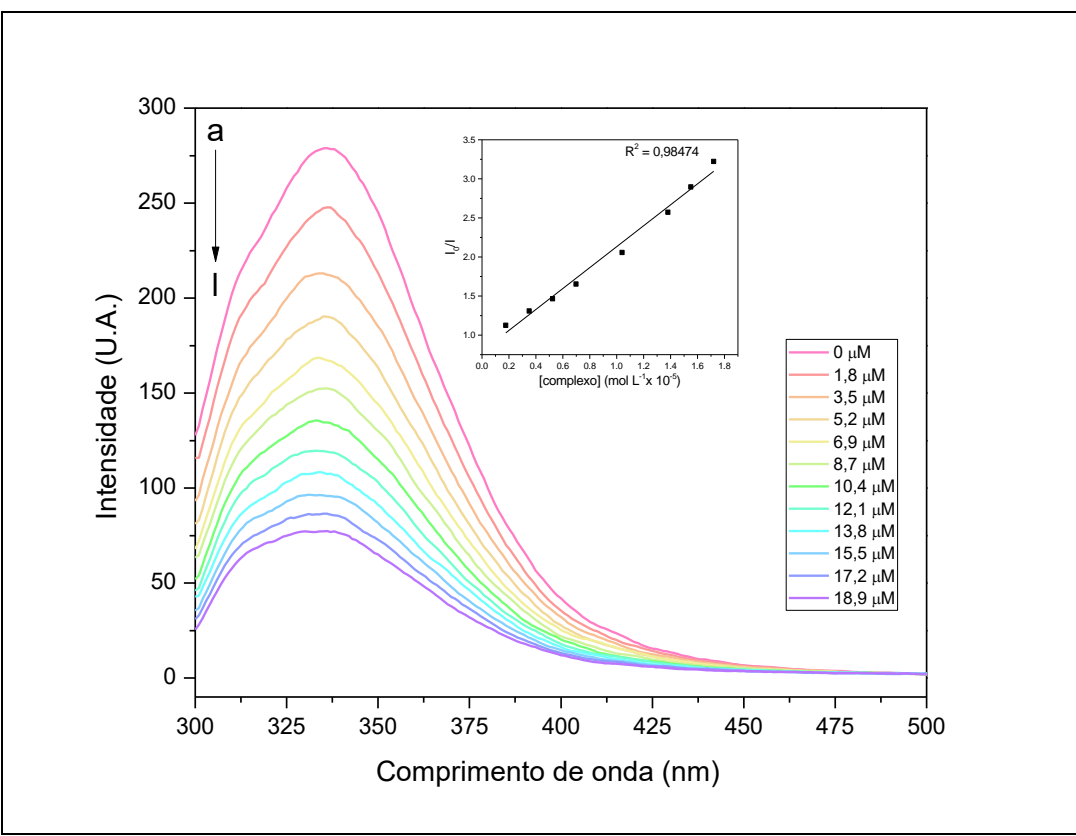

Fonte: Autora

Figura 126: Gráfico da equação $\log \left[\left(I_{0}-I\right) / I\right]=\log K_{b}+n \log [Q]$ referente à interação entre HSA e o complexo $\left[\operatorname{Ru}(\text { bpy })_{2}(\text { adrenalina })\right]^{+}, a^{\circ} \mathbf{C}(\mathrm{A})$ e Gráfico de Van't Hoff referente à interação entre HSA e o complexo $\left[\operatorname{Ru}(\text { bpy })_{2}(\operatorname{adrenalina})\right]^{+}(B)$

(A)

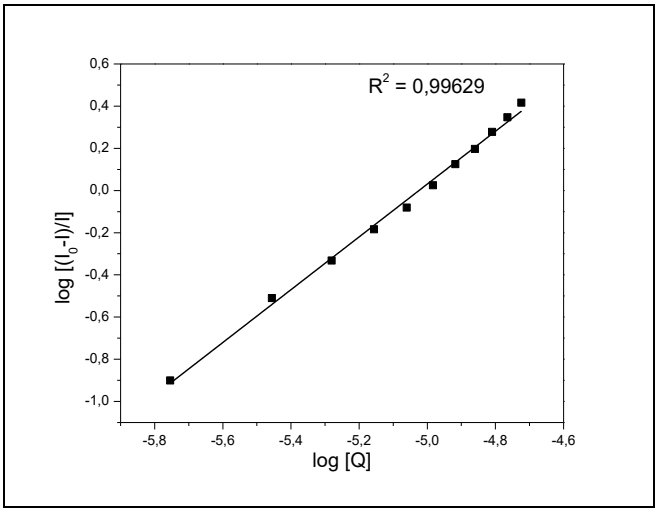

(B)

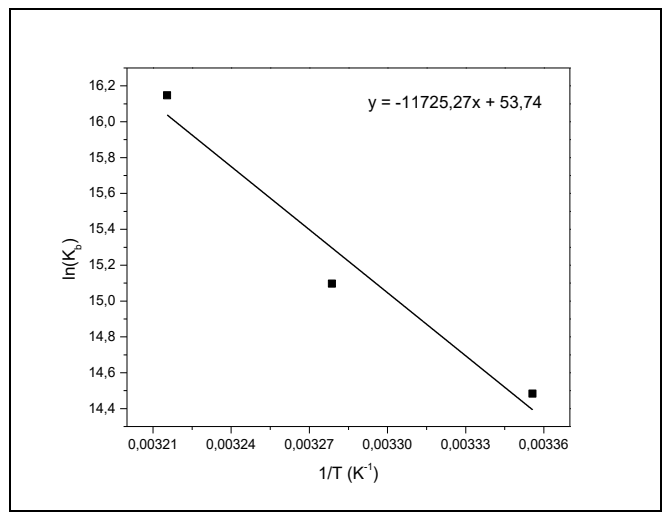

Fonte: Autora

Para promover uma melhor visualização dos resultados, eles seguem resumidos na tabela 27: 
Tabela 27: Parâmetros da interação dos complexos $\left[\mathbf{R u}(\mathbf{b p y})_{2} \mathbf{L}\right]^{+}(\mathrm{L}=$ isoproterenol, dopamina, noradrenalina, catecol e adrenalina) com HSA: $K_{s v} ; K_{b} ; n ; \Delta G ; \Delta H$ e $\Delta S$, a 25,32 e $38^{\circ} C(298,305$ e 311 $\mathrm{K}$, respectivamente)

\begin{tabular}{|c|c|c|c|}
\hline \multicolumn{4}{|c|}{$\left[\operatorname{Ru}(\text { bpy })_{2}(\text { iso })\right]^{+}$} \\
\hline 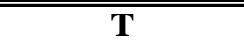 & $298 \mathrm{~K}$ & $305 \mathrm{~K}$ & $\overline{311 \mathrm{~K}}$ \\
\hline $\mathrm{K}_{\mathrm{SV}}\left(10^{3} \mathrm{M}^{-1}\right)$ & 160 & 160 & 181 \\
\hline $\mathrm{K}_{\mathrm{b}}\left(10^{3} \mathrm{M}^{-1}\right)$ & 38000 & 5100 & 2300 \\
\hline$n$ & 1,5 & 1,3 & 1,3 \\
\hline$\Delta \mathrm{G}\left(\mathrm{kJ} \mathrm{mol}^{-1}\right)$ & -43 & -39 & -40 \\
\hline$\Delta \mathrm{H}\left(\mathrm{kJ} \mathrm{mol}^{-1}\right)$ & & -120 & \\
\hline$\Delta \mathrm{S}\left(\mathrm{J} \mathrm{mol}^{-1} \mathrm{~K}^{-1}\right)$ & & -270 & \\
\hline \multicolumn{4}{|c|}{$\left[\operatorname{Ru}(\mathrm{bpy})_{2}(\mathrm{dop})\right]^{+}$} \\
\hline $\mathbf{T}$ & $298 \mathrm{~K}$ & $305 \mathrm{~K}$ & $310 \mathrm{~K}$ \\
\hline $\mathrm{K}_{\mathrm{SV}}\left(10^{3} \mathrm{M}^{-1}\right)$ & 131 & 125 & 151 \\
\hline $\mathrm{K}_{\mathrm{b}}\left(10^{3} \mathrm{M}^{-1}\right)$ & 490 & 10800 & 2300 \\
\hline$n$ & 1,1 & 1,4 & 1,3 \\
\hline$\Delta \mathrm{G}\left(\mathrm{kJ} \mathrm{mol}^{-1}\right)$ & -32 & -41 & -38 \\
\hline$\Delta \mathrm{H}\left(\mathrm{kJ} \mathrm{mol}^{-1}\right)$ & & 100 & \\
\hline$\Delta \mathrm{S}\left(\mathrm{J} \mathrm{mol}^{-1} \mathrm{~K}^{-1}\right)$ & & 450 & \\
\hline \multicolumn{4}{|c|}{$\left[\operatorname{Ru}(\text { bpy })_{2} \text { (nor) }\right]^{+}$} \\
\hline $\mathbf{T}$ & $298 \mathrm{~K}$ & $305 \mathrm{~K}$ & $310 \mathrm{~K}$ \\
\hline $\mathrm{K}_{\mathrm{SV}}\left(10^{3} \mathrm{M}^{-1}\right)$ & 550 & 64 & 56,8 \\
\hline $\mathrm{K}_{\mathrm{b}}\left(10^{3} \mathrm{M}^{-1}\right)$ & 0,99 & 850 & 41 \\
\hline$n$ & 0,6 & 1,2 & 1 \\
\hline$\Delta \mathrm{G}\left(\mathrm{kJ} \mathrm{mol}^{-1}\right)$ & -17 & -35 & -27 \\
\hline$\Delta \mathrm{H}\left(\mathrm{kJ} \mathrm{mol}^{-1}\right)$ & & 240 & \\
\hline$\Delta \mathrm{S}\left(\mathrm{J} \mathrm{mol}^{-1} \mathrm{~K}^{-1}\right)$ & & 870 & \\
\hline \multicolumn{4}{|c|}{$\left[\mathbf{R u}(\text { bpy })_{2}(\text { cat })\right]^{+}$} \\
\hline $\bar{T}$ & $2298 \mathrm{~K}$ & $305 \mathrm{~K}$ & $3 \mathbf{3 1 1} \mathrm{K}$ \\
\hline $\mathrm{K}_{\mathrm{SV}}\left(10^{3} \mathrm{M}^{-1}\right)$ & 80 & 83,5 & 66,7 \\
\hline $\mathrm{K}_{\mathrm{b}}\left(10^{3} \mathrm{M}^{-1}\right)$ & 340 & 29800 & 1100 \\
\hline$n$ & 1,1 & 1,5 & 1,3 \\
\hline$\Delta \mathrm{G}\left(\mathrm{kJ} \mathrm{mol}^{-1}\right)$ & -32 & -44 & -36 \\
\hline$\Delta \mathrm{H}\left(\mathrm{kJ} \mathrm{mol}^{-1}\right)$ & & 84 & \\
\hline$\Delta \mathrm{S}\left(\mathrm{J} \mathrm{mol}^{-1} \mathrm{~K}^{-1}\right)$ & & 399 & \\
\hline \multicolumn{4}{|c|}{$\left[\operatorname{Ru}(\text { bpy })_{2}(\text { adre })\right]^{+}$} \\
\hline$\overline{\mathbf{T}}$ & $298 \mathrm{~K}$ & $305 \mathrm{~K}$ & $311 \mathrm{~K}$ \\
\hline $\mathrm{K}_{\mathrm{SV}}\left(10^{3} \mathrm{M}^{-1}\right)$ & 134 & 116 & 140 \\
\hline $\mathrm{K}_{\mathrm{b}}\left(10^{3} \mathrm{M}^{-1}\right)$ & 1950 & 3600 & 10300 \\
\hline$n$ & 1,3 & 1,3 & 1,4 \\
\hline$\Delta \mathrm{G}\left(\mathrm{kJ} \mathrm{mol}^{-1}\right)$ & -36 & -38 & -42 \\
\hline$\Delta \mathrm{H}\left(\mathrm{kJ} \mathrm{mol}^{-1}\right)$ & & 970 & \\
\hline$\Delta \mathrm{S}\left(\mathrm{J} \mathrm{mol}^{-1} \mathrm{~K}^{-1}\right)$ & & 450 & \\
\hline
\end{tabular}

Fonte: Autora 
Para esta série de complexos, os valores das constantes de Stern-Volmer da interação com a HSA são da ordem de $10^{4}$ e $10^{5}$. Tais valores permitem afirmar, desde logo, que a inserção dos coligantes bipiridinas modifica a interação com a proteína HSA, intensificando a interação em, no mínimo, uma ordem de grandeza, em relação aos complexos do tipo tetramino estudados anteriormente. Estes resultados corroboram a tendência observada nos experimentos com of $f s$-DNA - com o qual a interação também foi intensificada pela troca dos ligantes amônia por bipiridinas.

Em relação às constantes de ligação $\left(\mathrm{K}_{\mathrm{b}}\right)$, observa-se o mesmo comportamento evidenciado para as constantes de Stern-Volmer, ou seja, maiores valores de constantes, quando comparadas àquelas obtidas para a primeira série de complexos, embora as tendências não sejam tão lineares conforme visualizado para aqueles. Os valores de $\mathrm{K}_{\mathrm{b}}$ foram calculados para todos os complexos, embora tenham ocorrido oscilações nos valores de $\mathrm{K}_{\mathrm{SV}}$ - o que não permitiu inferir o tipo de supressão ocorrida, razão pela qual serão conduzidos experimentos de medida do tempo de vida do estado excitado. No mesmo sentido, tal como para a série anterior, é possível evidenciar que cada molécula de proteína interage, aproximadamente, com uma molécula de complexo, para todos os complexos, nas três temperaturas $(n \sim 1)$.

Em relação à variação da energia livre de Gibbs, para todos os complexos, nas três temperaturas, observaram-se valores negativos, advertindo para a espontaneidade da interação em todos os casos estudados. Por fim, observou-se que os valores dos parâmetros termodinâmicos foram $\Delta \mathrm{H}$ e $\Delta \mathrm{S}>0$, para todos os complexos - exceto o de isoproterenol indicando que as interações entre a proteína HSA e os complexos possuem natureza predominantemente hidrofóbica, assim como para a série anteriormente estudada.

Para o complexo de isoproterenol, observaram-se valores condizentes com interações do tipo de van der Waals $(\Delta \mathrm{H}$ e $\Delta \mathrm{S}<0)$, o que a princípio parece estranho, haja vista o fato de a estrutura do ligante não ter sido modificada em relação ao ensaio previamente apresentado, porém, é importante resssaltar que o isoprotereol contém o grupamento hidroxila (no carbono $\beta$ ) e uma amina secundária em sua estrutura, o que após a coordenação das bipiridinas pode ter favorecido a formação, nesta região da molécula, de um dipolo negativo $\delta^{-}$, justificando este tipo de interação.

Embora as tendências oriundas das cadeias carbônicas pareçam influenciar menos nas propriedades, de um modo geral, a ligação com as bipiridinas aumenta a interação com a HSA, assim como observado no estudo com o $f s$-DNA - o que, consequentemente, promove o aumento da atividade biológica. 


\section{CONSIDERAÇÕES FINAIS}

Em relação aos complexos metálicos do tipo tetraminodioxolenorutênio(III), não obstante o fato de alguns deles já terem sido descritos na literatura, estes não foram mais explorados, resumindo suas publicações nos trabalhos publicados no âmbito do grupo ao qual a autora deste pertence e, nessas publicações prévias, o enfoque realizado neste trabalho nunca foi abordado.

Foi possível notar que os complexos de rutênio cujos ligantes são dioxolenos, possuem algumas propriedades espectroscópicas e eletroquímicas com tendência de variação dependente do quadrado do $\mathrm{pH}$ e, não linearmente como geralmente observado para ligantes piridínicos e monodentados coordenados a metais, principalmente rutênio. Além de apresentarem acentuada deslocalização eletrônica no que se refere ao elétron desemparelhado, proporcionando, desta maneira, propriedades espectroscópicas, eletroquímicas e biológicas interessantes, diversas das comumente encontradas para complexos de dioxolenos com outros metais, e mesmo diferentes daquelas observadas para os ligantes não coordenados.

Em relação aos complexos bis(bipiridil)dioxolenorutênio(II), somente o complexo metálico de catecol fora reportado previamente, de modo que a síntese e caracterização de quatro complexos não publicados foi abordada neste trabalho. Acredita-se que a síntese proposta foi eficiente para a obtenção dos mesmos e que as fórmulas e estruturas propostas foram alcançadas satisfatoriamente. Embora sua caracterização tenha sido menos explorada em relação à primeira série, foi suficiente para comprovar a obtenção dos referidos complexos metálicos.

Para os complexos dioxolenos estudados, a coordenação dos ligantes 2,2'-bipiridil promoveu maiores interações com o DNA e com a HSA, bem como menores viabilidades celulares, razão pela qual se pode afirmar que, de fato, os coligantes aromáticos favoreceram as interações com os alvos, aumentando, consideravelmente, as atividades biológicas.

Uma vez que os complexos do tipo tetramino possuem atividade na angiogênese e, considerando-se que os complexos com bipiridinas apresentaram interações maiores com as biomoléculas estudadas, bem como menores valores de viabilidades celulares, comparadas às daqueles, estudo futuro essencial consiste na avaliação angiogênica dos complexos com bipiridinas, a fim de se averiguar se tal efeito também é favorecido pela coordenação dos ligantes bidentados. 
As moléculas de dopamina, noradrenalina e adrenalina não se comportaram de forma consideravelmente pró e antiangiogênica, tal como a literatura descreve, ao menos não nas condições abordadas neste trabalho. Possivelmente este fato se deve à análise de regiões tumorais abordadas pelos autores de alguns dos artigos sobre o tema. Na ausência de tumores, não se observou os efeitos descritos anteriormente - ao menos, não com as mesmas intensidades.

A toxicidade dos complexos, quando comparada à dos ligantes livres é menor, tanto em células, quanto nos ensaios realizados na membrana corioalantoica, o que possibilita aplicações biológicas futuras dos mesmos, pois a administração dos ligantes catecolaminas livres se mostra inviável para a finalidade antiangiogênica, uma vez que nas mesmas concentrações que aquelas utilizadas para os complexos, provocou a morte dos embriões, no ensaio realizado na CAM.

Tal como observado para os complexos de rutênio atualmente em fases clínicas, os complexos aqui estudados apresentaram baixa toxicidade no ensaio pré-clínico realizado (nos embriões de galinha) - a qual é um dos ideais norteadores das buscas por metalofármacos alternativos aos de platina.

Apesar de se ter avançado na compreensão da atividade angiogênese das catecolaminas, ainda há muito a ser elucidado sobre o tema, o que, definitivamente, não é um problema, bem como não impede que os complexos aqui reportados sejam considerados promissores, haja vista o fato de os mecanismos de ação dos complexos que já se encontram em fase clínica (NAMI-A e KP1019), ainda não terem sido totalmente esclarecidos. Neste sentido, resgatando a ideia trazida na primeira página da introdução, pode-se afirmar que muito há ainda a ser descoberto, no que tange à ação de compostos já descritos, já conhecidos e, às vezes, endógenos - categoria na qual estão inseridas as catecolaminas.

Em relação aos complexos tetramino envolvendo os ligantes adrenalina e noradrenalina, a ligação com o metal reduziu o efeito agonista $\alpha$-adrenérgico, ousa-se afirmar, $\alpha_{1}$ - culminando na redução dos efeitos vasoconstritores, por exemplo. Além disso, viabilizou maior interação com os receptores $\beta$-adrenérgicos, principalmente $\beta_{2}$, mas não no sentido de se tornarem agonistas plenos destes últimos receptores, mas sim agonistas parciais, ou mesmos antagonistas. Logo, promoveram menor contração vascular (o efeito $\beta$-adrenérgico modulou o efeito constritor dos receptores $\alpha$-adrenérgicos), bem como atuaram no sentido de impedir a proliferação celular, que foi observada tanto no experimento do ciclo celular (para noradrenalina e seu complexo), quanto nos experimentos de recuperação da lesão e 
viabilidade celular. Além disso, o efeito antiangiogênico observado pelo complexo de noradrenalina, bem como a redução do efeito pró-angiogênico evidenciado para o complexo de adrenalina, demonstram que os complexos, de fato, podem atuar como antagonistas $\beta$ adrenérgicos. Esta afirmação vai ao encontro do que reporta a literatura em relação ao uso de $\beta$-bloqueadores na inibição da angiogênese tumoral.

Ademais, conforme descreve a literatura clássica, alterações no grupamento catecólico tende a produzir compostos com maior tendência ao antagonismo $\beta$-adrenérgico.

Há que se considerar, ainda, que a imobilização do sítio catecólico dos dioxolenos, culmina no impedimento da degradação pela enzima COMT, restringindo-os à MAO, a qual é presente, principalmente, nos tecidos neuronais. Considerando-se o desenvolvimento embrionário das aves utilizadas nos ensaios e a ausência do seu sistema nervoso - razão pela qual o experimento é considerado in vitro - completo, possivelmente ocorreu a dessensibilização dos receptores, em razão da dificuldade de se degradar os compostos no organismo em formação, resultando em menores respostas, quando da segunda dose aplicada nos embriões.

Em relação ao complexo contendo dopamina como ligante, observou-se, tanto pelo experimento da reatividade vascular, quanto por aqueles realizados na membrana corioalantoica, que as vias envolvidas na ação deste são distintas daquelas envolvidas na ação do ligante livre, indicando que a coordenação ao metal promoveu total mudança do seu efeito agonista - fato que está diretamente relacionado à alteração da densidade eletrônica do anel aromático. Isso porque este complexo (assim como o de catecol) foi o que mais apresentou deslocamentos químicos diferentes daqueles obtidos para o ligante livre, no espectro de RMN, demonstrando que os hidrogênios do anel catecólico sofrem mais intensos efeitos de blindagem e desblindagem, em relação aos demais complexos, em razão da ausência do grupo hidroxila no carbono $\beta$, o que contribui, nos demais complexos, na estabilização da densidade de spin, deslocalizada sobre o ligante. O conjunto de dados permite concluir que para este complexo, para além de se ter obtido um agonista parcial (ou mesmo antagonista), possivelmente este complexo possui maior efeito agonista por receptores dopaminérgicos diferentes daqueles para os quais o ligante livre apresentou, nestes ensaios, maior interação.

Pode-se afirmar, ainda, que a existência do grupamento amínico é condição essencial para interação com os receptores, pois nem o catecol livre, nem seu complexo foram capazes de proporcionar efeitos no tônus vascular, embora por outra via este tenha promovido o aumento de cálcio intracelular. 
No que se refere à hipótese inicial, a qual delineou o presente trabalho, acredita-se que de fato as catecolaminas estão envolvidas no processo de angiogênese, bem como que a coordenação ao íon metálico, ou seja, a modificação da densidade eletrônica sobre os ligantes, promove alterações nos processos regulados por estes dioxolenos. Alterações estas provenientes tanto do impedimento estérico ocasionado pela ligação, quanto pelo efeito paramagnético proporcionado pelo metal. Os efeitos biológicos observados para os complexos metálicos indicam que seus efeitos são contrários aos observados pelos ligantes livres principalmente no que se refere à noradrenalina e à dopamina -, sendo considerados, portanto, no mínimo agonistas parciais (se não antagonistas) dos receptores cujos ligantes são agonistas.

Não obstante o fato de os complexos do tipo tetramino apresentarem diversas respostas biológicas interessantes, bem como atuação no mecanismo de angiogênese, os mesmos não apresentam consideráveis respostas de redução da viabilidade celular. Esta foi reduzida apenas para os complexos nos quais os quatro ligantes amônia são substituídos por dois bipiridil, cujas razões já foram amplamente discutidas neste texto.

Importante salientar que os complexos de noradrenalina, adrenalina e isoproterenol possuem os dois enantiômeros, logo, uma das hipóteses de melhora dos bons resultados já obtidos consiste na obtenção de apenas um dos isômeros isolados.

Por fim, em relação à formação da aluna, o presente trabalho representa diversos outros aspectos positivos: neste ponto, peço sua autorização, caro leitor, para concluir este texto da forma como foram escritas as considerações preliminares: em primeira pessoa.

A execução deste projeto proporcionou, de forma ímpar, meu crescimento como química e pesquisadora em razão da possibilidade de ter trabalhado com diversas técnicas físico-químicas de caracterização, ter aprendido sobre o planejamento químico de estruturas com possível atividade biológica, bem como a execução e planejamento de variados ensaios biológicos, a fim de encontrar respostas para as possíveis atividades de um composto químico. Além, disso, certamente o projeto agregou algum avanço à Ciência (pequeno ou não, isto não importa agora) - razão pela qual concluo que houve cumprimento dos "objetivos maiores" de um curso de Doutorado, bem como dos financiamentos governamentais, os quais são a contribuição à Ciência de um modo geral e a formação do estudante, para a pesquisa e a docência. 


\section{REFERÊNCIAS}

1. ACUC. Institutional Animal Care and Use Committee. GUIDELINE - The Use and Euthanasia Procedures of Chicken/Avian Embryos. Disponível em: $<$ https://www.cpp.edu/ research/acuc/doc/acuc\%20guidelines\%20on\%20euthanasia\%20of\% 20chicken\%20and\%20embryos.pdf $>$. Acesso em 24/02/2017.

2. ADAMO, C.; BARONE, V. Toward reliable density functional methods without adjustable parameters: The PBE0 model.The Journal of Chemical Physics, v. 110, p. 61586169, 1999.

3. ALEKSANDROWICZ, E.; HERR, I. Ethical euthanasia and short-term anesthesia of the chick embryo. Altex, v. 32, n.2, p. 143-147, 2015.

4. ALESSIO, E.; BALDUCCI, G.; LUTMAN, A.; MESTRONI, G.; CALLIGARIS, M.; M.ATTIA, W. Inorganica Chimica Acta, v. 203, p. 205-217, 1993.

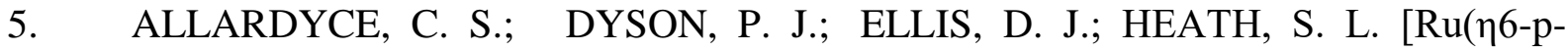
cymene)Cl2(pta)] (pta = 1,3,5-triaza-7-phosphatricyclo- [3.3.1.1]decane): a water soluble compound that exhibits $\mathrm{pH}$ dependent DNA binding providing selectivity for diseased cells. Chemical Communications, p. 1396-1397, 2001.

6. ALLEN, A. D.; BOTTOMLE, F.; HARRIS, R. O.; REINSALU, V. P.; SENOFF, C. V. Ruthenium Complexes Containing Molecular Nitrogen. Journal of the American Chemical Society, v. 89, n. 22, p. 5595-5599, 1987.

7. ANDERSON, C.; BEAUCHAMP, A. L. Can. Journal of Chemistry, v. 73, p. 471$482,1995$.

8. ANDRAE, D.; HÄUßERMANN, U.; DOLG, M.; STOLL, H.; PREUß, H. Energyadjustedab initio pseudopotentials for the second and third row transition elements. Theoretical Chimica. Acta, v. 77, p. 123-141, 1990.

9. ARMSTRONG, J.; BARLOW, R.B. The ionization of phenolic amines, including apomorphine, dopamine and catecholamines and an assessment of zwitterion constants. British Journal of Pharmacology, v. 57, p. 501-516, 1976.

10. AUERBACH, R.; LEWIS, R.; SHINNERS, B.; KUBAI, L.; AKHTAR, N. Angiogenesis Assays: A Critical Overview. Clinical Chemistry, v. 49, n. 1, p. 32-40, 2003.

11. BARRETO, W. J.; ANDOB, R. A.; SANTOS, P. S.; SILVA, W.P. Preparation, UVvis, IR, EPR and resonance Raman study of $\mathrm{Fe}, \mathrm{Ni}, \mathrm{Co}$ and $\mathrm{Zn}$ dioxolene complexes. Spectrochimica. Acta Part A, v. 68, p. 612-618, 2007.

12. BARRY, N. P. E.; SADLER, P. J. Exploration of the medical periodic table: Towards new target. Chemical Communications, v. 49, p. 5106-5131, 2013.

13. BASU, S.; A.NAGY, J,; PAL, S.; VASILE, E.; ECKELHOEFER, I. A.; BLISS, V. S. MANSEAU E. J.; .DASGUPTA, P. S.; DVORAK, H. F.; MUKHOPADHYAY, D. The 
Neurotransmitter Dopamine Inhibits Angiogenesis Induced by Vascular Permeability Factor/Vascular Endothelial Growth Factor. Nature Medicine, v. 7, n. 5, p. 569-574, 2001.

14. BASU, S.; SARKAR, C.; CHAKROBORTY, D.; NAGY, J.; MITRA, R. B.; DASGUPTA, P. S.; DEBABRATA, M. Ablation of Peripheral Dopaminergic Nerves Stimulates Malignant Tumor Growth by Inducing Vascular Permeability Factor/Vascular Endothelial Growth Factor- Mediated Angiogenesis. Cancer Research, v. 64, p. 5551-5555, 2004.

15. BECKFORD, F.; THESSING, J.; WOODS, J.; DIDION, J.; GERASIMCHUK, N.; GONZALEZ-SARRIAS, A.; SEERAM, N.P. Synthesis and structure of [ $\left(\eta^{6}-p-c y m e n e\right) R u(2-$ anthracen-9-ylmethylene-N-ethylhydrazinecarbothioamide) $\mathrm{Cl}] \mathrm{Cl}$; biological evaluation, topoisomerase II inhibition and reaction with DNA and human serum albumin. Metallomics, v. 3(5), p. 491-502, 2011.

16. BERGERS, G.; SONG, S. The role of pericytes in blood-vessel formation and maintenance. Neuro-Oncology, v. 7, n. 4, p. 452-464, 2005.

17. BERTINI, I.; DRAGO, R. S.. Springer Science \& Business Media, 1980.

18. BERTINI, I.; LUCHINAT, C.; AIME, S. NMR of paramagnetic substances. Coordination Chemistry Reviews. v. 150, n. 1, 1996.

19. BERTOLINI, F. Anti-angiogenesis in cancer; met and unmet goals - an interview with Robert Kerbel. The International Journal of Developmental Biology, v. 55, p. 395-398, 2011.

20. BOONE, S. R.; PIERPONT, C. G. Charge Delocalization in Ruthenium-Quinone Complexes. Structural Characterization of Bis( bipyridine) (3,5-di-fertbutylsemiquinonato)ruthenium(II) Perchlorate and trans -Bis( 4- tert -butylpyridine) bis( 3,5di-tert-butylquinone)ruthenium. Inorganic Chemistry, v. 26, p. 1769-1773, 1987.

21. BOWN, S. G. Photodynamic therapy for photochemists. Philosophical Transactions of the Royal Society of London A: Mathematical, Physical and Engineering Sciences, v. 371, p. 1-16, 1995.

22. BOZZUTO, G.; MOLINARI, A. Liposomes as nanomedical devices. International Journal of Nanomedicine, v. 10, p. 975-999, 2015.

23. BRITTAIN, H. G..(Ed.) Profiles of Drug Substances, Excipients and Related Methodology: Critical Compilation of pKa Values for Pharmaceutical Substances, v. 33. [S.I.]: Academic Press, 2007.

24. BRUNTON, LAURENCE; CHABNER, BRUCE A.; KNOLLMAN, BJORN. Goodman and Gilman's The Pharmacological Basis of Therapeutics. 12. ed., [S.I.]: McGraw-Hill Education, 2011.

25. BRUNTON, LAURENCE; PARKER, KEITH; BLUMENTHAL, DONALD; BUXTON, IAIN. Goodman E Gilman: Manual de Farmacologia e Terapêutica. Porto Alegre: AMGH, 2010. 
26. CACITA, N.; NIKOLAOU, S. Studying the interaction between trinuclear ruthenium complexes and human serum albumin by means of fluorescence quenching. Journal of Luminescence v. 169, p. 115-120, 2016.

27. CACITA, N.; POSSATO, B.; DA SILVA, C. F. N.; PAULO, M.; FORMIGA, A. L. B.; BENDHACK, L. M.; NIKOLAOU, S. Investigation of a novel trinuclear 1-oxo ruthenium complex as a potential nitric oxide releaser for biological purposes. Inorganica Chimica Acta, v. 429, p. 114-121, 2015.

28. CALDERÓN, D. M. B. Migração e invasão do câncer de boca via ativação de receptor beta 2 adrenérgico por mediador de estresse. Tese de Doutorado. Faculdade de Odontologia de Bauru, Universidade de São Paulo. Bauru, 2015.

29. CALLIER, S.; SNAPYAN, M.; LE CROM, S.; PROU, D.; VINCENT, J.-D.; VERNIER, P. Evolution and cell biology of dopamine receptors in vertebrates. Biology of the Cell, v. 95, p. 489-502, 2003.

30. CAO, Y.; CAO, R.; EVA-MARIA HEDLUND, E. M. Regulation of tumor angiogenesis and metastasis by FGF and PDGF signaling pathways. Journal of Molecular Medicine, v. 86, p. 785-789, 2008.

31. CARNEIRO, Z. A.; DE MORAES, J. C. B.;.RODRIGUES, F. P; DE LIMA, R. G.; CURTI, C.; DA ROCHA, Z. N.; PAULO, M.; BENDHACK, L. M.; TEDESCO, A. C.; FORMIGA, A. L. B.; DA SILVA, R. S. Nitric oxide photorelease from a trinuclear ruthenium nitrosyl complex and its in vitro cytotoxicity against melanoma cells. Journal of Inorganic Biochemistry, v. 105, p. 1035-1043. 2011.

32. CHAKROBORTY, D.; CHOWDHURY, U. R.; SARKAR, C.; BARAL, R.; DASGUPTA, P. S.; BASU, S. Dopamine regulates endothelial progenitor cell mobilization from mouse bone marrow in tumor vascularization. The Journal of Clinical Investigation, v. 118, n. 4, p. 1380-1389, 2008.

33. CHAKROBORTY, D.; SARKAR, C.; BASU, B.; DASGUPTA, P. S.; BASU, S. Catecholamines Regulate Tumor Angiogenesis. Cancer Research. (Rev), v. 69, n. 9, p. 3727-3730, 2009.

34. CHAKROBORTY, D.; SARKAR, C.; MITRA, R. B.; BANERJEE, S.; DASGUPTA, P. S.; BASU, S. Depleted Dopamine in Gastric Cancer Tissues: Dopamine Treatment Retards Growth of Gastric Cancer by Inhibiting Angiogenesis. Clinical Cancer Research, v. 10, p. 4349-4356, 2004.

35. COLOMBO, A. C. Papel dos receptores dopaminérgicos D1 e D2 do colículo inferior na expressão de respostas incondicionadas e condicionadas ao medo. Dissertação de Mestrado. Faculdade de Filosofia Ciências e Letras de Ribeirão Preto, Universidade de São Paulo. Ribeirão Preto, 2014.

36. CONNERY, M. Effects of nitrite and oxygen on angiogenesis in vascular networks of the chicken embryo. Tese de Doutorado. University of Virginia, 2013. 
37. COOK, K. M.; FIGG, W. D. Angiogenesis Inhibitors - Current Strategies and Future Prospects. CA a Cancer Journal for Clinicians; v. 60, n. 4, p. 222-243, 2010.

38. COOLIDGE, A. S.; JAMES, H. M.; PRESENT, R. D. A Study of the Franck-Condon Principle. Journal of chemical Physics, v. 4, n. 3, p. 193-211, 1936.

39. CUNHA, J. Propriedades espectroscópicas e eletroquímicas de clusters trigonais de rutênio com ligantes $\mathbf{N}$-heterocíclicos. Dissertação de Mestrado. Universidade de São Paulo. São Paulo, 1989.

40. DA COSTA, P. M. Avaliação do potencial antitumoral e antiangiogênico de novos análogo ftalimídicos da talidomida. Tese de Doutorado. Departamento de Fisiologia e Farmacologia, Universidade Federal do Ceará. Fortaleza, 2011.

41. DA SILVA, R. S.; GORELSKY, S. I.; DODSWORTH, E. S.; TFOUNI, E.; LEVER, A. B. P.; Synthesis, spectral and redox properties of tetraammine dioxolene ruthenium complexes. Dalton Transactions, p. 4078-4088, 2000.

42. DA SILVA, R. S.; TFOUNI, E.; LEVER, A. B. P.;. A new procedure to synthesize cis- $\left[\mathrm{Ru}\left(\mathrm{NH}_{3}\right)_{4} \mathrm{~L}_{2}\right]^{\mathrm{n}+}$ species containing ruthenium(II) or ruthenium(III) using tetrammino $(3,4-$ diolatobenzoato)ruthenium(II) as precursor. Inorganica Chimica Acta, v. 235, p. 427-430, 1995.

43. DALEPRANE, J.B. Atividade anti-angiogênica e modulação das proteínas envolvidas na neoformação vascular por compostos bioativos da própolis. Tese de Doutorado. Faculdade de Ciências Farmacêuticas da Universidade de São Paulo, Universidade de São Paulo. São Paulo, 2011.

44. DAVIES, M. J. Singlet oxygen-mediated damage to proteins and its consequences. Biochemical. Biophysical. Research. Communications, v. 305, p. 761-770, 2003.

45. DE LIMA, R. G. Efeito da coordenação do rutênio nas propriedades físicoquímicas e biológicas de catecolaminas em complexo tipo $\left[\mathrm{RU}\left(\mathrm{NH}_{3}\right)_{4}(\text { catecolamina-R) }]^{\mathrm{n}+}\right.$. Dissertação de Mestrado. Faculdade de Filosofia, Ciências e Letras de Ribeirão Preto, Universidade de São Paulo. Ribeirão Preto, 2001.

46. DE LIMA, R. G.; LEVER, A. B. P.; ITO, I. Y.; DA SILVA, R. S. Antifungal activity of novel catecholamine ruthenium(III) complexes. Transition Metal Chemistry, v. 28, p. 272-275, 2003.

47. DE LIMA, R. G.; MARCHESI, M. S. P.; DE GODOY, M. A. F.; CASSANO, A .O.; DE OLIVEIRA, A. M.; DA SILVA, R. S. Structure-activity relationship of coordinated catecholamine in the $\left[\mathrm{Ru}^{\mathrm{III}}\left(\mathrm{NH}_{3}\right)\left({ }_{4}\right) \text { (catecholamine) }\right]^{+}$complex. Internationa Journal of Pharmaceutics, v. 1-2, p. 271-278, 2004.

48. DE OLIVEIRA, G. S. Caracterização espectroscópica e por modelagem mecânicoquântica, de compostos com potencial aplicação em dispositivos ópticos não-lineares. Dissertação de Mestrado. Instituto de Química, Universidade Federal de Uberlândia. Uberlândia, 2009. 
49. DRAGO, R. S. Physical Methods in Inorganic Chemistry. Vau Nostrand Reinhold Company. Holland, 1965.

50. DVORAK, H.F. Angiogenesis: Update 2005. Journal of Thrombosis and Haemostasis, v. 3, p. 1835-1842, 2005.

51. DYSON, P. J.; SAVA, G. Metal-based antitumour drugs in the post genomic era. Dalton Transactions, p. 1929-1933, 2006.

52. EBOS, J. M. L.; LEE, C. R.; CRUZ-MUNOZ, W.; BJARNASON, G. A.; CHRISTENSEN, J. G.; KERBEL, R. S. Accelerated Metastasis after Short-Term Treatment with a Potent Inhibitor of Tumor Angiogenesis. Cancer Cell, v. 15, p. 232-239, 2009.

53. EISENHOFER, G.; KOPIN, I. J.; GOLDSTEIN, D. S. Catecholamine Metabolism: A Contemporary View with Implications for Physiology and Medicine. Pharmacological Reviews, v. 56, n. 3, p. 331-349, 2004.

54. ESHKOURFU, R.; ČOBELJIĆ, B.; VUJČIĆ, M.; TUREL, I.; PEVEC, A.; SEPČIĆ, K.; ZEC, M.; RADULOVIĆ S.; SRDIĆ-RADIĆ, T.; MITIĆ, D.; ANDJELKOVIĆ, K.; SLADIĆ, D. Synthesis, characterization, cytotoxic activity and DNA binding properties of the novel dinuclear cobalt(III) complex with the condensation product of 2-acetylpyridine and malonic acid dihydrazide. Journal of Inorganic Biochemistry, v. 105, p.1196-1203, 2011.

55. FANALI, G.; DI MAIS, A.; TREZZA, V.; MARINO, M.; FASANO, M.; ASCENZI, P. Human serum albumin: From bench to bedside. Molecular Aspects of Medicine (Rev), v. 33, p. 209-290, 2012.

56. FERRARA, N.; GERBER, H. P.; LECOUTER, J. The Biology of VEGF and Its Receptors. Nature Medicine, v. 9, p. 669-676, 2003.

57. FERRARA, N.; KERBEL, R. S. Angiogenesis as a therapeutic target. Nature, v. 438, n. 15, p. 967-974, 2005.

58. FERRARO, J. R.; NAKAMOTO, K.. Introductory Raman Spectroscopy. San Diego: Academic Press, Inc, 1994.

59. FERREIRA, C. S.. Atividade anti-angiogênica de inibidores de tripsina em membrana corioalantóica de gallus domesticus. Dissertação de Mestrado. Instituto de Ciências Exatas e Biológicas, Universidade Federal de Ouro Preto. Ouro Preto, 2013.

60. FOLKMAN, J. Angiogenesis: an organizing principle for drug discovery? Nature. Reviews. Drug Discovery, v. 6, p. 273-286, 2007.

61. FOLKMAN, J. Tumor Angiogenesis: Therapeutic Implications. The New England Journal of Medicine, v. 285, p. 1182-1186, 1971.

62. FOLKMAN, J.; LONG JUNIOR, D. M.; BECKER, F. F. Growth and metastasis of tumor in organ culture. Cancer, v. 16, p.453-467, 1963. 
63. FREZZA, M.; HINDO, S.; CHEN, D.; DAVENPORT, A.; SCHMITT, S.; TOMCO D.; DOU Q. P. Novel Metals and Metal Complexes as Platforms for Cancer Therapy. Current Pharmaceutical Design, v. 16, n. 16, p. 1813-1825, 2010.

64. GEDDES, C.D. Optical halide sensing using fluorescence quenching: theory, simulations and applications - a review. Measurement Science and Technology, v. 12, p. 53-88, 2001.

65. GIRALDO, J.; VIVAS, N. M.; VILA, E.; BADIA, A. Assessing the (a)symmetry of concentration-effect curves: empirical versus mechanistic models. Pharmacology \& Therapeutics, v. 95, p. 21-45, 2002.

66. GRAAF, P. H. V.; SCHOEMAKER, R. C. Analysis of asymmetry of agonist concentration-effect curves. Journal of Pharmacology andl Toxicology, v. 41, p. 107-115, 1999.

67. GRAHAM, D. Oxidative pathways for catecholamines in the genesis of neuromelanin and cytotoxic quinones. Molecular pharmacology, v. 14, p. 633-643, 1978.

68. H.P. RANG; J.M. RITTER; R.J. FLOWER; G. HENDERSON. Farmacologia. 8. ed. Tradução Gea Consultoria Editorial. Rio de Janeiro: Elsevier, 2016.

69. HAGA, M.-A.; DODSWORTH, E. S.; LEVER, A. B. P. Catechol-Quinone Redox Series Involving Bis(bipyridine)ruthenium(II) and Tetrakis(pyridine)rutbenium (II). Inorganic Chemistry, v. 25, p. 447-453, 1986.

70. HAGA, M.-A.; ISOBE, K.; BOONE, S. R.; CORTLANDT G. Pierpont Comparative Studies on Charge Distribution for the Ruthenium and Osmium Quinone Complexes [M(bpy)z(quinone)y (M = Ru, Os; $\mathrm{R}=0,+1,+2)$. Inorganic Chemistry, v. 29, n. 19, 1990.

71. HARRY S. N.; GREENE, M. D. Heterologous transplantation of mammalian tumors i. The transfer of rabbit tumors to alien species. The Journal of Experimental Medicine, v. 73, p. 461-474, 1941.

72. HEINRICH, T. A. Aspectos químicos, fitoquímicos e fotobiológicos de complexo rutênio-nitrosilo como precursor de óxido nítrico. Princípios de aplicação como agente citotóxico em linhagens de células tumorais. Tese de Doutorado. Faculdade de Ciências Farmacêuticas de Ribeirão Preto, Universidade de São Paulo. Ribeirão Preto, 2013.

73. HOEBEN, ANN; LANDUYT, B.; HIGHLEY, M. S.; WILDIERS. H.; OOSTEROM, A. T. V.; BRUIJN, E. A. Vascular Endothelial Growth Factor and Angiogenesis. Pharmacological Reviews, v. 56, n. 4. p. 549-580, 2004.

74. HORVATHOVA, L.; PADOVA, A.; TILlINGER, A.; OSACKA, J.; BIZIK, J.; MRAVEC, B. Sympathectomy reduces tumor weight and affects expression of tumor-related genes in melanoma tissue in the mouse. Stress, v. 19, n. 5, p. 528-534, 2016.

75. INSTITUTO NACIONAL DE CÂNCER JOSÉ ALENCAR GOMES DA SILVA. Estimativa 2016: incidência de câncer no Brasil. Rio de Janeiro: INCA, 2015. 
76. IZSÁK, R.; NEESE, F. An overlap fitted chain of spheres exchange method. The Journal of Chemical Physics, v. 135, 2011.

77. JEMAL, A; VINEIS, P; BRAY, F; TORRE, L; FORMAN, D. (Eds). The Cancer Atlas. 2. ed. Atlanta, GA: American Cancer Society; 2014. Disponível em: 〈www.cancer.org/canceratlas $>$. Acesso em: 20 jan. 2017.

78. Jmol: an open-source Java viewer for chemical structures in 3D. < $\underline{\text { htp://www.jmol.org/>. }}$

79. KREBS, R. E. The history and use of our earth's chemical elements: a reference guide. 2. ed. London: Greenwood Press, 2006.

80. LAI, H.; ZHAO, Z.; LI, L.; ZHENG, W.; CHEN, T. Antiangiogenic ruthenium(II) benzimidazole complexes, structure-based activation of distinct signaling pathways. Metallomics, v. 7 p. 439-447, 2015.

81. LAKOWICZ, J. R. Principles of Fluorescence Spectroscopy. New York: Plenum Press, 1983.

82. LEVER, A. B. P.; AUBURN, P. R.; DODSWORTH, E. S.; HAGA, M.-A.; LIU, W.; MELNIK, M.; NEVINLD W. A. Bis(dioxolene) bipyridine)ruthenium Redox Series. Journal of American Chemical Society, v. 110, p. 8076-8084, 1998.

83. LEVER, A. B. P.; MASUI, H.; MCTCALFE, R. A.; STUFKENSA, D. J.; DODSWORTH, E. S.; AUBURN, P. R. The Ground and Excited State Electronic Structures of Ruthenium Quinones and Related Species. Coordination Chemistry Reviews, v. 125, p. 317-332. 1993.

84. LIU, H.; SADLER, P. J. Metal Complexes as DNA Intercalators. Accounts of Chemical Research, v. 44, n. 5, p. 349-359, 2011.

85. LIU, J.; ZHANG, T,; LU, T.; QU, L.; ZHOU, H.; ZHANG, Q.; JI, L. DNA-binding and cleavage studies of macrocyclic copper(II) complexes. Journal of Inorganic Biochemistry, v. 91, p. 269-276, 2002.

86. LIU, Y.; HAN, Z.-P.; ZHANG, S.-S.; JING, Y.-Y.; BU, X.-X.; WANG, C.-Y.; SUN, K.;. JIANG, G.-C; ZHAO, X.; LI, R.; GAO, L.; ZHAO, Q.-D.; WU, M.-C.; WEI, L.-X. Effects of Inflammatory Factors on Mesenchymal Stem Cells and Their Role in the Promotion of Tumor Angiogenesis in Colon Cancer. The Journal of Biological Chemistry, v. 286, n.28, p. 25007-25015, 2011.

87. LODISH, H.; BERK, A.; MATSUDAIRA, P.; CHRIS A. KAISER, C. A.; SCOTT, M. P; ZIPURSKY, L.; DARNELL, J. Molecular Cell Biology. 5. ed. New York: W. H. Freeman, 2005.

88. HORVATHOVA, L.; PADOVA, A.; TILllNGER, A.; OSACKA, J.; BIZIK, J.; MRAVEC, B. Sympathectomy reduces tumor weight and affects expression of tumor-related genes in melanoma tissue in the mouse. Stress - The International Journal on the Biology of Stress, v. 19, n. 5, 528-534, 2016. 
89. LUCA, A. D.; CAROTENUTO, A.; RACHIGLIO, A.; GALLO, M.; MAIELLO, M. R.; ALDINUCCI, D.; PINTO, A.; NORMANNO, N. The role of the EGFR signaling in tumor microenvironment. Journal of Cellular Physiology, v. 214, n. 3, p. 559-567, 2008.

90. LUPO, G.; CAPORARELLO, N.; OLIVIERI, M.; CRISTALDI, M.; MOTTA, C.; BRAMANTI, V.; AVOLA, R.; SALMERI, M.; NICOLETTI, F.; ANFUSO, C. D. Antiangiogenic Therapy in Cancer: Downsides and New Pivots for Precision Medicine. Frontiers in Pharmacology, v. 7, 519, p.1-9, 2017.

91. MARECH, I.; LEPORINI, C.; AMMENDOLA, M.; PORCELLI, M.; GADALETA, C. D.; RUSSO, E.; DE SARRO, G.; GIROLAMO RANIERI, G. Classical and non-classical proangiogenic factors as a target of antiangiogenic therapy in tumor microenvironment. Cancer Letters, p. 1-11, 2015.

92. MARTINHO, O.; SILVA-OLIVEIRA, R.; MIRANDA-GONÇALVES, V.; CLARA, C.; ALMEIDA, J. R.; CARVALHO, A. L.; BARATA, J. T.; REIS, R. M. In Vitro and In Vivo Analysis of RTK Inhibitor Efficacy and Identification of Its Novel Targets in Glioblastomas. Translational Oncology, v. 6, p. 187-196, 2013.

93. MASUI, H.; LEVER, A. B. P.; AUBURN, P. R. The Control of Orbital Mixing in Ruthenium Complexes Containing Quinone Related Ligands (No. TR-38). YORK UNIV NORTH YORK (Ontario) Dept Of Chemistry. 1991.

94. MEDEIROS, M. A. A. Investigação do efeito vasorelaxante e caracterização eletrofisiológica dos alcaloides curina e reticulina. Dissertação de Mestrado. Centro de Ciências da Saúde, Universidade Federal da Paraíba. João Pessoa, 2009.

95. MIGNOLET, A.; DERENNE, A.; SMOLINA, M.; WOOD, B. R.; GOORMAGHTIGH, E. FTIR spectral signature of anticancer drugs. Can drug mode of action be identified? Biochimica et Biophysica Acta (Rev), v. 1864, p. 85-101, 2016.

96. MONTANARI, T. Histologia: texto, atlas e roteiro de aulas práticas. 3. ed. Porto Alegre: Edição do Autor, 2016.

97. MOREIRA, M. B. Complexos trinucleares de rutênio com ponte $\mu$-oxo contendo ligantes N-heterocíclicos e monóxido de carbono: síntese, caracterização e estudo de interação com biomoléculas. Tese de Doutorado. Faculdade de Filosofia, Ciências e Letras de Ribeirão Preto, Universidade de São Paulo. Ribeirão Preto, 2016.

98. NAHID SHAHABADI; SOMAYEMOHAMMADI; ROBABEH ALIZADEH. DNA Interaction Studies of a New Platinum(II) Complex Containing Different Aromatic Dinitrogen Ligands. Bioinorganic Chemistry and Applications, v. 2011, 2011.

99. NAKAMOTO, K. Infrared and Raman Spectra of Inorganic and Coordination Compounds Part B: application in coordination, organometallic, and bioinorganic chemistry. 6. ed. New Jersey: John Wiley \& Sons, Inc, 2009.

100. NEESE, F. The ORCA program system. Computacionl Molecular Science, v. 2, p. 73-78, 2012. 
101. NEGRI, L. B. Complexos rutênio-ftalocianinas como fotossensibilizadores para terapia fotodinâmica. Aspectos fotoquímicos e fotobiológicos. Dissertação de Mestrado. Faculdade de Ciências Farmacêuticas de Ribeirão Preto, Universidade de São Paulo. Ribeirão Preto, 2015.

102. NI, Y.; LIN, D.; KOKOT, S. Synchronous fluorescence, UV-visible spectrophotometric, and voltammetric studies of the competitive interaction of bis $(1,10-$ phenanthroline)copper(II) complex and neutral red with DNA. Analytical Biochemistry, v. 352, p. 231-242, 2006.

103. NIH. National Institute of Health. Open Chemistry Database. Disponível em: <https://pubchem.ncbi.nlm.nih.gov>. Acesso em: 21 fev. 2017.

104. NIH. National Institute of Health. Toxicology Data Network. Disponível em: <https://toxnet.nlm.nih.gov >. Acesso em 04 mar. 2017.

105. NIH. NCI Dictionary of Cancer Terms. Disponível em: $<$ https://www.cancer.gov/publications/dictionaries/cancer-terms?cdrid=44329>. Acesso em 02 fev. 2017.

106. NOWAK-SLIWINSKA, P.; BALLINI, J.; WAGNIÈRES, G.; VAN DEN BERGH, H. Processing of fluorescence angiograms for the quantification of vascular effects induced by anti-angiogenic agents in the CAM model. Microvascular Research, v. 79, p. 21-28, 2010.

107. NOWAK-SLIWINSKA, P.; SEGURA, T.; IRUELA-ARISPE, M.L. The chicken chorioallantoic membrane model in biology, medicine and bioengineering. Angiogenesis, v. 17, p. 779-804, 2014.

108. NOWAK-SLIWINSKA, P.; VAN BEIJNUM, J. R.; CASINI, A.; NAZAROV, A. A.; WAGNIÈRES, G.; VAN DEN BERGH, H.; DYSON, P. J.; GRIFFIOEN, A. W. Organometallic Ruthenium(II) Arene Compounds with Antiangiogenic Activity. Journal of Medicinal Chemistry, v. 54, p. 3895-3902, 2011.

109. OLSON, R. E.; CHRIST, D. D. Plasma Protein Binding of Drugs. Annual Reports in Medicinal Chemistry, v. 31, 33, p. 327-336, 1996.

110. PAGES, B. J.; SAKOFF, J.; GILBERT, J.; RODGER, A.; CHMEL, N. P.; JONES, N. C.; KELLY, S. M.; ANG, D. L.; ALDRICH-WRIGHT, J. R. Multifaceted Studies of the DNA Interactions and In Vitro Cytotoxicity of Anticancer Polyaromatic Platinum(II) Complexes. Chemistry A European Jorunal, v. 22, p. 8943-8954, 2016.

111. PETRENKO, T.; KOSSMANN, S.; NEESE, F. Efficient time-dependent density functional theory approximations for hybrid density functionals: Analytical gradients and parallelization. Journal of Chemical Physics, v. 134, 2011.

112. PINTON, P.; GIORGI, C.; SIVIERO, R.; E. ZECCHINI, E.; RIZZUTO, R. Calcium and apoptosis: ER-mitochondria $\mathrm{Ca}^{2+}$ transfer in the control of apoptosis. Oncogene, v. 27, n. 50, p. 6407-6418, 2008. 
113. PIZARRO, A. M.; SADLER, P. J. Unusual DNA binding modes for metal anticancer complexes. Biochimie, v. 91, n. 10, p. 1198-1211, 2009.

114. PRAVIN, N.; UTTHRA P. P.; KUMARAVEL G.; RAMAN N. Effective DNA binding and cleaving tendencies of malonic acid coupled transition metal complexes. Journal of Molecular Structure, v.1123, p. 162-170, 2016.

115. RAMOS, L. CARLA BARBOSA. Interação anticorpo policlonal-complexo de rutênio como sistemas de liberação de óxido nítrico. Medida de especificidade e avaliação citotóxica. Dissertação de Mestrado. Faculdade de Ciências Farmacêuticas de Ribeirão Preto, Universidade de São Paulo. Ribeirão Preto, 2012.

116. RAMOS, S. Cancer chemoprevention and chemotherapy: Dietary polyphenols and signalling pathways. Molecular Nutrition \& Food Research (Rev), v. 507, n. 52, p. 507$526,2008$.

117. RANG, H. P.; DALE, M. M. Farmacologia. 4. ed. Rio de Janeiro: Guanabara Koogan S.A., 1993.

118. RAPOSO, L. R.; ROMA-RODRIGUES, C.; FAÍSCA, P.; ALVES, M.; HENRIQUES, J.; CARVAlHEIRO, M. C.; CORVO, M. L.; BAPTISTA, P. V.; POMBEIRO, A. J.; FERNANDES, A. R. Immortalization and characterization of a new canine mammary tumour cell line FR37-CMT. Veterinary .and Comparative Oncology, v.1, p. 1-16, 2016.

119. RASTRELli, F.; BAGNO, A. Predicting the 1Hand 13CNMR spectra of paramagnetic Ru(III) complexes by DFT. Magnetic Resonance in Chemistry, v. 48, p. 132 $141,2010$.

120. REIS, F. C. C. Investigação química de complexos de coordenação dos antibióticos enrofloxacina e norfloxacina combinados ao íon $R u($ III) e suas interações com biomoléculas alvo. Dissertação de Mestrado. Faculdade de Filosofia, Ciências e Letras de Ribeirão Preto, Universidade de São Paulo. Ribeirão Preto, 2014.

121. RIBATTI, D. Chick embryo chorioallantoic membrane as a useful toolto study angiogenesis. International Review of Cell and Molecular Biology, v. 270, p. 181, 2008.

122. RIBATTI, D.; FOLKMAN, J. A pioneer in the study of angiogenesis. Angiogenesis, v. 11, n. 1, p. 3-10, 2008.

123. RIBATTI, D.; RANIERI, G.; NICO, B.; BENAGIANO, V.; CRIVELLATO, E. Tryptase and chymase are angiogenic in vivo in the chorioallantoic membrane assay. The International Journal of developmental Biology, v.55, p. 99-102, 2011.

124. ROCHA, CAROLINA VALÉRIO BARROS. Novos complexos de 'Pd'(II): síntese, caracterização e efeito dos ligantes na citotoxicidade e interação com DNA. Tese de Doutorado. Instituto de Química, Universidade Estadual Paulista "Júlio de Mesquita Filho". Araraquara, 2014.

125. ROSS, P.D., SUBRAMANIAN, S. Thermodynamics of protein association reactions: forces contributing to stability. Biochemistry, v. 20 (11), p. 3096-3102, 1981. 
126. SANTIAGO, M. O. Síntese, caracterização e estudos cinéticos da isomerização de compostos de $\mathrm{Ru}(\mathrm{II})$ contendo ligantes $\left(\mathrm{X}\right.$-bipy) $\left(\mathrm{X}=-\mathrm{OH},-\mathrm{NO}_{2},-\mathrm{Me},-\mathrm{COOH},-\mathrm{SMe}\right.$, -O=SMe, - Cl, -OMe). Tese de Doutorado. Centro de Ciências Exatas e de Tecnologia, Universidade Federal de São Carlos. São Carlos, 2004.

127. SARKAR, C.; CHAKROBORTY, D.; BASU, S. Neurotransmitters as Regulators of Tumor Angiogenesis and Immunity: The Role of Catecholamines. Journal of Neuroimmune Pharmacology, v. 8, p. 7-14, 2013.

128. SARKAR, C.; CHAKROBORTY, D.; CHOWDHURY, U. R.; DASGUPTA, P. S.; BASU, S. Dopamine Increases the Efficacy of Anticancer Drugs in Breast and Colon Cancer Preclinical Models. Clinical Cancer Research, v. 14, n. 8, p. 2502-2510, 2008.

129. SARKAR, C.; CHAKROBORTY, D.; MITRA, R. B.; BANERJEE, S.; DASGUPTA, P. S.; BASU, S. Dopamine in vivo inhibits VEGF-induced phosphorylation of VEGFR-2, MAPK, and focal adhesion kinase in endothelial cells. American Journal of PhysiologyHeart and Circulatory Physiology, v. 287, n. 4, H1554-H1560, 2004.

130. SAUAIA, M. G. Síntese, caracterização e estudo da reatividade de complexos nitrosilos de rutênio contendo ligantes piridínicos. Dissertação de Mestrado. Faculdade de Filosofia, Ciências e Letras de Ribeirão Preto. Universidade de São Paulo. Ribeirão Preto, 2001.

131. SCHÄFER, A.; HORN, H.; AHLRICHS, R. Fully optimized contracted Gaussian basis sets for atoms Li to Kr. Journal of Chemical Physics, v. 97, p. 2571, 1992.

132. SCHMIDT, R. D.; KENT, C. A.; CONCEPCION, J. J.; LIN, W.; MEYER, T. J.; FORBES, M. D. E. A little spin on the side: solvent and temperature dependent paramagnetism in $[\mathrm{RuII}(\mathrm{bpy}) 2 \text { (phendione) }]^{2+}$. Dalton Transactions, v. 43, p. 17729-17739, 2014.

133. SEIDLITZ, E.; KORBIE, D.; MARIEN, L.; RICHARDSON, M.; SINGH, G. Quantification of anti-angiogenesis using the capillaries of the chick chorioallantoic membrane demonstrates that the effect of human angiostatin is age-dependent. Microvascular Research, v. 67, p. 105-116, 2004.

134. SHAKED, Y.; HENKE, E.; ROODHART, J. M. L.; MANCUSO, P.; LANGENBERG, M. H. G.; COLLEONI, M.; DAENEN, L. G.; MAN, S. ; XU, P.; EMMENEGGER, U.; TANG, T.; ZHU, Z.; WITTE, L.; STRIETER, R. M.; BERTOLINI, F.; VOEST, E. E.; BENEZRA, R. ; KERBEL, R. S. Rapid Chemotherapy-Induced Acute Endothelial Progenitor Cell Mobilization: Implications for Antiangiogenic Drugs as Chemosensitizing Agents. Cancer Cell, v. 14, p. 263-273, 2008.

135. SHI, S.; LIU, J.; ZHENG, K.-C.; HUANG, X.-M.; TAN, C.-P.; CHEN, L.-M.; JI, L.N. Synthesis, characterization and DNA-binding of novel chiral complexes $\Delta$ - and $\Lambda$ $[\mathrm{Ru}(\mathrm{bpy}) 2 \mathrm{~L}] 2+(\mathrm{L}=\mathrm{o}$-mopip and p-mopip). Journal of Inorganic Biochemistry, v. 100, p. 385-395, 2006. 
136. SHOME, S.; RANA, T.; GANGULY, S.; BASU, B.; CHOUDHURY, C. S.; SARKAR, C.; CHAKROBORTY, D.; SARATHI, D. P.; BASU, S. Dopamine regulates angiogenesis in normal dermal wound tissues. PLoS One, v. 6, n. 9, e25215, 2011.

137. SHRIVER, D. F.; ATKINS, P. W.; OVERTON, T. L.; ROURKE, J. P.; WELLER, M. T.; ARMSTRONG, F. A.. Química Inorgânica. Tradução: Roberto de Barros Faria. 4. ed. Porto Alegre: Bookman, 2008.

138. SINGH, K.; SRIVASTSAVA, P.; PATRA, A. K.. Binding interactions with biological targets and DNA photocleavage activity of $\operatorname{Pr}(\mathrm{III})$ and $\mathrm{Nd}$ (III) complexes of dipyridoquinoxaline. Inorganica Chimica Acta, v. 451, p. 73-81, 2016.

139. SIRAJUDDIN, M.; ALI, S.; BADSHAH, A. Drug-DNA interactions and their study by UV-Visible, fluorescence spectroscopies and cyclic voltametry. Journal of Photochemistry and Photobiology B: Biology, v.124, p.1-19, 2013.

140. SMITH, E.; DENT, G. Modern Raman Spectroscopy: a practical approach. Chichester: John Wiley \& Sons, Ltd., 2005.

141. SOKER, S.; TAKASHIMA, S.; MIAO, H. Q.; NEUFELD, G.; KLAGSBRUN, M. Neuropilin-1 is expressed by endothelial and tumor cells as an isoform-specific receptor for vascular endothelial growth factor. Cell, v. 92, p. 735-745, 1998.

142. SOUZA, A. P. C. Complexos de rutênio (II) de interesse biológico: avaliação in vitro e in vivo do potencial antitumoral e genotóxico. Tese de Doutorado. Centro de Ciências Exatas e de Tecnologia, Universidade Federal de São Carlos. São Carlos, 2014.

143. STEPHEN G. BOWN. Photodynamic therapy for photochemists. Philosophical Transactions of the Royal Society of London A: Mathematical, Physical and Engineering Sciences, v. 371, n. 1995, p. 20120371, 2013.

144. STÍBAL, D.; THERRIEN, B.; SUSS-FINK, G.; NOWAK-SLIWINSKA, P; DYSON, P. J.; ČERMÁKOVÁ, E.; ŘEZÁC`OVÁ, M.; TOMŠÍK, P. Chlorambucil conjugates of dinuclear p-cymene ruthenium trithiolato complexes: synthesis, characterization and cytotoxicity study in vitro and in vivo. Journal of Biological Inorganic Chemistry, v. 21, n. 4, p. 443-452, 2016.

145. STRUKL, J. S.; WALTER, J. L. Infrared and Raman spectra of heterocyclic compounds-III: The infrared studies and normal vibrations of 2, 2'-bipyridine. Spectrochimica Acta Part A: Molecular Spectroscopy, v. 27, n. 2, p. 209-221, 1971.

146. SULLIVAN, L. B.; CHANDEL, N. S. Mitochondrial reactive oxygen species and cancer. Cancer \& Metabolism. v. 2, n. 17, p. 1-12, 2014.

147. TANIMOTO, M. K.; DIAS, K.; DOVIDAUSKAS, S.; NIKOLAOU, S. Tuning the reaction products of ruthenium and ciprofloxacin for studies of DNA interactions. Journal of Coordination Chemistry, v. 65, n. 9, p. 1504-1517, 2012.

148. THAKER, P. H.; HAN, L. Y.; KAMAT, A. A.; AREVALO, J. M.; TAKAHASHI, R.; LU, C.; JENNINGS, N. B.; ARMAIZ-PENA, G.; BANKSON, J. A.; RAVOORI, M.; 
MERRITT, W. M.; LIN, Y. G.; MANGALA, L. S.; KIM, T. J.; COLEMAN, R. L.; LANDEN, C. N.; LI, Y.; FELIX, E.; SANGUINO, A. M.; NEWMAN, R. A.; LLOYD, M.; GERSHENSON, D. M.; KUNDRA, V.; LOPEZ-BERESTEIN, G.; LUTGENDORF, S. K.; COLE, S. W.; SOOD, A. K. Chronic stress promotes tumor growth and angiogenesis in a mouse model of ovarian carcinoma. Nature Medicine, v. 12, n. 8, p. 939-944, 2006.

149. THIJSSEN, V. L. J. L.; POIRIER, F.; BAUM, L. G.; GRIFFIOEN A. W. Galectins in the tumor endothelium: opportunities for combined cancer therapy. Blood, v. 110, n. 8, p. 2819-2827, 2007.

150. THOMAS C. WESTFALL; DAVID P. WESTFALL. Adrenergic Agonists and Antagonists. In: BRUNTON, LAURENCE; CHABNER, BRUCE A.; KNOLLMAN, BJORN. Goodman and Gilman's The Pharmacological Basis of Therapeutics. 12. ed., [S.I.]: McGraw-Hill Education, p. 277-333, 2011.

151. TILAN, J.; KITLINSKA, J. Sympathetic Neurotransmitters and Tumor Angiogenesis-Link between Stress and Cancer Progression. Journal of Oncology (Rev), v. 2010, p. 1-6, 2010.

152. TRIPATHI, S. K.; KAUR, G.; KHURANA, R. K.; KAPOOR, S.; SINGH, B. Quantum Dots and their Potential Role in Cancer Theranostics. Critical Review in Therapeutic Drug carrier System, v. 32, n. 6, p. 461-502, 2015.

153. VEGAS, L. A. C. Síntese de complexos semi-sanduíche $\eta^{6}$-p-cimeno-Ru(II) contendo ligantes binitrogenados, interação com o dna e potenciais atividades farmacológicas. Dissertação de Mestrado. Centro de Ciências Exatas e de Tecnologia, Universidade de São Carlos. São Carlos, 2013.

154. WEIDNER, N.; CARROLL, P. R.; FLAX, J.; BLUMENFELD, W.; FOLKMAN, J. Tumor angiogenesis correlates with metastasis in invasive prostate carcinoma. American Journal of Pathology, v. 143, p.401-409, 1993.

155. WEIGEND, F.; AHLRICHS, R. Balanced basis sets of split valence, triple zeta valence and quadruple zeta valence quality for $\mathrm{H}$ to $\mathrm{Rn}$ : Design and assessment of accuracy. Physical Chemistry Chemical Physics, v. 7, p. 3297-3305, 2005.

156. WEINBERG, R.A. The biology of cancer. 2. ed. New York: Garland Science, Taylor \& Francis Group, LLC, 2014.

157. WONG, H. P. S.; HO, J. W. C.; KOO, M. W. L.; YU, L.; WU, W. K.K.; LAM, E. K.Y.; TAI, E. K.K.; KO, J. K.S.; SHIN, V. Y.; CHU, K. M.; CHO, C. H. Effects of adrenaline in human colon adenocarcinoma HT-29 cells. Life Sciences, v. 88, p. 1108-1112, 2011.

158. WORLD HEALTH ORGANIZATION. Cancer. Disponível em: <http://www.who.int/cancer/en/>. Acesso em: 14 fev. 2017.

159. WORLD HEALTH ORGANIZATION. STEWART, B. W.; WILD, C. P. (Ed.). World Cancer Report 2014. Lyon, International Agency for Research on Cancer, 2014. 
160. WU, F. T. H.; LEE, C. R.; BOGDANOVIC, E.; PRODEUS, A.; GARIÉPY, J.; KERBEL, R. S. Vasculotide reduces endothelial permeability and tumor cell extravasation in the absence of binding to or agonistic activation of Tie2. EMBO Molecular Medicine, v. 7, p. 770-787, 2015.

161. XIE, H.; LI, C.; HE, Y.; GRIFFIN, R.; YE, Q.; LI, L. Chronic stress promotes oral cancer growth and angiogenesis with increased circulating catecholamine and glucocorticoid levels in a mouse model. Oral Oncology, v. 51, p. 991-997, 2015.

162. YANG, E.V. Role for catecholamines in tumor progression: Possible use for $\beta$ blockers in the treatment of cancer. Cancer Biology \&. Therapy, v. 10, n. 1, p. 30-32, 2010.

163. ZENG, L.; CHEN, Y.; LIU, J.; HUANG, H.; GUAN, R.; JI, L.; CHAO, H. Ruthenium(II) Complexes with 2-Phenylimidazo[4,5-f][1,10]phenanthroline Derivatives that Strongly Combat Cisplatin-Resistant Tumor Cells. Scientific Reports, v. 6, p. 1-13, 2016.

164. ZHANG, J.-F.; ELLINOR, P. T.; ALDRICH, R. W.; TSIEN, R. W. Molecular determinants of voltage-dependent inactivation in calcium channels. Nature, v. 372, p. 97 100, 1994. 


\section{APÊNDICE}

\subsection{Parte 1: Complexos com fórmula geral: [Ru(NH$\left.)_{4} \mathrm{Cat}-\mathrm{R}\right] \mathrm{Cl}$}

\subsubsection{Espectroscopia eletrônica de absorção na região $U V$-vis}

Figura 127: Espectro eletrônico qualitativo do cloridrato de isoproterenol

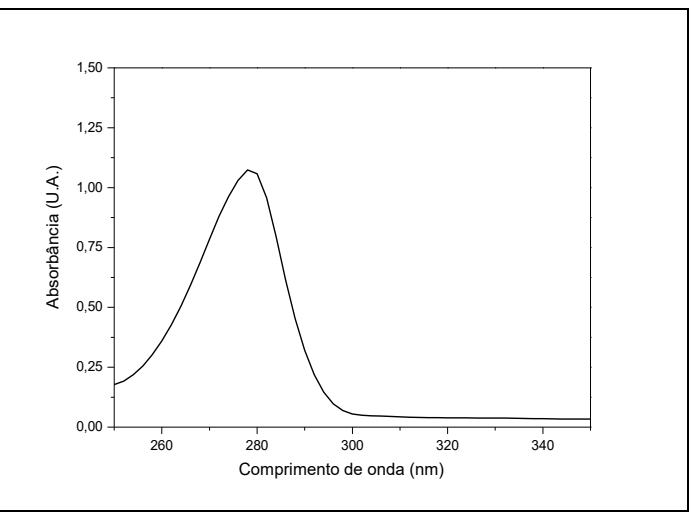

Fonte: Autora

Figura 128: Espectro eletrônico qualitativo do cloridrato de dopamina

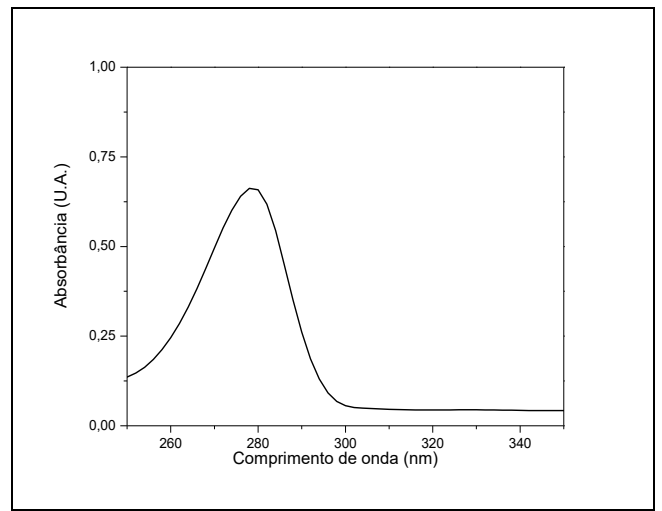

Fonte: Autora

Figura 129: Espectro eletrônico qualitativo do cloridrato de noradrenalina

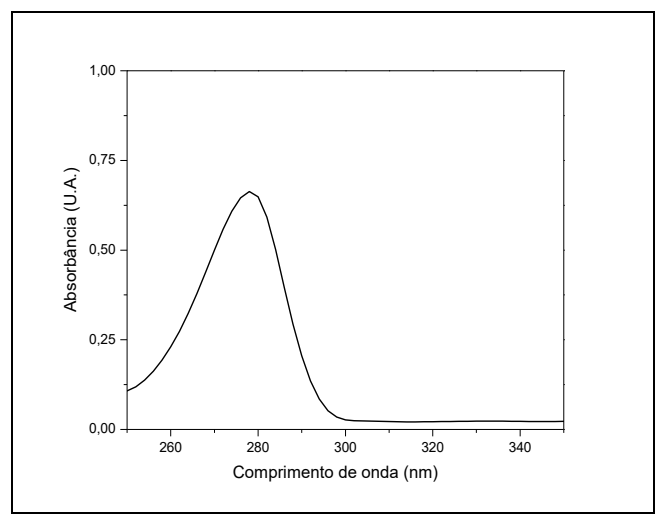

Fonte: Autora 
Figura 130: Espectro eletrônico qualitativo do catecol

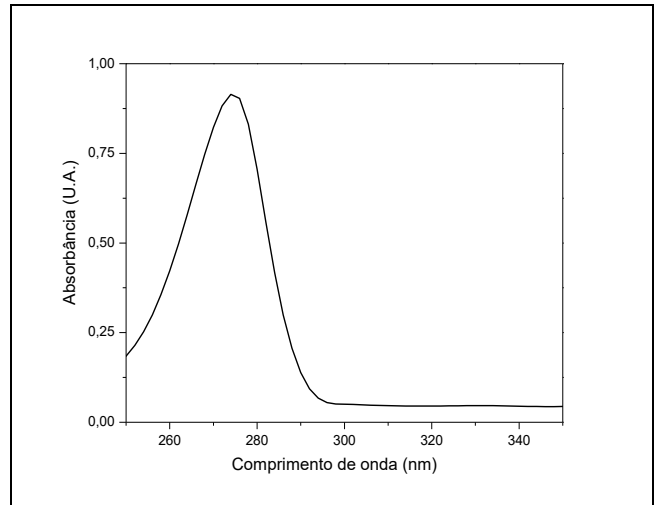

Fonte: Autora

\subsubsection{Estabilidade fotoquímica $(\lambda=532,447$ e $377 \mathrm{~nm})$}

Figura 131: Estabilidade do perfil espectroscópico de $\left[\mathrm{Ru}\left(\mathrm{NH}_{3}\right)_{4}(\text { isoproterenol })\right]^{+}$, com irradiação em $\lambda=$ $532 \mathrm{~nm}(\mathrm{~A}) ; \lambda=447 \mathrm{~nm}(\mathrm{~B}) ; \lambda=337 \mathrm{~nm}(\mathrm{C})$; solução aquosa $10^{-4} \mathrm{M}$; 0 - 60 minutos

(A)

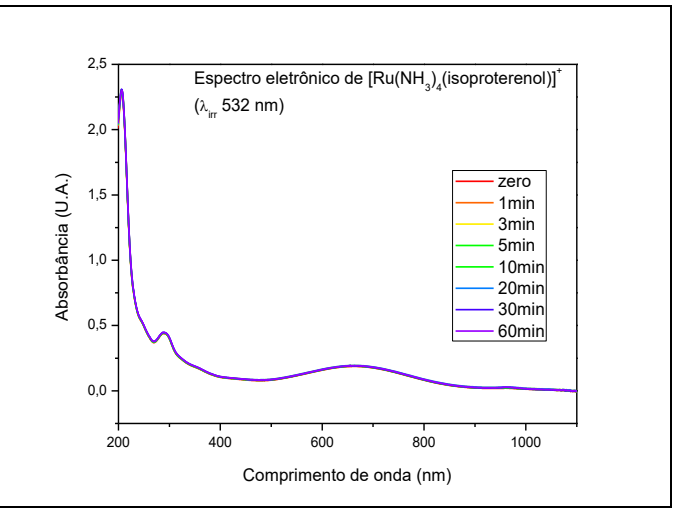

(B)

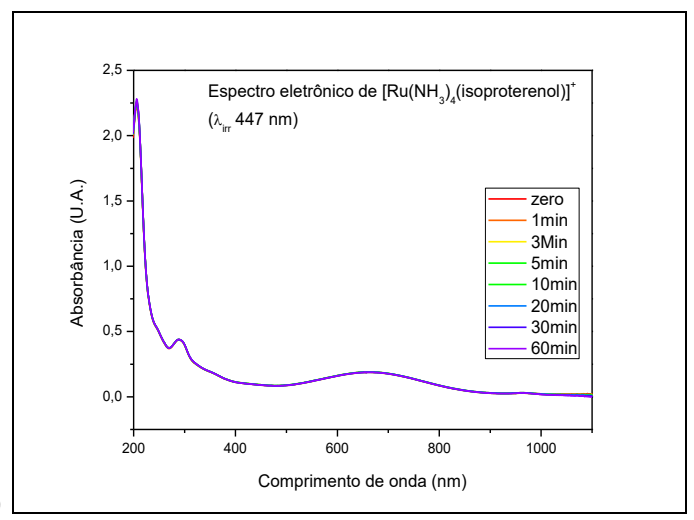

Fonte: Autora

(C)

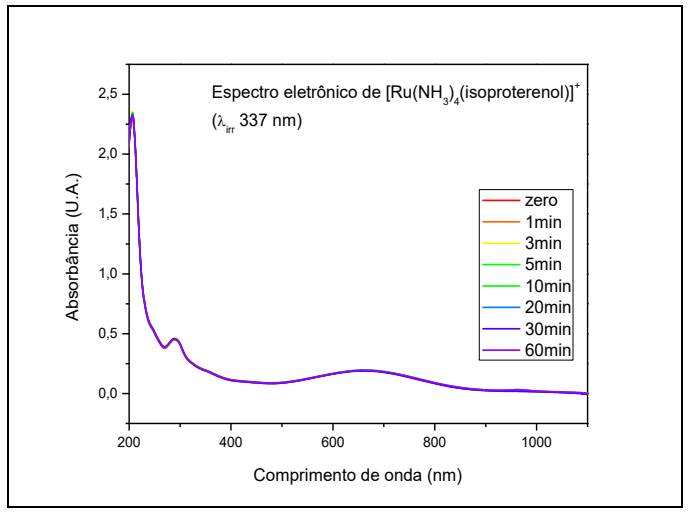


Figura 132: Estabilidade do perfil espectroscópico de $\left[\mathrm{Ru}\left(\mathrm{NH}_{3}\right)_{4}(\text { noradrenalina })\right]^{+}$, com irradiação em $\lambda=$ $532 \mathrm{~nm}(\mathrm{~A}) ; \lambda=447 \mathrm{~nm}(\mathrm{~B}) ; \lambda=337 \mathrm{~nm}(\mathrm{C})$; solução aquosa $10^{-4} \mathrm{M} ; 0$ - 60 minutos

(A)

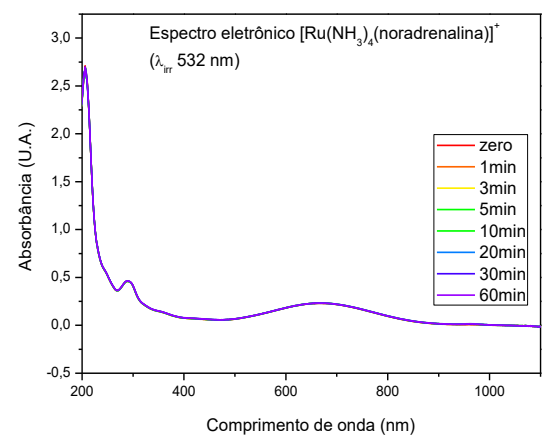

(C)

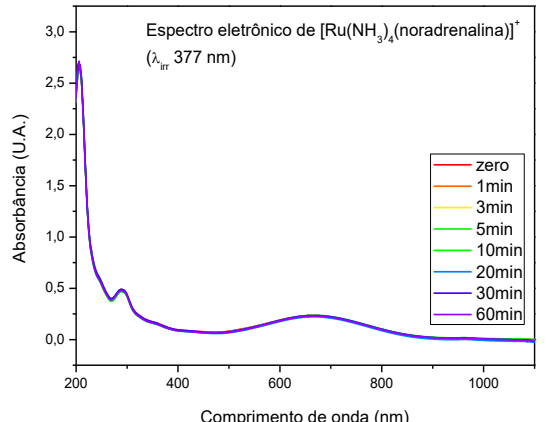

(B)

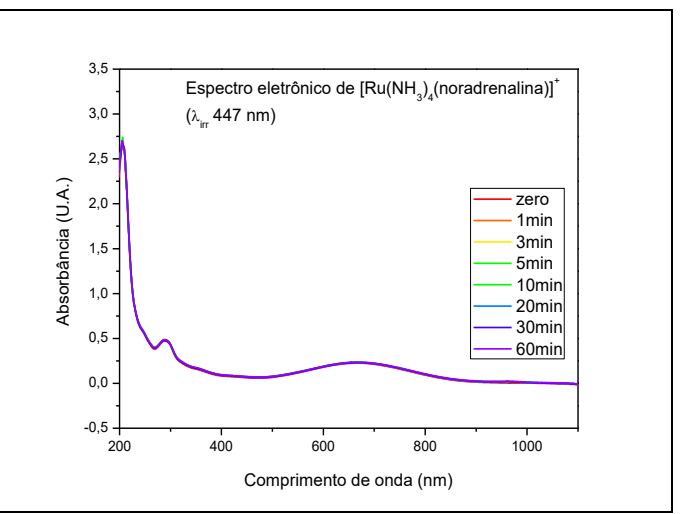

Fonte: Autora 
Figura 133: Estabilidade do perfil espectroscópico de $\left[\mathrm{Ru}\left(\mathrm{NH}_{3}\right)_{4}(\text { adrenalina })\right]^{+}$, com irradiação em $\lambda=532$ $\mathrm{nm}(\mathrm{A}) ; \lambda=447 \mathrm{~nm}(\mathrm{~B}) ; \lambda=337 \mathrm{~nm}(\mathrm{C})$; solução aquosa $10^{-4} \mathrm{M} ; 0$ - 60 minutos

(A)

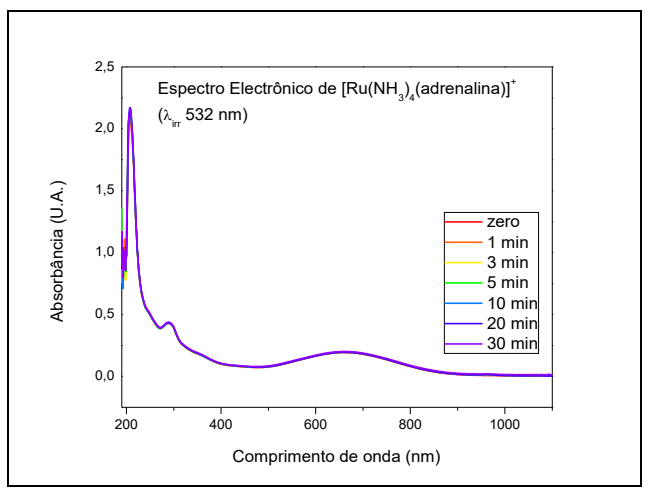

(B)

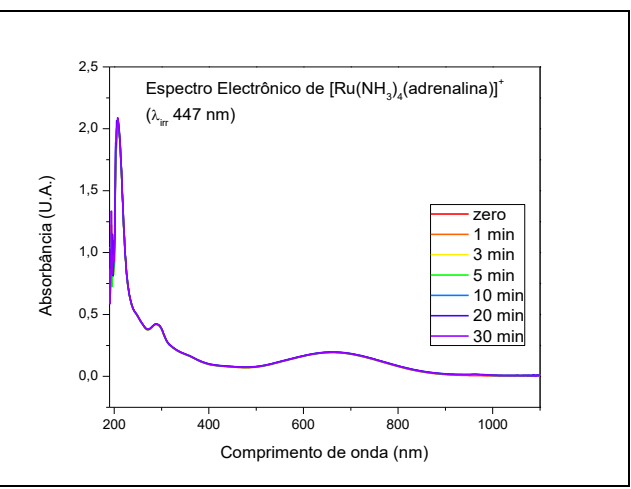

(C)

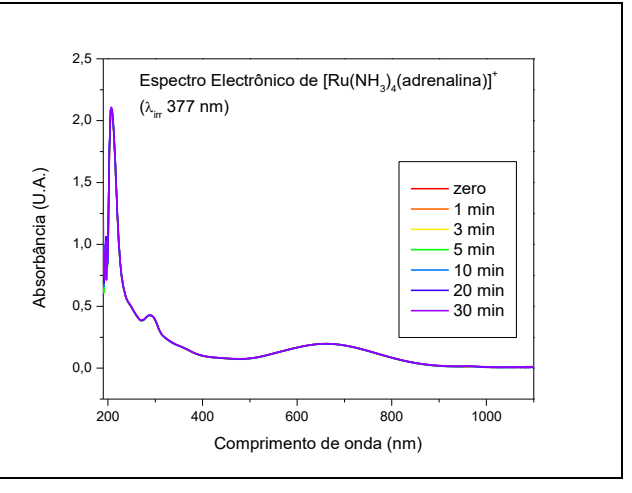

Fonte: Autora 


\subsubsection{Espectroscopia de absorção na região do infravermelho}

Figura 134: Espectro de absorção na região do infravermelho (pastilhas de KBr): (A) cloridrato de isoproterenol, $(\mathrm{B})$ cloridrato de dopamina e $(\mathrm{C})$ cloridrato de noradrenalina

(A)

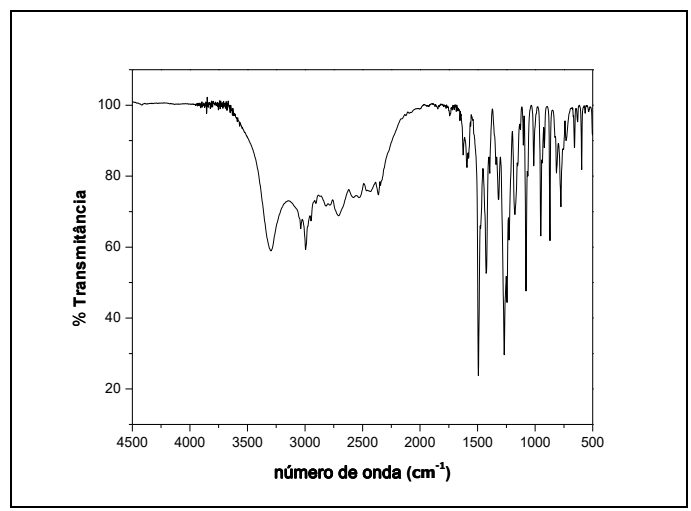

(B)

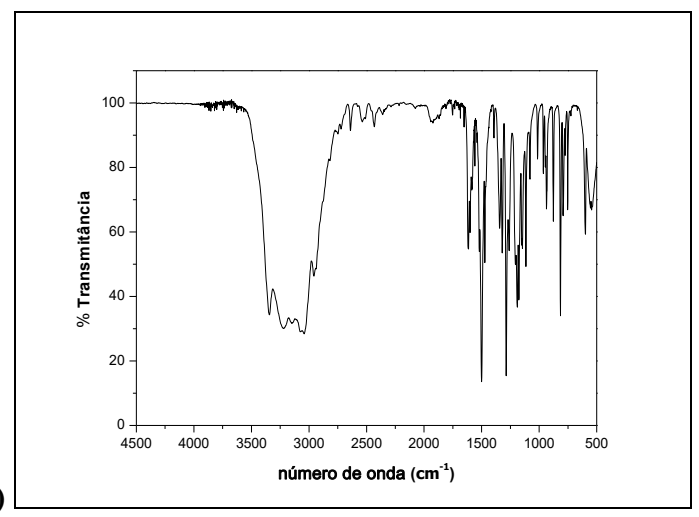

(C)

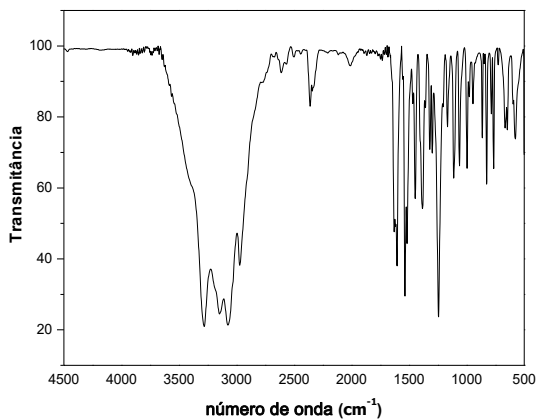

Fonte: Autora 


\subsubsection{Cálculos teóricos}

Tabela 28: Coordenadas cartesianas para o complexo $\left[\mathrm{Ru}\left(\mathrm{NH}_{3}\right)_{4}(\text { catecol })\right]^{+}$obtidas por PBE0/def2-TZVP

\begin{tabular}{cccc}
\hline $\mathrm{Ru}$ & 0.000000 & 0.000000 & 1.094 .616 \\
$\mathrm{~N}$ & -0.030848 & 2.116 .988 & 0.865099 \\
$\mathrm{H}$ & 0.168261 & 2.721 .312 & 1.657 .136 \\
$\mathrm{H}$ & 0.666293 & 2.333 .994 & 0.154904 \\
$\mathrm{H}$ & -0.924747 & 2.412 .529 & 0.479236 \\
$\mathrm{~N}$ & 0.028705 & -2.128 .787 & 1.055 .199 \\
$\mathrm{H}$ & -0.185383 & -2.658 .354 & 1.895 .116 \\
$\mathrm{H}$ & -0.661039 & -2.399 .724 & 0.357019 \\
$\mathrm{H}$ & 0.925327 & -2.460 .244 & 0.707917 \\
$\mathrm{~N}$ & 1.632 .262 & 0.146882 & 2.487 .008 \\
$\mathrm{H}$ & 1.812 .568 & -0.672353 & 3.059 .765 \\
$\mathrm{H}$ & 2.460 .032 & 0.279757 & 1.908 .647 \\
$\mathrm{H}$ & 1.604 .939 & 0.927784 & 3.137 .188 \\
$\mathrm{~N}$ & -1.631 .953 & -0.040904 & 2.498 .658 \\
$\mathrm{H}$ & -1.867 .412 & 0.848746 & 2.929 .819 \\
$\mathrm{H}$ & -2.446 .432 & -0.311016 & 1.950 .300 \\
$\mathrm{H}$ & -1.564 .475 & -0.701930 & 3.267 .600 \\
$\mathrm{O}$ & 1.320 .950 & 0.000000 & -0.412341 \\
$\mathrm{O}$ & -1.317 .590 & -0.121903 & -0.414016 \\
$\mathrm{C}$ & 0.717723 & 0.013665 & -1.573 .195 \\
$\mathrm{C}$ & -0.716955 & -0.062337 & -1.574 .020 \\
$\mathrm{C}$ & -1.410 .583 & -0.081598 & -2.795 .530 \\
$\mathrm{C}$ & -0.704676 & -0.014292 & -3.971 .420 \\
$\mathrm{C}$ & 0.703128 & 0.074457 & -3.970 .203 \\
$\mathrm{C}$ & 1.410 .308 & 0.086564 & -2.793 .142 \\
$\mathrm{H}$ & -2.492 .287 & -0.147319 & -2.779 .038 \\
$\mathrm{H}$ & -1.234 .793 & -0.027089 & -4.916 .014 \\
$\mathrm{H}$ & 1.231 .859 & 0.132268 & -4.913 .877 \\
$\mathrm{H}$ & 2.492 .015 & 0.151670 & -2.774 .882 \\
\hline & & &
\end{tabular}

Fonte: Autora 
Tabela 29: Coordenadas cartesianas para o complexo $\left[\mathrm{Ru}\left(\mathrm{NH}_{3}\right)_{4}(\text { dopamina })\right]^{+}$obtidas por PBE0/def2TZVP

\begin{tabular}{cccc}
\hline $\mathrm{Ru}$ & 0.000000 & 0.000000 & 1.991 .783 \\
$\mathrm{~N}$ & 0.046432 & 2.120 .570 & 1.809 .682 \\
$\mathrm{H}$ & 0.288872 & 2.698 .558 & 2.608 .939 \\
$\mathrm{H}$ & 0.733909 & 2.320 .569 & 1.085 .369 \\
$\mathrm{H}$ & -0.844134 & 2.459 .153 & 1.453 .416 \\
$\mathrm{~N}$ & -0.046445 & -2.127 .577 & 1.881 .412 \\
$\mathrm{H}$ & -0.240096 & -2.684 .871 & 2.708 .333 \\
$\mathrm{H}$ & -0.776479 & -2.347 .951 & 1.206 .677 \\
$\mathrm{H}$ & 0.820996 & -2.475 .124 & 1.479 .382 \\
$\mathrm{~N}$ & 1.747 .094 & 0.066171 & 3.248 .109 \\
$\mathrm{H}$ & 1.985 .291 & -0.803912 & 3.715 .759 \\
$\mathrm{H}$ & 2.522 .891 & 0.270808 & 2.620 .701 \\
$\mathrm{H}$ & 1.768 .094 & 0.775542 & 3.975 .558 \\
$\mathrm{~N}$ & -1.509 .105 & 0.026933 & 3.520 .810 \\
$\mathrm{H}$ & -1.464 .077 & 0.773209 & 4.208 .756 \\
$\mathrm{H}$ & -2.385 .389 & 0.148864 & 3.016 .556 \\
$\mathrm{H}$ & -1.606 .920 & -0.829201 & 4.059 .693 \\
$\mathrm{O}$ & 1.184 .097 & 0.000000 & 0.363555 \\
$\mathrm{O}$ & -1.446 .154 & -0.045430 & 0.602746 \\
$\mathrm{C}$ & 1.050 .792 & 0.133883 & -2.011 .826 \\
$\mathrm{C}$ & 0.478464 & 0.050022 & -0.735337 \\
$\mathrm{C}$ & -0.952917 & 0.008105 & -0.604053 \\
$\mathrm{C}$ & -1.749 .037 & 0.009883 & -1.761 .049 \\
$\mathrm{C}$ & -1.151 .042 & 0.085989 & -2.992 .166 \\
$\mathrm{C}$ & 0.257693 & 0.161745 & -3.140 .524 \\
$\mathrm{H}$ & -2.826 .242 & -0.048060 & -1.655 .767 \\
$\mathrm{H}$ & -1.775 .921 & 0.085826 & -3.875 .958 \\
$\mathrm{H}$ & 2.132 .277 & 0.173135 & -2.088 .839 \\
$\mathrm{C}$ & 0.888227 & 0.273014 & -4.499 .143 \\
$\mathrm{H}$ & 1.122 .529 & 1.327 .691 & -4.699 .267 \\
$\mathrm{H}$ & 1.849 .279 & -0.248352 & -4.493 .756 \\
$\mathrm{C}$ & 0.060510 & -0.282197 & -5.649 .953 \\
$\mathrm{H}$ & -0.315387 & -1.273 .435 & -5.375 .686 \\
$\mathrm{H}$ & -0.823227 & 0.354428 & -5.813 .896 \\
$\mathrm{~N}$ & 0.893594 & -0.431270 & -6.826 .615 \\
$\mathrm{H}$ & 0.382309 & -0.877816 & -7.576 .840 \\
$\mathrm{H}$ & 1.200 .200 & 0.470291 & -7.172 .600 \\
\hline
\end{tabular}

Fonte: Autora 
Tabela 30: Coordenadas cartesianas para o complexo $\left[\mathrm{Ru}\left(\mathrm{NH}_{3}\right)_{4}(\text { noradrenalina })\right]^{+}$obtidas por PBE0/def2TZVP

\begin{tabular}{cccc}
\hline $\mathrm{Ru}$ & 0.000000 & 0.000000 & 2.167 .327 \\
$\mathrm{~N}$ & -0.286879 & 2.074 .959 & 1.776 .436 \\
$\mathrm{H}$ & -0.162405 & 2.761 .587 & 2.514 .414 \\
$\mathrm{H}$ & 0.355733 & 2.330 .190 & 1.028 .524 \\
$\mathrm{H}$ & -1.222 .096 & 2.211 .666 & 1.398 .823 \\
$\mathrm{~N}$ & 0.216222 & -2.125 .706 & 2.269 .506 \\
$\mathrm{H}$ & 0.164039 & -2.608 .890 & 3.161 .380 \\
$\mathrm{H}$ & -0.543692 & -2.488 .791 & 1.696 .873 \\
$\mathrm{H}$ & 1.077 .608 & -2.420 .864 & 1.817 .645 \\
$\mathrm{~N}$ & 1.805 .783 & 0.434254 & 3.270 .973 \\
$\mathrm{H}$ & 2.179 .562 & -0.332641 & 3.822 .514 \\
$\mathrm{H}$ & 2.505 .790 & 0.641650 & 2.561 .592 \\
$\mathrm{H}$ & 1.785 .222 & 1.232 .965 & 3.898 .422 \\
$\mathrm{~N}$ & -1.329 .421 & 0.038636 & 3.861 .727 \\
$\mathrm{H}$ & -1.388 .768 & 0.929435 & 4.346 .570 \\
$\mathrm{H}$ & -2.260 .539 & -0.142969 & 3.491 .401 \\
$\mathrm{H}$ & -1.168 .558 & -0.653410 & 4.588 .407 \\
$\mathrm{O}$ & 1.037 .385 & 0.000000 & 0.442261 \\
$\mathrm{O}$ & -1.525 .363 & -0.399388 & 0.917721 \\
$\mathrm{C}$ & -0.220615 & 0.109051 & -2.947 .057 \\
$\mathrm{C}$ & 0.674215 & 0.179964 & -1.905 .636 \\
$\mathrm{C}$ & 0.237266 & -0.036130 & -0.589300 \\
$\mathrm{C}$ & -1.152 .901 & -0.295554 & -0.331270 \\
$\mathrm{C}$ & -2.035 .581 & -0.436448 & -1.416 .591 \\
$\mathrm{C}$ & -1.570 .221 & -0.232977 & -2.691 .404 \\
$\mathrm{H}$ & -3.077 .634 & -0.662045 & -1.221 .809 \\
$\mathrm{H}$ & -2.258 .742 & -0.299663 & -3.527 .698 \\
$\mathrm{H}$ & 1.707 .377 & 0.447158 & -2.089 .678 \\
$\mathrm{C}$ & 0.220550 & 0.418300 & -4.351 .574 \\
$\mathrm{H}$ & -0.633420 & 0.878365 & -4.877 .624 \\
$\mathrm{O}$ & 1.302 .004 & 1.307 .995 & -4.323 .440 \\
$\mathrm{H}$ & 1.749 .039 & 1.164 .028 & -5.175 .462 \\
$\mathrm{C}$ & 0.632675 & -0.837750 & -5.134 .113 \\
$\mathrm{H}$ & 1.386 .854 & -1.366 .633 & -4.545 .272 \\
$\mathrm{H}$ & -0.226542 & -1.508 .890 & -5.260 .241 \\
$\mathrm{~N}$ & 1.247 .737 & -0.404974 & -6.378 .200 \\
1.879 .143 & -1.098 .466 & -6.752 .962 \\
$\mathrm{H}+50152$ & -0.190700 & -7.088 .922 \\
\hline & & \\
\hline
\end{tabular}

Fonte: Autora 
Tabela 31: Coordenadas cartesianas para o complexo $\left[\mathrm{Ru}\left(\mathrm{NH}_{3}\right)_{4}(\text { adrenalina })\right]^{+}$obtidas por PBE0/def2TZVP

\begin{tabular}{cccc}
\hline $\mathrm{Ru}$ & 0.000000 & 0.000000 & 2.451 .845 \\
$\mathrm{~N}$ & -0.055143 & 2.126 .468 & 2.273 .713 \\
$\mathrm{H}$ & 0.142331 & 2.722 .765 & 3.071 .662 \\
$\mathrm{H}$ & 0.603999 & 2.387 .850 & 1.542 .973 \\
$\mathrm{H}$ & -0.975647 & 2.387 .106 & 1.926 .354 \\
$\mathrm{~N}$ & 0.020237 & -2.129 .640 & 2.316 .051 \\
$\mathrm{H}$ & 0.227886 & -2.697 .925 & 3.131 .479 \\
$\mathrm{H}$ & -0.879897 & -2.439 .093 & 1.954 .413 \\
$\mathrm{H}$ & 0.705409 & -2.370 .575 & 1.603 .498 \\
$\mathrm{~N}$ & 1.901 .176 & -0.006596 & 3.477 .160 \\
$\mathrm{H}$ & 2.043 .879 & -0.709181 & 4.197 .096 \\
$\mathrm{H}$ & 2.587 .498 & -0.194471 & 2.749 .042 \\
$\mathrm{H}$ & 2.174 .763 & 0.874097 & 3.902 .864 \\
$\mathrm{~N}$ & -1.289 .932 & 0.045081 & 4.187 .215 \\
$\mathrm{H}$ & -1.123 .252 & 0.787622 & 4.860 .046 \\
$\mathrm{H}$ & -2.227 .488 & 0.195648 & 3.819 .005 \\
$\mathrm{H}$ & -1.341 .418 & -0.810583 & 4.732 .617 \\
$\mathrm{O}$ & 0.978123 & 0.000000 & 0.701760 \\
$\mathrm{O}$ & -1.606 .104 & -0.023838 & 1.238 .077 \\
$\mathrm{C}$ & -0.327369 & 0.379015 & -2.650 .911 \\
$\mathrm{C}$ & 0.590955 & 0.280014 & -1.632 .232 \\
$\mathrm{C}$ & 0.155449 & 0.118493 & -0.308109 \\
$\mathrm{C}$ & -1.251 .856 & 0.080093 & -0.015982 \\
$\mathrm{C}$ & -2.172 .024 & 0.147857 & -1.078 .288 \\
$\mathrm{C}$ & -1.709 .840 & 0.296733 & -2.361 .443 \\
$\mathrm{H}$ & -3.233 .000 & 0.112114 & -0.859203 \\
$\mathrm{H}$ & -2.419 .227 & 0.380277 & -3.178 .528 \\
$\mathrm{H}$ & 1.650 .894 & 0.353298 & -1.842 .406 \\
$\mathrm{C}$ & 0.125447 & 0.567549 & -4.072 .440 \\
$\mathrm{H}$ & -0.650820 & 1.148 .990 & -4.598 .333 \\
$\mathrm{O}$ & 1.343 .609 & 1.262 .043 & -4.104 .427 \\
$\mathrm{H}$ & 1.751 .320 & 0.996988 & -4.945 .233 \\
$\mathrm{C}$ & 0.285707 & -0.770556 & -4.799 .698 \\
$\mathrm{H}$ & 0.988480 & -1.387 .870 & -4.229 .801 \\
$\mathrm{H}$ & -0.674020 & -1.310 .424 & -4.834 .267 \\
$\mathrm{H}$ & 0.869659 & -0.516984 & -6.099 .740 \\
$\mathrm{H}$ & 0.206876 & -0.022346 & -6.685 .857 \\
$\mathrm{H}$ & 1.737 .496 & -1.710 .641 & -6.783 .327 \\
-1.4363 & -2.184 .368 & -6.748 .869 \\
& -2.456 .939 & -6.951 .584 \\
\hline
\end{tabular}


Tabela 32: Coordenadas cartesianas para o complexo $\left[\mathrm{Ru}\left(\mathrm{NH}_{3}\right)_{4}(\text { isoprotereno })\right]^{+}$obtidas por PBE0/def2TZVP

\begin{tabular}{|c|c|c|c|}
\hline $\mathrm{Ru}$ & 0.000000 & 0.000000 & 2.742 .634 \\
\hline $\mathrm{N}$ & -0.157408 & 2.119 .822 & 2.537 .337 \\
\hline $\mathrm{H}$ & 0.032691 & 2.734 .956 & 3.322 .716 \\
\hline $\mathrm{H}$ & 0.467964 & 2.404.339 & 1.785 .951 \\
\hline $\mathrm{H}$ & -1.098 .660 & 2.331 .873 & 2.212 .983 \\
\hline $\mathrm{N}$ & 0.116552 & -2.128 .253 & 2.640 .737 \\
\hline $\mathrm{H}$ & 0.371078 & -2.674 .111 & 3.458 .093 \\
\hline $\mathrm{H}$ & -0.773843 & -2.487 .322 & 2.301.977 \\
\hline $\mathrm{H}$ & 0.798287 & -2.341 .542 & 1.916 .125 \\
\hline $\mathrm{N}$ & 1.903 .021 & 0.108043 & 3.754 .826 \\
\hline $\mathrm{H}$ & 2.094 .049 & -0.578588 & 4.478 .848 \\
\hline $\mathrm{H}$ & 2.587 .573 & -0.048654 & 3.017 .642 \\
\hline $\mathrm{H}$ & 2.133 .168 & 1.006 .766 & 4.168 .641 \\
\hline $\mathrm{N}$ & -1.283 .998 & 0.013922 & 4.484.364 \\
\hline $\mathrm{H}$ & -1.145 .479 & 0.772587 & 5.145 .645 \\
\hline $\mathrm{H}$ & -2.231 .555 & 0.115712 & 4.125 .266 \\
\hline $\mathrm{H}$ & -1.288 .697 & -0.835429 & 5.041 .654 \\
\hline $\mathrm{O}$ & 0.984923 & 0.000000 & 0.999306 \\
\hline $\mathrm{O}$ & -1.602 .966 & -0.106277 & 1.516 .008 \\
\hline $\mathrm{C}$ & -0.289760 & 0.313947 & -2.366 .589 \\
\hline $\mathrm{C}$ & 0.613409 & 0.228970 & -1.335 .122 \\
\hline $\mathrm{C}$ & 0.165726 & 0.076983 & -0.015501 \\
\hline $\mathrm{C}$ & -1.241 .556 & 0.007297 & 0.264987 \\
\hline $\mathrm{C}$ & -2.149 .054 & 0.060504 & -0.810965 \\
\hline $\mathrm{C}$ & -1.677 .014 & 0.221544 & -2.090 .020 \\
\hline $\mathrm{H}$ & -3.212 .092 & 0.005451 & -0.605173 \\
\hline $\mathrm{H}$ & -2.385 .185 & 0.298980 & -2.908 .560 \\
\hline $\mathrm{H}$ & 1.673 .540 & 0.311175 & -1.534 .811 \\
\hline $\mathrm{C}$ & 0.203799 & 0.564410 & -3.767 .912 \\
\hline $\mathrm{H}$ & -0.354129 & 1.434 .954 & -4.153 .632 \\
\hline $\mathrm{O}$ & 1.574 .377 & 0.844869 & -3.746 .572 \\
\hline $\mathrm{H}$ & 1.900 .637 & 0.481561 & -4.590 .968 \\
\hline $\mathrm{C}$ & -0.037251 & -0.621240 & -4.719 .214 \\
\hline $\mathrm{H}$ & 0.278418 & -1.538 .111 & -4.214 .096 \\
\hline $\mathrm{H}$ & -1.110 .814 & -0.713119 & -4.952 .959 \\
\hline $\mathrm{N}$ & 0.782223 & -0.468111 & -5.905 .033 \\
\hline $\mathrm{C}$ & 1.028 .168 & -1.726 .361 & -6.579 .221 \\
\hline $\mathrm{H}$ & 1.714 .766 & -1.565 .669 & -7.412 .062 \\
\hline $\mathrm{H}$ & 1.494 .165 & -2.430 .393 & -5.887 .041 \\
\hline $\mathrm{H}$ & 0.110660 & -2.186 .125 & -6.981 .188 \\
\hline $\mathrm{C}$ & 0.303295 & 0.555343 & -6.812 .201 \\
\hline $\mathrm{H}$ & 0.973840 & 0.618542 & -7.670 .165 \\
\hline $\mathrm{H}$ & -0.713444 & 0.351694 & -7.186 .557 \\
\hline $\mathrm{H}$ & 0.303473 & 1.531 .011 & -6.322 .121 \\
\hline
\end{tabular}

Fonte: Autora 
Figura 135: Plots dos orbitais alfa e beta Kohn-Sham com as maiores contribuições de Ru 4d obtidas por PBE0/def2-TZVP para o complexo $\left[\mathrm{Ru}\left(\mathrm{NH}_{3}\right)_{4}(\text { catecol })\right]^{+}$
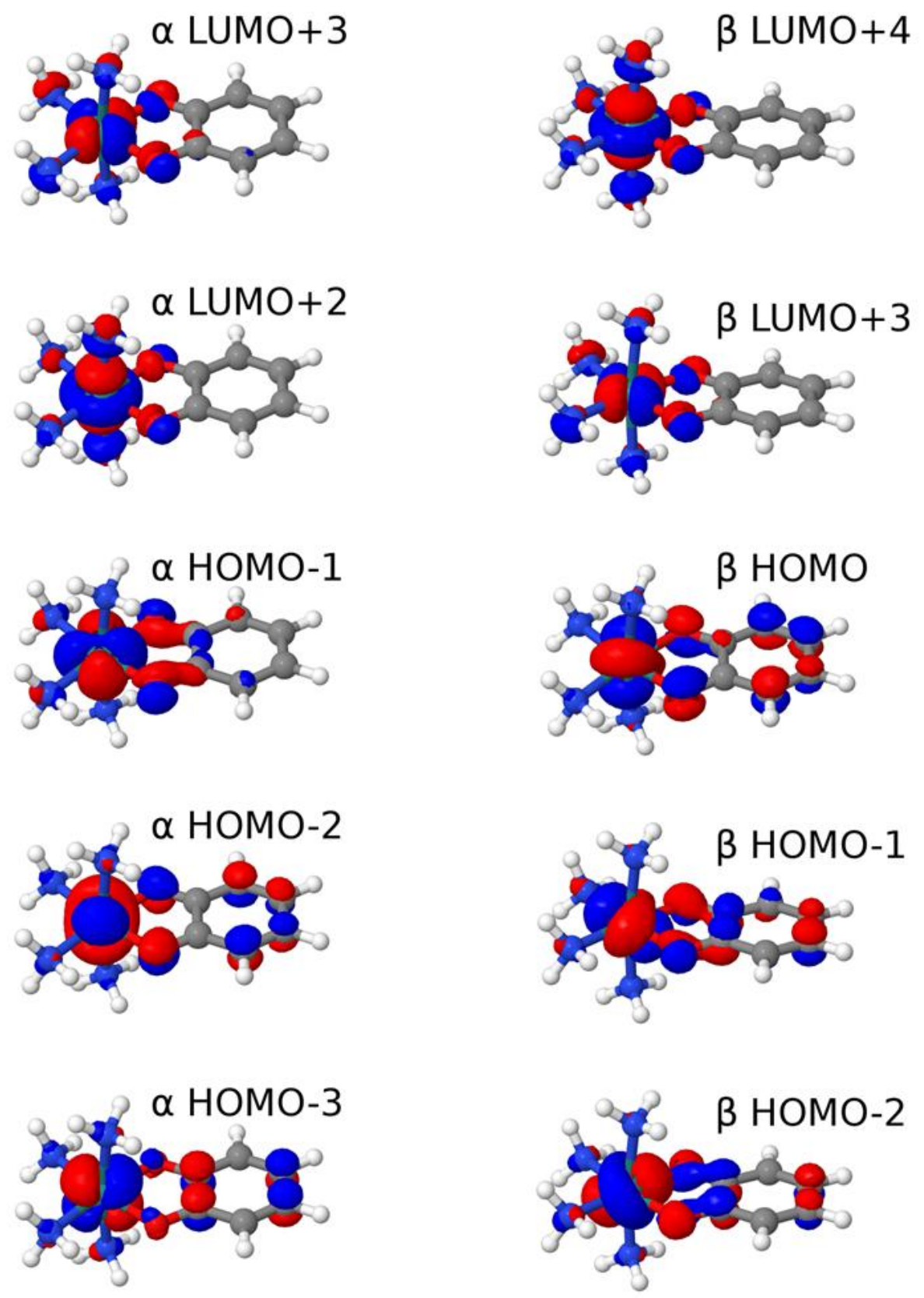

Fonte: Autora 


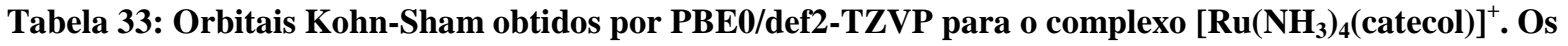
orbitais destacados são os orbitais de fronteira

\begin{tabular}{|c|c|c|c|c|c|c|c|c|c|}
\hline \multicolumn{2}{|c|}{ alpha } & \multicolumn{3}{|c|}{ Contribuição (\%) } & \multicolumn{2}{|c|}{ beta } & \multicolumn{3}{|c|}{ Contribuição (\%) } \\
\hline \# & $\mathrm{E} / \mathrm{eV}$ & $\mathrm{Ru}$ & $\mathrm{NH}_{3}$ & $\mathrm{~L}$ & \# & $\mathrm{E} / \mathrm{eV}$ & $\mathrm{Ru}$ & $\mathrm{NH}_{3}$ & $\mathrm{~L}$ \\
\hline 35 & -17.07 & 7.6 & 10.1 & 82.3 & 35 & -16.98 & 7.9 & 9.2 & 82.9 \\
\hline 36 & -16.48 & 7.4 & 2.2 & 90.3 & 36 & -16.44 & 7.2 & 2.2 & 90.5 \\
\hline 37 & -16.13 & 4.5 & 3.9 & 91.6 & 37 & -16.03 & 4.7 & 3.9 & 91.4 \\
\hline 38 & -15.31 & 5.5 & 13.8 & 80.7 & 38 & -15.20 & 18.5 & 40.4 & 41.1 \\
\hline 39 & -15.23 & 16.1 & 33.2 & 50.6 & 39 & -14.92 & 14.8 & 49.3 & 35.9 \\
\hline 40 & -14.97 & 16.2 & 50.7 & 33.0 & 40 & -14.72 & 4.2 & 12.0 & 83.8 \\
\hline 41 & -14.67 & 2.5 & 6.2 & 91.2 & 41 & -14.65 & 2.4 & 6.2 & 91.4 \\
\hline 42 & -14.30 & 11.2 & 61.2 & 27.6 & 42 & -14.26 & 10.7 & 63.9 & 25.4 \\
\hline 43 & -14.15 & 10.5 & 62.7 & 26.8 & 43 & -14.11 & 9.4 & 61.9 & 28.7 \\
\hline 44 & -13.64 & 3.2 & 3.9 & 92.9 & 44 & -13.36 & 5.8 & 87.9 & 6.3 \\
\hline 45 & -13.40 & 6.1 & 88.6 & 5.3 & 45 & -13.10 & 0.6 & 3.5 & 95.9 \\
\hline 46 & -13.15 & 0.6 & 4.7 & 94.7 & 46 & -12.97 & 4.7 & 6.7 & 88.7 \\
\hline 47 & -13.02 & 4.8 & 7.3 & 87.9 & 47 & -12.78 & 5.0 & 3.7 & 91.3 \\
\hline 48 & -12.18 & 5.3 & 9.6 & 85.1 & 48 & -11.91 & 5.4 & 11.5 & 83.1 \\
\hline 49 & -12.03 & 5.2 & 12.5 & 82.3 & 49 & -11.71 & 6.0 & 8.4 & 85.5 \\
\hline 50 & -11.20 & 18.7 & 2.6 & 78.7 & 50 & -11.09 & 19.1 & 2.6 & 78.4 \\
\hline 51 & -9.78 & 26.7 & 2.2 & 71.2 & 51 & -9.61 & 34.0 & 2.8 & 63.2 \\
\hline 52 & -9.64 & 74.1 & 4.0 & 21.8 & 52 & -8.68 & 76.1 & 4.6 & 19.3 \\
\hline 53 & -8.82 & 70.5 & 5.3 & 24.2 & 53 & -8.58 & 70.1 & 4.9 & 25.0 \\
\hline 54 & -8.77 & 79.7 & 4.6 & 15.7 & 54 & -8.56 & 63.4 & 4.9 & 31.7 \\
\hline 55 & $\mathbf{- 8 . 2 7}$ & 21.4 & 4.5 & 74.2 & 55 & -5.97 & 28.1 & 7.4 & 64.5 \\
\hline 56 & -3.85 & 47.0 & 47.3 & 5.7 & 56 & -3.84 & 47.0 & 47.4 & 5.6 \\
\hline 57 & -3.03 & 38.0 & 19.1 & 42.9 & 57 & -3.00 & 37.2 & 19.3 & 43.5 \\
\hline 58 & -2.89 & 18.1 & 63.5 & 18.4 & 58 & -2.84 & 4.2 & 9.3 & 86.4 \\
\hline 59 & -2.87 & 4.4 & 9.9 & 85.7 & 59 & -2.82 & 17.8 & 62.2 & 20.1 \\
\hline 60 & -2.57 & 1.0 & 20.8 & 78.2 & 60 & -2.28 & 0.3 & 27.1 & 72.7 \\
\hline 61 & -2.29 & 11.7 & 2.5 & 85.8 & 61 & -2.11 & 21.9 & 4.0 & 74.1 \\
\hline 62 & -2.19 & 18.0 & 3.0 & 79.0 & 62 & -2.05 & 44.3 & 4.7 & 50.9 \\
\hline 63 & -2.09 & 44.2 & 5.2 & 50.7 & 63 & -1.76 & 4.6 & 4.1 & 91.3 \\
\hline 64 & -1.25 & 4.0 & 88.4 & 7.6 & 64 & -1.21 & 4.3 & 88.3 & 7.5 \\
\hline 65 & -1.06 & 13.0 & 61.1 & 25.9 & 65 & -1.04 & 12.7 & 61.6 & 25.7 \\
\hline 66 & -0.94 & 12.4 & 52.7 & 35.0 & 66 & -0.93 & 12.2 & 53.2 & 34.5 \\
\hline 67 & -0.63 & 3.5 & 82.7 & 13.8 & 67 & -0.62 & 3.7 & 82.8 & 13.5 \\
\hline 68 & -0.37 & 4.9 & 2.7 & 92.4 & 68 & -0.35 & 4.9 & 2.8 & 92.4 \\
\hline 69 & -0.14 & 1.5 & 73.1 & 25.4 & 69 & -0.13 & 2.2 & 75.4 & 22.5 \\
\hline 70 & -0.09 & 5.0 & 78.4 & 16.5 & 70 & -0.08 & 4.1 & 75.7 & 20.1 \\
\hline 71 & 0.05 & 0.5 & 84.2 & 15.4 & 71 & 0.06 & 0.4 & 83.9 & 15.6 \\
\hline 72 & 0.20 & 2.5 & 70.9 & 26.6 & 72 & 0.20 & 2.5 & 70.9 & 26.6 \\
\hline 73 & 0.45 & 0.2 & 2.0 & 97.8 & 73 & 0.45 & 0.2 & 2.0 & 97.8 \\
\hline 74 & 0.88 & 17.8 & 17.9 & 64.3 & 74 & 0.90 & 16.9 & 16.0 & 67.0 \\
\hline 75 & 1.16 & 12.2 & 15.4 & 72.4 & 75 & 1.19 & 14.2 & 18.7 & 67.0 \\
\hline 76 & 1.35 & 0.2 & 0.5 & 99.3 & 76 & 1.37 & 0.2 & 0.5 & 99.3 \\
\hline
\end{tabular}

Fonte: Autora 


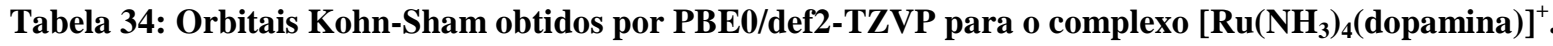
Os orbitais destacados são os orbitais de fronteira

\begin{tabular}{|c|c|c|c|c|c|c|c|c|c|}
\hline \multicolumn{2}{|c|}{ alpha } & \multicolumn{3}{|c|}{ Contribuição (\%) } & \multicolumn{2}{|c|}{ beta } & \multicolumn{3}{|c|}{ Contribuição (\%) } \\
\hline$\#$ & $\mathrm{E} / \mathrm{eV}$ & $\mathrm{Ru}$ & $\mathrm{NH}_{3}$ & $\mathrm{~L}$ & $\#$ & $\mathrm{E} / \mathrm{eV}$ & $\mathrm{Ru}$ & $\mathrm{NH}_{3}$ & $\mathrm{~L}$ \\
\hline 47 & -14.88 & 22.3 & 65.4 & 12.3 & 47 & -14.68 & 4.1 & 12.8 & 83.2 \\
\hline 48 & -14.59 & 3.6 & 10.8 & 85.6 & 48 & -14.51 & 3.0 & 8.4 & 88.7 \\
\hline 49 & -14.48 & 3.5 & 9.5 & 86.9 & 49 & -14.41 & 5.0 & 16.3 & 78.7 \\
\hline 50 & -14.14 & 10.8 & 60.6 & 28.6 & 50 & -14.10 & 10.2 & 62.5 & 27.4 \\
\hline 51 & -14.05 & 9.3 & 54.3 & 36.5 & 51 & -14.00 & 8.2 & 52.8 & 38.9 \\
\hline 52 & -13.72 & 1.6 & 11.6 & 86.8 & 52 & -13.67 & 1.5 & 11.3 & 87.1 \\
\hline 53 & -13.49 & 3.1 & 4.4 & 92.5 & 53 & -13.21 & 5.0 & 68.1 & 27.0 \\
\hline 54 & -13.25 & 5.2 & 68.2 & 26.6 & 54 & -13.14 & 3.6 & 32.0 & 64.4 \\
\hline 55 & -13.18 & 3.7 & 33.9 & 62.3 & 55 & -12.65 & 4.6 & 3.8 & 91.6 \\
\hline 56 & -12.55 & 2.4 & 5.3 & 92.3 & 56 & -12.49 & 2.2 & 4.0 & 93.8 \\
\hline 57 & -12.27 & 1.8 & 5.6 & 92.7 & 57 & -12.14 & 1.4 & 3.6 & 95.0 \\
\hline 58 & -11.95 & 3.1 & 6.3 & 90.6 & 58 & -11.87 & 2.1 & 3.7 & 94.2 \\
\hline 59 & -11.75 & 3.2 & 6.5 & 90.3 & 59 & -11.67 & 4.0 & 7.9 & 88.2 \\
\hline 60 & -11.50 & 3.4 & 3.2 & 93.4 & 60 & -11.16 & 5.3 & 4.8 & 90.0 \\
\hline 61 & -11.01 & 17.6 & 2.4 & 80.0 & 61 & -10.91 & 18.1 & 2.4 & 79.6 \\
\hline 62 & -9.56 & 29.7 & 2.5 & 67.9 & 62 & -9.40 & 33.6 & 2.9 & 63.4 \\
\hline 63 & -9.36 & 68.4 & 3.9 & 27.7 & 63 & -8.67 & 4.3 & 0.4 & 95.3 \\
\hline 64 & -8.67 & 5.2 & 0.4 & 94.4 & 64 & -8.47 & 71.9 & 5.1 & 23.0 \\
\hline 65 & -8.60 & 62.5 & 4.8 & 32.7 & 65 & -8.40 & 66.9 & 4.0 & 29.1 \\
\hline 66 & -8.55 & 76.8 & 4.7 & 18.5 & 66 & -8.35 & 58.5 & 4.8 & 36.7 \\
\hline 67 & -8.06 & 19.4 & 4.0 & 76.6 & 67 & -5.81 & 22.2 & 6.6 & 71.2 \\
\hline 68 & -3.74 & 44.4 & 45.4 & 10.2 & 68 & -3.73 & 44.4 & 45.6 & 10.0 \\
\hline 69 & -2.92 & 48.0 & 23.9 & 28.1 & 69 & -2.90 & 45.6 & 23.9 & 30.5 \\
\hline 70 & -2.75 & 4.0 & 8.7 & 87.3 & 70 & -2.72 & 3.9 & 8.2 & 87.8 \\
\hline 71 & -2.72 & 15.1 & 50.2 & 34.7 & 71 & -2.66 & 16.4 & 53.5 & 30.1 \\
\hline 72 & -2.48 & 1.5 & 17.4 & 81.2 & 72 & -2.18 & 1.3 & 21.8 & 76.9 \\
\hline 73 & -2.18 & 9.5 & 1.9 & 88.7 & 73 & -1.95 & 27.6 & 4.2 & 68.2 \\
\hline 74 & -2.04 & 20.3 & 3.7 & 76.1 & 74 & -1.94 & 38.6 & 3.8 & 57.5 \\
\hline 75 & -1.97 & 36.9 & 3.8 & 59.3 & 75 & -1.65 & 4.5 & 2.4 & 93.0 \\
\hline 76 & -1.14 & 4.5 & 89.0 & 6.5 & 76 & -1.10 & 4.5 & 88.8 & 6.6 \\
\hline 77 & -0.97 & 11.9 & 61.3 & 26.8 & 77 & -0.95 & 11.7 & 61.9 & 26.4 \\
\hline 78 & -0.87 & 6.1 & 24.8 & 69.1 & 78 & -0.85 & 6.1 & 25.2 & 68.7 \\
\hline 79 & -0.59 & 0.2 & 1.2 & 98.5 & 79 & -0.57 & 0.3 & 1.5 & 98.2 \\
\hline 80 & -0.45 & 5.2 & 77.5 & 17.3 & 80 & -0.44 & 5.0 & 74.8 & 20.3 \\
\hline 81 & -0.12 & 1.3 & 1.6 & 97.1 & 81 & -0.11 & 1.2 & 1.7 & 97.1 \\
\hline 82 & -0.09 & 1.0 & 46.9 & 52.2 & 82 & -0.06 & 0.9 & 44.8 & 54.2 \\
\hline 83 & 0.03 & 0.1 & 1.6 & 98.3 & 83 & 0.03 & 0.1 & 1.7 & 98.2 \\
\hline 84 & 0.10 & 6.8 & 78.5 & 14.6 & 84 & 0.11 & 6.5 & 75.5 & 17.9 \\
\hline 85 & 0.23 & 1.6 & 44.4 & 54.1 & 85 & 0.23 & 1.5 & 44.9 & 53.6 \\
\hline 86 & 0.32 & 3.6 & 81.7 & 14.7 & 86 & 0.32 & 3.6 & 81.5 & 14.9 \\
\hline 87 & 0.59 & 0.2 & 0.7 & 99.1 & 87 & 0.62 & 0.2 & 0.7 & 99.2 \\
\hline 88 & 0.68 & 1.0 & 1.6 & 97.4 & 88 & 0.70 & 1.2 & 1.3 & 97.4 \\
\hline
\end{tabular}

Fonte: Autora 
Tabela 35: Orbitais Kohn-Sham obtidos por PBE0/def2-TZVP para o complexo $\left[\mathrm{Ru}\left(\mathrm{NH}_{3}\right)_{4}(\text { adrenalina })\right]^{+}$. Os orbitais destacados são os orbitais de fronteira

\begin{tabular}{|c|c|c|c|c|c|c|c|c|c|c|}
\hline \multicolumn{3}{|c|}{ alpha } & \multicolumn{3}{|c|}{ Contribuição (\%) } & \multicolumn{2}{|c|}{ beta } & \multicolumn{3}{|c|}{ Contribuição (\%) } \\
\hline \multirow[t]{2}{*}{ \# } & \multicolumn{2}{|c|}{$\mathrm{E} / \mathrm{eV}$} & \multicolumn{2}{|c|}{$\mathrm{NH}_{3}$} & \multirow{2}{*}{79.7} & \multicolumn{2}{|c|}{$\mathrm{E} / \mathrm{eV}$} & \multicolumn{2}{|c|}{$\mathrm{NH}_{3}$} & $\mathrm{~L}$ \\
\hline & 55 & -14.15 & 3.4 & 16.9 & & 55 & -14.13 & 3.8 & 19.4 & 76.8 \\
\hline & 56 & -14.07 & 10.8 & 60.9 & 28.3 & 56 & -14.03 & 10.1 & 63.1 & 26.8 \\
\hline & 57 & -13.91 & 8.2 & 52.7 & 39.1 & 57 & -13.87 & 7.3 & 51.1 & 41.7 \\
\hline & 58 & -13.44 & 3.0 & 4.3 & 92.7 & 58 & -13.29 & 0.6 & 6.0 & 93.4 \\
\hline & 59 & -13.30 & 0.9 & 9.3 & 89.8 & 59 & -13.15 & 5.4 & 84.2 & 10.4 \\
\hline & 60 & -13.18 & 5.6 & 82.4 & 12.1 & 60 & -12.96 & 0.3 & 1.7 & 98.0 \\
\hline & 61 & -12.99 & 0.4 & 2.5 & 97.1 & 61 & -12.78 & 3.2 & 5.2 & 91.6 \\
\hline & 62 & -12.82 & 3.2 & 6.0 & 90.7 & 62 & -12.58 & 4.7 & 4.1 & 91.2 \\
\hline & 63 & -12.49 & 1.8 & 4.0 & 94.1 & 63 & -12.42 & 1.5 & 2.3 & 96.2 \\
\hline & 64 & -12.27 & 0.2 & 0.4 & 99.4 & 64 & -12.26 & 0.2 & 0.3 & 99.5 \\
\hline & 65 & -11.94 & 4.1 & 10.7 & 85.2 & 65 & -11.82 & 4.3 & 10.2 & 85.5 \\
\hline & 66 & -11.85 & 4.0 & 8.4 & 87.6 & 66 & -11.50 & 3.8 & 6.0 & 90.2 \\
\hline & 67 & -11.24 & 3.6 & 1.1 & 95.3 & 67 & -11.15 & 3.3 & 1.7 & 95.0 \\
\hline & 68 & -10.96 & 15.4 & 2.2 & 82.5 & 68 & -10.86 & 16.6 & 2.2 & 81.2 \\
\hline & 69 & -9.84 & 3.9 & 0.4 & 95.7 & 69 & -9.76 & 1.5 & 0.3 & 98.2 \\
\hline & 70 & -9.54 & 28.9 & 2.3 & 68.9 & 70 & -9.37 & 27.4 & 2.3 & 70.3 \\
\hline & 71 & -9.29 & 56.3 & 3.1 & 40.6 & 71 & -8.76 & 6.0 & 0.5 & 93.5 \\
\hline & 72 & -8.77 & 12.7 & 0.9 & 86.4 & 72 & -8.48 & 73.1 & 4.4 & 22.4 \\
\hline & 73 & -8.55 & 68.2 & 4.2 & 27.6 & 73 & -8.37 & 69.1 & 4.6 & 26.3 \\
\hline & 74 & -8.55 & 66.4 & 4.4 & 29.2 & 74 & -8.30 & 56.8 & 4.5 & 38.7 \\
\hline & 75 & -8.03 & 19.3 & 4.2 & 76.4 & 75 & -5.78 & 23.7 & 7.1 & 69.3 \\
\hline & 76 & -3.70 & 43.3 & 44.7 & 12.0 & 76 & -3.69 & 43.2 & 44.9 & 11.9 \\
\hline & 77 & -2.87 & 51.8 & 22.4 & 25.8 & 77 & -2.85 & 50.5 & 22.6 & 26.9 \\
\hline & 78 & -2.72 & 3.5 & 8.9 & 87.6 & 78 & -2.69 & 3.5 & 8.5 & 88.0 \\
\hline & 79 & -2.71 & 17.2 & 56.7 & 26.0 & 79 & -2.64 & 16.6 & 54.6 & 28.8 \\
\hline & 80 & -2.40 & 0.8 & 17.9 & 81.3 & 80 & -2.10 & 0.4 & 22.8 & 76.9 \\
\hline & 81 & -2.19 & 7.1 & 2.3 & 90.6 & 81 & -1.96 & 20.9 & 3.4 & 75.7 \\
\hline & 82 & -2.02 & 18.1 & 2.9 & 79.0 & 82 & -1.90 & 37.5 & 3.5 & 59.1 \\
\hline & 83 & -1.94 & 36.9 & 3.6 & 59.5 & 83 & -1.66 & 4.3 & 3.9 & 91.9 \\
\hline & 84 & -1.11 & 2.6 & 86.0 & 11.4 & 84 & -1.07 & 2.8 & 84.0 & 13.2 \\
\hline & 85 & -0.93 & 10.5 & 54.8 & 34.7 & 85 & -0.92 & 10.2 & 54.9 & 34.9 \\
\hline & 86 & -0.82 & 9.1 & 39.3 & 51.6 & 86 & -0.80 & 9.5 & 41.5 & 49.0 \\
\hline & 87 & -0.75 & 0.0 & 0.2 & 99.8 & 87 & -0.74 & 0.0 & 0.2 & 99.7 \\
\hline & 88 & -0.36 & 0.6 & 78.6 & 20.9 & 88 & -0.36 & 0.5 & 80.3 & 19.2 \\
\hline & 89 & -0.14 & 0.5 & 0.8 & 98.8 & 89 & -0.13 & 0.5 & 0.8 & 98.7 \\
\hline & 90 & -0.03 & 0.8 & 35.3 & 63.9 & 90 & -0.01 & 0.7 & 34.1 & 65.2 \\
\hline & 91 & 0.09 & 1.4 & 2.2 & 96.4 & 91 & 0.10 & 1.4 & 2.4 & 96.2 \\
\hline & 92 & 0.16 & 7.9 & 80.7 & 11.4 & 92 & 0.16 & 7.7 & 79.2 & 13.2 \\
\hline & 93 & 0.26 & 4.1 & 48.8 & 47.1 & 93 & 0.27 & 4.3 & 53.2 & 42.5 \\
\hline & 94 & 0.31 & 2.4 & 53.6 & 44.0 & 94 & 0.32 & 2.5 & 53.4 & 44.1 \\
\hline & 95 & 0.54 & 0.1 & 1.3 & 98.6 & 95 & 0.55 & 0.1 & 1.1 & 98.8 \\
\hline & 96 & 0.58 & 1.6 & 1.2 & 97.2 & 96 & 0.59 & 1.6 & 1.2 & 97.2 \\
\hline
\end{tabular}

Fonte: Autora 
Tabela 36: Orbitais Kohn-Sham obtidos por PBE0/def2-TZVP para o complexo $\left[\mathbf{R u}\left(\mathrm{NH}_{3}\right)_{4}(\text { noradrenalina })\right]^{+}$. Os orbitais destacados são os orbitais de fronteira

\begin{tabular}{|c|c|c|c|c|c|c|c|c|c|}
\hline \multicolumn{2}{|c|}{ alpha } & \multicolumn{3}{|c|}{ Contribuição (\%) } & \multicolumn{2}{|c|}{ beta } & \multicolumn{3}{|c|}{ Contribuição (\%) } \\
\hline$\#$ & $\mathrm{E} / \mathrm{eV}$ & $\mathrm{Ru}$ & $\mathrm{NH}_{3}$ & $\mathrm{~L}$ & $\#$ & $\mathrm{E} / \mathrm{eV}$ & $\mathrm{Ru}$ & $\mathrm{NH}_{3}$ & $\mathrm{~L}$ \\
\hline 51 & -14.66 & 0.9 & 1.1 & 98.0 & 51 & -14.45 & 4.1 & 12.4 & 83.5 \\
\hline 52 & -14.37 & 4.7 & 17.2 & 78.1 & 52 & -14.33 & 4.0 & 16.2 & 79.9 \\
\hline 53 & -14.35 & 3.1 & 9.2 & 87.7 & 53 & -14.30 & 4.1 & 12.9 & 83.0 \\
\hline 54 & -14.08 & 10.3 & 59.8 & 29.9 & 54 & -14.04 & 9.8 & 62.1 & 28.1 \\
\hline 55 & -13.94 & 8.2 & 55.2 & 36.6 & 55 & -13.89 & 7.2 & 53.2 & 39.6 \\
\hline 56 & -13.40 & 3.2 & 4.8 & 92.1 & 56 & -13.13 & 5.5 & 85.2 & 9.3 \\
\hline 57 & -13.17 & 5.9 & 85.7 & 8.5 & 57 & -12.93 & 0.7 & 5.3 & 94.0 \\
\hline 58 & -12.98 & 0.8 & 6.8 & 92.4 & 58 & -12.67 & 3.9 & 4.1 & 92.0 \\
\hline 59 & -12.69 & 3.8 & 4.3 & 91.9 & 59 & -12.55 & 4.6 & 4.4 & 91.0 \\
\hline 60 & -12.44 & 0.6 & 2.4 & 97.0 & 60 & -12.38 & 0.5 & 1.2 & 98.3 \\
\hline 61 & -11.90 & 4.1 & 11.1 & 84.8 & 61 & -11.77 & 4.0 & 9.6 & 86.4 \\
\hline 62 & -11.85 & 4.0 & 7.0 & 89.0 & 62 & -11.49 & 3.6 & 5.0 & 91.5 \\
\hline 63 & -11.30 & 2.1 & 1.3 & 96.6 & 63 & -11.21 & 2.6 & 2.4 & 94.9 \\
\hline 64 & -10.94 & 16.9 & 2.4 & 80.6 & 64 & -10.84 & 17.6 & 2.4 & 79.9 \\
\hline 65 & -9.84 & 2.4 & 0.3 & 97.4 & 65 & -9.79 & 0.5 & 0.1 & 99.4 \\
\hline 66 & -9.62 & 12.3 & 1.1 & 86.7 & 66 & -9.51 & 11.6 & 1.0 & 87.4 \\
\hline 67 & -9.40 & 44.8 & 2.7 & 52.5 & 67 & -9.16 & 15.1 & 1.3 & 83.6 \\
\hline 68 & -9.12 & 27.3 & 1.6 & 71.1 & 68 & -8.49 & 75.0 & 4.7 & 20.3 \\
\hline 69 & -8.56 & 70.7 & 4.7 & 24.5 & 69 & -8.33 & 68.3 & 4.5 & 27.1 \\
\hline 70 & -8.53 & 72.0 & 4.5 & 23.5 & 70 & -8.29 & $\mathbf{5 7 . 5}$ & 4.2 & 38.2 \\
\hline 71 & -8.00 & 20.2 & 4.3 & 75.5 & 71 & -5.75 & 24.1 & 7.2 & 68.7 \\
\hline 72 & -3.72 & 45.8 & 45.0 & 9.2 & 72 & -3.71 & 45.7 & 45.1 & 9.1 \\
\hline 73 & -2.86 & 57.6 & 29.0 & 13.3 & 73 & -2.84 & 57.0 & 29.7 & 13.3 \\
\hline 74 & -2.72 & 4.0 & 10.4 & 85.7 & 74 & -2.69 & 3.8 & 9.7 & 86.4 \\
\hline 75 & -2.69 & 15.6 & 53.5 & 30.9 & 75 & -2.63 & 16.7 & 57.3 & 26.0 \\
\hline 76 & -2.38 & 0.6 & 17.2 & 82.3 & 76 & -2.08 & 1.3 & 22.6 & 76.1 \\
\hline 77 & -2.21 & 9.0 & 3.3 & 87.7 & 77 & -1.96 & 23.0 & 3.8 & 73.2 \\
\hline 78 & -1.99 & 20.2 & 3.5 & 76.3 & 78 & -1.88 & 38.2 & 4.1 & 57.6 \\
\hline 79 & -1.92 & 38.1 & 4.4 & 57.5 & 79 & -1.64 & 8.2 & 5.3 & 86.4 \\
\hline 80 & -1.14 & 3.1 & 75.7 & 21.2 & 80 & -1.09 & 3.1 & 73.0 & 23.9 \\
\hline 81 & -0.93 & 12.4 & 60.2 & 27.4 & 81 & -0.92 & 11.9 & 59.6 & 28.5 \\
\hline 82 & -0.85 & 0.1 & 0.7 & 99.1 & 82 & -0.85 & 0.1 & 0.6 & 99.3 \\
\hline 83 & -0.78 & 12.0 & 51.9 & 36.2 & 83 & -0.76 & 11.6 & 50.6 & 37.8 \\
\hline 84 & -0.39 & 1.8 & 46.6 & 51.5 & 84 & -0.39 & 1.9 & 46.8 & 51.3 \\
\hline 85 & -0.25 & 0.3 & 0.8 & 99.0 & 85 & -0.23 & 0.3 & 0.8 & 98.9 \\
\hline 86 & 0.03 & 0.5 & 41.4 & 58.1 & 86 & 0.05 & 0.5 & 42.4 & 57.1 \\
\hline 87 & 0.14 & 4.0 & 46.0 & 50.0 & 87 & 0.14 & 3.8 & 44.3 & 51.9 \\
\hline 88 & 0.17 & 0.9 & 29.8 & 69.3 & 88 & 0.18 & 0.8 & 29.4 & 69.8 \\
\hline 89 & 0.29 & 3.3 & 5.1 & 91.6 & 89 & 0.30 & 3.2 & 5.2 & 91.6 \\
\hline 90 & 0.34 & 1.6 & 37.7 & 60.6 & 90 & 0.35 & 1.8 & 38.6 & 59.6 \\
\hline 91 & 0.53 & 0.2 & 0.9 & 99.0 & 91 & 0.54 & 0.2 & 0.8 & 99.1 \\
\hline 92 & 0.84 & 1.6 & 2.0 & 96.4 & 92 & 0.84 & 1.4 & 1.8 & 96.8 \\
\hline
\end{tabular}

Fonte: Autora 
Tabela 37: Orbitais Kohn-Sham obtidos por PBE0/def2-TZVP para o complexo $\left[\mathrm{Ru}\left(\mathrm{NH}_{3}\right)_{4} \text { (isoproterenol) }\right]^{+}$. Os orbitais destacados são os orbitais de fronteira

\begin{tabular}{|c|c|c|c|c|c|c|c|c|c|}
\hline \multicolumn{2}{|c|}{ alpha } & \multicolumn{3}{|c|}{ Contribuição (\%) } & \multicolumn{2}{|c|}{ beta } & \multicolumn{3}{|c|}{ Contribuição (\%) } \\
\hline \# & $\mathrm{E} / \mathrm{eV}$ & $\mathrm{Ru}$ & $\mathrm{NH}_{3}$ & $\mathrm{~L}$ & $\#$ & $\mathrm{E} / \mathrm{eV}$ & $\mathrm{Ru}$ & $\mathrm{NH}_{3}$ & $\mathrm{~L}$ \\
\hline 59 & -13.90 & 9.6 & 60.6 & 29.7 & 59 & -13.86 & 0.9 & 5.8 & 93.3 \\
\hline 60 & -13.87 & 0.3 & 2.2 & 97.4 & 60 & -13.86 & 8.3 & 57.0 & 34.7 \\
\hline 61 & -13.38 & 3.0 & 4.3 & 92.7 & 61 & -13.11 & 4.5 & 67.5 & 28.0 \\
\hline 62 & -13.15 & 5.0 & 71.8 & 23.2 & 62 & -13.09 & 1.7 & 23.2 & 75.2 \\
\hline 63 & -13.12 & 1.5 & 19.9 & 78.5 & 63 & -12.95 & 0.3 & 3.5 & 96.3 \\
\hline 64 & -12.96 & 0.3 & 3.2 & 96.6 & 64 & -12.72 & 3.4 & 5.1 & 91.5 \\
\hline 65 & -12.76 & 3.5 & 5.8 & 90.7 & 65 & -12.53 & 4.7 & 4.0 & 91.3 \\
\hline 66 & -12.45 & 1.6 & 4.3 & 94.2 & 66 & -12.38 & 1.4 & 2.4 & 96.2 \\
\hline 67 & -12.26 & 0.1 & 0.2 & 99.7 & 67 & -12.25 & 0.2 & 0.2 & 99.6 \\
\hline 68 & -12.08 & 0.7 & 1.9 & 97.4 & 68 & -12.06 & 0.3 & 0.8 & 98.9 \\
\hline 69 & -11.90 & 3.8 & 9.9 & 86.4 & 69 & -11.77 & 3.9 & 9.3 & 86.8 \\
\hline 70 & -11.75 & 3.7 & 7.0 & 89.3 & 70 & -11.45 & 3.5 & 5.5 & 91.0 \\
\hline 71 & -11.17 & 1.4 & 1.0 & 97.6 & 71 & -11.06 & 2.2 & 1.8 & 96.0 \\
\hline 72 & -10.92 & 17.3 & 2.3 & 80.4 & 72 & -10.82 & 17.8 & 2.3 & 79.9 \\
\hline 73 & -9.78 & 4.3 & 0.5 & 95.2 & 73 & -9.70 & 1.4 & 0.3 & 98.3 \\
\hline 74 & -9.50 & 27.2 & 2.2 & 70.6 & 74 & -9.33 & 30.0 & 2.5 & 67.5 \\
\hline 75 & -9.22 & 62.4 & 3.4 & 34.2 & 75 & -8.53 & 15.2 & 1.1 & 83.7 \\
\hline 76 & -8.58 & 45.2 & 3.5 & 51.4 & 76 & -8.42 & 67.4 & 4.2 & 28.5 \\
\hline 77 & -8.49 & 76.3 & 4.3 & 19.4 & 77 & -8.32 & 69.4 & 4.6 & 26.0 \\
\hline 78 & -8.43 & 23.1 & 1.8 & 75.1 & 78 & -8.22 & 51.3 & 4.0 & 44.7 \\
\hline 79 & -7.96 & 19.2 & 4.1 & 76.7 & 79 & -5.71 & 22.5 & 7.0 & 70.6 \\
\hline 80 & -3.66 & 41.9 & 43.5 & 14.6 & 80 & -3.65 & 41.9 & 43.7 & 14.4 \\
\hline 81 & -2.84 & 54.2 & 23.4 & 22.3 & 81 & -2.81 & 52.9 & 23.6 & 23.5 \\
\hline 82 & -2.69 & 3.5 & 8.7 & 87.9 & 82 & -2.66 & 3.5 & 8.4 & 88.2 \\
\hline 83 & -2.66 & 16.1 & 53.2 & 30.7 & 83 & -2.60 & 14.8 & 48.4 & 36.8 \\
\hline 84 & -2.33 & 1.0 & 14.6 & 84.4 & 84 & -2.02 & 1.2 & 22.8 & 76.0 \\
\hline 85 & -2.16 & 5.3 & 3.1 & 91.6 & 85 & -1.92 & 20.7 & 3.0 & 76.3 \\
\hline 86 & -1.98 & 19.2 & 2.9 & 77.8 & 86 & -1.86 & 35.0 & 3.3 & 61.7 \\
\hline 87 & -1.90 & 33.8 & 3.2 & 63.0 & 87 & -1.63 & 3.4 & 3.2 & 93.5 \\
\hline 88 & -1.08 & 2.5 & 86.2 & 11.3 & 88 & -1.03 & 2.7 & 85.4 & 11.9 \\
\hline 89 & -0.89 & 11.1 & 57.8 & 31.1 & 89 & -0.88 & 10.9 & 58.5 & 30.6 \\
\hline 90 & -0.78 & 9.7 & 41.8 & 48.4 & 90 & -0.76 & 10.7 & 46.7 & 42.6 \\
\hline 91 & -0.66 & 0.1 & 0.2 & 99.8 & 91 & -0.65 & 0.1 & 0.2 & 99.7 \\
\hline 92 & -0.33 & 0.5 & 71.7 & 27.8 & 92 & -0.32 & 0.4 & 74.3 & 25.2 \\
\hline 93 & -0.17 & 0.4 & 0.6 & 99.0 & 93 & -0.16 & 0.4 & 0.6 & 99.0 \\
\hline 94 & -0.01 & 0.5 & 37.9 & 61.6 & 94 & 0.01 & 0.5 & 37.8 & 61.8 \\
\hline 95 & 0.19 & 6.9 & 71.2 & 21.9 & 95 & 0.20 & 7.0 & 73.8 & 19.2 \\
\hline 96 & 0.27 & 1.5 & 3.7 & 94.8 & 96 & 0.29 & 1.6 & 4.9 & 93.5 \\
\hline 97 & 0.30 & 1.1 & 42.0 & 56.9 & 97 & 0.31 & 1.0 & 42.3 & 56.7 \\
\hline 98 & 0.35 & 1.6 & 31.6 & 66.9 & 98 & 0.36 & 1.5 & 27.1 & 71.3 \\
\hline 99 & 0.50 & 2.1 & 1.4 & 96.5 & 99 & 0.51 & 2.1 & 1.4 & 96.5 \\
\hline 100 & 0.59 & 0.3 & 2.6 & 97.1 & 100 & 0.60 & 0.3 & 2.3 & 97.4 \\
\hline
\end{tabular}

Fonte: Autora 
Figura 136: Espectros experimental e simulado para os complexos $\left[\mathrm{Ru}\left(\mathrm{NH}_{3}\right)_{4}(\text { isoproterenol) }]^{+}\right.$

Fonte: Autora

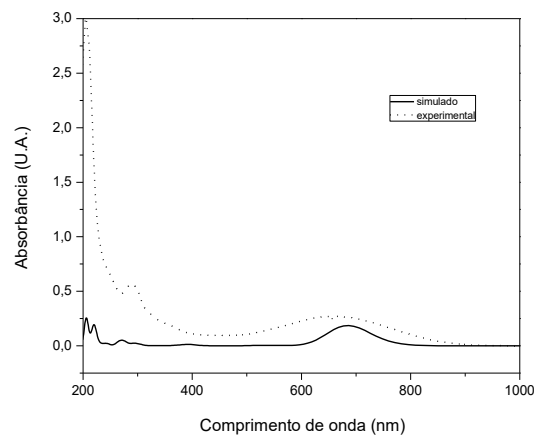

Figura 137: Espectros experimental e simulado para os complexos $\left[\mathrm{Ru}\left(\mathrm{NH}_{3}\right)_{4}(\text { dopamina })\right]^{+}$

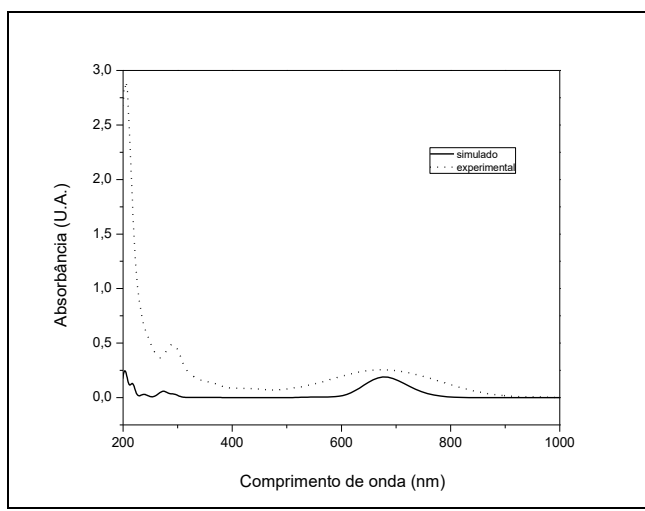

Fonte: Autora

Figura 138: Espectros experimental e simulado para os complexos $\left[\mathrm{Ru}\left(\mathrm{NH}_{3}\right)_{4}(\text { noradrenalina })\right]^{+}$

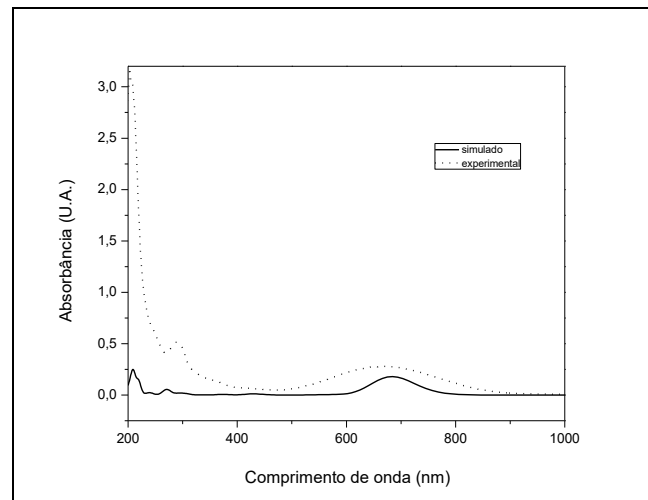

Fonte: Autora 
Figura 139: Espectros experimental e simulado para os complexos $\left[\mathrm{Ru}\left(\mathrm{NH}_{3}\right)_{4}(\mathrm{catecol})\right]^{+}$

Fonte: Autora

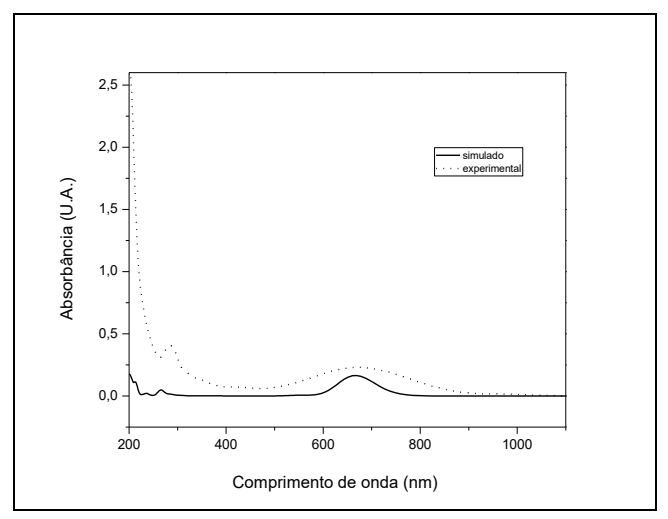

\subsubsection{Ensaios na membrana corioalantoica (CAM)}

Figura 140: Efeitos angiogênicos induzidos por complexos ou ligantes: $\left[\mathrm{Ru}\left(\mathrm{NH}_{3}\right)_{4}(\text { noradrenalina })\right]^{+}(\mathrm{Ru}-$ NA), noradrenalina (NA), $\left[\mathrm{Ru}\left(\mathrm{NH}_{3}\right)_{4}(\text { adrenalina }]^{+} \quad(\mathrm{Ru}-\mathrm{Adr}), \quad\right.$ adrenalina (Adr), $\left[\mathrm{Ru}\left(\mathrm{NH}_{3}\right)_{4} \text { (isoproterenol) }\right]^{+}(\mathrm{Ru}-\mathrm{Iso})$, isoproterenol (Iso), $\left[\mathrm{Ru}\left(\mathrm{NH}_{3}\right)_{4} \text { (dopamina) }\right]^{+}$( $\left.\mathrm{Ru}-\mathrm{Dopa}\right)$, dopamina (Dopa), $\left[\mathrm{Ru}\left(\mathrm{NH}_{3}\right)_{4} \text { (catecol) }\right]^{+}$(Ru-Cat), ou o veículo (PBS), na área total de vasos (A) e na lacunaridade (B), na CAM. Os tratamentos aplicados foram na dose de $50 \mathrm{nmol}$ e a área total de vasos (A) e a lacunaridade (B) analisadas $48 \mathrm{~h}$ após os tratamentos. Os dados são apresentados como media \pm E.P.M. " diferente do controle (PBS); "diferente da respectiva catecolamina, n=3-6; One-way ANOVA, Newman-Keuls $(P<0.05)$

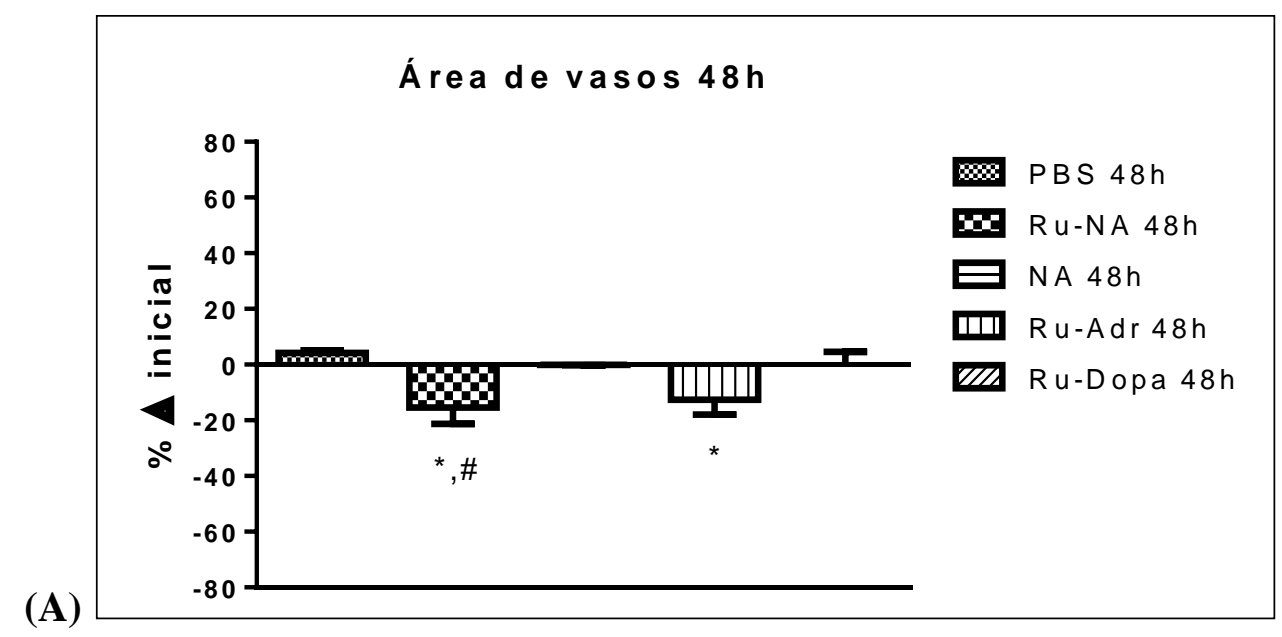




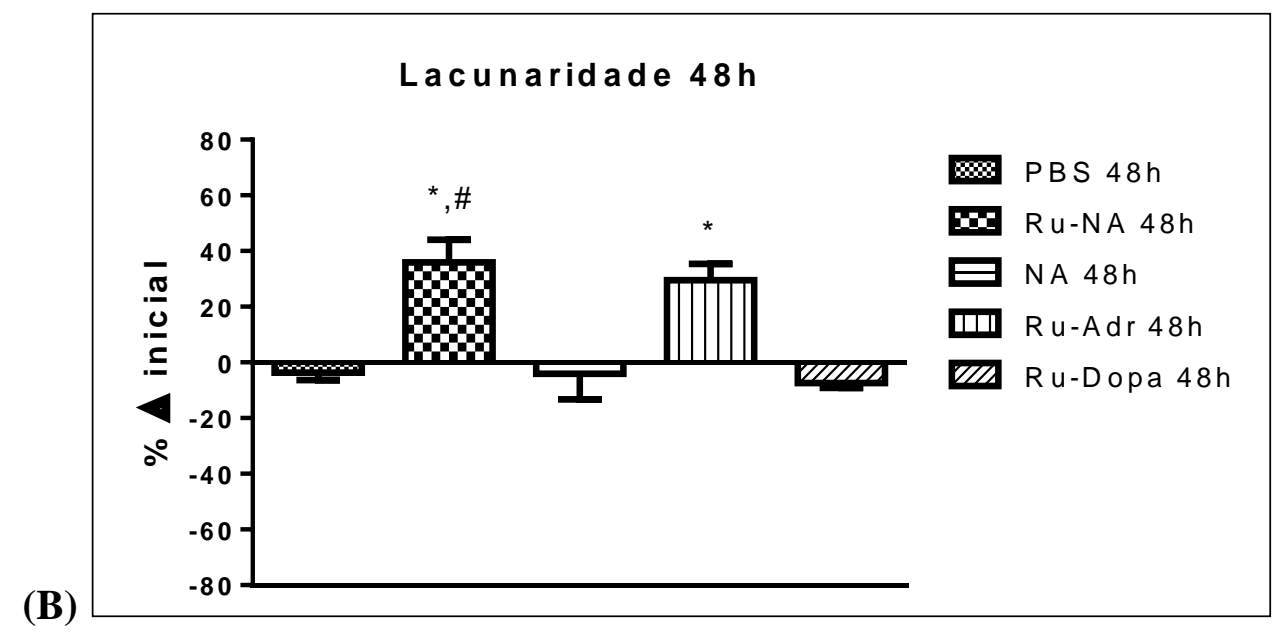

Fonte: Autora

Figura 141: Fotografias representativas da modulação da angiogênese induzida por complexos ou ligantes: $\left[\mathbf{R u}\left(\mathrm{NH}_{3}\right)_{4}(\text { noradrenalina })\right]^{+}(\mathrm{Ru}-\mathrm{NA})$, noradrenalina $(\mathrm{NA}),\left[\mathbf{R u}\left(\mathrm{NH}_{3}\right)_{4}(\text { adrenalina })\right]^{+}(\mathbf{R u}-\mathbf{A d r})$, adrenalina (Adr), $\left[\mathrm{Ru}\left(\mathrm{NH}_{3}\right)_{4} \text { (isoproterenol) }\right]^{+}(\mathrm{Ru}-\mathrm{Iso})$, isoproterenol (Iso), $\left[\mathrm{Ru}\left(\mathrm{NH}_{3}\right)_{4}(\text { dopamina) }]^{+}(\mathrm{Ru}-\right.$ Dopa), dopamina (Dopa), $\left[\mathrm{Ru}\left(\mathrm{NH}_{3}\right)_{4}(\mathrm{catecol})\right]^{+}$(Ru-Cat), ou o veículo (PBS), 48h após os tratamentos. Olympus SZ2-LHAD stereomicroscopy, 8x

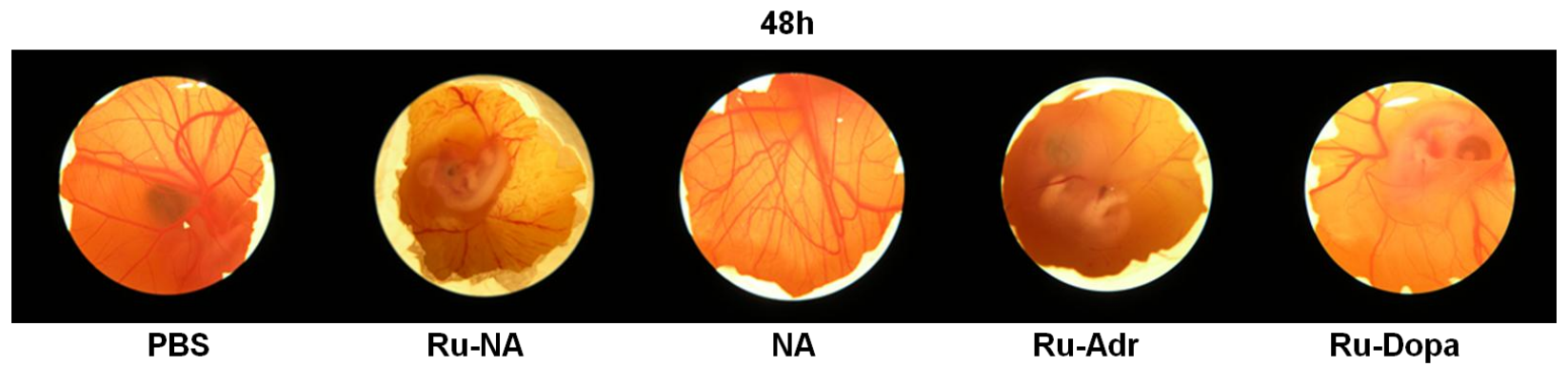

Fonte: Autora 


\subsubsection{Interação com fs-DNA - titulação espectrofotométrica na região do $U V$-Vis}

Figura 142: Titulação do complexo $\left[\mathrm{Ru}\left(\mathrm{NH}_{3}\right)_{4}(\text { isoproterenol })\right]^{+}$, a $30^{\circ} \mathrm{C}$, acompanhada por espectroscopia na região do UV-vis, $\operatorname{com} f s$-DNA

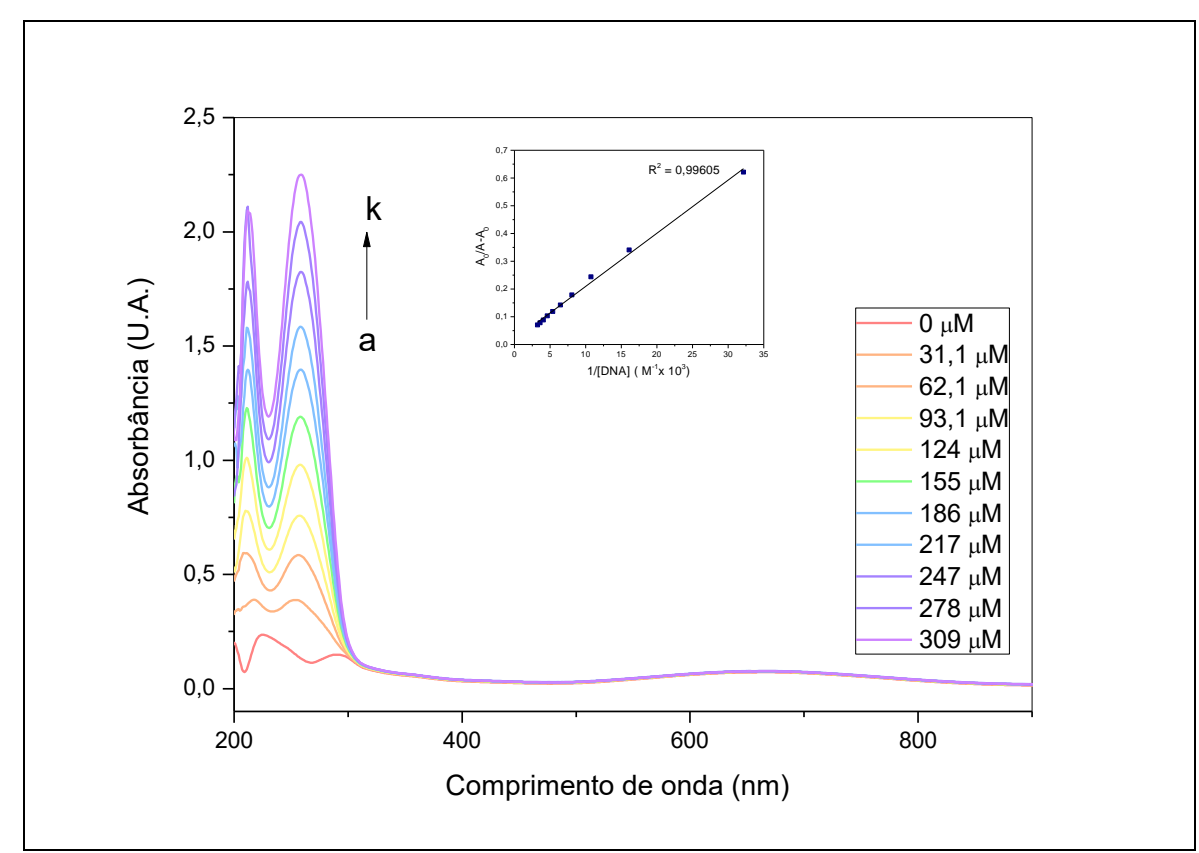

Fonte: Autora

Figura 143: Titulação do complexo $\left[\mathrm{Ru}\left(\mathrm{NH}_{3}\right)_{4}(\text { isoproterenol })\right]^{+}$, a $37^{\circ} \mathrm{C}, \operatorname{com} f s$-DNA, acompanhada por espectroscopia na região do $\mathrm{UV}$-vis

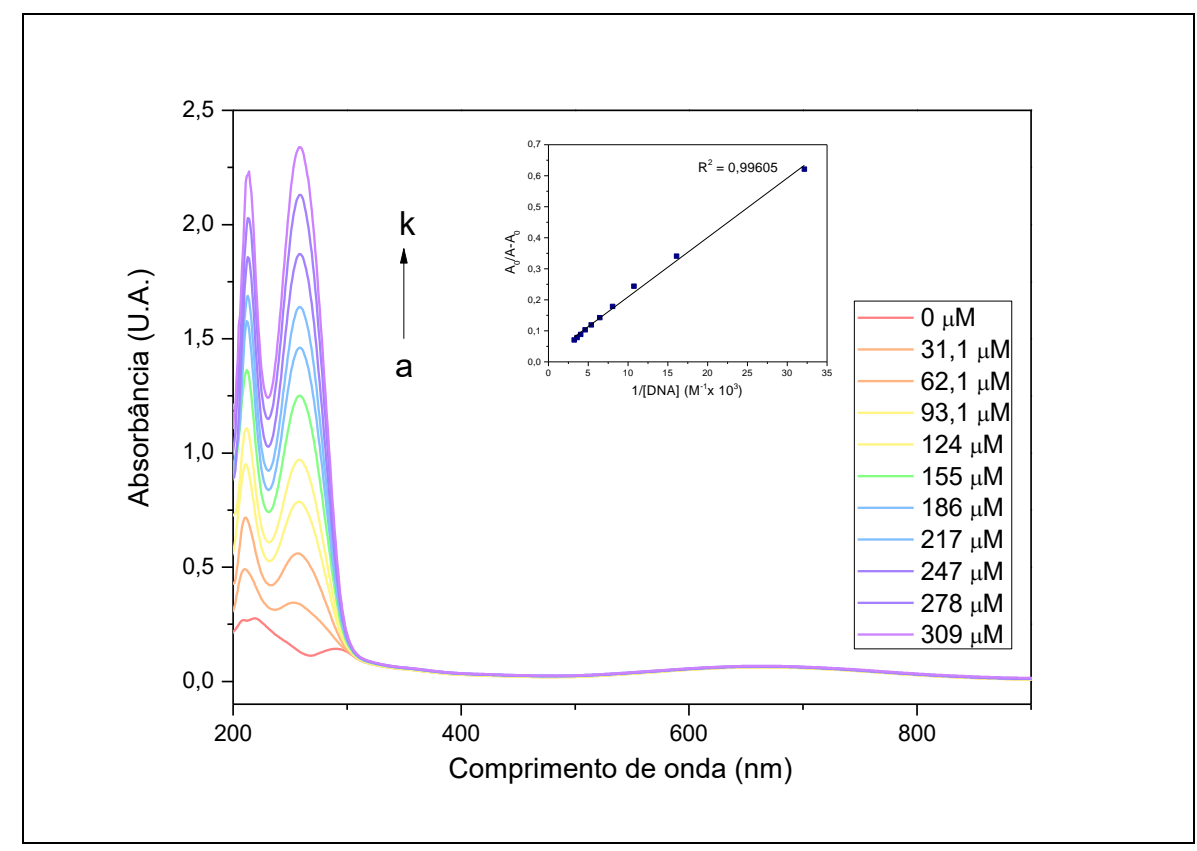

Fonte: Autora 
Figura 144: Titulação do complexo $\left[\mathrm{Ru}\left(\mathrm{NH}_{3}\right)_{4}(\text { dopamina })\right]^{+}$, a $30^{\circ} \mathrm{C}, \operatorname{com} f s-\mathrm{DNA}$, acompanhada por espectroscopia na região do $\mathrm{UV}$-vis

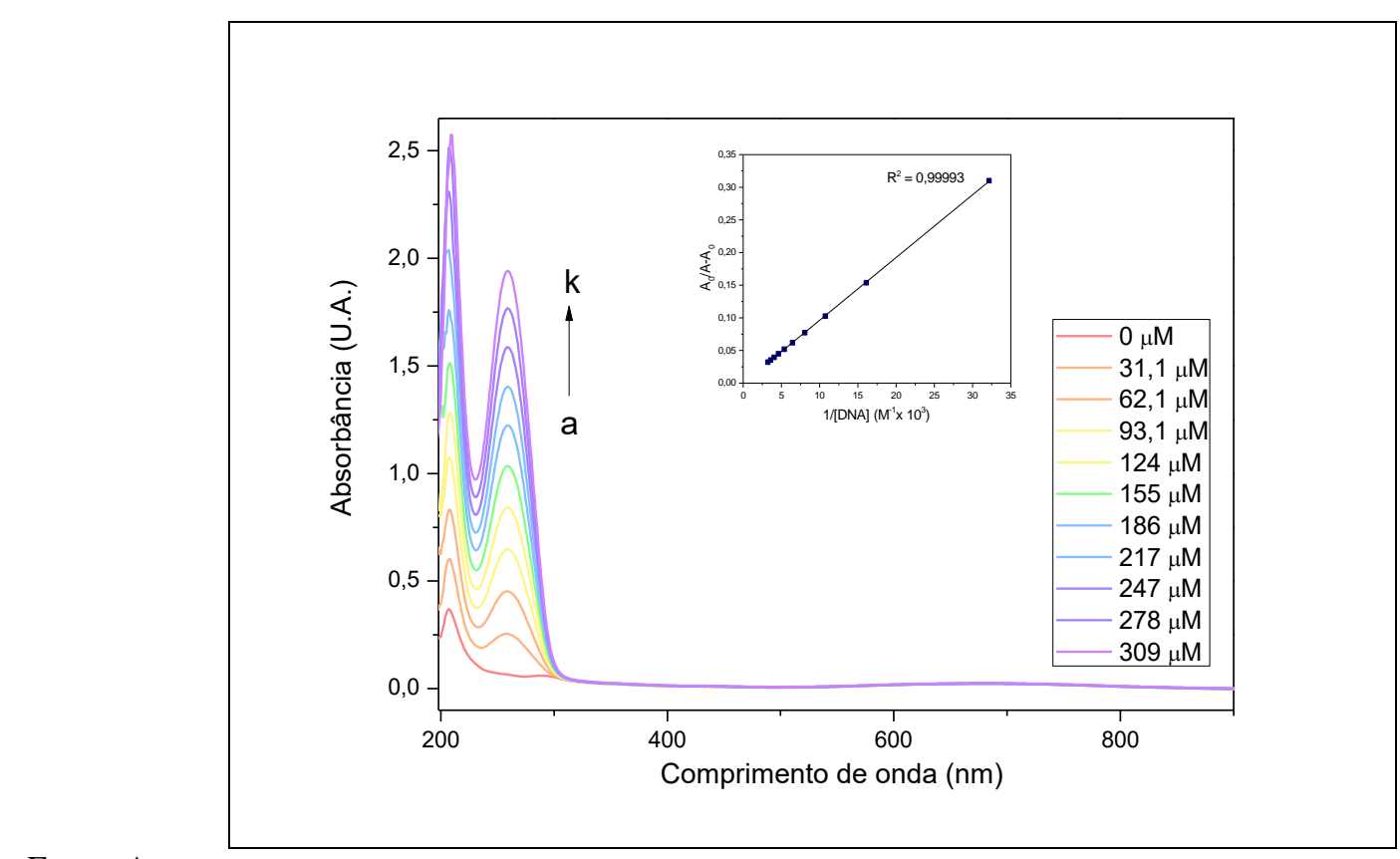

Fonte: Autora

Figura 145: Titulação do complexo $\left[\mathrm{Ru}\left(\mathrm{NH}_{3}\right)_{4}(\text { dopamina })\right]^{+}$, a $37^{\circ} \mathrm{C}, \operatorname{com} f s-\mathrm{DNA}$, acompanhada por espectroscopia na região do UV-vis

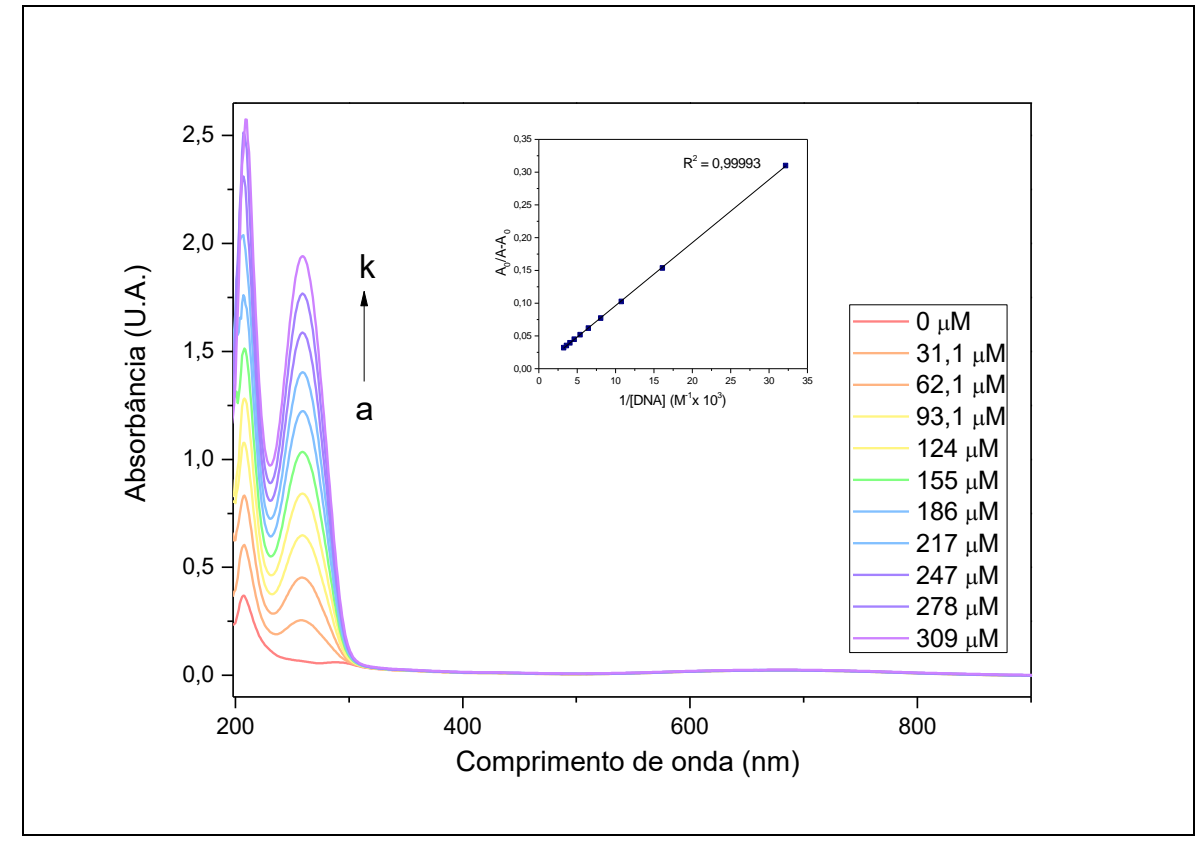

Fonte: Autora 
Figura 146: Titulação do complexo $\left[\mathrm{Ru}\left(\mathrm{NH}_{3}\right)_{4}(\text { noradrenalina })\right]^{+}$, a $30^{\circ} \mathrm{C}, \operatorname{com} f s$-DNA, acompanhada por espectroscopia na região do UV-vis

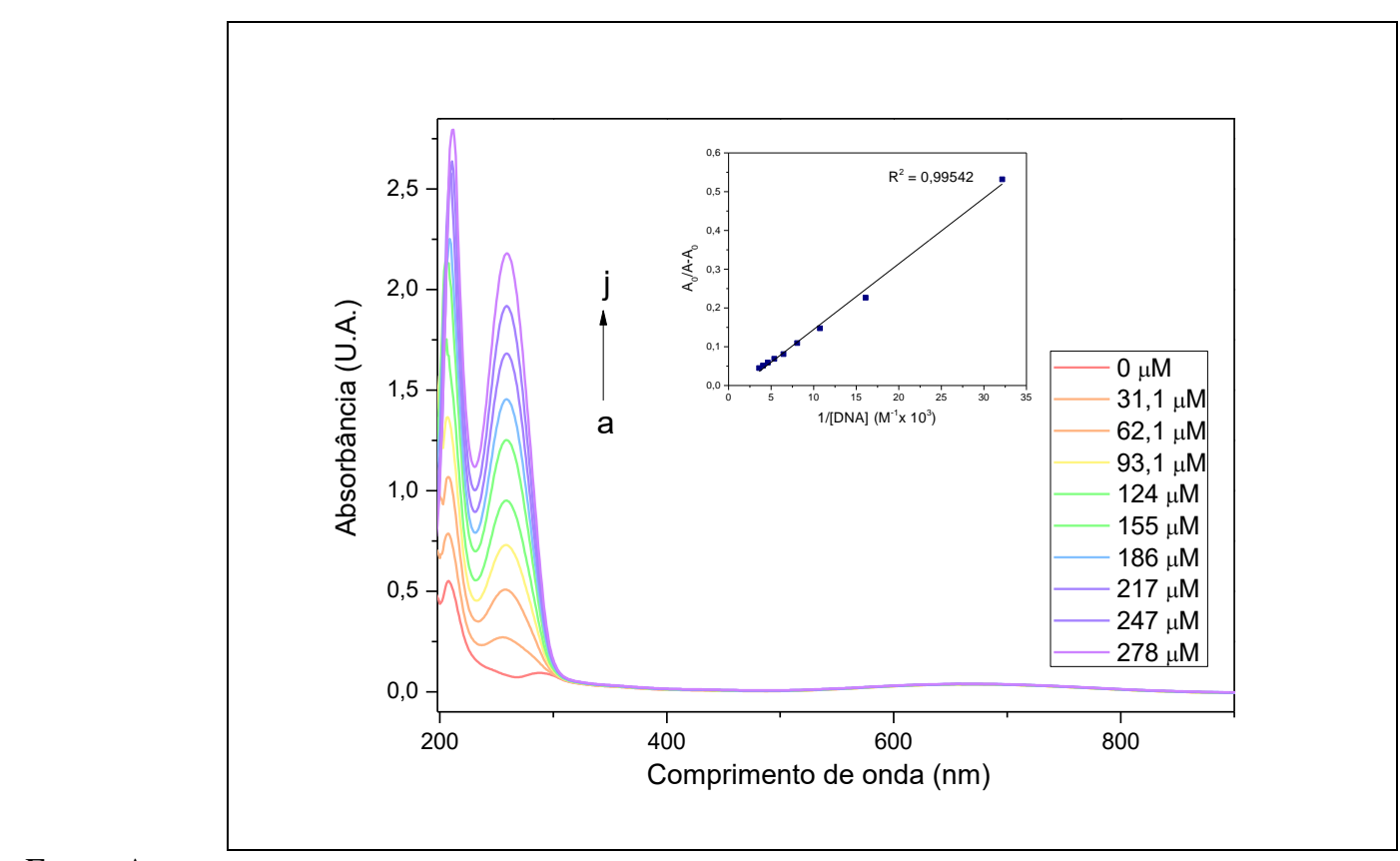

Fonte: Autora

Figura 147: Titulação do complexo $\left[\mathrm{Ru}\left(\mathrm{NH}_{3}\right)_{4}(\text { noradrenalina })\right]^{+}$, a $37^{\circ} \mathrm{C}, \operatorname{com} f s$-DNA, acompanhada por espectroscopia na região do UV-vis

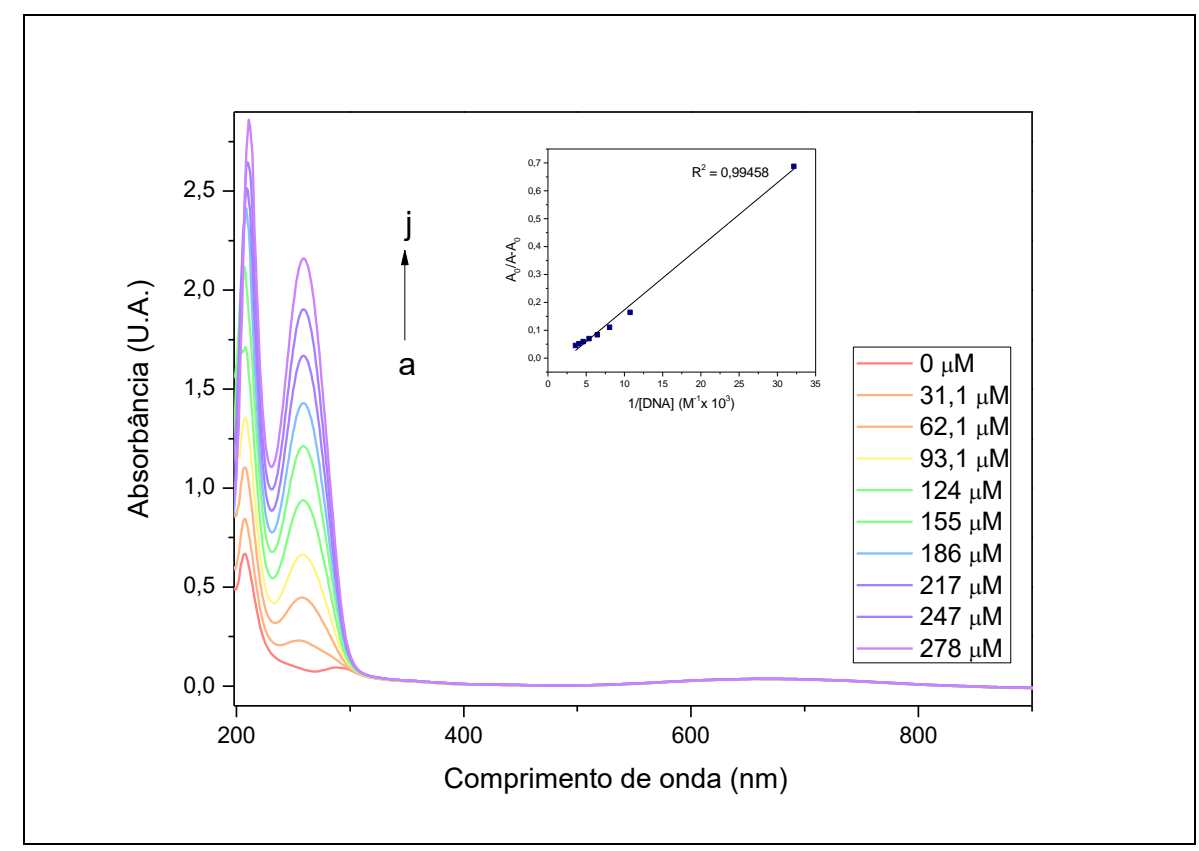

Fonte: Autora 
Figura 148: Titulação do complexo $\left[\mathrm{Ru}\left(\mathrm{NH}_{3}\right)_{4}(\text { catecol })\right]^{+}$, a $30^{\circ} \mathrm{C}, \operatorname{com} f s-\mathrm{DNA}$, acompanhada por espectroscopia na região do $\mathrm{UV}$-vis

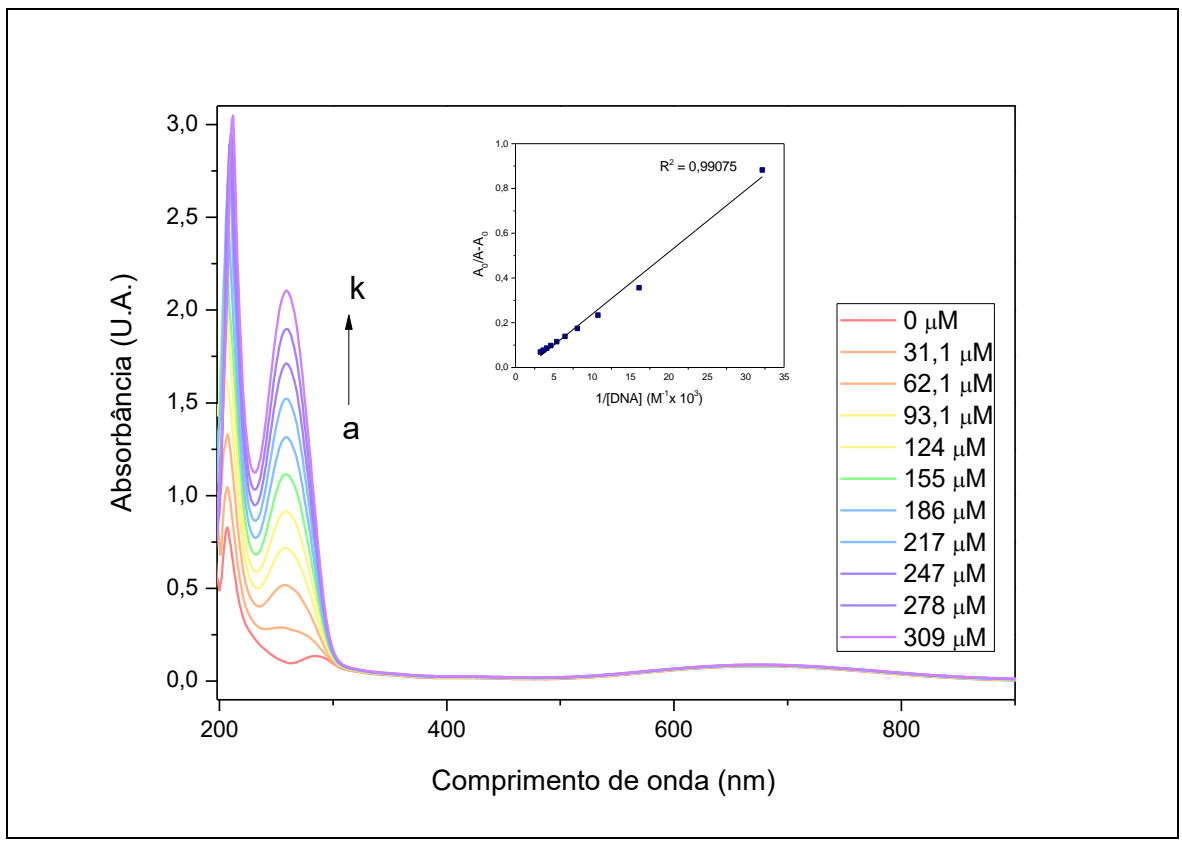

Fonte: Autora

Figura 149: Titulação do complexo $\left[\mathrm{Ru}\left(\mathrm{NH}_{3}\right)_{4}(\text { catecol })\right]^{+}$, a $37^{\circ} \mathrm{C}, \operatorname{com} f s-\mathrm{DNA}$, acompanhada por espectroscopia na região do $\mathrm{UV}$-vis

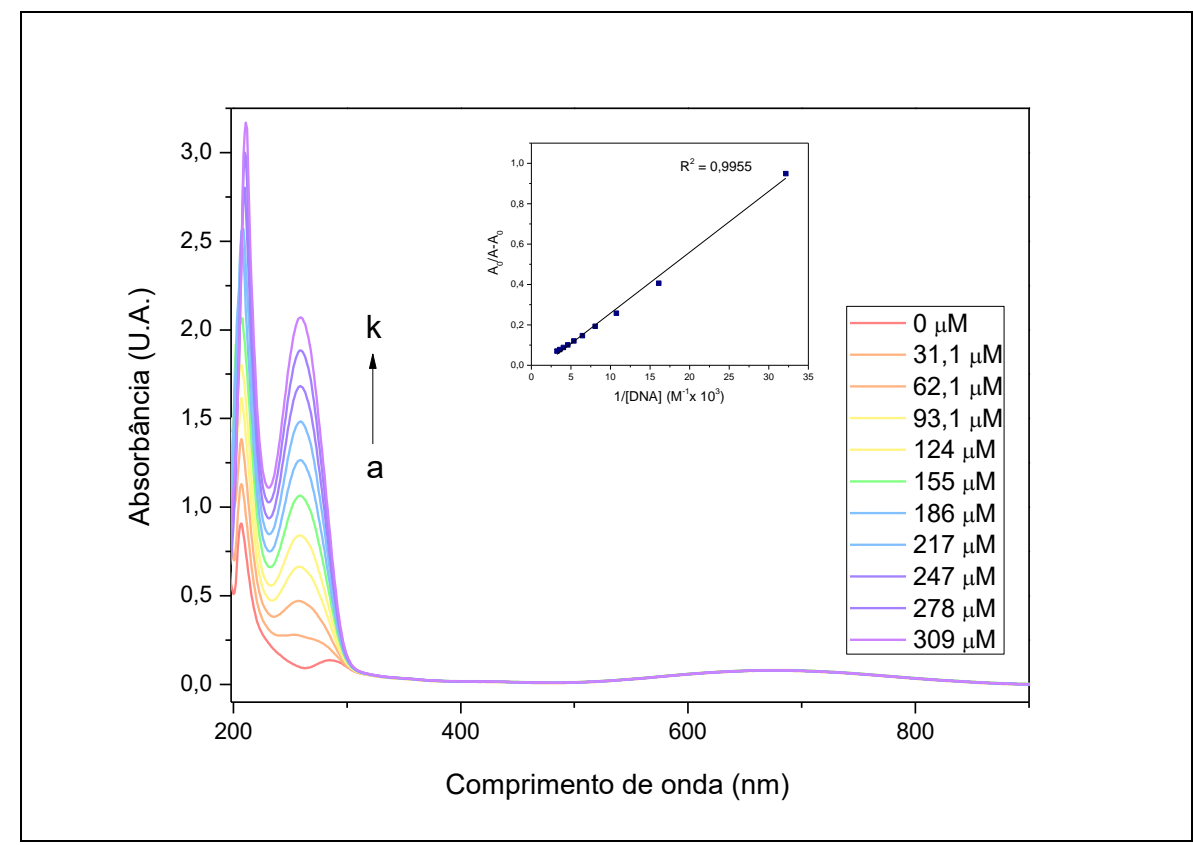

Fonte: Autora 
Figura 150: Titulação do complexo $\left[\mathrm{Ru}\left(\mathrm{NH}_{3}\right)_{4}(\operatorname{adrenalina})\right]^{+}$, a $30^{\circ} \mathrm{C}, \operatorname{com} f s-\mathrm{DNA}$, acompanhada por espectroscopia na região do $\mathrm{UV}$-vis

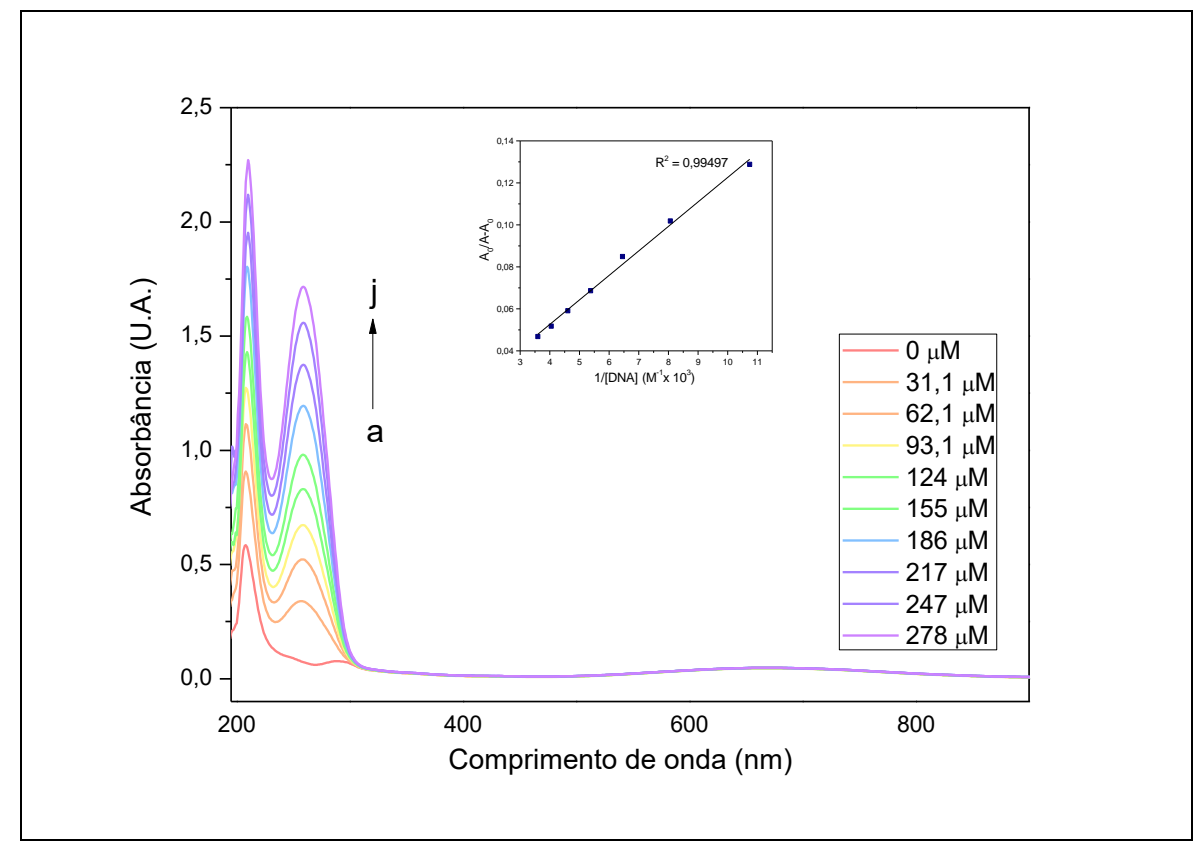

Fonte: Autora

Figura 151: Titulação do complexo $\left[\mathrm{Ru}\left(\mathrm{NH}_{3}\right)_{4}(\operatorname{adrenalina})\right]^{+}, a^{\circ} \mathrm{C}, \operatorname{com} f s-\mathrm{DNA}$, acompanhada por espectroscopia na região do $\mathrm{UV}$-vis

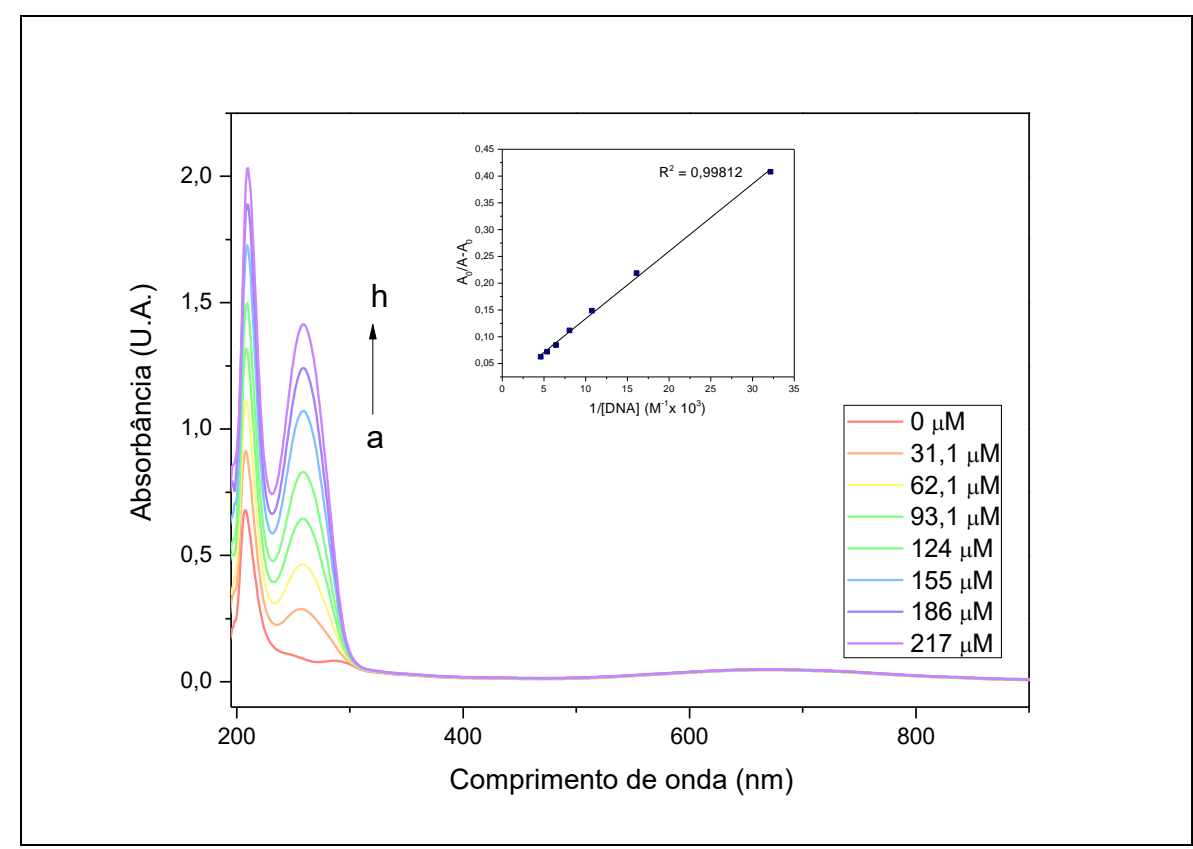

Fonte: Autora 


\subsubsection{Interação com proteína carreadora (HSA) - mimetizando transporte in vivo}

Figura 152: Espectros de emissão de fluorescência da HSA, na presença de diferentes concentrações de $\left[\mathrm{Ru}\left(\mathrm{NH}_{3}\right)_{4}(\text { isoproterenol })\right]^{+}$, a $32^{\circ} \mathrm{C}$. Gráfico de Stern-Volmer inserido

Fonte: Autora

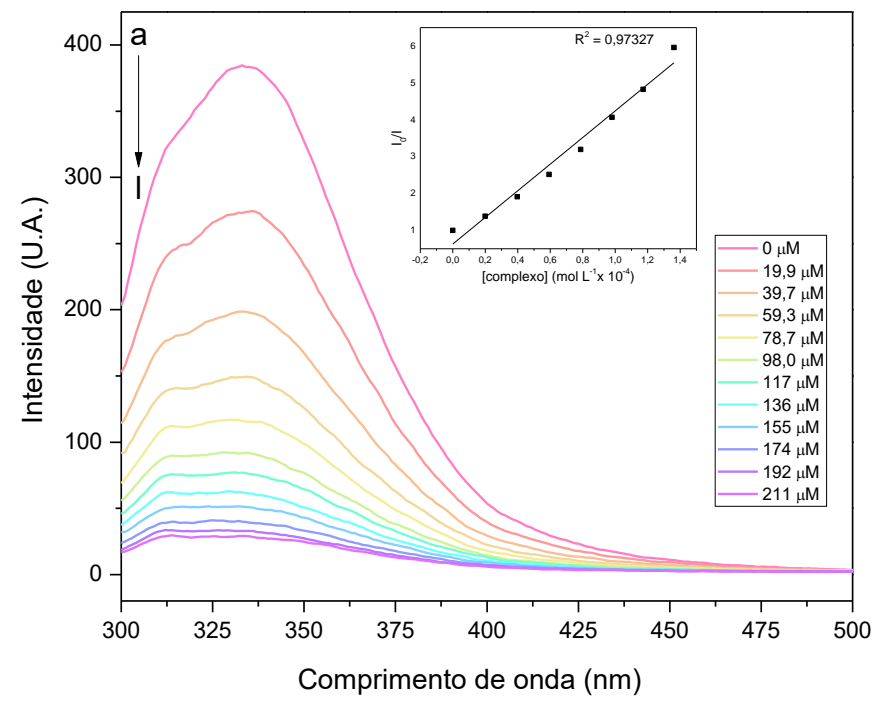

Figura 153: Gráfico da equação $\log \left[\left(I_{0}-I\right) / I\right]=\log K_{b}+n \log [Q]$ referente à interação entre HSA e o complexo $\left[\mathrm{Ru}\left(\mathrm{NH}_{3}\right)_{4}(\text { isoproterenol })\right]^{+},{\text {a } 32^{\circ} \mathrm{C}}^{\circ}$

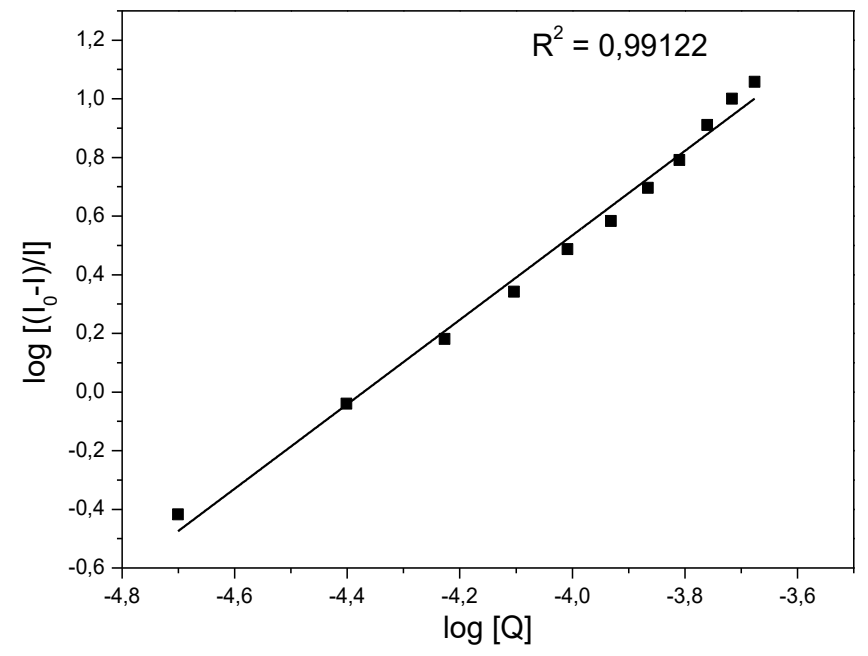

Fonte: Autora 
Figura 154: Espectros de emissão de fluorescência da HSA, na presença de diferentes concentrações de $\left[\mathrm{Ru}\left(\mathrm{NH}_{3}\right)_{4}(\text { isoproterenol })\right]^{+}$, a $37^{\circ} \mathrm{C}$. Gráfico de Stern-Volmer inserido

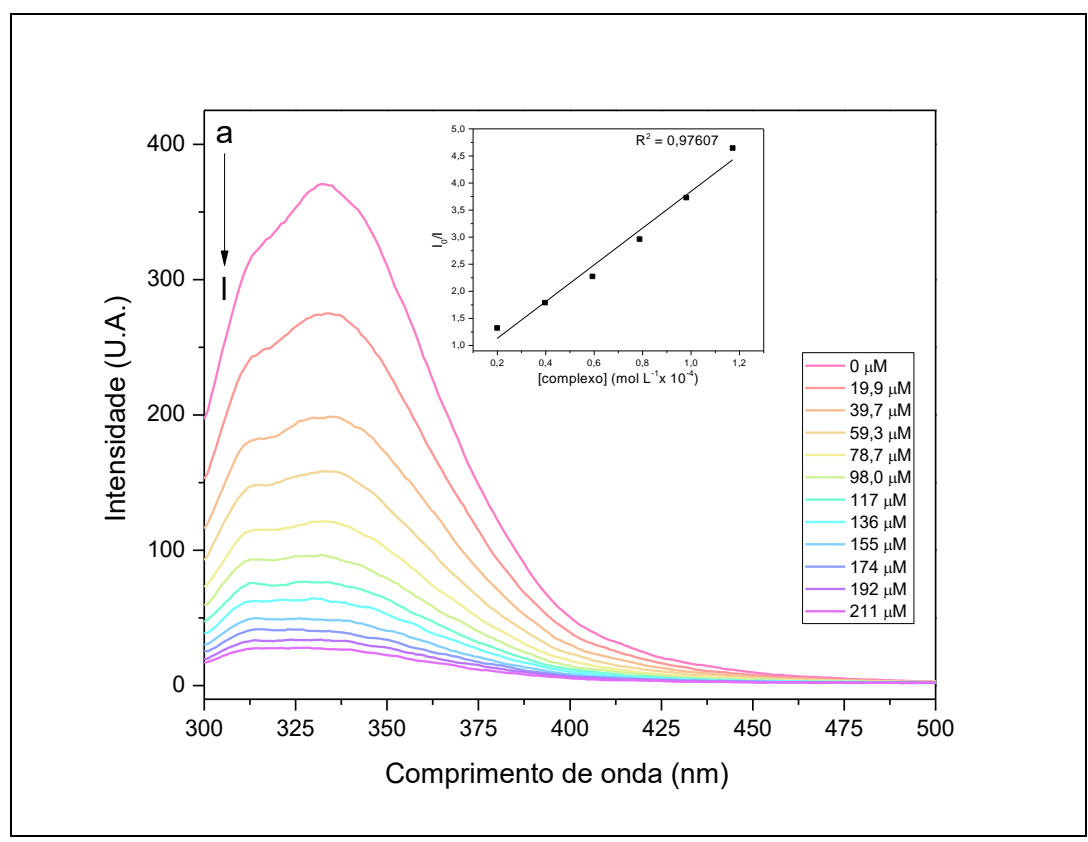

Fonte: Autora

Figura 155: Gráfico da equação $\log \left[\left(\mathrm{I}_{0}-\mathrm{I}\right) / \mathrm{I}\right]=\log \mathrm{K}_{\mathrm{b}}+\mathrm{nlog}[\mathrm{Q}]$ referente à interação entre HSA e o complexo $\left[\mathrm{Ru}\left(\mathrm{NH}_{3}\right)_{4}(\text { isoproterenol })\right]^{+}, a^{3} 7^{\circ} \mathrm{C}$

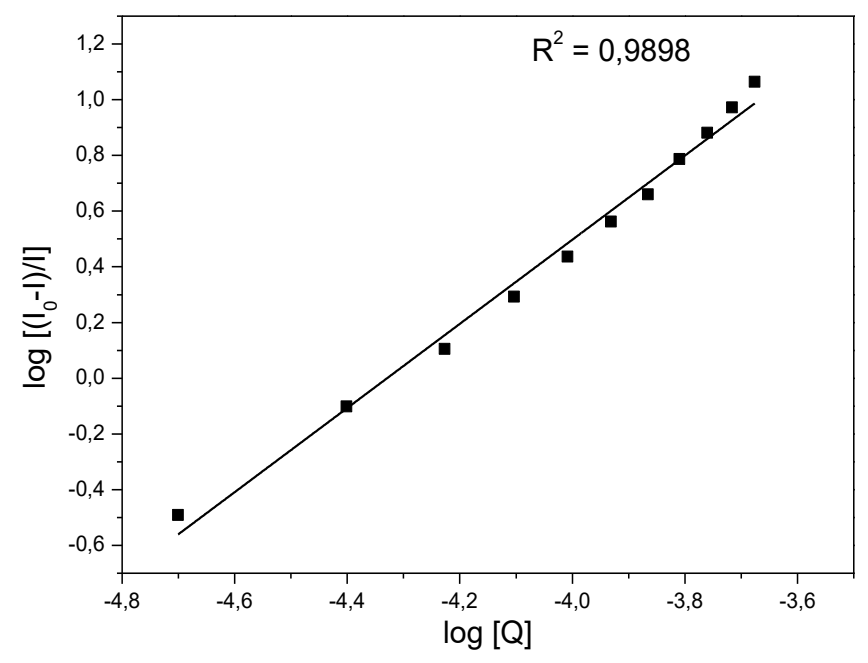

Fonte: Autora 
Figura 156: Espectros de emissão de fluorescência da HSA, na presença de diferentes concentrações de $\left[\mathrm{Ru}\left(\mathrm{NH}_{3}\right)_{4}(\text { dopamina })\right]^{+}$, a $32^{\circ} \mathrm{C}$. Gráfico de Stern-Volmer inserido

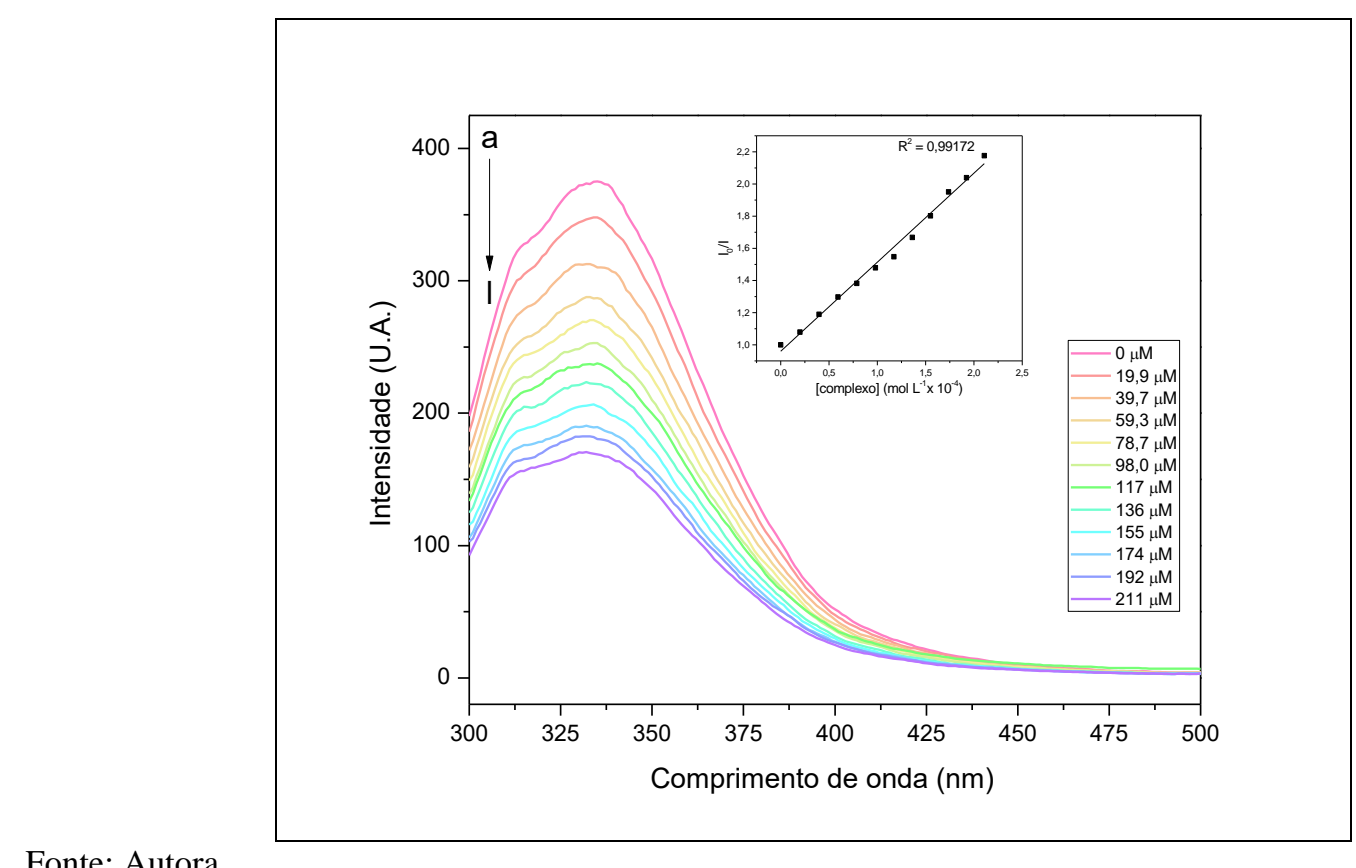

Fonte: Autora

Figura 157: Gráfico da equação $\log \left[\left(I_{0}-I\right) / I\right]=\log K_{b}+n \log [Q]$ referente à interação entre HSA e o complexo $\left[\mathrm{Ru}\left(\mathrm{NH}_{3}\right)_{4}(\text { dopamina })\right]^{+}$, a $32^{\circ} \mathrm{C}$

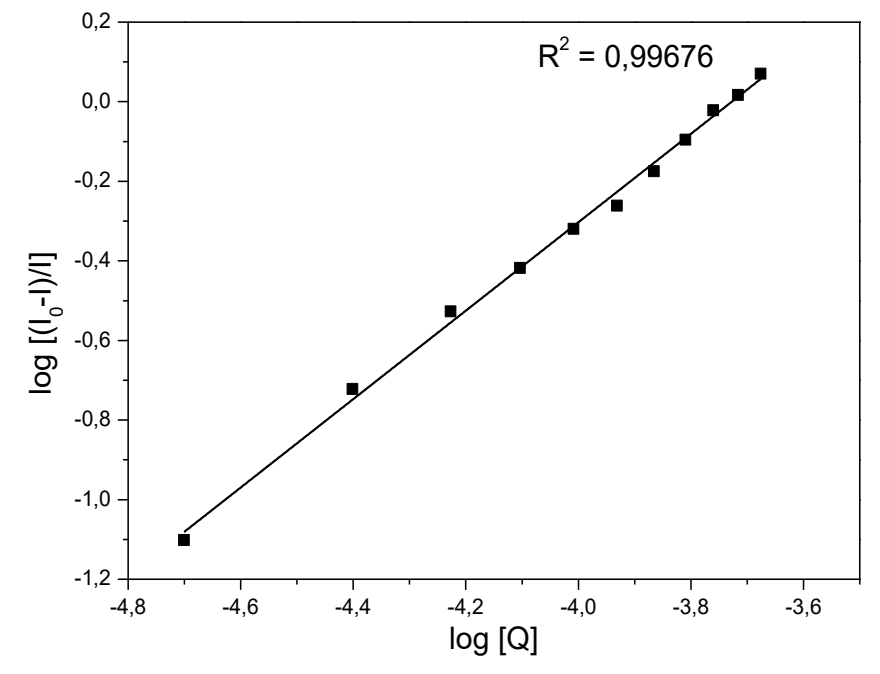

Fonte: Autora 
Figura 158: Espectros de emissão de fluorescência da HSA, na presença de diferentes concentrações de $\left[\mathrm{Ru}\left(\mathrm{NH}_{3}\right)_{4}(\text { dopamina })\right]^{+}$, a $37^{\circ} \mathrm{C}$. Gráfico de Stern-Volmer inserido

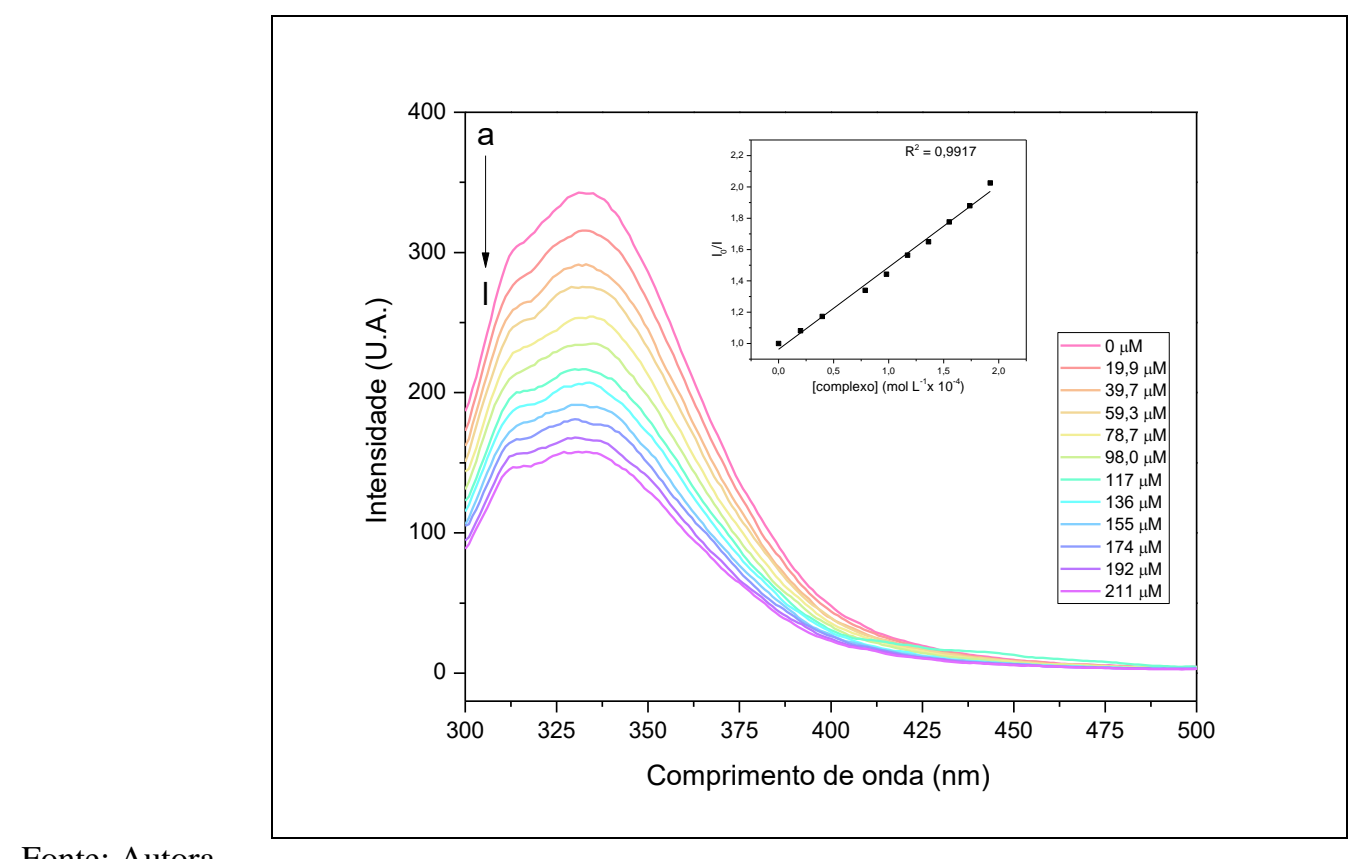

Figura 159: Gráfico da equação $\log \left[\left(\mathrm{I}_{0}-\mathrm{I}\right) / \mathrm{I}\right]=\log \mathrm{K}_{\mathrm{b}}+\mathrm{nlog}[\mathrm{Q}]$ referente à interação entre HSA e o complexo $\left[\mathrm{Ru}\left(\mathrm{NH}_{3}\right)_{4}(\text { dopamina })\right]^{+}$, a $37^{\circ} \mathrm{C}$

Fonte: Autora

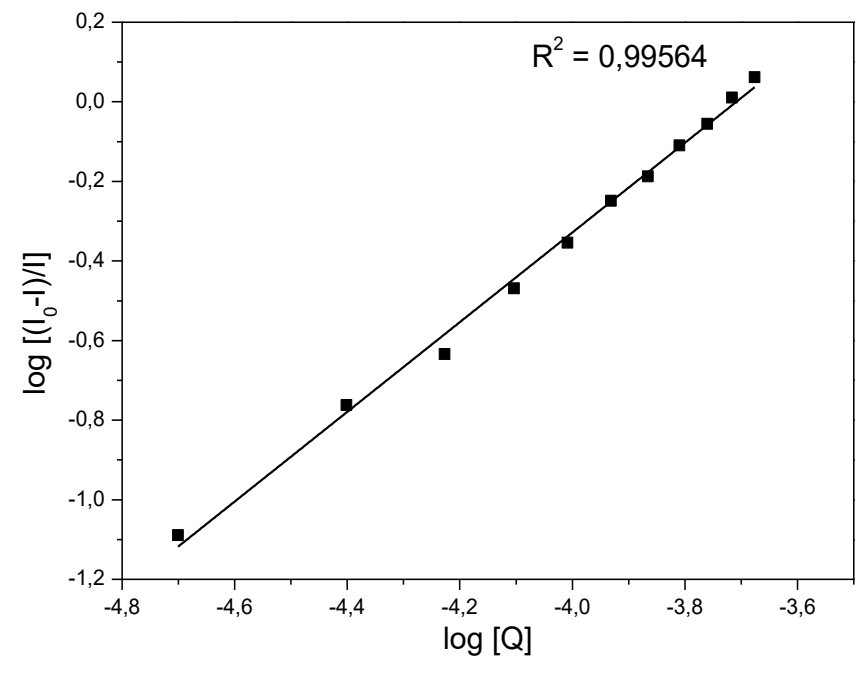


Figura 160: Espectros de emissão de fluorescência da HSA, na presença de diferentes concentrações de $\left[\mathrm{Ru}\left(\mathrm{NH}_{3}\right)_{4}(\text { noradrenalina })\right]^{+}$, a $32^{\circ}$ C. Gráfico de Stern-Volmer inserido

Fonte: Autora

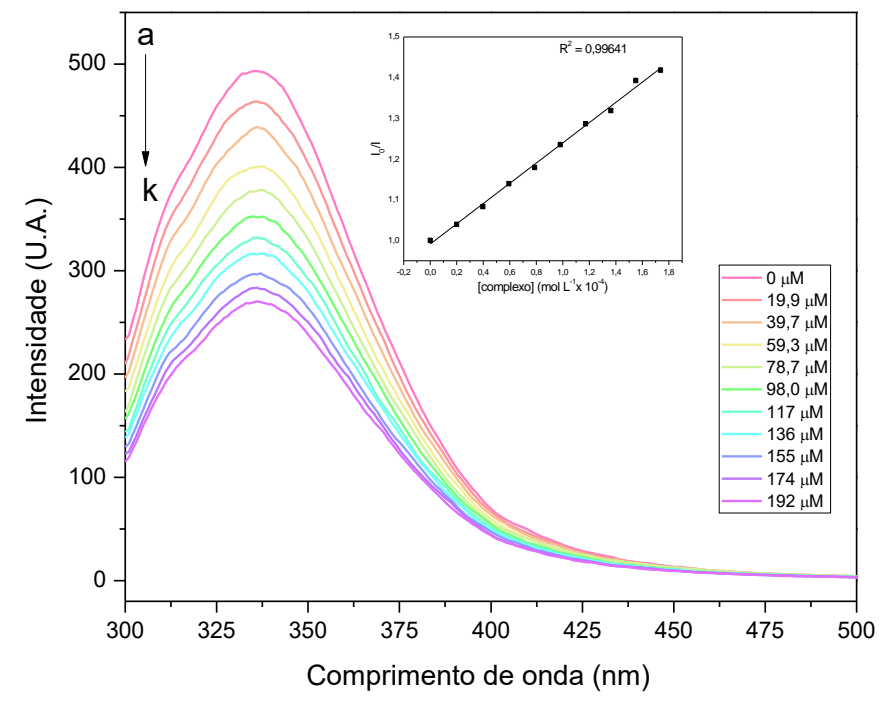

Figura 161: Gráfico da equação $\log \left[\left(\mathrm{I}_{0}-\mathrm{I}\right) / \mathrm{I}\right]=\log \mathrm{K}_{\mathrm{b}}+n \log [\mathrm{Q}]$ referente à interação entre HSA e o complexo $\left[\mathrm{Ru}\left(\mathrm{NH}_{3}\right)_{4}(\text { noradrenalina })\right]^{+}$, a $32^{\circ} \mathrm{C}$

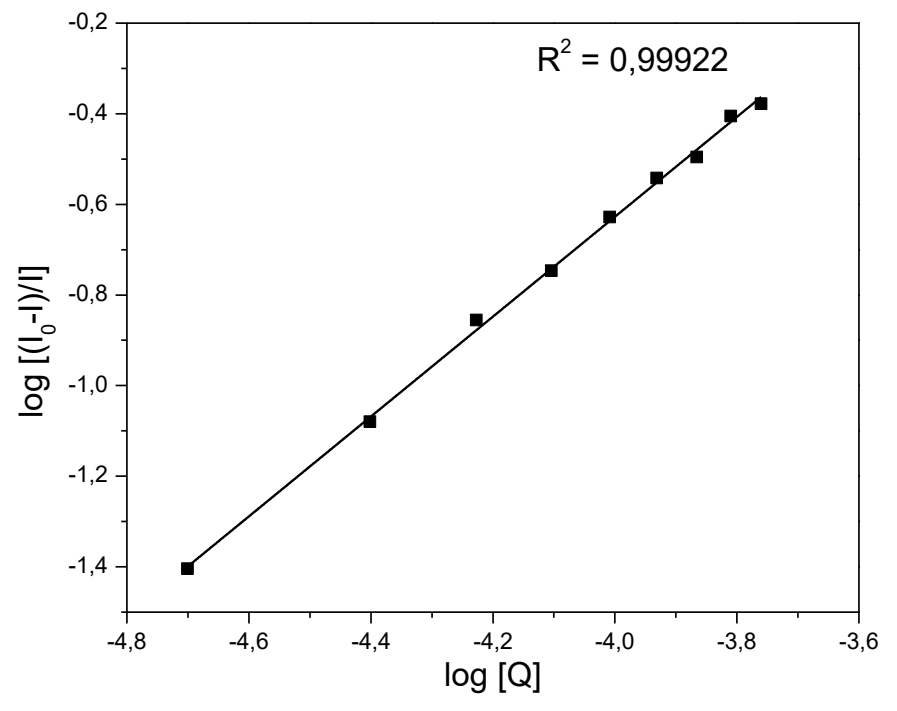

Fonte: Autora 
Figura 162: Espectros de emissão de fluorescência da HSA, na presença de diferentes concentrações de $\left[\mathrm{Ru}\left(\mathrm{NH}_{3}\right)_{4}(\text { noradrenalina })\right]^{+}$, a $37^{\circ} \mathrm{C}$. Gráfico de Stern-Volmer inserido

Fonte: Autora

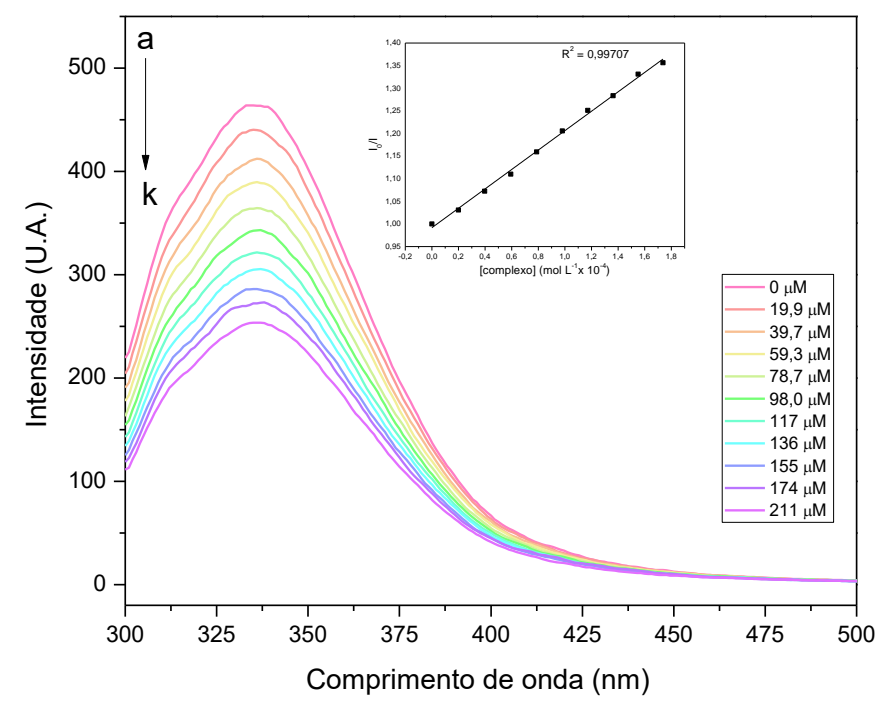

Figura 163: Gráfico da equação $\log \left[\left(\mathrm{I}_{0}-\mathrm{I}\right) / \mathrm{I}\right]=\log \mathrm{K}_{\mathrm{b}}+n \log [\mathrm{Q}]$ referente à interação entre HSA e o complexo $\left[\mathrm{Ru}\left(\mathrm{NH}_{3}\right)_{4}(\text { noradrenalina })\right]^{+}$, a $37^{\circ} \mathrm{C}$

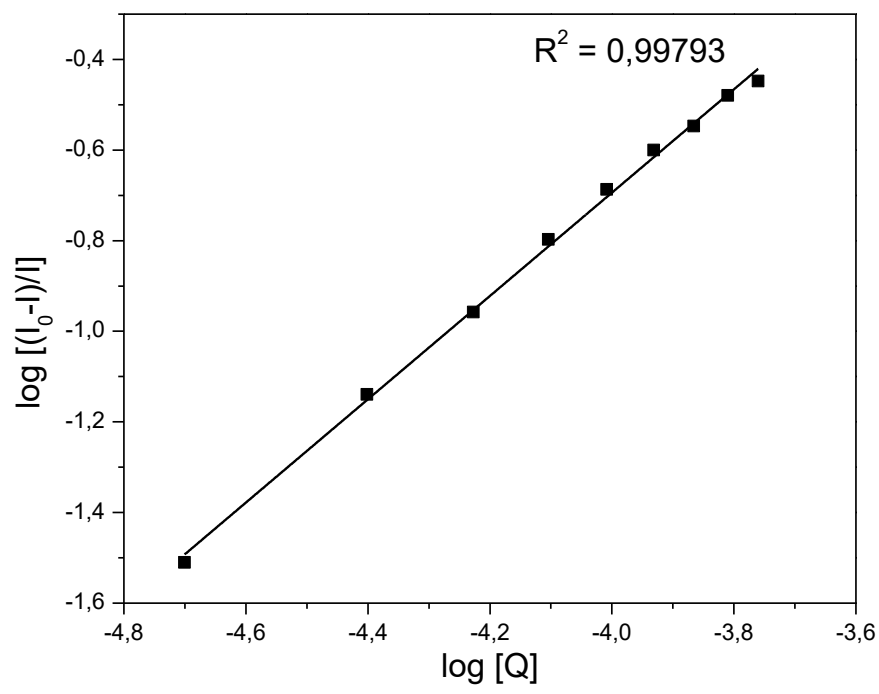

Fonte: Autora 
Figura 164: Espectros de emissão de fluorescência da HSA, na presença de diferentes concentrações de $\left[\mathrm{Ru}\left(\mathrm{NH}_{3}\right)_{4}(\text { catecol })\right]^{+}$, a 32 ${ }^{\circ}$ C. Gráfico de Stern-Volmer inserido

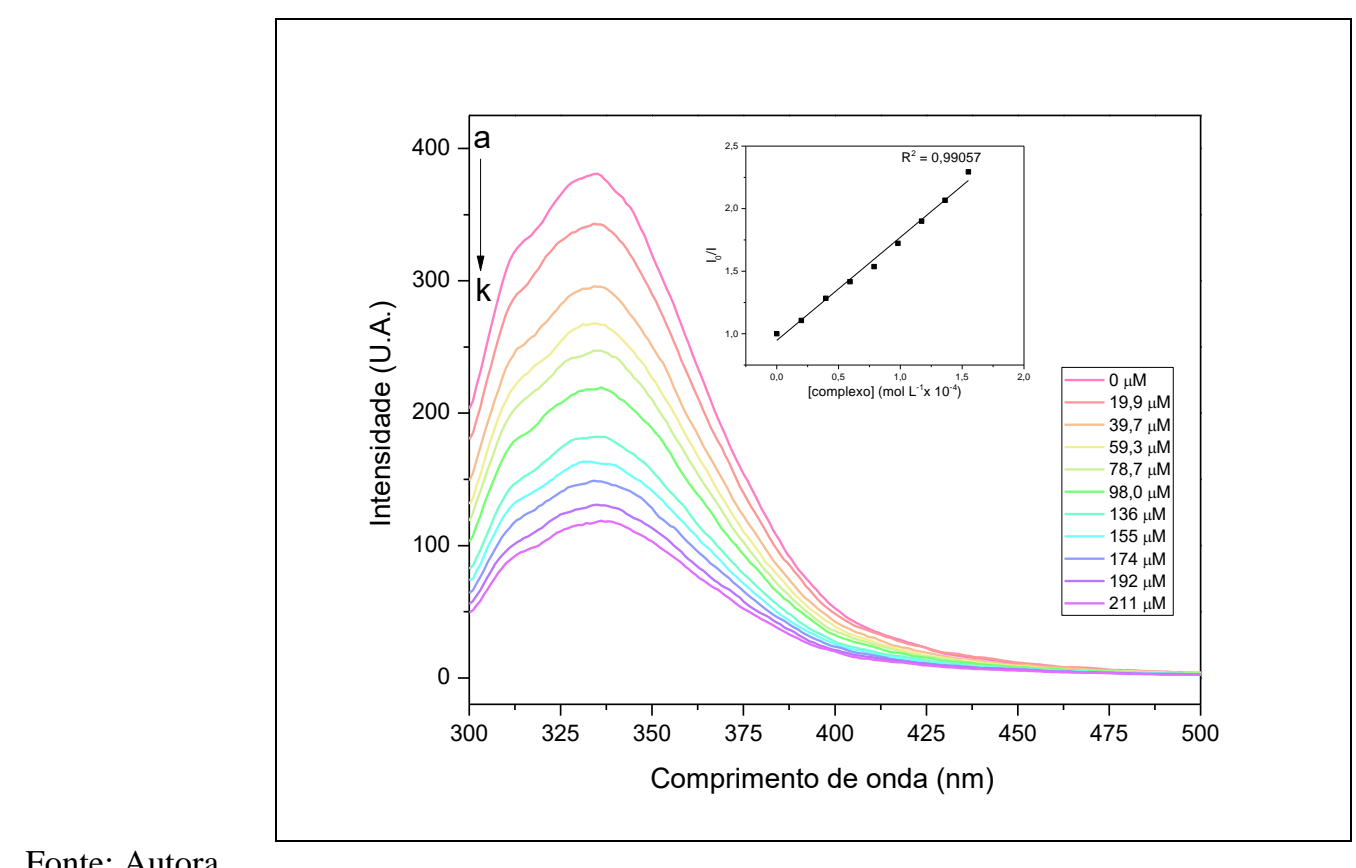

Figura 165: Gráfico da equação $\log \left[\left(\mathrm{I}_{0}-\mathrm{I}\right) / \mathrm{I}\right]=\log \mathrm{K}_{\mathrm{b}}+\mathrm{nlog}[\mathrm{Q}]$ referente à interação entre HSA e o complexo $\left[\mathrm{Ru}\left(\mathrm{NH}_{3}\right)_{4}(\text { catecol })\right]^{+},{\text {a } 32^{\circ} \mathrm{C}}^{\circ}$

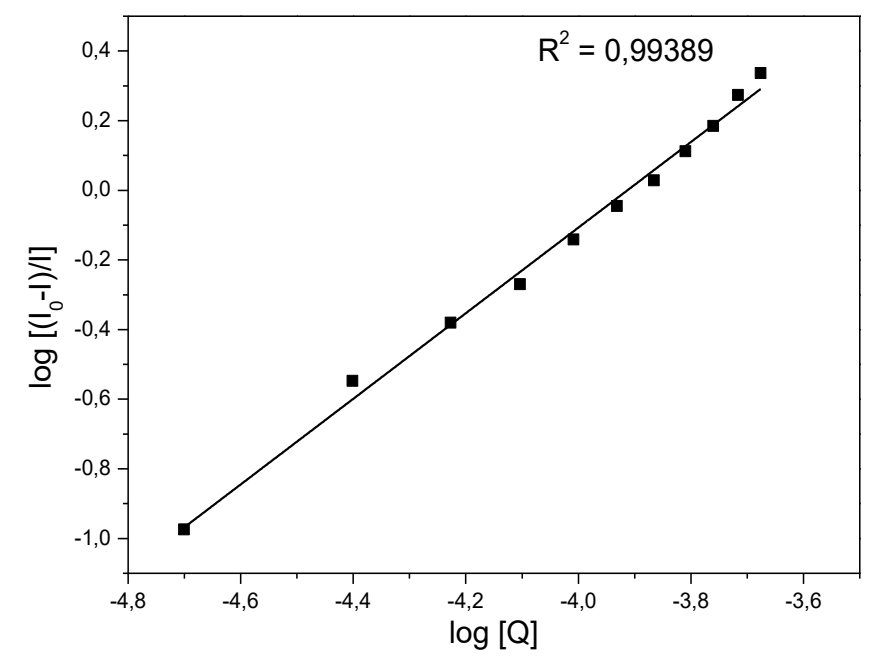

Fonte: Autora 
Figura 166: Espectros de emissão de fluorescência da HSA, na presença de diferentes concentrações de $\left[\mathrm{Ru}\left(\mathrm{NH}_{3}\right)_{4}(\text { catecol })\right]^{+}$, a $37^{\circ} \mathrm{C}$. Gráfico de Stern-Volmer inserido

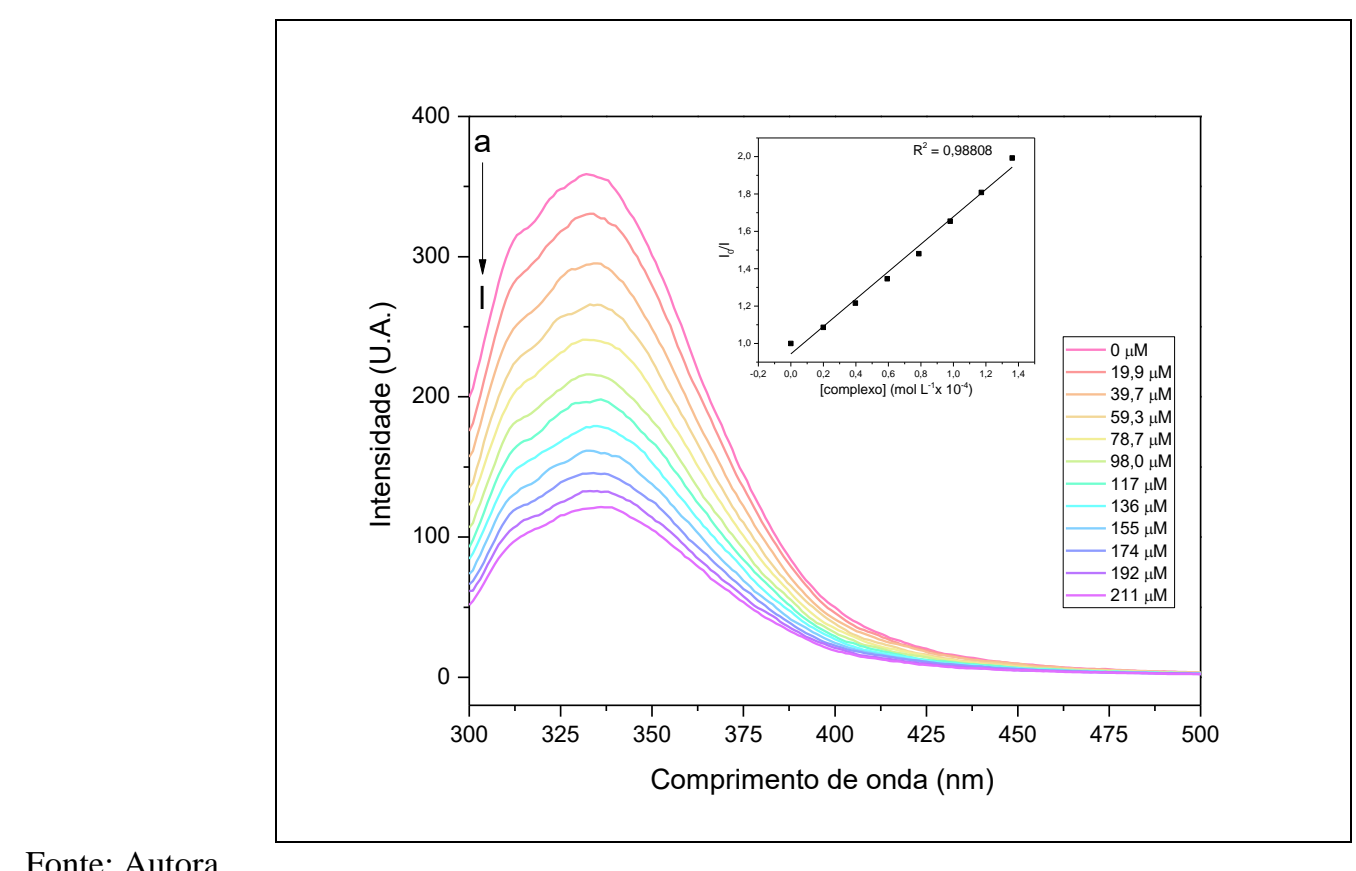

Figura 167: Gráfico da equação $\log \left[\left(\mathrm{I}_{0}-\mathrm{I}\right) / \mathrm{I}\right]=\log \mathrm{K}_{\mathrm{b}}+\mathrm{nlog}[\mathrm{Q}]$ referente à interação entre HSA e o complexo $\left[\mathrm{Ru}\left(\mathrm{NH}_{3}\right)_{4}(\text { catecol })\right]^{+},{\text {a } 37^{\circ} \mathrm{C}}^{-}$

Fonte: Autora

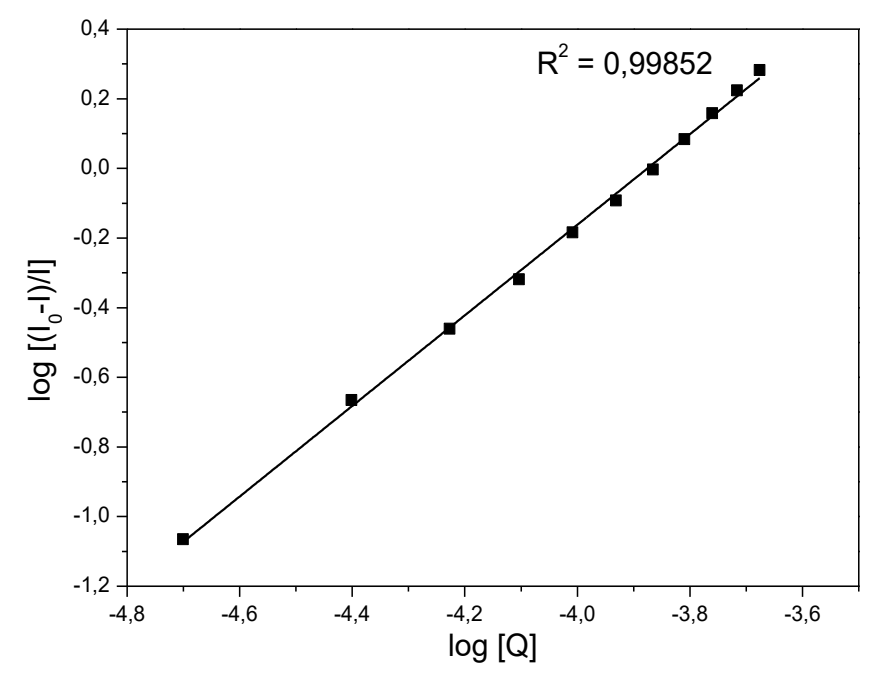


Figura 168: Espectros de emissão de fluorescência da HSA, na presença de diferentes concentrações de $\left[\mathrm{Ru}\left(\mathrm{NH}_{3}\right)_{4}(\text { adrenalina })\right]^{+}$, a $32^{\circ} \mathrm{C}$. Gráfico de Stern-Volmer inserido

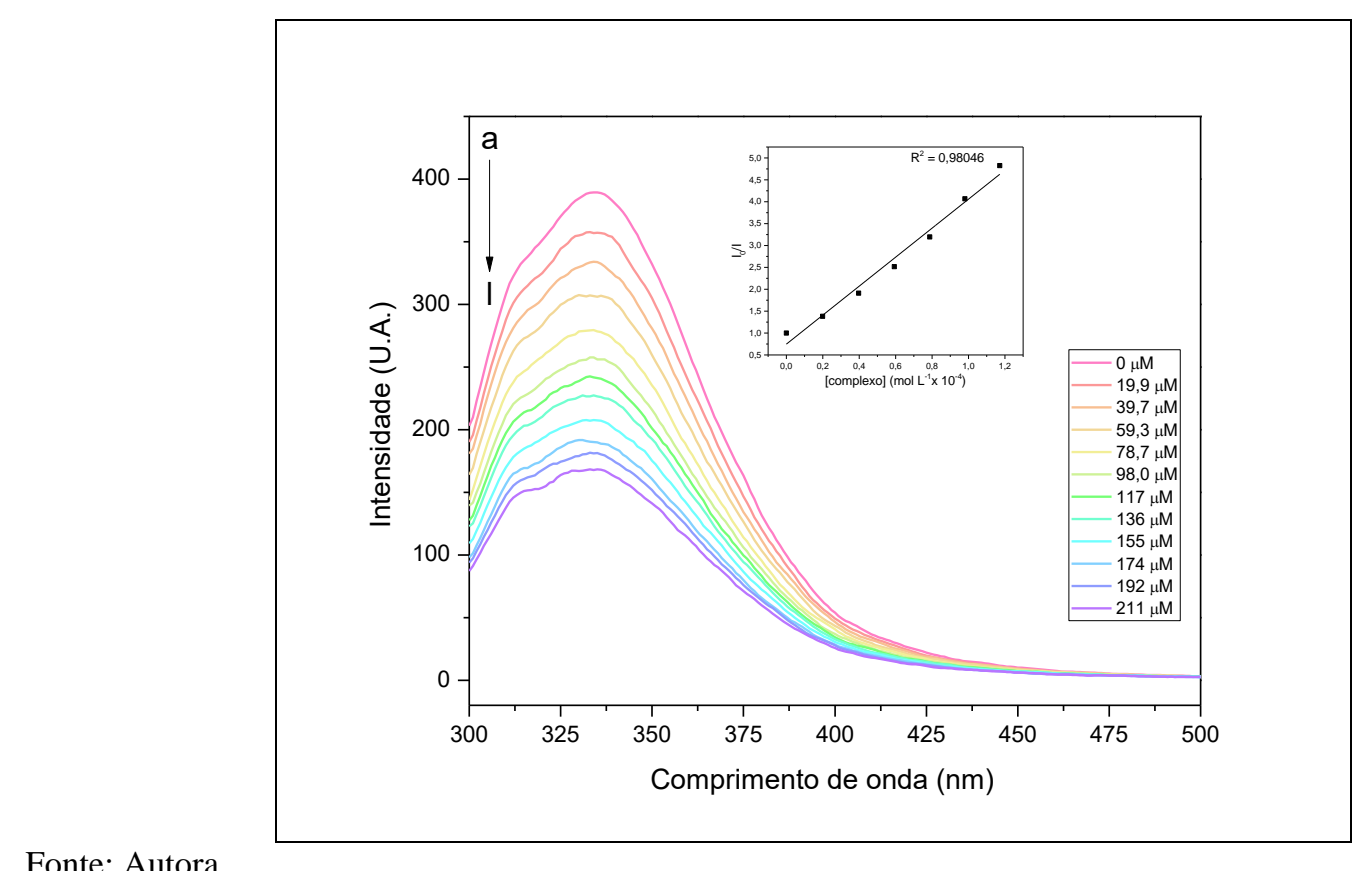

Figura 169: Gráfico da equação $\log \left[\left(\mathrm{I}_{0}-\mathrm{I}\right) / \mathrm{I}\right]=\log \mathrm{K}_{\mathrm{b}}+\mathrm{nlog}[\mathrm{Q}]$ referente à interação entre HSA e o complexo $\left[\mathrm{Ru}\left(\mathrm{NH}_{3}\right)_{4}(\text { adrenalina })\right]^{+},{\text {a } 32^{\circ} \mathrm{C}}^{-}$

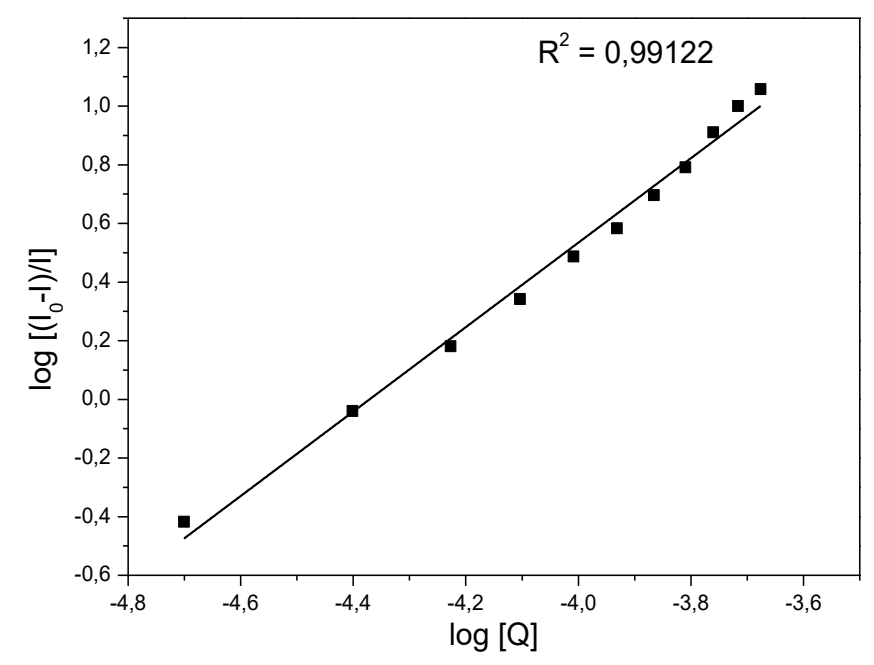

Fonte: Autora 
Figura 170: Espectros de emissão de fluorescência da HSA, na presença de diferentes concentrações de $\left[\mathrm{Ru}\left(\mathrm{NH}_{3}\right)_{4}(\text { adrenalina })\right]^{+}$, a $37^{\circ} \mathrm{C}$. Gráfico de Stern-Volmer inserido

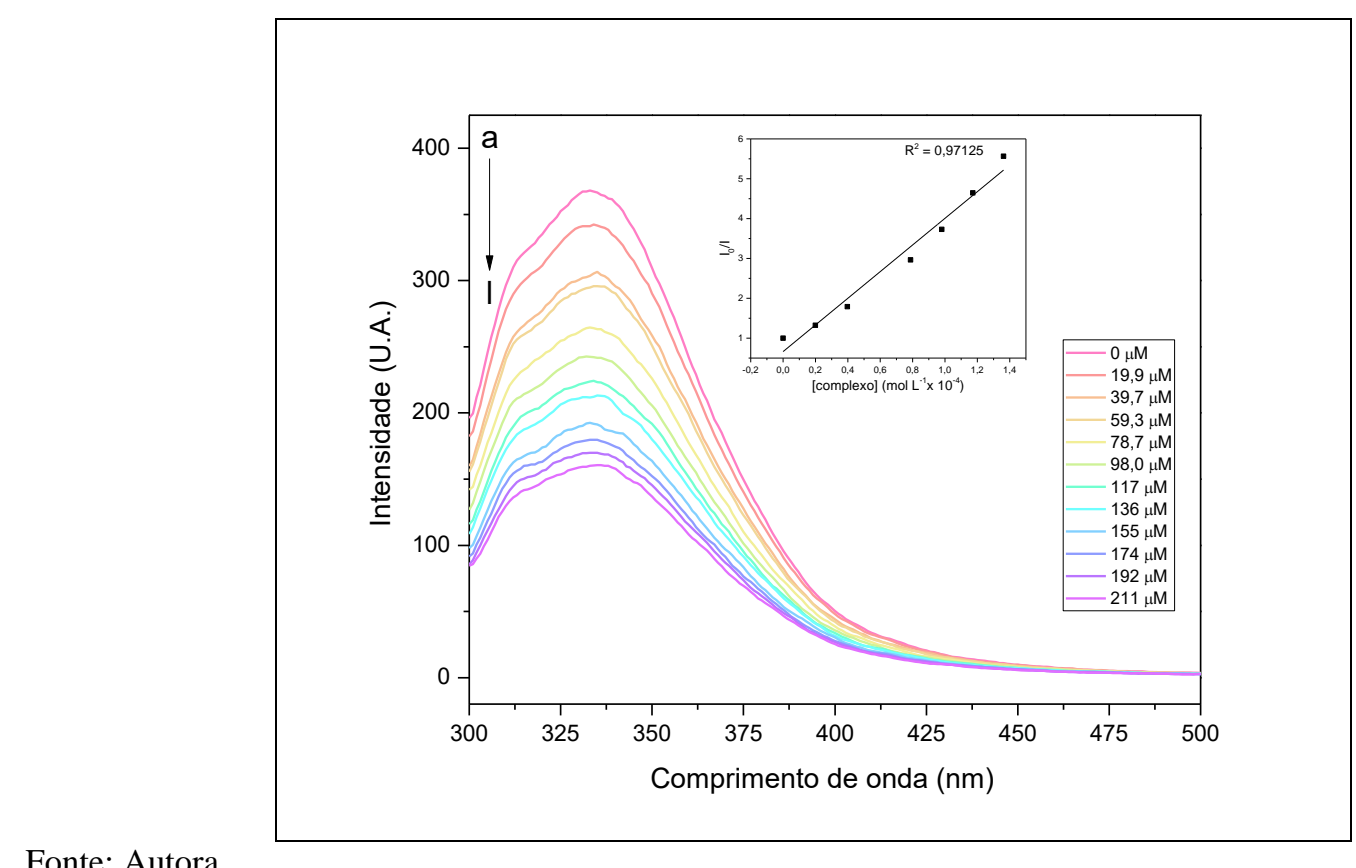

Fonte: Autora

Figura 171: Gráfico da equação $\log \left[\left(\mathrm{I}_{0}-\mathrm{I}\right) / \mathrm{I}\right]=\log \mathrm{K}_{\mathrm{b}}+\mathrm{n} \log [\mathrm{Q}]$ referente à interação entre HSA e o complexo $\left[\mathrm{Ru}\left(\mathrm{NH}_{3}\right)_{4}(\text { adrenalina })\right]^{+}$, a $37^{\circ} \mathrm{C}$

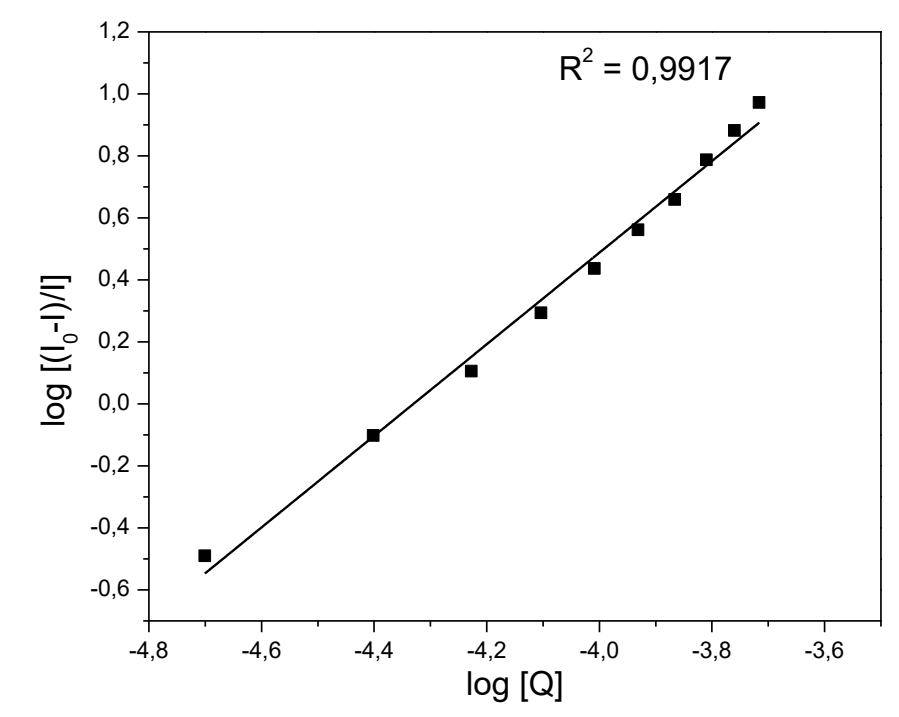

Fonte: Autora 


\subsection{Parte 2: Complexos com fórmula geral: [Ru(bpy) ${ }_{2}$ cat-R]Cl}

\subsubsection{Espectroscopia de absorção na região do infravermelho}

Figura 172: Espectro de absorção na região do infravermelho $\mathrm{RuCl}_{2}(\mathrm{bpy})_{2}$ (pastilha de $\mathrm{KBr}$ )

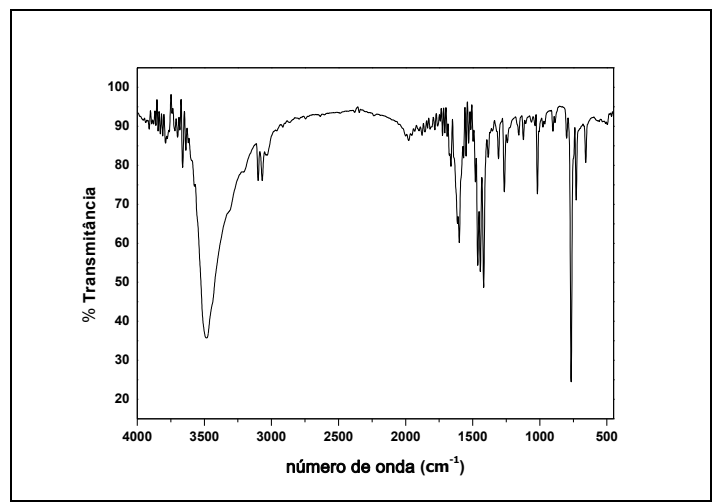

Fonte: Autora

\subsubsection{Interação com fs-DNA - titulação espectrofotométrica na região do $U V$-Vis}

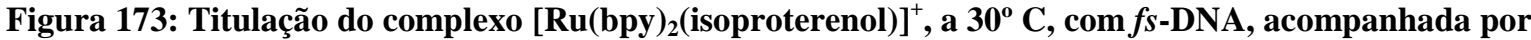
espectroscopia na região do UV-vis

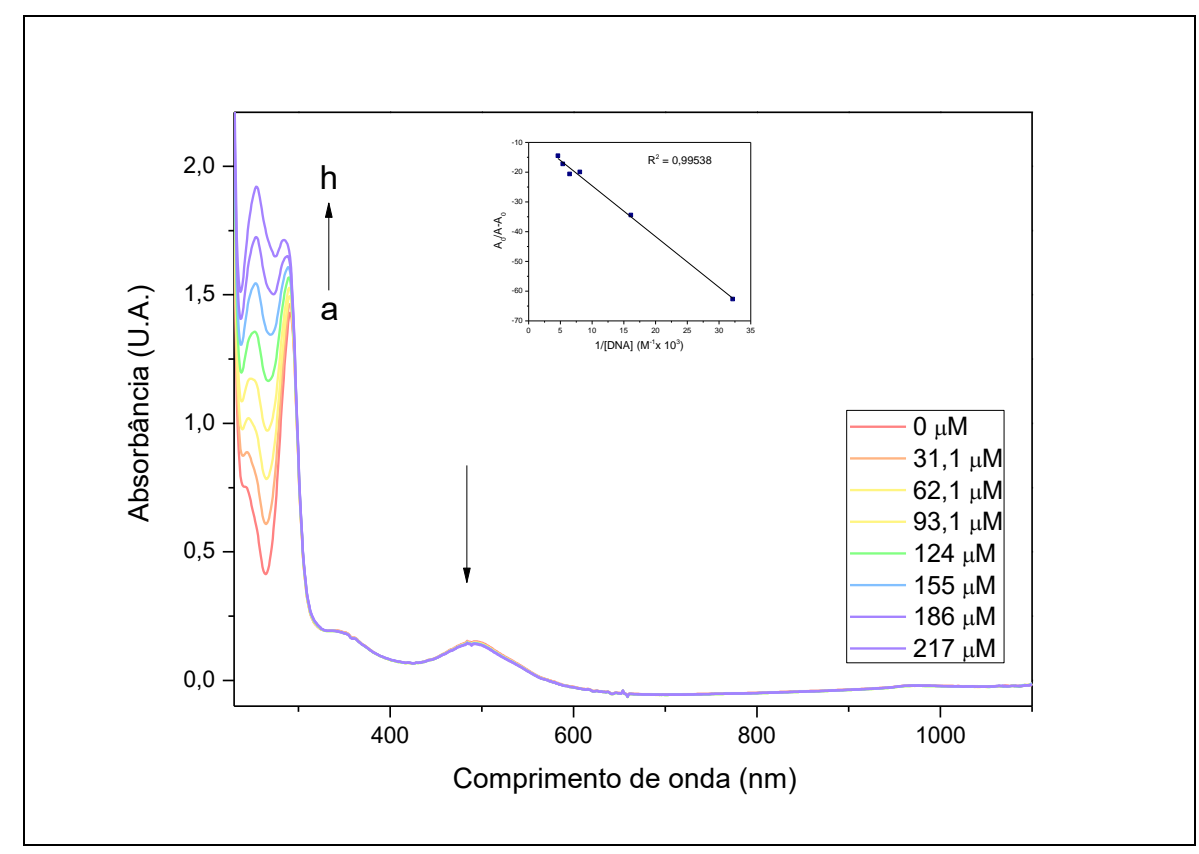

Fonte: Autora 
Figura 174: Titulação do complexo $\left[\operatorname{Ru}(b p y)_{2}(\text { isoproterenol })\right]^{+}, a^{\circ} \mathrm{C}, \operatorname{com} f s-\mathrm{DNA}, \operatorname{acompanhada}$ por espectroscopia na região do $\mathrm{UV}$-vis

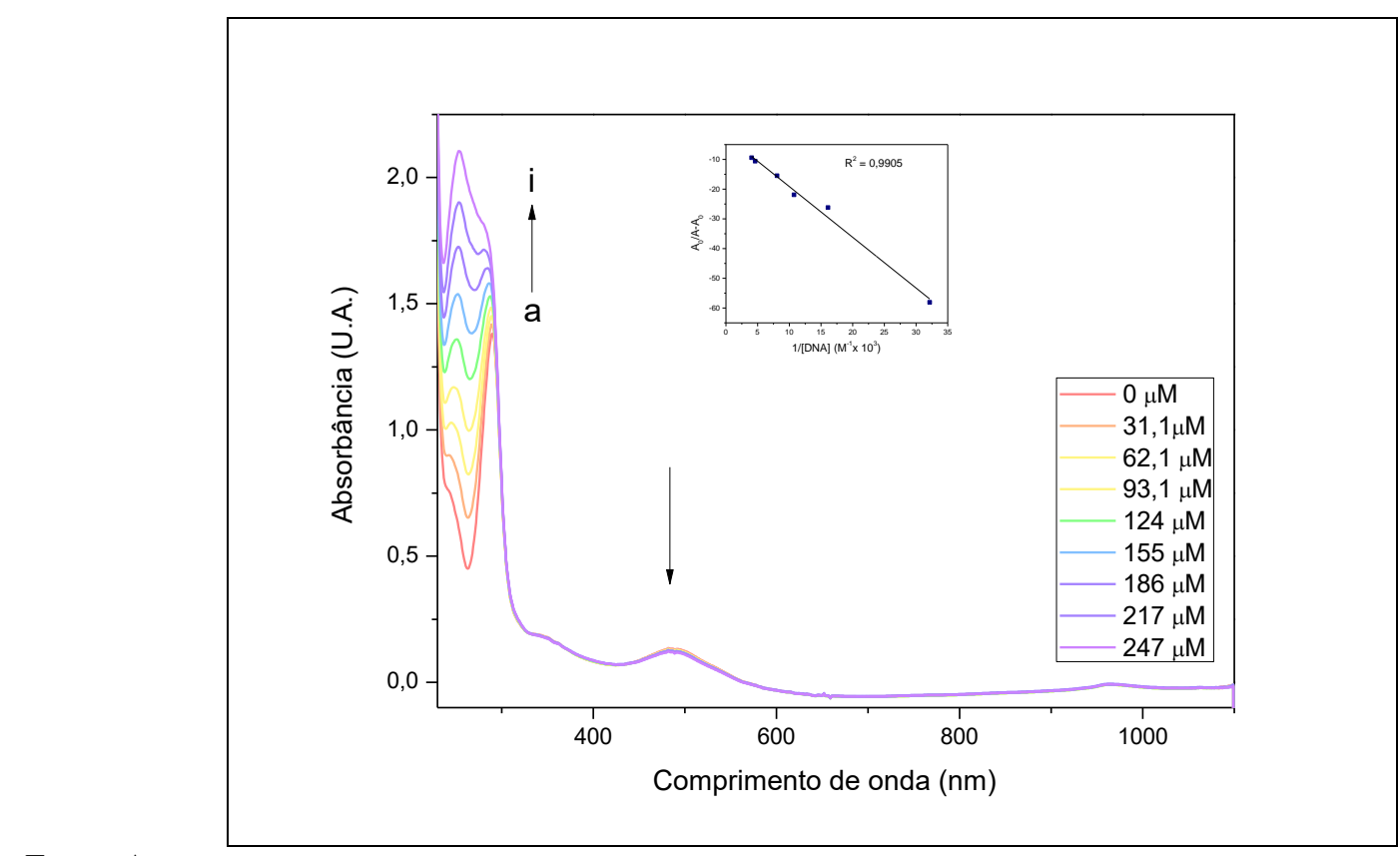

Fonte: Autora

Figura 175: Titulação do complexo $\left[\operatorname{Ru}(\operatorname{bpy})_{2}(\text { dopamina })\right]^{+}$, a $30^{\circ} \mathrm{C}, \operatorname{com} f s-\mathrm{DNA}$, acompanhada por espectroscopia na região do $\mathrm{UV}$-vis

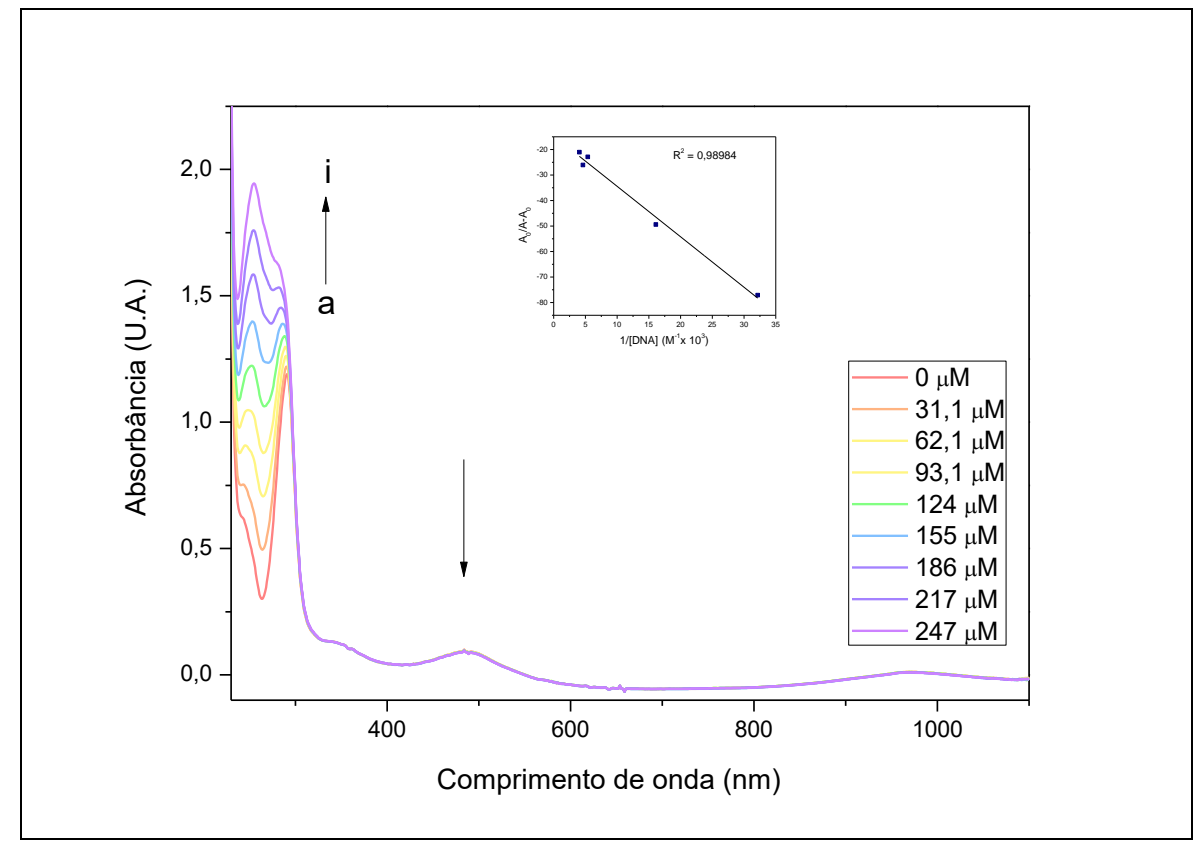

Fonte: Autora 
Figura 176: Titulação do complexo $\left[\operatorname{Ru}(\operatorname{bpy})_{2}(\operatorname{dopamina})\right]^{+}$, a $37^{\circ} \mathrm{C}, \operatorname{com} f s-\mathrm{DNA}$, acompanhada por espectroscopia na região do $\mathrm{UV}$-vis

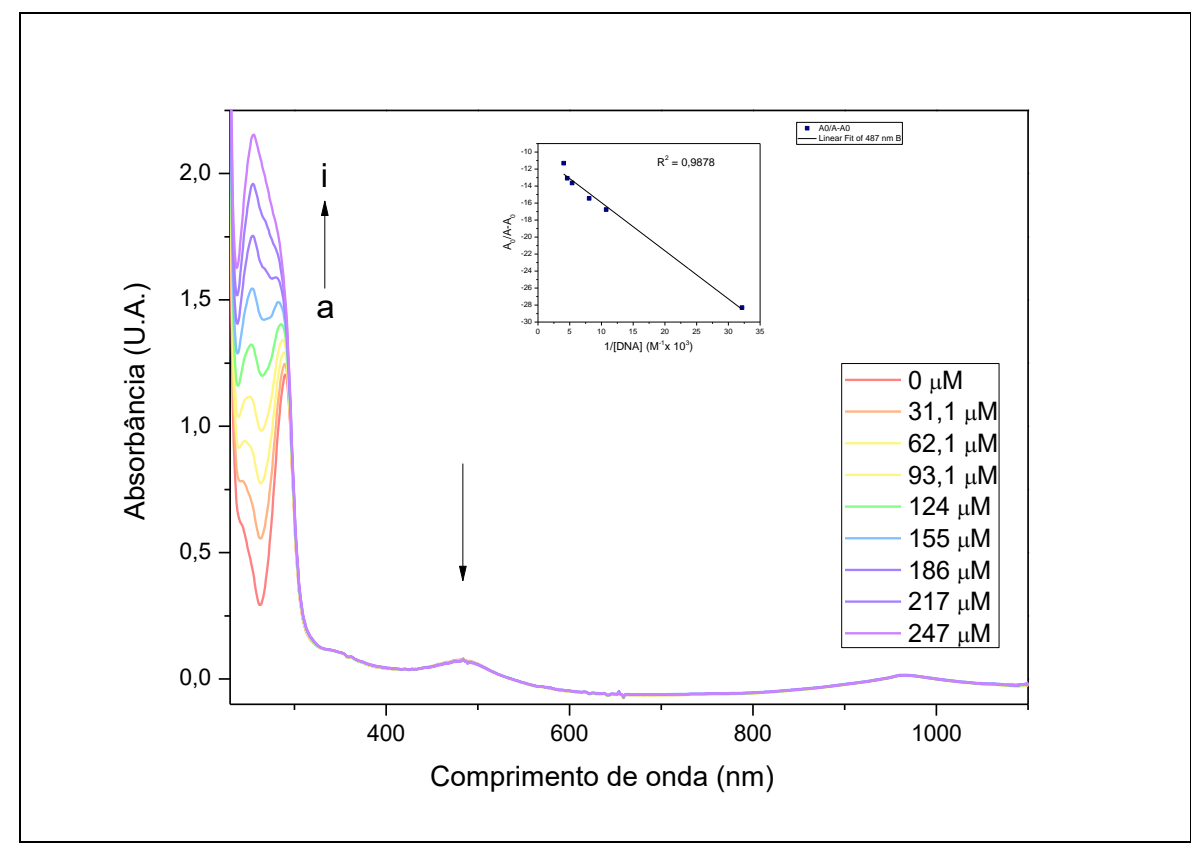

Fonte: Autora

Figura 177: Titulação do complexo $\left[\operatorname{Ru}(\text { bpy })_{2}(\text { noradrenalina })\right]^{+}, a^{3} 0^{\circ} \mathrm{C}, \operatorname{com} f s-\mathrm{DNA}, \operatorname{acompanhada}$ por espectroscopia na região do $\mathrm{UV}$-vis

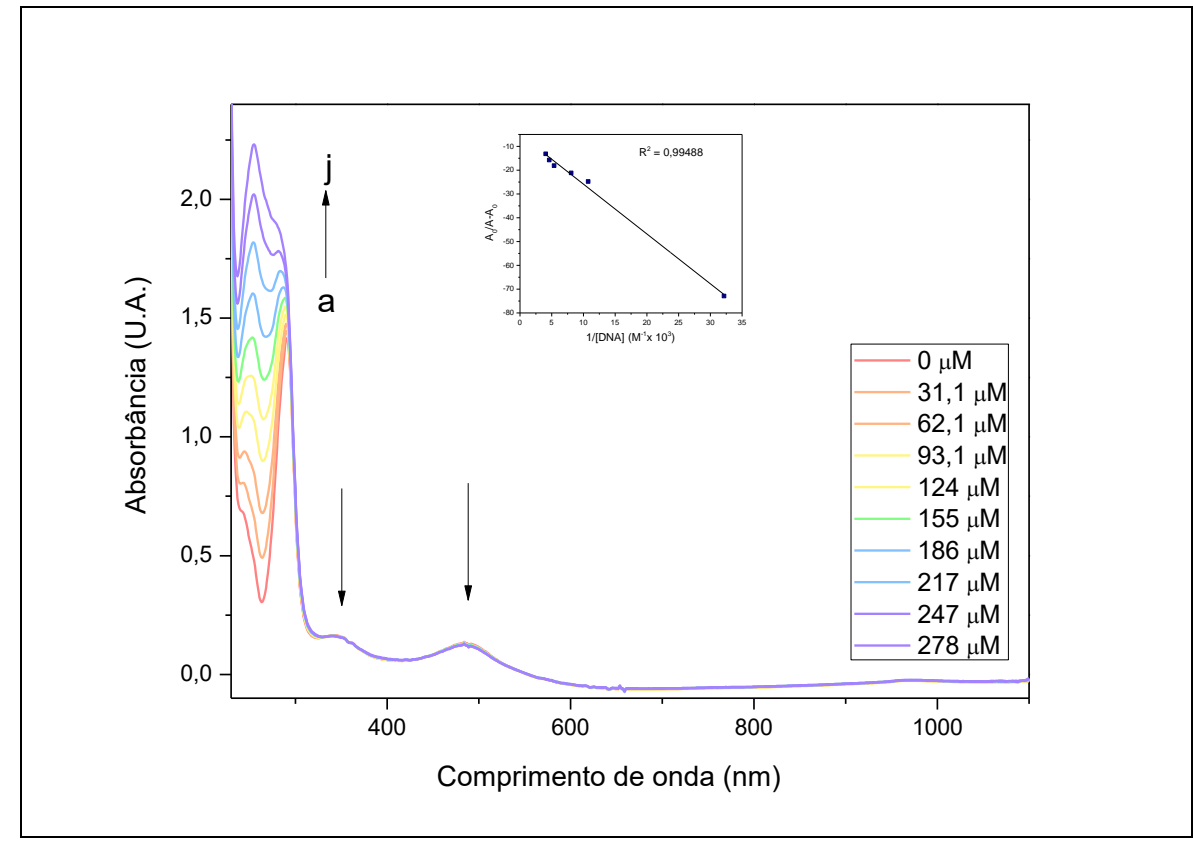

Fonte: Autora 
Figura 178: Titulação do complexo $\left[\operatorname{Ru}(\text { bpy })_{2}(\text { noradrenalina })\right]^{+}$, a $37^{\circ} \mathrm{C}, \operatorname{com} f s-\mathrm{DNA}$, acompanhada por espectroscopia na região do $\mathrm{UV}$-vis

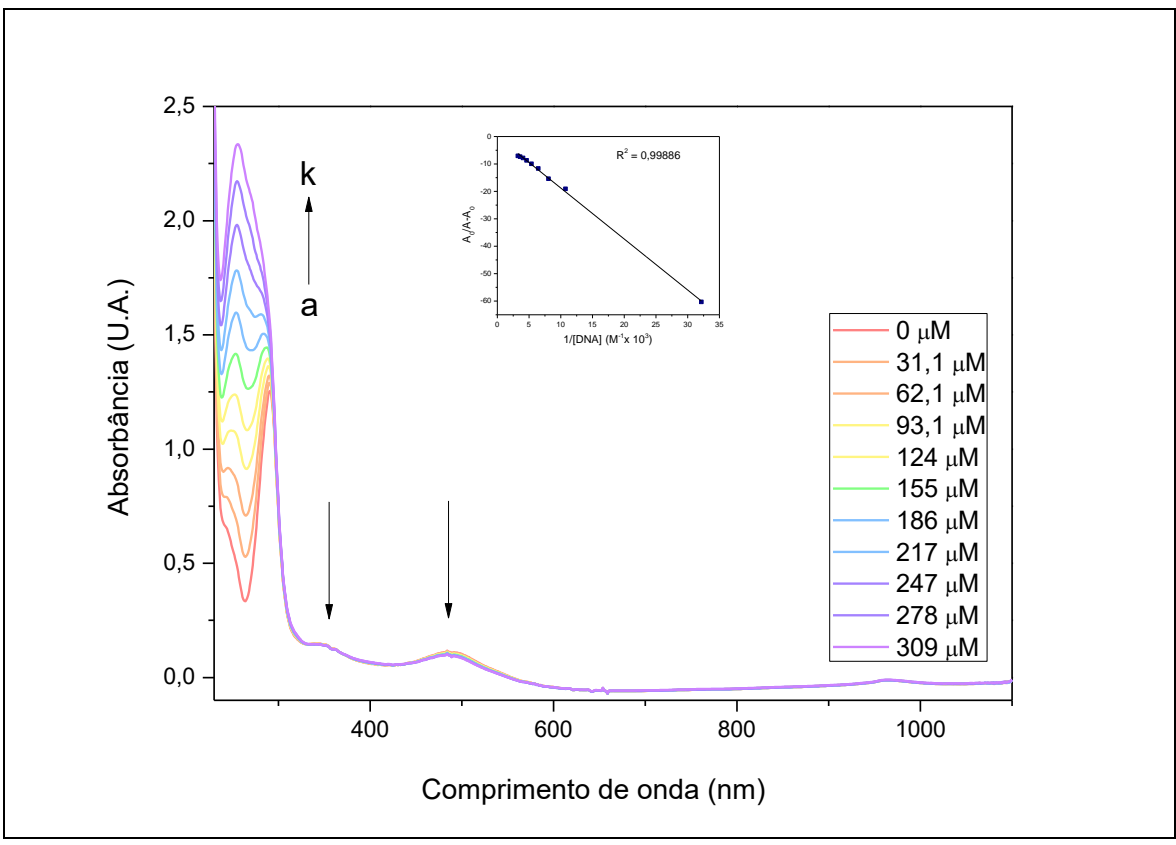

Fonte: Autora

Figura 179: Titulação do complexo $\left[\operatorname{Ru}(\operatorname{bpy})_{2}(\text { catecol })\right]^{+}$, a $30^{\circ} \mathrm{C}, \operatorname{com} f s-\mathrm{DNA}$, acompanhada por espectroscopia na região do $\mathrm{UV}$-vis

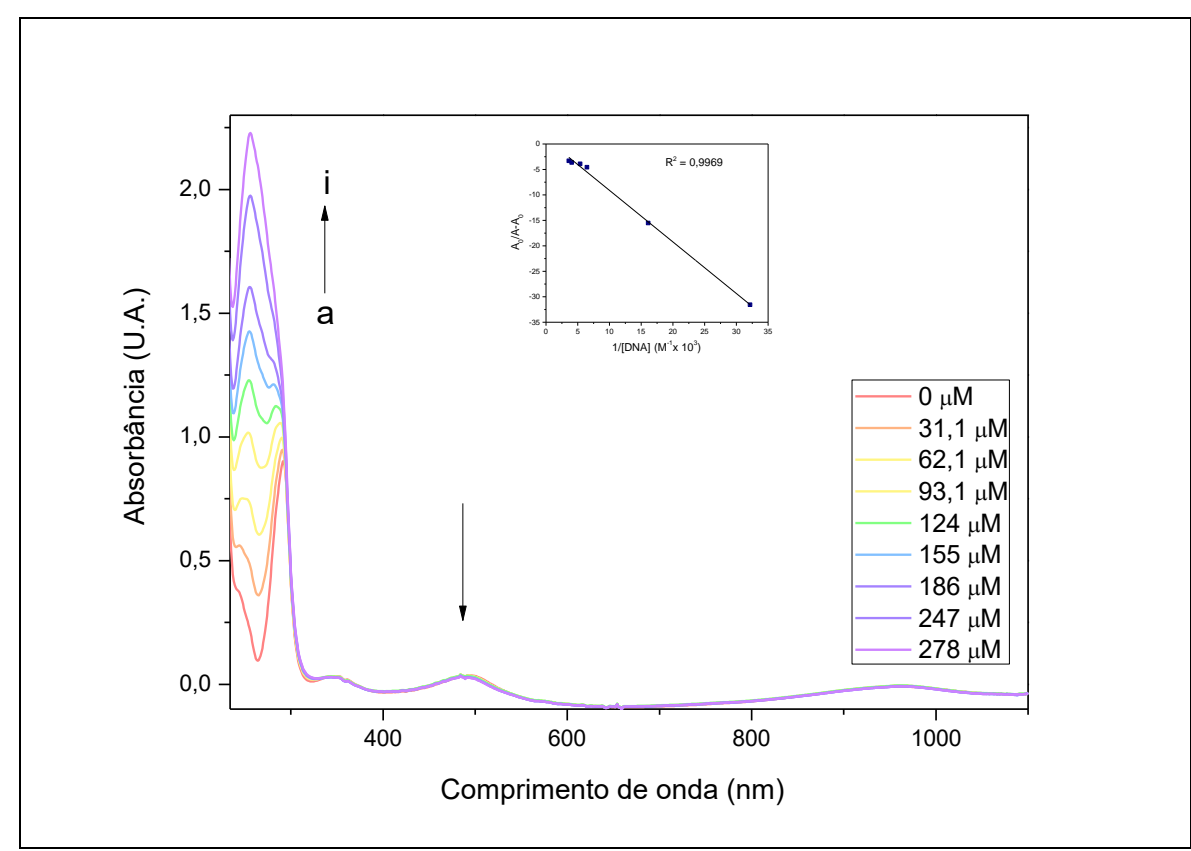

Fonte: Autora 
Figura 180: Titulação do complexo $\left[\operatorname{Ru}(b p y)_{2}(\text { catecol })\right]^{+}$, a $37^{\circ} \mathrm{C}, \operatorname{com} f s-\mathrm{DNA}$, acompanhada por espectroscopia na região do $\mathrm{UV}$-vis

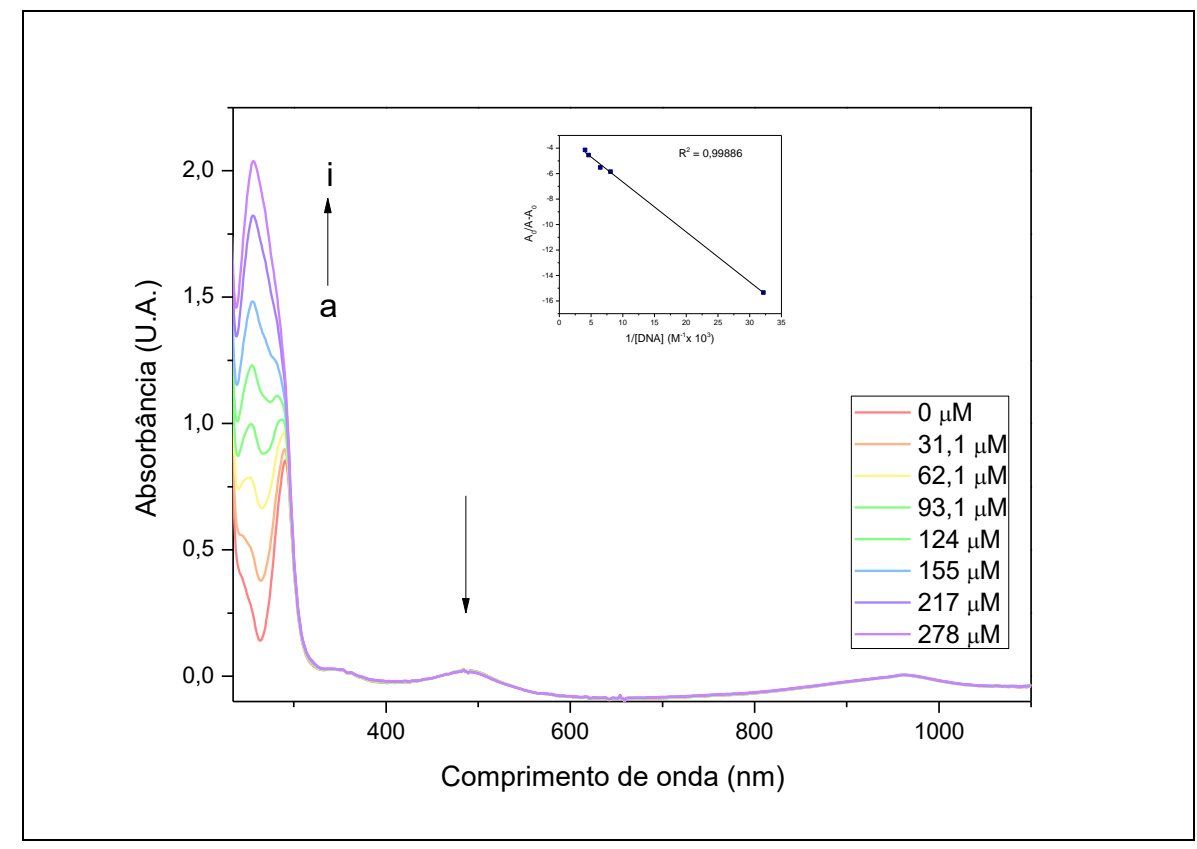

Fonte: Autora

Figura 181: Titulação do complexo $\left[\operatorname{Ru}(b p y)_{2}(\operatorname{adrenalina})\right]^{+}$, a $30^{\circ} \mathrm{C}, \operatorname{com} f s-\mathrm{DNA}$, acompanhada por espectroscopia na região do $\mathrm{UV}$-vis

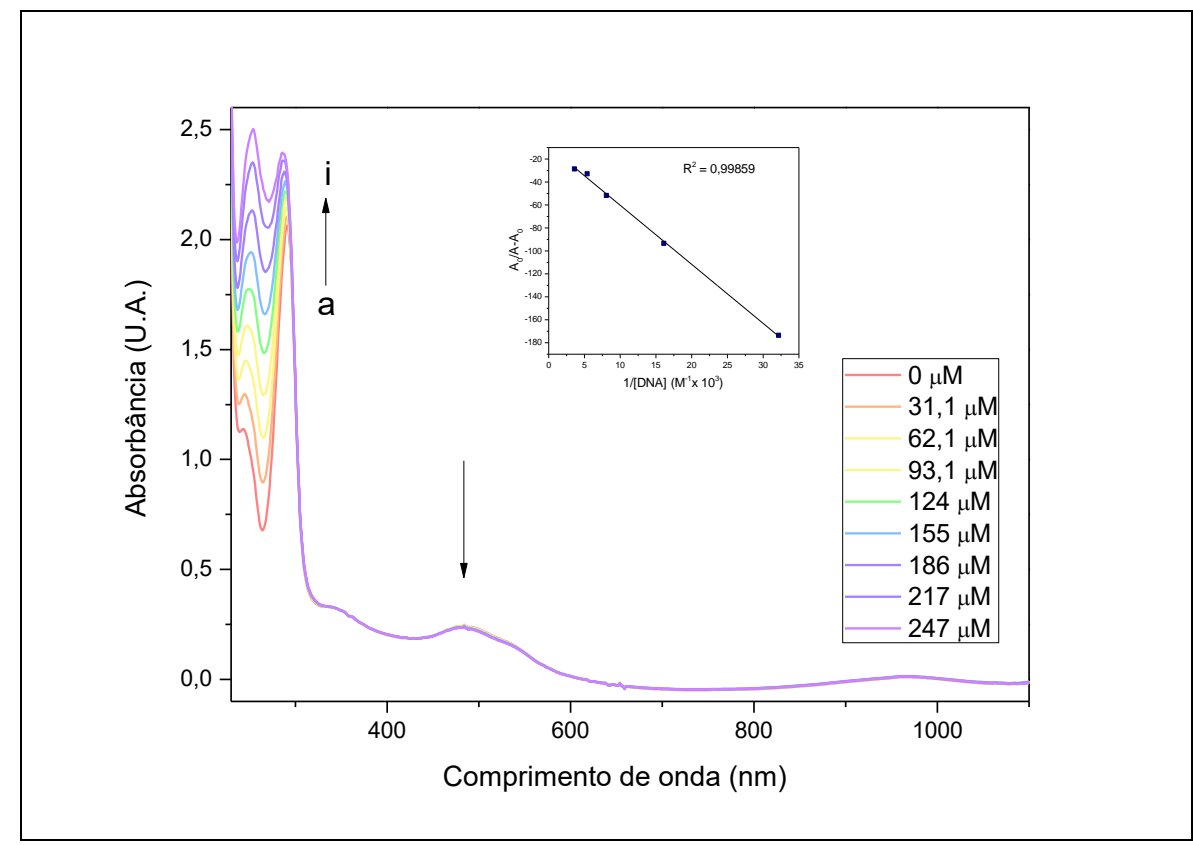

Fonte: Autora 
Figura 182: Titulação do complexo $\left[\operatorname{Ru}(\text { bpy })_{2}(\text { adrenalina })\right]^{+}$, a $37^{\circ} \mathrm{C}, \operatorname{com} f s-D N A$, acompanhada por espectroscopia na região do $\mathrm{UV}$-vis

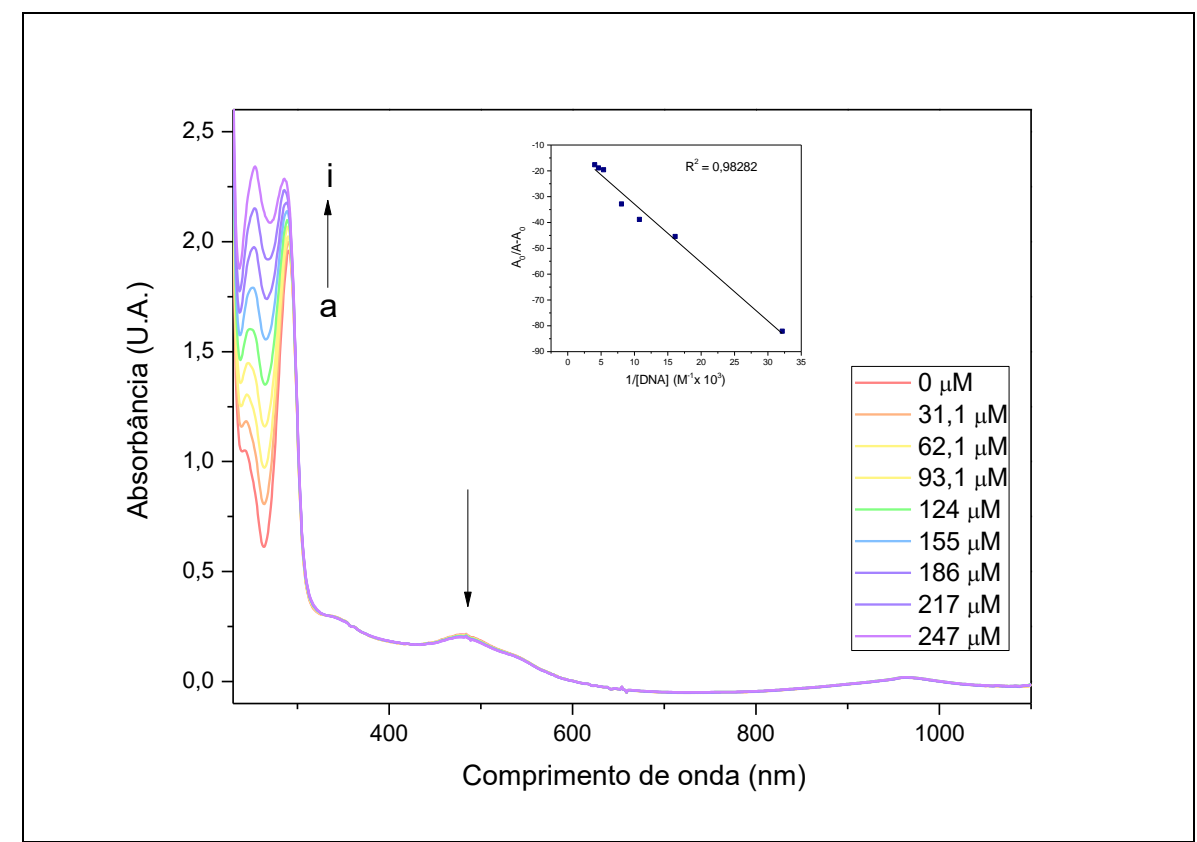

Fonte: Autora 


\subsubsection{Interação com proteína carreadora (HSA) - mimetizando transporte in vivo}

Figura 183: Espectros de emissão de fluorescência da HSA, na presença de diferentes concentrações de $\left[\operatorname{Ru}(\mathbf{b p y})_{2}(\text { isoproterenol })\right]^{+}$, a $32^{\circ} \mathrm{C}$. Gráfico de Stern-Volmer inserido

Fonte: Autora

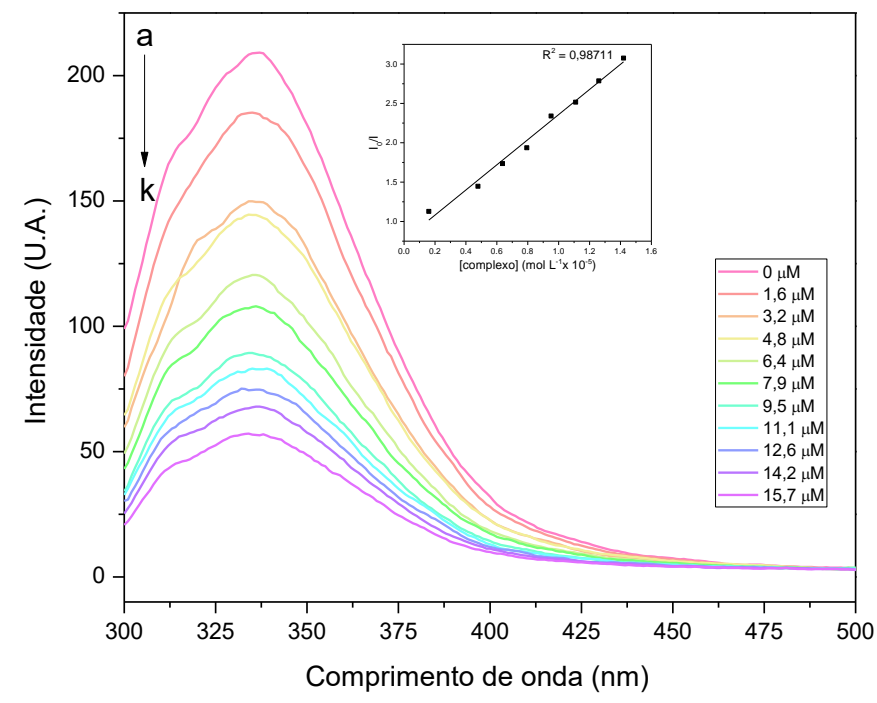

Figura 184: Gráfico da equação $\log \left[\left(I_{0}-I\right) / I\right]=\log K_{b}+n \log [Q]$ referente à interação entre HSA e o complexo $\left[\mathbf{R u}(\text { bpy })_{2}(\text { isoproterenol })\right]^{+}$, a $32^{\circ} \mathrm{C}$

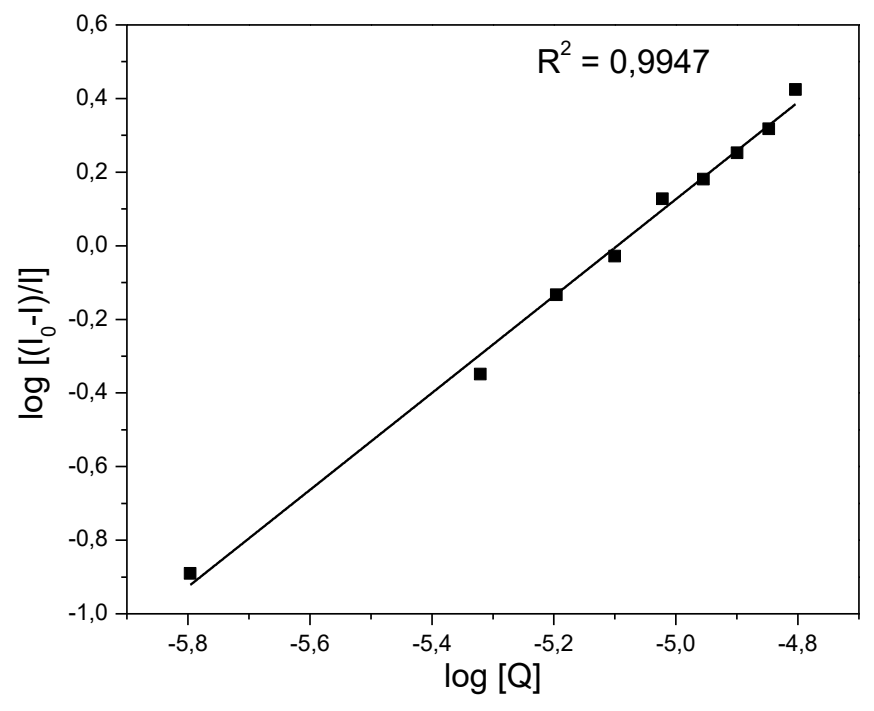

Fonte: Autora 
Figura 185: Espectros de emissão de fluorescência da HSA, na presença de diferentes concentrações de $\left[\operatorname{Ru}(\text { bpy })_{2}(\text { isoproterenol })\right]^{+}$, a $38^{\circ}$ C. Gráfico de Stern-Volmer inserido

Fonte: Autora

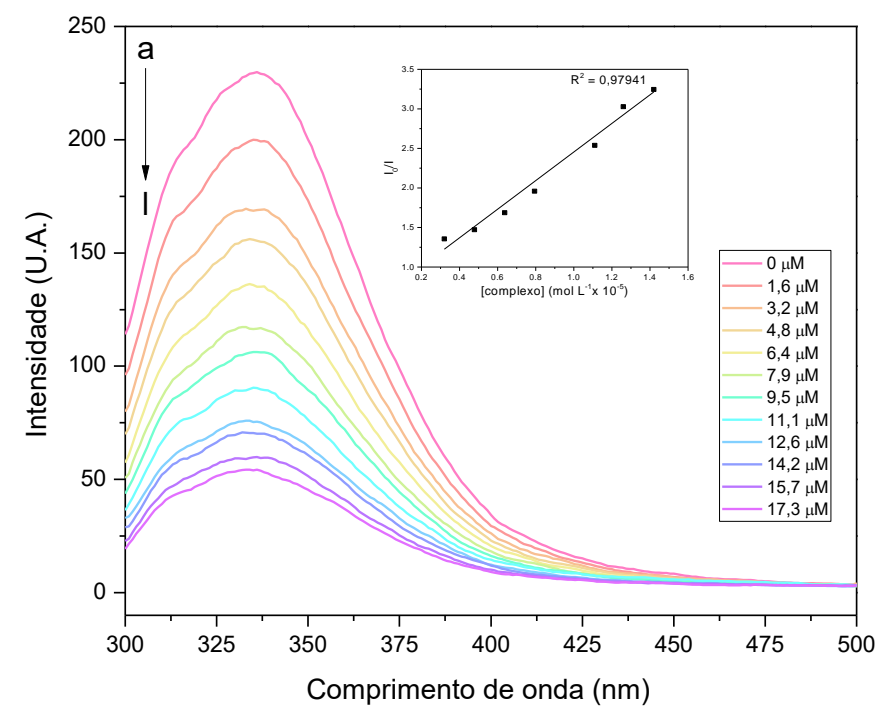

Figura 186: Gráfico da equação $\log \left[\left(\mathrm{I}_{0}-\mathrm{I}\right) / \mathrm{I}\right]=\log \mathrm{K}_{\mathrm{b}}+n \log [Q]$ referente à interação entre HSA e o complexo $\left[\mathbf{R u}(\text { bpy })_{2}(\text { isoproterenol })\right]^{+}$, a $38^{\circ} \mathrm{C}$

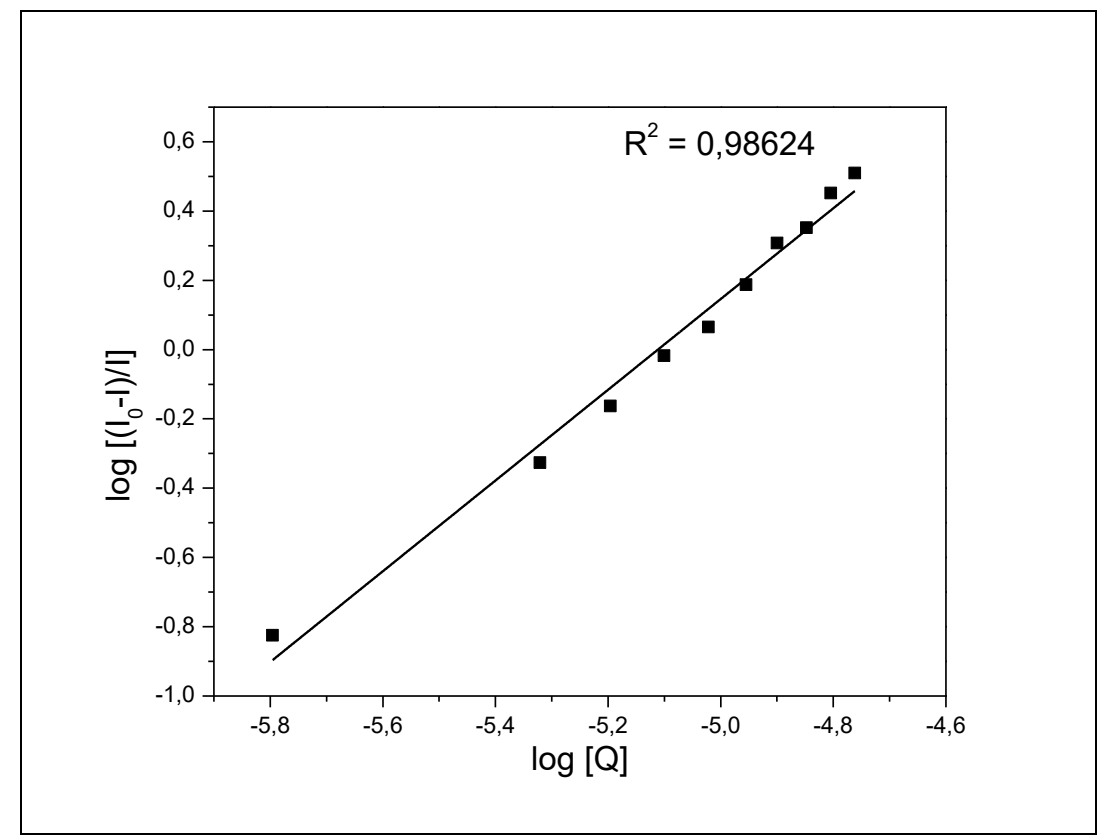

Fonte: Autora 
Figura 187: Espectros de emissão de fluorescência da HSA, na presença de diferentes concentrações de $\left[\operatorname{Ru}(\text { bpy })_{2}(\text { dopamina })\right]^{+}$, a $32^{\circ}$ C. Gráfico de Stern-Volmer inserido

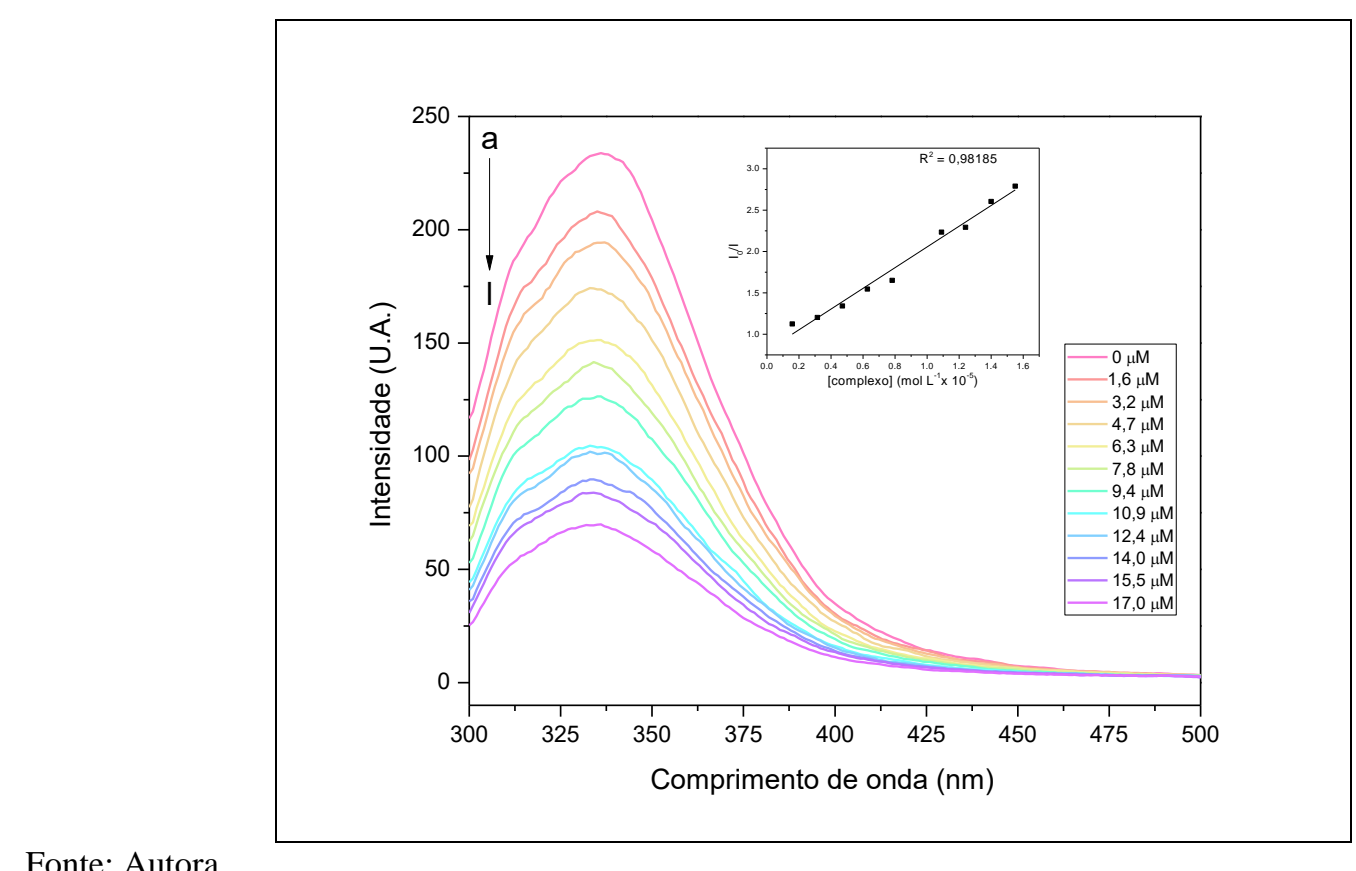

Figura 188: Gráfico da equação $\log \left[\left(I_{0}-I\right) / I\right]=\log K_{b}+n \log [Q]$ referente à interação entre HSA e o

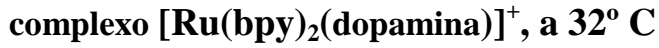

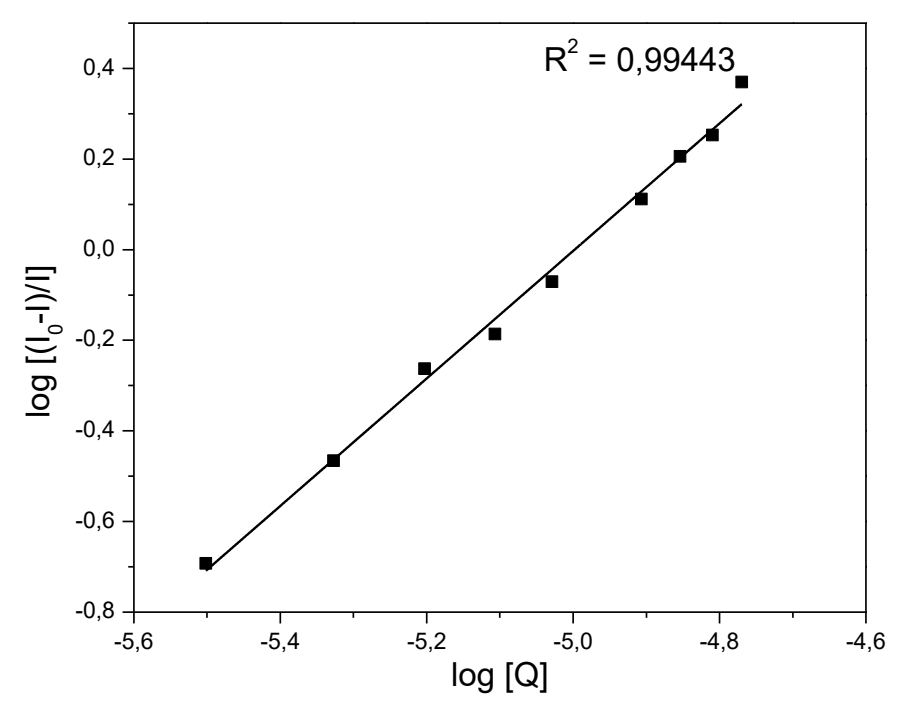


Figura 189: Espectros de emissão de fluorescência da HSA, na presença de diferentes concentrações de $\left[\operatorname{Ru}(\text { bpy })_{2}(\text { dopamina })\right]^{+}$, a $38^{\circ}$ C. Gráfico de Stern-Volmer inserido

Fonte: Autora

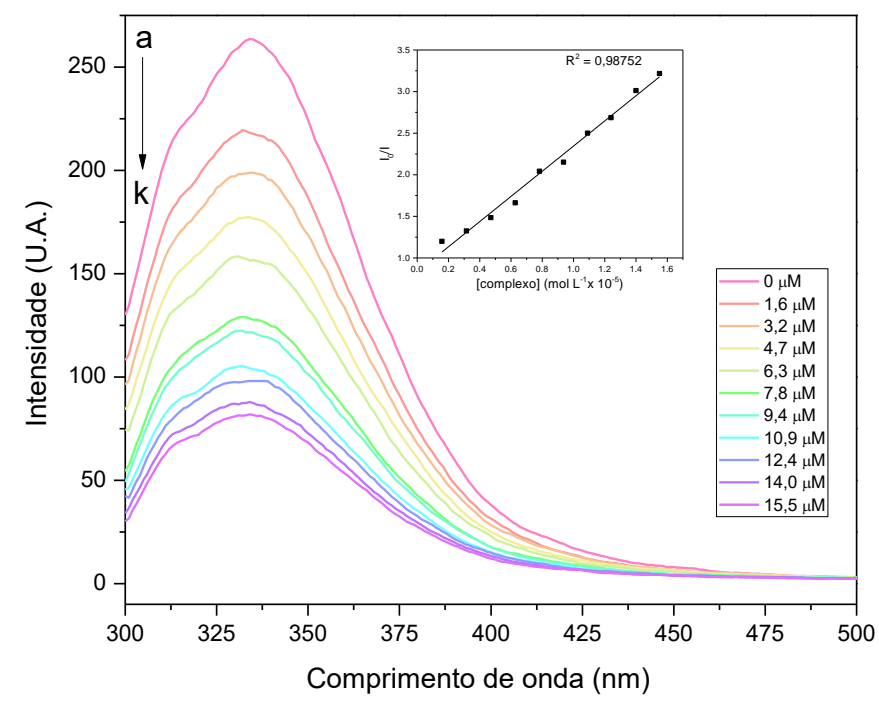

Figura 190: Gráfico da equação $\log \left[\left(\mathrm{I}_{0}-\mathrm{I}\right) / \mathrm{I}\right]=\log \mathrm{K}_{\mathrm{b}}+n \log [Q]$ referente à interação entre HSA e o complexo $\left[\operatorname{Ru}(\text { bpy })_{2}(\text { dopamina })\right]^{+},{\mathbf{a ~} 38^{\circ} \mathrm{C}}^{\circ}$

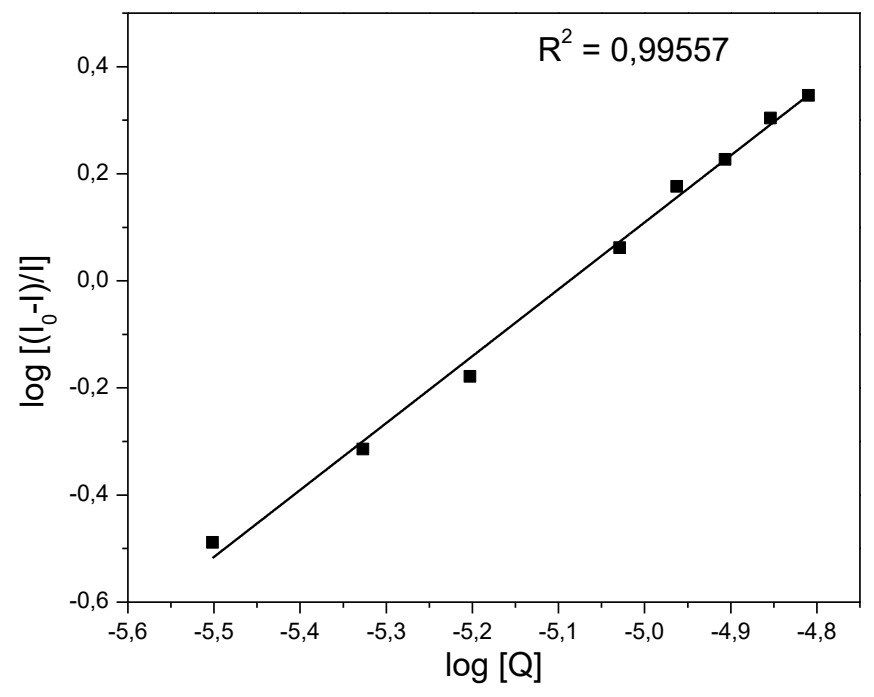

Fonte: Autora 
Figura 191: Espectros de emissão de fluorescência da HSA, na presença de diferentes concentrações de $\left[\operatorname{Ru}(\text { bpy })_{2}(\text { noradrenalina })\right]^{+}$, a $32^{\circ}$ C. Gráfico de Stern-Volmer inserido

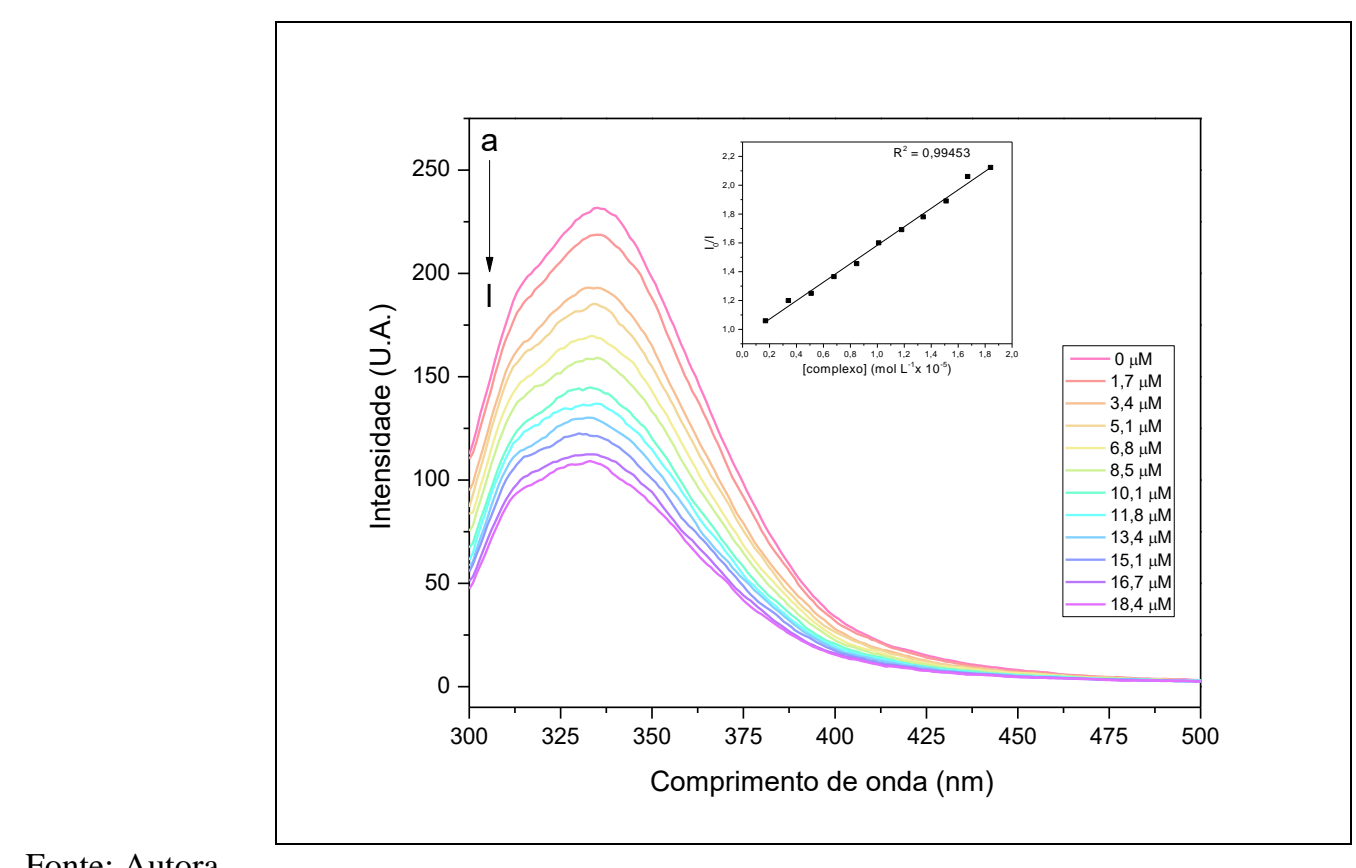

Figura 192: Gráfico da equação $\log \left[\left(I_{0}-I\right) / I\right]=\log K_{b}+n \log [Q]$ referente à interação entre HSA e o complexo $\left[\operatorname{Ru}(\text { bpy })_{2}(\text { noradrenalina })\right]^{+}, a^{3} 2^{\circ} \mathrm{C}$

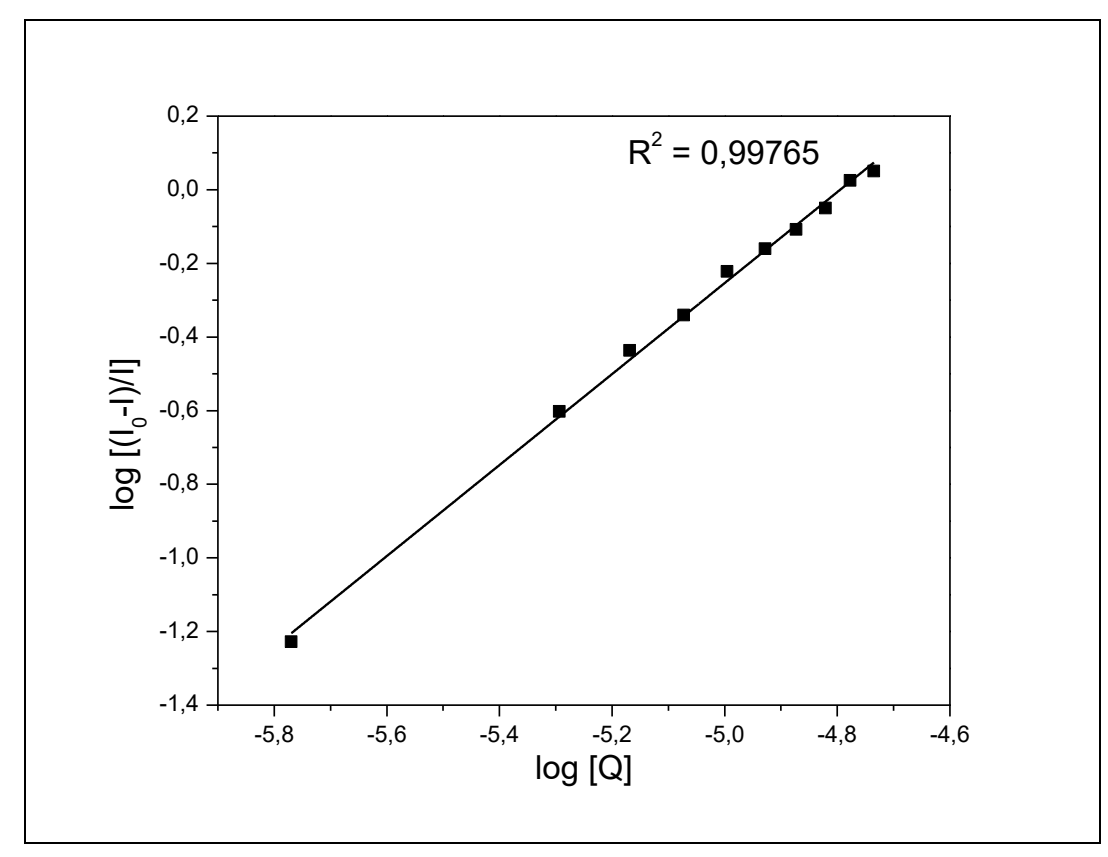

Fonte: Autora 
Figura 193: Espectros de emissão de fluorescência da HSA, na presença de diferentes concentrações de $\left[\operatorname{Ru}(\text { bpy })_{2}(\text { noradrenalina })\right]^{+}$, a $38^{\circ}$ C. Gráfico de Stern-Volmer inserido

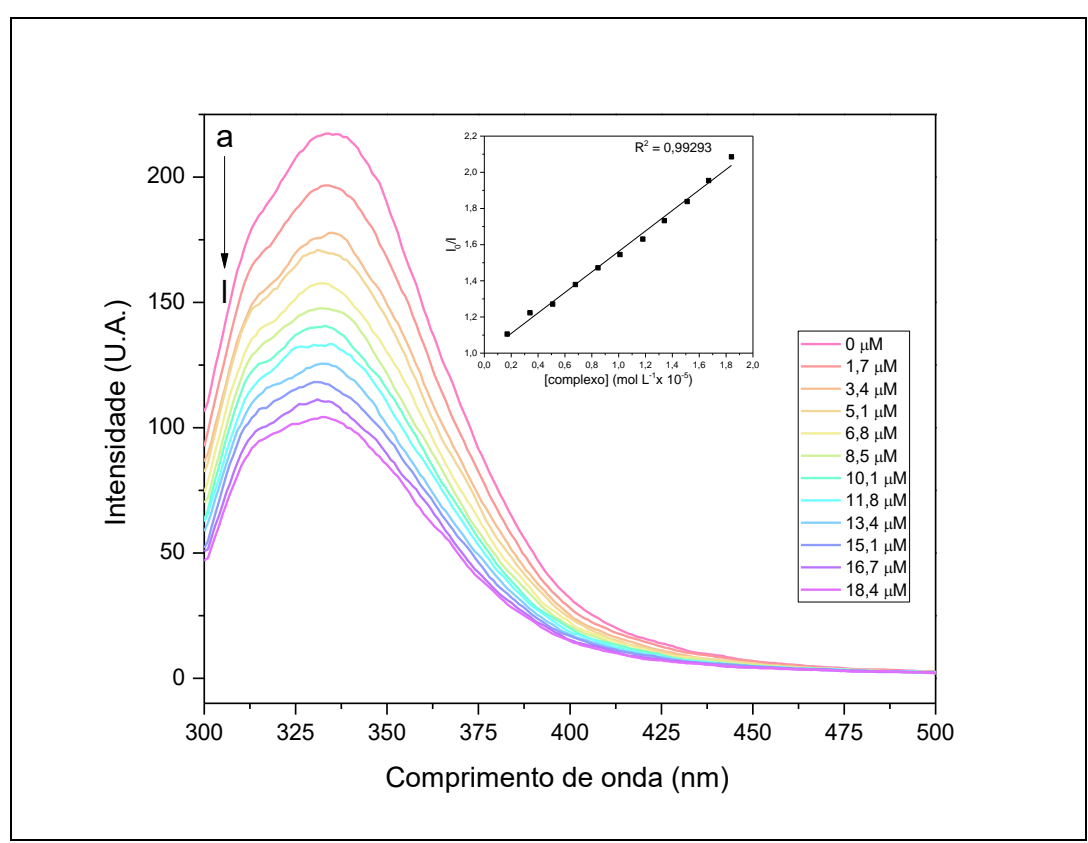

Fonte: Autora

Figura 194: Gráfico da equação $\log \left[\left(I_{0}-I\right) / I\right]=\log K_{b}+n \log [Q]$ referente à interação entre HSA e o complexo $\left[\operatorname{Ru}(b p y)_{2}(\text { noradrenalina })\right]^{+},{\text {a } 38^{\circ} \mathrm{C}}^{\circ}$

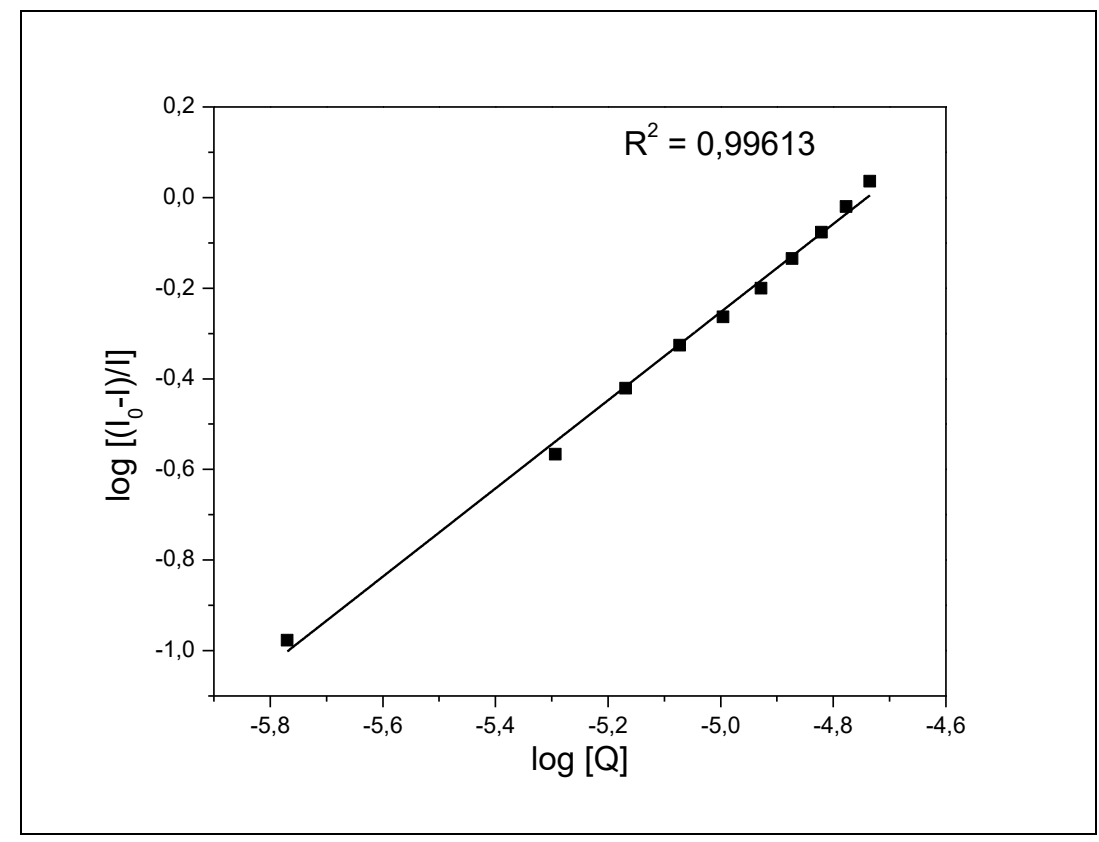

Fonte: Autora 
Figura 195: Espectros de emissão de fluorescência da HSA, na presença de diferentes concentrações de $\left[\operatorname{Ru}(\text { bpy })_{2}(\text { catecol })\right]^{+}$, a $32^{\circ}$ C. Gráfico de Stern-Volmer inserido

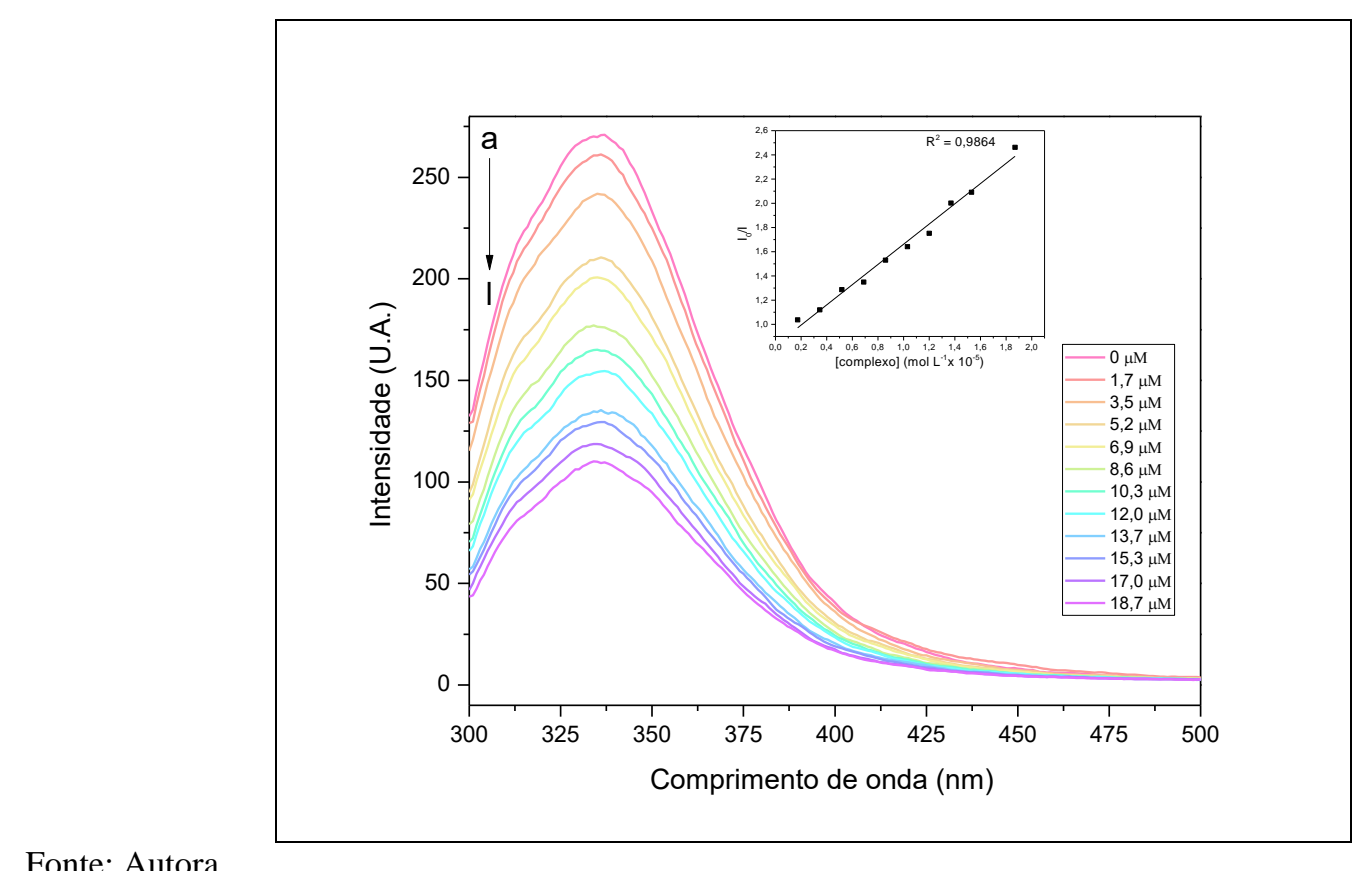

Figura 196: Gráfico da equação $\log \left[\left(I_{0}-I\right) / I\right]=\log K_{b}+n \log [Q]$ referente à interação entre HSA e o complexo $\left[\operatorname{Ru}(\text { bpy })_{2}(\text { catecol })\right]^{+}, a^{3} 2^{\circ} \mathrm{C}$

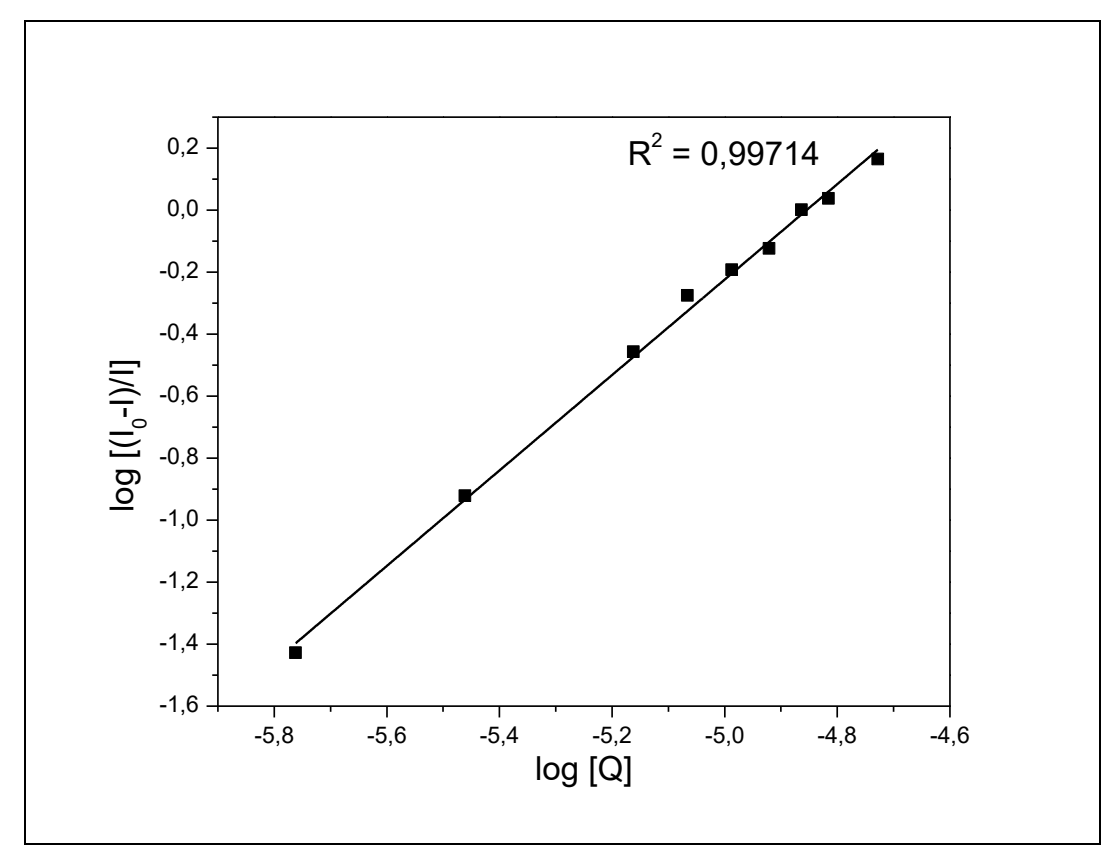

Fonte: Autora 
Figura 197: Espectros de emissão de fluorescência da HSA, na presença de diferentes concentrações de $\left[\operatorname{Ru}(\text { bpy })_{2}(\text { catecol })\right]^{+}$, a $38^{\circ}$ C. Gráfico de Stern-Volmer inserido

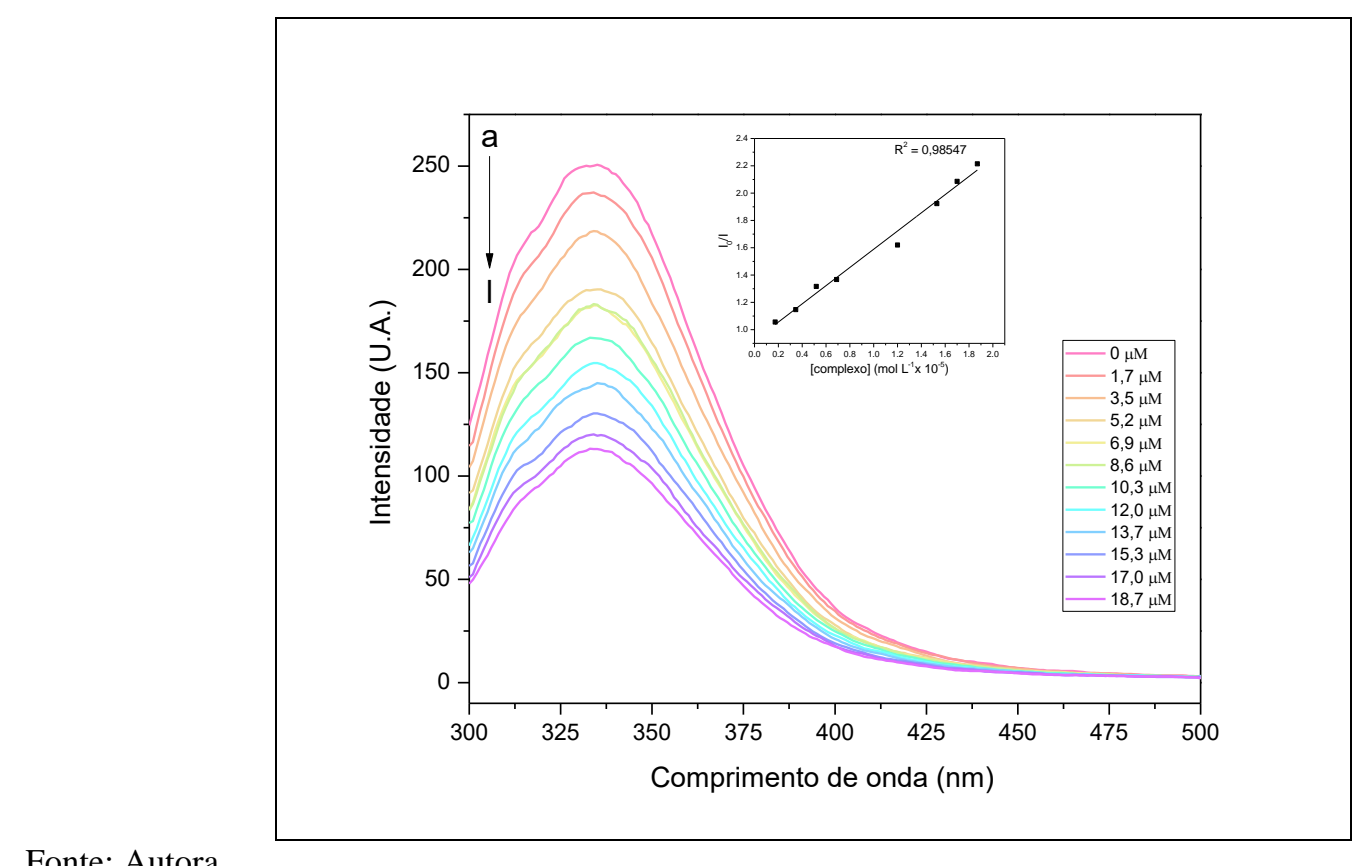

Figura 198: Gráfico da equação $\log \left[\left(I_{0}-I\right) / I\right]=\log K_{b}+n \log [Q]$ referente à interação entre HSA e o complexo $\left[\operatorname{Ru}(\text { bpy })_{2}(\text { catecol })\right]^{+}, a^{3} 38^{\circ} \mathrm{C}$

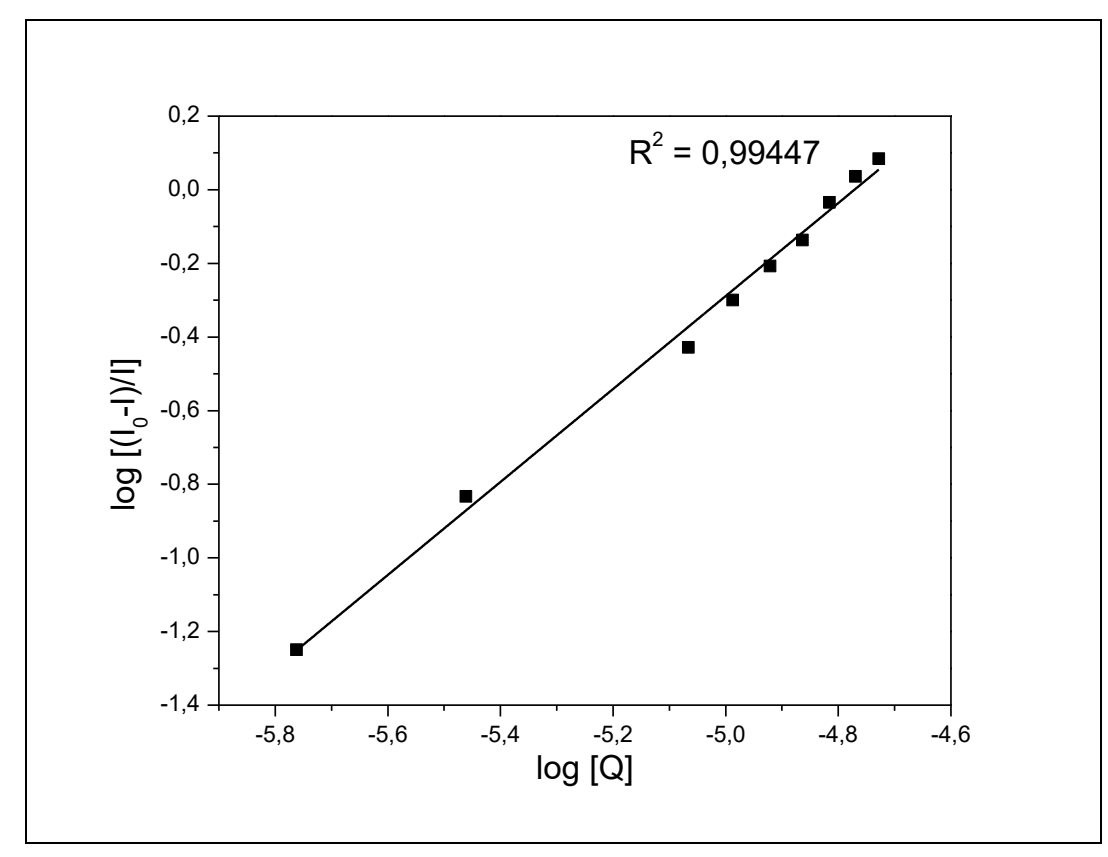

Fonte: Autora 
Figura 199: Espectros de emissão de fluorescência da HSA, na presença de diferentes concentrações de $\left[\operatorname{Ru}(\text { bpy })_{2}(\text { adrenalina })\right]^{+}$, a $32^{\circ}$ C. Gráfico de Stern-Volmer inserido

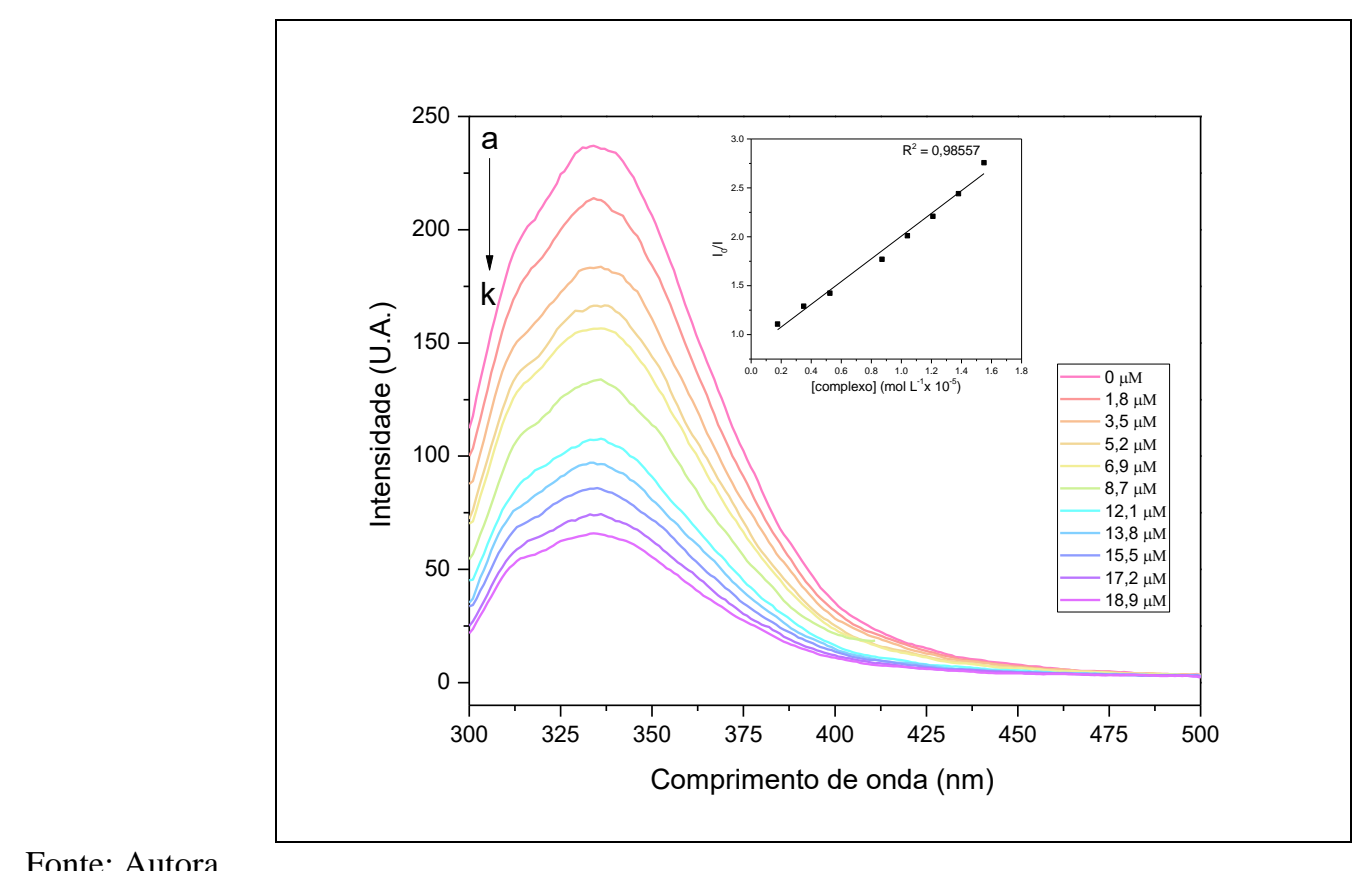

Figura 200: Gráfico da equação $\log \left[\left(\mathrm{I}_{0}-\mathrm{I}\right) / \mathrm{I}\right]=\log \mathrm{K}_{\mathrm{b}}+\mathrm{nlog}[\mathrm{Q}]$ referente à interação entre HSA e o complexo $\left[\operatorname{Ru}(b p y)_{2}(\text { adrenalina })\right]^{+}, a^{3}{ }^{\circ} \mathrm{C}$

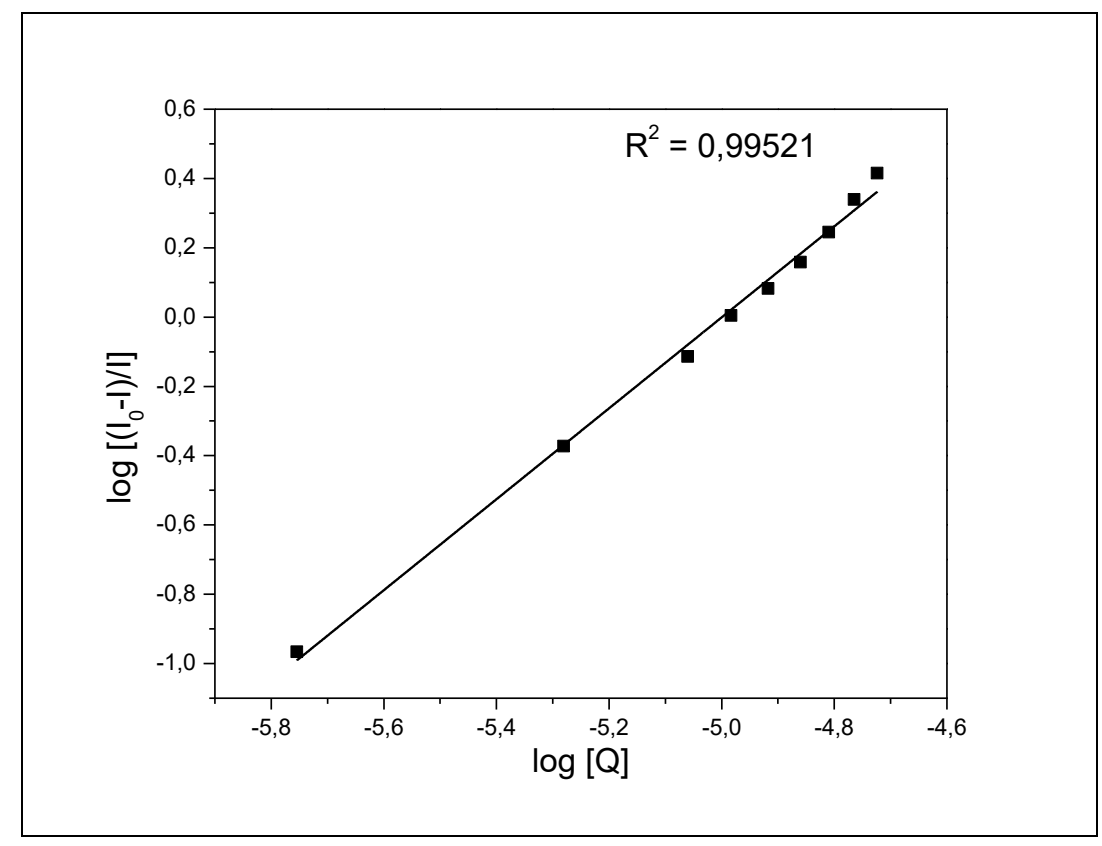

Fonte: Autora 
Figura 201: Espectros de emissão de fluorescência da HSA, na presença de diferentes concentrações de $\left[\operatorname{Ru}(\text { bpy })_{2} \text { (adrenalina) }\right]^{+}$, a $38^{\circ}$ C. Gráfico de Stern-Volmer inserido

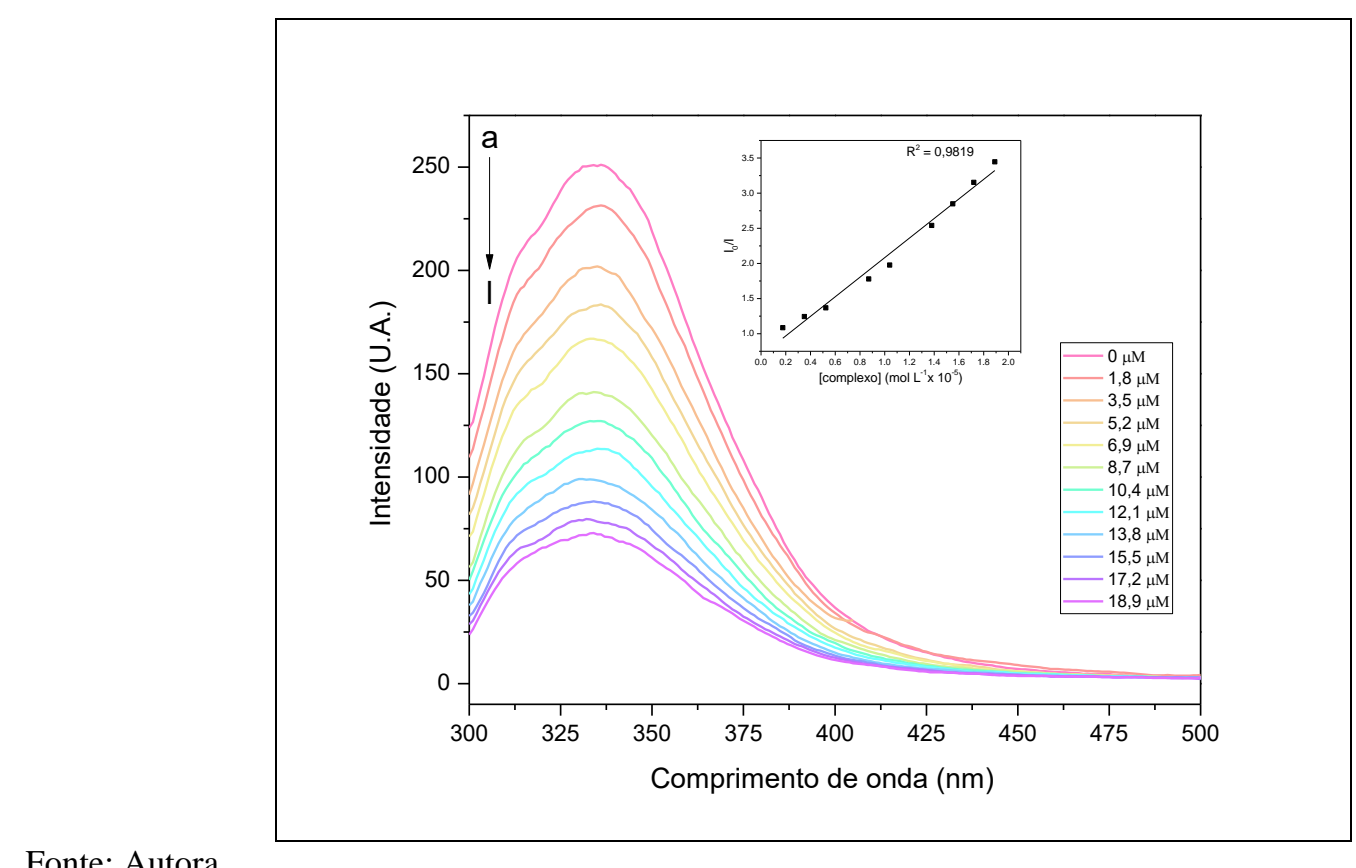

Figura 202: Gráfico da equação $\log \left[\left(I_{0}-I\right) / I\right]=\log K_{b}+n \log [Q]$ referente à interação entre HSA e o complexo $\left[\operatorname{Ru}(b p y)_{2}(\text { adrenalina })\right]^{+}, a^{\circ} 38^{\circ} \mathrm{C}$

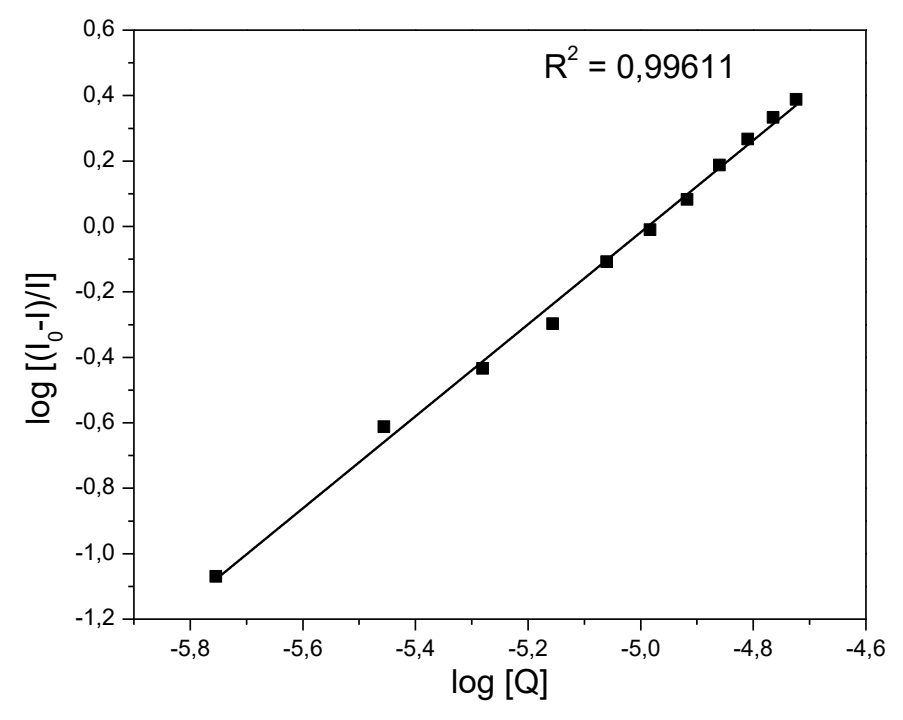

